\title{
Development of Multi-Catchment Rating Curves for Streams of Appalachian Mixed-Land-Use Watersheds: Preliminary Results
}

\author{
Zachary A. Heck \\ West Virginia University, zheck@mix.wvu.edu
}

Follow this and additional works at: https://researchrepository.wvu.edu/etd

Part of the Environmental Monitoring Commons, and the Water Resource Management Commons

\author{
Recommended Citation \\ Heck, Zachary A., "Development of Multi-Catchment Rating Curves for Streams of Appalachian Mixed- \\ Land-Use Watersheds: Preliminary Results" (2021). Graduate Theses, Dissertations, and Problem Reports. \\ 10308. \\ https://researchrepository.wvu.edu/etd/10308
}

This Thesis is protected by copyright and/or related rights. It has been brought to you by the The Research Repository @ WVU with permission from the rights-holder(s). You are free to use this Thesis in any way that is permitted by the copyright and related rights legislation that applies to your use. For other uses you must obtain permission from the rights-holder(s) directly, unless additional rights are indicated by a Creative Commons license in the record and/ or on the work itself. This Thesis has been accepted for inclusion in WVU Graduate Theses, Dissertations, and Problem Reports collection by an authorized administrator of The Research Repository @ WVU. For more information, please contact researchrepository@mail.wvu.edu. 


\title{
Development of Multi-Catchment Rating Curves for Streams of Appalachian Mixed-Land- Use Watersheds: Preliminary Results
}

\author{
Zachary Heck \\ Thesis submitted to the \\ faculty of the Davis College of Agriculture, Natural Resources and Design \\ at West Virginia University
}

in partial fulfillment of the requirements for the degree of

Master of Science in

Forestry

Approved by:

Jason A. Hubbart, Ph.D., Chair

Kirsten Stephan, Ph.D.

Elliott Kellner, Ph.D.

Morgantown, West Virginia

2021

Keywords: Rating Curve; Streamflow; Stage; Cross-section Copyright 2021 Zachary Heck 


\section{ABSTRACT}

\section{Development of Multi-Catchment Rating Curves for Streamflow of Appalachian Mixed-Land-Use Watersheds: Preliminary Results Zachary Heck}

Anthropogenic activities can alter the quantity and quality of water. Traditional monitoring of streamflow involves measurements of stage $(\mathrm{mm})$, or water height, and discharge (i.e., streamflow) $\left(\mathrm{m}^{3} \mathrm{~s}^{-1}\right)$ above a local datum. However, while stage is relatively easily monitored, continuous streamflow measurement is often impractical and prohibitively expensive. To address this challenge, rating curve equations can be developed to convert stage to flow. To establish a series of rating curves for flow estimations in Appalachia, an investigation was conducted in a representative urbanizing, mixed-land-use watershed in north-central West Virginia consisting of 21 nested stream gauge sites. At each site, stage was continuously recorded at 5-minute intervals using a Solinst Levelogger. Streamflow was observed using the cross-section method and an Acoustic Doppler Velocimeter (ADV). Stream cross-sections were conducted over a range of low to high flow events. A preliminary rating curve was developed for each of the 21 study sites, with sample sizes ranging from 21 to 53 per site. Preliminary results generated $\mathrm{R}^{2}$ values ranging from 0.98 to 1 . Three empirical streamflow models, Manning's equation, Chezy equation, and Dingman and Sharma equation, were used to estimate streamflow for comparison to observed flow (i.e., velocity-area method) at each site. Validation of the empirical models showed a significant difference $(\alpha=0.05)$ between observed and modeled mean streamflow at sites 3, 4, 5 , $8,11,15,17$, and 21 . Even though only 8 sites showed significant differences between observed and modeled mean streamflow, the models inaccurately estimated streamflow during low flow events. While results from this study are preliminary, and not yet appropriate for stream flow estimates, work to date advances the understanding of stage versus discharge relationships in mixed-land-use watersheds of Appalachia. Ongoing research will result in a completed data set and regionally relevant rating curves. 
The undersigned approve the thesis entitled

\title{
Development of Multi-Catchment Rating Curves for Streams of Appalachian Mixed-Land-Use Watersheds: Preliminary Results
}

\author{
Presented by Zachary Heck,
}

as partial fulfillment to the requirement of the degree of M.S. of Forestry

and hereby certify that, in their opinion, it is worthy of acceptance

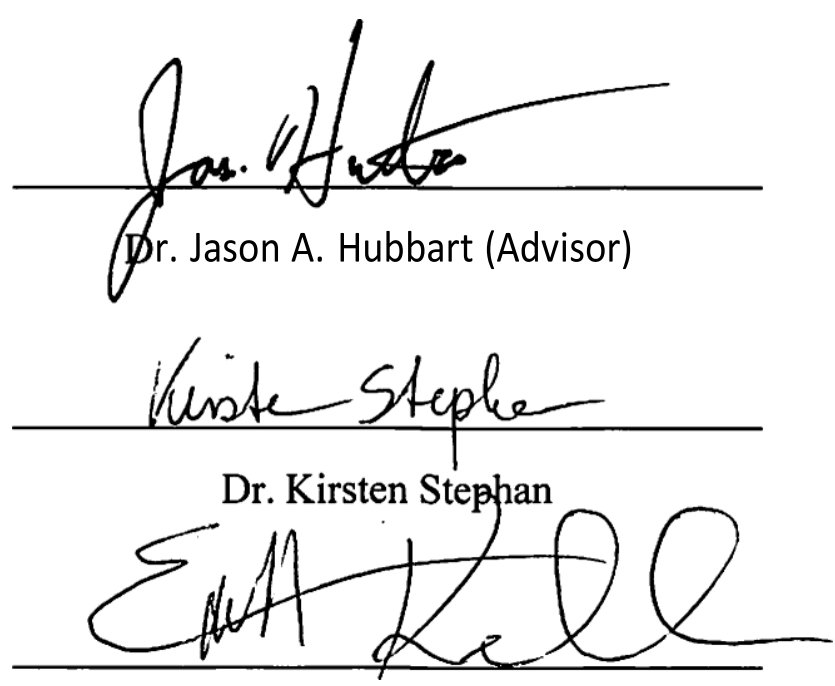

Dr. Elliot Kellner 


\section{ACKNOWLEDGEMENTS}

I would first like to acknowledge my advisor, Dr. Jason Hubbart, who gave me the chance to continue my education by working towards a master's degree. His guidance and experience were always helpful when working in the field and processing data. Working with Dr. Hubbart with various tasks accomplished during my master's degree helped my growth as a scientist and person.

I would also like to thank my committee members, Dr. Kirsten Stephan and Dr. Elliott Kellner, for sharing their knowledge and guidance. This support from my committee helped with my growth as a scientist.

I would also like to thank all current and former Interdisciplinary Hydrology Laboratory members who helped install gauging sites, collect data, and provide helpful advice during this project. I would especially like to thank Fritz Petersen and Jason Horne for their help in collecting streamflow data during high-flow events. With their help, we could divide the watershed into groups and collect more data during each event.

Finally, I would like to thank my wife, Lacey Smith, who kept an eye on me during sampling of high flows and provided tremendous encouragement and always knew how to push me to keep me on track. Her patience and dedication were invaluable. 


\section{TABLE OF CONTENTS}

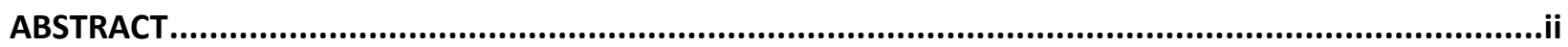

Development of Multi-Catchment Rating Curves for Streamflow of Appalachian Mixed-Land-Use

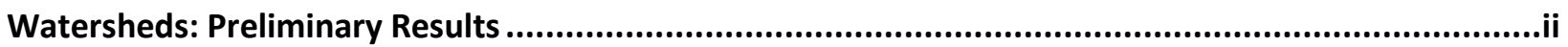

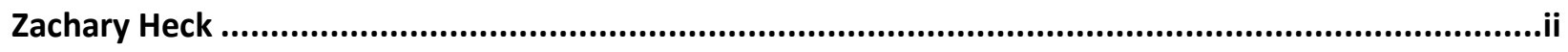

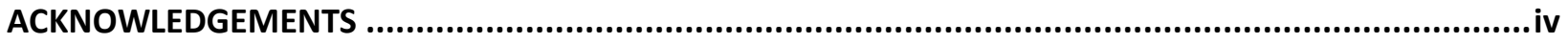

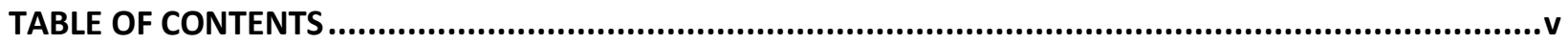

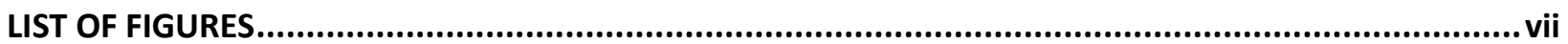

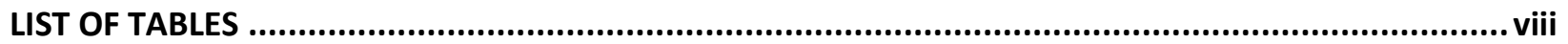

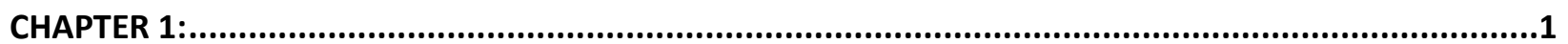

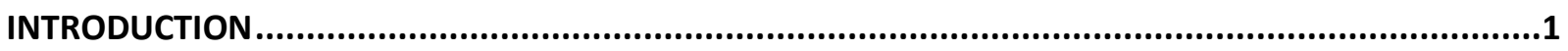

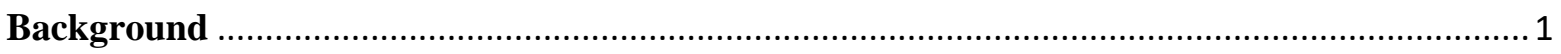

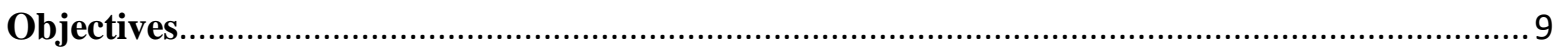

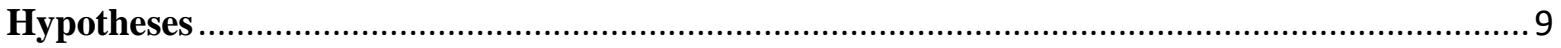

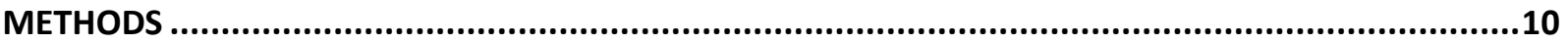

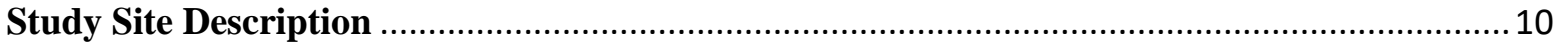

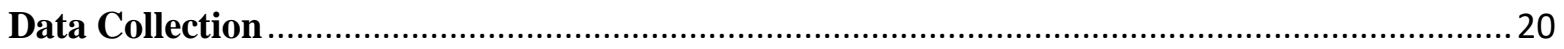

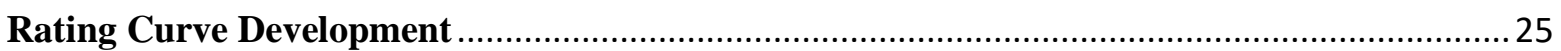

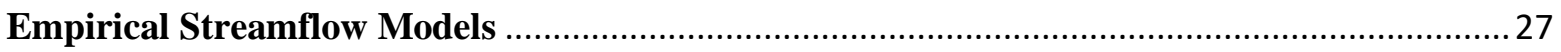

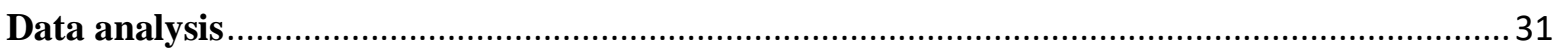

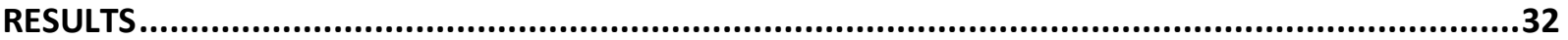

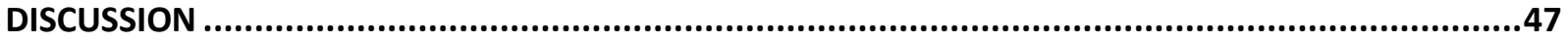

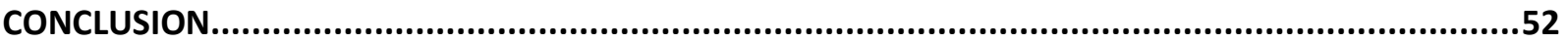

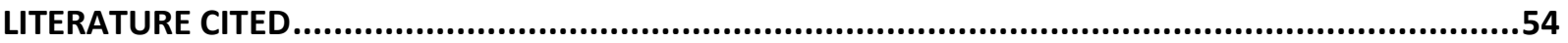

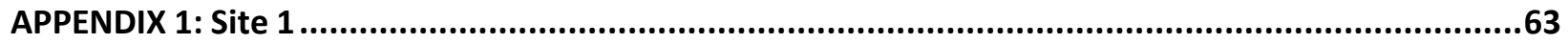

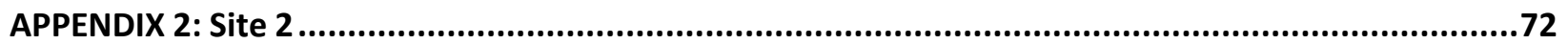

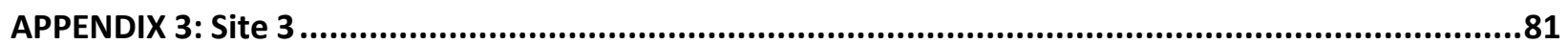

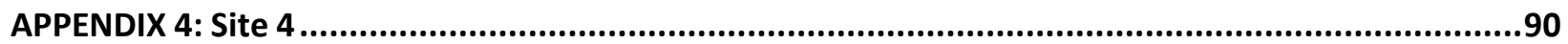

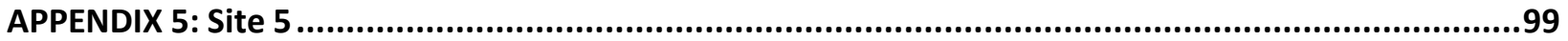

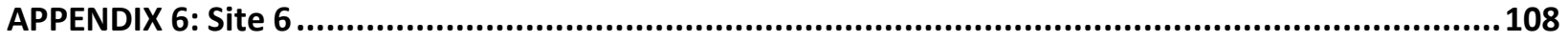

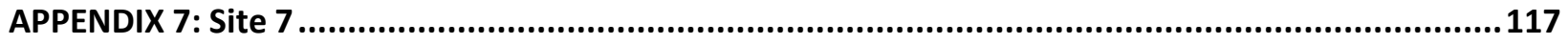




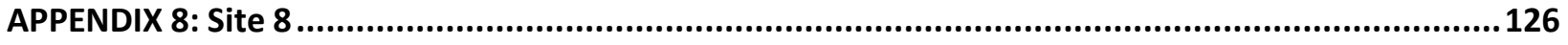

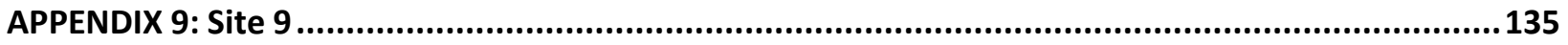

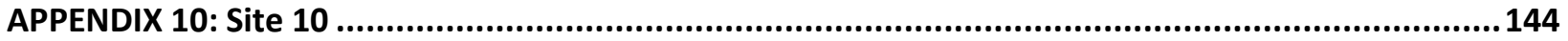

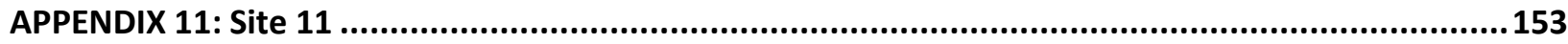

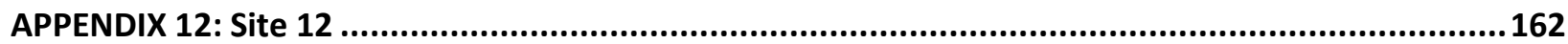

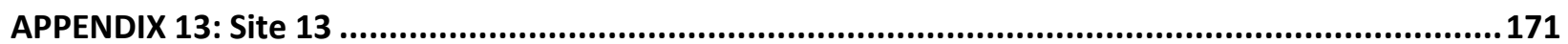

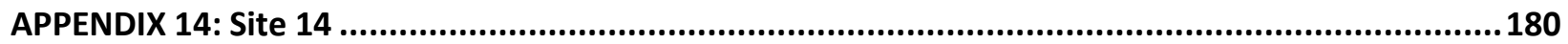

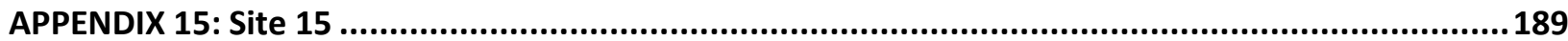

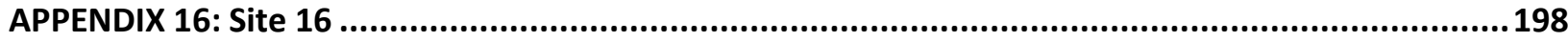

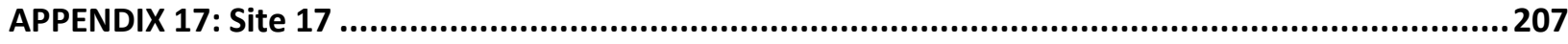

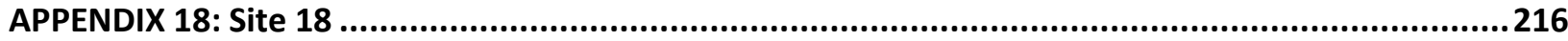

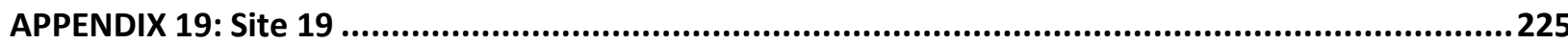

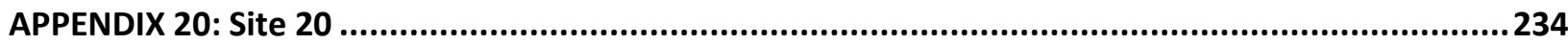

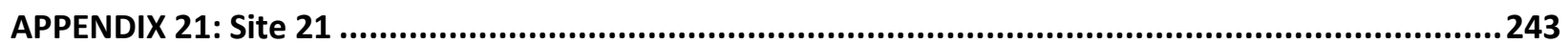




\section{LIST OF FIGURES}

Figures

Figure 1. A representation of the float method utilized to measure streamflow..................2

Figure 2. Map of experimental study design comprising 21 monitoring sites, with land-use and land cover, in West Run Watershed (WRW), Morgantown, West Virginia, U.S.A. Note:

Legend colors appear slightly lighter in comparison to map, this is due to a hillside overlay on the map to give elevation contrast.

Figure 3. Surface geology in the West Run Watershed (WRW), Morgantown, West Virginia, U.S.A. Map units represent the following: Pnc- Pennsylvanian shale, PnmPennsylvanian sandstone, and Qal- Quaternary alluvium (Table 3). Note: Legend colors appear slightly lighter in comparison to map, this is due to a hillside overlay on the map to give elevation contrast. 16

Figure 4. Soil textures in the West Run Watershed (WRW), Morgantown, West Virginia, U.S.A. Soil data from the most recent Soil Survey Geographic Database (SSURGO), 2011. Note: Legend colors appear slightly lighter in comparison to map, this is due to a hillside overlay on the map to give elevation contrast. 18

Figure 5. Soil orders found in the West Run Watershed (WRW), Morgantown, West Virginia, U.S.A. Soil data from the Soil Survey Geographic Database (SSURGO), 2011. Note: Legend colors appear slightly lighter in comparison to map, this is due to a hillside overlay on the map to give elevation contrast.

Figure 6. A representation of a typical cross-section with stream channel divided into vertical transects for water depth and velocity to be measured when using the 0.6 method.

Figure 7. The generated rating curve (left) next to the "ideal curve" (right). This "ideal curve" was used during the initial development of the rating curves for the WRW. 


\section{LIST OF TABLES}

Table

Table 1. Categorical breakdown of the four-primary land-use types used in the WRW using the 2016 NLCD. 13

Table 2. Distribution of primary land-use practices in the West Run Watershed, Morgantown, West Virginia, U.S.A. Also, including the longitude and latitude coordinates of each monitoring site.

Table 3. Geologic units present in the West Run Watershed, Morgantown, West Virginia, U.S.A.

Table 4. Accuracy, resolution, and timing of the Solinst ${ }^{\circledR}$ products used during this study in the West Run Watershed, Morgantown, West Virginia, U.S.A. 21

Table 5. Reference table for estimating Manning's $n$ (recreated from Arcement and Schneider 1989).

Table 6. Field observed slope, calculated slope using DEMs in ArcGIS, and assigned roughness coefficients (Manning's $n$ ) for the 21 gauging sites in the West Run Watershed, Morgantown, West Virginia, U.S.A. 33

Table 7. Measurements at each stream gauging site including bankfull channel width, wetted perimeter, average depth, and cross-sectional area in West Run Watershed, Morgantown, West Virginia, U.S.A.

Table 8. Measurements at each site of bankfull at, above, and below the stilling well. The distance the stilling well is from the bank and the distance between the stilling well and where streamflow was measured for the gauging sites located in West Run Watershed, Morgantown, West Virginia, U.S.A. 
Table 9. Number of observations (n) used to generate the observed and modeled rating curves, and associated $\mathrm{R}^{2}$ values for each of the study sites in the West Run Watershed, Morgantown, West Virginia, U.S.A.

Table 10. Observed and modeled rating curves for sites 1-3 in the West Run Watershed, Morgantown, West Virginia, U.S.A. 38

Table 11. Observed and modeled rating curves for sites 4-6 in the West Run Watershed, Morgantown, West Virginia, U.S.A. 38

Table 12. Observed and modeled rating curves for sites 7-9 in the West Run Watershed, Morgantown, West Virginia, U.S.A. 38

Table 13. Observed and modeled rating curves for sites 10-12 in the West Run Watershed, Morgantown, West Virginia, U.S.A. 39

Table 14. Observed and modeled rating curves for sites 13-15 in the West Run Watershed, Morgantown, West Virginia, U.S.A. 39

Table 15. Observed and modeled rating curves for sites 16-18 in the West Run Watershed, Morgantown, West Virginia, U.S.A. 39

Table 16. Observed and modeled rating curves for sites 19-21 in the West Run Watershed, Morgantown, West Virginia, U.S.A. 40

Table 17. Minimum observed and modeled streamflow $\left(\mathrm{m}^{3} / \mathrm{s}\right)$ estimates for each of the study sites in the West Run Watershed, Morgantown, West Virginia, U.S.A. Note: (Obs.) refers to streamflow estimated using observed slope and (Calc.) refers to streamflow estimated using calculated slope. 41

Table 18. Maximum observed and modeled streamflow $\left(\mathrm{m}^{3} / \mathrm{s}\right)$ estimates for each of the study sites in the West Run Watershed, Morgantown, West Virginia, U.S.A. Note: (Obs.) refers 
to streamflow estimated using observed slope and (Calc.) refers to streamflow estimated using calculated slope

Table 19. Average observed and modeled streamflow $\left(\mathrm{m}^{3} / \mathrm{s}\right)$ estimates for each of the study sites in the West Run Watershed, Morgantown, West Virginia, U.S.A. Note: (Obs.) refers to streamflow estimated using observed slope and (Calc.) refers to streamflow estimated using calculated slope.

Table 20. Standard Deviation of observed and modeled streamflow estimates for each of the study sites in the West Run Watershed, Morgantown, West Virginia, U.S.A. Note: (Obs.) refers to streamflow estimated using observed slope and (Calc.) refers to streamflow estimated using calculated slope.

Table 21. Site by site comparison of the developed observed and modeled rating curves used to estimate streamflow for sites 3-11 in the West Run Watershed, Morgantown, West Virginia, U.S.A. Obs. slope represents observed slope collected in the field. Calc. slope represents calculated slope using ArcGIS. Only significant $(\alpha=0.05)$ results from the analysis are shown.

Table 22. Site by site comparison of the developed observed and modeled rating curves used to estimate streamflow for sites 5-21 in the West Run Watershed, Morgantown, West Virginia, U.S.A. Obs. slope represents observed slope collected in the field. Calc. slope represents calculated slope using ArcGIS. Only significant $(\alpha=0.05)$ results from the analysis are shown.

Table 23. P-values for statistically significant study sites in WRW. Note: (Obs.) refers to streamflow estimated using observed slope and (Calc.) refers to streamflow estimated using calculated slope 


\section{INTRODUCTION}

\section{Background}

\section{CHAPTER 1:}

Anthropogenic activities can impact the quality and quantity of water (Erwin and Hamilton 2002). For example, anthropogenic alterations to terrestrial landscape management practices (e.g., urbanization) were shown to disrupt natural stream geomorphological evolution, thereby altering stream ecological habitat and suspended sediment regimes (Sunde et al. 2018; Erwin and Hamilton 2002). Urban development often includes increased impervious surface area that can reduce infiltration, increase runoff (Sunde et al. 2018; Arnold and Gibbons 1996), affect streamflow volume and timing, baseflow, and contaminant transport processes (Sunde et al. 2018; Pappas et al. 2007). The changes caused by the introduction of impervious surfaces can lead to an increase in stream velocity resulting in channel incision and mass wasting (Kellner and Hubbart 2019; Leopold 1968), and subsequent sedimentation increases (Borah and Bera 2004). For example, previous studies showed that as little as $8-13 \%$ of total urban land-use is needed to significantly impact streamflow and bank erosion (Zeiger and Hubbart 2019; Zeiger and Hubbart 2018; Walsh et al. 2012).

Without accurate stream flow estimates, it is challenging to confidently quantify flowrelated changes/impacts due to anthropogenic activities and in-situ changes in pollutant loading. Some of the original methods for estimating streamflow included the float method and the bucket and stopwatch method (Michuad and Wierenga 2005). To use the float method (Figure 1), the cross-sectional area of the stream channel needs to be calculated. After the cross-sectional area is calculated, an 8 to $30 \mathrm{~m}$ long section of the channel is measured and marked with a marker on 
either end. The length used, greatly depends upon the velocity of the water (the higher the velocity, the greater the distance needs to be) (Michuad and Wierenga 2005). By using the average time it takes for an object to travel between point A and B (Figure 1), velocity can be estimated. Then by multiplying the velocity by the cross-sectional area, streamflow can be estimated (Michuad and Wierenga 2005). The bucket and stopwatch method is commonly used in stream channels with small waterfalls or v-notch weirs. Streamflow is calculated by recording the amount of time it takes for a bucket of known volume to fill up (Michuad and Wierenga 2005). Both of these techniques are replicated several times during one collecting event, and then the streamflow measurements are averaged (Michuad and Wierenga 2005).

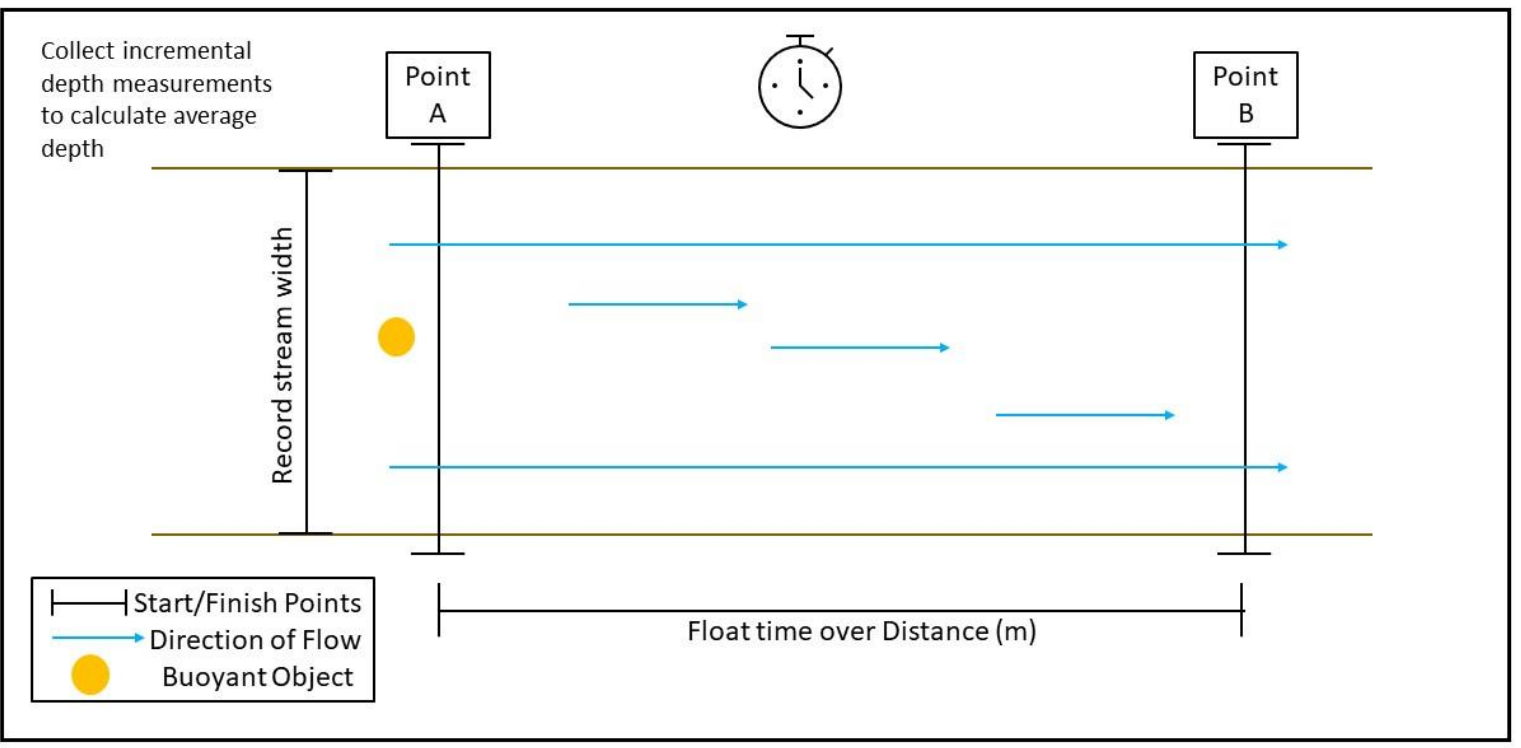

Figure 1. A representation of the float method utilized to measure streamflow.

Other means for collecting streamflow have been developed, including the use of current meters (USGS 2019). Several different types of current meters are available, including rotating- 
element mechanical meters and acoustic doppler velocimeters (ADV) (Turnipseed and Sauer 2010; Rehmel 2007; Buchanan and Somers 1969). Historically, the United States Geological Survey (USGS) has used the Price AA mechanical current meters to collect streamflow measurements (USGS 2019; Turnipseed and Sauer 2010). The Price AA can be used in velocities between 0.06 and $3.66 \mathrm{~m} / \mathrm{s}$, and depths greater than $0.38 \mathrm{~m}$ (Turnipseed and Sauer 2010; Buchanan and Somers 1969). For gauging sites with low velocities, the Price pygmy, a variation of the Price AA, is often used (Turnipseed and Sauer 2010). The Price pygmy is a scaled down version of the Price AA, that can measure stream velocity between 0.06 and 0.12 $\mathrm{m} / \mathrm{s}$, and depths between 0.09 and $0.5 \mathrm{~m}$ (Turnipseed and Sauer 2010). Both current meters are designed to attach to a top-setting wading rod to facilitate streamflow measurements in wadable streams (USGS 2019; Buchanan and Somers 1969). However, the Price AA can also measure stream velocity in deeper water by attaching it to a cable and reel system (USGS 2019).

In the early 2000s, USGS began using $\mathrm{ADV}^{\odot}$ current meters, as replacements for the Price AA mechanical current meter, due to being more accurate at low flow (Rehmel 2007; Sontek 2003). Unlike the Price AA and Price Pygmy, that use velocity to rotate mechanical parts, $\mathrm{ADV}^{\odot}$, such as the Sontek Flowtracker ${ }^{\odot}$ and the more recent Flowtracker $2^{\odot}$, measure velocity by sensing the velocity phase change of light reflected from suspended particles, by using the Doppler effect (Rehmel 2007; Sontek 2003). Similar to the Price AA and the Pygmy Price, the Sontek Flowtracker ${ }^{\odot}$ and Flowtracker $2^{\odot}$ are most effective when used on a top-setting wading rod for measurements (USGS 2019; Turnipseed and Sauer 2010, Sontek 2003).

The use of a wading rod is the preferred method when collecting streamflow measurements using a current meter. This is due to the advantages that field personnel have when selecting the best location to conduct a velocity reading (Turnipseed and Sauer 2010). Top- 
setting wading rods comprise a stationary rod that has a foot on the bottom and an adjustable rod that holds the sensor the for the current meter. The top-setting wading rod is generally preferred among wading rod types due to the convenience of setting the current meter sensor to the proper water depth without the need for the operator to place their hands in the water (Buchanan and Somers 1969). With the stationary rod on the streambed, the adjustable rod is moved up and down depending upon the water depth, this adjustment allows for velocity to be recorded at the appropriate depth (Sontek 2003; Buchanan and Somers 1969). When using current meters on a top-setting wading rod (mechanical current-meters or ADV), velocity is usually measured at three different point settings: the single point method (0.6), the two-point method (0.2 and 0.8), and the three-point method $(0.2,0.6$, and 0.8$)$. These numbers represent the fractional distance from the water surface (WSC 2015). The 0.6 method (60\%) is generally used when the water depth is below $0.5 \mathrm{~m}$, where it is understood that the mean velocity in the water column is found at this location (Sontek 2003; WSC 2015; Herschy 1995). The 0.2 (20\%) and 0.8 (80\%) method is generally used when the water depth is greater than $0.5 \mathrm{~m}$. Using this method, velocity is measured at both points then averaged to determine the average velocity for the water column (Sontek 2003; Herschy 1995). The 0.2, 0.6, and 0.8 method is a combination of the other two methods. This method is generally used when the stream channel is covered in aquatic vegetation or contain large rocks. By using this the latter method, any accuracy errors due to turbulence or obstructions can be avoided (WSC 2015). The only detriment to this method is the amount of time required to collect all three velocity points, which may not be feasible during storm events where stream stage may rise and fall quickly (Herschy 1995).

By combining the point settings while using a wading rod and the velocity-area method, streamflow can be measured within a stream cross-section. The velocity-area method is one of 
the most widely used methods for measuring streamflow $\left(\mathrm{m}^{3} / \mathrm{s}\right)$ (USGS 2019; Turnipseed and Sauer 2010). Streamflow, using this method, is calculated by dividing the channel into segments or subsections. Within each segment or subsection, water depth and velocity are measured. Velocity is averaged then multiplied by the cross-section area to give streamflow. The number of segments within a stream channel greatly depends upon channel width (i.e., the wider the channel, the more segments) (USGS 2019; Turnipseed and Sauer 2010).

However, continuously monitoring streamflow can be costly in terms of instrumentation and labor, and the method is potentially dangerous for field personnel. To address these issues and reduce the need for streamflow monitoring in all places (an infeasible proposition), rating curves can be developed that are regionally relevant (i.e., transferrable) and reflect many different land-use practices. A rating curve is a graphical representation of the relationship between stage and discharge (i.e., streamflow) (USGS 2019). The graphical representation represents a mathematical model of the data, that can be applied to stage data (water depth) to estimate streamflow.

Traditionally, rating curves have been constructed using the power-law function (Equation 1) or $2^{\text {nd }} / 3^{\text {rd }}$ degree polynomial functions (Equation 2 and 3, respectively) (Phillips 2009; Sivapragasam and Muttil 2005).

\section{Power-law \\ $Q=c(h-a)^{n}$}

where $Q$ represents streamflow, $h$ represents stage, and $c, a$, and $n$ are constants that are determined using site specific observations of streamflow $(Q)$ and stage $(h)$. The constant $a$ represents stage when streamflow is zero (Sivapragasam and Muttil 2005). Since $a$ is an inferred 
constant from collected data (streamflow and stage), these rating curves are generated for sites that have a stable stream channel, such as weirs or other manmade channels (Phillips 2009; Sivapragasam and Muttil 2005).

\section{Polynomial Method}

$Q=c(h-a)^{2}+b(h-a)+d$

$Q=c(h-a)^{3}+b(h-a)^{2}+d(h-a)+e$

where $Q$ represents streamflow, $h$ represents stage, and $a, b, c, d$, and $e$ are constants that are determined using the observed data of $h$ and $Q$. The constant $a$ represents stage when streamflow is zero (Sivapragasam and Muttil 2005). Since $a$ is an inferred constant from collected data (streamflow and stage), these rating curves are generated for sites that have a stable stream channel (Phillips 2009; Sivapragasam and Muttil 2005; Fenton 2001). Once a well-developed rating curve is created, future streamflow can be estimated using stage measurements at a gauging site in the original study watershed or in other physiographically and climatically comparable watersheds (i.e., is transferrable) (USGS 2019; Ayele 2017; Pan et al. 2016; Bouska and Paukert 2010; Fenton 2001).

In cases where observed monitoring of stream stage and flow are lacking, less reliable yet still critically useful (empirical) methods are employed to improve confidence in land-use / land management decisions. These methods utilize a hybrid approach by using hydrologic models that require the collection of site-specific characteristics, but not the labor-intensive necessity of collecting cross-sections. The channel morphology measurements needed to calculate streamflow using this approach include channel width and depth, slope, wetted width, and streambed roughness $(n)$ (Chow 1959). 
For example, the Manning's equation (Equation 4), the Chezy equation (Equation 5 and Equation 6), and the Dingman and Sharma equation (Equation 7) are commonly used streamflow models that utilize a hybrid approach, due to the need of site-specific measurements (Dingman 2008; Sivapragasam and Muttil 2005; Dingman and Sharma 1997; Rantz et al. 1982b).

\section{Manning's Equation}

$Q=V A=\left(\frac{1.00}{n}\right) A R^{\frac{2}{3}} \sqrt{S}$

where $Q$ represents streamflow, $V$ represents velocity, and $A$ represents flow area. This is then further broken down so that $n$ represents Manning's coefficient, $A$ represents flow area, $R$ represents hydraulic radius, and $S$ represents channel slope.

\section{Chezy Equation}

$Q=C A_{C} R^{\frac{1}{2}} S^{\frac{1}{2}}$

where $Q$ represents streamflow, $C$ is the Chezy C coefficient (Equation 5), $A_{c}$ represents the wetted channel area, $R_{H}$ represents hydraulic radius, and $S$ represents slope.

$C=\left(\frac{1}{n}\right) R_{H^{\frac{1}{6}}}$

where $n$ is Manning's coefficient of roughness and $R_{H}$ represents hydraulic radius.

\section{Dingman and Sharma Equation}

$Q=1.564 A^{1.173} Y^{0.400} S^{-0.056(\log (S))}$

where $Q$ is streamflow $\left(\mathrm{m}^{3} / \mathrm{s}\right), A$ is the average cross-sectional area $\left(\mathrm{m}^{2}\right), Y$ is average depth $(\mathrm{m})$, and $S$ is the slope of the water surface. 
Over or underestimation of streamflow using empirical models is common due to assigning incorrect values to constants within the equations, especially in mountainous regions. For example, errors in streamflow estimation using the Manning's and Chezy equation are often due to assigning the incorrect value for Manning's $n$ coefficient of roughness. Many techniques for estimating $n$ have been developed in lowland rivers that are characterized by shallow slopes and streambed particle sizes for small streams (Marcus 1992; Jarrett 1984; Bathurst 1978). There is therefore a need for advancing rating curve development in_mountainous regions such as the Appalachians of eastern North America. The Appalachian region is characterized by physiographic complexity that can further confound watershed hydrologic processes and development of reliable rating curves (Hubbart et al. 2019; Hubbart 2011). Further, much of the region lacks reliable streamflow data that can be used to develop regionally relevant rating curves. There is therefore a need for observed streamflow and development of accurate rating curves for Appalachian streams and rivers that reflect the terrain and land-use practices and are therefore transferrable throughout the region. 


\section{Objectives}

The overarching objective of this research was to develop a series of rating curve equations for several mixed-land-use catchments in a representative Appalachian mixed-land-use watershed. Additionally, select empirical flow estimation models, were validated using the observed streamflow measurements. Study results advance understanding of the stage and discharge relationship for mixed-land-use watersheds in mountainous terrain of the Appalachian region of the United States and similar physiographic regions globally.

\section{Hypotheses}

This research tested the following hypotheses related to the objectives:

1. Validation of developed rating curves based on observed and modeled data.

$\mathrm{H}_{0}$ : There is no difference between observed and modeled data.

$\mathrm{H}_{\mathrm{a}}$ Developed rating curves differ between observed and modeled data.

2. Validation of select empirical flow estimations for observed streamflow data.

$\mathrm{H}_{0}$ : Selected empirical flow models showed no significant difference from the observed streamflow data.

$\mathrm{H}_{\mathrm{a}}$ : Selected empirical flow models showed significant differences from the observed streamflow data. 


\section{METHODS \\ Study Site Description}

This research was conducted in the West Run Watershed (WRW), located in northcentral West Virginia (Figure 2). The WRW is a 2,330-ha (5,760-ac), mixed-land-use watershed in Morgantown, WV. Located in north-central West Virginia in the Central Allegheny Plateau, the area is underlain by interbedded shale, siltstone, sandstone, coal, and limestone (Wright et al. 1982). Along the channels, there are numerous Pennsylvanian (Upper Carboniferous) rock outcroppings (Wright et al. 1982; West Virginia Geological and Economic Survey 1913). Within these rock formations are several coal seams, the Upper Kittanning coal and the Pittsburgh coal. The older formations, including the Upper Kittanning, are present at the Monongahela River's confluence. The Monongahela series, a younger formation, is present in the watershed headwaters and contains the Pittsburgh coal seam (West Virginia Geological and Economic Survey 1913). The Pittsburgh coal seam, which has an average thickness of $2.1 \mathrm{~m}$, has served as an essential resource for the Morgantown area and surrounding counties. The Pittsburgh coal seam and other coals seams have provided a valuable economic resource for the region since the early 1800s (Laing 1966). Much of the mining in WRW involved underground mining between 1930 and 1950 and had stopped before the 1977 Surface Mine Control and Reclamation Act (West Virginia Geological and Economical Survey 2009). Using a geologic overlay developed by the West Virginia Geological and Economic Survey in ArcGIS, an assessment of the surface geology distribution in the WRW was generated in Figure 3, and a breakdown of the units found in each group in Table 3.

The topography of WRW is predominantly rolling; elevation in WRW ranges from approximately $240-420 \mathrm{~m}$, and slope generally ranges from 3-30 percent, with some areas of short steep slopes greater than 50 percent. Soils of the uplands are formed in residual material 
weathered from the underlying sedimentary rocks, while soils of the foot slopes and in heads of drainageways are formed in colluvial materials that have eroded from the residual soils and parent materials (Wright et al. 1982). On the terraces and floodplains that are adjacent to West Run and its tributaries, soils formed in locally-derived alluvial materials eroded from the surrounding soils (Wright et al. 1982). Using the most recent Soil Survey Geographic Database (SSURGO) in ArcGIS, an assessment of the soil orders and textures was generated in Figures 4 and 5.

The climate in north-central West Virginia is characterized by strong seasonal frontal storm systems that deposit most precipitation during the spring and summer months (Horne and Hubbart 2020; Kutta and Hubbart 2019a; Kutta and Hubbart 2019b). The wettest month of the year is July, with the average precipitation of $11.7 \mathrm{~cm}$. West Virginia does not experience a dry season; however, the driest month of the year is February, with an average precipitation of 6.6 cm (Petersen and Hubbart 2020b; Peel et al. 2007). The average yearly precipitation in Morgantown, West Virginia is approximately $110 \mathrm{~cm}$, with previous studies showing a significant $(\mathrm{p}=0.01)$ increases by $2.2 \%$ over the past 111 years in the Appalachian region (Kutta and Hubbart 2019b). The temperatures in West Virginia are seasonal. The summers are generally hot and humid, with average monthly temperatures $>22^{\circ} \mathrm{C}$. The warmest month is July, with the average daily temperature of $23^{\circ} \mathrm{C}$. The winters are cold $\left(<0^{\circ} \mathrm{C}\right)$, with the coldest month being February with average daily temperatures of $-0.4^{\circ} \mathrm{C}$ (Petersen and Hubbart 2020b; Arguez 2010). The overall average annual temperature (between 1906-2016) ranged from $4.9^{\circ} \mathrm{C}$ to $18{ }^{\circ} \mathrm{C}$, with an annual average temperature of approximately $11.45^{\circ} \mathrm{C}$ (Kutta and Hubbart 2018). 
West Run Creek is a tributary of the Monongahela River. WRW is a mixed-land-use watershed encompassing $23 \mathrm{~km}^{2}$ of the northern part of Morgantown, West Virginia. West Run Creek is characterized by moderately entrenched channels with relatively narrow floodplains. The watershed headwaters have an average slope of approximately $1.1 \%$ that gradually becomes less than $1 \%$ at the river's mouth. Due to its low gradient and narrow channels, the watershed contains no dams or navigable waterways. Using the 2016 National Land Cover Dataset (NLCD) in ArcGIS, an assessment of the land-use and cover was generated. For this work, the 16 landuse and land cover (LULC) types provided in the 2016 NLCD were categorized into one of four categories: forested, agriculture, mixed development, and open water (Figure 2 and Table 1). While most of the watershed is undergoing development, sections of the watershed remain relatively undeveloped with minimal infrastructure (e.g., buildings, paved surfaces). Several undeveloped portions of the watershed are owned by West Virginia University (WVU) and are used as educational resources, experimental farms, and forests (Horne and Hubbart 2020, Petersen and Hubbart 2020a, Petersen and Hubbart 2020b, Petersen and Hubbart 2020c, Petersen et al. 2018). 
Table 1. Categorical breakdown of the four-primary land-use types used in the WRW using the 2016 NLCD.

\begin{tabular}{cc}
\hline Primary Land-Use Types & Included Land-Uses \\
\hline Forested & Mine Grass, Forest, Small Stream Riparian Habitats, Mixed \\
Mesophotic Forest, Dry Mesic Oak Forest, and Dry Pine Forests \\
Lgriculture & Low Vegetation, Hay Pasture, and Cultivated Crops \\
Mixed Development & Mixed Development, Barren, Impervious, and Roads \\
Open Water & Water, River Flood Plains, and Wetlands PEM \\
\hline
\end{tabular}

\section{Land-use and Land Cover}

For this research, a paired and scale-nested experimental watershed design (Petersen and Hubbart 2020b; Hubbart et al. 2019; Hubbart et al. 2007; Loftis et al. 2001) was implemented consisting of 21 study sites (i.e., gauging sites) (Figure 2). The study design includes numerous stream stage monitoring locations along the West Run Creek channel and in several $1^{\text {st }}$ and $2^{\text {nd }}$ order tributaries within the watershed. Sites 3, 4, 6, 10, 13, 18, 19, and 21 are located along West Run Creek (main tributary), while sites $1,2,5,7-9,11,12,14-17$, and 20 are located on $1^{\text {st }}$ and $2^{\text {nd }}$ order tributaries of West Run creek.

Based on the four land-use classifications designated for this study, WRW consists of $42.7 \%$ forested, $19.4 \%$ agriculture, $37.7 \%$ mixed development, and $0.2 \%$ open water. Within the sub-watersheds in WRW, sites 2-10, 12-14, 16-19, and 21 have the dominant land-use type of forested, and site 11 has a dominant land-use of agricultural and forested. Remaining study sites $(1,15$, and 20) have the dominant land-use type of mixed development (Table 2). 
Table 2. Distribution of primary land-use practices in the West Run Watershed, Morgantown, West Virginia, U.S.A. Also, including the longitude and latitude coordinates of each monitoring site.

\begin{tabular}{|c|c|c|c|c|c|}
\hline Site & Location & Forest (\%) & $\operatorname{Ag}(\%)$ & Mixed Developed (\%) & $\begin{array}{c}\text { Open Water } \\
(\%)\end{array}$ \\
\hline 1 & $\begin{array}{l}\mathrm{N}^{3} 9^{\circ} 38.546^{\prime} \\
\mathrm{W}^{\prime} 9^{\circ} 53.836^{\prime}\end{array}$ & 8.1 & 38.1 & 53.2 & 0.6 \\
\hline 2 & $\begin{array}{l}\mathrm{N}^{\circ} 9^{\circ} 38.528^{\prime} \\
\mathrm{W}^{\circ} 9^{\circ} 53.843^{\prime}\end{array}$ & 74.2 & 12.2 & 13.6 & 0 \\
\hline 3 & $\begin{array}{l}\mathrm{N}^{\circ} 9^{\circ} 38.539^{\prime} \\
\mathrm{W}^{\prime} 9^{\circ} 53.857^{\prime}\end{array}$ & 61.3 & 16.2 & 22.4 & 0.2 \\
\hline 4 & $\begin{array}{l}\mathrm{N}^{3} 9^{\circ} 38.670^{\prime} \\
\mathrm{W}^{\circ} 9^{\circ} 54.278^{\prime}\end{array}$ & 59.0 & 14.9 & 25.9 & 0.2 \\
\hline 5 & $\begin{array}{l}\mathrm{N}^{\circ} 9^{\circ} 38.665^{\prime} \\
\mathrm{W}^{\circ} 9^{\circ} 54.325^{\prime}\end{array}$ & 51.1 & 25.5 & 23.4 & 0 \\
\hline 6 & $\begin{array}{l}\text { N39 } 38.997^{\circ} \\
\text { W79 } 54.755^{\prime}\end{array}$ & 58.7 & 17.3 & 23.9 & 0.1 \\
\hline 7 & $\begin{array}{l}\mathrm{N}^{\circ} 39^{\circ} 39.189^{\prime} \\
\mathrm{W}^{\prime} 9^{\circ} 54.181^{\prime}\end{array}$ & 54.9 & 28.6 & 16.3 & 0.2 \\
\hline 8 & $\begin{array}{l}\mathrm{N} 39^{\circ} 39.172^{\prime} \\
\mathrm{W} 79^{\circ} 54.222^{\prime}\end{array}$ & 52.4 & 16.5 & 30.8 & 0.3 \\
\hline 9 & $\begin{array}{l}\mathrm{N}^{3} 9^{\circ} 39.059^{\prime} \\
\mathrm{W}^{\circ} 9^{\circ} 54.798^{\prime}\end{array}$ & 52.8 & 19.3 & 27.6 & 0.3 \\
\hline 10 & $\begin{array}{l}\mathrm{N}^{\circ} 9^{\circ} 39.072^{\prime} \\
\mathrm{W}^{\circ} 9^{\circ} 54.808^{\prime}\end{array}$ & 56.5 & 18.4 & 24.9 & 0.2 \\
\hline 11 & $\begin{array}{l}\mathrm{N} 39^{\circ} 39.310^{\prime} \\
\mathrm{W} 79^{\circ} 55.067^{\prime}\end{array}$ & 39.2 & 41.9 & 18.2 & 0.7 \\
\hline 12 & $\begin{array}{l}\text { N39 } 39.296^{\prime} \\
\text { W79 } 55.829^{\prime}\end{array}$ & 34.5 & 33.7 & 31.8 & 0 \\
\hline 13 & $\begin{array}{l}\mathrm{N}^{\circ} 9^{\circ} 39.443^{\prime} \\
\mathrm{W}^{\circ} 9^{\circ} 55.925^{\prime}\end{array}$ & 47.2 & 25.8 & 26.8 & 0.2 \\
\hline 14 & $\begin{array}{l}\text { N39 } 39.545^{\prime} \\
\text { W79 } 55.873^{\prime}\end{array}$ & 56.9 & 26.4 & 16.2 & 0.5 \\
\hline 15 & $\begin{array}{l}\mathrm{N}^{3} 9^{\circ} 39.678^{\prime} \\
\mathrm{W}^{\circ} 9^{\circ} 56.268^{\prime}\end{array}$ & 19.4 & 10.3 & 70.3 & 0 \\
\hline 16 & $\begin{array}{l}\mathrm{N}^{\circ} 9^{\circ} 39.844^{\prime} \\
\mathrm{W}^{\circ} 9^{\circ} 56.300^{\prime}\end{array}$ & 35.2 & 58.7 & 5.4 & 0.7 \\
\hline 17 & $\begin{array}{l}\mathrm{N}^{3} 9^{\circ} 39.922^{\prime} \\
\mathrm{W}^{\circ} 9^{\circ} 56.410^{\prime}\end{array}$ & 85.8 & 9.4 & 4.8 & 0 \\
\hline 18 & $\begin{array}{l}\mathrm{N}^{3} 9^{\circ} 39.889^{\prime} \\
\mathrm{W}^{\prime} 9^{\circ} 56.467^{\prime}\end{array}$ & 48.9 & 24.9 & 26.0 & 0.2 \\
\hline 19 & $\begin{array}{l}\text { N39 } 39^{\circ} 40.278^{\prime} \\
\text { W79 } 58.170^{\prime}\end{array}$ & 47.9 & 22.5 & 29.5 & 0.1 \\
\hline 20 & $\begin{array}{l}\mathrm{N}^{3} 9^{\circ} 40.254^{\prime} \\
\mathrm{W}^{\prime} 9^{\circ} 58.170^{\prime}\end{array}$ & 6.6 & 4.2 & 89.2 & 0 \\
\hline 21 & $\begin{array}{l}\mathrm{N}^{\circ} 9^{\circ} 40.671^{\prime} \\
\mathrm{W}^{\circ} 9^{\circ} 58.215^{\prime}\end{array}$ & 42.2 & 19.5 & 38.1 & 0.2 \\
\hline WRW & & 42.7 & 19.4 & 37.7 & 0.2 \\
\hline
\end{tabular}




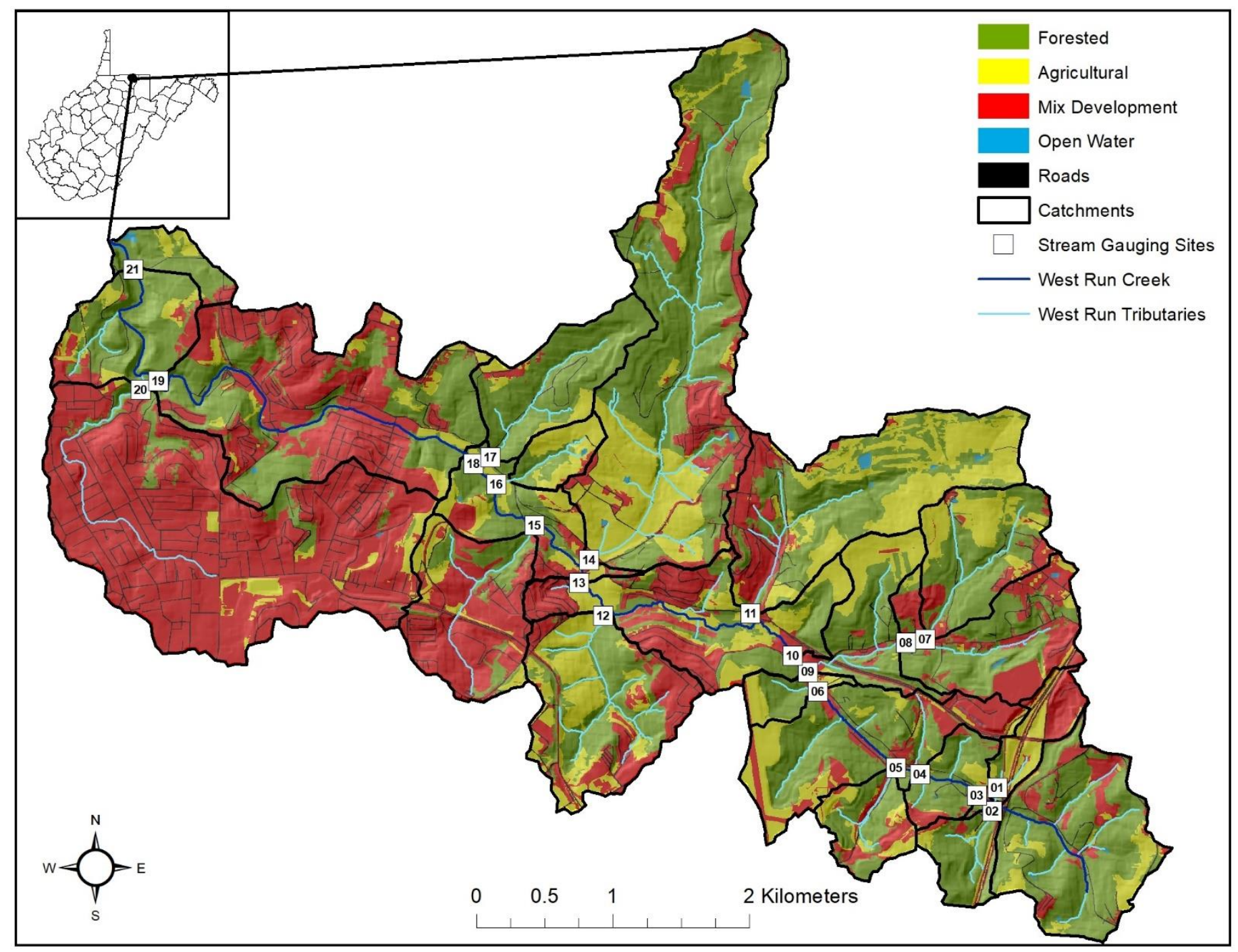

Figure 2. Map of experimental study design comprising 21 monitoring sites, with land-use and land cover, in West Run Watershed (WRW), Morgantown, West Virginia, U.S.A. Note: Legend colors appear slightly lighter in comparison to map, this is due to a hillside overlay on the map to give elevation contrast. 


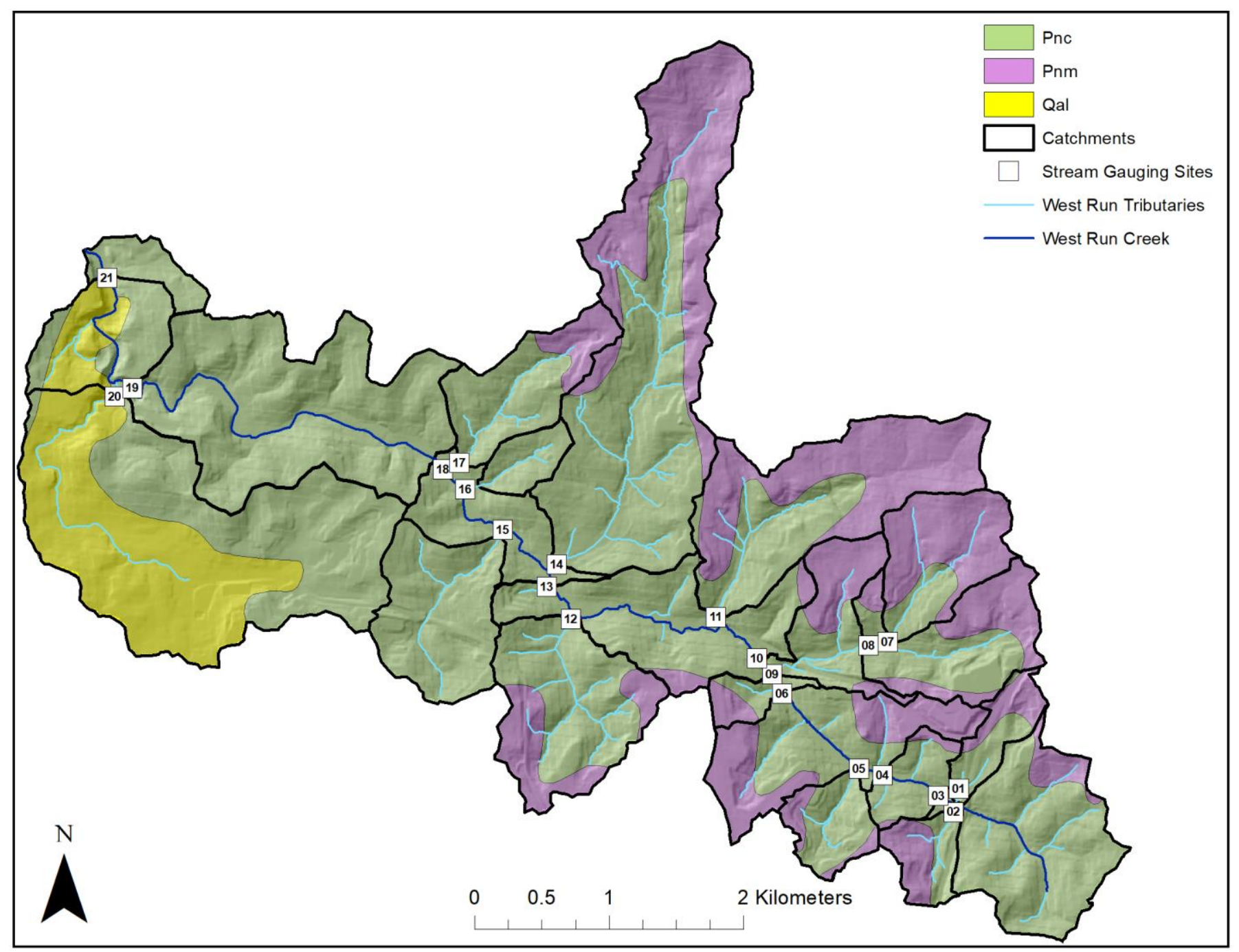

Figure 3. Surface geology in the West Run Watershed (WRW), Morgantown, West Virginia, U.S.A. Map units represent the following: Pnc- Pennsylvanian shale, Pnm- Pennsylvanian sandstone, and Qal- Quaternary alluvium (Table 3). Note: Legend colors appear slightly lighter in comparison to map, this is due to a hillside overlay on the map to give elevation contrast. 
Table 3. Geologic units present in the West Run Watershed, Morgantown, West Virginia, U.S.A.

\begin{tabular}{ccccc}
\hline Map Unit & Period & Rock Type & Formations & Coal Formations \\
\hline \multirow{2}{*}{ Pnc } & Pennsylvanian & Shale & Cassleman, Glenshaw & Elk Lick, \\
& & & & Bakerstown, \\
& & & Mahoning \\
& & & & Waynesburg, \\
& Pennsylvanian & Sandstone & & Uniontown, \\
& & & & Sewickley, \\
& & & & Redstone, \\
& & & & Pittsburgh \\
Qal & Quaternary & Alluvium & \\
\hline
\end{tabular}




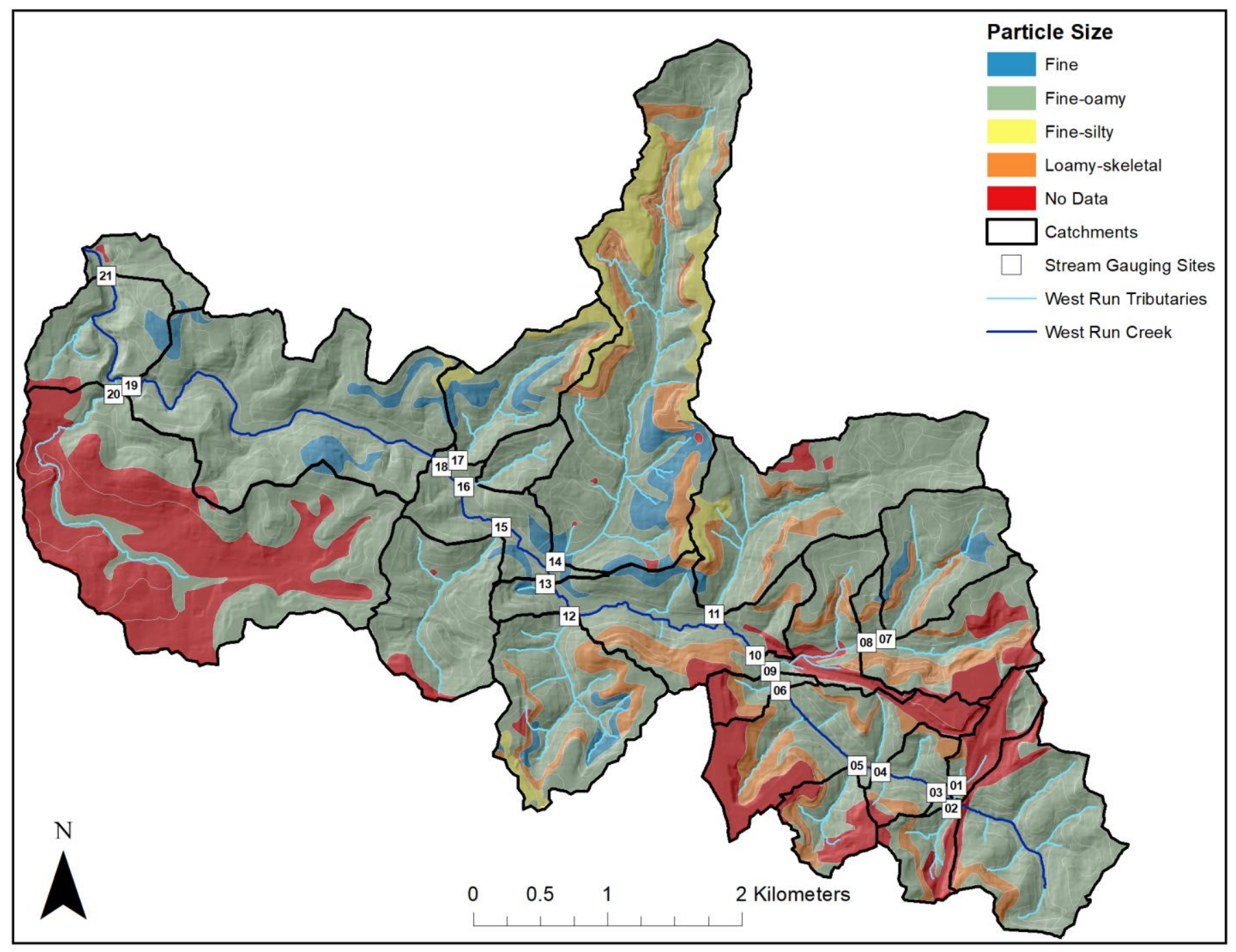

Figure 4. Soil textures in the West Run Watershed (WRW), Morgantown, West Virginia, U.S.A. Soil data from the most recent Soil Survey Geographic Database (SSURGO), 2011. Note: Legend colors appear slightly lighter in comparison to map, this is due to a hillside overlay on the map to give elevation contrast. 


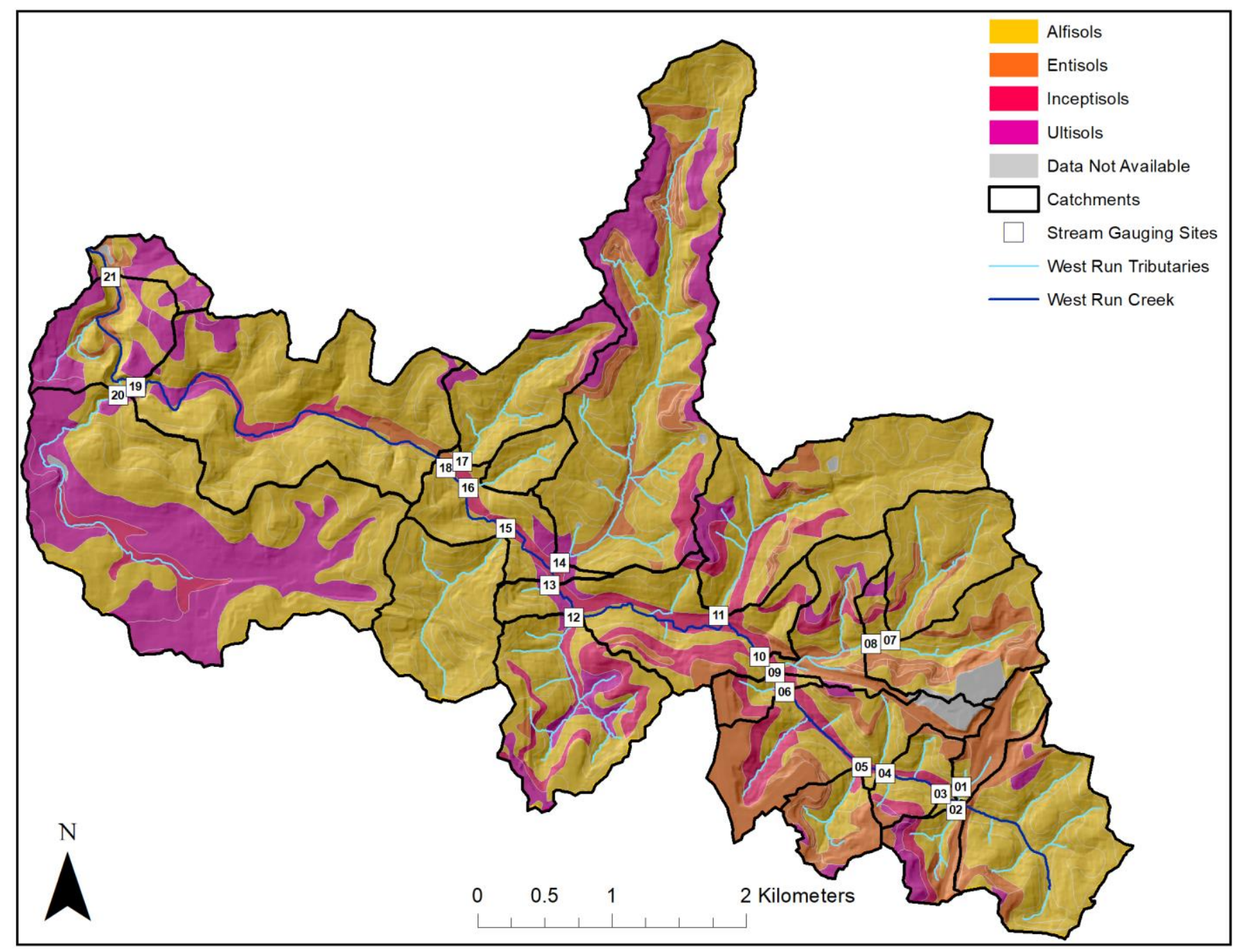

Figure 5. Soil orders found in the West Run Watershed (WRW), Morgantown, West Virginia, U.S.A. Soil data from the Soil Survey Geographic Database (SSURGO), 2011. Note: Legend colors appear slightly lighter in comparison to map, this is due to a hillside overlay on the map to give elevation contrast. 


\section{Data Collection}

\section{Stage Data}

Each of the 21 monitoring sites were instrumented to monitor stage $(\mathrm{cm})$ at 5 -minute

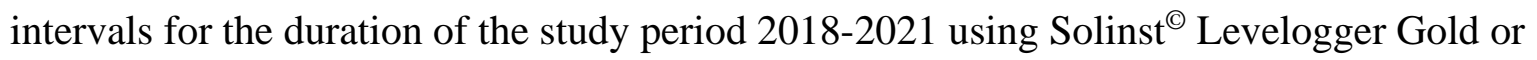
Levelogger Edge pressure transducers installed in two-inch polyvinyl chloride (PVC) stilling wells. Solinst ${ }^{\oplus}$ Leveloggers measure the absolute pressure, which includes water pressure and atmospheric pressure combined (Solinst 2018). To compensate for atmospheric pressure, a Solinst $^{\circledR}$ Barologger Gold/Edge, monitoring atmospheric pressure at 5-minute intervals, was installed at Site 13, due to being a central location within the watershed. To ensure the accuracy of stage recorded, the stilling wells were flushed of sediment periodically and freed of any sediment around the housing. Additionally, stilling well off-sets (distance between bottom of stilling well and streambed) were recorded once a year to guarantee recorded stage included the entire water column, then added to the stage during data processing (Table 4). The instruments used to monitor stage were replaced once during this study due to the age of previous sensors and the risk of sensor drift or failure. 
Table 4. Accuracy, resolution, and timing of the Solinst ${ }^{\odot}$ products used during this study in the West Run Watershed, Morgantown, West Virginia, U.S.A.

\begin{tabular}{cccccc}
\hline Instrumentation & $\begin{array}{c}\text { Instrument } \\
\text { Measurement }\end{array}$ & Time Used & $\begin{array}{c}\text { Full Scale } \\
\text { (FS) }\end{array}$ & Accuracy & Resolution \\
\hline $\begin{array}{c}\text { Levelogger } \\
\text { Gold }\end{array}$ & Water Depth & Jan. 2018 to Feb. & $5 \mathrm{~m}$ & $\pm 0.3 \mathrm{~cm}$ & $0.05 \% \mathrm{FS}$ \\
$\begin{array}{c}\text { Levelogger } \\
\text { Junior Edge }\end{array}$ & Water Depth & $\begin{array}{c}\text { Feb. } 2020 \mathrm{to} \mathrm{Dec} . \\
2021\end{array}$ & $5 \mathrm{~m}$ & $\pm 0.6 \mathrm{~cm}$ & $0.02 \% \mathrm{FS}$ \\
$\begin{array}{c}\text { Barologger } \\
\text { Gold }\end{array}$ & $\begin{array}{c}\text { Atmospheric } \\
\text { Pressure }\end{array}$ & $\begin{array}{c}\text { Jan. } 2018 \text { to Feb. } \\
2020\end{array}$ & Air Only & $\pm 0.1 \mathrm{~cm}$ & $0.05 \% \mathrm{FS}$ \\
$\begin{array}{c}\text { Barologger } \\
\text { Edge }\end{array}$ & $\begin{array}{c}\text { Atmospheric } \\
\text { Pressure }\end{array}$ & $\begin{array}{c}\text { Feb. } 2020 \text { to Dec. } \\
2021\end{array}$ & Air Only & $\pm 0.05 \mathrm{kPa}$ & $0.002 \% \mathrm{FS}$ \\
\hline
\end{tabular}

\section{Streamflow Measurement}

Streamflow was measured using the Sontek Flowtracker $2^{\odot}$ at all 21 study sites in the WRW following the cross-section and velocity-area method (Figure 6) approved by the USGS (Turnipseed and Sauer 2010) and used in previous works (Hubbart et al. 2017; Zeiger and Hubbart 2017, Zeiger and Hubbart 2016, Rehmel 2007). Streamflow measurements were conducted on a regular basis and during medium and high (peak) flow events.

Prior to conducting streamflow measurements at each study site, the wetted widths were determined to ensure an appropriate number of vertical transects were taken. Prior studies conducted by the USGS, have shown that the distance between each vertical should not exceed more than $10 \%$ of the total streamflow and consist of approximately 20 transects, with the sample time of 40 seconds. This ensures that an appropriate number of velocity recordings are recorded to accurately calculate streamflow for the stream channel (Turnipseed and Sauer 2010; Buchanan and Somers 1976). Therefore, in this study, sites that had a wetted width less than 200 $\mathrm{cm}$, the maximum distance between each collected vertical transect was $7.5 \mathrm{~cm}$. For the sites that had a wetted width between 200 and $400 \mathrm{~cm}$, the maximum distance between each vertical 
transect was $15 \mathrm{~cm}$. Finally, for sites that had a wetted width over $400 \mathrm{~cm}$, the maximum distance between vertical transects was $30 \mathrm{~cm}$.

The appropriate point-method was determined at each transect and was variable based upon water depth during data collection. For transects that had a water depth less than $50 \mathrm{~cm}$, the single-point method (0.6) was used. For transects that had a water depth above $50 \mathrm{~cm}$, the twopoint method (0.2 and 0.8$)$ was used. For several of the transects collected, the three-point method $(0.2,0.6$, and 0.8$)$ was used when the Flowtracker $2^{\odot}$ had abnormal readings in velocity between the 0.2 and 0.8 observations (Turnipseed and Sauer 2010; Rantz et al. 1982a).

During high flow events, when stage rapidly changed, streamflow measurements were recorded as quickly as possible. This reduced the chances of errors in the streamflow measurement caused by shifting in velocity patterns or any other variables that might occur during changes in stage (Turnipseed and Sauer 2010). This was accomplished by reducing the number of vertical transects collected to the maximum of 15 , reducing sample time to between 20 to 30 seconds, and only using the single-point method (0.6) (Turnipseed and Sauer 2010; Rantz et al. 1982a). Previous studies by Carter and Anderson (1963) and the USGS (Turnipseed and Sauer 2010; Rantz et al. 1982a; Buchanan and Somers 1969) have shown that using this method will produce a standard error of $4.2 \%$. This is comparable to the $2.2 \%$ standard error that is obtained when using the two-point method with approximately 25 verticals with a sampling time of 40 seconds. 


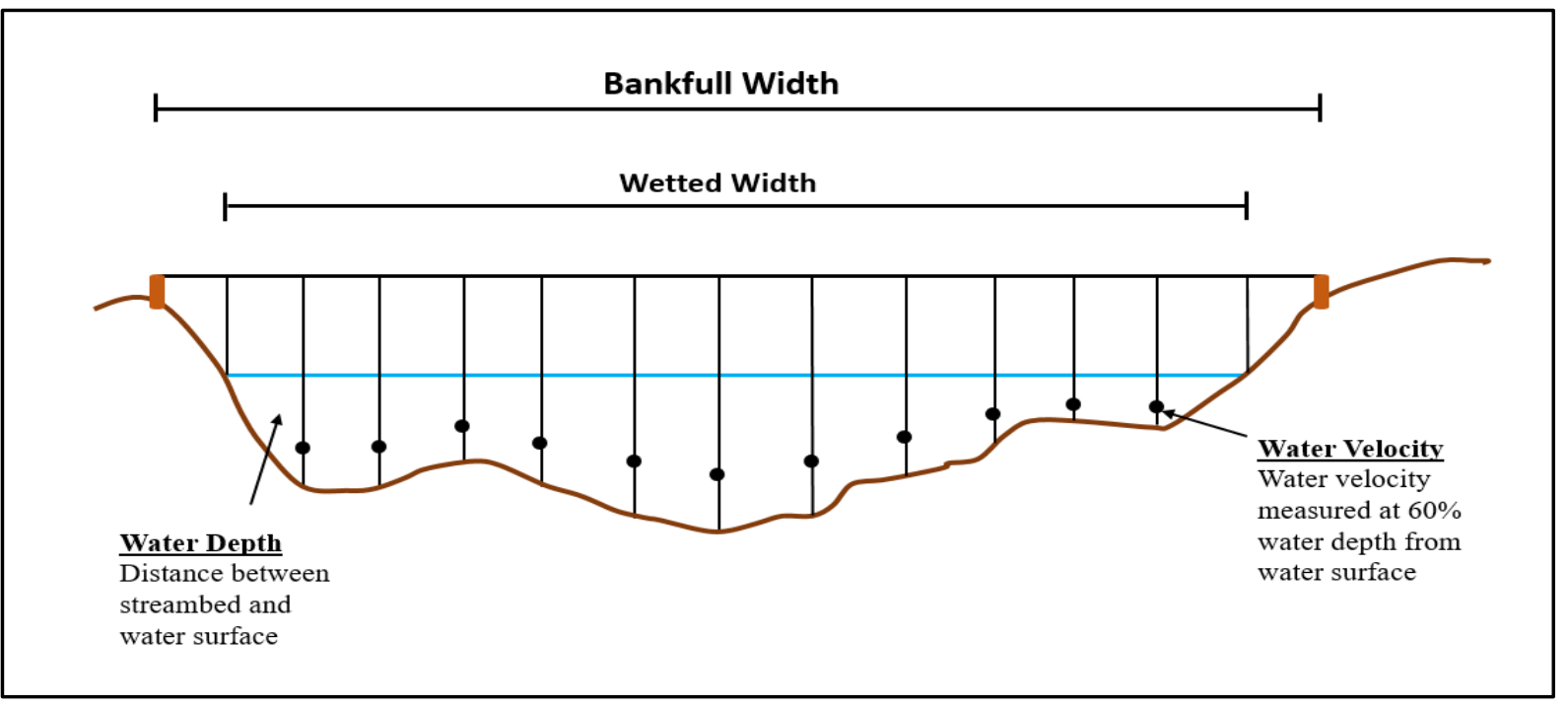

Figure 6. A representation of a typical cross-section with stream channel divided into vertical transects for water depth and velocity to be measured when using the 0.6 method.

\section{Stream Channel Morphological Features}

At each study site, a series of channel morphological features were recorded, including channel width (m), depth (m), and bankfull (m) as per the methods of Harrelson et al. 1994. Using the measured channel depth and width, the cross-sectional area was calculated. In addition to measuring the morphological features, each stilling well's position and depth was recorded in relation to the stream bank, along with the distance between the stilling well and the location of the stream cross-section. Using these data, a series of stream channel profiles were created, including a cross-section view and plan view profile for each site (Figures A1-3 to A21-3, A1-4 to A21-4). The profiles included positioning of the stilling well in reference to the cross-section where streamflow was measured. The availability of both the cross-section and plan view profiles for each study site will allow practitioners to select the rating curve that best represents their stream

Before either of the channel profiles could be created, bankfull was identified. To determine bankfull, key indicators were assessed, which included vegetation shifts (e.g., aquatic 
to terrestrial), bank slope, changes in bank material (e.g., from coarse gravel to sand), undercuts, or mineral deposits (stain lines) along boulders or bedrock (Hooper and Hubbart 2016; Harrelson et al. 1994). Once bankfull was determined, a tag line was stretched across the stream channel and leveled. For the cross-sectional profile, channel depth was recorded at $10 \mathrm{~cm}$ increments for channels widths equal to or less than $5 \mathrm{~m}$. For bankfull widths greater than $5 \mathrm{~m}$, channel depth was recorded at increments of $25 \mathrm{~cm}$.

For the development of the plan view profile, bankfull was measured at four different locations at each monitoring site; at stilling well, at the point where streamflow was measured (cross-section), and upstream and downstream from the stilling well. The distance measured upstream and downstream, depended upon the distance between the stilling well and the location where streamflow was measured. Any meanders, bends, or other permanent manmade features (bridges, culverts, etc.) in the channel that were encompassed in the section were noted. When measuring bankfull at the stilling well, the distance between stilling well and the bank were also noted. By including these features upstream and downstream from where the streamflow measurements were collected, a better understanding of the channel was gained. A list of channel characteristics recorded at each site can be found in Tables 10 and 11. For visual aids of channel characteristics, photos were taken at each gauging site (Figure A1-5 to A21-5). 


\section{Rating Curve Development}

To find the best fit function for the 21 gauging sites in the WRW, observed streamflow measurements and simultaneous stage were plotted and fitted with both the power-law regression and $2^{\text {nd }}$ degree polynomial equations. These two functions have commonly been used to generate rating curve equations by the USGS, Phillips (2009), and Sivapragasam and Muttil (2005). Upon reviewing the coefficient of determination $\left(\mathrm{R}^{2}\right)$ for both best fit functions used, the $2^{\text {nd }}$ degree polynomial function was found to produce a better $\mathrm{R}^{2}$ value. The $2^{\text {nd }}$ degree polynomial functions were then used to develop the rating curve at each gauging site.

Observed streamflow estimates were then modeled using the generated $2^{\text {nd }}$ degree polynomial equations to create an "ideal curve" for each site. The "ideal curves" were used while collecting additional stream cross section data to target specific stage depths needed to fill missing points along the observed rating curves. An example of the observed rating curve next to the corresponding "ideal curve" can be found in Figure 7. For final rating curve development, outliers were removed from the data set and a final rating equation and $\mathrm{R}^{2}$ value was generated. Tables containing the final rating equations and $\mathrm{R}^{2}$ values can be found in Figures A1-3 to A213. 


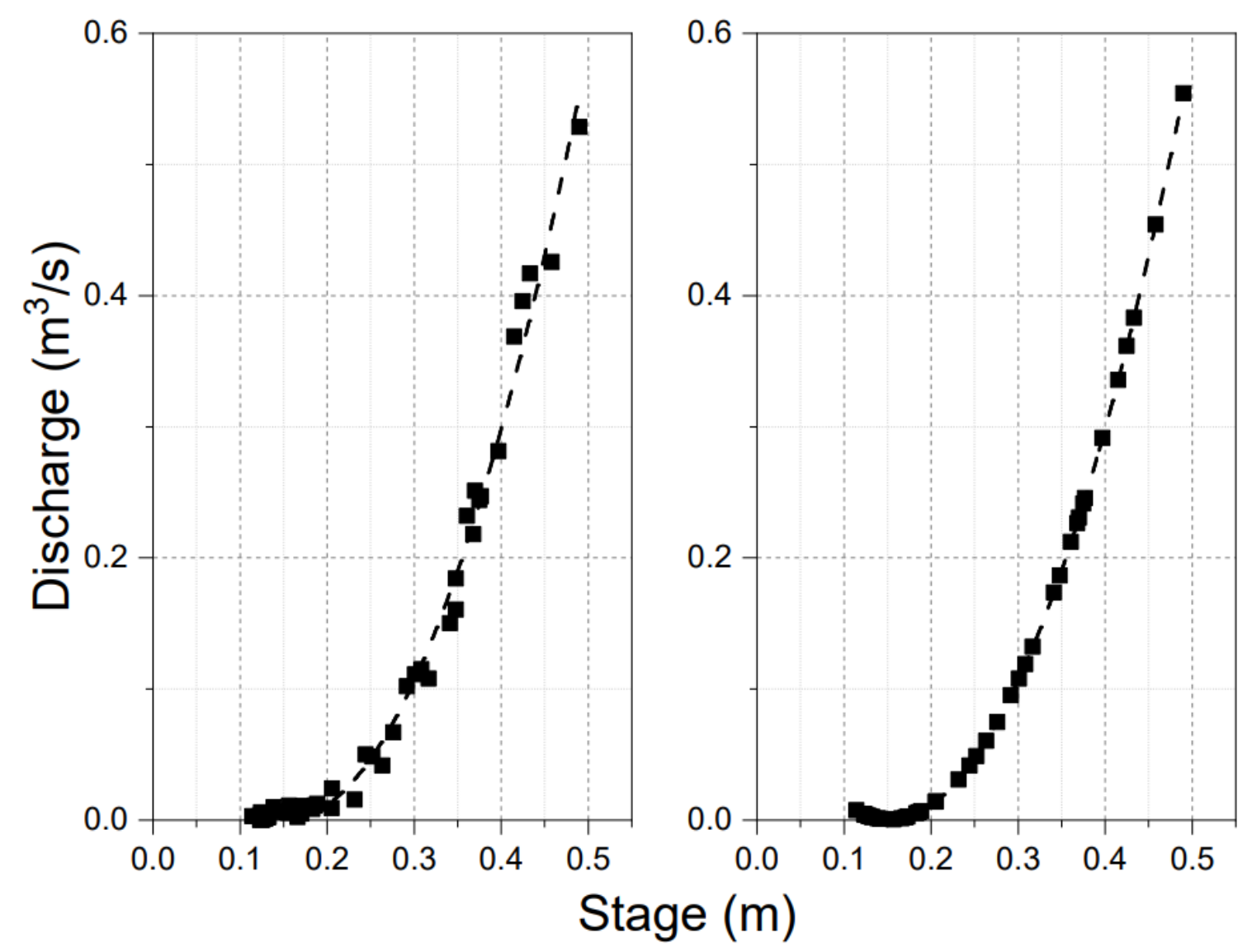

Figure 7. The generated rating curve (left) next to the "ideal curve" (right). This "ideal curve" was used during the initial development of the rating curves for the WRW. 


\section{Empirical Streamflow Models}

Streamflow was estimated at each site using three empirical models, including:

Manning's Discharge Equation (Equation 4), Chezy Discharge Equation (Equation 5 and 6), and Dingman \& Sharma Discharge Equation (Equation 7). Originally developed in the mid-1700s, by Antoine Chezy, the Chezy equation was based on the principles of the force-balance but was later modified for open-channel streamflow (Dingman and Sharma 1997). Derived from the Chezy equation, Manning's equation is one of the most used empirical streamflow models due to the ability to estimate streamflow in rough, turbulent open-channel streamflow (Dingman and Sharma 1997; Rantz et al. 1982b). However, determining the roughness coefficients for both the Chezy equation and the Manning's equation can be difficult in streams with steep slopes and rocky channels, so Dingman and Sharma (1997) developed an equation that does not rely on a constant, such as Manning's $n$, but instead relies on hydraulic radius and slope to estimate streamflow (Dingman and Sharma 1997). Because of the frequency of use and results from previous studies completed in similar terrains and land-uses, these three empirical models were selected for this work (Dingman 2008; Sivapragasam and Muttil 2005; Dingman and Sharma 1997; Rantz et al. 1982b).

Additional characteristics and analyses of the stream channel needed to force the above models were collected at each site. This included channel slope (m), roughness, cross-sectional area $\left(\mathrm{m}^{2}\right)$, wetted perimeter $(\mathrm{m})$, and hydraulic radius $(\mathrm{m})$. Channel roughness values were assigned during a field visit to each site using the method developed by Cowan (1956). Where the value $n$ is determined by

$\mathrm{n}=\mathrm{m}\left(n_{0}+n_{1}+n_{2}+n_{3}+n_{4}\right)$ 
where $m$ is the meander correction factor, $\mathrm{n}_{0}$ is the base value of $\mathrm{n}$ for a smooth, uniform channel, $\mathrm{n}_{1}$ is the correction for surface irregularities, $\mathrm{n}_{2}$ is the correction for channel shape and size, $\mathrm{n}_{3}$ is a correction for obstructions in the channel (non-living), $\mathrm{n}_{4}$ is a correction for vegetation and flow conditions within the channel. A list of values used to assign the Manning's $n$ roughness coefficient can be found in Table 5. The Manning's $n$ value determined for each of the study sites can be found in Tables A1-2 to A21-2.

The channel slope was estimated using two different methods at each of the monitoring sites including an infield survey and Digital Elevation Models (DEM). The infield method included utilization of a tag line, inclinometer, stadia rod, and two field workers. A 25-m tag line was stretched out so that the measured section would include both the location of the stilling well and where the cross-sections were collected. One field worker took a gauging rod with a yellow piece of tape marking eye height for the other field worker, upstream to the end of the tag line and placed the bottom of the stadia rod at the water surface. The other field worker went downstream to the other end of the tag line and stood on a rock at the water surface. Then using the inclinometer, the lower field worker targeted the yellow piece of tape and recorded the slope (Fitz et. al. 2006, Kaufmann and Robinson 1998, Gordon et al. 1994). To measure channel slope using Digital Elevation Models (DEM), the 10-m DEM and National Hydrography Dataset (NHD) streamline data sets were downloaded to ArcGIS for the study watershed. A 50-m section of the stream channel was marked using the pour-point feature. The 50-m section of stream channel was established so that it would include both the stilling well and location where the cross-sections were collected. The elevation was recorded at the bottom and the top of the 50-m stream section. Slope was then calculated using the rise over run method (Nagel et al. 2010; Nagel et al. 2006). A list of observed and calculated slopes can be found in Tables A1-2 to A21- 
2. The cross-sectional area and wetted perimeter were calculated for each streamflow measurement using the Sontek Flowtracker $2^{\odot}$. The Flowtracker $2^{\odot}$ handheld automatically calculated the cross-section area, based the total width of the channel (distance traveled along the tag line) and mean depth of all the vertical transects (Sontek/YSI 2003). Wetted perimeter was calculated by hand using the same measurements (Fritz et al. 2006; Harrelson et al. 1994). Hydraulic radius was then calculated for each of the streamflow measurements using the calculated cross-sectional area and wetted perimeter. Cross-sectional area and wetted perimeter were also calculated for bankfull using the measurements collected at each site (Fritz et al. 2006; Harrelson et al. 1994). Utilizing the cross-sectional area and wetted perimeter, the hydraulic radius was calculated for collected streamflow measurement and bankfull at each site. 
Table 5. Reference table for estimating Manning's $n$ (recreated from Arcement and Schneider 1989).

\begin{tabular}{|c|c|c|c|}
\hline \multicolumn{4}{|c|}{$n$ Base Values $\left(n_{0}\right)$} \\
\hline \multicolumn{2}{|c|}{ Bed Material } & $\begin{array}{c}\text { Size of Bed } \\
\text { Material }(\mathbf{m m})\end{array}$ & n Values \\
\hline & $1-2$ & $0.026-0.035$ \\
\hline \multirow{2}{*}{\multicolumn{2}{|c|}{$\begin{array}{l}\text { Gravel } \\
\text { Cobble }\end{array}$}} & $2-64$ & $0.028-0.035$ \\
\hline & & $64-256$ & $0.03-0.05$ \\
\hline \multicolumn{2}{|c|}{ Boulder } & $>256$ & $0.04-0.07$ \\
\hline \multicolumn{4}{|l|}{ Adjustments for $n_{0}$} \\
\hline \multicolumn{2}{|c|}{ Channel Conditions } & $\begin{array}{c}n \text { value } \\
\text { adjustments }\end{array}$ & Example \\
\hline \multirow{3}{*}{$\begin{array}{l}\text { Surface Irregularities } \\
\qquad\left(n_{1}\right)\end{array}$} & Minor & 0.001-0.005 & Slightly eroded or scoured side slopes. \\
\hline & Moderate & $0.006-0.01$ & $\begin{array}{l}\text { Moderate to considerable bed roughness and } \\
\text { moderately eroded side slopes. }\end{array}$ \\
\hline & Severe & $0.011-0.02$ & $\begin{array}{l}\text { Badly eroded banks and side slopes, irregular } \\
\text { surfaces of channel in rock. }\end{array}$ \\
\hline \multirow{2}{*}{$\begin{array}{l}\text { Variations in Channel } \\
\qquad\left(n_{2}\right)\end{array}$} & $\begin{array}{l}\text { Alternating } \\
\text { Occasional }\end{array}$ & $0.001-0.005$ & $\begin{array}{l}\text { Wide and narrow channel widths } \\
\text { occasionally altering or main flow } \\
\text { occasionally change from side to side. }\end{array}$ \\
\hline & $\begin{array}{l}\text { Alternation } \\
\text { Frequently }\end{array}$ & $0.01-0.015$ & $\begin{array}{l}\text { Wide and narrow channel widths frequently } \\
\text { altering or main flow frequently change from } \\
\text { side to side. }\end{array}$ \\
\hline \multirow{4}{*}{ Obstructions $\left(n_{3}\right)$} & Negligible & $0.000-0.004$ & $\begin{array}{l}\text { Scattered obstructions, less than 5\% of } \\
\text { channel obstructed. }\end{array}$ \\
\hline & Minor & $0.005-0.015$ & $\begin{array}{c}\text { Obstructions occupy less than } 15 \% \text { of } \\
\text { channel. }\end{array}$ \\
\hline & Appreciable & $0.02-0.03$ & $\begin{array}{l}\text { Obstructions occupy between } 15 \text { to } 50 \% \text { of } \\
\text { the channel. }\end{array}$ \\
\hline & Severe & $0.04-0.05$ & $\begin{array}{l}\text { Obstructions occupy more than } 50 \% \text { of the } \\
\text { channel, areas of turbulence caused due to } \\
\text { obstructions. }\end{array}$ \\
\hline \multirow{4}{*}{$\begin{array}{l}\text { Vegetation and Flow } \\
\text { Conditions }\left(n_{4}\right)\end{array}$} & Small & $0.002-0.01$ & $\begin{array}{l}\text { Little to no vegetation, flow about two times } \\
\text { the height of vegetation, minor weeds and } \\
\text { vegetation on stream side. }\end{array}$ \\
\hline & Medium & $0.01-0.025$ & $\begin{array}{l}\text { Light vegetation, flow equal to one to two } \\
\text { times the height of vegetation, little to no } \\
\text { vegetation in streambed and moderate weeds } \\
\text { along stream side. }\end{array}$ \\
\hline & Large & $0.025-0.05$ & $\begin{array}{l}\text { Moderate vegetation, flow equal to half the } \\
\text { height of vegetation, no significant vegetation } \\
\text { in streambed and woody plants with some } \\
\text { weeds along stream side. }\end{array}$ \\
\hline & Very Large & $0.05-0.1$ & $\begin{array}{l}\text { Densely vegetation, flow less than half the } \\
\text { height of vegetation, with vegetation in the } \\
\text { streambed and woody plants with intergrown } \\
\text { weeds along stream side. }\end{array}$ \\
\hline \multicolumn{2}{|l|}{$\begin{array}{c}\text { Degree of } \\
\text { Meandering } \\
(m) \\
\end{array}$} & 1.00 & e \\
\hline
\end{tabular}




\section{Data analysis}

Descriptive statistics were generated for all collected streamflow characteristics, observed streamflow, and modeled streamflow. Coefficient of determination $\left(\mathrm{R}^{2}\right)$ was generated for all observed rating curves and modeled rating curves (Manning's equation, Chezy equations, Dingman and Sharma equation). Using the empirical streamflow models, streamflow was estimated using both observed and calculated slopes, then estimated streamflow was compared. A comparison of observed and modeled streamflow was conducted for each using an Analysis of variance (ANOVA) Tukey multiple comparison test, with a significance threshold of $\alpha=0.05$. The Tukey MCT compares the means of all variables to the mean of every other variable and has been shown to work well when considering confidence intervals (Tukey 1949). The Tukey MCT can be applied to samples sizes that are both equal and unequal. The ability of the Tukey MCT to yield the smallest pairwise error rates have made it a standard procedure for multiple comparison tests (Helsel and Hirsch 1992). All statistical analyses were conducted using Origin Pro 2018 (OriginLab Corporation, Massachusetts, U.S.A.). 


\section{RESULTS \\ Steam Channel Characteristics}

Stream channel characteristics for each of the 21 stream gauging sites within the West Run Watershed (WRW) encompass observed measurements and descriptive statistics(e.g., minimum, maximum, and average) (Tables 6-8).

During the 2018 to 2021 study period, observed slope ranged from $0.0075 \mathrm{~m}$ at Site 13 to $0.061 \mathrm{~m}$ at Site 2, with the average observed slope of $0.025 \mathrm{~m}$. Calculated slopes ranged from $0.008 \mathrm{~m}$ at Site 13 to $0.085 \mathrm{~m}$ at Site 16 , with the average calculated slope of $0.04 \mathrm{~m}$.

Channel roughness (Manning's $n$ ) was estimated from 0.064 at Site 13 to 0.2 at Site 5, with the average $n$ value of 0.13 . Additional channel characteristics were collected to aid in development of the cross-sectional and plan view profiles for each site. Bankfull width at the crosssection ranged from $2.63 \mathrm{~m}$ at Site 11 to $15.48 \mathrm{~m}$ at Site 19, with an average bankfull width of $6.78 \mathrm{~m}$. Channel depth from bankfull at cross-section ranged from $0.29 \mathrm{~m}$ at Site 11 to $1.05 \mathrm{~m}$ at Site 18, with an average depth of $0.61 \mathrm{~m}$. The wetted perimeter at cross-section ranged from $3.17 \mathrm{~m}$ at Site 17 to $17.48 \mathrm{~m}$ at Site 19, with an average wetted perimeter of $7.99 \mathrm{~m}$. The cross-sectional area ranged from $0.83 \mathrm{~m}^{2}$ at Site 17 to $15.51 \mathrm{~m}^{2}$ at Site 19 , with an average cross-sectional area of $4.77 \mathrm{~m}^{2}$. Bankfull width at the stilling wells ranged from $3.07 \mathrm{~m}$ at Site 14 to $15.48 \mathrm{~m}$ at Site 19, with an average bankfull width of 7.01 $\mathrm{m}$. Distance from stilling well to the stream bank at bankfull ranged from $0.57 \mathrm{~m}$ at Site 8 to $6.4 \mathrm{~m}$ at Site 5 , with the average distance of $2.32 \mathrm{~m}$. Distance from stilling well to location where streamflow measurements were collected ranged from $0 \mathrm{~m}$ at sites 1, 5, 6, 8, 9, 13, 19, and 21 to $24.41 \mathrm{~m}$ at Site 20, with the average distance of $5.11 \mathrm{~m}$. Bankfull width at the stilling well ranged from $3.07 \mathrm{~m}$ at Site 14 to 15.48 at Site19, with the average width of $7.01 \mathrm{~m}$. Bankfull widths $25.5 \mathrm{~m}$ upstream from the stilling well ranged from $0.86 \mathrm{~m}$ at Sites 16 and 17 to $25.43 \mathrm{~m}$ at Site 19, with an average bankfull width of 5.92 . Bankfull widths $25.5 \mathrm{~m}$ downstream from the stilling well ranged from $0.82 \mathrm{~m}$ at Site 7 to $15.61 \mathrm{~m}$ at Site 19. 
Table 6. Field observed slope, calculated slope using DEMs in ArcGIS, and assigned roughness coefficients (Manning's $n$ ) for the 21 gauging sites in the West Run Watershed, Morgantown, West Virginia, U.S.A.

\begin{tabular}{cccc}
\hline Site & Observed Slope $(\mathbf{m})$ & Calculated Slope $(\mathbf{m})$ & Manning's $\boldsymbol{n}$ \\
\hline $\mathbf{1}$ & 0.025 & 0.07 & 0.165 \\
$\mathbf{2}$ & 0.061 & 0.11 & 0.14 \\
$\mathbf{3}$ & 0.03 & 0.04 & 0.13 \\
$\mathbf{4}$ & 0.01 & 0.022 & 0.127 \\
$\mathbf{5}$ & 0.05 & 0.078 & 0.2 \\
$\mathbf{6}$ & 0.02 & 0.016 & 0.072 \\
$\mathbf{7}$ & 0.02 & 0.044 & 0.105 \\
$\mathbf{8}$ & 0.01 & 0.03 & 0.14 \\
$\mathbf{9}$ & 0.05 & 0.032 & 0.17 \\
$\mathbf{1 0}$ & 0.01 & 0.005 & 0.085 \\
$\mathbf{1 1}$ & 0.035 & 0.04 & 0.185 \\
$\mathbf{1 2}$ & 0.02 & 0.059 & 0.095 \\
$\mathbf{1 3}$ & 0.0075 & 0.008 & 0.064 \\
$\mathbf{1 4}$ & 0.04 & 0.027 & 0.09 \\
$\mathbf{1 5}$ & 0.01 & 0.041 & 0.135 \\
$\mathbf{1 6}$ & 0.04 & 0.085 & 0.135 \\
$\mathbf{1 7}$ & 0.02 & 0.06 & 0.16 \\
$\mathbf{1 8}$ & 0.01 & 0.017 & 0.088 \\
$\mathbf{1 9}$ & 0.015 & 0.011 & 0.135 \\
$\mathbf{2 0}$ & 0.03 & 0.011 & 0.11 \\
$\mathbf{2 1}$ & 0.01 & 0.029 & 0.115 \\
\hline
\end{tabular}


Table 7. Measurements at each stream gauging site including bankfull channel width, wetted perimeter, average depth, and cross-sectional area in West Run Watershed, Morgantown, West Virginia, U.S.A.

\begin{tabular}{ccccc}
\hline Site & $\begin{array}{c}\text { Bankfull Width at } \\
\text { Cross-section }(\mathbf{m})\end{array}$ & $\begin{array}{c}\text { Bankfull } \\
\text { Average Depth } \\
(\mathbf{m})\end{array}$ & $\begin{array}{c}\text { Bankfull Wetted } \\
\text { Perimeter }(\mathbf{m})\end{array}$ & $\begin{array}{c}\text { Bankfull Cross- } \\
\text { Sectional Area } \\
\left(\mathbf{m}^{\mathbf{2}}\right)\end{array}$ \\
\hline $\mathbf{1}$ & 7.24 & 0.66 & 8.56 & 4.79 \\
$\mathbf{2}$ & 5.87 & 0.56 & 6.99 & 3.28 \\
$\mathbf{3}$ & 8.00 & 0.87 & 9.73 & 6.93 \\
$\mathbf{4}$ & 6.40 & 0.41 & 7.22 & 2.61 \\
$\mathbf{5}$ & 10.47 & 0.78 & 12.22 & 8.29 \\
$\mathbf{6}$ & 5.87 & 0.63 & 7.13 & 3.69 \\
$\mathbf{7}$ & 6.78 & 0.67 & 8.12 & 4.53 \\
$\mathbf{8}$ & 4.37 & 0.37 & 5.11 & 1.62 \\
$\mathbf{9}$ & 7.16 & 0.78 & 8.72 & 5.60 \\
$\mathbf{1 0}$ & 8.84 & 0.79 & 10.41 & 6.96 \\
$\mathbf{1 1}$ & 2.63 & 0.32 & 3.28 & 1.03 \\
$\mathbf{1 2}$ & 2.63 & 0.34 & 3.30 & 0.88 \\
$\mathbf{1 3}$ & 4.42 & 0.61 & 5.65 & 2.72 \\
$\mathbf{1 4}$ & 2.86 & 0.29 & 3.44 & 0.83 \\
$\mathbf{1 5}$ & 5.19 & 0.50 & 6.19 & 2.60 \\
$\mathbf{1 6}$ & 3.56 & 0.44 & 4.44 & 1.57 \\
$\mathbf{1 7}$ & 2.41 & 0.35 & 3.12 & 0.85 \\
$\mathbf{1 8}$ & 8.93 & 1.05 & 11.02 & 9.35 \\
$\mathbf{1 9}$ & 15.48 & 1.00 & 17.48 & 15.51 \\
$\mathbf{2 0}$ & 10.21 & 0.55 & 11.31 & 5.63 \\
$\mathbf{2 1}$ & 12.78 & 0.86 & 14.51 & 11.03 \\
\hline
\end{tabular}


Table 8. Measurements at each site of bankfull at, above, and below the stilling well. The distance the stilling well is from the bank and the distance between the stilling well and where streamflow was measured for the gauging sites located in West Run Watershed, Morgantown, West Virginia, U.S.A.

\begin{tabular}{ccccccc}
\hline Site & $\begin{array}{c}\text { Stilling Well } \\
\text { Distanced } \\
\text { from Bank } \\
\text { (m) }\end{array}$ & $\begin{array}{c}\text { Distance from } \\
\text { Stilling Well to } \\
\text { Cross-Section } \\
\text { Location(m) }\end{array}$ & $\begin{array}{c}\text { Bankfull } \\
\text { Width at } \\
\text { Stilling } \\
\text { Well(m) }\end{array}$ & $\begin{array}{c}\text { Bankfull At } \\
\text { Cross- } \\
\text { Section(m) }\end{array}$ & $\begin{array}{c}\text { Bankfull } \\
\text { Width } \\
\text { Upstream } \\
\text { from Stilling } \\
\text { Well(m) }\end{array}$ & $\begin{array}{c}\text { Bankfull Width } \\
\text { Down Stream } \\
\text { from Stilling } \\
\text { Well(m) }\end{array}$ \\
\hline $\mathbf{1}$ & 2.48 & 0 & 7.24 & 7.24 & 6.81 & 4.66 \\
$\mathbf{2}$ & 2.83 & 0.93 & 5.37 & 5.87 & 2.97 & 4.21 \\
$\mathbf{3}$ & 3.35 & 2.87 & 8.18 & 8.0 & 2.71 & 7.62 \\
$\mathbf{4}$ & 2.51 & 1.48 & 4.27 & 6.4 & 3.67 & 4.20 \\
$\mathbf{5}$ & 6.40 & 0 & 10.67 & 10.67 & 7.7 & 6.51 \\
$\mathbf{6}$ & 1.15 & 0 & 5.87 & 5.87 & 6.14 & 6.24 \\
$\mathbf{7}$ & 3.27 & 1.12 & 6.22 & 6.78 & 1.55 & 0.82 \\
$\mathbf{8}$ & 0.57 & 0 & 4.37 & 4.37 & 6.50 & 3.9 \\
$\mathbf{9}$ & 2.89 & 0 & 7.16 & 7.16 & 3.72 & 5.01 \\
$\mathbf{1 0}$ & 2.09 & 14.41 & 8.75 & 8.84 & 7.27 & 6.38 \\
$\mathbf{1 1}$ & 0.95 & 14.67 & 3.11 & 2.63 & 2.26 & 1.97 \\
$\mathbf{1 2}$ & 0.73 & 8.92 & 5.32 & 2.63 & 4.81 & 2.64 \\
$\mathbf{1 3}$ & 1.4 & 0 & 4.42 & 4.42 & 3.84 & 4.87 \\
$\mathbf{1 4}$ & 1.07 & 3.23 & 3.07 & 2.86 & 4.01 & 3.83 \\
$\mathbf{1 5}$ & 1.13 & 6.34 & 6.81 & 5.19 & 4.36 & 6.85 \\
$\mathbf{1 6}$ & 1.61 & 4.65 & 4.29 & 3.56 & 0.86 & 3.76 \\
$\mathbf{1 7}$ & 1.53 & 4.34 & 3.71 & 2.41 & 0.86 & 3.11 \\
$\mathbf{1 8}$ & 5.63 & 19.85 & 10.42 & 8.93 & 6.31 & 11.81 \\
$\mathbf{1 9}$ & 2.43 & 0 & 15.48 & 15.48 & 25.43 & 15.61 \\
$\mathbf{2 0}$ & 3.2 & 24.41 & 9.71 & 10.21 & 8.83 & 8.64 \\
$\mathbf{2 1}$ & 1.53 & 0 & 12.78 & 12.78 & 13.71 & 12.12 \\
\hline
\end{tabular}




\section{Observed and Modeled Rating Curves}

Observed and modeled rating curves were generated using a sample size (n) of observed streamflow estimates ranging from 21 to 53 (Table 9). The $\mathrm{R}^{2}$ value for the observed rating curves ranged from 0.98 to 1 at Site 16 . The $\mathrm{R}^{2}$ value for Manning's curve (observed slope) ranged from 0.68 to 0.97 . The $\mathrm{R}^{2}$ value for Manning's curve (calculated slope) ranged from 0.68 to 0.97 . The $\mathrm{R}^{2}$ value for the Chezy curve (observed slope) ranged from 0.68 to 0.97 . The $\mathrm{R}^{2}$ value for the Chezy curve (calculated slope) ranged from 0.68 to 0.97 . The $\mathrm{R}^{2}$ value for Dingman and Sharma's curve (observed slope) ranged from 0.69 to 0.97 . The $\mathrm{R}^{2}$ value for Dingman and Sharma's curve (calculated slope) ranged from 0.69 to 0.97 . The sites specific $\mathrm{R}^{2}$ values can be found in Table 9 and the $2^{\text {nd }}$ degree polynomial equations for each observed and modeled rating curve can be found in Tables 10-16, along with Figure A1-1 to A21-1, Tables A1-3 to A21-3. 
Table 9. Number of observations (n) used to generate the observed and modeled rating curves, and associated $\mathrm{R}^{2}$ values for each of the study sites in the West Run Watershed, Morgantown, West Virginia, U.S.A.

\begin{tabular}{|c|c|c|c|c|c|c|c|c|}
\hline Site & $\mathbf{n}$ & $\begin{array}{c}\text { Observed } \\
\text { Rating } \\
\text { Curve }\end{array}$ & $\begin{array}{c}\text { Manning's } \\
\text { Curve } \\
\text { (Obs. } \\
\text { Slope) }\end{array}$ & $\begin{array}{l}\text { Manning's } \\
\text { Curve } \\
\text { (Calc. } \\
\text { Slope) }\end{array}$ & $\begin{array}{l}\text { Chezy } \\
\text { Curve } \\
\text { (Obs. } \\
\text { Slope) }\end{array}$ & $\begin{array}{l}\text { Chezy } \\
\text { Curve } \\
\text { (Calc } \\
\text { Slope) }\end{array}$ & $\begin{array}{c}\text { Dingman } \\
\text { And } \\
\text { Sharma's } \\
\text { Curve } \\
\text { (Obs. } \\
\text { Slope) } \\
\end{array}$ & $\begin{array}{c}\text { Dingman } \\
\text { And } \\
\text { Sharma's } \\
\text { Curve } \\
\text { (Calc } \\
\text { Slope) } \\
\end{array}$ \\
\hline 1 & 47 & 0.99 & 0.92 & 0.92 & 0.92 & 0.92 & 0.92 & 0.92 \\
\hline 2 & 43 & 0.99 & 0.95 & 0.95 & 0.95 & 0.95 & 0.94 & 0.94 \\
\hline 3 & 30 & 0.99 & 0.87 & 0.87 & 0.87 & 0.87 & 0.87 & 0.87 \\
\hline 4 & 33 & 0.99 & 0.95 & 0.95 & 0.95 & 0.95 & 0.95 & 0.95 \\
\hline 5 & 26 & 0.98 & 0.93 & 0.93 & 0.93 & 0.93 & 0.93 & 0.93 \\
\hline 6 & 36 & 0.99 & 0.97 & 0.97 & 0.97 & 0.97 & 0.96 & 0.96 \\
\hline 7 & 23 & 0.99 & 0.90 & 0.90 & 0.90 & 0.90 & 0.89 & 0.89 \\
\hline 8 & 30 & 0.98 & 0.85 & 0.85 & 0.85 & 0.85 & 0.88 & 0.88 \\
\hline 9 & 28 & 0.98 & 0.95 & 0.95 & 0.95 & 0.95 & 0.94 & 0.94 \\
\hline 10 & 41 & 0.99 & 0.97 & 0.97 & 0.97 & 0.97 & 0.97 & 0.97 \\
\hline 11 & 21 & 0.98 & 0.87 & 0.87 & 0.87 & 0.87 & 0.89 & 0.89 \\
\hline 12 & 46 & 0.99 & 0.70 & 0.70 & 0.70 & 0.70 & 0.69 & 0.69 \\
\hline 13 & 53 & 0.98 & 0.88 & 0.88 & 0.88 & 0.88 & 0.88 & 0.88 \\
\hline 14 & 34 & 0.99 & 0.91 & 0.91 & 0.91 & 0.91 & 0.91 & 0.91 \\
\hline 15 & 51 & 0.99 & 0.68 & 0.68 & 0.68 & 0.68 & 0.73 & 0.73 \\
\hline 16 & 22 & 1 & 0.79 & 0.79 & 0.79 & 0.79 & 0.80 & 0.80 \\
\hline 17 & 42 & 0.98 & 0.89 & 0.89 & 0.89 & 0.89 & 0.90 & 0.90 \\
\hline 18 & 53 & 0.99 & 0.94 & 0.94 & 0.94 & 0.94 & 0.93 & 0.93 \\
\hline 19 & 31 & 0.98 & 0.95 & 0.95 & 0.95 & 0.95 & 0.95 & 0.95 \\
\hline 20 & 44 & 0.98 & 0.96 & 0.96 & 0.96 & 0.96 & 0.97 & 0.97 \\
\hline 21 & 23 & 0.98 & 0.94 & 0.94 & 0.94 & 0.94 & 0.95 & 0.95 \\
\hline Average & 36 & 0.99 & 0.89 & 0.89 & 0.89 & 0.89 & 0.9 & 0.9 \\
\hline
\end{tabular}


Table 10. Observed and modeled rating curves for sites 1-3 in the West Run Watershed, Morgantown, West Virginia, U.S.A.

\begin{tabular}{llcc}
\hline \multicolumn{1}{c}{ Site } & $\mathbf{1}$ & $\mathbf{2}$ \\
\hline Observed Rating Curve & $\mathrm{y}=4.8531 \mathrm{x}^{2}-1.4771 \mathrm{x}+0.1128$ & $\mathrm{y}=5.1563 \mathrm{x}^{2}-1.8167 \mathrm{x}+0.1632$ & $\mathrm{y}=0.2855 \mathrm{x}^{2}+0.8084 \mathrm{x}-0.11$ \\
Manning's Curve (Obs. Slope & $\mathrm{y}=1.4828 \mathrm{x}^{2}-0.2545 \mathrm{x}+0.0252$ & $\mathrm{y}=1.015 \mathrm{x}^{2}+0.6122 \mathrm{x}-0.1125$ & $\mathrm{y}=-0.5839 \mathrm{x}^{2}+1.6111 \mathrm{x}-0.1058$ \\
Manning's Curve (Calc. Slope) & $\mathrm{y}=2.4812 \mathrm{x}^{2}-0.4259 \mathrm{x}+0.0421$ & $\mathrm{y}=1.363 \mathrm{x}^{2}+0.8221 \mathrm{x}-0.1511$ & $\mathrm{y}=-0.6742 \mathrm{x}^{2}+1.8604 \mathrm{x}-0.1222$ \\
Chezy Curve (Obs. Slope) & $\mathrm{y}=1.4828 \mathrm{x}^{2}-0.2545 \mathrm{x}+0.0252$ & $\mathrm{y}=1.015 \mathrm{x}^{2}+0.6122 \mathrm{x}-0.1125$ & $\mathrm{y}=-0.5839 \mathrm{x}^{2}+1.6111 \mathrm{x}-0.1058$ \\
Chezy Curve (Calc Slope) & $\mathrm{y}=2.4812 \mathrm{x}^{2}-0.4259 \mathrm{x}+0.0421$ & $\mathrm{y}=1.363 \mathrm{x}^{2}+0.8221 \mathrm{x}-0.1511$ & $\mathrm{y}=-0.6742 \mathrm{x}^{2}+1.8604 \mathrm{x}-0.1222$ \\
Dingman And Sharma's Curve (Obs. Slope) & $\mathrm{y}=2.2489 \mathrm{x}^{2}-0.3577 \mathrm{x}+0.0365$ & $\mathrm{y}=0.9841 \mathrm{x}^{2}+0.605 \mathrm{x}-0.1103$ & $\mathrm{y}=-0.7748 \mathrm{x}^{2}+2.0814 \mathrm{x}-0.1385$ \\
Dingman And Sharma's Curve (Calc Slope) & $\mathrm{y}=2.6236 \mathrm{x}^{2}-0.4173 \mathrm{x}+0.0425$ & $\mathrm{y}=1.055 \mathrm{x}^{2}+0.6486 \mathrm{x}-0.1182$ & $\mathrm{y}=-0.811 \mathrm{x}^{2}+2.1786 \mathrm{x}-0.145 \quad$ \\
\hline
\end{tabular}

Table 11. Observed and modeled rating curves for sites 4-6 in the West Run Watershed, Morgantown, West Virginia, U.S.A.

\begin{tabular}{lccc}
\hline \multicolumn{1}{c}{ Site } & $\mathbf{4}$ & $\mathbf{5}$ \\
\hline Observed Rating Curve & $\mathrm{y}=2.6263 \mathrm{x}^{2}-1.0531 \mathrm{x}+0.0971$ & $\mathrm{y}=14.772 \mathrm{x}^{2}-6.6645 \mathrm{x}+0.7517$ & $\mathrm{y}=8.0958 \mathrm{x}^{2}-2.7406 \mathrm{x}+0.2133$ \\
Manning's Curve (Obs. Slope & $\mathrm{y}=0.4886 \mathrm{x}^{2}+0.8166 \mathrm{x}-0.1505$ & $\mathrm{y}=5.1071 \mathrm{x}^{2}-1.8233 \mathrm{x}+0.192$ & $\mathrm{y}=6.926 \mathrm{x}^{2}-1.5484 \mathrm{x}+0.0768$ \\
Manning Curve (Calc. Slope) & $\mathrm{y}=0.2689 \mathrm{x}^{2}+0.4495 \mathrm{x}-0.0828$ & $\mathrm{y}=6.3787 \mathrm{x}^{2}-2.2774 \mathrm{x}+0.2398$ & $\mathrm{y}=6.1948 \mathrm{x}^{2}-1.3849 \mathrm{x}+0.0687$ \\
Chezy Curve (Obs. Slope) & $\mathrm{y}=0.4886 \mathrm{x}^{2}+0.8166 \mathrm{x}-0.1505$ & $\mathrm{y}=5.1071 \mathrm{x}^{2}-1.8233 \mathrm{x}+0.192$ & $\mathrm{y}=6.926 \mathrm{x}^{2}-1.5484 \mathrm{x}+0.0768$ \\
Chezy's Curve (Calc Slope) & $\mathrm{y}=0.2689 \mathrm{x}^{2}+0.4495 \mathrm{x}-0.0828$ & $\mathrm{y}=6.3787 \mathrm{x}^{2}-2.2774 \mathrm{x}+0.2398$ & $\mathrm{y}=6.1948 \mathrm{x}^{2}-1.3849 \mathrm{x}+0.0687$ \\
Dingman And Sharma's Curve (Obs. Slope) & $\mathrm{y}=0.6055 \mathrm{x}^{2}+0.598 \mathrm{x}-0.1082$ & $\mathrm{y}=6.6269 \mathrm{x}^{2}-2.1068 \mathrm{x}+0.202$ & $\mathrm{y}=5.4636 \mathrm{x}^{2}-1.1135 \mathrm{x}+0.0356$ \\
Dingman And Sharma's Curve (Calc Slope) & $\mathrm{y}=0.7589 \mathrm{x}^{2}+0.7494 \mathrm{x}-0.1356$ & $\mathrm{y}=7.0238 \mathrm{x}^{2}-2.2329 \mathrm{x}+0.2141$ & $\mathrm{y}=5.237 \mathrm{x}^{2}-1.0673 \mathrm{x}+0.0341$ \\
\hline
\end{tabular}

Table 12. Observed and modeled rating curves for sites 7-9 in the West Run Watershed, Morgantown, West Virginia, U.S.A.

\begin{tabular}{lccc}
\hline \multicolumn{1}{c}{ Site } & $\mathbf{7}$ & $\mathbf{8}$ & $\mathbf{9}$ \\
\hline Observed Rating Curve & $\mathrm{y}=4.3642 \mathrm{x}^{2}-0.5242 \mathrm{x}+0.0131$ & $\mathrm{y}=5.2729 \mathrm{x}^{2}-1.3358 \mathrm{x}+0.062$ & $\mathrm{y}=5.15 \mathrm{x}^{2}-0.6067 \mathrm{x}-0.0302$ \\
Manning's Curve (Obs. Slope & $\mathrm{y}=5.5033 \mathrm{x}^{2}-1.2968 \mathrm{x}+0.0942$ & $\mathrm{y}=0.445 \mathrm{x}^{2}+0.0598 \mathrm{x}-0.0133$ & $\mathrm{y}=2.926 \mathrm{x}^{2}+0.9381 \mathrm{x}-0.2067$ \\
Manning's Curve (Calc. Slope) & $\mathrm{y}=8.1627 \mathrm{x}^{2}-1.9235 \mathrm{x}+0.1397$ & $\mathrm{y}=0.7708 \mathrm{x}^{2}+0.1036 \mathrm{x}-0.023$ & $\mathrm{y}=2.3408 \mathrm{x}^{2}+0.7505 \mathrm{x}-0.1653$ \\
Chezy Curve (Obs. Slope) & $\mathrm{y}=5.5033 \mathrm{x}^{2}-1.2968 \mathrm{x}+0.0942$ & $\mathrm{y}=0.445 \mathrm{x}^{2}+0.0598 \mathrm{x}-0.0133$ & $\mathrm{y}=2.926 \mathrm{x}^{2}+0.9381 \mathrm{x}-0.2067$ \\
Chezy Curve (Calc Slope) & $\mathrm{y}=8.1627 \mathrm{x}^{2}-1.9235 \mathrm{x}+0.1397$ & $\mathrm{y}=0.7708 \mathrm{x}^{2}+0.1036 \mathrm{x}-0.023$ & $\mathrm{y}=2.3408 \mathrm{x}^{2}+0.7505 \mathrm{x}-0.1653$ \\
Dingman And Sharma's Curve (Obs. Slope) & $\mathrm{y}=5.9797 \mathrm{x}^{2}-1.419 \mathrm{x}+0.1033$ & $\mathrm{y}=0.9378 \mathrm{x}^{2}+0.0967 \mathrm{x}-0.0274$ & $\mathrm{y}=2.8521 \mathrm{x}^{2}+1.738 \mathrm{x}-0.3295$ \\
Dingman And Sharma's Curve (Calc Slope) & $\mathrm{y}=6.8154 \mathrm{x}^{2}-1.6173 \mathrm{x}+0.1178$ & $\mathrm{y}=1.1571 \mathrm{x}^{2}+0.1194 \mathrm{x}-0.0339$ & $\mathrm{y}=2.6652 \mathrm{x}^{2}+1.6242 \mathrm{x}-0.3079$ \\
\hline
\end{tabular}


Table 13. Observed and modeled rating curves for sites 10-12 in the West Run Watershed, Morgantown, West Virginia, U.S.A.

\begin{tabular}{|c|c|c|c|}
\hline Site & 10 & 11 & 12 \\
\hline Observed Rating Curve & $y=7.9224 x^{2}-2.4494 x+0.1803$ & $y=3.8475 x^{2}-2.4672 x+0.405$ & $y=0.8172 x^{2}+0.7243 x-0.1282$ \\
\hline Manning's Curve (Obs. Slope & $y=5.985 x^{2}-2.1592 x+0.2923$ & $y=-0.1135 x^{2}+0.6359 x-0.0757$ & $y=2.8829 x^{2}-0.5451 x+0.0722$ \\
\hline Manning's Curve (Calc. Slope) & $y=4.2321 x^{2}-1.5268 x+0.2067$ & $y=-0.1213 x^{2}+0.6798 x-0.081$ & $y=4.9515 x^{2}-0.9362 x+0.1239$ \\
\hline Chezy Curve (Obs. Slope) & $y=5.985 x^{2}-2.1592 x+0.2923$ & $y=-0.1135 x^{2}+0.6359 x-0.0757$ & $y=2.8829 x^{2}-0.5451 x+0.0722$ \\
\hline Chezy Curve (Calc Slope) & $y=4.2321 x^{2}-1.5268 x+0.2067$ & $y=-0.1213 x^{2}+0.6798 x-0.081$ & $y=4.9515 x^{2}-0.9362 x+0.1239$ \\
\hline Dingman And Sharma's Curve (Obs. Slope) & $y=6.6746 x^{2}-2.0624 x+0.2565$ & $y=0.253 x^{2}+0.714 x-0.0638$ & $y=2.9506 x^{2}-0.5409 x+0.0625$ \\
\hline Dingman And Sharma's Curve (Calc Slope) & $y=5.677 x^{2}-1.7542 x+0.2181$ & $y=0.2583 x^{2}+0.7289 x-0.0651$ & $y=3.5044 x^{2}-0.6425 x+0.0742$ \\
\hline
\end{tabular}

Table 14. Observed and modeled rating curves for sites 13-15 in the West Run Watershed, Morgantown, West Virginia, U.S.A.

\begin{tabular}{lccc}
\hline \multicolumn{1}{c}{ Site } & $\mathbf{1 3}$ & $\mathbf{1 4}$ \\
\hline Observed Rating Curve & $\mathrm{y}=4.4741 \mathrm{x}^{2}-1.2173 \mathrm{x}+0.0741$ & $\mathrm{y}=10.518 \mathrm{x}^{2}-4.4843 \mathrm{x}+0.4972$ & $\mathrm{y}=2.8601 \mathrm{x}^{2}-2.5768 \mathrm{x}+0.5719$ \\
Manning's Curve (Obs. Slope & $\mathrm{y}=3.1634 \mathrm{x}^{2}-0.7756 \mathrm{x}+0.1051$ & $\mathrm{y}=-1.617 \mathrm{x}^{2}+2.6303 \mathrm{x}-0.4351$ & $\mathrm{y}=1.8729 \mathrm{x}^{2}-2.0178 \mathrm{x}+0.6895$ \\
Manning's Curve (Calc. Slope) & $\mathrm{y}=3.2671 \mathrm{x}^{2}-0.801 \mathrm{x}+0.1086$ & $\mathrm{y}=-1.3285 \mathrm{x}^{2}+2.161 \mathrm{x}-0.3575$ & $\mathrm{y}=3.7924 \mathrm{x}^{2}-4.0858 \mathrm{x}+1.3961$ \\
Chezy Curve (Obs. Slope) & $\mathrm{y}=3.1634 \mathrm{x}^{2}-0.7756 \mathrm{x}+0.1051$ & $\mathrm{y}=-1.617 \mathrm{x}^{2}+2.6303 \mathrm{x}-0.4351$ & $\mathrm{y}=1.8729 \mathrm{x}^{2}-2.0178 \mathrm{x}+0.6895$ \\
Chezy Curve (Calc Slope) & $\mathrm{y}=3.2671 \mathrm{x}^{2}-0.801 \mathrm{x}+0.1086$ & $\mathrm{y}=-1.3285 \mathrm{x}^{2}+2.161 \mathrm{x}-0.3575$ & $\mathrm{y}=3.7924 \mathrm{x}^{2}-4.0858 \mathrm{x}+1.3961$ \\
Dingman And Sharma's Curve (Obs. Slope) & $\mathrm{y}=3.047 \mathrm{x}^{2}-0.8263 \mathrm{x}+0.1122$ & $\mathrm{y}=-1.1147 \mathrm{x}^{2}+1.9015 \mathrm{x}-0.3156$ & $\mathrm{y}=3.461 \mathrm{x}^{2}-3.5824 \mathrm{x}+1.1681$ \\
Dingman And Sharma's Curve (Calc Slope) & $\mathrm{y}=3.0924 \mathrm{x}^{2}-0.8387 \mathrm{x}+0.1139$ & $\mathrm{y}=-1.0463 \mathrm{x}^{2}+1.7848 \mathrm{x}-0.2962$ & $\mathrm{y}=4.4865 \mathrm{x}^{2}-4.6438 \mathrm{x}+1.5142$ \\
\hline
\end{tabular}

Table 15. Observed and modeled rating curves for sites 16-18 in the West Run Watershed, Morgantown, West Virginia, U.S.A.

\begin{tabular}{lccc}
\hline \multicolumn{1}{c}{ Site } & $\mathbf{1 6}$ & $\mathbf{1 7}$ \\
\hline Observed Rating Curve & $\mathrm{y}=1.5195 \mathrm{x}^{2}-0.3594 \mathrm{x}+0.0222$ & $\mathrm{y}=3.3489 \mathrm{x}^{2}-3.7972 \mathrm{x}+1.0815$ & $\mathrm{y}=1.0725 \mathrm{x}^{2}+2.9085 \mathrm{x}-1.0574$ \\
Manning's Curve (Obs. Slope & $\mathrm{y}=0.6688 \mathrm{x}^{2}-0.1891 \mathrm{x}+0.0343$ & $\mathrm{y}=1.2628 \mathrm{x}^{2}-1.4439 \mathrm{x}+0.4352$ & $\mathrm{y}=8.2173 \mathrm{x}^{2}-4.167 \mathrm{x}+0.6718$ \\
Manning's Curve (Calc. Slope) & $\mathrm{y}=0.9692 \mathrm{x}^{2}-0.274 \mathrm{x}+0.0497$ & $\mathrm{y}=2.1873 \mathrm{x}^{2}-2.501 \mathrm{x}+0.7537$ & $\mathrm{y}=10.714 \mathrm{x}^{2}-5.4331 \mathrm{x}+0.8759$ \\
Chezy Curve (Obs. Slope) & $\mathrm{y}=0.6688 \mathrm{x}^{2}-0.1891 \mathrm{x}+0.0343$ & $\mathrm{y}=1.2628 \mathrm{x}^{2}-1.4439 \mathrm{x}+0.4352$ & $\mathrm{y}=8.2173 \mathrm{x}^{2}-4.167 \mathrm{x}+0.6718$ \\
Chezy Curve (Calc Slope) & $\mathrm{y}=0.9692 \mathrm{x}^{2}-0.274 \mathrm{x}+0.0497$ & $\mathrm{y}=2.1873 \mathrm{x}^{2}-2.501 \mathrm{x}+0.7537$ & $\mathrm{y}=10.714 \mathrm{x}^{2}-5.4331 \mathrm{x}+0.8759$ \\
Dingman And Sharma's Curve (Obs. Slope) & $\mathrm{y}=0.7683 \mathrm{x}^{2}-0.2102 \mathrm{x}+0.0383$ & $\mathrm{y}=2.1191 \mathrm{x}^{2}-2.4314 \mathrm{x}+0.7331$ & $\mathrm{y}=10.727 \mathrm{x}^{2}-5.5025 \mathrm{x}+0.8895$ \\
Dingman And Sharma's Curve (Calc Slope) & $\mathrm{y}=0.8488 \mathrm{x}^{2}-0.2322 \mathrm{x}+0.0423$ & $\mathrm{y}=2.5225 \mathrm{x}^{2}-2.8942 \mathrm{x}+0.8726$ & $\mathrm{y}=11.957 \mathrm{x}^{2}-6.1338 \mathrm{x}+0.9915$ \\
\hline
\end{tabular}


Table 16. Observed and modeled rating curves for sites 19-21 in the West Run Watershed, Morgantown, West Virginia, U.S.A.

\begin{tabular}{|c|c|c|c|}
\hline Site & 19 & 20 & 21 \\
\hline Observed Rating Curve & $y=8.3797 x^{2}-1.6169 x+0.0435$ & $y=9.1928 x^{2}-6.1895 x+1.0677$ & $y=5.563 x^{2}+0.4385 x-0.7907$ \\
\hline Manning's Curve (Obs. Slope & $y=6.2508 x^{2}-2.5353 x+0.4757$ & $y=5.6124 x^{2}-3.3138 x+0.6755$ & $y=3.5201 x^{2}-0.9027 x+0.2264$ \\
\hline Manning's Curve (Calc. Slope) & $y=5.3528 x^{2}-2.1711 x+0.4074$ & $y=3.3985 x^{2}-2.0066 x+0.409$ & $y=3.4025 x^{2}+1.3579 x-0.3888$ \\
\hline Chezy Curve (Obs. Slope) & $y=6.2508 x^{2}-2.5353 x+0.4757$ & $y=5.6124 x^{2}-3.3138 x+0.6755$ & $y=3.5201 x^{2}-0.9027 x+0.2264$ \\
\hline Chezy Curve (Calc Slope) & $y=5.3528 x^{2}-2.1711 x+0.4074$ & $y=3.3985 x^{2}-2.0066 x+0.409$ & $y=5.9945 x^{2}-1.5373 x+0.3855$ \\
\hline Dingman And Sharma's Curve (Obs. Slope) & $y=10.387 x^{2}-3.7392 x+0.7198$ & $y=7.0352 x^{2}-4.2963 x+0.8733$ & $y=5.3559 x^{2}-0.4927 x+0.1239$ \\
\hline Dingman And Sharma's Curve (Calc Slope) & $y=9.7462 x^{2}-3.5084 x+0.6754$ & $y=5.8198 x^{2}-3.5541 x+0.7224$ & $y=6.5714 x^{2}-0.6046 x+0.152$ \\
\hline
\end{tabular}


During the 2018 to 2021 study period, the minimum observed and modeled streamflow estimates at the 21 gauging sites ranged from $0.0001 \mathrm{~m}^{3} / \mathrm{s}$ to $0.745 \mathrm{~m}^{3} / \mathrm{s}$ (Table 17). The maximum observed and modeled streamflow estimates ranged from $0.077 \mathrm{~m}^{3} / \mathrm{s}$ to $4.771 \mathrm{~m}^{3} / \mathrm{s}$ (Table 18). The average observed and modeled streamflow estimates ranged from $0.037 \mathrm{~m}^{3} / \mathrm{s}$ to $1.115 \mathrm{~m}^{3} / \mathrm{s}$ (Table 19).

Table 17. Minimum observed and modeled streamflow $\left(\mathrm{m}^{3} / \mathrm{s}\right)$ estimates for each of the study sites in the West Run Watershed, Morgantown, West Virginia, U.S.A. Note: (Obs.) refers to streamflow estimated using observed slope and (Calc.) refers to streamflow estimated using calculated slope.

\begin{tabular}{cccccccc}
\hline Site & $\begin{array}{c}\text { Observed } \\
\text { Streamflow }\end{array}$ & $\begin{array}{c}\text { Manning's } \\
\text { Streamflow } \\
\text { (Obs.) }\end{array}$ & $\begin{array}{c}\text { Manning's } \\
\text { Streamflow } \\
\text { (Calc.) }\end{array}$ & $\begin{array}{c}\text { Chezy's } \\
\text { Streamflow } \\
\text { (Obs.) }\end{array}$ & $\begin{array}{c}\text { Chezy's } \\
\text { Streamflow } \\
\text { (Calc.) }\end{array}$ & $\begin{array}{c}\text { Dingman } \\
\text { and } \\
\text { Sharma's } \\
\text { Streamflow } \\
\text { (Obs.) }\end{array}$ & $\begin{array}{c}\text { Dingman } \\
\text { and } \\
\text { Sharma's } \\
\text { Streamflow } \\
\text { (Calc.) }\end{array}$ \\
\hline $\mathbf{1}$ & 0.0001 & 0.007 & 0.011 & 0.007 & 0.011 & 0.011 & 0.013 \\
$\mathbf{2}$ & 0.002 & 0.025 & 0.034 & 0.025 & 0.034 & 0.025 & 0.027 \\
$\mathbf{3}$ & 0.010 & 0.018 & 0.021 & 0.018 & 0.021 & 0.022 & 0.023 \\
$\mathbf{4}$ & 0.004 & 0.046 & 0.084 & 0.046 & 0.084 & 0.077 & 0.097 \\
$\mathbf{5}$ & 0.001 & 0.015 & 0.019 & 0.015 & 0.019 & 0.025 & 0.025 \\
$\mathbf{6}$ & 0.007 & 0.073 & 0.065 & 0.073 & 0.065 & 0.060 & 0.057 \\
$\mathbf{7}$ & 0.004 & 0.01 & 0.015 & 0.01 & 0.015 & 0.01 & 0.012 \\
$\mathbf{8}$ & 0.008 & 0.008 & 0.014 & 0.008 & 0.014 & 0.015 & 0.018 \\
$\mathbf{9}$ & 0.012 & 0.037 & 0.03 & 0.037 & 0.03 & 0.05 & 0.047 \\
$\mathbf{1 0}$ & 0.02 & 0.06 & 0.042 & 0.06 & 0.042 & 0.076 & 0.065 \\
$\mathbf{1 1}$ & 0.014 & 0.111 & 0.119 & 0.111 & 0.119 & 0.184 & 0.188 \\
$\mathbf{1 2}$ & 0.005 & 0.021 & 0.037 & 0.021 & 0.037 & 0.021 & 0.025 \\
$\mathbf{1 3}$ & 0.021 & 0.026 & 0.027 & 0.026 & 0.027 & 0.025 & 0.025 \\
$\mathbf{1 4}$ & 0.008 & 0.043 & 0.036 & 0.043 & 0.036 & 0.031 & 0.029 \\
$\mathbf{1 5}$ & 0.001 & 0.008 & 0.015 & 0.008 & 0.015 & 0.013 & 0.016 \\
$\mathbf{1 6}$ & 0.006 & 0.014 & 0.02 & 0.014 & 0.02 & 0.017 & 0.019 \\
$\mathbf{1 7}$ & 0.001 & 0.006 & 0.011 & 0.006 & 0.011 & 0.009 & 0.011 \\
$\mathbf{1 8}$ & 0.022 & 0.134 & 0.175 & 0.134 & 0.175 & 0.152 & 0.17 \\
$\mathbf{1 9}$ & 0.074 & 0.199 & 0.17 & 0.199 & 0.17 & 0.367 & 0.344 \\
$\mathbf{2 0}$ & 0.007 & 0.083 & 0.05 & 0.083 & 0.05 & 0.103 & 0.085 \\
$\mathbf{2 1}$ & 0.091 & 0.334 & 0.568 & 0.334 & 0.568 & 0.607 & 0.745 \\
\hline
\end{tabular}


Table 18. Maximum observed and modeled streamflow $\left(\mathrm{m}^{3} / \mathrm{s}\right)$ estimates for each of the study sites in the West Run Watershed, Morgantown, West Virginia, U.S.A. Note: (Obs.) refers to streamflow estimated using observed slope and (Calc.) refers to streamflow estimated using calculated slope.

\begin{tabular}{cccccccc}
\hline Site & $\begin{array}{c}\text { Observed } \\
\text { Streamflow }\end{array}$ & $\begin{array}{c}\text { Manning's } \\
\text { Streamflow } \\
\text { (Obs.) }\end{array}$ & $\begin{array}{c}\text { Manning's } \\
\text { Streamflow } \\
\text { (Calc.) }\end{array}$ & $\begin{array}{c}\text { Chezy's } \\
\text { Streamflow } \\
\text { (Obs.) }\end{array}$ & $\begin{array}{c}\text { Chezy's } \\
\text { Streamflow } \\
\text { (Calc.) }\end{array}$ & $\begin{array}{c}\text { Dingman } \\
\text { and } \\
\text { Sharma's } \\
\text { Streamflow } \\
\text { (Obs.) }\end{array}$ & $\begin{array}{c}\text { Dingman } \\
\text { and } \\
\text { Sharma's } \\
\text { Streamflow } \\
\text { (Calc.) }\end{array}$ \\
\hline $\mathbf{1}$ & & & & & & 0.488 & 0.569 \\
$\mathbf{2}$ & 0.528 & 0.321 & 0.537 & 0.321 & 0.537 & 0.384 & 0.412 \\
$\mathbf{3}$ & 0.514 & 0.392 & 0.528 & 0.393 & 0.528 & 1.258 & 1.317 \\
$\mathbf{4}$ & 0.902 & 0.998 & 1.152 & 0.998 & 1.152 & 0.573 & 0.717 \\
$\mathbf{5}$ & 0.611 & 0.342 & 0.622 & 0.342 & 0.622 & 0.237 & 0.304 \\
$\mathbf{6}$ & 0.267 & 0.187 & 0.234 & 0.187 & 0.234 & 0.287 \\
$\mathbf{7}$ & 1.271 & 1.383 & 1.237 & 1.383 & 1.237 & 1.124 & 1.078 \\
$\mathbf{8}$ & 0.173 & 0.146 & 0.216 & 0.146 & 0.216 & 0.157 & 0.179 \\
$\mathbf{9}$ & 0.34 & 0.077 & 0.134 & 0.077 & 0.134 & 0.149 & 0.184 \\
$\mathbf{1 0}$ & 0.626 & 0.672 & 0.538 & 0.672 & 0.538 & 0.856 & 0.8 \\
$\mathbf{1 1}$ & 2.058 & 1.562 & 1.105 & 1.562 & 1.105 & 1.892 & 1.609 \\
$\mathbf{1 2}$ & 0.296 & 0.284 & 0.303 & 0.284 & 0.303 & 0.487 & 0.497 \\
$\mathbf{1 3}$ & 0.904 & 1.748 & 3.002 & 1.748 & 3.002 & 1.821 & 2.163 \\
$\mathbf{1 4}$ & 0.938 & 0.861 & 0.889 & 0.861 & 0.889 & 0.799 & 0.811 \\
$\mathbf{1 5}$ & 0.9 & 0.511 & 0.42 & 0.511 & 0.42 & 0.381 & 0.357 \\
$\mathbf{1 6}$ & 1.734 & 0.825 & 1.671 & 0.825 & 1.671 & 1.577 & 2.045 \\
$\mathbf{1 7}$ & 0.155 & 0.096 & 0.14 & 0.096 & 0.14 & 0.113 & 0.125 \\
$\mathbf{1 8}$ & 0.415 & 0.184 & 0.318 & 0.184 & 0.318 & 0.302 & 0.359 \\
$\mathbf{1 9}$ & 2.559 & 3.319 & 4.328 & 3.319 & 4.328 & 4.28 & 4.771 \\
$\mathbf{2 0}$ & 2.081 & 1.202 & 1.03 & 1.202 & 1.03 & 2.21 & 2.074 \\
$\mathbf{2 1}$ & 3.048 & 2.385 & 1.444 & $2 / 385$ & 1.444 & 2.843 & 2.352 \\
\hline & 2.366 & 1.414 & 2.408 & 1.414 & 2.408 & 2.570 & 3.153 \\
\hline
\end{tabular}


Table 19. Average observed and modeled streamflow $\left(\mathrm{m}^{3} / \mathrm{s}\right)$ estimates for each of the study sites in the West Run Watershed, Morgantown, West Virginia, U.S.A. Note: (Obs.) refers to streamflow estimated using observed slope and (Calc.) refers to streamflow estimated using calculated slope.

\begin{tabular}{cccccccc}
\hline Site & $\begin{array}{c}\text { Observed } \\
\text { Streamflow }\end{array}$ & $\begin{array}{c}\text { Manning's } \\
\text { Streamflow } \\
\text { (Obs.) }\end{array}$ & $\begin{array}{c}\text { Manning's } \\
\text { Streamflow } \\
\text { (Calc.) }\end{array}$ & $\begin{array}{c}\text { Chezy's } \\
\text { Streamflow } \\
\text { (Obs.) }\end{array}$ & $\begin{array}{c}\text { Chezy's } \\
\text { Streamflow } \\
\text { (Calc.) }\end{array}$ & $\begin{array}{c}\text { Dingman } \\
\text { and } \\
\text { Sharma's } \\
\text { Streamflow } \\
\text { (Obs.) }\end{array}$ & $\begin{array}{c}\text { Dingman } \\
\text { and } \\
\text { Sharma's } \\
\text { Streamflow } \\
\text { (Calc.) }\end{array}$ \\
\hline $\mathbf{1}$ & & & & & & 0.113 & 0.132 \\
$\mathbf{2}$ & 0.104 & 0.071 & 0.119 & 0.071 & 0.119 & 0.142 & 0.152 \\
$\mathbf{3}$ & 0.103 & 0.144 & 0.193 & 0.144 & 0.193 & 0.429 & 0.449 \\
$\mathbf{4}$ & 0.207 & 0.336 & 0.388 & 0.336 & 0.388 & 0.241 & 0.302 \\
$\mathbf{5}$ & 0.135 & 0.147 & 0.267 & 0.147 & 0.267 & 0.203 \\
$\mathbf{6}$ & 0.130 & 0.123 & 0.154 & 0.123 & 0.154 & 0.191 & 0.270 \\
$\mathbf{7}$ & 0.229 & 0.345 & 0.308 & 0.345 & 0.308 & 0.282 & 0.270 \\
$\mathbf{8}$ & 0.051 & 0.040 & 0.059 & 0.040 & 0.059 & 0.043 & 0.049 \\
$\mathbf{9}$ & 0.119 & 0.039 & 0.068 & 0.039 & 0.068 & 0.075 & 0.092 \\
$\mathbf{1 0}$ & 0.142 & 0.193 & 0.155 & 0.193 & 0.155 & 0.255 & 0.238 \\
$\mathbf{1 1}$ & 0.428 & 0.369 & 0.261 & 0.369 & 0.261 & 0.465 & 0.396 \\
$\mathbf{1 2}$ & 0.097 & 0.183 & 0.196 & 0.183 & 0.196 & 0.305 & 0.311 \\
$\mathbf{1 3}$ & 0.180 & 0.257 & 0.441 & 0.257 & 0.441 & 0.256 & 0.305 \\
$\mathbf{1 4}$ & 0.365 & 0.344 & 0.356 & 0.344 & 0.356 & 0.311 & 0.316 \\
$\mathbf{1 5}$ & 0.312 & 0.243 & 0.199 & 0.243 & 0.199 & 0.181 & 0.170 \\
$\mathbf{1 6}$ & 0.191 & 0.226 & 0.458 & 0.226 & 0.458 & 0.407 & 0.527 \\
$\mathbf{1 7}$ & 0.047 & 0.037 & 0.054 & 0.037 & 0.054 & 0.044 & 0.048 \\
$\mathbf{1 8}$ & 0.188 & 0.089 & 0.154 & 0.089 & 0.154 & 0.146 & 0.174 \\
$\mathbf{1 9}$ & 0.549 & 0.705 & 0.920 & 0.705 & 0.920 & 0.904 & 1.008 \\
$\mathbf{2 0}$ & 0.683 & 0.474 & 0.406 & 0.474 & 0.406 & 0.887 & 0.832 \\
$\mathbf{2 1}$ & 0.589 & 0.616 & 0.373 & 0.616 & 0.373 & 0.727 & 0.601 \\
& 0.467 & 0.514 & 0.876 & 0.514 & 0.876 & 0.941 & 1.155 \\
\hline
\end{tabular}


Table 20. Standard Deviation of observed and modeled streamflow estimates for each of the study sites in the West Run Watershed, Morgantown, West Virginia, U.S.A. Note: (Obs.) refers to streamflow estimated using observed slope and (Calc.) refers to streamflow estimated using calculated slope.

\begin{tabular}{cccccccc}
\hline Site & $\begin{array}{c}\text { Observed } \\
\text { Streamflow }\end{array}$ & $\begin{array}{c}\text { Manning's } \\
\text { Streamflow } \\
\text { (Obs.) }\end{array}$ & $\begin{array}{c}\text { Manning's } \\
\text { Streamflow } \\
\text { (Calc.) }\end{array}$ & $\begin{array}{c}\text { Chezy's } \\
\text { Streamflow } \\
\text { (Obs.) }\end{array}$ & $\begin{array}{c}\text { Chezy's } \\
\text { Streamflow } \\
\text { (Calc.) }\end{array}$ & $\begin{array}{c}\text { Dingman } \\
\text { and } \\
\text { Sharma's } \\
\text { Streamflow } \\
\text { (Obs.) }\end{array}$ & $\begin{array}{c}\text { Dingman } \\
\text { and } \\
\text { Sharma's } \\
\text { Streamflow } \\
\text { (Calc.) }\end{array}$ \\
\hline $\mathbf{1}$ & & & & & & 0.105 & 0.123 \\
$\mathbf{2}$ & 0.142 & 0.067 & 0.113 & 0.067 & 0.113 & 0.122 & 0.13 \\
$\mathbf{3}$ & 0.14 & 0.124 & 0.167 & 0.124 & 0.167 & 0.338 & 0.354 \\
$\mathbf{4}$ & 0.254 & 0.265 & 0.306 & 0.265 & 0.306 & 0.131 & 0.164 \\
$\mathbf{5}$ & 0.144 & 0.08 & 0.145 & 0.08 & 0.145 & 0.94 & 0.099 \\
$\mathbf{6}$ & 0.1 & 0.061 & 0.077 & 0.061 & 0.077 & 0.273 \\
$\mathbf{7}$ & 0.318 & 0.347 & 0.31 & 0.347 & 0.31 & 0.285 & 0.273 \\
$\mathbf{8}$ & 0.05 & 0.034 & 0.05 & 0.034 & 0.05 & 0.037 & 0.042 \\
$\mathbf{9}$ & 0.124 & 0.024 & 0.042 & 0.024 & 0.042 & 0.048 & 0.059 \\
$\mathbf{1 0}$ & 0.179 & 0.203 & 0.163 & 0.203 & 0.163 & 0.263 & 0.246 \\
$\mathbf{1 1}$ & 0.535 & 0.372 & 0.263 & 0.372 & 0.263 & 0.457 & 0.389 \\
$\mathbf{1 2}$ & 0.108 & 0.051 & 0.055 & 0.051 & 0.055 & 0.091 & 0.093 \\
$\mathbf{1 3}$ & 0.266 & 0.423 & 0.727 & 0.423 & 0.727 & 0.439 & 0.521 \\
$\mathbf{1 4}$ & 0.336 & 0.263 & 0.271 & 0.263 & 0.271 & 0.243 & 0.247 \\
$\mathbf{1 5}$ & 0.369 & 0.179 & 0.147 & 0.179 & 0.147 & 0.134 & 0.126 \\
$\mathbf{1 6}$ & 0.377 & 0.228 & 0.462 & 0.228 & 0.462 & 0.437 & 0.566 \\
$\mathbf{1 7}$ & 0.056 & 0.024 & 0.034 & 0.024 & 0.034 & 0.028 & 0.031 \\
$\mathbf{1 8}$ & 0.154 & 0.059 & 0.103 & 0.059 & 0.103 & 0.098 & 0.117 \\
$\mathbf{1 9}$ & 0.651 & 0.869 & 1.133 & 0.869 & 1.133 & 1.127 & 1.257 \\
$\mathbf{2 0}$ & 0.663 & 0.33 & 0.283 & 0.33 & 0.283 & 0.609 & 0.571 \\
$\mathbf{2 1}$ & 0.82 & 0.591 & 0.358 & 0.591 & 0.358 & 0.713 & 0.59 \\
\hline & 0.524 & 0.237 & 0.403 & 0.237 & 0.403 & 0.435 & 0.534 \\
\hline
\end{tabular}

Estimated streamflow using observed and modeled streamflow in sites 1, 2, 6, 7, 9, 10, $12,13,14,16,18,19$, and 20 had no differences. Differences in observed and/or modeled streamflow were found in sites $3,4,5,8,11,15,17$, and 21. Manning and Chezy models were significantly different from observed in sites 4, 8, 11, 15, 17, and 21. Dingman and Sharma model was significantly different from observed in sites $3,4,5,11,15$, and 21 (Table 21-22). 
Table 21. Site by site comparison of the developed observed and modeled rating curves used to estimate streamflow for sites 3-11 in the West Run Watershed, Morgantown, West Virginia, U.S.A. Obs. slope represents observed slope collected in the field. Calc. slope represents calculated slope using ArcGIS. Only significant $(\alpha=0.05)$ results from the analysis are shown.

\begin{tabular}{|c|c|c|c|c|}
\hline \multirow{2}{*}{$\frac{\text { Site }}{\mathbf{3}}$} & \multicolumn{3}{|c|}{ Site Comparison } & \multirow{2}{*}{$\begin{array}{c}p \text {-Value } \\
(\boldsymbol{\alpha}=\mathbf{0 . 0 5}) \\
0.04\end{array}$} \\
\hline & Observed Curve & VS & Dingman and Sharma's Curve (calc. slope) & \\
\hline \multirow[t]{14}{*}{4} & Observed Curve & vs & Manning's Curve (calc. slope) & $<0.05$ \\
\hline & & vs & Chezy’s Curve (calc slope) & $<0.05$ \\
\hline & & vs & Dingman And Sharma's Curve (obs. slope) & 0.03 \\
\hline & & vs & Dingman And Sharma's Curve (calc. slope) & $<0.05$ \\
\hline & Rating Equation Curve & vs & Manning's Curve (calc. slope) & $<0.05$ \\
\hline & & vs & Chezy's Curve (calc slope) & $<0.05$ \\
\hline & & vs & Dingman And Sharma's Curve (obs. slope) & 0.03 \\
\hline & & vs & Dingman And Sharma's Curve (calc. slope) & $<0.05$ \\
\hline & Manning's Curve (obs. slope) & vs & Manning's Curve (calc. slope) & $<0.05$ \\
\hline & & vs & Chezy’s Curve (calc slope) & $<0.05$ \\
\hline & & vs & Dingman And Sharma's Curve (calc. slope) & $<0.05$ \\
\hline & Manning's Curve (calc. slope) & vs & Chezy’s Curve (obs. slope) & $<0.05$ \\
\hline & Chezy's Curve (obs. slope) & vs & Chezy's Curve (calc slope) & $<0.05$ \\
\hline & & vs & Dingman And Sharma's Curve (calc. slope) & $<0.05$ \\
\hline \multirow[t]{4}{*}{5} & Observed Curve & vs & Dingman And Sharma's Curve (calc. slope) & 0.05 \\
\hline & Rating Equation Curve & vs & Dingman And Sharma's Curve (calc. slope) & 0.05 \\
\hline & Manning's Curve (obs. slope) & vs & Dingman And Sharma's Curve (calc. slope) & 0.02 \\
\hline & Chezy’s Curve (obs. slope) & vs & Dingman And Sharma's Curve (calc. slope) & 0.02 \\
\hline \multirow[t]{4}{*}{8} & Observed Curve & VS & Manning's Curve (obs. slope) & $<0.05$ \\
\hline & & vs & Chezy's Curve (obs. slope) & $<0.05$ \\
\hline & Rating Equation Curve & vs & Manning's Curve (obs. slope) & $<0.05$ \\
\hline & & vs & Chezy's Curve (obs. slope) & $<0.05$ \\
\hline \multirow[t]{20}{*}{11} & Observed Curve & vs & Manning's Curve (obs. slope) & $<0.05$ \\
\hline & & vs & Manning's Curve (calc. slope) & $<0.05$ \\
\hline & & vs & Chezy’s Curve (obs. slope) & $<0.05$ \\
\hline & & vs & Chezy’s Curve (calc. slope) & $<0.05$ \\
\hline & & vs & Dingman and Sharma's Curve (obs. slope) & $<0.05$ \\
\hline & & vs & Dingman and Sharma's Curve (calc. slope) & $<0.05$ \\
\hline & Rating Equation Curve & vs & Manning's Curve (obs. slope) & $<0.05$ \\
\hline & & vs & Manning's Curve (calc. slope) & $<0.05$ \\
\hline & & vs & Chezy's Curve (obs. slope) & $<0.05$ \\
\hline & & vs & Chezy's Curve (calc. slope) & $<0.05$ \\
\hline & & vs & Dingman and Sharma's Curve (obs. slope) & $<0.05$ \\
\hline & & vs & Dingman and Sharma's Curve (calc. slope) & $<0.05$ \\
\hline & Manning's Curve (obs. slope) & vs & Dingman and Sharma's Curve (obs. slope) & $<0.05$ \\
\hline & & vs & Dingman and Sharma's Curve (calc. slope) & $<0.05$ \\
\hline & Manning's Curve (calc. slope) & vs & Dingman and Sharma's Curve (obs. slope) & $<0.05$ \\
\hline & & vs & Dingman and Sharma's Curve (calc. slope) & $<0.05$ \\
\hline & Chezy's Curve (obs. slope) & vs & Dingman and Sharma's Curve (obs. slope) & $<0.05$ \\
\hline & & vs & Dingman and Sharma's Curve (calc. slope) & $<0.05$ \\
\hline & Chezy's Curve (calc. slope) & vs & Dingman and Sharma's Curve (obs. slope) & $<0.05$ \\
\hline & & vs & Dingman and Sharma's Curve (calc. slope) & $<0.05$ \\
\hline
\end{tabular}


Table 22. Site by site comparison of the developed observed and modeled rating curves used to estimate streamflow for sites 5-21 in the West Run Watershed, Morgantown, West Virginia, U.S.A. Obs. slope represents observed slope collected in the field. Calc. slope represents calculated slope using ArcGIS. Only significant $(\alpha=0.05)$ results from the analysis are shown.

\begin{tabular}{|c|c|c|c|c|}
\hline \multirow{2}{*}{$\frac{\text { Site }}{15}$} & \multicolumn{3}{|c|}{ Site Comparison } & \multirow{2}{*}{$\begin{array}{c}\begin{array}{c}p \text {-Value } \\
(\boldsymbol{\alpha}=\mathbf{0 . 0 5})\end{array} \\
0.02\end{array}$} \\
\hline & Observed Curve & vs & Manning's Curve (calc. slope) & \\
\hline & & vs & Chezy's Curve (calc slope) & 0.02 \\
\hline & & vs & Dingman And Sharma's Curve (calc. slope) & $<0.05$ \\
\hline & Rating Equation Curve & vs & Manning's Curve (calc. slope) & 0.02 \\
\hline & & vs & Chezy’s Curve (calc slope) & 0.02 \\
\hline & & vs & Dingman And Sharma's Curve (calc. slope) & $<0.05$ \\
\hline & Manning's Curve (obs. slope) & vs & Dingman And Sharma's Curve (calc. slope) & 0.05 \\
\hline & Chezy's Curve (obs. slope) & vs & Dingman And Sharma's Curve (calc. slope) & 0.05 \\
\hline \multirow[t]{6}{*}{17} & Observed Curve & vs & Manning's Curve (obs. slope) & $<0.05$ \\
\hline & & vs & Chezy’s Curve (obs. slope) & $<0.05$ \\
\hline & Rating Equation Curve & vs & Manning's Curve (obs. slope) & $<0.05$ \\
\hline & & vs & Chezy's Curve (obs. slope) & $<0.05$ \\
\hline & Manning's Curve (obs. slope) & vs & Dingman And Sharma's Curve (calc. slope) & $<0.05$ \\
\hline & Chezy's Curve (obs. slope) & vs & Dingman And Sharma's Curve (calc. slope) & $<0.05$ \\
\hline \multirow[t]{12}{*}{21} & Observed Curve & vs & Manning's Curve (calc. slope) & 0.03 \\
\hline & & & Chezy’s Curve (calc slope) & 0.03 \\
\hline & & vs & Dingman and Sharma's Curve (obs.slope) & $<0.05$ \\
\hline & & vs & Dingman And Sharma's Curve (calc. slope) & $<0.05$ \\
\hline & Rating Equation Curve & vs & Manning's Curve (calc. slope) & 0.03 \\
\hline & & & Chezy’s Curve (calc slope) & \\
\hline & & vs & Dingman and Sharma's Curve (obs.slope) & $<0.05$ \\
\hline & & vs & Dingman And Sharma's Curve (calc. slope) & $<0.05$ \\
\hline & Manning's Curve (obs. slope) & vs & Dingman and Sharma's Curve (obs.slope) & 0.02 \\
\hline & & vs & Dingman And Sharma's Curve (calc. slope) & $<0.05$ \\
\hline & Chezy's Curve (obs. slope) & vs & Dingman and Sharma's Curve (obs.slope) & 0.02 \\
\hline & & vs & Dingman And Sharma's Curve (calc. slope) & $<0.05$ \\
\hline
\end{tabular}




\section{DISCUSSION}

\section{Stream Channel Characteristics}

Slope was an important component used to estimate streamflow in the models selected. Slope varied significantly between field observed and computer (ArcGIS) calculated. Percent difference ranged from $6.7 \%$ at Site 13 to $310 \%$ at Site 15 . The main objective of this project was to develop a series of rating curve equations in a mixed-land-use watershed using observed and computer-generated data. Our results show the need of caution when using computer generated slope, as it may vary significantly from field observed measurements, which may create an unreliable streamflow estimation.

Another key component for estimating streamflow via the Manning's and Chezy models is the roughness coefficient $(n)$. Determining the appropriate $n$ value was difficult at several of the study sites, particularly at sites that have had major influences from anthropogenic activities or with slopes greater than $0.04 \mathrm{~m}$. The challenge of assigning an $n$ value at sites with steep slopes followed closely with previous studies by Dingman and Sharma (2007), Jarrett (1984), and Riggs (1976), which were also conducted in mountainous steams.

\section{Observed and Modeled Rating Curve}

During development of the observed rating curve, the coefficient of determination $\left(\mathrm{R}^{2}\right)$ was used to validate rating curve accuracy. The minimum $\mathrm{R}^{2}$ value (i.e., threshold) chosen for this study was $R^{2} \geq 0.95$. For the observed rating curves, the minimum $R^{2}$ values were 0.98 at Sites $8,9,11,13,17,19,20$, and 21 , the maximum $\mathrm{R}^{2}$ value was 1 at Site 16 , with an average $\mathrm{R}^{2}$ value of 0.99 . However, many of the modeled ratings curves used in this study did not generate $\mathrm{R}^{2}$ values greater than 0.95 . For rating curves generated at Sites $2,4,6,10,19,20$, and 21, at least one empirical model did produce a $R^{2} \geq 0.95$. The lowest $R^{2}$ values generated for the Manning's and Chezy equations were at Site $15\left(R^{2}=0.68\right)$ and for the Dingman and Sharma 
equation was at Site $12\left(\mathrm{R}^{2}=0.69\right)$. The highest $\mathrm{R}^{2}$ value generated from the empirical models was 0.97 . This $\mathrm{R}^{2}$ value was produced at Site 10 for all three of the models used. Variations in the $\mathrm{R}^{2}$ values means that several of the models would not be reliable for estimating future streamflow.

\section{Observed and Modeled Streamflow Estimates}

In this study, observed streamflow estimates were compared against modeled streamflow estimates using Manning, Chezy, and Dingman and Sharma equations. 8 of 21 study sites showed significant differences between observed and/or modeled streamflow estimates. In general, the Dingman and Sharma model performed the worst in comparison to the Manning and Chezy models (Table 23). The Dingman and Sharma model showed at least one model estimated streamflow (observed slope or calculated slope), with significant differences to observed estimated streamflow. For example, at Sites 4 and 21, the Dingman and Sharma model showed significant differences with observed streamflow when using both the observed and calculated slopes. A notable difference between the Dingman and Sharma model and the Manning/Chezy models is the use of a roughness coefficient $(n)$. The Dingman and Sharma model utilizes crosssectional area, hydraulic radius, and water-surface slope to avoid uncertainty in selecting a roughness coefficient (Dingman and Sharma 2007; Riggs 1976). In this study, the use of a roughness coefficient $(n)$ was more reliable at estimating streamflow. 
Table 23. P-values for statistically significant study sites in WRW. Note: (Obs.) refers to streamflow estimated using observed slope and (Calc.) refers to streamflow estimated using calculated slope.

\begin{tabular}{|c|c|c|c|c|c|c|}
\hline \multirow[t]{2}{*}{ Site } & \multicolumn{2}{|c|}{ Manning } & \multicolumn{2}{|c|}{ Chezy } & \multicolumn{2}{|c|}{ Dingman and Sharma } \\
\hline & Obs. & Calc. & Obs. & Calc. & Obs. & Calc. \\
\hline 3 & & & & & & $<0.05$ \\
\hline 4 & & $<0.05$ & & $<0.05$ & $<0.05$ & $<0.05$ \\
\hline 5 & & & & & & 0.05 \\
\hline 8 & $<0.05$ & & $<0.05$ & & & \\
\hline 11 & $<0.05$ & $<0.05$ & $<0.05$ & $<0.05$ & $<0.05$ & $<0.05$ \\
\hline 15 & & $<0.05$ & & $<0.05$ & & $<0.05$ \\
\hline 17 & $<0.05$ & & $<0.05$ & & & \\
\hline 21 & & $<0.05$ & & $<0.05$ & $<0.05$ & $<0.05$ \\
\hline
\end{tabular}

Significant differences were found between modeled streamflow and observed streamflow for all the models used at Site 11. This issue could be the result of several factors, including the incorrectly assigned roughness coefficient $(n)$, incorrectly measured slope (observed and calculated), or anthropogenic stream channel alterations. Assigning $n$ was difficult at Site 11 due to a rapid change in vegetation in the stream channel during different flow events and variations in channel width associated with physical channel alterations (e.g., a bridge). Channel confinement caused by the bridge could easily lead to backwatering at the location where streamflow was measurement.

Even though only 8 sites showed significant differences between observed and modeled streamflow, this was based on mean streamflow. Relative to observed results, empirical models 
poorly estimated low flows at the majority of the 21 study sites. Percent differences between observed and modeled low flows ranged from $12.5 \%$ at Site 8 to $12,900 \%$ at Site 1 . The models were more accurate when estimating streamflow during high flow events, with the precent differences ranging from $0 \%$ at Site 2 to $232 \%$ at Site 12 . The inaccuracy of model estimated streamflow, especially from the Manning's and Chezy equations, could be a result of incorrectly assigned $n$ values. Since channel roughness can change during different flow events (e.g., low, medium, and high), the $n$ value for a site can also change, resulting in a need to assign more than one $n$ value at each site (Dingman and Sharma 2007). Studies by Harmel et al. (2006), and Slade (2004) have shown that modeled streamflow using the Manning's equation can result in uncertainties ranging from $\pm 15 \%$, in stable channels with a poor $n$ value, to $\pm 35 \%$, in unstable channels with a poor $n$ value. Additionally, studies by Hodgkin et al. (2020), Farmer et al. (2015), have shown that, in general, models are calibrated for estimating streamflow during medium and high flow events, but inaccurately estimate streamflow during low flow events. These results emphasize the need for model validation to improve streamflow estimates, especially for low flow events.

\section{Implications of Study}

This study measured cross-sectional streamflow at 21 gauging sites throughout West Run Watershed. A total of 757 cross-sections were performed, with an average of 36 at each site. Manually measuring streamflow at multiple sites throughout a watershed can be a difficult task, with limited instruments and users available during rain events. While using models to estimate streamflow is a much easier task, there can be estimation errors if slope is incorrectly calculated or if the roughness coefficient is incorrectly selected. If directly relying on models to estimate streamflow, the user should practice caution as the estimation could vary from observed flow. 
This study showed that GIS calculated slope using $10 \mathrm{~m}$ DEM can vary from field calculated slope, emphasizing the need for the use of a higher resolution DEM or field surveys to measure slope.

\section{Study Challenges}

Several challenges were encountered during the completion of this study. For example, as mentioned in previous studies by the USGS and Dingman and Sharma (2007), assigning the correct $n$ value can be difficult, especially for inexperienced researchers. Inexperience researchers would benefit from either hands-on training from an experienced researcher or the development of an in-depth key that thoroughly explains the assignment selection of the roughness coefficient $(n)$. Additional challenges included a period of drought during the summer of 2020, that resulted in no observable streamflow at several of the gauging sites. Moreover, towards the middle of the 2021 study year, locally intense rainfall events occurred that produced flashy, high flow. These flashy storm events posed a challenge for targeting sites for streamflow collection. Due to distance between certain study sites, the limited number of field personnel to collect streamflow, and the rapid recession of stage and streamflow, certain sites did not have streamflow measurements collected as frequently. This infrequent streamflow collection resulted in sample size (n) variability from 21-53 across the 21 study sites. Future work would benefit from a larger field crew to be able to collect streamflow estimates simultaneously, especially during droughts with flashy rain events. 


\section{CONCLUSION}

Modeled and observed streamflow varied in this study. The models selected poorly estimated streamflow, especially during low flow events. Accurate streamflow estimation is important for improved management of water resources (e.g., water allocation, pollutant loading, etc.) and aquatic habitat (Erwin and Hamilton 2002). Due to labor constraints caused by the need to continuously collect streamflow measurements to generate site specific rating curves, streamflow is commonly estimated using various streamflow models (USGS 2019). However, previous studies by Hodgkins et al. (2020), Farmer et al. (2014), Dingman and Sharma (2007), Jarrett (1984), and Riggs (1976) have shown that several streamflow models greatly overestimate/underestimate streamflow. For example, estimated streamflow using the Manning or Chezy equations can be difficult due to the reliance of the models on the correctly assigned roughness coefficient $(n)$ and slope of a stream channel (Dingman and Sharma 2007). Assigning $n$ can be especially difficult in stream channels with steep gradients, like ones found in mountainous regions similar to the Appalachians.

To advance understanding of observed streamflow and estimating streamflow using models in mountainous regions, a 21-site, nested-scale, experimental watershed study design was implemented in a mixed-land-use Appalachian watershed of the eastern United States (Petersen and Hubbart 2020b; Hubbart et al. 2019; Hubbart et al. 2007; Loftis et al. 2001). Using the high spatial resolution of the experimental watershed design, understanding of the stage versus streamflow relationship, on a site-by-site level, can be improved by developing transferable rating curves. Additionally, observed streamflow measurements were compared with streamflow estimated using three different empirical streamflow models (Manning's, Chezy, and Dingman and Sharma) to validate model accuracy. 
Results from this study showed that there were significant differences $(\alpha=0.05)$ between observed and modeled mean streamflow estimates at 8 of the 21 sites in the West Run watershed (WRW). Out of the sites that showed significant differences between observed and modeled streamflow, 8 sites showed significant differences between observed streamflow and modeled streamflow using the Dingman and Sharma's equation and 6 sites showed significant differences between observed streamflow and modeled streamflow using the Manning's or Chezy equations. The significant differences between observed streamflow and modeled streamflow using the Manning's or Chezy equations could be due to incorrectly assigned roughness coefficients $(n)$ or variations in observed and calculated slope. Differences between observed streamflow and modeled streamflow using the Dingman and Sharma's equation, may well be linked to the variations between observed slope and calculated slope.

Even though only 8 of the 21 sites showed significant differences between mean observed and modeled streamflow, the models inaccurately estimated streamflow during low flow events at most of the study sites within the WRW. Percent differences between observed streamflow and modeled streamflow ranged from $12.8 \%$ at Site 8 to $12,900 \%$ at Site 1 . Most of the differences between observed and modeled streamflow estimates during low flow events were overestimations. This inability to properly estimate low flows using these models poses a potential problem for land and water resource managers. The findings in this study, though preliminary, emphasize the need to validate estimated streamflow with observed streamflow when using models. Additionally, conclusions made by previous researchers were both reinforced and expanded on through the investigation and interpretation of these data. 


\section{LITERATURE CITED}

Arcement, G. J. and Schneider, V. R. (1989). Guide for Selecting Manning's Roughness Coefficients for Natural Channels and Floodplains. US Geological Survey Water Supply Paper 2339.

Arnold, C. L. Jr., and Gibbons, C. J. (1996). Impervious Surface Coverage: The emergence of a key environmental indicator. American Association. Journal of the American Planning Association. Spring 1996. 62, 2. ABI/INFROM Global. 243

Arguez, A., Durre, I., Applequist, S., Squires, M., Vose, R., Yin, X., Bilotta, R. (2010). NOAA's U.S. Climate Normals (1981-2010). NOAA National Centers for Environmental Information. DOI: 10.7289/V5PN93JP. Accessed [7/7/2021].

Ayele, G. T., Teshale, E. Z., Yu, B. F., Rutherfurd, I. D., and Jeong, J. (2017). Streamflow and Sediment Yield Prediction for Watershed Prioritization in the Upper Blue Nile River Basin, Ethiopia. Water, 9(10). doi: 782.10.3390/w9100782

Bathurst, J. C. (1978). Flow resistance of large-scale roughness. Journal of Hydraulics Division, American Society of Civil Engineers, 104(HY12): 1587-1603

Borah, D. K. and Bera, M. (2004). Watershed-scale hydrologic and nonpoint-source Pollution models: Review of applications. Transactions of the American Society of Agricultural Engineers 47:789-803.

Braca, G. (2008). Stage-discharge relationships in open channels: Practices and Problems. FORALPS Technical Report, 11. Universita degli Studi di Trento, Dipartimento di Ingegneria Civile e Ambientale. Trento, Italy. 24 pp.

Buchanan, T. J., and Somers, W. P. (1969). Discharge Measurements at Gaging Stations. U.S. Geological Survey Techniques of Water-Resources Investigations, Book 3, Chpt. A-8.

Bull, L. J. (1997). Magnitude and variation in the contribution of bank erosion to the suspended sediment load of the River Severn, UK. Earth Surface Processes and Landforms, 22(12), 1109-1123.

Bouska, W. W., and Paukert, C. P. (2010). Road Crossing Designs and Their Impact on Fish Assemblages of Great Plains Streams. Transactions of the American Fisheries Society, 139(1), 214-222. doi: 10.1577/t09-040.1

Carter, R. W., and Anderson, I. E. (1963). Accuracy of current-meter mesurement : Am. Soc. Civil Engineers Jour., v. 89. HY4, p. 105-115.

Chow, V. T. (1959). Open-channel hydraulics. New York: McGraw-Hill. 
Cowan, W. L. (1956). Estimating hydraulic roughness coefficients: Agricultural Engineering, v. 37, no. 7, p. 473-475

Danehy, R. J. and Johnson, S. L. (2013). Applying four principles of headwater system aquatic biology to forest management. In: Anderson. P.D. and Ronnenberg, K. L. (Eds.). Density Management in the $21^{\text {st }}$ Century: West Side Story. Gen. Tech.Rep. PNW-GTR-0. 880. US Department of Agriculture, Forest Service, Pacific Northwest Research Station, Portland, OR. 189-202.

Dingman, S. L. (2008). Physical hydrology. Long Grove (Illinois): Waveland.

Dingman, S. L., \& Sharma, K. P. (1997). Statistical development and validation of discharge equations for natural channels. Journal of Hydrology, 199(1-2), 13-35. doi: 10.1016/S0022-1694(96)03313-6

Dottori, F., Martina, M. L. V., and Todini, E. (2009). A dynamic rating curve approach to indirect discharge measurement. Hydrology and Earth System Sciences, 13(6), 847-863. doi: 10.5194/hess-13-847. 2009

Erwin, M. L., and Hamilton, P. A. (2005). Monitoring our rivers and streams. Reston, Va.: U.S. Dept. of the Interior, U.S. Geological Survey.

Farmer, W. H., Archfield, S. A., Over, T. M., Hay, L. E., LaFontaine, J. H., and Kiang, J. E. (2015). A comparison of methods to predict historical daily streamflow time series in the Southeastern United States. Scientific Investigations Report. https://doi.org/10.3133/sir20145231.

Fenton, J. D., (2001), Rating Curves: Part 2-Representation and Approximation, Conference on Hydraulics in Civil Engineering, The Institution of Engineers, Australia, pp. 319-328.

Fitz, K.M., Johnson, B.R., and Walters, D.M. (2006). Field Operations Manual for Assessing the Hydrologic Permanence and Ecological Condition of Headwater Streams. EPA/R-06/126. U.S. Environmental Protection Agency, Office of Research and Development, Washington DC.

Franklin, P., Gee, E., Baker, C., and Bowie, S. (2018). New Zealand Fish Passage Guidelines: For Structures up to 4 meters. Aquatic Conservation Marine and Freshwater Ecosystems. DOI: $10.1002 /$ aqc.3049

Ghimire, B. N. and Reddy, M. J. (2010) Development of stage-discharge rating curve in the river using genetic algorithm and model tree. International Workshop Advanced in Statistical Hydrology, Italy.

Gordon, N.D., McMahon, T.A., and Finlayson, B.L. (1994). Stream Hydrology: An Introduction for Ecologists. John Wiley and Son, Chichester, United Kingdom. 
Gore, A., and Banning, J. (2017). Chapter 3 - Discharge Measurements and Streamflow Analysis. In F. R. Hauer and G. A. Lamberti (Eds.), Methods in Stream Ecology, Volume 1 (Third Edition) (pp. 49-70). Boston: Academic Press.

Harmel, R.D. and P.K. Smith. (2007). Consideration of measurement uncertainty in the evaluation of goodness-of-fit in hydrologic and water quality modeling. Journal of Hydrology 337:326-336

Harmel, R. D., Cooper, R. J., Slade, R. M., Haney, R. L., and Arnold, J. H. (2006). Cumulative uncertainty in measured streamflow and water quality data for small water sheds. Transactions of the ASABE, 49(3), 689-701. http://doi.org/10.13031/2013.20488.

Harrelson, C. C., Rawlins, C. L., and Potyondy, J. P. (1994). Stream channel reference sites: An illustrated guide to field technique. doi: 10.2737/rm-gtr-245.

Helsel, D. R., Hirsch, R. M. (1992). Statistical Methods in Water Resources, 1st ed. Elsevier: Amsterdam, The Netherlands. Volume 49; ISBN 978-0-08-087508-8.

Herschy, R. W. (1995). Streamflow Measurement ( $2^{\text {nd }}$ Edition). Taylor and Francis, London. 524pp. ISBN 0-419-19490-8.

Hirsch, R. M., and J. E. Costa (2004), U.S. streamflow measurement and data dissemination improve, Eos Trans. AGU,85(20),197-203.

Hodgkins, G. A., Dudley, R. W., Russell, A. M., and LaFontaine, J. H. (2020). Comparing trends in modeled and observed streamflows at minimally altered basins in the United States.

Water, 12(6), 1728. https://doi.org/10.3390/w12061728

Homer, C. G., Dewitz, J. A., Yang, L., Jin, S., Danielson, P., Xian, G., Coulston, J., Herold, N. D., Wickham, J. D., and Megown, K. (2015). Completion of the 2011 national land cover data-base for the conterminous United States-representing a de-cade of land cover change information. Photogrammetric Engineering and Remote Sensing, 81(5), 345-354.

Hooper, L. and Hubbart, J. A. (2016). A rapid physical habitat assessment of wadeable streams for mixed-land-use watersheds. Hydrology 3, 37.

Horne, J. P., and Hubbart, J. A. (2020). A Spatially Distributed Investigation of Stream Water Temperature in a Contemporary Mixed-Land-Use Watershed. https://doi.org/10.33915/etd.7741

Hubbart, J. A., Kellner, E., Hooper, L. W., and Zeiger, S. (2017) Quantifying loading, toxic concentrations, and systemic persistence of chloride in a contemporary mixed-landuse watershed using an experimental watershed approach. Sci Total Environ. 581:822832, https ://doi.org/10.1016/j.scito tenv.2017.01.019 
Hubbart, J. A. (2011). Urban floodplain management: understanding consumptive water use potential in urban forested floodplains. Stormwater Journal, 12(6), 56-57.

Hubbart, J. A. and Freeman, G. (2010). Sediment laser diffraction: a new approach to an old problem in the central US. Stormwater Journal, 11, 36-44.

Hubbart, J. A., Holmes, J., and Bowman, G. (2010). TMDLs: Improving stakeholder acceptance with science-based allocations. Watershed Sci Bull, 1, 19-24.

Hubbart, J. A., Link, T. E., Gravelle, J. A., and Elliot, W. J. (2007). Timber harvest impacts on water yield in the continental/maritime hydroclimatic region of the United States. Forest Science, 53(2), 169-180.

Jarrett, R. D. (1984). Hydraulics of high-gradient streams. Journal of Hydraulic Engineering, 110(11): 1519-1539

Kaufmann, P. R. and E. G. Robison. (1998). Physical habitat characterization. Environmental Monitoring and Assessment Program - Surface Waters: Field Operations and Methods for Measuring the Ecological Condition of Wadeable Streams. EPA/620/R-94/004F. U.S. Environmental Protection Agency, Washington, D.C., USA.

Kellner, E., and Hubbart, J. A. (2019). A method for advancing understanding of streamflow and geomorphological characteristics in mixed-land-use watersheds. Science of the Total Environment, 657, 634-643. doi: 10.1016/j.scitotenv.2018.12.070

Kellner, E., Hubbart, J., Stephan, K., Morrissey, E., Freedman, Z., Kutta, E., and Kelly, C. (2018). Characterization of sub-watershed-scale stream chemistry regimes in an Appalachian mixed-land-use watershed. Environmental Monitoring and Assessment, 190(10). doi: 586 10.1007/s10661-018-6968-9

Kellner, E., and Hubbart, J. A. (2017). Application of the experimental watershed approach to advance urban watershed precipitation/discharge understanding. Urban Ecosystems, 20(4), 799-810.

King, K. W., Arnold, J. G., and Bingner, R. L. (1999). Comparison of Green-Ampt and Curve Number Methods on Goodwin Creek Watershed Using Swat. Transactions of the ASAE, 42(4), 919-926. doi:10.13031/2013.13272.

Kutta, E., Hubbart, J. A., (2019a). Observed Mesoscale Hydroclimate Variability of North America’s Allegheny Mountains at 40.2॰ N. Climate 7, 1-24.

Kutta, E., and Hubbart, J. A. (2019b). Climatic Trends of West Virginia: A Representative Appalachian Microcosm. Water 11, 1117. https://doi.org/10.3390/w11061117 
Kutta, E., and Hubbart, J. A. (2018). Changing Climatic Averages and Variance: Implications for Mesophication at the Eastern Edge of North America's Eastern Deciduous Forest.

Forests, 9(10). doi: 605

$10.3390 / \mathrm{f} 9100605$

Laing, J. L. (1996). The Early Development of the Coal Industry in the Western Counties of Virginia, 1800-1815. West Virginia History. Volume 27, No. 2, 144-55

Leopold, L. B. (1968). Hydrology for urban land planning - A guidebook on the hydrologic effects of urban land-use. Circular. doi:10.3133/cir554

Loftis, C. L., MacDonoald, L. H., Streett, S., Iyer, H. K., and BUNTE, K. (2001). Detecting cumulative watershed effects: The statistical power of pairing. J. Hydrol. 251:49-64.

Marcus, W. A., Roberts, K., Harvey, L., \& Tackman, G. (1992). An evaluation of methods for estimating Manning's N in small mountain streams. Mountain Research and Development, 12(3), 227. https://doi.org/10.2307/3673667

Michaud, J. P. and Wierenga, M. (2005). Estimating Discharge and Streamflows: A Guide for Sand and Gravel Operations. Washington State Department of Ecology. 05-10-070.

Mooney, C. N. and Latimer, W. J. (1912). Soil survey of the Morgantown Area West Virginia. United States Department of Agriculture. Washington: Government Printing Office, 1912.

Mosley, M. P., and McKerchar, A. I. (1992). Streamflow. In: D. R. Maidment (Ed), Handbook of Hydrology. New York, NY: 8.1-8.39.

Nagel, D., Buffington, J.M., Isaak, D., (2010). Estimating Stream Gradient Using NHD Streamlines and DEM Data. ESRI International User Conference, July 12-16, San Diego, Ca.

Nagel D, Buffington J, Isaak D. (2006). Comparison of methods for estimating stream channel gradient using GIS. Boise, Idaho: USDA Forest Service, Rocky Mountain Research Station Boise Aquatic Sciences Lab.

Nichols, J., Hubbart, J. A., and Poulton, B. C. (2016). Using macroinvertebrate assemblages and multiple stressors to infer urban stream system condition: a case study in the central US. Urban Ecosystems, 19(2), 679-704.

Pan, F. F., Wang, C., and Xi, X. H. (2016). Constructing river stage-discharge rating curves using remotely sensed river cross-sectional inundation areas and river bathymetry. Journal of Hydrology, 540, 670-687. doi: 10.1016/j.jhydrol.2016.06.024 
Pappas, E. A., Smith, D. R., Huang, C., Shuster, W. D., and Bonta, J. V. (2008). Impervious surface impacts to runoff and sediment discharge under laboratory rainfall simulation. Catena, 72(1), 146-152. doi: 10.1016/j.catena.2007.05.001.

Peel, M.C., Finlayson, B.L., McMahon, T.A. (2007). Updated world map of the Köppen-Geiger climate classification. Hydrology and Earth System Sciences Discussions, 4(2), pp.439473.

Petersen, F., and Hubbart, J. A. (2020a). Spatial and temporal characterization of escherichia coli, suspended particulate matter and land use practice relationships in a mixed-land use contemporary watershed. Water, 12(5), 1228. https://doi.org/10.3390/w12051228

Petersen, F. and Hubbart, J. A. (2020b). Advancing Quantitative Understanding of Escherichia Coli Concentrations in a Contemporary Mixed Land-Use Watershed, in Advancing Quantitative Understanding of Escherichia Coli Concentrations in a Contemporary Mixed Land-Use Watershed. Water, 12(4), 1094. https://doi.org/10.3390/w12041094

Petersen, F., and Hubbart, J.A.(2020c) Quantifying Escherichia coli and Suspended Particulate Matter Concentrations in a Mixed-Land Use Appalachian Watershed. Water 2020, 12 , 532, doi:10.3390/w12020532.

Petersen, F., Hubbart, J. A., Kellner, E., and Kutta, E. (2018). Land-use-mediated Escherichia coli concentrations in a contemporary Appalachian watershed. [Article]. Environmental Earth Sciences, 77(22). doi: 754.10.1007/s12665-018-7948-7.

Phillips, J. C., and Eaton, B. C. (2009). Detecting the Timing of Morphologic Change Using Stage-Discharge Regressions: A Case Study at Fishtrap Creek, British Columbia, Canada. Canadian Water Resources Journal, 34(3), 285-299. doi: 10.4296/cwrj3403285

Poff, N. L., Bledsoe, B. P., and Cuhaciyan, C.O. (2006). Hydrologic variation with land-use across the contiguous United States: geomorphic and ecological consequences for stream ecosystems. Geomorphology, 79(3), 264-285.

Olson, S. A., and Norris, J. M. (2007). U.S. Geological Survey Streamgaging. National Streamflow Information Program. United States Geological Survey.

Rantz, S. E. et al. (1982a). Measurement and Computation of Streamflow: Vol. I, Measurement of Stage and Discharge. U.S. Geological Survey, Water Supply Paper 2175.

Rantz, S. E. et al (1982b). Measurement and Computation of Streamflow: Vol. II, Computation of discharge. U.S. Geological Survey,Water Supply Paper 2175.

Rehmel, M. (2007). Application of acoustic Doppler velocimeters for streamflow measurements. Journal of Hydraulic Engineering-Asce, 133(12), 1433-1438. doi: 10.1061/(asce)07339429(2007)133:12(1433). 
Riggs, H. C. (1976) A simplified slope-area method for estimating flood discharges in natural channels. J. Res. United States Geological Survey. 4: 285-291.

Rosgen, D. and Silvey, H. L. (1996). Applied River Morphology. Pagosa Springs: Wildland Hydrology.

Sivapragasam, C. and Muttil, N. (2005). Discharge Rating Curve Extension- A New Approach. Water Resource Management 19: 505-520.

Slade, R. M. (2004). General Methods, Information, and Sources for Collecting and Analyzing Water -Resources Data. CD-ROM. Copyright 2004 Raymond M. Slade, Jr.

Solinst. Barometric Compensation. (2018). Retrieved on De. 21, 2018 from https://www.solinst.com/products/dataloggersand-telemetry/3001-levelogger series/levelogger-edge/datasheet/barometriccompensation.php

SonTek/YSI. (2003). Retrieved on Dec. 21, 2018. Flowtracker handheld ADV principles Of operation, SonTek/YSI, San Diego.

Sunde, M. G., He, H. S., and Hubbart, J. A., Craig, S. (2016). Forecasting streamflow responses to increased imperviousness in an urbanizing Midwestern watershed using coupled modeling. Appl. Geography. 72,14-25.

Sunde, M. G., He, H. S., Hubbart, J. A., and Urban, M. A. (2018). An integrated modeling approach for estimating hydrologic responses to future urbanization and climate changes in a mixed-use midwestern watershed. Journal of Environmental Management, 220, 149162. doi: 10.1016/j.jenvman.2018.05.025

Thompson, D. (2007). The Rational Method, R.O. Anderson Engineering, Minden, Nevada. Available at: http://drdthompson.net/writings/rational.pdf.

Tukey. J. (1949). Comparing Individual Means in the Analysis of Variance. Biometrics. 5 (2):99114. JSTOR 3001913

Turnipseed, D. P., and Sauer, V. B. (2010), Discharge measurements at gaging stations in U.S. Geol. Surv. Tech. Methods, Book 3, Chapter A8,106 pp

United States Climate Data (USCD). Available online: http://usclimatedata.com/climate/morgantown/west-virginia/united states/uswv0507/2012/7 (accessed on November $3^{\text {rd }}, 2021$ )

USGS. (2019). How Streamflow is Measured. (n.d.). United States Geological Survey. Retrieved August 11, 2019, from https://www.usgs.gov/special-topic/water-science school/science/how-streamflow-measured?qt-science_center_objects=0\#qt science_center_objects. 
Uri, N. D. N. (2001) The environmental implications of soil erosion in the United States. Environmental Monitoring and Assessment, 66(3), 293-312.

Water Survey of Canada (WSC). (2015). Measuring Discharge with FlowTracker Acoustic Doppler Velocimeters. Environment Canada. Revision 4. qSOP-NA022-04-2015.

Walsh, C. J., Fletcher, T. D., and Burns, M.J. (2012). Urban stormwater runoff: A new class of environmental flow problems. PLoS One 7. 9. E45814.

Wahl, K. L., Thomas, W. O., and Hirsch, R. M. (1995). Overview of the Stream-Gauging Program. Retrieved March 25, 2019, from https://pubs.usgs.gov/circ/circ1123/overview.html.

West Virginia Geological and Economic Survey, Hennen, R. V., Reger, D. B., and White, I. C. (1913) County Reports and Maps, Marion, Monongalia, and Taylor counties. Wheeling, Wheeling news litho.

West Virginia Geologic and Economic Survey, 2009. Scanned Upper Freeport mine maps. Retrieved Dec. 19.2018, from: http://www.wvgs.wvnet.edu/www/coal/wvminemaps.htm.

West Virginia Water Research Institute, T. W. R. W. A. W. (2008). Watershed Based Plan for West Run of the Monongahela River. Retrieved Dec. 16, 2018, from https://dep.wv.gov/WWE/Programs/nonptsource/WBP/Documents/WP/WestRun_WBP.p df.

Willis I. C. (2011) Rating Curve. In: Singh V.P., Singh P., Haritashya U.K. (eds) Encyclopedia of Snow, Ice and Glaciers. Encyclopedia of Earth Sciences Series. Springer, Dordrecht.

Wohl, E. (2017). The significance of small streams. Front. Earth Science 11 (3). 447-456.

Wright, E.L., C.H. Delp, K. Sponaugle, C. Cole, J.T. Ammons, J. Gorman, and F.D. Childs. (1982). Soil Survey of Marion and Monongalia Counties, West Virginia. USDA Soil Conservation Service. U.S. Govt. Printing Office. Washington, D.C.

WVDEP. (2008). Water Quality Standards. Retrieved from https://dep.wv.gov/WWE/Programs/wqs/Pages/default.asx

Yadav, S. R., Singh, H. D., and Panda, J. (2017). Stage-Discharge Rating Curve for a Perennial River in Sikkim, India. Journal of Agroecology and Natural Resource Management. Volume 4, Issue 3. 238-242.

Zeiger, S. J., and Hubbart, J. A. (2019). Quantifying relationships between urban land-use and flow frequency of small Missouri streams. Science of the Total Environment, 659, 10081015. doi: 10.1016/j.scitotenv.2018.12.416 
Zeiger, S.J.; Hubbart, J.A. (2018). Quantifying land-use influences on event-based flow frequency, timing, magnitude, and rate of change in an urbanizing watershed of the central USA. Environ. Earth Sci. 77, 107.

Zeiger, S. and Hubbart, J. A. (2015). Urban stormwater temperature surges: a central US watershed study. Hydrology 2 (4), 193-209.

Zeiger, S. and Hubbart, J. A. (2016). Nested-scale nutrient flux in a mixed-land-use urbanizing watershed. Hydrol. Process. 30,1475-1490.

Zeiger, S., Hubbart, J. A., Anderson, S. H., and Stambaugh, M. C. (2016). Quantifying and modeling urban stream temperature: a central US watershed study. Hydrological Processes, 30(4), 503-514. 


\section{APPENDIX 1: Site 1}

Table A1-1. Streamflow measurements and stage collected at Site 1, West Run Watershed, Morgantown, WV, U.S.A. (Figure 2).

\begin{tabular}{|c|c|c|c|c|c|c|c|c|c|}
\hline Date & $\begin{array}{c}\text { Mean Depth of } \\
\text { Cross-Section } \\
\text { (m) }\end{array}$ & Stage (PT in cm) & $\begin{array}{c}\text { Barometric } \\
\text { Pressure (in cm) }\end{array}$ & $\begin{array}{c}\text { Pressure } \\
\text { Corrected Stage } \\
\text { (cm) }\end{array}$ & $\begin{array}{l}\text { Stilling Well } \\
\text { Offset }(\mathrm{cm})\end{array}$ & $\begin{array}{c}\text { P-Corrected } \\
\text { Stage + Offset } \\
\text { (cm) }\end{array}$ & $\begin{array}{c}\text { P-Corrected } \\
\text { Stage + Offset } \\
\text { (m) }\end{array}$ & $\begin{array}{c}\text { SonTec } \\
\text { Discharge }(\mathrm{m} 3 / \mathrm{s})\end{array}$ & $\begin{array}{l}\text { Rating Equation } \\
\text { Discharge }(\mathrm{m} 3 / \mathrm{s})\end{array}$ \\
\hline $12 / 2 / 2017$ & 0.0605 & 97.54 & 89.21 & 8.33 & 3.2 & 11.53 & 0.1153 & 0.0030 & 0.007007918 \\
\hline $1 / 2 / 2018$ & 0.0543 & 111.7 & 103.13 & 8.57 & 3.2 & 11.77 & 0.1177 & 0.0018 & 0.006176732 \\
\hline $1 / 9 / 2018$ & 0.0586 & 102.44 & 94.2 & 8.24 & 3.2 & 11.44 & 0.1144 & 0.0029 & 0.007334027 \\
\hline $1 / 23 / 2018$ & 0.1031 & 89.83 & 74.14 & 15.69 & 3.2 & 18.89 & 0.1889 & 0.0122 & 0.006949996 \\
\hline $3 / 8 / 2018$ & 0.0586 & 88.86 & 77.9 & 10.96 & 3.2 & 14.16 & 0.1416 & 0.0063 & 0.000950013 \\
\hline $3 / 29 / 2018$ & 0.0721 & 92.36 & 79.92 & 12.44 & 3.2 & 15.64 & 0.1564 & 0.0109 & 0.000493045 \\
\hline $4 / 4 / 2018$ & 0.1096 & 92.98 & 75.59 & 17.39 & 3.2 & 20.59 & 0.2059 & 0.0240 & 0.014411362 \\
\hline $4 / 20 / 2018$ & 0.0713 & 107.56 & 96.88 & 10.68 & 3.2 & 13.88 & 0.1388 & 0.0096 & 0.001275627 \\
\hline $7 / 16 / 2018$ & 0.0604 & 93.16 & 83.78 & 9.38 & 3.2 & 12.58 & 0.1258 & 0.0002 & 0.003784233 \\
\hline $7 / 23 / 2018$ & 0.0622 & 89.63 & 80.44 & 9.19 & 3.2 & 12.39 & 0.1239 & 0.0014 & 0.004288267 \\
\hline $7 / 23 / 2018$ & 0.0750 & 89.62 & 80.5 & 9.12 & 3.2 & 12.32 & 0.1232 & 0.0001 & 0.004482797 \\
\hline $7 / 25 / 2018$ & 0.0753 & 92.67 & 82.94 & 9.73 & 3.2 & 12.93 & 0.1293 & 0.0009 & 0.002947474 \\
\hline $7 / 25 / 2018$ & 0.0759 & 92.58 & 82.99 & 9.59 & 3.2 & 12.79 & 0.1279 & 0.0018 & 0.00326791 \\
\hline $8 / 30 / 2018$ & 0.0826 & 99.12 & 89.03 & 10.09 & 3.2 & 13.29 & 0.1329 & 0.0023 & 0.002210852 \\
\hline $8 / 30 / 2018$ & 0.0808 & 99.2 & 89.2 & 10 & 3.2 & 13.2 & 0.132 & 0.0020 & 0.002383214 \\
\hline 9/9/2018 & 0.2411 & 124.11 & 81.51 & 42.6 & 3.2 & 45.8 & 0.458 & 0.4256 & 0.454293868 \\
\hline $9 / 11 / 2018$ & 0.0805 & 104.55 & 89.4 & 15.15 & 3.2 & 18.35 & 0.1835 & 0.0085 & 0.005166946 \\
\hline $9 / 18 / 2018$ & 0.1199 & 97.2 & 81.83 & 15.37 & 3.2 & 18.57 & 0.1857 & 0.0111 & 0.005859208 \\
\hline $9 / 25 / 2018$ & 0.1890 & 119.74 & 92.1 & 27.64 & 3.2 & 30.84 & 0.3084 & 0.1151 & 0.118843419 \\
\hline $10 / 4 / 2018$ & 0.1006 & 94.54 & 85.3 & 9.24 & 3.2 & 12.44 & 0.1244 & 0.0026 & 0.00415223 \\
\hline $10 / 4 / 2018$ & 0.0930 & 94.33 & 85.13 & 9.2 & 3.2 & 12.4 & 0.124 & 0.0058 & 0.004260866 \\
\hline $10 / 30 / 2018$ & 0.0954 & 103.46 & 89.61 & 13.85 & 3.2 & 17.05 & 0.1705 & 0.0048 & 0.00203528 \\
\hline $12 / 17 / 2018$ & 0.0860 & 97.7 & 85.18 & 12.52 & 3.2 & 15.72 & 0.1572 & 0.0072 & 0.000528911 \\
\hline $12 / 31 / 2018$ & 0.1518 & 100.07 & 78.85 & 21.22 & 3.2 & 24.42 & 0.2442 & 0.0500 & 0.041500198 \\
\hline $12 / 31 / 2018$ & 0.1643 & 102.66 & 79.51 & 23.15 & 3.2 & 26.35 & 0.2635 & 0.0416 & 0.060545802 \\
\hline $1 / 23 / 2019$ & 0.0978 & 92.3 & 78.18 & 14.12 & 3.2 & 17.32 & 0.1732 & 0.0108 & 0.002550739 \\
\hline $2 / 12 / 2019$ & 0.1460 & 98.21 & 76.2 & 22.01 & 3.2 & 25.21 & 0.2521 & 0.0485 & 0.048858997 \\
\hline $3 / 25 / 2019$ & 0.1024 & 100.44 & 83.12 & 17.32 & 3.2 & 20.52 & 0.2052 & 0.0090 & 0.014048756 \\
\hline $4 / 2 / 2019$ & 0.0884 & 99.45 & 86.02 & 13.43 & 3.2 & 16.63 & 0.1663 & 0.0024 & 0.001374099 \\
\hline $4 / 12 / 2019$ & 0.1170 & 100.93 & 80.97 & 19.96 & 3.2 & 23.16 & 0.2316 & 0.0156 & 0.031016936 \\
\hline $7 / 5 / 2019$ & 0.4109 & 131.71 & 85.91 & 45.8 & 3.2 & 49.00 & 0.49 & 0.5284 & 0.55425031 \\
\hline $10 / 31 / 2019$ & 0.2567 & 103.61 & 70.71 & 32.9 & 3.2 & 36.10 & 0.361 & 0.2318 & 0.212027745 \\
\hline $12 / 17 / 2019$ & 0.1785 & 98 & 73.6 & 24.4 & 3.2 & 27.60 & 0.276 & 0.0669 & 0.074810146 \\
\hline $11 / 11 / 2020$ & 0.248 & 1022.4 & 996.41 & 26 & 3.2 & 29.20 & 0.292 & 0.102 & 0.095281518 \\
\hline $11 / 11 / 2020$ & 0.261 & 1024.9 & 996.45 & 28.5 & 3.2 & 31.70 & 0.317 & 0.1077 & 0.132242466 \\
\hline $4 / 29 / 2021$ & 0.237 & 1022.4 & 988.82 & 33.6 & 3.2 & 36.80 & 0.368 & 0.218 & 0.226453414 \\
\hline $4 / 29 / 2021$ & 0.221 & 1019.9 & 988.99 & 30.9 & 3.2 & 34.10 & 0.341 & 0.1502 & 0.173432221 \\
\hline $4 / 29 / 2021$ & 0.209 & 1016.2 & 989.26 & 26.9 & 3.2 & 30.10 & 0.301 & 0.1112 & 0.107888613 \\
\hline $8 / 16 / 2021$ & 0.251 & 1039 & 1002.48 & 36.5 & 3.2 & 39.70 & 0.397 & 0.2812 & 0.291283538 \\
\hline $8 / 16 / 2021$ & 0.228 & 1036.4 & 1002.56 & 33.8 & 3.2 & 37.00 & 0.37 & 0.251 & 0.23066239 \\
\hline $8 / 16 / 2021$ & 0.219 & 1034.2 & 1002.60 & 31.6 & 3.2 & 34.80 & 0.348 & 0.1842 & 0.186499022 \\
\hline $8 / 16 / 2021$ & 0.2 & 1034.2 & 1002.65 & 31.6 & 3.2 & 34.80 & 0.348 & 0.1606 & 0.186499022 \\
\hline $9 / 1 / 2021$ & 0.326 & 1028.3 & 988.24 & 40.1 & 3.2 & 43.30 & 0.433 & 0.4169 & 0.383118566 \\
\hline $9 / 1 / 2021$ & 0.287 & 1027.6 & 988.28 & 39.3 & 3.2 & 42.50 & 0.425 & 0.3957 & 0.361623688 \\
\hline $9 / 1 / 2021$ & 0.275 & 1026.6 & 988.34 & 38.3 & 3.2 & 41.50 & 0.415 & 0.3688 & 0.335628648 \\
\hline $9 / 1 / 2021$ & 0.234 & 1023 & 988.53 & 34.5 & 3.2 & 37.70 & 0.377 & 0.2469 & 0.24569955 \\
\hline $9 / 1 / 2021$ & 0.226 & 1022.7 & 988.36 & 34.3 & 3.2 & 37.50 & 0.375 & 0.2439 & 0.241354688 \\
\hline
\end{tabular}


Table A1-2. Modeled streamflow at Site 1, West Run Watershed, Morgantown, WV, U.S.A.

\begin{tabular}{|c|c|c|c|c|c|c|c|c|c|c|c|c|c|}
\hline $\begin{array}{c}\text { Cross- } \\
\text { Section } \\
\text { Area }\left(\mathrm{m}^{2}\right)\end{array}$ & $\begin{array}{l}\text { A (Cross } \\
\text { Section } \\
\text { area of } \\
\text { flow) } \mathrm{m}^{2}\end{array}$ & $\begin{array}{c}\text { P (Wetted } \\
\text { Perimeter } \\
\text { ) }\end{array}$ & $\begin{array}{c}\text { RH=A/P } \\
\text { Hydraulic } \\
\text { Radius } \\
\text { (m) }\end{array}$ & $\begin{array}{l}\text { Observed } \\
\text { Slope }(\mathrm{m})\end{array}$ & $\begin{array}{l}\text { Calculated } \\
\text { Slope using } \\
\text { ArcGIS (m) }\end{array}$ & $\begin{array}{c}\text { Roughness } \\
\text { Coefficient } \\
\text { (n) }\end{array}$ & $\begin{array}{c}\text { Manning } \\
\text { Discharge } \\
\left(\mathrm{m}^{3} / \mathrm{s}\right)(\text { Obs } \\
\text { Slope) }\end{array}$ & $\begin{array}{c}\text { Manning } \\
\text { Discharge } \\
\left(\mathrm{m}^{3} / \mathrm{s}\right) \text { (Calc } \\
\text { Slope) }\end{array}$ & $\begin{array}{c}\text { Chezy } \\
\text { Coefficient } \\
\text { (C) }\end{array}$ & $\begin{array}{c}\text { Chezy } \\
\text { Discharge } \\
\left(\mathrm{m}^{3} / \mathrm{s}\right) \text { (Obs } \\
\text { Slope) }\end{array}$ & $\begin{array}{c}\text { Chezy } \\
\text { Discharge } \\
\left(\mathrm{m}^{3} / \mathrm{s}\right) \text { (Calc } \\
\text { Slope) }\end{array}$ & $\begin{array}{c}\text { Dingman \& } \\
\text { Sharma } \\
\text { Discharge } \\
\left(\mathrm{m}^{3} / \mathrm{s}\right) \text { (Obs. } \\
\text { Slope) }\end{array}$ & $\begin{array}{c}\text { Dingman \& } \\
\text { Sharma } \\
\text { Discharge } \\
\left(\mathrm{m}^{3} / \mathrm{s}\right) \text { (Calc } \\
\text { Slope) }\end{array}$ \\
\hline 4.79 & 0.061 & 1.5484 & 0.039716 & 0.025 & 0.07 & 0.165 & 0.00685975 & 0.01147855 & 3.54005725 & 0.006859746 & 0.01147855 & 0.011851463 & 0.013826519 \\
\hline 4.79 & 0.065 & 1.5586 & 0.041913 & 0.025 & 0.07 & 0.165 & 0.00755331 & 0.012639113 & 3.57197146 & 0.007553314 & 0.012639113 & 0.012998837 & 0.015165105 \\
\hline 4.79 & 0.060 & 1.5445 & 0.038885 & 0.025 & 0.07 & 0.165 & 0.00660574 & 0.011053518 & 3.52760095 & 0.00660574 & 0.011053518 & 0.011430342 & 0.013335219 \\
\hline 4.79 & 0.179 & 1.8388 & 0.097319 & 0.025 & 0.07 & 0.165 & 0.03628062 & 0.060709087 & 4.11038344 & 0.036280619 & 0.060709087 & 0.059373727 & 0.069268411 \\
\hline 4.79 & 0.103 & 1.6575 & 0.062422 & 0.025 & 0.07 & 0.165 & 0.0156018 & 0.0261068 & 3.81715276 & 0.015601797 & 0.0261068 & 0.026143338 & 0.030500149 \\
\hline 4.79 & 0.127 & 1.7163 & 0.074045 & 0.025 & 0.07 & 0.165 & 0.02147366 & 0.035932302 & 3.92734524 & 0.021473658 & 0.035932302 & 0.035625823 & 0.041562898 \\
\hline 4.79 & 0.206 & 1.8992 & 0.108506 & 0.025 & 0.07 & 0.165 & 0.04492423 & 0.075172611 & 4.18560511 & 0.044924228 & 0.075172611 & 0.073181967 & 0.085377806 \\
\hline 4.79 & 0.098 & 1.5146 & 0.064704 & 0.025 & 0.07 & 0.165 & 0.01513553 & 0.025326581 & 3.84005469 & 0.015135527 & 0.025326581 & 0.024885709 & 0.029032934 \\
\hline 4.79 & 0.073 & 1.3394 & 0.054502 & 0.025 & 0.07 & 0.165 & 0.01005582 & 0.016826598 & 3.73179819 & 0.010055816 & 0.016826598 & 0.016448008 & 0.019189083 \\
\hline 4.79 & 0.08 & 1.4192 & 0.05637 & 0.025 & 0.07 & 0.165 & 0.01127043 & 0.018859029 & 3.75281469 & 0.011270425 & 0.018859029 & 0.018561526 & 0.021654821 \\
\hline 4.79 & 0.097 & 1.4452 & 0.067119 & 0.025 & 0.07 & 0.165 & 0.0153516 & 0.02568814 & 3.86358098 & 0.0153516 & 0.02568814 & 0.024951194 & 0.029109332 \\
\hline 4.79 & 0.109 & 1.5988 & 0.068176 & 0.025 & 0.07 & 0.165 & 0.01743147 & 0.029168436 & 3.87365955 & 0.017431475 & 0.029168436 & 0.028788882 & 0.033586575 \\
\hline 4.79 & 0.11 & 1.6 & 0.06875 & 0.025 & 0.07 & 0.165 & 0.01768997 & 0.02960099 & 3.87907497 & 0.017689975 & 0.02960099 & 0.029196667 & 0.034062317 \\
\hline 4.79 & 0.12 & 1.6012 & 0.074944 & 0.025 & 0.07 & 0.165 & 0.02044048 & 0.034203464 & 3.93524703 & 0.02044048 & 0.034203464 & 0.033469131 & 0.039046792 \\
\hline 4.79 & 0.118 & 1.6132 & 0.073147 & 0.025 & 0.07 & 0.165 & 0.01977716 & 0.033093519 & 3.91935879 & 0.01977716 & 0.033093519 & 0.032498677 & 0.037914611 \\
\hline 4.79 & 0.625 & 3.0734 & 0.203358 & 0.025 & 0.07 & 0.165 & 0.20711268 & 0.346565808 & 4.6475729 & 0.207112684 & 0.346565808 & 0.345734092 & 0.403350984 \\
\hline 4.79 & 0.129 & 1.7612 & 0.073246 & 0.025 & 0.07 & 0.165 & 0.02164029 & 0.036211135 & 3.92024216 & 0.021640292 & 0.036211135 & 0.036099794 & 0.042115856 \\
\hline 4.79 & 0.177 & 1.9546 & 0.090556 & 0.025 & 0.07 & 0.165 & 0.03420342 & 0.057233274 & 4.06133317 & 0.034203423 & 0.057233274 & 0.05695205 & 0.06644316 \\
\hline 4.79 & 0.417 & 2.5878 & 0.161141 & 0.025 & 0.07 & 0.165 & 0.11832931 & 0.198002814 & 4.47078323 & 0.118329314 & 0.198002814 & 0.195962199 & 0.228619473 \\
\hline 4.79 & 0.115 & 1.3442 & 0.085553 & 0.025 & 0.07 & 0.165 & 0.02139636 & 0.035802956 & 4.02304645 & 0.021396359 & 0.035802956 & 0.03357088 & 0.039165496 \\
\hline 4.79 & 0.106 & 1.3292 & 0.079747 & 0.025 & 0.07 & 0.165 & 0.01881925 & 0.031490626 & 3.97620388 & 0.018819249 & 0.031490626 & 0.029664741 & 0.034608397 \\
\hline 4.79 & 0.138 & 1.639 & 0.084198 & 0.025 & 0.07 & 0.165 & 0.02540379 & 0.042508677 & 4.01235556 & 0.025403793 & 0.042508677 & 0.041311294 & 0.048195857 \\
\hline 4.79 & 0.15 & 1.9246 & 0.077938 & 0.025 & 0.07 & 0.165 & 0.02622675 & 0.04388575 & 3.96102745 & 0.026226752 & 0.04388575 & 0.044169851 & 0.051530795 \\
\hline 4.79 & 0.263 & 1.9234 & 0.136737 & 0.025 & 0.07 & 0.165 & 0.06689072 & 0.111929591 & 4.35007834 & 0.066890724 & 0.111929591 & 0.106864417 & 0.124673467 \\
\hline 4.79 & 0.258 & 1.9288 & 0.133762 & 0.025 & 0.07 & 0.165 & 0.06466373 & 0.108203121 & 4.33415868 & 0.064663733 & 0.108203121 & 0.103569885 & 0.120829897 \\
\hline 4.79 & 0.142 & 1.6438 & 0.086385 & 0.025 & 0.07 & 0.165 & 0.02659096 & 0.044495183 & 4.02954445 & 0.026590958 & 0.044495183 & 0.043159912 & 0.050352549 \\
\hline 4.79 & 0.245 & 1.968 & 0.124492 & 0.025 & 0.07 & 0.165 & 0.05853462 & 0.097947154 & 4.28258726 & 0.05853462 & 0.097947154 & 0.094715005 & 0.110499344 \\
\hline 4.79 & 0.156 & 1.729 & 0.090226 & 0.025 & 0.07 & 0.165 & 0.0300721 & 0.050320245 & 4.05886235 & 0.030072098 & 0.050320245 & 0.049038544 & 0.057210861 \\
\hline 4.79 & 0.115 & 1.472 & 0.078125 & 0.025 & 0.07 & 0.165 & 0.02013928 & 0.03369946 & 3.96260753 & 0.020139279 & 0.03369946 & 0.032373164 & 0.037768181 \\
\hline 4.79 & 0.17 & 1.6822 & 0.101058 & 0.025 & 0.07 & 0.165 & 0.03534401 & 0.059141844 & 4.13629277 & 0.035344012 & 0.059141844 & 0.056756509 & 0.066215032 \\
\hline 4.79 & 0.72 & 2.2696 & 0.317237 & 0.025 & 0.07 & 0.165 & 0.3209278 & 0.537014923 & 5.00510568 & 0.3209278 & 0.537014923 & 0.487612536 & 0.568873595 \\
\hline 4.79 & 0.43 & 2.1894 & 0.196401 & 0.025 & 0.07 & 0.165 & 0.13922485 & 0.232967725 & 4.62068766 & 0.139224845 & 0.232967725 & 0.219880345 & 0.256523598 \\
\hline 4.79 & 0.286 & 1.957 & 0.146142 & 0.025 & 0.07 & 0.165 & 0.07603885 & 0.12723734 & 4.39857421 & 0.076038854 & 0.12723734 & 0.121087138 & 0.141266416 \\
\hline 4.79 & 0.416 & 2.172 & 0.191529 & 0.025 & 0.07 & 0.165 & 0.13245501 & 0.221639628 & 4.60138219 & 0.132455012 & 0.221639628 & 0.209392178 & 0.24428757 \\
\hline 4.79 & 0.417 & 2.122 & 0.196513 & 0.025 & 0.07 & 0.165 & 0.13506699 & 0.226010308 & 4.62112626 & 0.135066993 & 0.226010308 & 0.212151661 & 0.247506923 \\
\hline 4.79 & 0.398 & 2.15 & 0.185116 & 0.025 & 0.07 & 0.165 & 0.12387934 & 0.207289779 & 4.57534125 & 0.123879337 & 0.207289779 & 0.196115203 & 0.228797975 \\
\hline 4.79 & 0.354 & 2.042 & 0.173359 & 0.025 & 0.07 & 0.165 & 0.10546807 & 0.176481839 & 4.52557719 & 0.105468072 & 0.176481839 & 0.1665062 & 0.194254606 \\
\hline 4.79 & 0.335 & 2.018 & 0.166006 & 0.025 & 0.07 & 0.165 & 0.09696462 & 0.162252842 & 4.49300253 & 0.096964619 & 0.162252842 & 0.153390192 & 0.178952803 \\
\hline 4.79 & 0.40181 & 2.102 & 0.191156 & 0.025 & 0.07 & 0.165 & 0.12777096 & 0.213801708 & 4.59988945 & 0.127770959 & 0.213801708 & 0.200882505 & 0.234359752 \\
\hline 4.79 & 0.34723 & 1.98 & 0.175369 & 0.025 & 0.07 & 0.165 & 0.10424886 & 0.174441716 & 4.53427717 & 0.104248865 & 0.174441716 & 0.16352924 & 0.190781532 \\
\hline 4.79 & 0.33329 & 1.962 & 0.169873 & 0.025 & 0.07 & 0.165 & 0.0979619 & 0.163921611 & 4.51027756 & 0.097961899 & 0.163921611 & 0.153882922 & 0.179527647 \\
\hline 4.79 & 0.30542 & 1.924 & 0.158742 & 0.025 & 0.07 & 0.165 & 0.08580484 & 0.143578965 & 4.45962276 & 0.085804843 & 0.143578965 & 0.135186172 & 0.157715067 \\
\hline 4.79 & 0.57106 & 2.405 & 0.237447 & 0.025 & 0.07 & 0.165 & 0.20983547 & 0.351121905 & 4.7691813 & 0.209835473 & 0.351121905 & 0.330890974 & 0.386034247 \\
\hline 4.79 & 0.48135 & 2.25 & 0.213933 & 0.025 & 0.07 & 0.165 & 0.16499319 & 0.276086406 & 4.68700912 & 0.164993186 & 0.276086406 & 0.259721966 & 0.303004861 \\
\hline 4.79 & 0.46045 & 2.226 & 0.206851 & 0.025 & 0.07 & 0.165 & 0.15432635 & 0.258237375 & 4.66078363 & 0.154326349 & 0.258237375 & 0.24324647 & 0.283783709 \\
\hline 4.79 & 0.37393 & 2.068 & 0.180817 & 0.025 & 0.07 & 0.165 & 0.11457844 & 0.191726393 & 4.5574581 & 0.114578435 & 0.191726393 & 0.18057163 & 0.210664051 \\
\hline 4.79 & 0.34374 & 1.976 & 0.173957 & 0.025 & 0.07 & 0.165 & 0.10264668 & 0.17176074 & 4.52817544 & 0.102646675 & 0.17176074 & 0.161081514 & 0.18792589 \\
\hline
\end{tabular}




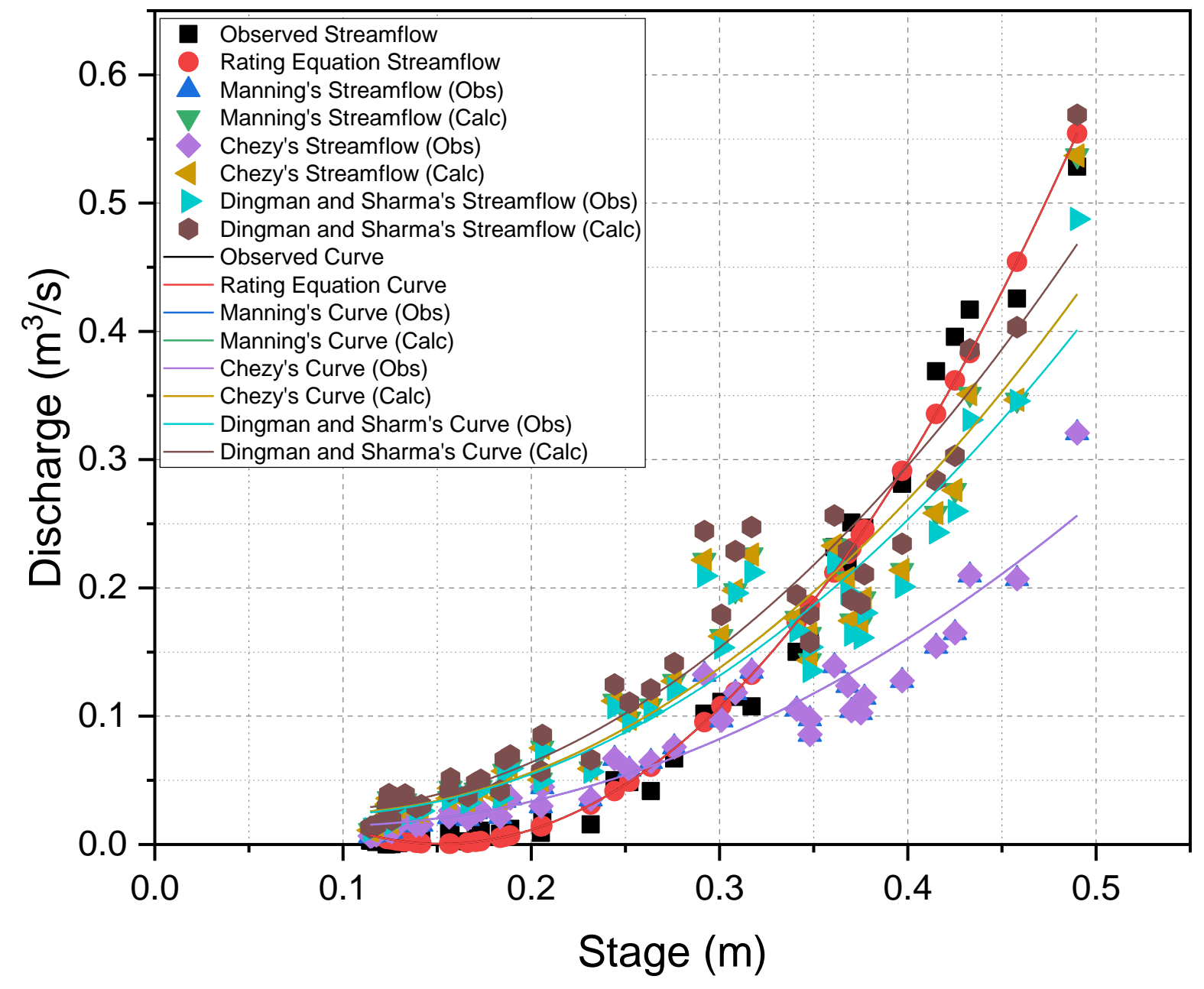

Figure A1-1. Observed and modeled rating curves and streamflow from Site 1, West Run Watershed, Morgantown, West Virginia, U.S.A. 
Table A1-3. Polynomial rating equations and $\mathrm{R}^{2}$ values for observed and modeled rating curves at Site 1, West Run Watershed, Morgantown, WV, U.S.A.

\begin{tabular}{ccc}
\hline & $\begin{array}{c}\mathbf{R}^{\mathbf{2}} \\
\text { Value }\end{array}$ & Polynomial Equation \\
\hline Observed Curve & 0.99 & $\mathrm{y}=4.8531 \mathrm{x}^{2}-1.4771 \mathrm{x}+0.1128$ \\
Manning's Curve (Obs Slope) & 0.92 & $\mathrm{y}=1.4828 \mathrm{x}^{2}-0.2545 \mathrm{x}+0.0252$ \\
Manning's Curve (Calc Slope) & 0.92 & $\mathrm{y}=2.4812 \mathrm{x}^{2}-0.4259 \mathrm{x}+0.0421$ \\
$\begin{array}{c}\text { Chezy's Curve (Obs Slope) } \\
\text { Chezy's Curve (Calc Slope) }\end{array}$ & 0.92 & $\mathrm{y}=1.4828 \mathrm{x}^{2}-0.2545 \mathrm{x}+0.0252$ \\
$\begin{array}{c}\text { Dingman and Sharma's Curve } \\
\text { (Obs Slope) }\end{array}$ & 0.92 & $\mathrm{y}=2.4812 \mathrm{x}^{2}-0.4259 \mathrm{x}+0.0421$ \\
$\begin{array}{c}\text { Dingman and Sharma's Curve } \\
\text { (Calc Slope) }\end{array}$ & 0.92 & $\mathrm{y}=2.2489 \mathrm{x}^{2}-0.3577 \mathrm{x}+0.0365$ \\
\hline
\end{tabular}

Table A1-4. Descriptive statistics for observed and modeled streamflow used to generate the rating curves for Site 1, West Run Watershed, Morgantown, WV, U.S.A.

\begin{tabular}{|c|c|c|c|c|}
\hline & Sample Size & Mean $\left(\mathbf{m}^{3} / \mathbf{s}\right)$ & St. Dev. & SE of Mean \\
\hline Observed & 47 & 0.104 & 0.142 & 0.021 \\
\hline Manning's & 47 & 0.071 & 0.067 & 0.01 \\
\hline \multicolumn{5}{|l|}{$\begin{array}{l}\text { Curve (Obs } \\
\text { Slope) }\end{array}$} \\
\hline \multirow{2}{*}{\multicolumn{5}{|c|}{$\begin{array}{c}\text { Curve (Calc } \\
\text { Slope) }\end{array}$}} \\
\hline & & & & \\
\hline $\begin{array}{c}\text { Chezy's Curve } \\
\text { (Obs Slope) }\end{array}$ & 47 & 0.071 & 0.067 & 0.01 \\
\hline $\begin{array}{c}\text { Chezy's Curve } \\
\text { (Calc Slope) }\end{array}$ & 47 & 0.119 & 0.113 & 0.016 \\
\hline $\begin{array}{l}\text { Dingman and } \\
\text { Sharma's } \\
\text { Curve (Obs } \\
\text { Slope) }\end{array}$ & 47 & 0.113 & 0.105 & 0.015 \\
\hline $\begin{array}{l}\text { Dingman and } \\
\text { Sharma's } \\
\text { Curve (Calc } \\
\text { Slope) }\end{array}$ & 47 & 0.132 & 0.123 & 0.018 \\
\hline
\end{tabular}


Table A1-5. P-values of the statistical analyses (post-hoc ANOVA) for observed and modeled rating curves at Site 1, West Run Watershed, Morgantown, WV, U.S.A.

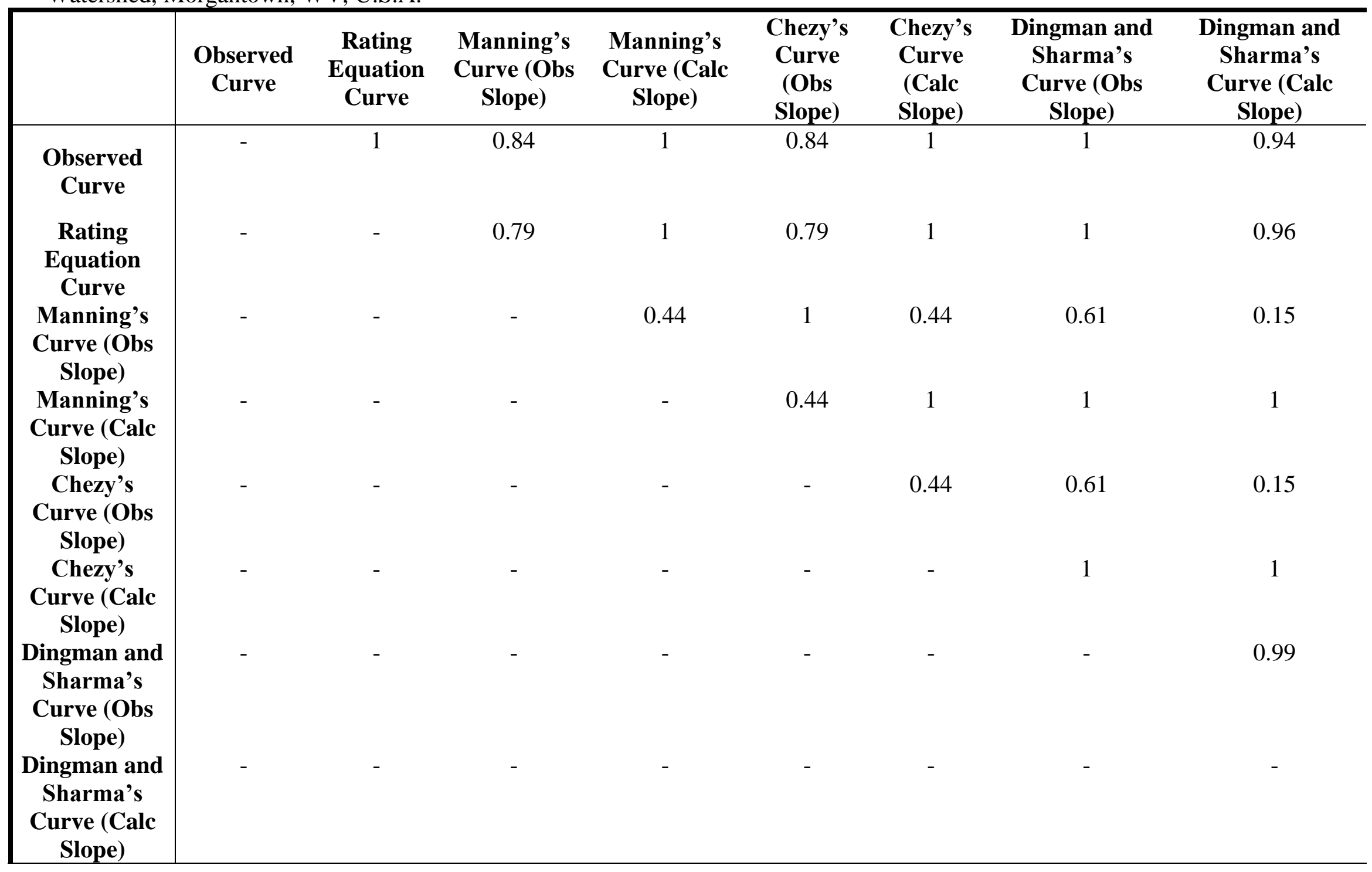




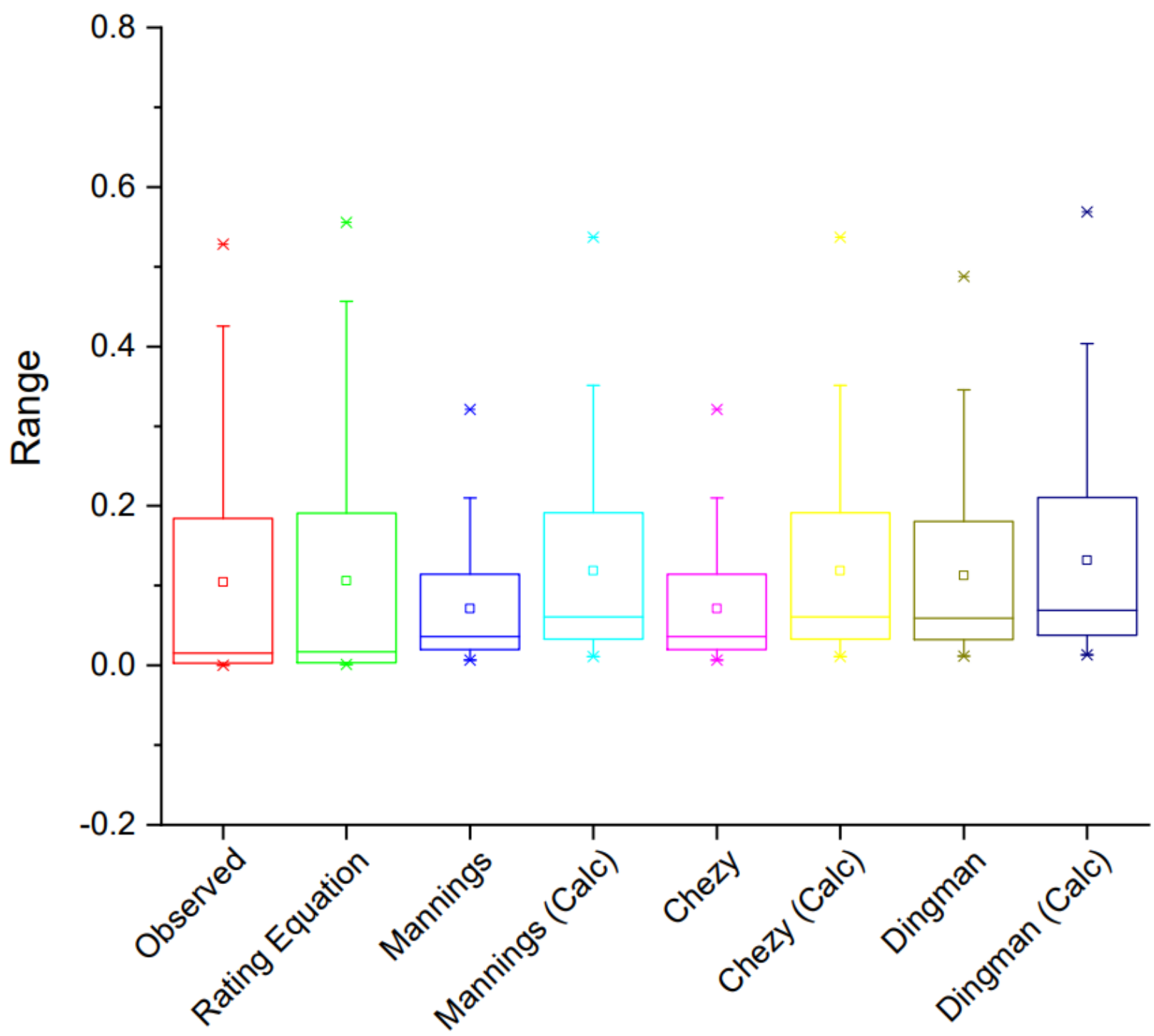

Figure A1-2. Box and whisker plots for the results of the statistical analyses ( post-hoc ANOVA) of observed and modeled rating curves at Site 1, West Run Watershed, Morgantown, WV, U.S.A. 


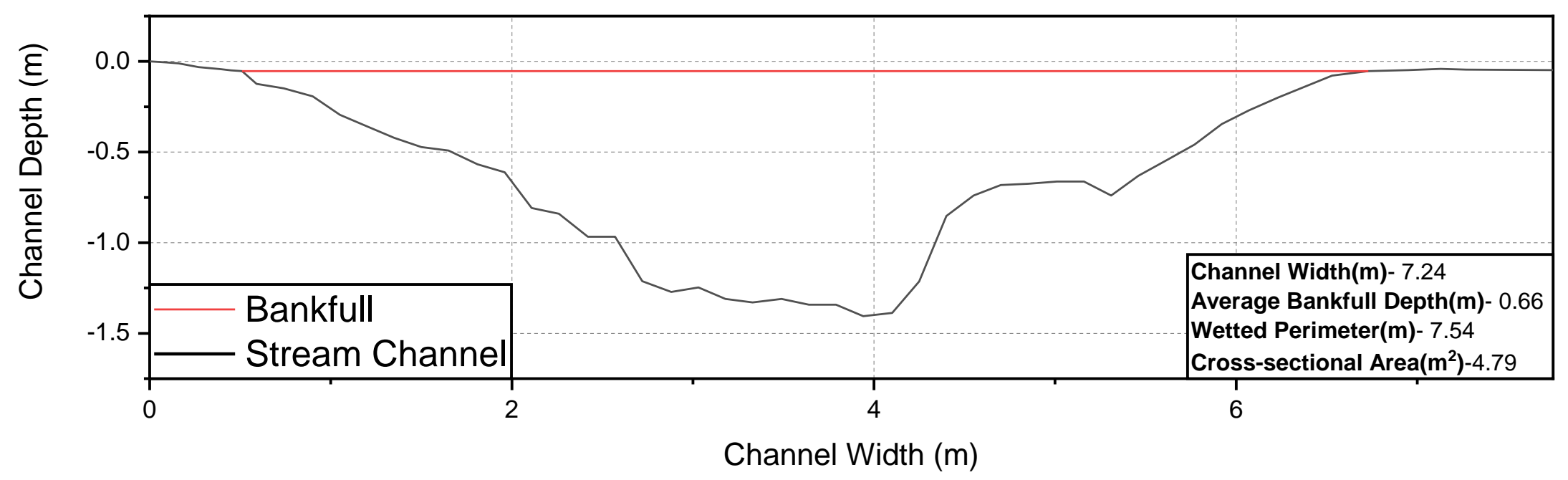

Figure A1-3. Cross-sectional profile of WRW Site 1, West Run Watershed, Morgantown, WV, U.S.A. (Figure 2). Channel Width of zero (0) represents the left bank facing downstream. 


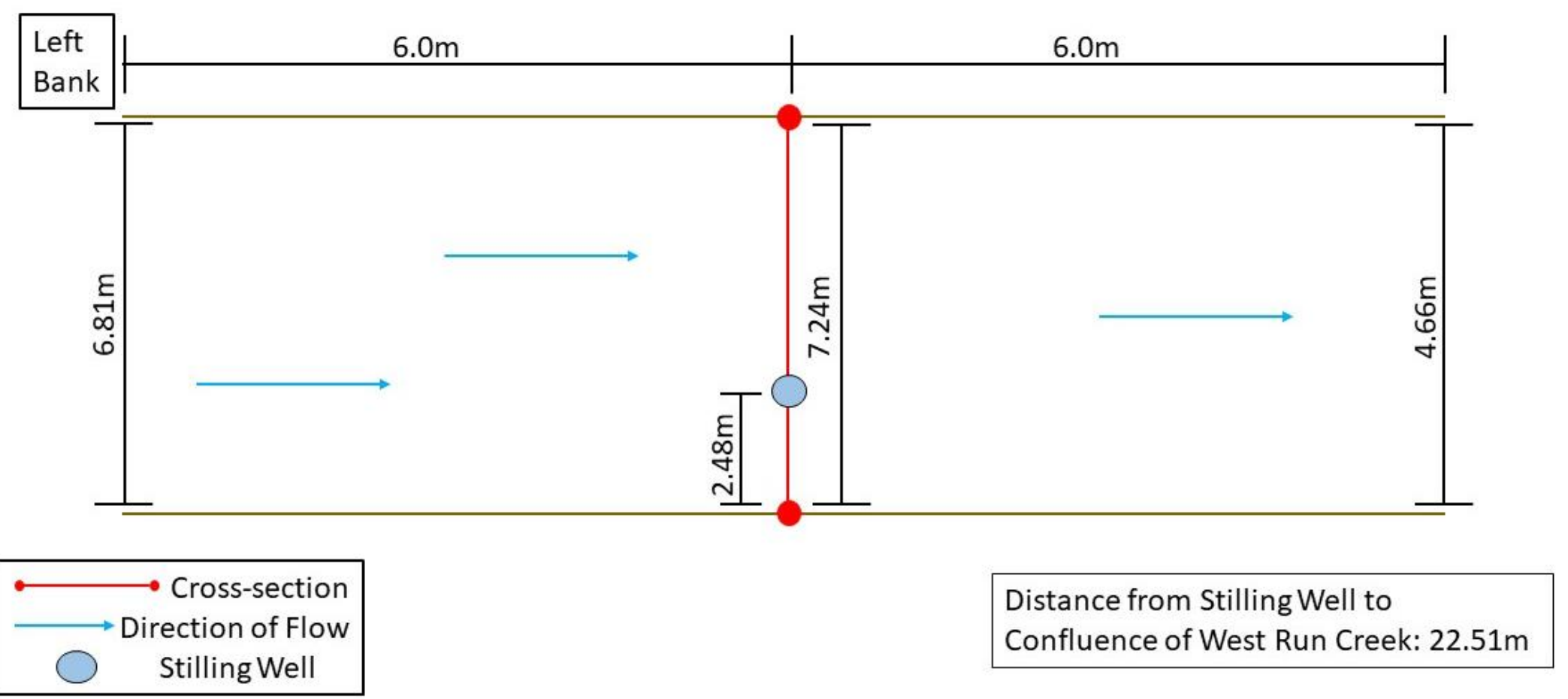

Figure A1-4. Plan view profile of WRW Site 1, West Run Watershed, Morgantown, WV, U.S.A. (Figure 2). Showing the positioning of stilling well in relation to where the streamflow was measured. Along with the channel width at the stilling well, point where crosssections were performed, and $6.0 \mathrm{~m}$ upstream and downstream from the stilling well. 


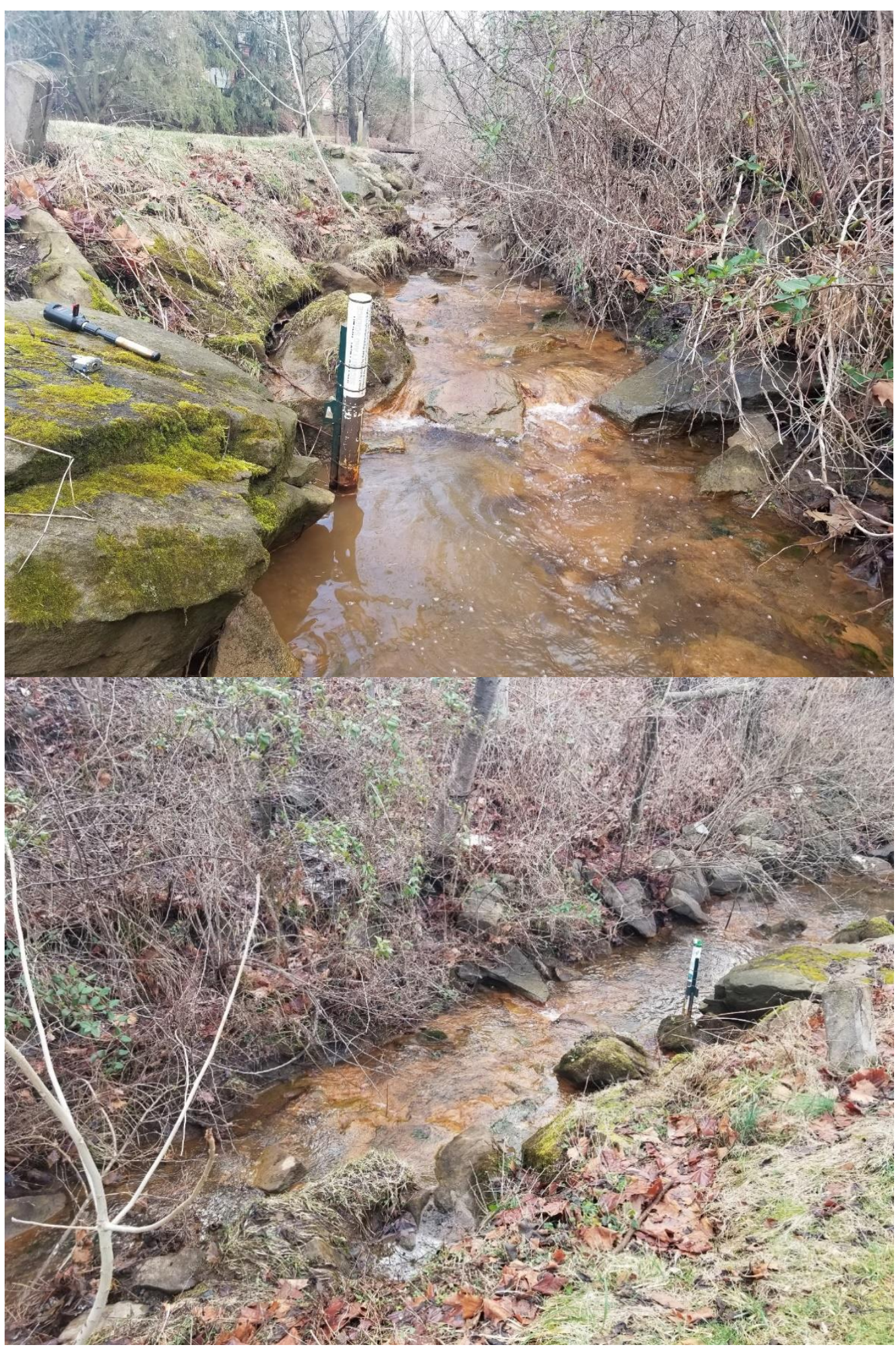

Figure A1-5. Photographs showing channel characteristics at Site \#1, West Run Watershed, Morgantown, WV, U.S.A. Photo 1 was taken looking upstream in the channel. Photo 2 was taken from the right bank looking downstream. 


\section{APPENDIX 2: Site 2}

Table A2-1. Streamflow measurements and stage collected at Site 2, West Run Watershed, Morgantown, WV, U.S.A. (Figure 2).

\begin{tabular}{|c|c|c|c|c|c|c|c|c|c|}
\hline Date & $\begin{array}{l}\text { Mean Depth of } \\
\text { Cross-Section } \\
\text { (m) }\end{array}$ & Stage(PT in cm) & $\begin{array}{c}\text { Barometric } \\
\text { Pressure (in } \mathrm{cm} \text { ) }\end{array}$ & $\begin{array}{c}\text { Pressure } \\
\text { Corrected Stage } \\
\text { (cm) }\end{array}$ & $\begin{array}{l}\text { Stilling Well } \\
\text { Offset (cm) }\end{array}$ & $\begin{array}{l}\text { P-Corrected } \\
\text { Stage + Offset } \\
\text { (cm) }\end{array}$ & $\begin{array}{l}\text { P-Corrected } \\
\text { Stage + Offset } \\
\text { (m) }\end{array}$ & $\begin{array}{c}\text { SonTec } \\
\text { Discharge }(\mathrm{m} 3 / \mathrm{s})\end{array}$ & $\begin{array}{l}\text { Rating Equation } \\
\text { Discharge }(\mathrm{m} 3 / \mathrm{s})\end{array}$ \\
\hline $1 / 23 / 2018$ & 0.0838 & 89.43 & 74.32 & 15.11 & 3.2 & 18.31 & 0.1831 & 0.0045 & 0.003430333 \\
\hline $3 / 8 / 2018$ & 0.0838 & 93.01 & 77.92 & 15.09 & 3.2 & 18.29 & 0.1829 & 0.0038 & 0.003416232 \\
\hline $3 / 29 / 2018$ & 0.0889 & 98.04 & 80.06 & 17.98 & 3.2 & 21.18 & 0.2118 & 0.0152 & 0.009730639 \\
\hline $4 / 4 / 2018$ & 0.1283 & 90.15 & 66.91 & 23.24 & 3.2 & 26.44 & 0.2644 & 0.0598 & 0.04332784 \\
\hline $8 / 30 / 2018$ & 0.0869 & 103.43 & 89.11 & 14.32 & 3.2 & 17.52 & 0.1752 & 0.0026 & 0.003186995 \\
\hline 9/11/2018 & 0.0823 & 106.69 & 90.11 & 16.58 & 3.2 & 19.78 & 0.1978 & 0.0089 & 0.005596152 \\
\hline 9/18/2018 & 0.1049 & 100.49 & 81.82 & 18.67 & 3.2 & 21.87 & 0.2187 & 0.0207 & 0.012511941 \\
\hline $9 / 25 / 2018$ & 0.1625 & 114.53 & 90.95 & 23.58 & 3.2 & 26.78 & 0.2678 & 0.0488 & 0.046481282 \\
\hline $10 / 4 / 2018$ & 0.0820 & 98.78 & 85.16 & 13.62 & 3.2 & 16.82 & 0.1682 & 0.0022 & 0.003509181 \\
\hline $10 / 4 / 2018$ & 0.0799 & 98.61 & 85.1 & 13.51 & 3.2 & 16.71 & 0.1671 & 0.0022 & 0.003605753 \\
\hline $10 / 18 / 2018$ & 0.0899 & 113.51 & 100.2 & 13.31 & 3.2 & 16.51 & 0.1651 & 0.0037 & 0.003813307 \\
\hline $10 / 18 / 2018$ & 0.0857 & 113.88 & 100.33 & 13.55 & 3.2 & 16.75 & 0.1675 & 0.0015 & 0.003569192 \\
\hline $10 / 30 / 2018$ & 0.0878 & 108.32 & 89.82 & 18.5 & 3.1 & 21.57 & 0.2157 & 0.0034 & 0.01124235 \\
\hline $12 / 17 / 2018$ & 0.1067 & 101.6 & 82.2 & 19.4 & 3.1 & 22.47 & 0.2247 & 0.0126 & 0.015329561 \\
\hline $12 / 31 / 2018$ & 0.1021 & 96.63 & 77.46 & 19.17 & 3.1 & 22.24 & 0.2224 & 0.0125 & 0.014205593 \\
\hline $1 / 17 / 2019$ & 0.0765 & 104.83 & 88.81 & 16.02 & 3.1 & 19.09 & 0.1909 & 0.0040 & 0.004302031 \\
\hline $1 / 23 / 2019$ & 0.0902 & 95.66 & 77.94 & 17.72 & 3.1 & 20.79 & 0.2079 & 0.0050 & 0.008375783 \\
\hline $1 / 23 / 2019$ & 0.0972 & 95.12 & 77.02 & 18.1 & 3.1 & 21.17 & 0.2117 & 0.0044 & 0.00969394 \\
\hline 2/12/2019 & 0.1509 & 99.76 & 76.11 & 23.65 & 3.1 & 26.72 & 0.2672 & 0.0563 & 0.04591613 \\
\hline 2/12/2019 & 0.1521 & 98.7 & 75.7 & 23 & 3.1 & 26.07 & 0.2607 & 0.0500 & 0.04003161 \\
\hline $3 / 25 / 2019$ & 0.0817 & 96.88 & 83.02 & 13.86 & 3.1 & 16.93 & 0.1693 & 0.0024 & 0.003425087 \\
\hline 4/2/2019 & 0.0704 & 99.16 & 86.1 & 13.06 & 3.1 & 16.13 & 0.1613 & 0.0021 & 0.004321305 \\
\hline 4/12/2019 & 0.0832 & 96 & 80.54 & 15.46 & 3.1 & 18.53 & 0.1853 & 0.0025 & 0.003612671 \\
\hline $7 / 5 / 2019$ & 0.1731 & 111.87 & 85.88 & 25.99 & 3.1 & 29.06 & 0.2906 & 0.0637 & 0.070708059 \\
\hline 10/31/2019 & 0.1716 & 95.36 & 70.91 & 24.45 & 3.1 & 27.55 & 0.2755 & 0.0452 & 0.054063609 \\
\hline $12 / 17 / 2019$ & 0.2107 & 97.08 & 73.68 & 23.4 & 3.1 & 26.5 & 0.2650 & 0.0641 & 0.043875668 \\
\hline $3 / 1 / 2021$ & 0.21 & 1024.3 & 997.28 & 27 & 3.1 & 30.1 & 0.3010 & 0.0772 & 0.083539236 \\
\hline $3 / 1 / 2021$ & 0.211 & 1023.5 & 997.19 & 26.3 & 3.1 & 29.4 & 0.2940 & 0.0622 & 0.074780147 \\
\hline $3 / 1 / 2021$ & 0.209 & 1023.5 & 997.09 & 26.4 & 3.1 & 29.5 & 0.2950 & 0.0735 & 0.076000508 \\
\hline $3 / 1 / 2021$ & 0.199 & 1023.6 & 997.35 & 26.3 & 3.1 & 29.4 & 0.2940 & 0.0711 & 0.074780147 \\
\hline $3 / 1 / 2021$ & 0.2 & 1023.7 & 997.46 & 26.2 & 3.1 & 29.3 & 0.2930 & 0.0687 & 0.073570099 \\
\hline $3 / 1 / 2021$ & 0.201 & 1022.4 & 997.52 & 24.9 & 3.1 & 28 & 0.2800 & 0.0705 & 0.05877792 \\
\hline $8 / 16 / 2021$ & 0.342 & 1049.7 & 1003.71 & 46 & 3.1 & 49.1 & 0.4910 & 0.5136 & 0.51428626 \\
\hline $8 / 16 / 2021$ & 0.327 & 1048 & 1003.58 & 44.4 & 3.1 & 47.5 & 0.4750 & 0.4616 & 0.463657688 \\
\hline $8 / 16 / 2021$ & 0.293 & 1042.2 & 1003.04 & 39.2 & 3.1 & 42.3 & 0.4230 & 0.3046 & 0.317347503 \\
\hline $8 / 16 / 2021$ & 0.251 & 1039.8 & 1002.74 & 37.1 & 3.1 & 40.2 & 0.4020 & 0.2325 & 0.266165305 \\
\hline $8 / 16 / 2021$ & 0.235 & 1035.4 & 1002.61 & 32.8 & 3.1 & 35.9 & 0.3590 & 0.1302 & 0.1755538 \\
\hline $9 / 1 / 2021$ & 0.299 & 1023.9 & 988.06 & 35.8 & 3.1 & 38.9 & 0.3890 & 0.2518 & 0.236760172 \\
\hline $9 / 1 / 2021$ & 0.299 & 1024.4 & 988.02 & 36.4 & 3.1 & 39.5 & 0.3950 & 0.2852 & 0.250115208 \\
\hline 9/1/2021 & 0.323 & 1027.3 & 988.01 & 39.3 & 3.1 & 42.4 & 0.4240 & 0.367 & 0.319898189 \\
\hline 9/1/2021 & 0.315 & 1027.3 & 988.01 & 39.3 & 3.1 & 42.4 & 0.4240 & 0.3488 & 0.319898189 \\
\hline $9 / 1 / 2021$ & 0.308 & 1027.7 & 988.04 & 39.7 & 3.1 & 42.8 & 0.4280 & 0.3097 & 0.330204059 \\
\hline 9/1/2021 & 0.299 & 1027.7 & 988.03 & 39.7 & 3.1 & 42.8 & 0.4280 & 0.3079 & 0.330204059 \\
\hline
\end{tabular}


Table A2-2. Modeled streamflow at Site 2, West Run Watershed, Morgantown, WV, U.S.A.

\begin{tabular}{|c|c|c|c|c|c|c|c|c|c|c|c|c|c|}
\hline $\begin{array}{c}\text { Cross- } \\
\text { Section } \\
\text { Area }\left(\mathrm{m}^{2}\right)\end{array}$ & $\begin{array}{c}\text { A (Cross } \\
\text { Section } \\
\text { area of } \\
\text { flow) }\end{array}$ & $\begin{array}{c}\text { P } \\
\text { (Wetted } \\
\text { Perimete } \\
\text { r) }\end{array}$ & $\begin{array}{c}\mathrm{RH}=\mathrm{A} / \mathrm{P} \\
\text { Hydraulic } \\
\text { Radius (m) }\end{array}$ & $\begin{array}{l}\text { Observed } \\
\text { Slope }(m)\end{array}$ & $\begin{array}{l}\text { Calculated } \\
\text { Slope using } \\
\text { ArcGIS (m) }\end{array}$ & $\begin{array}{c}\text { Roughness } \\
\text { Coefficient } \\
\text { (n) }\end{array}$ & $\begin{array}{c}\text { Manning } \\
\text { Discharge } \\
\left(\mathrm{m}^{3} / \mathrm{s}\right) \text { (Obs } \\
\text { Slope) }\end{array}$ & $\begin{array}{c}\text { Manning } \\
\text { Discharge } \\
\left(\mathrm{m}^{3} / \mathrm{s}\right) \text { (Calc } \\
\text { Slope) }\end{array}$ & $\begin{array}{c}\text { Chezy } \\
\text { Coefficient } \\
\text { (C) }\end{array}$ & $\begin{array}{c}\text { Chezy } \\
\text { Discharge } \\
\left(\mathrm{m}^{3} / \mathrm{s}\right)(\text { Obs } \\
\text { Slope) }\end{array}$ & $\begin{array}{c}\text { Chezy } \\
\text { Discharge } \\
\left(\mathrm{m}^{3} / \mathrm{s}\right) \text { (Calc } \\
\text { Slope) }\end{array}$ & $\begin{array}{c}\text { Dingman \& } \\
\text { Sharma } \\
\text { Discharge } \\
\text { (m } \mathrm{m}^{3} / \mathrm{s} \text { ) (Obs. } \\
\text { Slope) }\end{array}$ & $\begin{array}{c}\text { Dingman \& } \\
\text { Sharma } \\
\text { Discharge } \\
\text { ( } \mathrm{m}^{3} / \mathrm{s} \text { ) (Calc } \\
\text { Slope) }\end{array}$ \\
\hline 3.28 & 0.170 & 1.8176 & 0.093361354 & 0.061 & 0.11 & 0.14 & 0.061608467 & 0.082731676 & 4.810975601 & 0.061608467 & 0.082731676 & 0.062889454 & 0.067421054 \\
\hline 3.28 & 0.169 & 1.8168 & 0.093223501 & 0.061 & 0.11 & 0.14 & 0.061432045 & 0.082494767 & 4.809790931 & 0.061432045 & 0.082494767 & .062713651 & 0.067232583 \\
\hline 3.28 & 0.215 & 1.9196 & 0.112257697 & 0.061 & 0.11 & 0.14 & 0.088465848 & 0.118797436 & 4.961061977 & 0.088465848 & 0.118797436 & 0.089602216 & 0.096058647 \\
\hline 3.28 & 0.299 & 2.0882 & 0.143390475 & 0.061 & 0.11 & 0.14 & 144714383 & 0.194331464 & 5.167637188 & 0.144714383 & 0.194331464 & 0.145352649 & 0.155826266 \\
\hline 3.28 & 0.099 & 1.3168 & 0.07518226 & 0.061 & 0.11 & 0.14 & 0.031111121 & 0.041777946 & 4.640426096 & 0.031111121 & 0.041777946 & 0.0306512 & 0.032859821 \\
\hline 3.28 & 0.094 & 3078 & 0.071876434 & 0.061 & 0.11 & 0.14 & 0.028667451 & 0.038496435 & 4.605778531 & 0.028667451 & 0.038496435 & 0.028329234 & 0.030370542 \\
\hline 3.28 & 0.128 & 1.427 & 0.089698669 & 0.061 & 0.11 & 0.14 & 0.0452485 & 0.060762496 & 4.778991929 & 0.0452485 & 0.060762496 & 0.044462404 & 0.047666213 \\
\hline 3.28 & 0.21 & 1.62 & 0.12962963 & 0.061 & 0.11 & 0.14 & 0.094891147 & 0.127425728 & 5.081469748 & 0.094891147 & 0.127425728 & 0.092080187 & 0.098715171 \\
\hline 3.28 & 0.094 & 1.307 & 0.071920428 & 0.061 & 0.11 & 0.14 & 0.028679148 & 0.038512142 & 4.606248269 & 0.028679148 & 0.038512142 & 0.028336168 & 0.030377976 \\
\hline 3.28 & 0.091 & 3026 & 0.069860279 & 0.061 & 0.11 & 0.14 & 027231098 & 0.03656761 & 4.583990238 & 0.027231098 & 0.03656761 & 0.026963044 & 0.02890591 \\
\hline 3.28 & 0.109 & 1.3986 & 0.077935078 & 0.061 & 0.11 & 0.14 & 0.035084775 & 0.047114016 & 4.668321884 & 0.035084775 & 0.047114016 & 0.034810937 & 0.037319295 \\
\hline 3.28 & 0.105 & 1.3904 & 0.075517837 & 0.061 & 0.11 & 0.14 & 0.033094758 & 0.044441697 & 4.643871789 & 0.033094758 & 0.044441697 & 0.032900016 & 0.035270679 \\
\hline 3.28 & 0.1 & 3182 & 0.075861023 & 0.061 & 0.11 & 0.14 & 031614235 & 0.042453559 & 4.647382444 & 0.031614235 & 0.042453559 & 0.031126388 & 0.033369249 \\
\hline 3.28 & 0.122 & 1.3564 & 0.089943969 & 0.061 & 0.11 & 0.14 & 0.043206068 & 0.058019792 & 4.781167653 & 0.043206068 & 0.058019792 & 0.042073646 & 0.04510533 \\
\hline 3.28 & 0.132 & 1.4994 & 0.088035214 & 0.061 & 0.11 & 0.14 & 046083816 & 0.06188421 & 4.76410548 & 0.046083816 & 0.06188421 & 0.045752733 & 0.049049519 \\
\hline 3.28 & 0.087 & 296 & 0.06712963 & 061 & 0.11 & & 025351226 & 034043201 & 4.5536293 & 0.025351226 & 0.034043201 & 0.025173467 & 0.026987381 \\
\hline 3.28 & 0.11 & 1.3994 & 0.078605116 & 0.061 & 0.11 & 0.14 & 0.035609301 & 0.047818381 & 4.67498728 & 0.035609301 & 0.047818381 & 0.035306543 & 0.037850612 \\
\hline 3.28 & 0.118 & 4134 & 0.083486628 & 0.061 & 0.11 & 0.14 & 0.03976462 & 0.053398402 & 4.722168187 & 0.03976462 & 0.053398402 & 0.039272234 & 0.042102058 \\
\hline 3.28 & 0.242 & 9018 & 12724787 & .061 & 0.11 & & 108007172 & 145038741 & 5.065788473 & 0.108007172 & 0.145038741 & 0.107943596 & 0.115 \\
\hline 3.28 & 0.243 & 1.904 & 0.12762605 & 0.061 & 0.11 & 0.14 & 0.108668259 & 0.145926489 & 5.068294621 & 0.108668259 & 0.145926489 & 0.108595827 & 0.116420873 \\
\hline 3.28 & 0.093 & 306 & 0.071209801 & 061 & 0.11 & 0.14 & 028186837 & 0.037851036 & 4.598631321 & 0.028186837 & 0.037851036 & 0.027871969 & 0.029880328 \\
\hline 3.28 & 0.092 & 2838 & .071662253 & 0.061 & 0.11 & 0.14 & .02800174 & 0.037602476 & 4.603488264 & 0.02800174 & 0.037602476 & 0.027590562 & 0.029578644 \\
\hline 3.28 & 0.095 & 1.3096 & 0.072541234 & 0.061 & 0.11 & 0.14 & 0.029150798 & 0.039145502 & 4.612851292 & 0.029150798 & 0.039145502 & 0.028788896 & 0.030863326 \\
\hline 3.28 & 0.264 & 87 & 141176471 & 061 & 0.11 & & 126274509 & 0.169569256 & 5.15425243 & 0.126274509 & 0.169569256 & 0.124614214 & 0.133593489 \\
\hline 3.28 & 0.275 & 432 & .141519144 & 061 & & & 13174871 & 176920352 & 5.15633545 & 0.13174871 & 0.176920352 & 0.130853268 & 140282109 \\
\hline 3.28 & 0.321 & 1.9454 & 0.165004626 & 0.061 & 0.11 & 0.14 & 0.170361973 & 0.228772641 & 5.289987565 & 0.170361973 & 0.228772641 & 0.166820761 & .178841297 \\
\hline 3.28 & 0.316 & 9386 & 0.16300423 & 061 & 0.11 & 0.14 & 166350157 & 0.223385325 & 5.279244507 & 0.166350157 & 0.223385325 & 0.162979786 & .174723555 \\
\hline 3.28 & 0.321 & 9454 & 165004626 & .061 & 0.11 & 0.14 & 170361973 & 228772641 & 5.289987565 & 0.170361973 & 0.228772641 & 0.166820761 & 341297 \\
\hline 3.28 & 0.302 & 1.865 & 161930295 & 0.061 & 0.11 & 0.14 & 0.158281162 & 0.212549777 & 5.273431578 & 0.158281162 & 0.212549777 & 0.154134775 & .165241202 \\
\hline 3.28 & 0.288 & 8458 & 156029906 & 061 & & 0.14 & 0.147254282 & 0.197742199 & 5.240908836 & 0.147254282 & 0.197742199 & 0.143638802 & 0.153988925 \\
\hline 3.28 & 0.275 & .7728 & 0.155121841 & 0.061 & 0.11 & 0.14 & 140061318 & 0.18808304 & 5.235812948 & 0.140061318 & 0.18808304 & 0.135746199 & 0.145527607 \\
\hline 3.28 & 0.26 & 1.6966 & 0.153247672 & 0.061 & 0.11 & 0.14 & 0.131352846 & 0.176388762 & 5.225216367 & 0.131352846 & 0.176388762 & 0.126486023 & .135600175 \\
\hline 3.28 & 0.57251 & & 0.242588983 & & & & 392856559 & 0.527552193 & 5.640926963 & 0.392856559 & 0.527552193 & 0.383662388 & .411307793 \\
\hline 3.28 & 0.53652 & 2.292 & 0.23408377 & 0.061 & 0.11 & 0.14 & 0.35950395 & 0.482764238 & 5.607472875 & 0.35950395 & 0.482764238 & 0.350488721 & .375743745 \\
\hline 3.28 & 0.48019 & 2.224 & 0.21591277 & 0.061 & 0.11 & 0.14 & 0.30488464 & 0.409418036 & 5.532460889 & 0.30488464 & 0.409418036 & 0.297940922 & .319409531 \\
\hline 3.28 & 0.41052 & & 0.191831776 & & & & 240889701 & 0.323481656 & 5.424487617 & 0.240889701 & 0.323481656 & 0.236445266 & 0.253482707 \\
\hline 3.28 & 0.37626 & 2.07 & .181768116 & 0.061 & 0.11 & 0.14 & .212995324 & 0.286023354 & 5.37598748 & 0.212995324 & 0.286023354 & 0.208917978 & 0.223971895 \\
\hline 3.28 & 0.52374 & 2.351 & 222773288 & 0.061 & 0.11 & 0.14 & .339542938 & 0.455959351 & 5.561378882 & 0.339542938 & 0.455959351 & 0.334032912 & .358102186 \\
\hline 3.28 & 0.52432 & & 223019991 & & & & .340169864 & 0.456801226 & 5.562404873 & 0.340169864 & 0.456801226 & 0.334614973 & .358726188 \\
\hline 3.28 & 0.57774 & 2.437 & 0.237070168 & 0.061 & 0.11 & 0.14 & 0.390409692 & 0.524266389 & 5.619333172 & 0.390409692 & 0.524266389 & 0.384223708 & .411909559 \\
\hline 3.28 & 0.56439 & 2.421 & 233122677 & 0.061 & 0.11 & 0.14 & 0.377142845 & 0.506450842 & 5.603629132 & 0.377142845 & 0.506450842 & 0.371327904 & 0.398084528 \\
\hline 3.28 & 0.55074 & & 0.228807644 & 0.061 & & 0.1 & 0.363466053 & 0.488084797 & 5.58620736 & 0.363466053 & 0.488084797 & 0.358129292 & 0.383934869 \\
\hline 3.28 & 0.52316 & 2.351 & 0.222526584 & 0.061 & 0.11 & 0.14 & 0.338916475 & 0.455118098 & 5.560351945 & 0.338916475 & 0.455118098 & 0.333451221 & 0.357478581 \\
\hline
\end{tabular}




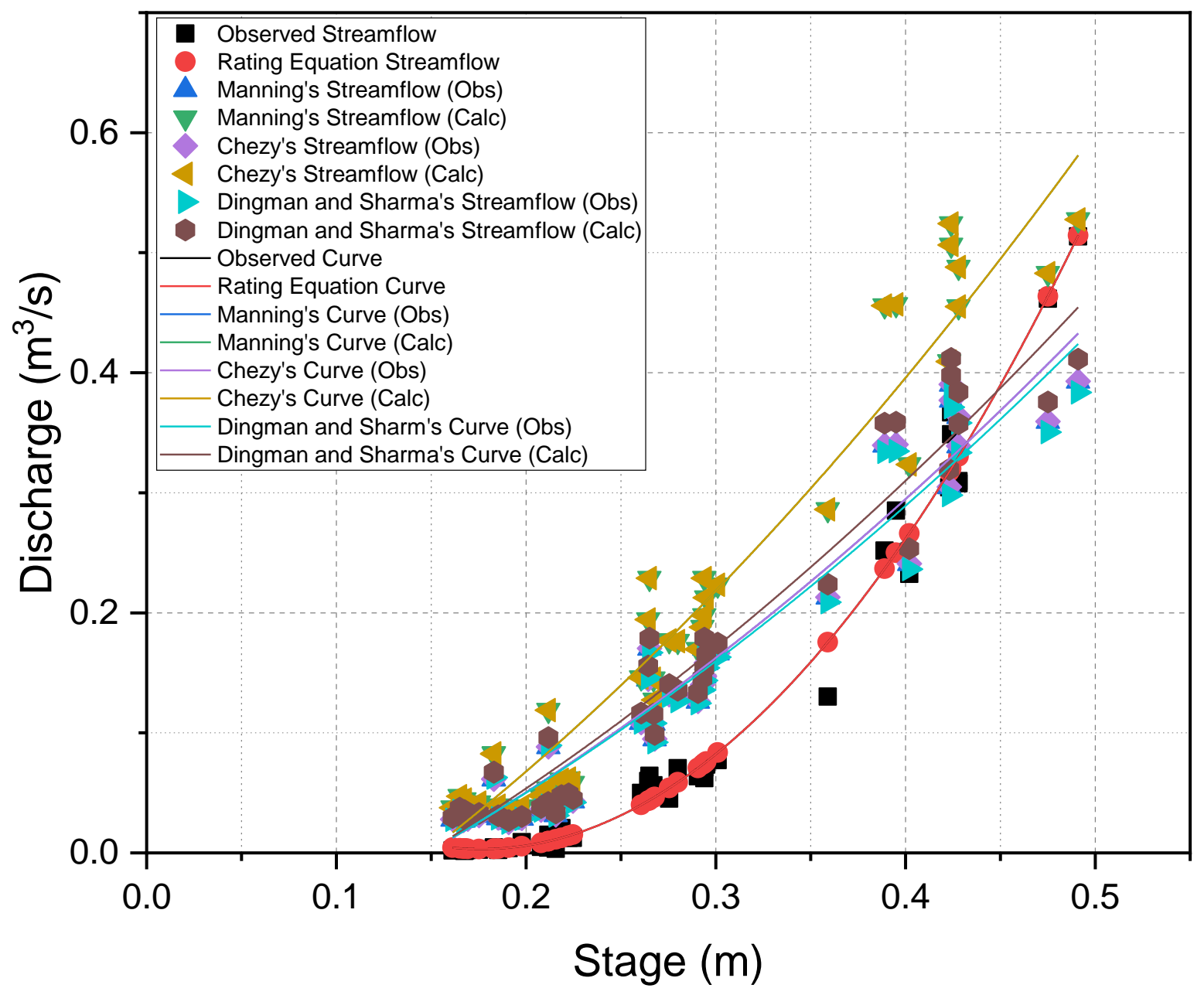

Figure A2-1. Observed and modeled rating curves and streamflow from Site 2, West Run Watershed, Morgantown, West Virginia, U.S.A 
Table A2-3. Polynomial rating equations and $\mathrm{R}^{2}$ values for observed and modeled rating curves at Site 2, West Run Watershed, Morgantown, WV, U.S.A.

\begin{tabular}{ccc}
\hline & $\begin{array}{c}\mathbf{R}^{\mathbf{2}} \\
\text { Value }\end{array}$ & Polynomial Equation \\
\hline $\begin{array}{c}\text { Observed Curve } \\
\text { Manning's Curve (Obs Slope) }\end{array}$ & 0.99 & $\mathrm{y}=5.1563 \mathrm{x}^{2}-1.8167 \mathrm{x}+0.1632$ \\
Manning's Curve (Calc Slope) & 0.95 & $\mathrm{y}=1.015 \mathrm{x}^{2}+0.6122 \mathrm{x}-0.1125$ \\
Chezy's Curve (Obs Slope) & 0.95 & $\mathrm{y}=1.363 \mathrm{x}^{2}+0.8221 \mathrm{x}-0.1511$ \\
Chezy's Curve (Calc Slope) & 0.95 & $\mathrm{y}=1.015 \mathrm{x}^{2}+0.6122 \mathrm{x}-0.1125$ \\
$\begin{array}{c}\text { Dingman and Sharma's Curve } \\
\text { (Obs Slope) }\end{array}$ & 0.94 & $\mathrm{y}=1.363 \mathrm{x}^{2}+0.8221 \mathrm{x}-0.1511$ \\
$\begin{array}{c}\text { Dingman and Sharma's Curve } \\
\text { (Calc Slope) }\end{array}$ & 0.94 & $\mathrm{y}=0.9841 \mathrm{x}^{2}+0.605 \mathrm{x}-0.1103$ \\
& & $\mathrm{y}=1.055 \mathrm{x}^{2}+0.6486 \mathrm{x}-0.1182$ \\
\hline
\end{tabular}

Table A2-4. Descriptive statistics for observed and modeled streamflow used to generate the rating curves for Site 2, West Run Watershed, Morgantown, WV, U.S.A.

\begin{tabular}{|c|c|c|c|c|}
\hline & Sample Size & Mean $\left(\mathrm{m}^{3} / \mathrm{s}\right)$ & St. Dev. & SE of Mean \\
\hline Observed & 43 & 0.103 & 0.140 & 0.021 \\
\hline Manning's & 43 & 0.144 & 0.124 & 0.019 \\
\hline $\begin{array}{l}\text { Curve (Obs } \\
\text { Slope) }\end{array}$ & & & & \\
\hline $\begin{array}{c}\text { Manning's } \\
\text { Curve (Calc } \\
\text { Slope) }\end{array}$ & 43 & 0.193 & 0.167 & 0.025 \\
\hline $\begin{array}{c}\text { Chezy's Curve } \\
\text { (Obs Slope) }\end{array}$ & 43 & 0.144 & 0.124 & 0.019 \\
\hline $\begin{array}{c}\text { Chezy's Curve } \\
\text { (Calc Slope) }\end{array}$ & 43 & 0.193 & 0.167 & 0.025 \\
\hline $\begin{array}{l}\text { Dingman and } \\
\text { Sharma's } \\
\text { Curve (Obs } \\
\text { Slope) }\end{array}$ & 43 & 0.142 & 0.122 & 0.019 \\
\hline $\begin{array}{l}\text { Dingman and } \\
\text { Sharma's } \\
\text { Curve (Calc } \\
\text { Slope) }\end{array}$ & 43 & 0.152 & 0.130 & 0.020 \\
\hline
\end{tabular}


Table A2-5. P-values of the statistical analyses (post-hoc ANOVA) for observed and modeled rating curves at Site 2, West Run Watershed, Morgantown, WV, U.S.A.

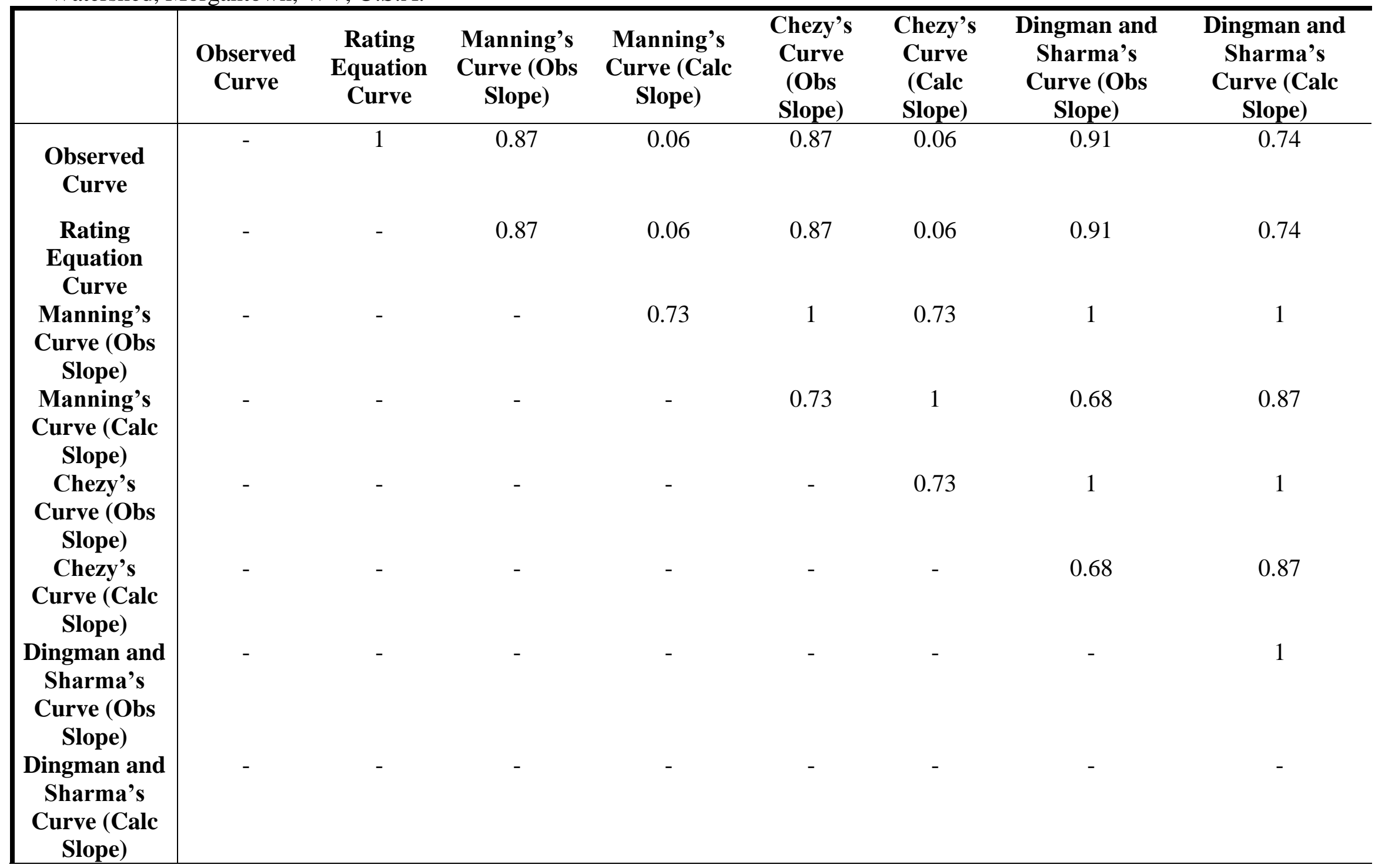




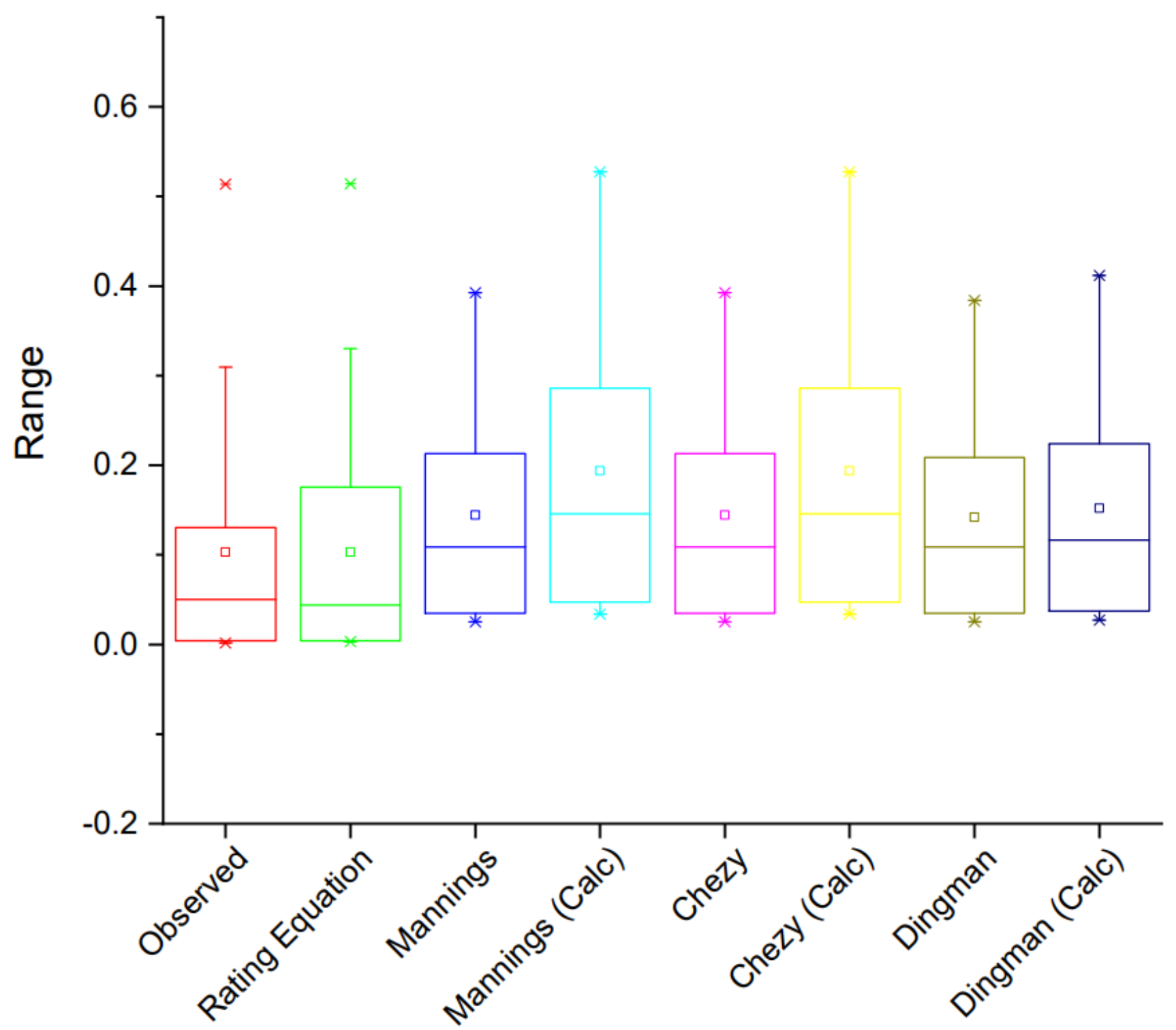

Figure A2-2. Box and whisker plots for the results of the statistical analyses (post-hoc ANOVA) of observed and modeled rating curves at Site 2, West Run Watershed, Morgantown, WV, U.S.A. 


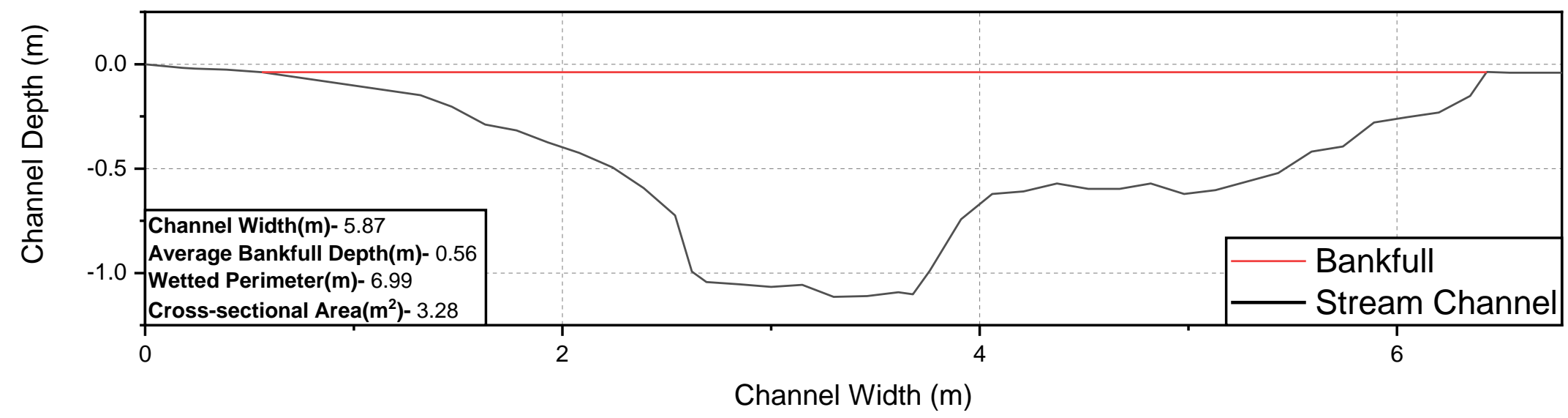

Figure A2-3. Cross-sectional profile of WRW Site 2, West Run Watershed, Morgantown, WV, USA (Figure 2). Channel Width of zero (0) represents the left bank facing downstream. 


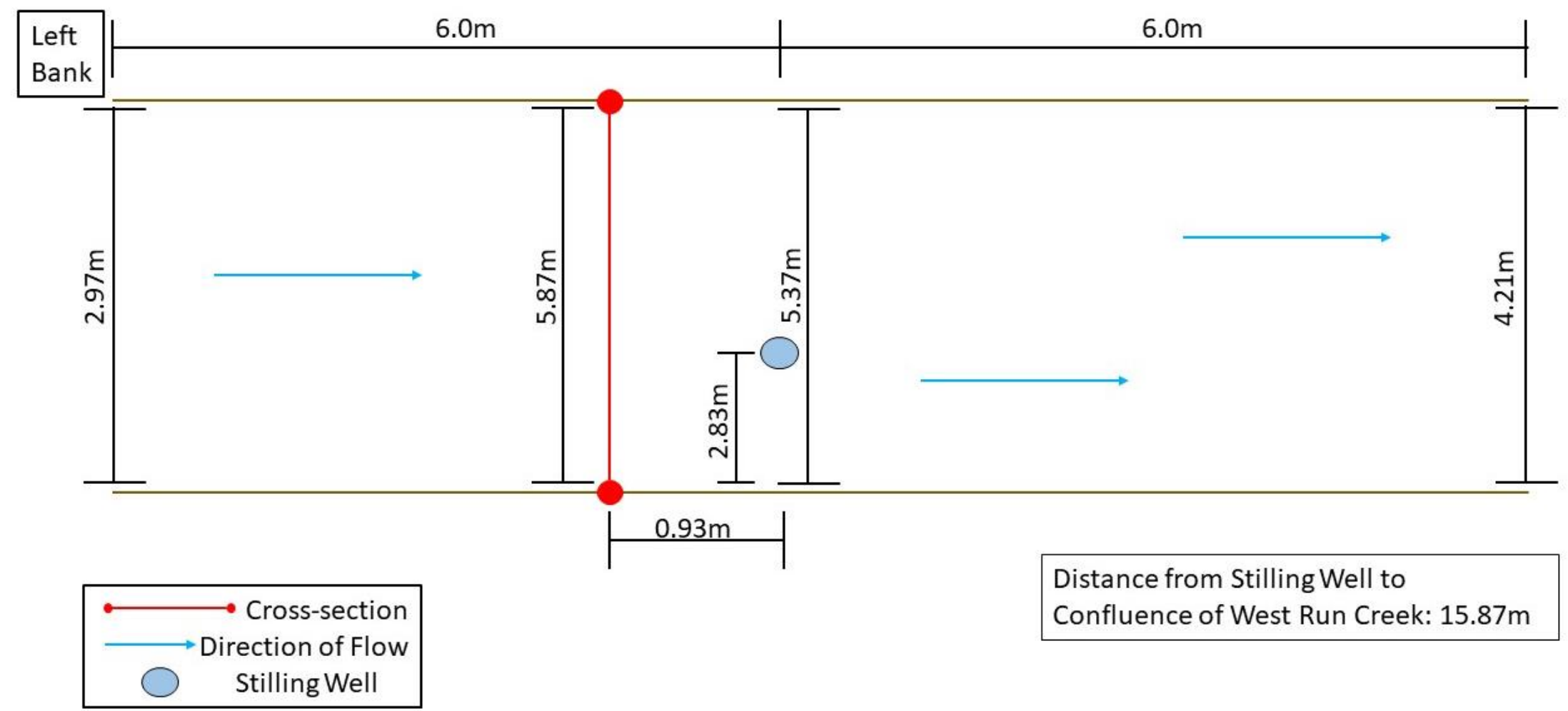

Figure A2-4. Plan view profile of WRW Site 2, West Run Watershed, Morgantown, WV, U.S.A. (Figure 2). Showing the positioning of stilling well in relation to where the streamflow was measured. Along with the channel width at the stilling well, point where crosssections were performed, and 6.0m upstream and downstream from the stilling well. 


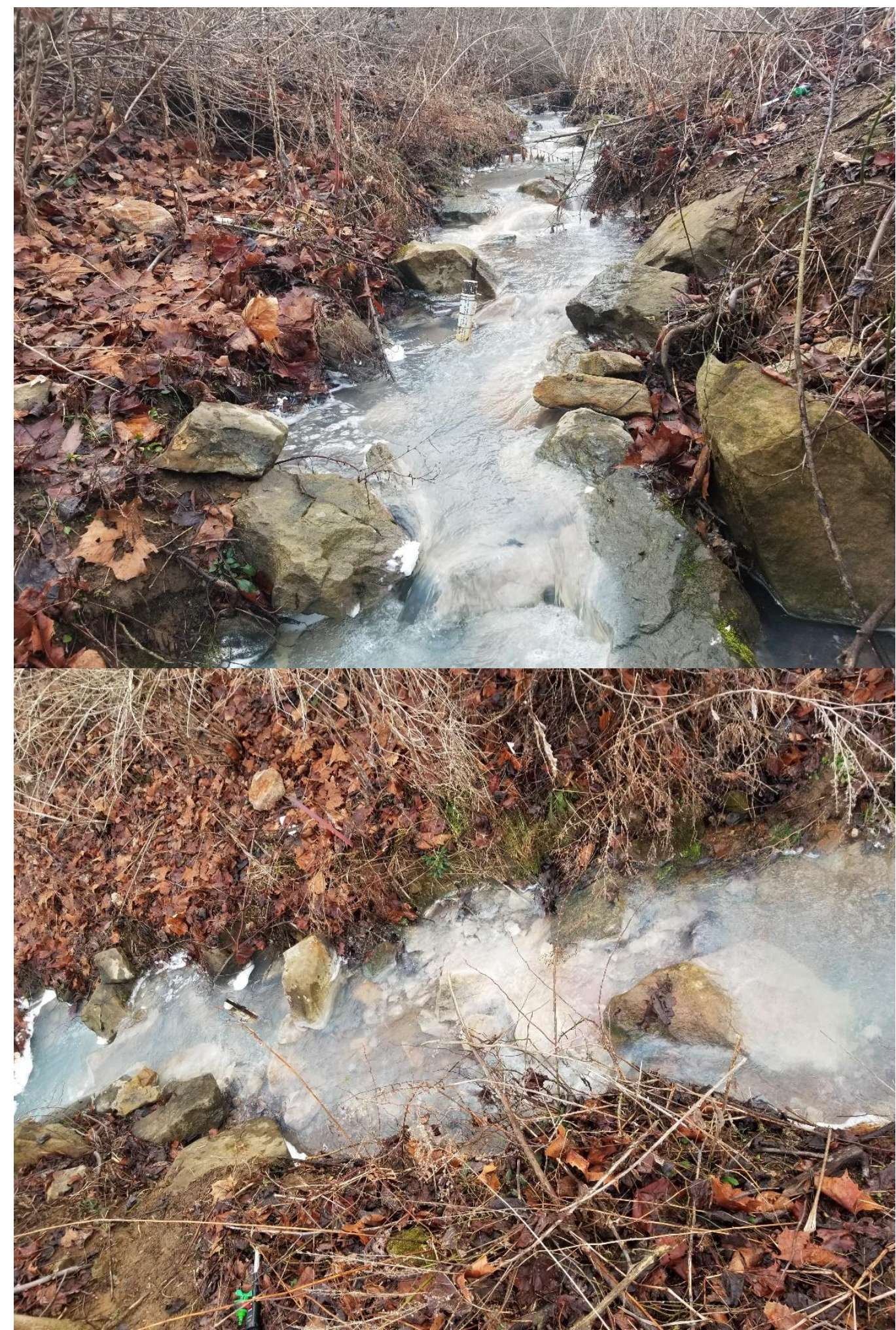

Figure A2-5. Photographs showing channel characteristics at Site \#2, West Run Watershed, Morgantown, WV, U.S.A. Photo 1 was taken looking upstream in the channel. Photo 2 was taken from the left bank looking downstream. 


\section{APPENDIX 3: Site 3}

Table A3-1. Streamflow measurements and stage collected at Site 3, West Run Watershed, Morgantown, WV, U.S.A. (Figure 2).

\begin{tabular}{|c|c|c|c|c|c|c|c|c|c|}
\hline Date & $\begin{array}{l}\text { Mean Depth of } \\
\text { Cross-Section } \\
\text { (m) }\end{array}$ & Stage(PT in $\mathrm{cm})$ & $\begin{array}{c}\text { Barometric } \\
\text { Pressure (in cm) }\end{array}$ & $\begin{array}{c}\text { Pressure } \\
\text { Corrected Stage } \\
\text { (cm) }\end{array}$ & $\begin{array}{l}\text { Stilling Well } \\
\text { Offset (cm) }\end{array}$ & $\begin{array}{c}\text { P-Corrected } \\
\text { Stage + Offset } \\
\text { (cm) }\end{array}$ & $\begin{array}{l}\text { P-Corrected } \\
\text { Stage + Offset } \\
\text { (m) }\end{array}$ & $\begin{array}{c}\text { SonTec } \\
\text { Discharge }(\mathrm{m} 3 / \mathrm{s})\end{array}$ & $\begin{array}{l}\text { Rating Equation } \\
\text { Discharge }(\mathrm{m} 3 / \mathrm{s})\end{array}$ \\
\hline $1 / 23 / 2018$ & 0.1490 & 91.87 & 74.32 & 17.55 & 2.2 & 19.75 & 0.1975 & 0.0706 & 0.10604525 \\
\hline $3 / 8 / 2018$ & 0.1208 & 91.11 & 77.95 & 13.16 & 2.2 & 15.36 & 0.1536 & 0.0263 & 0.05802304 \\
\hline $3 / 14 / 2018$ & 0.0868 & 91.04 & 79.86 & 11.18 & 2.2 & 13.38 & 0.1338 & 0.0197 & 0.03636382 \\
\hline $3 / 29 / 2018$ & 0.1861 & 102.44 & 80.2 & 22.24 & 2.2 & 24.44 & 0.2444 & 0.0892 & 0.15734916 \\
\hline $4 / 4 / 2018$ & 0.2777 & 110.29 & 75.96 & 34.33 & 2.2 & 36.53 & 0.3653 & 0.2354 & 0.28960167 \\
\hline $9 / 11 / 2018$ & 0.1771 & 106.01 & 90.25 & 15.76 & 2.2 & 17.96 & 0.1796 & 0.0497 & 0.08646444 \\
\hline 9/18/2018 & 0.1652 & 101.78 & 81.73 & 20.05 & 2.2 & 22.25 & 0.2225 & 0.0851 & 0.13339275 \\
\hline $9 / 25 / 2018$ & 0.2929 & 119.8 & 90.47 & 29.33 & 2.2 & 31.53 & 0.3153 & 0.1763 & 0.23490667 \\
\hline $10 / 4 / 2018$ & 0.1445 & 94.11 & 84.93 & 9.18 & 2.2 & 11.38 & 0.1138 & 0.0105 & 0.01448582 \\
\hline $10 / 18 / 2018$ & 0.1518 & 109.87 & 100.34 & 9.53 & 2.2 & 11.73 & 0.1173 & 0.0102 & 0.01831447 \\
\hline $10 / 18 / 2018$ & 0.1475 & 109.83 & 100.27 & 9.56 & 2.2 & 11.76 & 0.1176 & 0.0113 & 0.01864264 \\
\hline $12 / 4 / 2018$ & 0.1628 & 100.72 & 85.38 & 15.34 & 3.9 & 19.21 & 0.1921 & 0.0356 & 0.10013819 \\
\hline $1 / 17 / 2019$ & 0.1524 & 101.52 & 88.75 & 12.77 & 3.9 & 16.64 & 0.1664 & 0.0187 & 0.07202496 \\
\hline $1 / 17 / 2019$ & 0.1259 & 101.62 & 88.86 & 12.76 & 3.9 & 16.63 & 0.1663 & 0.0109 & 0.07191557 \\
\hline $1 / 23 / 2019$ & 0.1786 & 92.67 & 76.96 & 15.71 & 3.9 & 19.58 & 0.1958 & 0.0315 & 0.10418562 \\
\hline $1 / 23 / 2019$ & 0.1670 & 92.48 & 76.74 & 15.74 & 3.9 & 19.61 & 0.1961 & 0.0354 & 0.10451379 \\
\hline $2 / 12 / 2019$ & 0.2874 & 104.94 & 75.42 & 29.52 & 3.9 & 33.39 & 0.3339 & 0.2239 & 0.25525321 \\
\hline $4 / 2 / 2019$ & 0.1448 & 96.51 & 85.96 & 10.55 & 3.9 & 14.42 & 0.1442 & 0.0095 & 0.04774038 \\
\hline 4/12/2019 & 0.1597 & 96.25 & 81.08 & 15.17 & 3.9 & 19.04 & 0.1904 & 0.0278 & 0.09827856 \\
\hline $7 / 5 / 2019$ & 0.3042 & 118.37 & 85.91 & 32.46 & 3.9 & 36.33 & 0.3633 & 0.2392 & 0.28741387 \\
\hline $10 / 31 / 2019$ & 0.2709 & 105.12 & 70.73 & 34.39 & 3.9 & 38.29 & 0.3829 & 0.2536 & 0.30885431 \\
\hline $12 / 10 / 2019$ & 0.1941 & 113.69 & 78.89 & 34.8 & 3.9 & 38.7 & 0.387 & 0.2362 & 0.3133393 \\
\hline $12 / 17 / 2019$ & 0.3114 & 118.61 & 73.81 & 44.8 & 3.9 & 48.7 & 0.487 & 0.3745 & 0.4227293 \\
\hline $2 / 13 / 2020$ & 0.2889 & 1030.7 & 991.66 & 39 & 3.9 & 42.9 & 0.429 & 0.2947 & 0.3592831 \\
\hline $11 / 11 / 2020$ & 0.24 & 1019.2 & 996.52 & 22.7 & 3.9 & 26.6 & 0.266 & 0.0985 & 0.1809774 \\
\hline $8 / 16 / 2021$ & 0.377 & 1083.7 & 1002.65 & 81 & 3.9 & 84.9 & 0.849 & 0.7467 & 0.8187211 \\
\hline $8 / 16 / 2021$ & 0.346 & 1090.8 & 1002.63 & 88.2 & 3.9 & 92.1 & 0.921 & 0.9017 & 0.8974819 \\
\hline $8 / 16 / 2021$ & 0.328 & 1075.7 & 1002.49 & 73.2 & 3.9 & 77.1 & 0.771 & 0.6703 & 0.7333969 \\
\hline 8/16/2021 & 0.306 & 1075.4 & 1002.25 & 73.1 & 3.9 & 77 & 0.77 & 0.6978 & 0.732303 \\
\hline $8 / 16 / 2021$ & 0.303 & 1063.2 & 1002.37 & 60.8 & 3.9 & 64.7 & 0.647 & 0.5168 & 0.5977533 \\
\hline
\end{tabular}


Table A3-2. Modeled streamflow at Site 3, West Run Watershed, Morgantown, WV, U.S.A.

\begin{tabular}{|c|c|c|c|c|c|c|c|c|c|c|c|c|c|}
\hline $\begin{array}{c}\text { Cross- } \\
\text { Section } \\
\text { Area } \\
\left(\mathrm{m}^{2}\right)\end{array}$ & $\begin{array}{c}\text { A (Cross } \\
\text { Section } \\
\text { area of } \\
\text { flow) }\end{array}$ & $\begin{array}{c}\text { P } \\
\text { (Wetted } \\
\text { Perimete } \\
\text { r) }\end{array}$ & $\begin{array}{c}\mathrm{RH}=\mathrm{A} / \mathrm{P} \\
\text { Hydraulic } \\
\text { Radius } \\
\text { (m) }\end{array}$ & $\begin{array}{l}\text { Observed } \\
\text { Slope (m) }\end{array}$ & $\begin{array}{l}\text { Calculated } \\
\text { Slope using } \\
\text { ArcGIS (m) }\end{array}$ & $\begin{array}{c}\text { Roughness } \\
\text { Coefficient } \\
\text { (n) }\end{array}$ & $\begin{array}{c}\text { Manning } \\
\text { Discharge } \\
\left(\mathrm{m}^{3} / \mathrm{s}\right) \text { (Obs } \\
\text { Slope) }\end{array}$ & $\begin{array}{c}\text { Manning } \\
\text { Discharge } \\
\left(\mathrm{m}^{3} / \mathrm{s}\right) \text { (Calc } \\
\text { Slope) }\end{array}$ & $\begin{array}{c}\text { Chezy } \\
\text { Coefficient } \\
\text { (C) }\end{array}$ & $\begin{array}{c}\text { Chezy } \\
\text { Discharge } \\
\text { (m³/s) (Obs } \\
\text { Slope) }\end{array}$ & $\begin{array}{c}\text { Chezy } \\
\text { Discharge } \\
\left(\mathrm{m}^{3} / \mathrm{s}\right) \text { (Calc } \\
\text { Slope) }\end{array}$ & $\begin{array}{c}\text { Dingman \& } \\
\text { Sharma } \\
\text { Discharge } \\
\left(\mathrm{m}^{3} / \mathrm{s}\right) \text { (Obs. } \\
\text { Slope) }\end{array}$ & $\begin{array}{c}\text { Dingman \& } \\
\text { Sharma } \\
\text { Discharge } \\
\left(\mathrm{m}^{3} / \mathrm{s}\right) \text { (Calc } \\
\text { Slope) }\end{array}$ \\
\hline 6.93 & 0.193 & 1.8697 & 0.103052 & 0.03 & 0.04 & 0.13 & 0.056424639 & 0.065153561 & 5.267029121 & 0.056424639 & 0.065153561 & 0.068330785 & 0.071520699 \\
\hline 6.93 & 0.123 & 1.7053 & 0.071902 & 0.03 & 0.04 & 0.13 & 0.028247964 & 0.032617939 & 4.960361422 & 0.028247964 & 0.032617939 & 0.034822788 & 0.036448435 \\
\hline 6.93 & 0.091 & 1.6258 & 0.055985 & 0.03 & 0.04 & 0.13 & 0.017747014 & 0.020492487 & 4.757751798 & 0.017747014 & 0.020492487 & 0.022212183 & 0.023249123 \\
\hline 6.93 & 0.268 & 2.0269 & 0.131981 & 0.03 & 0.04 & 0.13 & 0.092392699 & 0.106685899 & 5.488773483 & 0.092392699 & 0.106685899 & 0.110863277 & 0.116038753 \\
\hline 6.93 & 0.460 & 2.3450 & 0.196351 & 0.03 & 0.04 & 0.13 & 0.207245214 & 0.23930616 & 5.864470978 & 0.207245214 & 0.23930616 & 0.24571291 & 0.257183627 \\
\hline 6.93 & 0.553 & 3.478 & 0.158999 & 0.03 & 0.04 & 0.13 & 0.216241698 & 0.249694405 & 5.661818024 & 0.216241698 & 0.249694405 & 0.279950456 & 0.293019498 \\
\hline 6.93 & 0.629 & 4.14 & 0.151932 & 0.03 & 0.04 & 0.13 & 0.238617041 & 0.275531226 & 5.619077625 & 0.238617041 & 0.275531226 & 0.319730235 & 0.334656333 \\
\hline 6.93 & 0.767 & 4.0146 & 0.191053 & 0.03 & 0.04 & 0.13 & 0.3389856687 & 0.391426955 & 5.83779484 & 0.338985687 & 0.391426955 & 0.442214088 & 0.46285815 \\
\hline 6.93 & 0.341 & 2.651 & 0.128631 & 0.03 & 0.04 & 0.13 & 0.115771436 & 0.13368134 & 5.46530105 & 0.115771436 & 0.13368134 & 0.145869712 & 0.152679408 \\
\hline 6.93 & 0.347 & 2.5892 & 0.134018 & 0.03 & 0.04 & 0.13 & 0.121075425 & 0.139805858 & 5.502802937 & 0.121075425 & 0.139805858 & 0.151348598 & 0.158414067 \\
\hline 6.93 & 0.337 & 2.5812 & 0.130559 & 0.03 & 0.04 & 0.13 & 0.115554272 & 0.13343058 & 5.478874532 & 0.115554272 & 0.13343058 & 0.144723664 & 0.151479859 \\
\hline 6.93 & 0.459 & 3.1442 & 0.145983 & 0.03 & 0.04 & 0.13 & 0.169550201 & 0.195779708 & 5.581793103 & 0.169550201 & 0.195779708 & 0.21743711 & 0.227587816 \\
\hline 6.93 & 0.43 & 3.1238 & 0.137653 & 0.03 & 0.04 & 0.13 & 0.152736401 & 0.176364805 & 5.527399482 & 0.152736401 & 0.176364805 & 0.196733796 & 0.205918 \\
\hline 6.93 & 0.354 & 3.0704 & 0.115294 & 0.03 & 0.04 & 0.13 & 0.111727327 & 0.129011604 & 5.36650286 & 0.111727327 & 0.129011604 & 0.145884962 & 0.15269537 \\
\hline 6.93 & 0.531 & 3.3292 & 0.159498 & 0.03 & 0.04 & 0.13 & 0.208072596 & 0.240261539 & 5.664771811 & 0.208072596 & 0.240261539 & 0.267266241 & 0.279743141 \\
\hline 6.93 & 0.509 & 3.382 & 0.150503 & 0.03 & 0.04 & 0.13 & 0.191880648 & 0.221564688 & 5.610230147 & 0.191880648 & 0.221564688 & 0.248487192 & 0.260087422 \\
\hline 6.93 & 0.842 & 4.08 & 0.206373 & 0.03 & 0.04 & 0.13 & 0.391769527 & 0.452376484 & 5.913328 & 0.391769527 & 0.452376484 & 0.50881304 & 0.532566168 \\
\hline 6.93 & 0.374 & 2.8796 & 0.129879 & 0.03 & 0.04 & 0.13 & 0.127795384 & 0.147565399 & 5.474106224 & 0.127795384 & 0.147565399 & 0.16319263 & 0.170811019 \\
\hline 6.93 & 0.449 & 3.2022 & 0.140216 & 0.03 & 0.04 & 0.13 & 0.161458981 & 0.186436773 & 5.544422224 & 0.161458981 & 0.186436773 & 0.208502128 & 0.218235718 \\
\hline 6.93 & 0.877 & 4.0372 & 0.21723 & 0.03 & 0.04 & 0.13 & 0.422243612 & 0.487564926 & 5.96407646 & 0.422243612 & 0.487564926 & 0.54476931 & 0.570200999 \\
\hline 6.93 & 0.908 & 3.8948 & 0.233131 & 0.03 & 0.04 & 0.13 & 0.458251169 & 0.529142872 & 6.034714967 & 0.458251169 & 0.529142872 & 0.583688791 & 0.610937375 \\
\hline 6.93 & 0.799 & 4.5032 & 0.177429 & 0.03 & 0.04 & 0.13 & 0.336135527 & 0.388135874 & 5.766260233 & 0.336135527 & 0.388135874 & 0.450405793 & 0.471432272 \\
\hline 6.93 & 1.068 & 4.0518 & 0.263587 & 0.03 & 0.04 & 0.13 & 0.584975076 & 0.675471036 & 6.159477264 & 0.584975076 & 0.675471036 & 0.741634217 & 0.776256232 \\
\hline 6.93 & 0.976 & 4.0828 & 0.239052 & 0.03 & 0.04 & 0.13 & 0.500873706 & 0.578359138 & 6.059990355 & 0.500873706 & 0.578359138 & 0.641693587 & 0.671650033 \\
\hline 6.93 & 0.629 & 3.6804 & 0.170905 & 0.03 & 0.04 & 0.13 & 0.258090292 & 0.298016999 & 5.73036895 & 0.258090292 & 0.298016999 & 0.335139668 & 0.350785131 \\
\hline 6.93 & 1.4993 & 4.564 & 0.328506 & 0.03 & 0.04 & 0.13 & 0.951045043 & 1.098172223 & 6.3896999955 & 0.951045043 & 1.098172223 & 1.205704271 & 1.261990658 \\
\hline 6.93 & 1.6643 & 4.502 & 0.36968 & 0.03 & 0.04 & 0.13 & 1.142175841 & 1.318871059 & 6.516699094 & 1.142175841 & 1.318871059 & 1.42870153 & 1.49539819 \\
\hline 6.93 & 1.3672 & 4.466 & 0.306135 & 0.03 & 0.04 & 0.13 & 0.827417837 & 0.955419821 & 6.315031718 & 0.827417837 & 0.955419821 & 1.051968426 & 1.1010779 \\
\hline 6.93 & 1.16593 & 4.422 & 0.263666 & 0.03 & 0.04 & 0.13 & 0.638742153 & 0.7375555908 & 6.159785713 & 0.638742153 & 0.7375555908 & 0.822119008 & 0.860498327 \\
\hline 6.93 & 1.15548 & 4.416 & 0.261658 & 0.03 & 0.04 & 0.13 & 0.62979898 & 0.727229222 & 6.15194167 & 0.62979898 & 0.727229222 & 0.810998516 & 0.848858692 \\
\hline
\end{tabular}




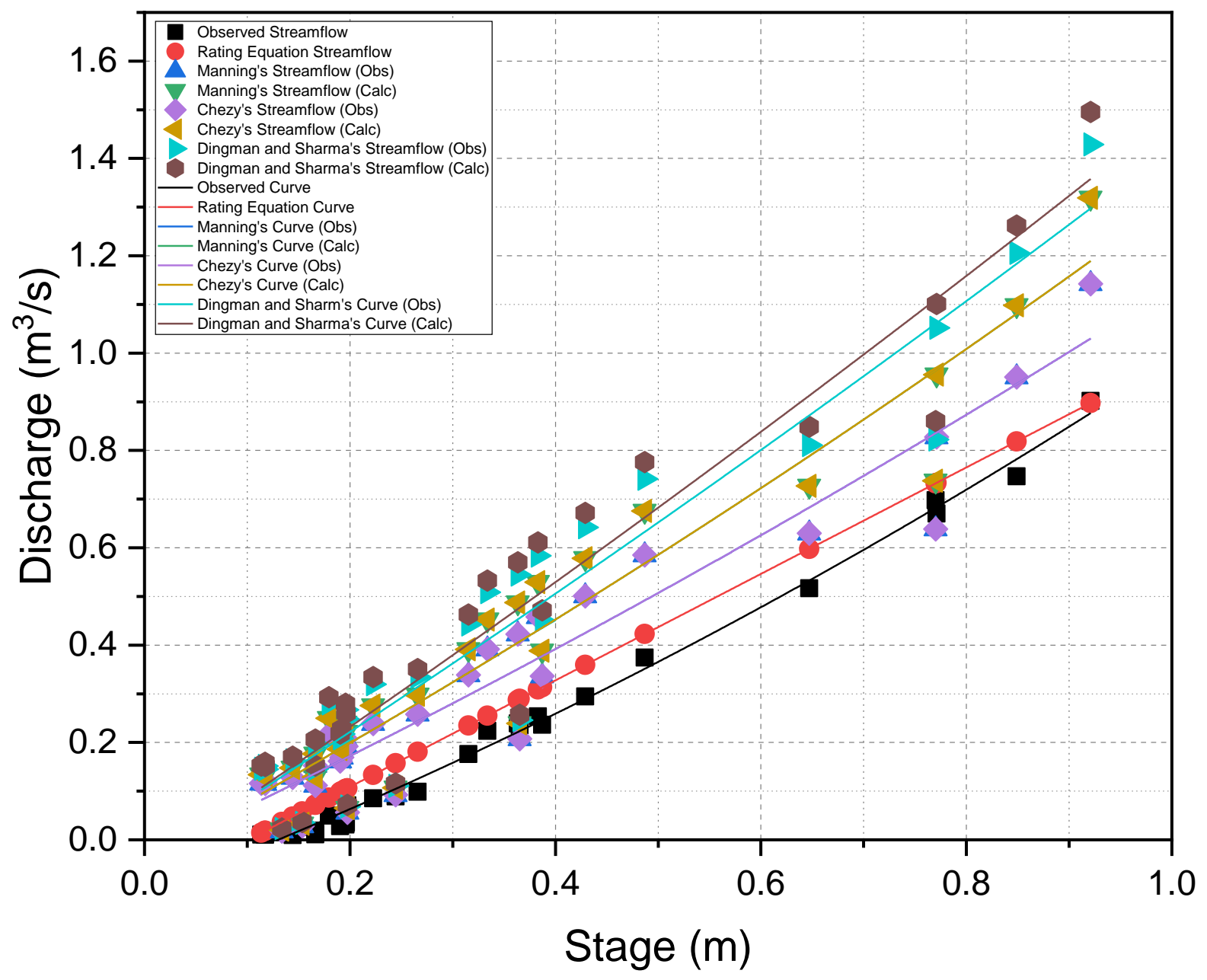

Figure A3-1. Observed and modeled rating curves and streamflow from Site 3, West Run Watershed, Morgantown, West Virginia, U.S.A 
Table A3-3. Polynomial rating equations and $\mathrm{R}^{2}$ values for observed and modeled rating curves at Site 3, West Run Watershed, Morgantown, WV, U.S.A.

\begin{tabular}{ccc}
\hline & $\begin{array}{c}\mathbf{R}^{\mathbf{2}} \\
\text { Value }\end{array}$ & Polynomial Equation \\
\hline Observed Curve & 0.99 & $\mathrm{y}=0.2855 \mathrm{x}^{2}+0.8084 \mathrm{x}-0.11$ \\
Manning's Curve (Obs Slope) & 0.87 & $\mathrm{y}=-0.5839 \mathrm{x}^{2}+1.6111 \mathrm{x}-0.1058$ \\
Manning's Curve (Calc Slope) & 0.87 & $\mathrm{y}=-0.6742 \mathrm{x}^{2}+1.8604 \mathrm{x}-0.1222$ \\
Chezy's Curve (Obs Slope) & 0.87 & $\mathrm{y}=-0.5839 \mathrm{x}^{2}+1.6111 \mathrm{x}-0.1058$ \\
Chezy's Curve (Calc Slope) & 0.87 & $\mathrm{y}=-0.6742 \mathrm{x}^{2}+1.8604 \mathrm{x}-0.1222$ \\
$\begin{array}{c}\text { Dingman and Sharma's Curve } \\
\text { (Obs Slope) }\end{array}$ & 0.87 & $\mathrm{y}=-0.7748 \mathrm{x}^{2}+2.0814 \mathrm{x}-0.1385$ \\
$\begin{array}{c}\text { Dingman and Sharma's Curve } \\
\text { (Calc Slope) }\end{array}$ & 0.87 & $\mathrm{y}=-0.811 \mathrm{x}^{2}+2.1786 \mathrm{x}-0.145$ \\
\hline
\end{tabular}

Table A3-4. Descriptive statistics for observed and modeled streamflow used to generate the rating curves for Site 3, West Run Watershed, Morgantown, WV, U.S.A.

\begin{tabular}{|c|c|c|c|c|}
\hline & Sample Size & Mean $\left(\mathbf{m}^{3} / \mathbf{s}\right)$ & St. Dev. & SE of Mean \\
\hline Observed & 30 & 0.207 & 0.254 & 0.046 \\
\hline Manning's & 30 & 0.336 & 0.265 & 0.048 \\
\hline \multicolumn{5}{|l|}{$\begin{array}{l}\text { Curve (Obs } \\
\text { Slope) }\end{array}$} \\
\hline \multirow{2}{*}{\multicolumn{5}{|c|}{$\begin{array}{c}\text { Curve (Calc } \\
\text { Slope) }\end{array}$}} \\
\hline & & & & \\
\hline $\begin{array}{c}\text { Chezy's Curve } \\
\text { (Obs Slope) }\end{array}$ & 30 & 0.336 & 0.265 & 0.048 \\
\hline $\begin{array}{c}\text { Chezy's Curve } \\
\text { (Calc Slope) }\end{array}$ & 30 & 0.388 & 0.306 & 0.056 \\
\hline $\begin{array}{l}\text { Dingman and } \\
\text { Sharma's } \\
\text { Curve (Obs } \\
\text { Slope) }\end{array}$ & 30 & 0.429 & 0.338 & 0.062 \\
\hline $\begin{array}{l}\text { Dingman and } \\
\text { Sharma's } \\
\text { Curve (Calc } \\
\text { Slope) }\end{array}$ & 30 & 0.449 & 0.354 & 0.065 \\
\hline
\end{tabular}


Table A3-5. P-values of the statistical analyses (post-hoc ANOVA) for observed and modeled rating curves at Site 3, West Run Watershed, Morgantown, WV, U.S.A.

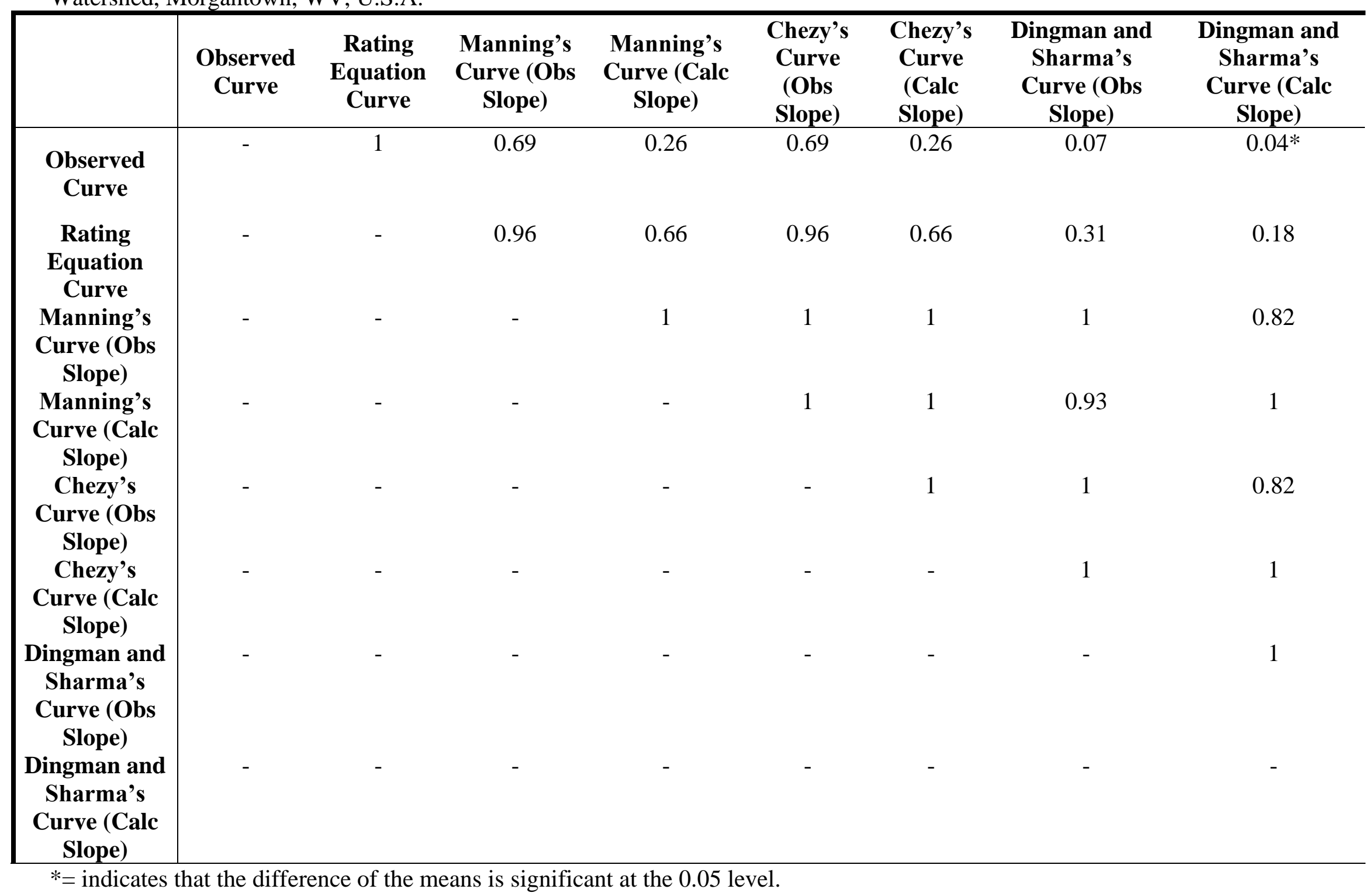




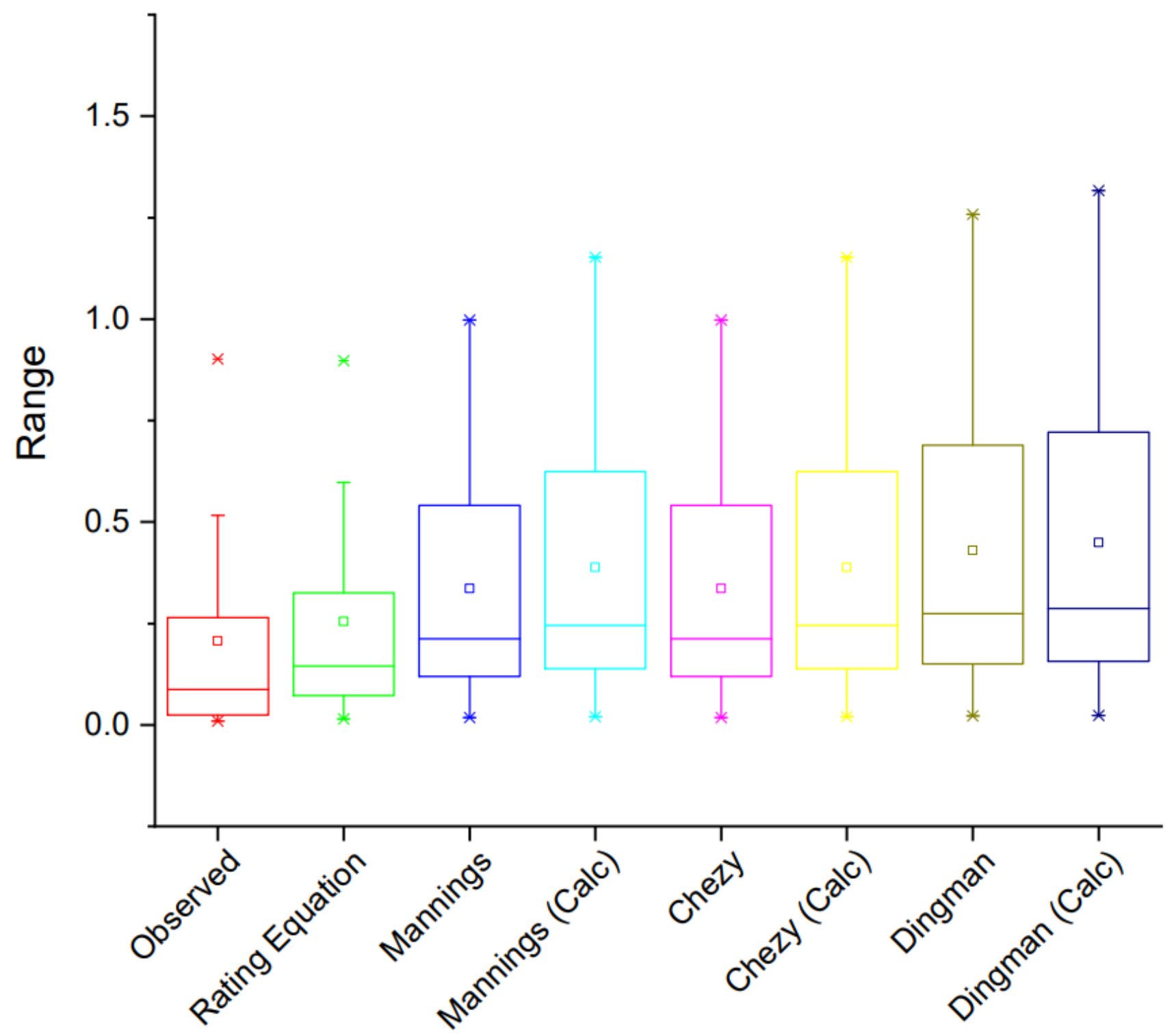

Figure A3-2. Box and whisker plots for the results of the statistical analyses (post-hoc ANOVA) of observed and modeled rating curves at Site 3, West Run Watershed, Morgantown, WV, U.S.A. 


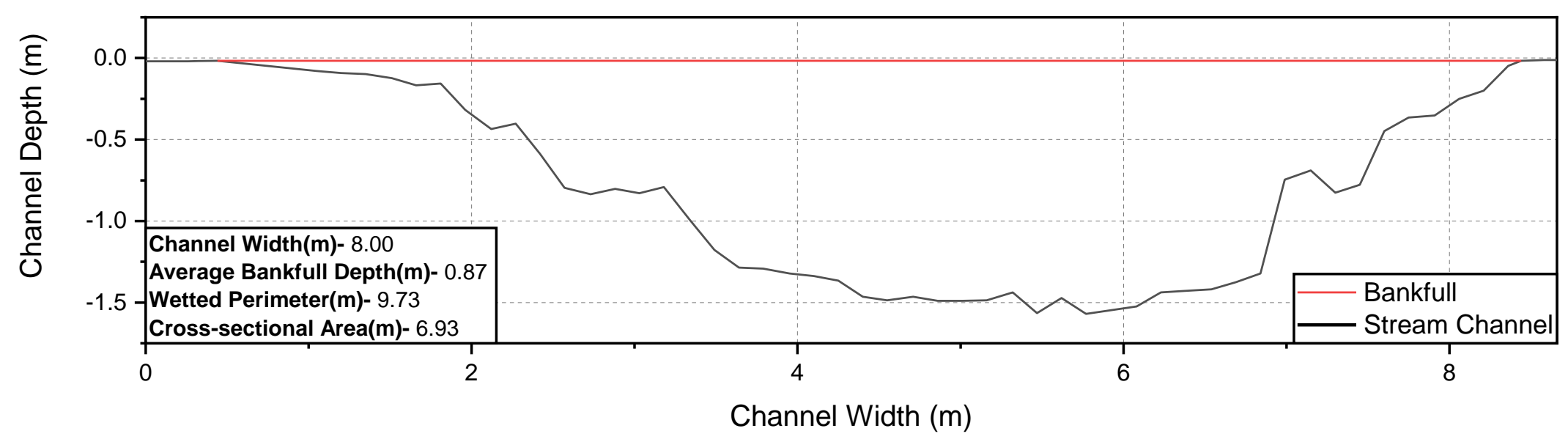

Figure A3-3. Cross-sectional profile of WRW Site 3, West Run Watershed, Morgantown, WV, USA (Figure 2). Channel Width of zero (0) represents the left bank facing downstream. 


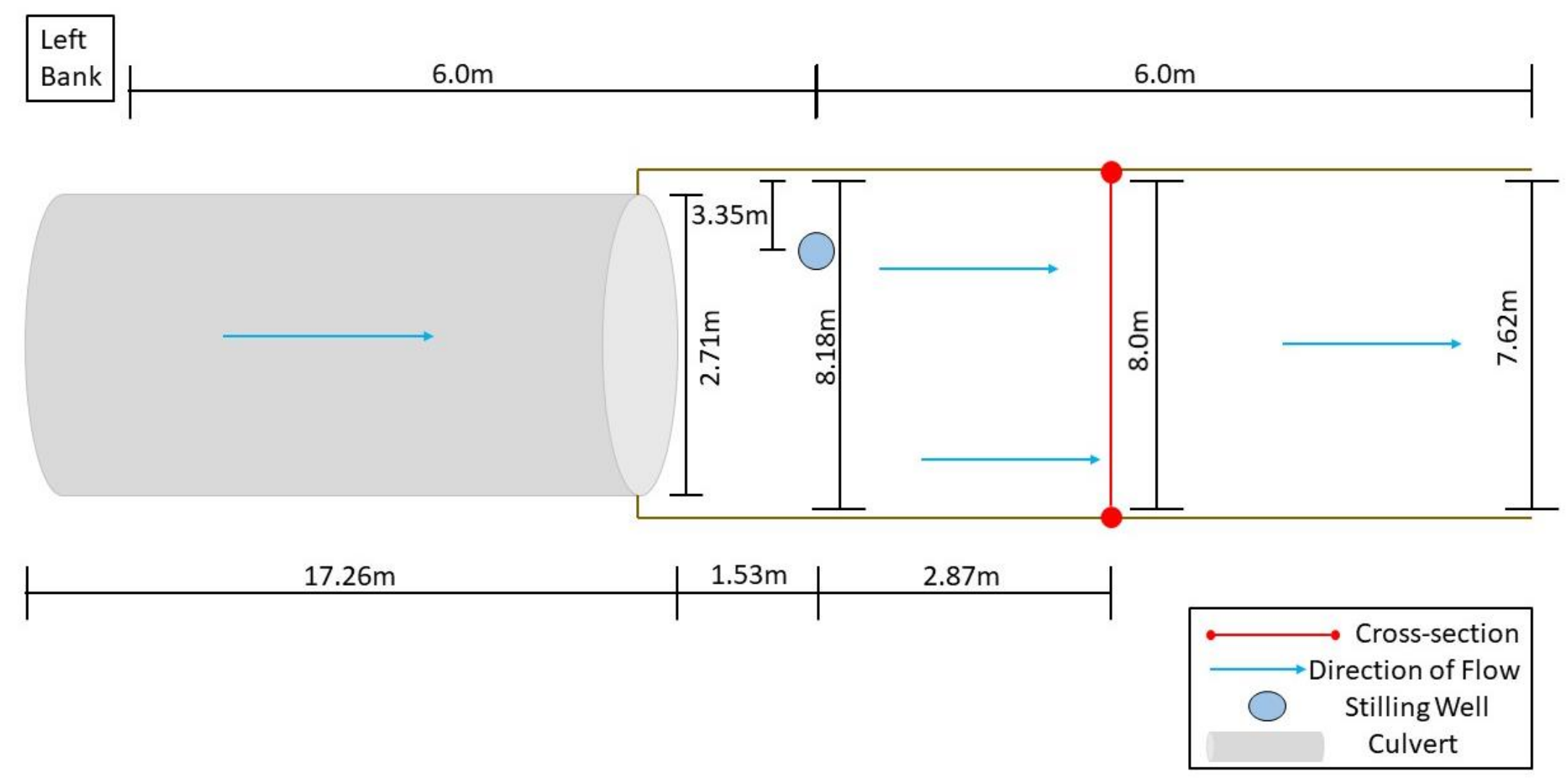

Figure A3-4. Plan view profile of WRW Site 3, West Run Watershed, Morgantown, WV, U.S.A. (Figure 2). Showing the positioning of stilling well in relation to where the streamflow was measured. Along with the channel width at the stilling well, point where crosssections were performed, and $6.0 \mathrm{~m}$ upstream and downstream from the stilling well. 


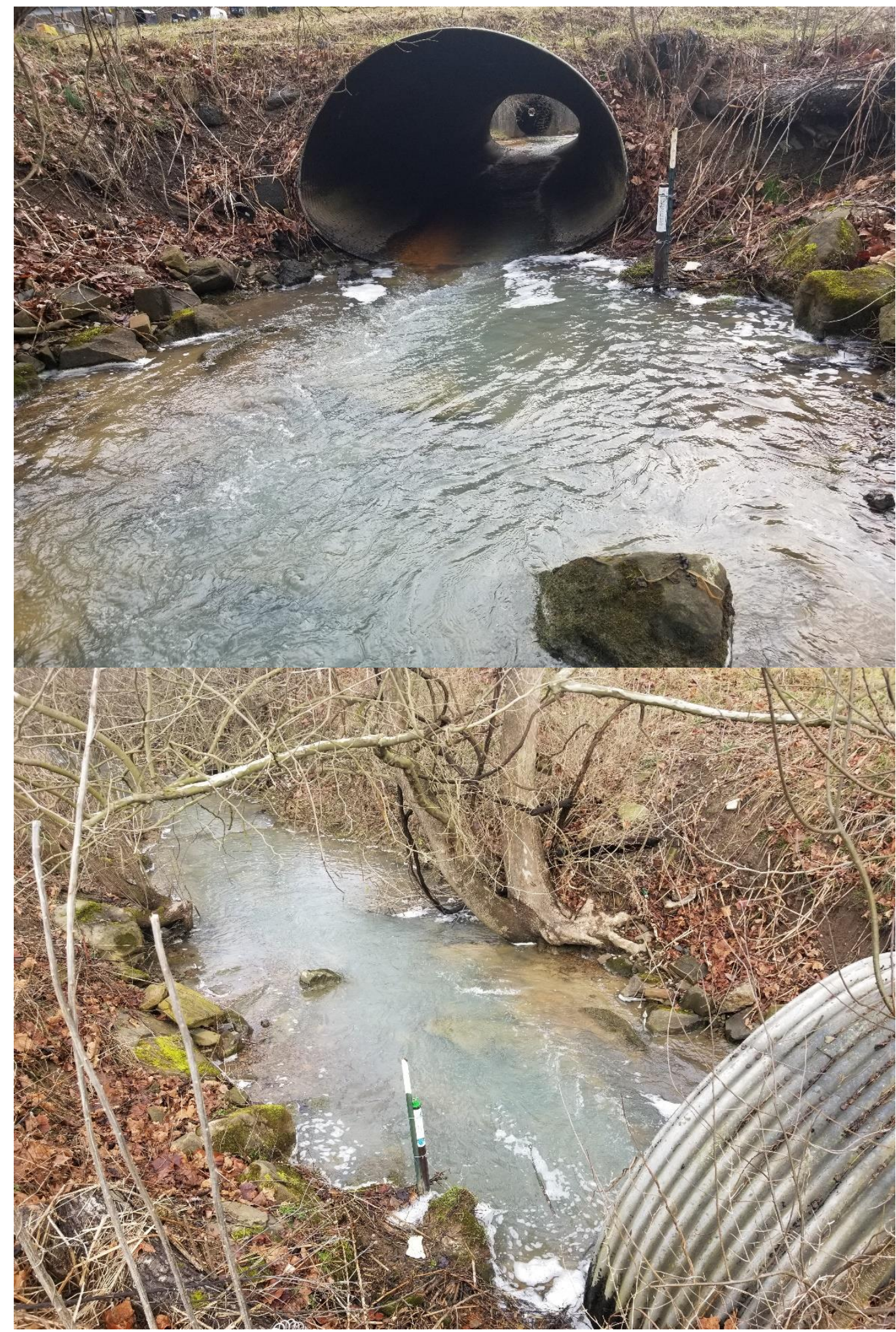

Figure A3-5. Photographs showing channel characteristics at Site \#3, West Run Watershed, Morgantown, WV, U.S.A. Photo 1 was taken looking upstream in the channel. Photo 2 was taken from the left bank looking downstream 


\section{APPENDIX 4: Site 4}

Table A4-1. Streamflow measurements and stage collected at Site 4, West Run Watershed, Morgantown, WV, U.S.A. (Figure 2).

\begin{tabular}{|c|c|c|c|c|c|c|c|c|c|}
\hline Date & $\begin{array}{l}\text { Mean Depth of } \\
\text { Cross-Section } \\
\text { (m) }\end{array}$ & Stage(PT in cm) & $\begin{array}{c}\text { Barometric } \\
\text { Pressure (in } \mathrm{cm} \text { ) }\end{array}$ & $\begin{array}{c}\text { Pressure } \\
\text { Corrected Stage } \\
\text { (cm) }\end{array}$ & $\begin{array}{l}\text { Stilling Well } \\
\text { Offset }(\mathrm{cm})\end{array}$ & $\begin{array}{l}\text { P-Corrected } \\
\text { Stage + Offset } \\
\text { (cm) }\end{array}$ & $\begin{array}{l}\text { P-Corrected } \\
\text { Stage + Offset } \\
\text { (m) }\end{array}$ & $\begin{array}{c}\text { SonTec } \\
\text { Discharge }(\mathrm{m} 3 / \mathrm{s})\end{array}$ & $\begin{array}{l}\text { Rating Equation } \\
\text { Discharge }(\mathrm{m} 3 / \mathrm{s})\end{array}$ \\
\hline $1 / 2 / 2018$ & 0.0986 & 129.15 & 103.5 & 25.65 & 4.2 & 29.85 & 0.2985 & 0.0096 & 0.016758889 \\
\hline $4 / 20 / 2018$ & 0.1333 & 130.11 & 96.94 & 33.17 & 4.2 & 37.37 & 0.3737 & 0.0767 & 0.070323763 \\
\hline $7 / 16 / 2018$ & 0.1439 & 105.91 & 83.24 & 22.67 & 4.2 & 26.87 & 0.2687 & 0.0035 & 0.003750076 \\
\hline $7 / 23 / 2018$ & 0.1341 & 103.38 & 80.92 & 22.46 & 4.2 & 26.66 & 0.2666 & 0.0046 & 0.003009283 \\
\hline $7 / 23 / 2018$ & 0.1466 & 103.38 & 81.01 & 22.37 & 4.2 & 26.57 & 0.2657 & 0.0040 & 0.002698892 \\
\hline $7 / 25 / 2018$ & 0.1680 & 105.73 & 82.67 & 23.06 & 4.2 & 27.26 & 0.2726 & 0.0085 & 0.005187289 \\
\hline $8 / 30 / 2018$ & 0.1667 & 115.78 & 89.07 & 26.71 & 4.2 & 30.91 & 0.3091 & 0.0118 & 0.022510872 \\
\hline $9 / 11 / 2018$ & 0.2597 & 125.1 & 90.06 & 35.04 & 4.2 & 39.24 & 0.3924 & 0.0801 & 0.088255351 \\
\hline $9 / 18 / 2018$ & 0.3335 & 121.67 & 81.49 & 40.18 & 4.2 & 44.38 & 0.4438 & 0.1557 & 0.147006171 \\
\hline $9 / 25 / 2018$ & 0.3679 & 141.17 & 89.45 & 51.72 & 4.2 & 55.92 & 0.5592 & 0.3637 & 0.329462676 \\
\hline $10 / 4 / 2018$ & 0.2112 & 110.52 & 85.07 & 25.45 & 4.2 & 29.65 & 0.2965 & 0.0231 & 0.015739792 \\
\hline $10 / 4 / 2018$ & 0.1975 & 110.37 & 84.97 & 25.4 & 4.2 & 29.6 & 0.2960 & 0.0241 & 0.015488301 \\
\hline $10 / 18 / 2018$ & 0.2012 & 127.14 & 100.19 & 26.95 & 4.2 & 31.15 & 0.3115 & 0.0148 & 0.023895148 \\
\hline $10 / 18 / 2018$ & 0.2091 & 127.01 & 100.28 & 26.73 & 4.2 & 30.93 & 0.3093 & 0.0150 & 0.022625073 \\
\hline $10 / 30 / 2018$ & 0.2548 & 122.69 & 89.87 & 32.82 & 4.2 & 37.02 & 0.3702 & 0.0503 & 0.067171647 \\
\hline $12 / 4 / 2018$ & 0.2173 & 116.57 & 85.35 & 31.22 & 4.2 & 35.42 & 0.3542 & 0.0352 & 0.05358138 \\
\hline $12 / 17 / 2018$ & 0.2725 & 119.51 & 82.87 & 36.64 & 4.2 & 40.84 & 0.4084 & 0.1026 & 0.105056008 \\
\hline $1 / 23 / 2019$ & 0.2387 & 108.32 & 76.44 & 31.88 & 4.2 & 36.08 & 0.3608 & 0.0740 & 0.05902443 \\
\hline $1 / 23 / 2019$ & 0.2381 & 108.37 & 76.67 & 31.7 & 4.2 & 35.9 & 0.3590 & 0.0750 & 0.05751727 \\
\hline $4 / 2 / 2019$ & 0.1652 & 110.58 & 85.73 & 24.85 & 4.2 & 29.05 & 0.2905 & 0.0156 & 0.012808564 \\
\hline $4 / 12 / 2019$ & 0.2228 & 111.96 & 81.82 & 30.14 & 4.2 & 34.34 & 0.3434 & 0.0468 & 0.045168106 \\
\hline $4 / 12 / 2019$ & 0.2170 & 109.97 & 82.03 & 27.94 & 4.2 & 32.14 & 0.3214 & 0.0409 & 0.029925092 \\
\hline $12 / 10 / 2019$ & 0.3005 & 129.07 & 79.47 & 49.6 & 4.2 & 53.8 & 0.5380 & 0.2857 & 0.290698977 \\
\hline $12 / 17 / 2019$ & 0.3716 & 139.52 & 74.82 & 64.7 & 4.2 & 68.9 & 0.6890 & 0.6114 & 0.618273862 \\
\hline $10 / 16 / 2021$ & 0.3730 & 1043.30 & 991.92 & 51.38 & 4.2 & 55.58 & 0.5558 & 0.3115 & 0.323086913 \\
\hline $10 / 16 / 2021$ & 0.3460 & 1042.10 & 991.80 & 50.3 & 4.2 & 54.5 & 0.5450 & 0.3033 & 0.303237258 \\
\hline $10 / 16 / 2021$ & 0.3440 & 1041.80 & 991.98 & 49.82 & 4.2 & 54.02 & 0.5402 & 0.3041 & 0.294611846 \\
\hline $10 / 16 / 2021$ & 0.3460 & 1040.30 & 992.13 & 48.17 & 4.2 & 52.37 & 0.5237 & 0.2723 & 0.265885006 \\
\hline $10 / 16 / 2021$ & 0.3280 & 1038.80 & 991.99 & 46.81 & 4.2 & 51.01 & 0.5101 & 0.2473 & 0.243282229 \\
\hline $10 / 16 / 2021$ & 0.3270 & 1038.30 & 992.20 & 46.1 & 4.2 & 50.3 & 0.5030 & 0.2240 & 0.231868237 \\
\hline $10 / 16 / 2021$ & 0.3140 & 1038.30 & 992.45 & 45.85 & 4.2 & 50.05 & 0.5005 & 0.2202 & 0.227912257 \\
\hline $10 / 16 / 2021$ & 0.3250 & 1038.00 & 992.38 & 45.62 & 4.2 & 49.82 & 0.4982 & 0.2089 & 0.224301749 \\
\hline $10 / 16 / 2021$ & 0.3130 & 1037.60 & 992.38 & 45.22 & 4.2 & 49.42 & 0.4942 & 0.2157 & 0.218088789 \\
\hline
\end{tabular}


Table A4-2. Modeled streamflow at Site 4, West Run Watershed, Morgantown, WV, U.S.A.

\begin{tabular}{|c|c|c|c|c|c|c|c|c|c|c|c|c|c|}
\hline $\begin{array}{l}\text { Cross- } \\
\text { Section } \\
\text { Area } \\
\left(\mathrm{m}^{2}\right)\end{array}$ & $\begin{array}{l}\text { A (Cross } \\
\text { Section } \\
\text { area of } \\
\text { flow) }\end{array}$ & $\begin{array}{c}\text { P } \\
\text { (Wetted } \\
\text { Perimete } \\
\text { r) }\end{array}$ & $\begin{array}{c}\text { RH=A/P } \\
\text { Hydraulic } \\
\text { Radius } \\
\text { (m) }\end{array}$ & $\begin{array}{l}\text { Observed } \\
\text { Slope }(m)\end{array}$ & $\begin{array}{l}\text { Calculated } \\
\text { Slope using } \\
\text { ArcGIS (m) }\end{array}$ & $\begin{array}{c}\text { Roughness } \\
\text { Coefficient } \\
\text { (n) }\end{array}$ & $\begin{array}{c}\text { Manning } \\
\text { Discharge } \\
\left(\mathrm{m}^{3} / \mathrm{s}\right)(\mathrm{Obs} \\
\text { Slope) }\end{array}$ & $\begin{array}{c}\text { Manning } \\
\text { Discharge } \\
\left(\mathrm{m}^{3} / \mathrm{s}\right) \text { (Calc } \\
\text { Slope) }\end{array}$ & $\begin{array}{c}\text { Chezy } \\
\text { Coefficient } \\
\text { (C) }\end{array}$ & $\begin{array}{c}\text { Chezy } \\
\text { Discharge } \\
\left(\mathrm{m}^{3} / \mathrm{s}\right) \text { (Obs } \\
\text { Slope) }\end{array}$ & $\begin{array}{c}\text { Chezy } \\
\text { Discharge } \\
\left(\mathrm{m}^{3} / \mathrm{s}\right) \text { (Calc } \\
\text { Slope) }\end{array}$ & $\begin{array}{c}\text { Dingman \& } \\
\text { Sharma } \\
\text { Discharge } \\
\left(\mathrm{m}^{3} / \mathrm{s}\right) \text { (Obs. } \\
\text { Slope) }\end{array}$ & $\begin{array}{c}\text { Dingman \& } \\
\text { Sharma } \\
\text { Discharge } \\
\left(\mathrm{m}^{3} / \mathrm{s}\right) \text { (Calc } \\
\text { Slope) }\end{array}$ \\
\hline 2.61 & 0.354 & 2.1848 & 0.161958 & 0.01 & 0.033 & 0.127 & 0.082784021 & 0.150384642 & 5.813399566 & 0.082784021 & 0.150384642 & 0.135380992 & 0.16966021 \\
\hline 2.61 & 0.366 & 3.0096 & 0.121611 & 0.01 & 0.033 & 0.127 & 0.070738998 & 0.128503771 & 5.542320846 & 0.070738998 & 0.128503771 & 0.125599811 & 0.157402379 \\
\hline 2.61 & 0.285 & 2.2688 & 0.125617 & 0.01 & 0.033 & 0.127 & 0.056286845 & 0.102250131 & 5.572341447 & 0.056286845 & 0.102250131 & 0.094883179 & 0.118908127 \\
\hline 2.61 & 0.245 & 2.0972 & 0.116822 & 0.01 & 0.033 & 0.127 & 0.046101302 & 0.083747173 & 5.505337966 & 0.046101302 & 0.083747173 & 0.077186093 & 0.09673004 \\
\hline 2.61 & 0.268 & 2.1224 & 0.126272 & 0.01 & 0.033 & 0.127 & 0.053113238 & 0.096484988 & 5.577174143 & 0.053113238 & 0.096484988 & 0.088463045 & 0.110862379 \\
\hline 2.61 & 0.307 & 2.1646 & 0.141828 & 0.01 & 0.033 & 0.127 & 0.065741832 & 0.119425969 & 5.686212241 & 0.065741832 & 0.119425969 & 0.108681182 & 0.13619986 \\
\hline 2.61 & 0.305 & 2.1624 & 0.141047 & 0.01 & 0.033 & 0.127 & 0.065073673 & 0.118212198 & 5.680984183 & 0.065073673 & 0.118212198 & 0.107613308 & 0.134861595 \\
\hline 2.61 & 0.475 & 2.3486 & 0.202248 & 0.01 & 0.033 & 0.127 & 0.128868347 & 0.234100978 & 6.032681142 & 0.128868347 & 0.234100978 & 0.209002834 & 0.26192351 \\
\hline 2.61 & 0.661 & 2.648 & 0.249622 & 0.01 & 0.033 & 0.127 & 0.206341567 & 0.374838071 & 6.248036033 & 0.206341567 & 0.374838071 & 0.335001269 & 0.419825449 \\
\hline 2.61 & 0.813 & 2.968 & 0.273922 & 0.01 & 0.033 & 0.127 & 0.270004659 & 0.49048782 & 6.345522483 & 0.270004659 & 0.49048782 & 0.443224357 & 0.555451222 \\
\hline 2.61 & 0.402 & 2.3272 & 0.17274 & 0.01 & 0.033 & 0.127 & 0.098178689 & 0.178350446 & 5.876178816 & 0.098178689 & 0.178350446 & 0.161343267 & 0.202196277 \\
\hline 2.61 & 0.376 & 2.3 & 0.163478 & 0.01 & 0.033 & 0.127 & 0.088516479 & 0.160798169 & 5.822456875 & 0.088516479 & 0.160798169 & 0.145920428 & 0.18286829 \\
\hline 2.61 & 0.368 & 2.2316 & 0.164904 & 0.01 & 0.033 & 0.127 & 0.087136158 & 0.158290692 & 5.83089011 & 0.087136158 & 0.158290692 & 0.142780476 & 0.178933285 \\
\hline 2.61 & 0.382 & 2.2472 & 0.169989 & 0.01 & 0.033 & 0.127 & 0.092301211 & 0.167673477 & 5.860480409 & 0.092301211 & 0.167673477 & 0.150996099 & 0.189229149 \\
\hline 2.61 & 0.466 & 2.3386 & 0.199265 & 0.01 & 0.033 & 0.127 & 0.125180162 & 0.227401057 & 6.017756458 & 0.125180162 & 0.227401057 & 0.203154019 & 0.254593743 \\
\hline 2.61 & 0.397 & 2.2634 & 0.1754 & 0.01 & 0.033 & 0.127 & 0.097950408 & 0.177935752 & 5.891164434 & 0.097950408 & 0.177935752 & 0.159966739 & 0.200471205 \\
\hline 2.61 & 0.498 & 2.3738 & 0.20979 & 0.01 & 0.033 & 0.127 & 0.138446644 & 0.251500819 & 6.069605742 & 0.138446644 & 0.251500819 & 0.22418206 & 0.280946201 \\
\hline 2.61 & 0.437 & 2.3066 & 0.189456 & 0.01 & 0.033 & 0.127 & 0.113505563 & 0.206193096 & 5.967344864 & 0.113505563 & 0.206193096 & 0.18463972 & 0.231391522 \\
\hline 2.61 & 0.435 & 2.305 & 0.18872 & 0.01 & 0.033 & 0.127 & 0.112693211 & 0.204717384 & 5.963474047 & 0.112693211 & 0.204717384 & 0.183363115 & 0.229791673 \\
\hline 2.61 & 0.302 & 2.1596 & 0.139841 & 0.01 & 0.033 & 0.127 & 0.064065709 & 0.11638114 & 5.672857613 & 0.064065709 & 0.11638114 & 0.106007927 & 0.132849722 \\
\hline 2.61 & 0.408 & 2.2748 & 0.179356 & 0.01 & 0.033 & 0.127 & 0.10217259 & 0.185605728 & 5.913107433 & 0.10217259 & 0.185605728 & 0.1666586665 & 0.208857563 \\
\hline 2.61 & 0.398 & 2.2732 & 0.175084 & 0.01 & 0.033 & 0.127 & 0.098079061 & 0.178169463 & 5.889392738 & 0.098079061 & 0.178169463 & 0.160323713 & 0.200918566 \\
\hline 2.61 & 0.641 & 2.7348 & 0.234386 & 0.01 & 0.033 & 0.127 & 0.191870974 & 0.348550934 & 6.182797492 & 0.191870974 & 0.348550934 & 0.315104206 & 0.394890339 \\
\hline 2.61 & 0.991 & 3.4102 & 0.290599 & 0.01 & 0.033 & 0.127 & 0.34234643 & 0.621903174 & 6.408335586 & 0.34234643 & 0.621903174 & 0.572464641 & 0.717415864 \\
\hline 2.61 & 0.85239 & 3.032 & 0.281131 & 0.01 & 0.033 & 0.127 & 0.28803199 & 0.523236093 & 6.373057016 & 0.28803199 & 0.523236093 & 0.473411919 & 0.593282444 \\
\hline 2.61 & 0.76355 & 2.902 & 0.263112 & 0.01 & 0.033 & 0.127 & 0.2468665543 & 0.448453529 & 6.303082012 & 0.2468655543 & 0.448453529 & 0.405192263 & 0.507789191 \\
\hline 2.61 & 0.76064 & 2.898 & 0.262471 & 0.01 & 0.033 & 0.127 & 0.245525135 & 0.446018557 & 6.300520208 & 0.245525135 & 0.446018557 & 0.402988094 & 0.505026914 \\
\hline 2.61 & 0.73858 & 2.826 & 0.261352 & 0.01 & 0.033 & 0.127 & 0.237726399 & 0.431851451 & 6.296035624 & 0.237726399 & 0.431851451 & 0.388648702 & 0.487056709 \\
\hline 2.61 & 0.68806 & 2.752 & 0.250022 & 0.01 & 0.033 & 0.127 & 0.215017848 & 0.390599318 & 6.249701275 & 0.215017848 & 0.390599318 & 0.351369098 & 0.440337703 \\
\hline 2.61 & 0.68545 & 2.75 & 0.249255 & 0.01 & 0.033 & 0.127 & 0.213763779 & 0.388321188 & 6.246500708 & 0.213763779 & 0.388321188 & 0.349376407 & 0.437840451 \\
\hline 2.61 & 0.64684 & 2.685 & 0.240909 & 0.01 & 0.033 & 0.127 & 0.197194531 & 0.358221655 & 6.211145583 & 0.197194531 & 0.358221655 & 0.321990091 & 0.403519768 \\
\hline 2.61 & 0.6689 & 2.707 & 0.2471 & 0.01 & 0.033 & 0.127 & 0.207398734 & 0.376758511 & 6.23746951 & 0.207398734 & 0.376758511 & 0.338325403 & 0.423991272 \\
\hline 2.61 & 0.64451 & 2.683 & 0.24022 & 0.01 & 0.033 & 0.127 & 0.196109484 & 0.35625057 & 6.208182048 & 0.196109484 & 0.35625057 & 0.320262976 & 0.401355338 \\
\hline
\end{tabular}




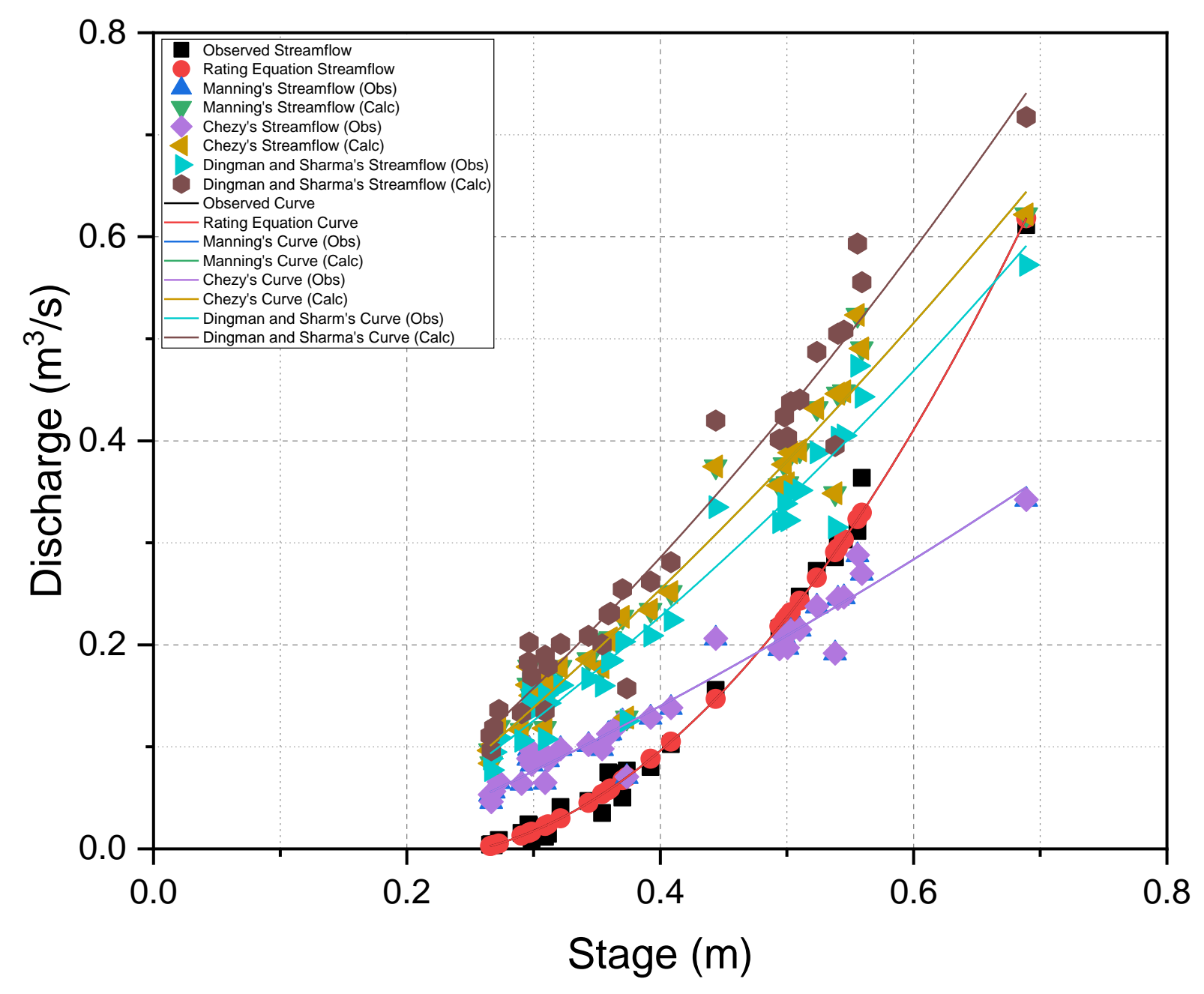

Figure A4-1. Observed and modeled rating curves and streamflow from Site 4, West Run Watershed, Morgantown, West Virginia, U.S.A 
Table A4-3. Polynomial rating equations and $\mathrm{R}^{2}$ values for observed and modeled rating curves at Site 4, West Run Watershed, Morgantown, WV, U.S.A.

\begin{tabular}{|c|c|c|}
\hline & $\begin{array}{c}\mathbf{R}^{2} \\
\text { Value }\end{array}$ & Polynomial Equation \\
\hline Observed Curve & 0.99 & $y=2.6263 x^{2}-1.0531 x+0.0971$ \\
\hline Manning's Curve (Obs Slope) & 0.95 & $y=0.4886 x^{2}+0.8166 x-0.1505$ \\
\hline Manning's Curve (Calc Slope) & 0.95 & $y=0.2689 x^{2}+0.4495 x-0.0828$ \\
\hline Chezy's Curve (Obs Slope) & 0.95 & $y=0.4886 x^{2}+0.8166 x-0.1505$ \\
\hline Chezy's Curve (Calc Slope) & 0.95 & $y=0.2689 x^{2}+0.4495 x-0.0828$ \\
\hline $\begin{array}{c}\text { Dingman and Sharma's Curve } \\
\text { (Obs Slope) }\end{array}$ & 0.95 & $y=0.6055 x^{2}+0.598 x-0.1082$ \\
\hline $\begin{array}{c}\text { Dingman and Sharma's Curve } \\
\text { (Calc Slope) }\end{array}$ & 0.95 & $y=0.7589 x^{2}+0.7494 x-0.1356$ \\
\hline
\end{tabular}

Table A4-4. Descriptive statistics for observed and modeled streamflow used to generate the rating curves for Site 4, West Run Watershed, Morgantown, WV, U.S.A.

\begin{tabular}{|c|c|c|c|c|}
\hline & Sample Size & Mean $\left(\mathrm{m}^{3} / \mathrm{s}\right)$ & St. Dev. & SE of Mean \\
\hline Observed & 33 & 0.135 & 0.144 & 0.025 \\
\hline Manning's & 33 & 0.147 & 0.08 & 0.014 \\
\hline $\begin{array}{l}\text { Curve (Obs } \\
\text { Slope) }\end{array}$ & & & & \\
\hline $\begin{array}{c}\text { Manning's } \\
\text { Curve (Calc } \\
\text { Slope) }\end{array}$ & 33 & 0.267 & 0.145 & 0.025 \\
\hline $\begin{array}{c}\text { Chezy's Curve } \\
\text { (Obs Slope) }\end{array}$ & 33 & 0.147 & 0.08 & 0.014 \\
\hline $\begin{array}{c}\text { Chezy's Curve } \\
\text { (Calc Slope) }\end{array}$ & 33 & 0.267 & 0.145 & 0.024 \\
\hline $\begin{array}{l}\text { Dingman and } \\
\text { Sharma's } \\
\text { Curve (Obs } \\
\text { Slope) }\end{array}$ & 33 & 0.241 & 0.131 & 0.023 \\
\hline $\begin{array}{l}\text { Dingman and } \\
\text { Sharma's } \\
\text { Curve (Calc } \\
\text { Slope) }\end{array}$ & 33 & 0.302 & 0.164 & 0.029 \\
\hline
\end{tabular}


Table A4-5. P-values of the statistical analyses (post-hoc ANOVA) for observed and modeled rating curves at Site 4, West Run Watershed, Morgantown, WV, U.S.A.

\begin{tabular}{|c|c|c|c|c|c|c|c|c|}
\hline & $\begin{array}{l}\text { Observed } \\
\text { Curve }\end{array}$ & $\begin{array}{c}\text { Rating } \\
\text { Equation } \\
\text { Curve }\end{array}$ & $\begin{array}{c}\text { Manning's } \\
\text { Curve (Obs } \\
\text { Slope) }\end{array}$ & $\begin{array}{c}\text { Manning's } \\
\text { Curve (Calc } \\
\text { Slope) }\end{array}$ & $\begin{array}{c}\text { Chezy's } \\
\text { Curve } \\
\text { (Obs } \\
\text { Slope) } \\
\end{array}$ & $\begin{array}{c}\text { Chezy's } \\
\text { Curve } \\
\text { (Calc } \\
\text { Slope) } \\
\end{array}$ & $\begin{array}{c}\text { Dingman and } \\
\text { Sharma's } \\
\text { Curve (Obs } \\
\text { Slope) } \\
\end{array}$ & $\begin{array}{c}\text { Dingman and } \\
\text { Sharma's } \\
\text { Curve (Calc } \\
\text { Slope) } \\
\end{array}$ \\
\hline $\begin{array}{c}\text { Rating } \\
\text { Equation } \\
\text { Curve }\end{array}$ & - & - & 1 & $0.002^{*}$ & 1 & $0.002 *$ & $0.03 *$ & $<0.05^{*}$ \\
\hline $\begin{array}{c}\text { Manning's } \\
\text { Curve (Obs } \\
\text { Slope) }\end{array}$ & - & - & - & $0.007 *$ & 1 & $0.007 *$ & 0.08 & $<0.05^{*}$ \\
\hline $\begin{array}{c}\text { Manning's } \\
\text { Curve (Calc } \\
\text { Slope) }\end{array}$ & - & - & - & - & $0.007 *$ & 1 & 1 & 0.96 \\
\hline $\begin{array}{c}\text { Chezy's } \\
\text { Curve (Calc } \\
\text { Slope) }\end{array}$ & - & - & - & - & - & - & 1 & 0.96 \\
\hline $\begin{array}{l}\text { Dingman and } \\
\text { Sharma's } \\
\text { Curve (Obs } \\
\text { Slope) }\end{array}$ & - & - & - & - & - & - & - & 0.57 \\
\hline $\begin{array}{l}\text { Dingman and } \\
\text { Sharma's } \\
\text { Curve (Calc } \\
\text { Slope) }\end{array}$ & - & - & - & - & - & - & - & - \\
\hline
\end{tabular}




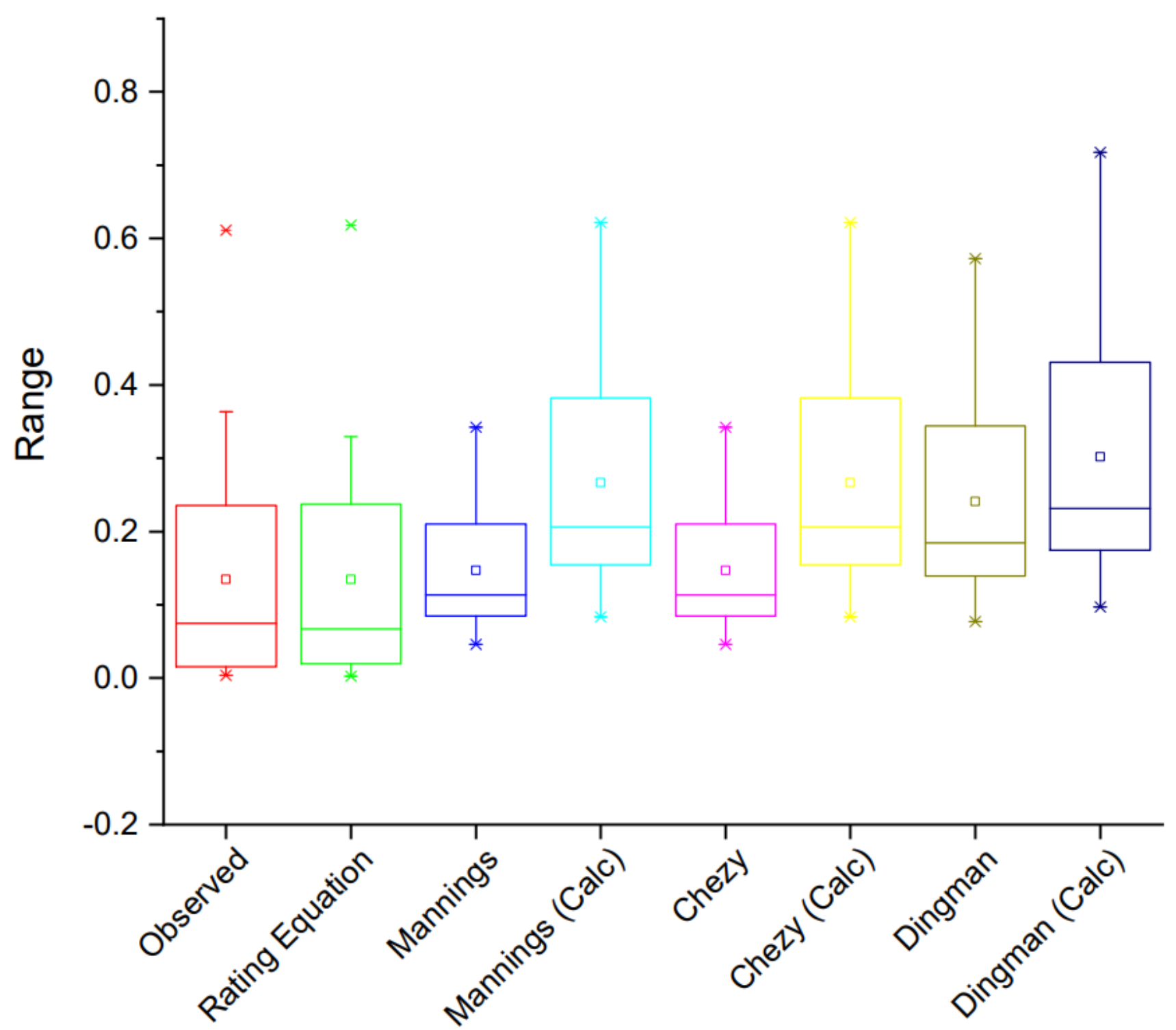

Figure A4-2. Box and whisker plots for the results of the statistical analyses ( post-hoc ANOVA) of observed and modeled rating curves at Site 4, West Run Watershed, Morgantown, WV, U.S.A. 


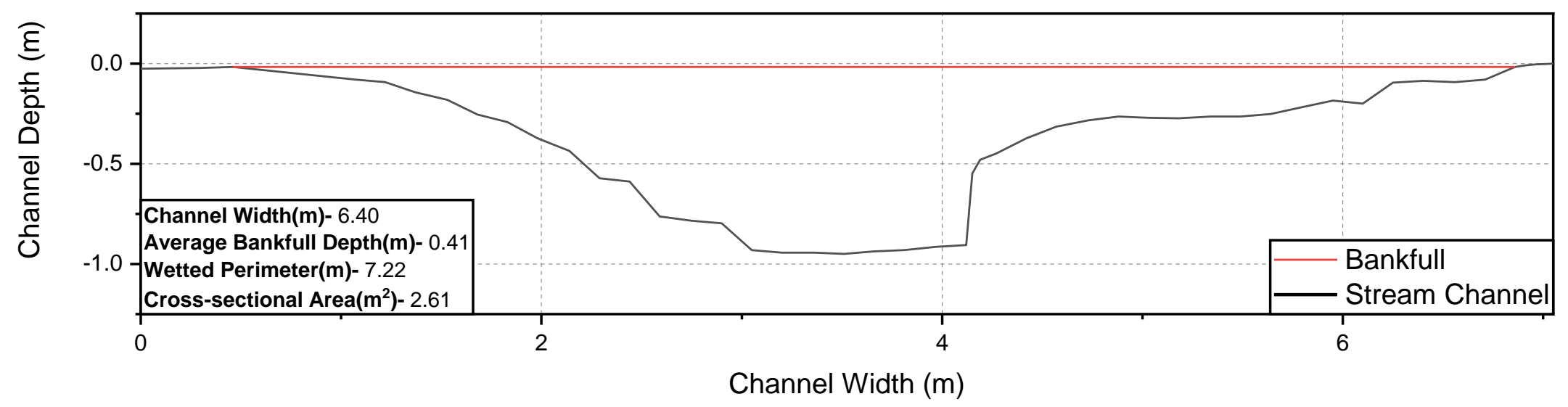

Figure A4-3. Cross-sectional profile of WRW Site 4, West Run Watershed, Morgantown, WV, USA (Figure 2). Channel Width of zero (0) represents the left bank facing downstream. 


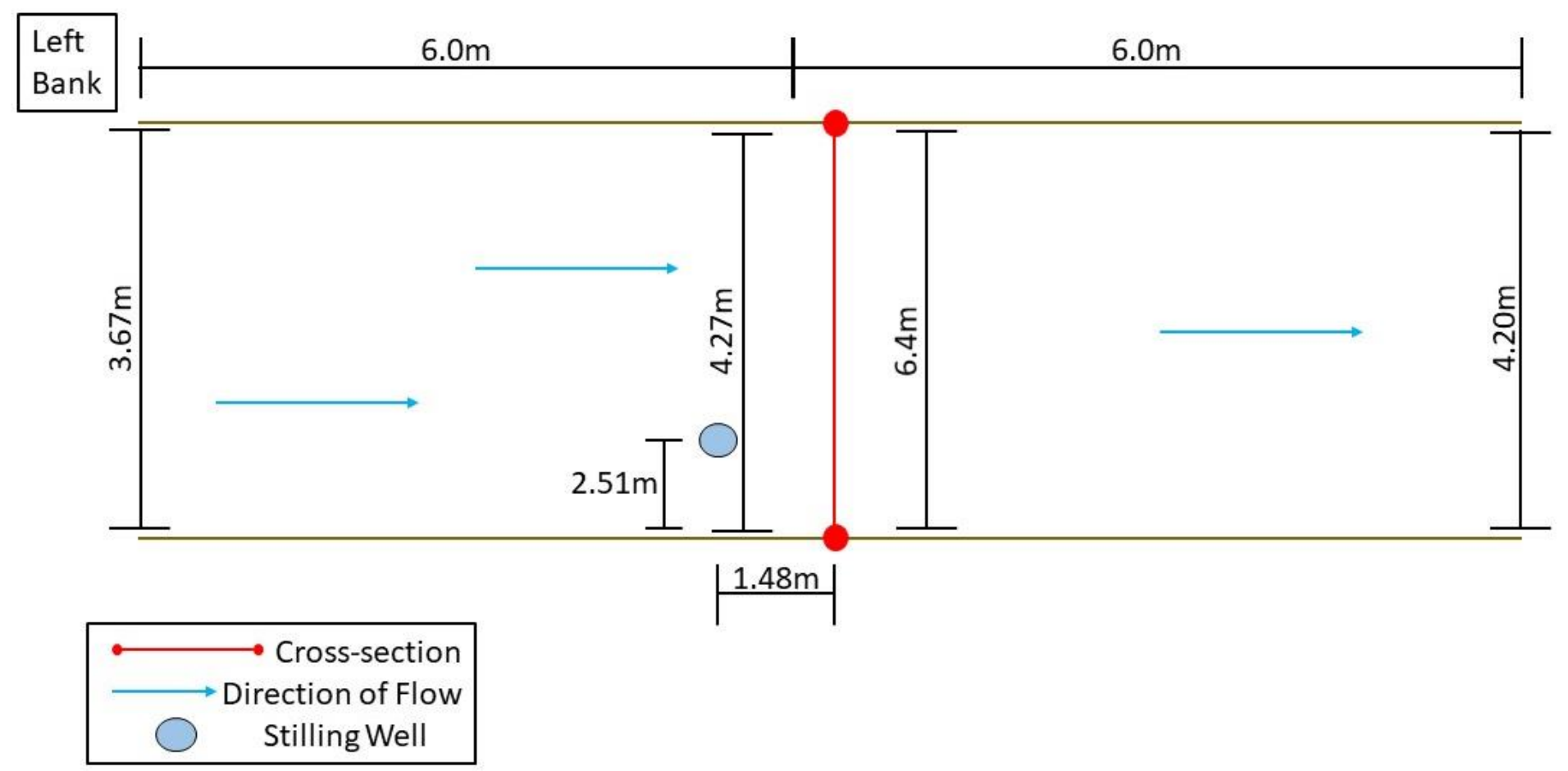

Figure A4-4. Plan view profile of WRW Site 4, West Run Watershed, Morgantown, WV, U.S.A. (Figure 2). Showing the positioning of stilling well in relation to where the streamflow was measured. Along with the channel width at the stilling well, point where crosssections were performed, and 6.0m upstream and downstream from the stilling well. 


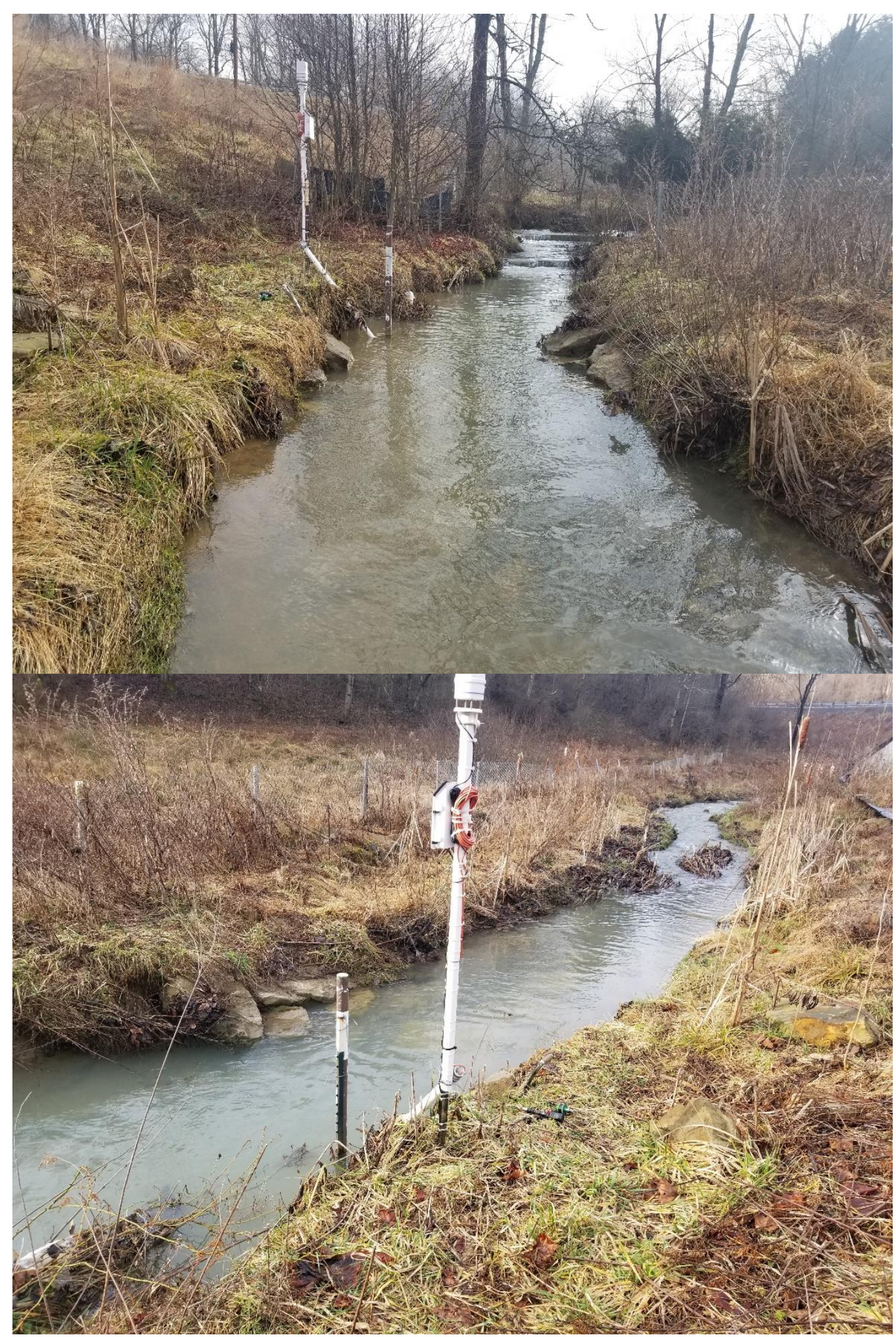

Figure A4-5. Photographs showing channel characteristics at Site \#4, West Run Watershed, Morgantown, WV, U.S.A. Photo 1 was taken looking upstream in the channel. Photo 2 was taken from the right bank looking downstream. 


\section{APPENDIX 5: Site 5}

Table A5-1. Streamflow measurements and stage collected at Site 5, West Run Watershed, Morgantown, WV, U.S.A. (Figure 2).

\begin{tabular}{|c|c|c|c|c|c|c|c|c|c|}
\hline Date & $\begin{array}{l}\text { Mean Depth of } \\
\text { Cross-Section } \\
\text { (m) }\end{array}$ & Stage(PT in cm) & $\begin{array}{c}\text { Barometric } \\
\text { Pressure (in } \mathrm{cm} \text { ) }\end{array}$ & $\begin{array}{c}\text { Pressure } \\
\text { Corrected Stage } \\
\text { (cm) }\end{array}$ & $\begin{array}{l}\text { Stilling Well } \\
\text { Offset }(\mathrm{cm})\end{array}$ & $\begin{array}{l}\text { P-Corrected } \\
\text { Stage + Offset } \\
\text { (cm) }\end{array}$ & $\begin{array}{c}\text { P-Corrected } \\
\text { Stage + Offset } \\
\text { (m) }\end{array}$ & $\begin{array}{c}\text { SonTec } \\
\text { Discharge }(\mathrm{m} 3 / \mathrm{s})\end{array}$ & $\begin{array}{l}\text { Rating Equation } \\
\text { Discharge }(\mathrm{m} 3 / \mathrm{s})\end{array}$ \\
\hline $3 / 8 / 2018$ & 0.0450 & 87.02 & 69.81 & 17.21 & 6.3 & 23.51 & 0.2351 & 0.0091 & 0.001354182 \\
\hline $3 / 29 / 2018$ & 0.0839 & 99.42 & 80.06 & 19.36 & 6.3 & 25.66 & 0.2566 & 0.0294 & 0.014230368 \\
\hline $4 / 20 / 2018$ & 0.0610 & 117.16 & 96.82 & 20.34 & 6.3 & 26.64 & 0.2664 & 0.0381 & 0.024630677 \\
\hline $10 / 4 / 2018$ & 0.0988 & 103.23 & 85 & 18.23 & 6.3 & 24.53 & 0.2453 & 0.0020 & 0.005760263 \\
\hline 10/18/2018 & 0.0994 & 114.85 & 100.05 & 14.8 & 6.3 & 21.1 & 0.2110 & 0.0012 & 0.003154712 \\
\hline $10 / 18 / 2018$ & 0.0972 & 114.68 & 99.97 & 14.71 & 6.3 & 21.01 & 0.2101 & 0.0016 & 0.003554322 \\
\hline 10/18/2018 & 0.1009 & 114.54 & 99.86 & 14.68 & 6.3 & 20.98 & 0.2098 & 0.0017 & 0.003692843 \\
\hline 10/30/2018 & 0.1018 & 107.1 & 89.77 & 17.33 & 6.3 & 23.63 & 0.2363 & 0.0045 & 0.001713007 \\
\hline 12/17/2018 & 0.1350 & 102.82 & 82.23 & 20.59 & 6.3 & 26.89 & 0.2689 & 0.0134 & 0.027738056 \\
\hline 2/12/2019 & 0.1265 & 98.08 & 74.18 & 23.9 & 6.3 & 30.2 & 0.3020 & 0.0633 & 0.086286488 \\
\hline 2/12/2019 & 0.1356 & 97.85 & 74.34 & 23.51 & 6.3 & 29.81 & 0.2981 & 0.0563 & 0.077705797 \\
\hline 5/5/2021 & 0.2400 & 1019.7 & 991.47 & 28.2 & 6.3 & 34.5 & 0.3450 & 0.2167 & 0.2106848 \\
\hline $5 / 5 / 2021$ & 0.2270 & 1021.2 & 991.98 & 29.2 & 6.3 & 35.5 & 0.3550 & 0.2453 & 0.2474438 \\
\hline $5 / 5 / 2021$ & 0.2180 & 1020.5 & 992.09 & 28.4 & 6.3 & 34.7 & 0.3470 & 0.2072 & 0.217800248 \\
\hline $5 / 5 / 2021$ & 0.2050 & 1019.3 & 992.04 & 27.3 & 6.3 & 33.6 & 0.3360 & 0.1994 & 0.180127712 \\
\hline $9 / 1 / 2021$ & 0.2460 & 1018.2 & 988.08 & 30.1 & 6.3 & 36.4 & 0.3640 & 0.2674 & 0.283052912 \\
\hline $9 / 1 / 2021$ & 0.2410 & 1016.7 & 988.07 & 28.6 & 6.3 & 34.9 & 0.3490 & 0.2398 & 0.225033872 \\
\hline $9 / 1 / 2021$ & 0.2460 & 1016.5 & 988.07 & 28.4 & 6.3 & 34.7 & 0.3470 & 0.2451 & 0.217800248 \\
\hline 9/1/2021 & 0.2510 & 1016.8 & 988.06 & 28.7 & 6.3 & 35 & 0.3500 & 0.2331 & 0.228695 \\
\hline 9/1/2021 & 0.2600 & 1017.2 & 988.01 & 29.2 & 6.3 & 35.5 & 0.3550 & 0.2228 & 0.2474438 \\
\hline 9/1/2021 & 0.2500 & 1016.5 & 988.06 & 28.4 & 6.3 & 34.7 & 0.3470 & 0.2023 & 0.217800248 \\
\hline $9 / 1 / 2021$ & 0.2400 & 1015.5 & 988.10 & 27.4 & 6.3 & 33.7 & 0.3370 & 0.1997 & 0.183404768 \\
\hline $9 / 1 / 2021$ & 0.2440 & 1015.6 & 988.10 & 27.5 & 6.3 & 33.8 & 0.3380 & 0.2018 & 0.186711368 \\
\hline 9/1/2021 & 0.2420 & 1014.8 & 988.02 & 26.8 & 6.3 & 33.1 & 0.3310 & 0.1704 & 0.164185592 \\
\hline $9 / 1 / 2021$ & 0.2380 & 1015.3 & 988.16 & 27.1 & 6.3 & 33.4 & 0.3340 & 0.1738 & 0.173662232 \\
\hline 9/1/2021 & 0.2260 & 1014.2 & 988.30 & 25.9 & 6.3 & 32.2 & 0.3220 & 0.1256 & 0.137351048 \\
\hline
\end{tabular}


Table A5-2. Modeled streamflow at Site 5, West Run Watershed, Morgantown, WV, U.S.A.

\begin{tabular}{|c|c|c|c|c|c|c|c|c|c|c|c|c|c|}
\hline $\begin{array}{l}\text { Cross- } \\
\text { Section } \\
\text { Area } \\
\left(\mathrm{m}^{2}\right)\end{array}$ & $\begin{array}{l}\text { A (Cross } \\
\text { Section } \\
\text { area of } \\
\text { flow) }\end{array}$ & $\begin{array}{c}\text { P } \\
\text { (Wetted } \\
\text { Perimete } \\
\text { r) }\end{array}$ & $\begin{array}{c}\mathrm{RH}=\mathrm{A} / \mathrm{P} \\
\text { Hydraulic } \\
\text { Radius } \\
\text { (m) }\end{array}$ & $\begin{array}{l}\text { Observed } \\
\text { Slope (m) }\end{array}$ & $\begin{array}{l}\text { Calculated } \\
\text { Slope using } \\
\text { ArcGIS (m) }\end{array}$ & $\begin{array}{l}\text { Roughness } \\
\text { Coefficient } \\
\text { (n) }\end{array}$ & $\begin{array}{c}\text { Manning } \\
\text { Discharge } \\
\left(\mathrm{m}^{3} / \mathrm{s}\right)(\mathrm{Obs} \\
\text { Slope) }\end{array}$ & $\begin{array}{c}\text { Manning } \\
\text { Discharge } \\
\left(\mathrm{m}^{3} / \mathrm{s}\right) \text { (Calc } \\
\text { Slope) }\end{array}$ & $\begin{array}{c}\text { Chezy } \\
\text { Coefficient } \\
\text { (C) }\end{array}$ & $\begin{array}{c}\text { Chezy } \\
\text { Discharge } \\
\left(\mathrm{m}^{3} / \mathrm{s}\right)(\mathrm{Obs} \\
\text { Slope) }\end{array}$ & $\begin{array}{c}\text { Chezy } \\
\text { Discharge } \\
\left(\mathrm{m}^{3} / \mathrm{s}\right) \text { (Calc } \\
\text { Slope) }\end{array}$ & $\begin{array}{l}\text { Dingman \& } \\
\text { Sharma } \\
\text { Discharge } \\
\left(\mathrm{m}^{3} / \mathrm{s}\right) \text { (Obs. } \\
\text { Slope) }\end{array}$ & $\begin{array}{c}\text { Dingman \& } \\
\text { Sharma } \\
\text { Discharge } \\
\text { (m } \mathrm{m}^{3} / \mathrm{s} \text { ) (Calc } \\
\text { Slope) }\end{array}$ \\
\hline 8.29 & 0.253 & 1.9972 & 0.126512 & 0.05 & 0.078 & 0.2 & 0.07119236 & 0.08891923 & 3.542624095 & 0.07119236 & 0.08891923 & 0.110249622 & 0.116852715 \\
\hline 8.29 & 0.287 & 2.0647 & 0.138994 & 0.05 & 0.078 & 0.2 & 0.086094199 & 0.107531621 & 3.598619718 & 0.086094199 & 0.107531621 & 0.132918848 & 0.140879652 \\
\hline 8.29 & 0.093 & 1.646 & 0.056501 & 0.05 & 0.078 & 0.2 & 0.015309936 & 0.019122104 & 3.097268512 & 0.015309936 & 0.019122104 & 0.024727262 & 0.026208232 \\
\hline 8.29 & 0.171 & 1.9412 & 0.08809 & 0.05 & 0.078 & 0.2 & 0.037850214 & 0.047274902 & 3.335218637 & 0.037850214 & 0.047274902 & 0.06033913 & 0.063952974 \\
\hline 8.29 & 0.151 & 1.7224 & 0.087668 & 0.05 & 0.078 & 0.2 & 0.033316592 & 0.04161241 & 3.332553724 & 0.033316592 & 0.04161241 & 0.052047684 & 0.055164935 \\
\hline 8.29 & 0.159 & 1.723 & 0.092281 & 0.05 & 0.078 & 0.2 & 0.036301678 & 0.045340781 & 3.361155813 & 0.036301678 & 0.045340781 & 0.056442708 & 0.059823186 \\
\hline 8.29 & 0.163 & 1.7232 & 0.094591 & 0.05 & 0.078 & 0.2 & 0.037833561 & 0.047254103 & 3.375037926 & 0.037833561 & 0.047254103 & 0.058689594 & 0.062204643 \\
\hline 8.29 & 0.171 & 1.8796 & 0.090977 & 0.05 & 0.078 & 0.2 & 0.038672736 & 0.048302232 & 3.353192221 & 0.038672736 & 0.048302232 & 0.061122482 & 0.064783243 \\
\hline 8.29 & 0.247 & 2.0988 & 0.117686 & 0.05 & 0.078 & 0.2 & 0.066318683 & 0.082832008 & 3.500184903 & 0.066318683 & 0.082832008 & 0.104291319 & 0.110537557 \\
\hline 8.29 & 0.405 & 3.4532 & 0.117283 & 0.05 & 0.078 & 0.2 & 0.108492294 & 0.135506831 & 3.49818054 & 0.108492294 & 0.135506831 & 0.186021154 & 0.197162372 \\
\hline 8.29 & 0.388 & 3.448 & 0.112529 & 0.05 & 0.078 & 0.2 & 0.101110528 & 0.126287009 & 3.474140801 & 0.101110528 & 0.126287009 & 0.173992159 & 0.184412934 \\
\hline 8.29 & 0.493 & 2.5364 & 0.19437 & 0.05 & 0.078 & 0.2 & 0.184950159 & 0.231002675 & 3.805469102 & 0.184950159 & 0.231002675 & 0.286738086 & 0.303911464 \\
\hline 8.29 & 0.472 & 2.5158 & 0.187614 & 0.05 & 0.078 & 0.2 & 0.172944835 & 0.216008029 & 3.783098525 & 0.172944835 & 0.216008029 & 0.268636237 & 0.284725455 \\
\hline 8.29 & 0.448 & 2.493 & 0.179703 & 0.05 & 0.078 & 0.2 & 0.159503485 & 0.199219789 & 3.756032086 & 0.159503485 & 0.199219789 & 0.248368023 & 0.263243333 \\
\hline 8.29 & 0.421 & 2.4666 & 0.17068 & 0.05 & 0.078 & 0.2 & 0.144830273 & 0.180892953 & 3.723921914 & 0.144830273 & 0.180892953 & 0.226193709 & 0.23974095 \\
\hline 8.29 & 0.48774 & 2.473 & 0.197226 & 0.05 & 0.078 & 0.2 & 0.184764934 & 0.230771329 & 3.81473213 & 0.184764934 & 0.230771329 & 0.284809809 & 0.301867697 \\
\hline 8.29 & 0.47787 & 2.463 & 0.194019 & 0.05 & 0.078 & 0.2 & 0.179058528 & 0.22364403 & 3.804324582 & 0.179058528 & 0.22364403 & 0.27624395 & 0.29278881 \\
\hline 8.29 & 0.48658 & 2.473 & 0.196757 & 0.05 & 0.078 & 0.2 & 0.184033133 & 0.229857309 & 3.813218523 & 0.184033133 & 0.229857309 & 0.283745035 & 0.300739153 \\
\hline 8.29 & 0.48861 & 2.445 & 0.19984 & 0.05 & 0.078 & 0.2 & 0.186726669 & 0.233221535 & 3.823114035 & 0.186726669 & 0.233221535 & 0.286913187 & 0.304097052 \\
\hline 8.29 & 0.48513 & 2.396 & 0.202475 & 0.05 & 0.078 & 0.2 & 0.187022568 & 0.233591113 & 3.831468188 & 0.187022568 & 0.233591113 & 0.28601209 & 0.303141987 \\
\hline 8.29 & 0.46626 & 2.376 & 0.196237 & 0.05 & 0.078 & 0.2 & 0.176037144 & 0.219870323 & 3.81153833 & 0.176037144 & 0.219870323 & 0.269611117 & 0.285758723 \\
\hline 8.29 & 0.44826 & 2.347 & 0.190993 & 0.05 & 0.078 & 0.2 & 0.16621221 & 0.207598984 & 3.794368334 & 0.16621221 & 0.207598984 & 0.254668781 & 0.269921457 \\
\hline 8.29 & 0.44564 & 2.317 & 0.192335 & 0.05 & 0.078 & 0.2 & 0.166013954 & 0.207351362 & 3.79879939 & 0.166013954 & 0.207351362 & 0.253633115 & 0.268823763 \\
\hline 8.29 & 0.44332 & 2.313 & 0.191665 & 0.05 & 0.078 & 0.2 & 0.164765694 & 0.205792286 & 3.796589302 & 0.164765694 & 0.205792286 & 0.251733129 & 0.266809983 \\
\hline 8.29 & 0.43519 & 2.305 & 0.188803 & 0.05 & 0.078 & 0.2 & 0.160129949 & 0.200002242 & 3.787081638 & 0.160129949 & 0.200002242 & 0.244848713 & 0.259513244 \\
\hline 8.29 & 0.41255 & 2.281 & 0.180864 & 0.05 & 0.078 & 0.2 & 0.147513738 & 0.1842446 & 3.760063869 & 0.147513738 & 0.1842446 & 0.226057458 & 0.239596539 \\
\hline
\end{tabular}




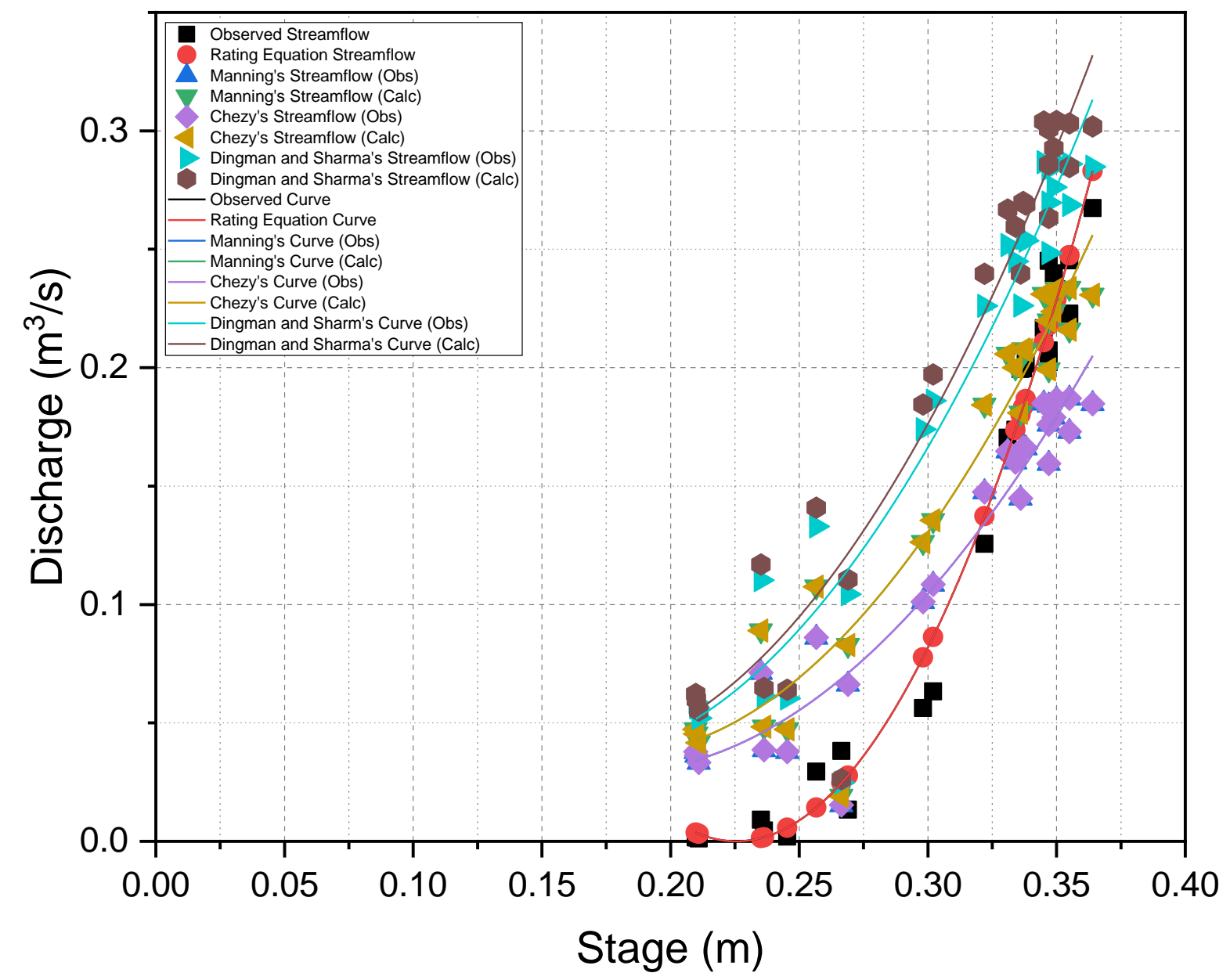

Figure A5-1. Observed and modeled rating curves and streamflow from Site 5, West Run Watershed, Morgantown, West Virginia, U.S.A 
Table A5-3. Polynomial rating equations and $\mathrm{R}^{2}$ values for observed and modeled rating curves at Site 5, West Run Watershed, Morgantown, WV, U.S.A.

\begin{tabular}{ccc}
\hline & $\begin{array}{c}\mathbf{R}^{\mathbf{2}} \\
\text { Value }\end{array}$ & Polynomial Equation \\
\hline Observed Curve & 0.98 & $\mathrm{y}=14.772 \mathrm{x}^{2}-6.6645 \mathrm{x}+0.7517$ \\
Manning's Curve (Obs Slope) & 0.93 & $\mathrm{y}=5.1071 \mathrm{x}^{2}-1.8233 \mathrm{x}+0.192$ \\
Manning's Curve (Calc Slope) & 0.93 & $\mathrm{y}=6.3787 \mathrm{x}^{2}-2.2774 \mathrm{x}+0.2398$ \\
Chezy's Curve (Obs Slope) & 0.93 & $\mathrm{y}=5.1071 \mathrm{x}^{2}-1.8233 \mathrm{x}+0.192$ \\
Chezy's Curve (Calc Slope) & 0.93 & $\mathrm{y}=6.3787 \mathrm{x}^{2}-2.2774 \mathrm{x}+0.2398$ \\
$\begin{array}{c}\text { Dingman and Sharma's Curve } \\
\text { (Obs Slope) }\end{array}$ & 0.93 & $\mathrm{y}=6.6269 \mathrm{x}^{2}-2.1068 \mathrm{x}+0.202$ \\
$\begin{array}{c}\text { Dingman and Sharma's Curve } \\
\text { (Calc Slope) }\end{array}$ & 0.93 & $\mathrm{y}=7.0238 \mathrm{x}^{2}-2.2329 \mathrm{x}+0.2141$ \\
\hline
\end{tabular}

Table A5-4. Descriptive statistics for observed and modeled streamflow used to generate the rating curves for Site 5, West Run Watershed, Morgantown, WV, U.S.A.

\begin{tabular}{|c|c|c|c|c|}
\hline & Sample Size & Mean $\left(\mathrm{m}^{3} / \mathrm{s}\right)$ & St. Dev. & SE of Mean \\
\hline Observed & 26 & 0.13 & 0.1 & 0.02 \\
\hline Manning's & 26 & 0.123 & 0.06 & 0.012 \\
\hline $\begin{array}{l}\text { Curve (Obs } \\
\text { Slope) }\end{array}$ & & & & \\
\hline $\begin{array}{c}\text { Manning's } \\
\text { Curve (Calc } \\
\text { Slope) }\end{array}$ & 26 & 0.154 & 0.08 & 0.015 \\
\hline $\begin{array}{c}\text { Chezy's Curve } \\
\text { (Obs Slope) }\end{array}$ & 26 & 0.123 & 0.06 & 0.012 \\
\hline $\begin{array}{c}\text { Chezy's Curve } \\
\text { (Calc Slope) }\end{array}$ & 26 & 0.154 & 0.08 & 0.015 \\
\hline $\begin{array}{l}\text { Dingman and } \\
\text { Sharma's } \\
\text { Curve (Obs } \\
\text { Slope) }\end{array}$ & 26 & 0.191 & 0.094 & 0.018 \\
\hline $\begin{array}{l}\text { Dingman and } \\
\text { Sharma's } \\
\text { Curve (Calc } \\
\text { Slope) }\end{array}$ & 26 & 0.202 & 0.1 & 0.019 \\
\hline
\end{tabular}


Table A5-5. P-values of the statistical analyses (post-hoc ANOVA) for observed and modeled rating curves at Site 5, West Run Watershed, Morgantown, WV, U.S.A.

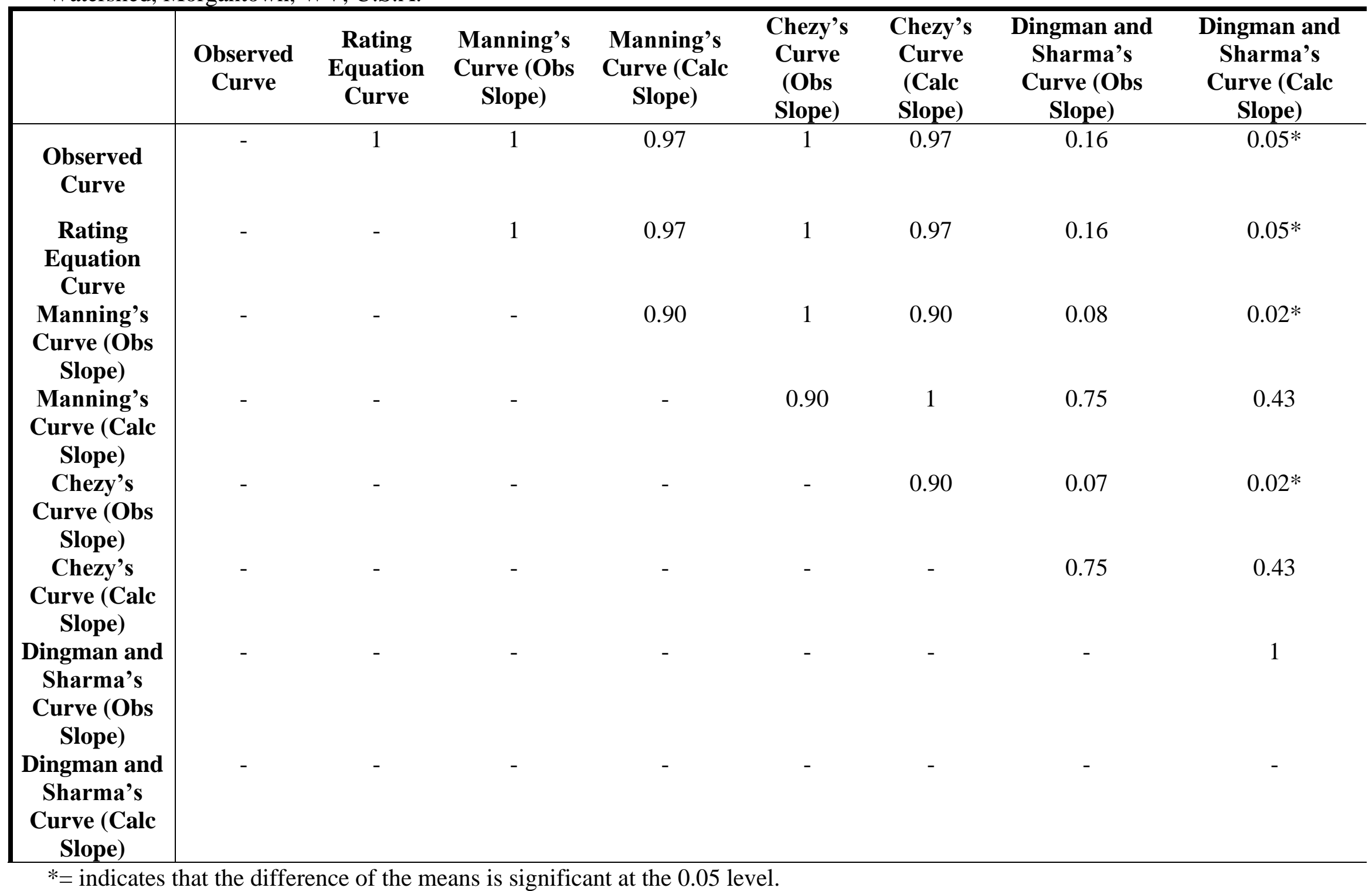




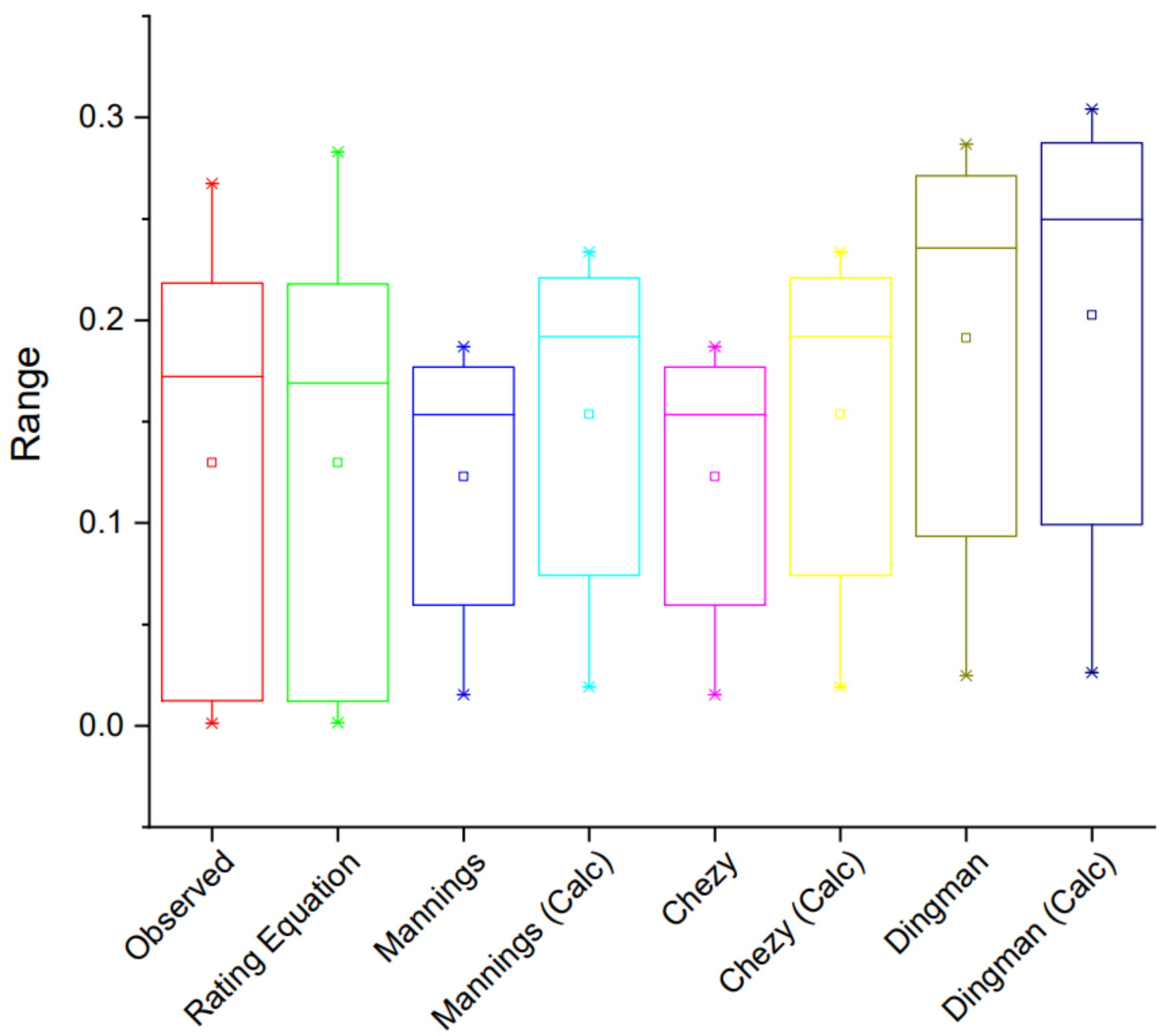

Figure A5-2. Box and whisker plots for the results of the statistical analyses (post-hoc ANOVA) of observed and modeled rating curves at Site 5, West Run Watershed, Morgantown, WV, U.S.A.

104 


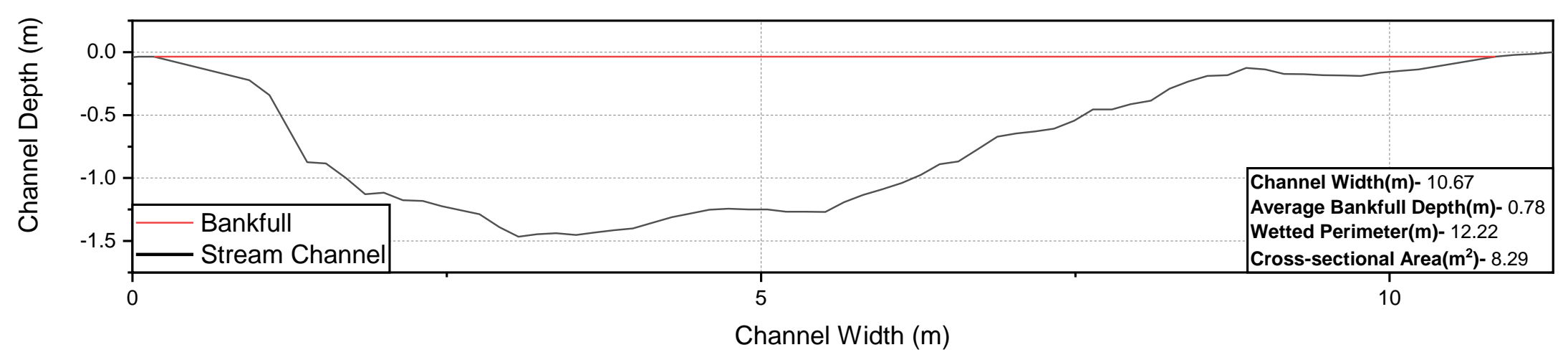

Figure A5-3. Cross-sectional profile of WRW Site 5, West Run Watershed, Morgantown, WV, USA (Figure 2). Channel Width of zero (0) represents the left bank facing downstream. 


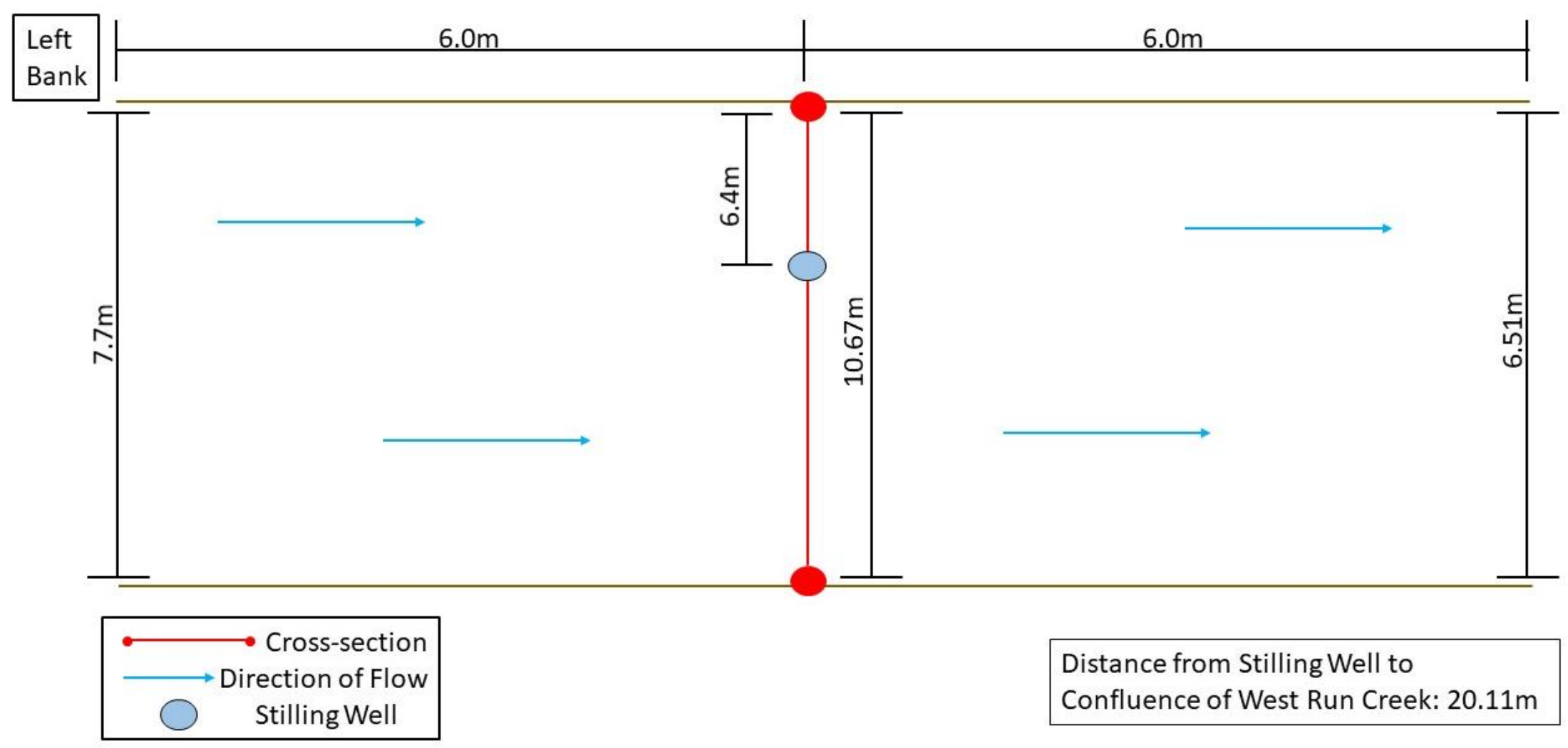

Figure A5-4. Plan view profile of WRW Site 5, West Run Watershed, Morgantown, WV, U.S.A. (Figure 2). Showing the positioning of stilling well in relation to where the streamflow was measured. Along with the channel width at the stilling well, point where crosssections were performed, and 6.0m upstream and downstream from the stilling well. 


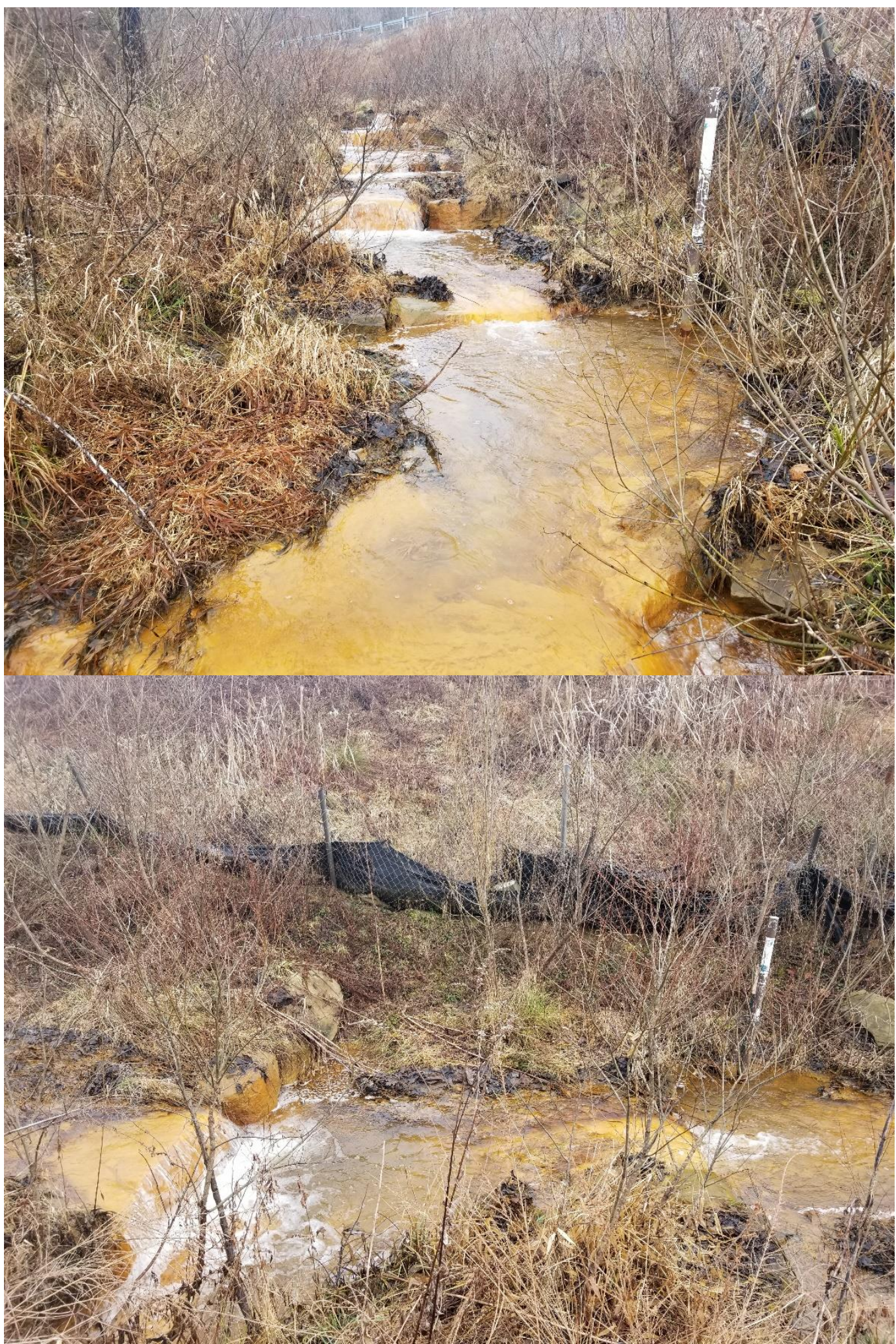

Figure A5-5. Photographs showing channel characteristics at Site \#5, West Run Watershed, Morgantown, WV, U.S.A. Photo 1 was taken looking upstream in the channel. Photo 2 was taken from the right bank looking downstream. 


\section{APPENDIX 6: Site 6}

Table A6-1. Streamflow measurements and stage collected at Site 6, West Run Watershed, Morgantown, WV, U.S.A. (Figure 2).

\begin{tabular}{|c|c|c|c|c|c|c|c|c|c|}
\hline Date & $\begin{array}{l}\text { Mean Depth of } \\
\text { Cross-Section } \\
\text { (m) }\end{array}$ & Stage(PT in cm) & $\begin{array}{c}\text { Barometric } \\
\text { Pressure (in cm) }\end{array}$ & $\begin{array}{l}\text { Pressure } \\
\text { Corrected Stage } \\
\text { (cm) }\end{array}$ & $\begin{array}{l}\text { Stilling Well } \\
\text { Offset (cm) }\end{array}$ & $\begin{array}{l}\text { P-Corrected } \\
\text { Stage + Offset } \\
\text { (cm) }\end{array}$ & $\begin{array}{l}\text { P-Corrected } \\
\text { Stage + Offset } \\
\text { (m) }\end{array}$ & $\begin{array}{c}\text { SonTec } \\
\text { Discharge }(\mathrm{m} 3 / \mathrm{s})\end{array}$ & $\begin{array}{l}\text { Rating Equation } \\
\text { Discharge }(\mathrm{m} 3 / \mathrm{s})\end{array}$ \\
\hline $12 / 5 / 2017$ & 0.0964 & 99.42 & 80.07 & 19.35 & 7.7 & 27.05 & 0.2705 & 0.0587 & 0.06433941 \\
\hline $1 / 3 / 2017$ & 0.0910 & 103.08 & 86.88 & 16.2 & 7.7 & 23.9 & 0.2390 & 0.0159 & 0.020736792 \\
\hline $1 / 12 / 2018$ & 0.1272 & 96.16 & 70.27 & 25.89 & 7.7 & 33.59 & 0.3359 & 0.2359 & 0.20617194 \\
\hline $2 / 9 / 2018$ & 0.0921 & 113.36 & 92.05 & 21.31 & 7.7 & 29.01 & 0.2901 & 0.1293 & 0.099578357 \\
\hline $2 / 14 / 2018$ & 0.0616 & 107.52 & 87.67 & 19.85 & 7.7 & 27.55 & 0.2755 & 0.0921 & 0.072737944 \\
\hline $3 / 8 / 2018$ & 0.0852 & 95.03 & 77.68 & 17.35 & 7.7 & 25.05 & 0.2505 & 0.0636 & 0.034793174 \\
\hline $3 / 29 / 2018$ & 0.0982 & 105.28 & 80.58 & 24.7 & 7.7 & 32.4 & 0.3240 & 0.1775 & 0.175210301 \\
\hline $4 / 4 / 2018$ & 0.2122 & 111.39 & 78.3 & 33.09 & 7.7 & 40.79 & 0.4079 & 0.5024 & 0.442407975 \\
\hline $4 / 20 / 2018$ & 0.0939 & 118.06 & 96.62 & 21.44 & 7.7 & 29.14 & 0.2914 & 0.1449 & 0.102135597 \\
\hline $6 / 18 / 2018$ & 0.1222 & 104.31 & 87.25 & 17.06 & 7.7 & 24.76 & 0.2476 & 0.0261 & 0.031046612 \\
\hline $6 / 18 / 2018$ & 0.1146 & 104.28 & 87.24 & 17.04 & 7.7 & 24.74 & 0.2474 & 0.0268 & 0.030793248 \\
\hline $7 / 18 / 2018$ & 0.1038 & 101.26 & 86.44 & 14.82 & 7.7 & 22.52 & 0.2252 & 0.0066 & 0.006695701 \\
\hline $7 / 18 / 2018$ & 0.0866 & 101.19 & 86.4 & 14.79 & 7.7 & 22.49 & 0.2249 & 0.0067 & 0.006424705 \\
\hline $7 / 23 / 2018$ & 0.1052 & 95.9 & 81.2 & 14.7 & 7.7 & 22.4 & 0.2240 & 0.0100 & 0.005620461 \\
\hline $7 / 23 / 2018$ & 0.1030 & 95.98 & 81.27 & 14.71 & 7.7 & 22.41 & 0.2241 & 0.0112 & 0.005709174 \\
\hline $7 / 26 / 2018$ & 0.0978 & 100.09 & 83.97 & 16.12 & 7.7 & 23.82 & 0.2382 & 0.0228 & 0.019838619 \\
\hline $7 / 26 / 2018$ & 0.1012 & 100.13 & 84 & 16.13 & 7.7 & 23.83 & 0.2383 & 0.0244 & 0.019950324 \\
\hline $9 / 11 / 2018$ & 0.1466 & 111.39 & 89.91 & 21.48 & 7.7 & 29.18 & 0.2918 & 0.0966 & 0.102927946 \\
\hline $9 / 18 / 2018$ & 0.1500 & 106.64 & 81.32 & 25.32 & 7.7 & 33.02 & 0.3302 & 0.1730 & 0.191055469 \\
\hline $9 / 25 / 2018$ & 0.2076 & 121.08 & 88.97 & 32.11 & 7.7 & 39.81 & 0.3981 & 0.3937 & 0.40531875 \\
\hline $10 / 16 / 2018$ & 0.1070 & 107.07 & 89.16 & 17.91 & 7.7 & 25.61 & 0.2561 & 0.0458 & 0.042413275 \\
\hline $10 / 16 / 2018$ & 0.1106 & 106.87 & 89.04 & 17.83 & 7.7 & 25.53 & 0.2553 & 0.0478 & 0.041293601 \\
\hline $12 / 17 / 2018$ & 0.1494 & 105.93 & 82.27 & 23.66 & 9.5 & 33.185 & 0.3319 & 0.1446 & 0.19537719 \\
\hline $1 / 24 / 2019$ & 0.3652 & 114.83 & 67.8 & 47.03 & 9.5 & 56.555 & 0.5656 & 1.2213 & 1.252769414 \\
\hline $1 / 24 / 2019$ & 0.3703 & 115.47 & 69.13 & 46.34 & 9.5 & 55.865 & 0.5587 & 1.2707 & 1.208880595 \\
\hline $2 / 26 / 2019$ & 0.1442 & 116.8 & 94.57 & 22.23 & 9.5 & 31.755 & 0.3176 & 0.1044 & 0.159386771 \\
\hline $2 / 26 / 2019$ & 0.1402 & 116.71 & 94.6 & 22.11 & 9.5 & 31.635 & 0.3164 & 0.1064 & 0.156517177 \\
\hline $3 / 28 / 2019$ & 0.1186 & 107.93 & 90.93 & 17 & 9.5 & 26.525 & 0.2653 & 0.0314 & 0.055956604 \\
\hline $12 / 17 / 2019$ & 0.3322 & 118.15 & 75.25 & 42.9 & 9.5 & 52.4 & 0.5240 & 0.9296 & 1.000137981 \\
\hline $4 / 9 / 2020$ & 0.2344 & 1009.9 & 983.27 & 26.6 & 9.5 & 36.1 & 0.3610 & 0.3258 & 0.278996152 \\
\hline $10 / 7 / 2021$ & 0.1890 & 1030.70 & 1005.66 & 25.04 & 9.5 & 34.54 & 0.3454 & 0.2364 & 0.232535091 \\
\hline $10 / 7 / 2021$ & 0.1820 & 1029.90 & 1005.60 & 24.3 & 9.5 & 33.8 & 0.3380 & 0.1982 & 0.211873775 \\
\hline $10 / 7 / 2021$ & 0.1680 & 1028.70 & 1005.47 & 23.23 & 9.5 & 32.73 & 0.3273 & 0.1705 & 0.183566543 \\
\hline $10 / 7 / 2021$ & 0.1610 & 1027.80 & 1005.40 & 22.4 & 9.5 & 31.9 & 0.3190 & 0.1216 & 0.162885304 \\
\hline $10 / 16 / 2021$ & 0.2640 & 1024.80 & 991.54 & 33.26 & 9.5 & 42.76 & 0.4276 & 0.5545 & 0.521669761 \\
\hline $10 / 16 / 2021$ & 0.2510 & 1024.20 & 991.47 & 32.73 & 9.5 & 42.23 & 0.4223 & 0.5200 & 0.499727652 \\
\hline
\end{tabular}


Table A6-2. Modeled streamflow at Site 6, West Run Watershed, Morgantown, WV, U.S.A.

\begin{tabular}{|c|c|c|c|c|c|c|c|c|c|c|c|c|c|}
\hline $\begin{array}{l}\text { Cross- } \\
\text { Section } \\
\text { Area } \\
\left(\mathrm{m}^{2}\right)\end{array}$ & $\begin{array}{c}\text { A (Cross } \\
\text { Section } \\
\text { area of } \\
\text { flow) }\end{array}$ & $\begin{array}{c}\text { P } \\
\text { (Wetted } \\
\text { Perimete } \\
\text { r) }\end{array}$ & $\begin{array}{c}\mathrm{RH}=\mathrm{A} / \mathrm{P} \\
\text { Hydraulic } \\
\text { Radius } \\
(\mathrm{m})\end{array}$ & $\begin{array}{l}\text { Observed } \\
\text { Slope }(m)\end{array}$ & $\begin{array}{l}\text { Calculated } \\
\text { Slope using } \\
\text { ArcGIS (m) }\end{array}$ & $\begin{array}{l}\text { Roughness } \\
\text { Coefficient } \\
\text { (n) }\end{array}$ & $\begin{array}{c}\text { Manning } \\
\text { Discharge } \\
\left(\mathrm{m}^{3} / \mathrm{s}\right) \text { (Obs } \\
\text { Slope) }\end{array}$ & $\begin{array}{c}\text { Manning } \\
\text { Discharge } \\
\left(\mathrm{m}^{3} / \mathrm{s}\right) \text { (Calc } \\
\text { Slope) }\end{array}$ & $\begin{array}{c}\text { Chezy } \\
\text { Coefficient } \\
\text { (C) }\end{array}$ & $\begin{array}{c}\text { Chezy } \\
\text { Discharge } \\
\left(\mathrm{m}^{3} / \mathrm{s}\right) \text { (Obs } \\
\text { Slope) }\end{array}$ & $\begin{array}{c}\text { Chezy } \\
\text { Discharge } \\
\left(\mathrm{m}^{3} / \mathrm{s}\right) \text { (Calc } \\
\text { Slope) }\end{array}$ & $\begin{array}{c}\text { Dingman \& } \\
\text { Sharma } \\
\text { Discharge } \\
\left(\mathrm{m}^{3} / \mathrm{s}\right) \text { (Obs. } \\
\text { Slope) }\end{array}$ & $\begin{array}{l}\text { Dingman \& } \\
\text { Sharma } \\
\text { Discharge } \\
\text { (m³ } / \mathrm{s} \text { ) (Calc } \\
\text { Slope) }\end{array}$ \\
\hline 3.69 & 0.309 & 2.1062 & 0.146786 & 0.02 & 0.016 & 0.072 & 0.168976961 & 0.151137589 & 10.08745378 & 0.168976961 & 0.151137589 & 0.12769239 & 0.122398013 \\
\hline 3.69 & 0.259 & 2.0098 & 0.128819 & 0.02 & 0.016 & 0.072 & 0.129706524 & 0.116013042 & 9.870312755 & 0.129706524 & 0.116013042 & 0.098421154 & 0.09434042 \\
\hline 3.69 & 0.414 & 2.2792 & 0.181434 & 0.02 & 0.016 & 0.072 & 0.260315977 & 0.232833688 & 10.4501021 & 0.260315977 & 0.232833688 & 0.195500961 & 0.187395108 \\
\hline 3.69 & 0.340 & 2.1619 & 0.157471 & 0.02 & 0.016 & 0.072 & 0.194995786 & 0.174409533 & 10.20628133 & 0.194995786 & 0.174409533 & 0.147050292 & 0.140953299 \\
\hline 3.69 & 0.317 & 2.1207 & 0.149543 & 0.02 & 0.016 & 0.072 & 0.175501674 & 0.156973469 & 10.1187868 & 0.175501674 & 0.156973469 & 0.132549537 & 0.127053774 \\
\hline 3.69 & 0.277 & 2.0460 & 0.135509 & 0.02 & 0.016 & 0.072 & 0.143669159 & 0.128501602 & 9.9539556 & 0.143669159 & 0.128501602 & 0.108835855 & 0.104323307 \\
\hline 3.69 & 0.395 & 2.2505 & 0.175313 & 0.02 & 0.016 & 0.072 & 0.242743861 & 0.21711671 & 10.39049894 & 0.242743861 & 0.21711671 & 0.182489955 & 0.174923563 \\
\hline 3.69 & 0.528 & 2.4271 & 0.217716 & 0.02 & 0.016 & 0.072 & 0.375630519 & 0.33597415 & 10.77248462 & 0.375630519 & 0.33597415 & 0.280360735 & 0.268736429 \\
\hline 3.69 & 0.429 & 4.7598 & 0.09013 & 0.02 & 0.016 & 0.072 & 0.169389123 & 0.151506237 & 9.29991405 & 0.169389123 & 0.151506237 & 0.154283573 & 0.147886673 \\
\hline 3.69 & 0.224 & 2.0734 & 0.108035 & 0.02 & 0.016 & 0.072 & 0.099802281 & 0.089265874 & 9.585063424 & 0.099802281 & 0.089265874 & 0.077404595 & 0.074195249 \\
\hline 3.69 & 0.244 & 2.3632 & 0.10325 & 0.02 & 0.016 & 0.072 & 0.105478811 & 0.094343117 & 9.512961263 & 0.105478811 & 0.094343117 & 0.084035706 & 0.080551421 \\
\hline 3.69 & 0.229 & 2.4176 & 0.094722 & 0.02 & 0.016 & 0.072 & 0.093465645 & 0.083598214 & 9.377261117 & 0.093465645 & 0.083598214 & 0.07536458 & 0.072239817 \\
\hline 3.69 & 0.198 & 2.4592 & 0.080514 & 0.02 & 0.016 & 0.072 & 0.072515123 & 0.064859497 & 9.126677969 & 0.072515123 & 0.064859497 & 0.059543815 & 0.057075011 \\
\hline 3.69 & 0.241 & 2.4966 & 0.096531 & 0.02 & 0.016 & 0.072 & 0.099611985 & 0.089095668 & 9.406878102 & 0.099611985 & 0.089095668 & 0.080625621 & 0.077282724 \\
\hline 3.69 & 0.235 & 2.4918 & 0.094309 & 0.02 & 0.016 & 0.072 & 0.095635724 & 0.085539192 & 9.370439271 & 0.095635724 & 0.085539192 & 0.07755045 & 0.074335057 \\
\hline 3.69 & 0.253 & 2.7864 & 0.090798 & 0.02 & 0.016 & 0.072 & 0.10038937 & 0.089790982 & 9.311372056 & 0.10038937 & 0.089790982 & 0.083289651 & 0.079836299 \\
\hline 3.69 & 0.262 & 2.7932 & 0.093799 & 0.02 & 0.016 & 0.072 & 0.106238835 & 0.095022902 & 9.361972905 & 0.106238835 & 0.095022902 & 0.087911758 & 0.084266765 \\
\hline 3.69 & 0.436 & 3.2652 & 0.133529 & 0.02 & 0.016 & 0.072 & 0.223727889 & 0.200108307 & 9.929566464 & 0.223727889 & 0.200108307 & 0.184012863 & 0.176383328 \\
\hline 3.69 & 0.548 & 3.9578 & 0.138461 & 0.02 & 0.016 & 0.072 & 0.288080726 & 0.257667234 & 9.989765398 & 0.288080726 & 0.257667234 & 0.244129426 & 0.234007341 \\
\hline 3.69 & 0.791 & 4.2252 & 0.18721 & 0.02 & 0.016 & 0.072 & 0.508446341 & 0.454768233 & 10.50483025 & 0.508446341 & 0.454768233 & 0.423635698 & 0.406070931 \\
\hline 3.69 & 0.286 & 2.8812 & 0.099264 & 0.02 & 0.016 & 0.072 & 0.120432477 & 0.107718082 & 9.450749995 & 0.120432477 & 0.107718082 & 0.099663069 & 0.095530843 \\
\hline 3.69 & 0.287 & 2.8124 & 0.102048 & 0.02 & 0.016 & 0.072 & 0.123102707 & 0.110106408 & 9.494417056 & 0.123102707 & 0.110106408 & 0.101185256 & 0.096989917 \\
\hline 3.69 & 0.547 & 3.957 & 0.138236 & 0.02 & 0.016 & 0.072 & 0.28724381 & 0.256918674 & 9.987061316 & 0.28724381 & 0.256918674 & 0.243448719 & 0.233354857 \\
\hline 3.69 & 1.524 & 4.8556 & 0.313864 & 0.02 & 0.016 & 0.072 & 1.382490571 & 1.236537158 & 11.44962284 & 1.382490571 & 1.236537158 & 1.124185659 & 1.077574717 \\
\hline 3.69 & 1.519 & 4.86 & 0.312551 & 0.02 & 0.016 & 0.072 & 1.374109298 & 1.22904072 & 11.44162618 & 1.374109298 & 1.22904072 & 1.117984338 & 1.071630515 \\
\hline 3.69 & 0.451 & 3.4124 & 0.132165 & 0.02 & 0.016 & 0.072 & 0.229845911 & 0.205580433 & 9.912585318 & 0.229845911 & 0.205580433 & 0.190675799 & 0.182770007 \\
\hline 3.69 & 0.438 & 3.4046 & 0.128649 & 0.02 & 0.016 & 0.072 & 0.219244457 & 0.196098204 & 9.868144634 & 0.219244457 & 0.196098204 & 0.182268738 & 0.174711519 \\
\hline 3.69 & 0.316 & 2.9044 & 0.1088 & 0.02 & 0.016 & 0.072 & 0.141456645 & 0.12652267 & 9.596347055 & 0.141456645 & 0.12652267 & 0.116221121 & 0.111402365 \\
\hline 3.69 & 1.392 & 4.8354 & 0.287877 & 0.02 & 0.016 & 0.072 & 1.192045839 & 1.066198211 & 11.28587689 & 1.192045839 & 1.066198211 & 0.976498102 & 0.936010576 \\
\hline 3.69 & 0.804 & 3.8978 & 0.20627 & 0.02 & 0.016 & 0.072 & 0.551310438 & 0.493107046 & 10.67595955 & 0.551310438 & 0.493107046 & 0.448889858 & 0.430278004 \\
\hline 3.69 & 0.75019 & 4.34 & 0.172855 & 0.02 & 0.016 & 0.072 & 0.457237105 & 0.408965299 & 10.36607692 & 0.457237105 & 0.408965299 & 0.385610069 & 0.36962192 \\
\hline 3.69 & 0.72174 & 4.326 & 0.166838 & 0.02 & 0.016 & 0.072 & 0.429628203 & 0.384271147 & 10.30504471 & 0.429628203 & 0.384271147 & 0.363327443 & 0.348263175 \\
\hline 3.69 & 0.65177 & 4.222 & 0.154375 & 0.02 & 0.016 & 0.072 & 0.36840679 & 0.329513051 & 10.17255843 & 0.36840679 & 0.329513051 & 0.312509336 & 0.299552086 \\
\hline 3.69 & 0.61287 & 4.132 & 0.148323 & 0.02 & 0.016 & 0.072 & 0.337305093 & 0.301694846 & 10.10498125 & 0.337305093 & 0.301694846 & 0.286131821 & 0.274268235 \\
\hline 3.69 & 1.07709 & 4.605 & 0.233896 & 0.02 & 0.016 & 0.072 & 0.803124241 & 0.718336159 & 10.90195948 & 0.803124241 & 0.718336159 & 0.665181836 & 0.637602092 \\
\hline 3.69 & 1.02484 & 4.579 & 0.223813 & 0.02 & 0.016 & 0.072 & 0.742042623 & 0.663703099 & 10.822188 & 0.742042623 & 0.663703099 & 0.616529109 & 0.590966603 \\
\hline
\end{tabular}




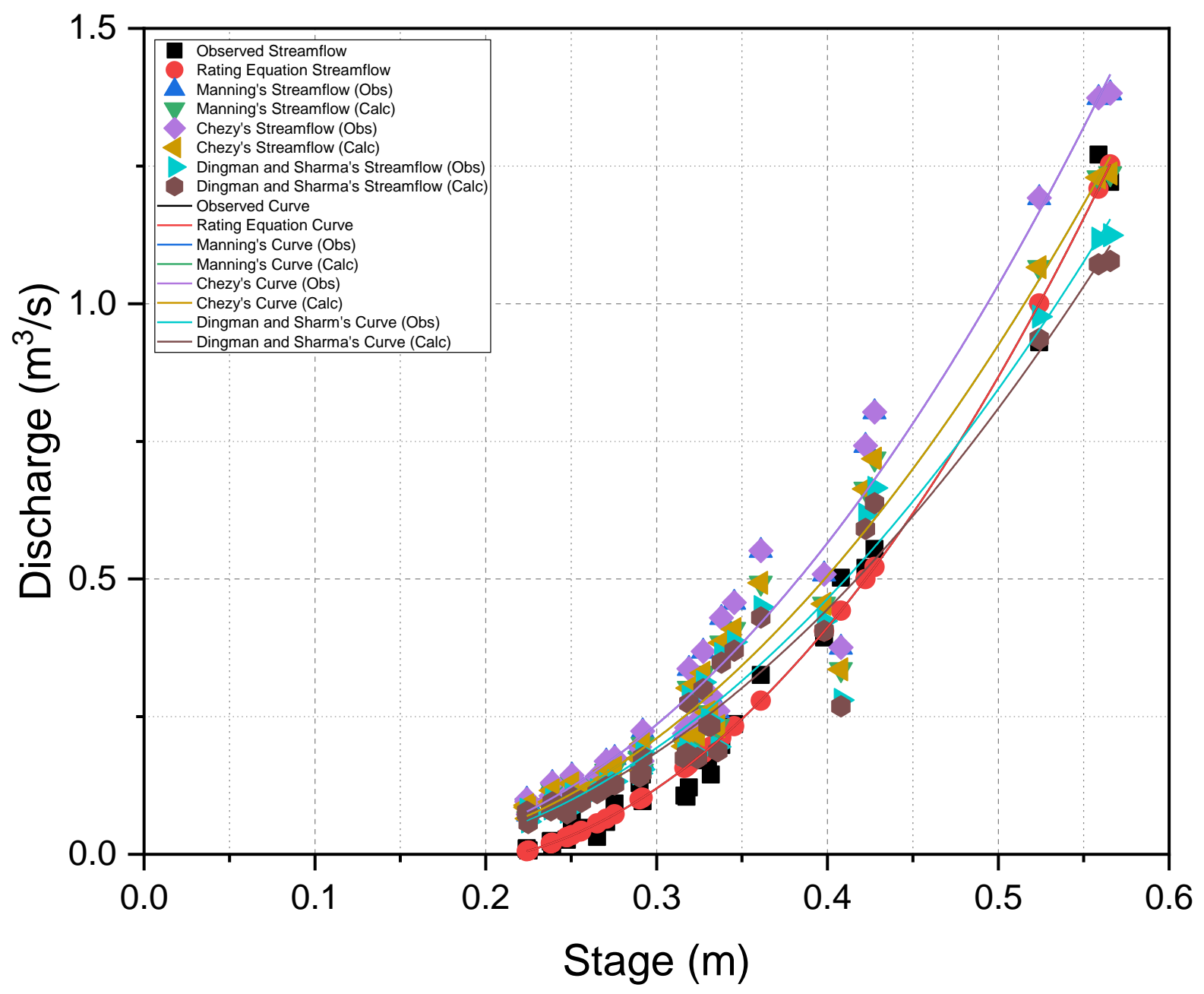

Figure A6-1. Observed and modeled rating curves and streamflow from Site 6, West Run Watershed, Morgantown, West Virginia, U.S.A 
Table A6-3. Polynomial rating equations and $\mathrm{R}^{2}$ values for observed and modeled rating curves at Site 6, West Run Watershed, Morgantown, WV, U.S.A.

\begin{tabular}{ccc}
\hline & $\mathbf{R}^{\mathbf{2}}$ & Polynomial Equation \\
Value & \\
\hline $\begin{array}{c}\text { Observed Curve } \\
\text { Manning's Curve (Obs Slope) }\end{array}$ & 0.99 & $\mathrm{y}=8.0958 \mathrm{x}^{2}-2.7406 \mathrm{x}+0.2133$ \\
Manning's Curve (Calc Slope) & 0.97 & $\mathrm{y}=6.926 \mathrm{x}^{2}-1.5484 \mathrm{x}+0.0768$ \\
Chezy's Curve (Obs Slope) & 0.97 & $\mathrm{y}=6.1948 \mathrm{x}^{2}-1.3849 \mathrm{x}+0.0687$ \\
$\begin{array}{c}\text { Chezy's Curve (Calc Slope) } \\
\text { Dingman and Sharma's Curve } \\
\text { (Obs Slope) }\end{array}$ & 0.97 & $\mathrm{y}=6.926 \mathrm{x}^{2}-1.5484 \mathrm{x}+0.0768$ \\
$\begin{array}{c}\text { Dingman and Sharma's Curve } \\
\text { (Calc Slope) }\end{array}$ & 0.96 & $\mathrm{y}=6.1948 \mathrm{x}^{2}-1.3849 \mathrm{x}+0.0687$ \\
& & $\mathrm{y}=5.237 \mathrm{x}^{2}-1.0673 \mathrm{x}+0.0341$ \\
\hline
\end{tabular}

Table A6-4. Descriptive statistics for observed and modeled streamflow used to generate the rating curves for Site 6, West Run Watershed, Morgantown, WV, U.S.A.

\begin{tabular}{|c|c|c|c|c|}
\hline & Sample Size & Mean $\left(\mathrm{m}^{3} / \mathrm{s}\right)$ & St. Dev. & SE of Mean \\
\hline Observed & 36 & 0.229 & 0.318 & 0.053 \\
\hline Manning's & 36 & 0.357 & 0.357 & 0.059 \\
\hline \multicolumn{5}{|l|}{$\begin{array}{l}\text { Curve (Obs } \\
\text { Slope) }\end{array}$} \\
\hline & 36 & 0.319 & 0.319 & 0.053 \\
\hline \multicolumn{5}{|l|}{$\begin{array}{c}\text { Curve (Calc } \\
\text { Slope) }\end{array}$} \\
\hline $\begin{array}{c}\text { Chezy's Curve } \\
\text { (Obs Slope) }\end{array}$ & 36 & 0.357 & 0.357 & 0.059 \\
\hline $\begin{array}{l}\text { Chezy's Curve } \\
\text { (Calc Slope) }\end{array}$ & 36 & 0.319 & 0.319 & 0.053 \\
\hline $\begin{array}{c}\text { Dingman and } \\
\text { Sharma's }\end{array}$ & 36 & 0.282 & 0.285 & 0.047 \\
\hline $\begin{array}{l}\text { Curve (Obs } \\
\text { Slope) }\end{array}$ & & & & \\
\hline $\begin{array}{l}\text { Dingman and } \\
\text { Sharma's }\end{array}$ & 36 & 0.27 & 0.273 & 0.045 \\
\hline $\begin{array}{l}\text { Curve (Calc } \\
\text { Slope) }\end{array}$ & & & & \\
\hline
\end{tabular}


Table A6-5. P-values of the statistical analyses (post-hoc ANOVA) for observed and modeled rating curves at Site 6, West Run Watershed, Morgantown, WV, U.S.A.

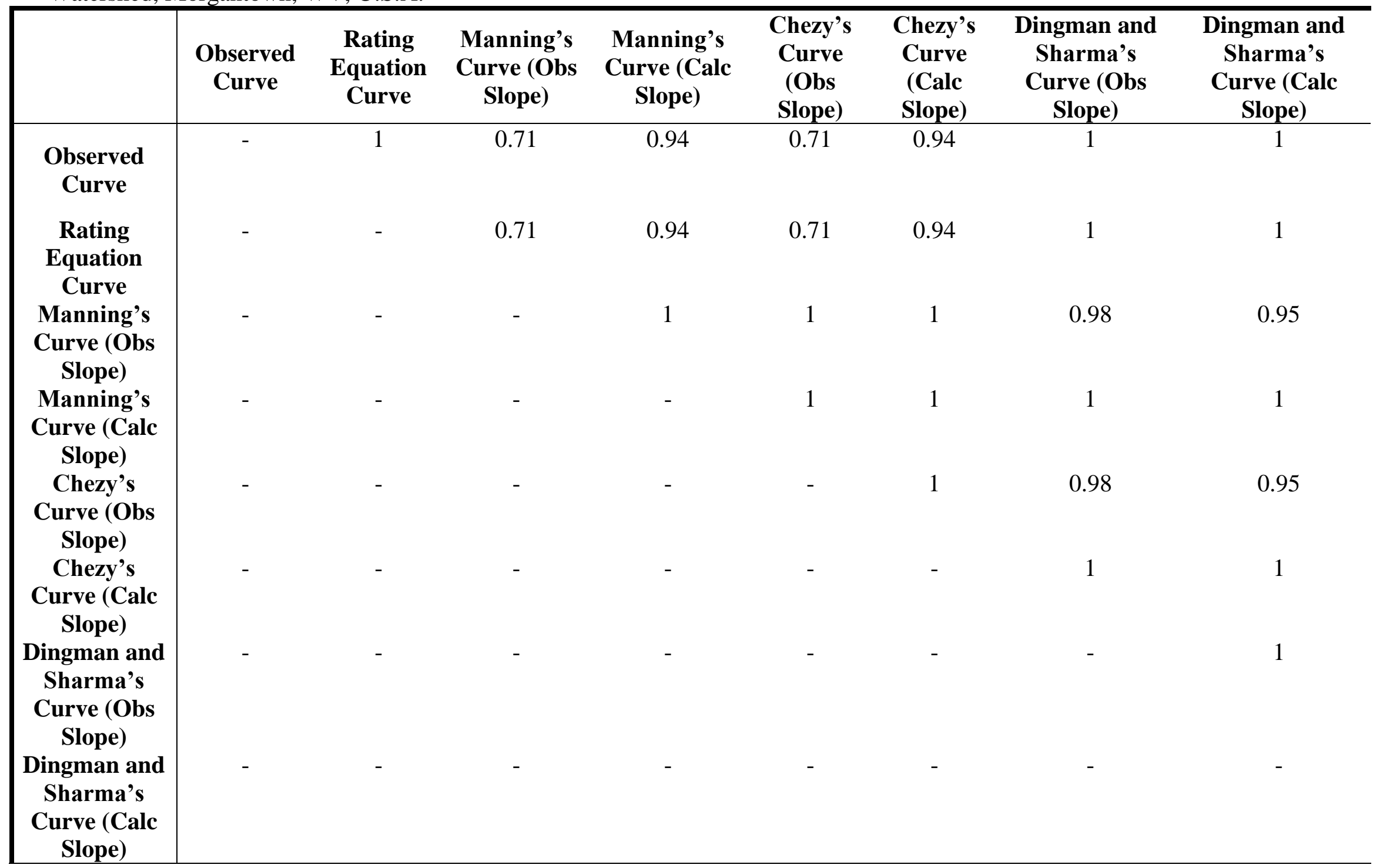




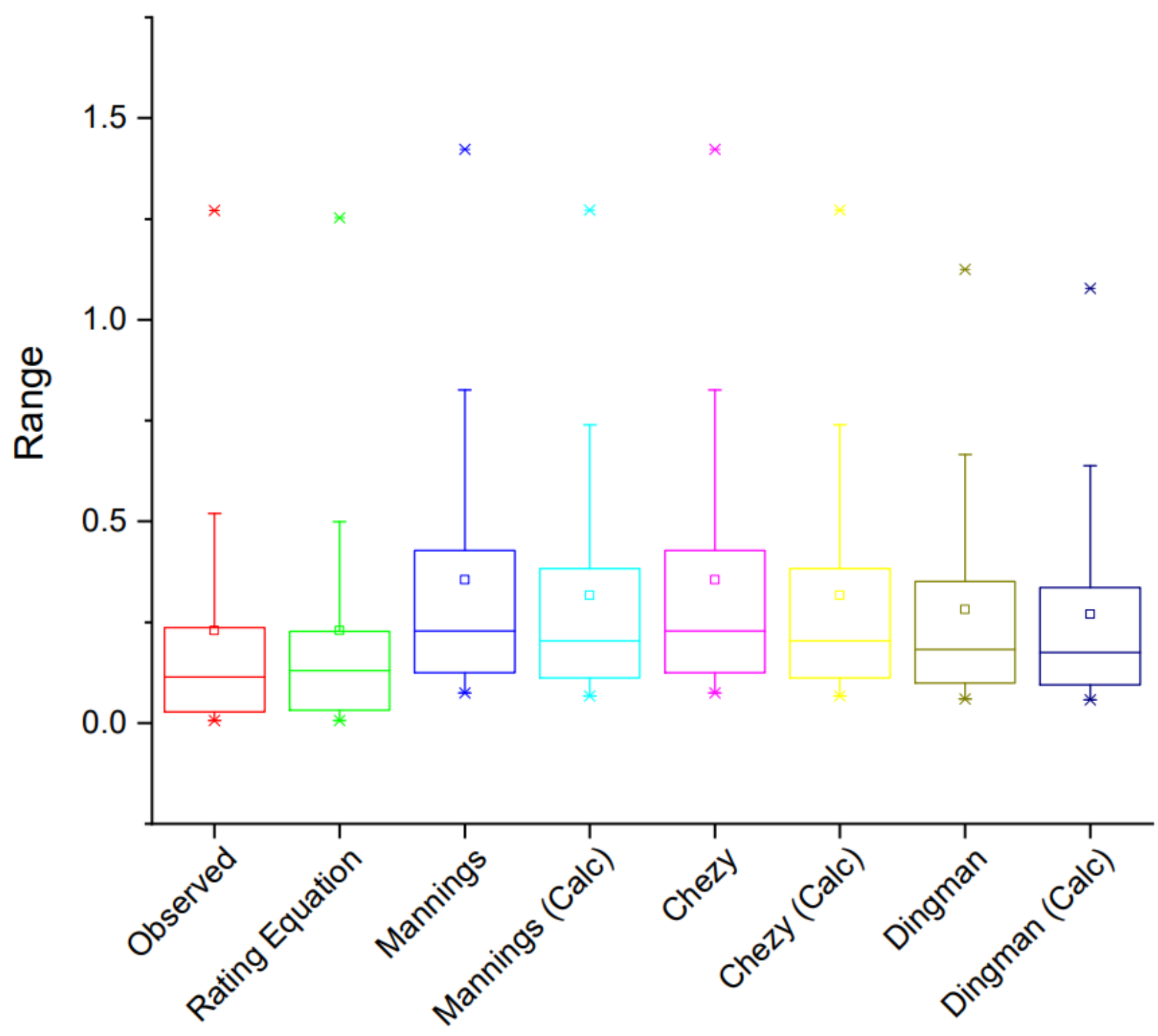

Figure A6-2. Box and whisker plots for the results of the statistical analyses (post-hoc ANOVA) of observed and modeled rating curves at Site 6, West Run Watershed, Morgantown, WV, U.S.A. 


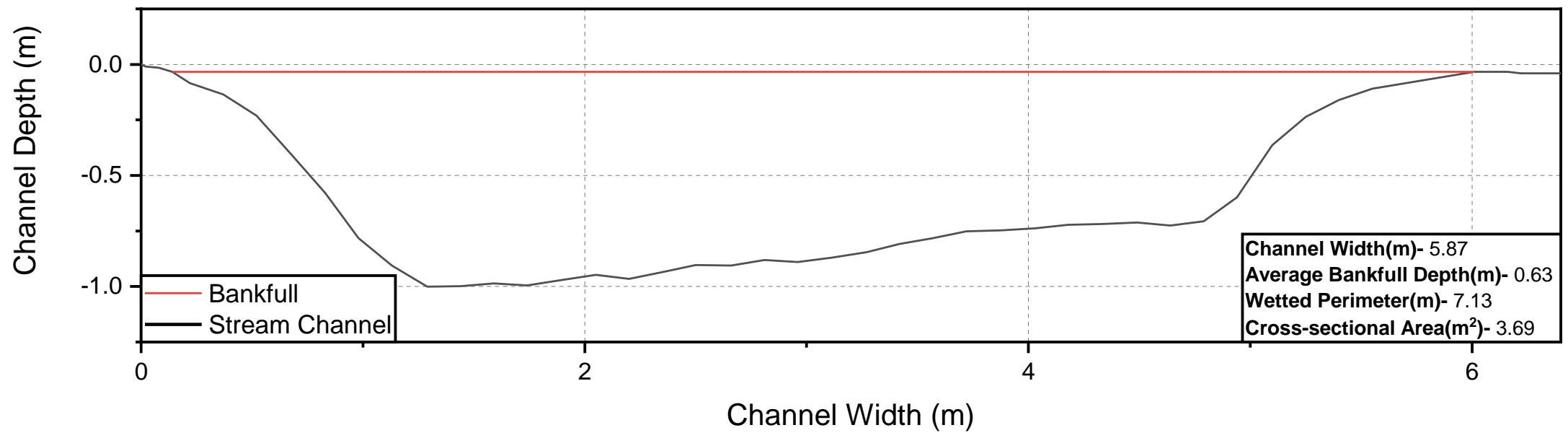

Figure A6-3. Cross-sectional profile of WRW Site 6, West Run Watershed, Morgantown, WV, USA (Figure 2). Channel Width of zero (0) represents the left bank facing downstream. 

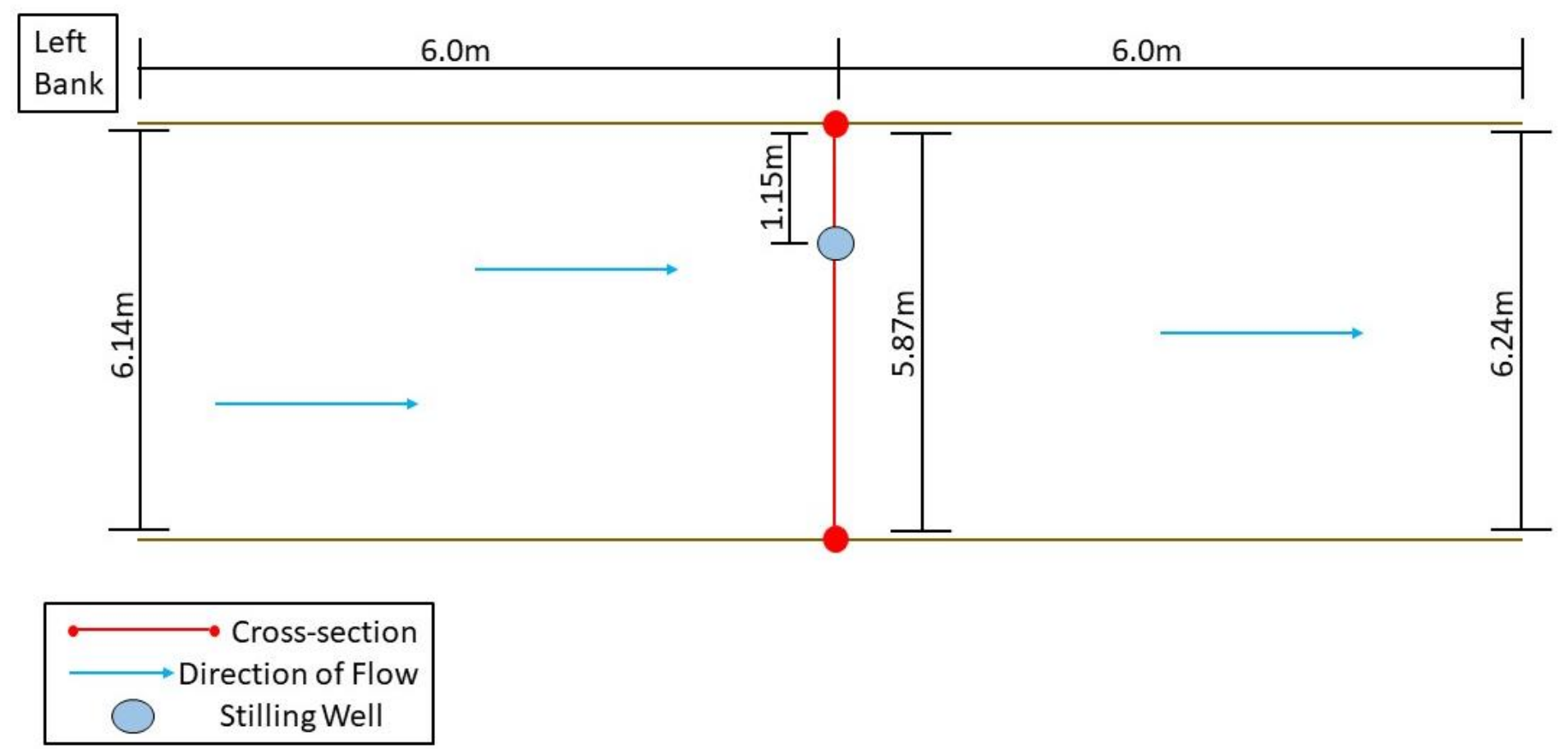

Figure A6-4. Plan view profile of WRW Site 6, West Run Watershed, Morgantown, WV, U.S.A. (Figure 2). Showing the positioning of stilling well in relation to where the streamflow was measured. Along with the channel width at the stilling well, point where crosssections were performed, and $6.0 \mathrm{~m}$ upstream and downstream from the stilling well. 


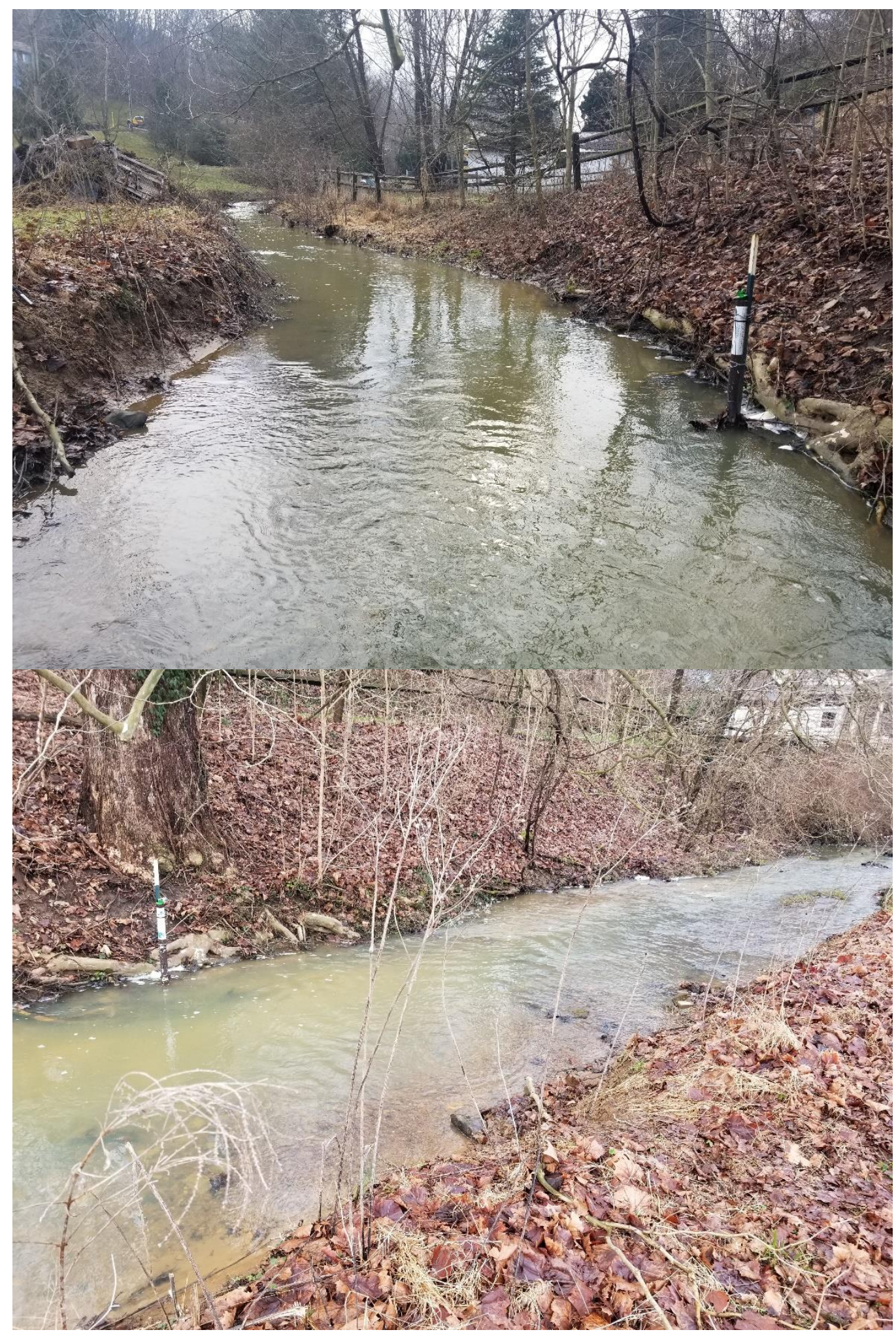

Figure A6-5. Photographs showing channel characteristics at Site \#6, West Run Watershed, Morgantown, WV, U.S.A. Photo 1 was taken looking upstream in the channel. Photo 2 was taken from the right bank looking downstream. 


\section{APPENDIX 7: Site 7}

Table A7-1. Streamflow measurements and stage collected at Site 7, West Run Watershed, Morgantown, WV, U.S.A. (Figure 2).

\begin{tabular}{|c|c|c|c|c|c|c|c|}
\hline Stage(PT in cm) & $\begin{array}{c}\text { Barometric } \\
\text { Pressure (in } \mathrm{cm} \text { ) }\end{array}$ & $\begin{array}{c}\text { Pressure } \\
\text { Corrected Stage } \\
\text { (cm) }\end{array}$ & $\begin{array}{l}\text { Stilling Well } \\
\text { Offset (cm) }\end{array}$ & $\begin{array}{l}\text { P-Corrected } \\
\text { Stage + Offset } \\
\text { (cm) }\end{array}$ & $\begin{array}{l}\text { P-Corrected } \\
\text { Stage + Offset } \\
\text { (m) }\end{array}$ & $\begin{array}{c}\text { SonTec } \\
\text { Discharge }(\mathrm{m} 3 / \mathrm{s})\end{array}$ & $\begin{array}{l}\text { Rating Equation } \\
\text { Discharge }(\mathrm{m} 3 / \mathrm{s})\end{array}$ \\
\hline 102.12 & 87.26 & 14.86 & 7.6 & 22.46 & 0.2246 & 0.1079 & 0.115517447 \\
\hline 92.19 & 89.6 & 2.59 & 7.6 & 10.19 & 0.1019 & 0.0039 & 0.005000171 \\
\hline 92.14 & 89.41 & 2.73 & 7.6 & 10.33 & 0.1033 & 0.0043 & 0.005520038 \\
\hline 86.56 & 82.04 & 4.52 & 7.6 & 12.12 & 0.1212 & 0.0092 & 0.013674614 \\
\hline 86.47 & 82.08 & 4.39 & 7.6 & 11.99 & 0.1199 & 0.0092 & 0.012988203 \\
\hline 89.55 & 70.81 & 18.74 & 7.6 & 26.34 & 0.2634 & 0.1731 & 0.177811996 \\
\hline 88.76 & 78.73 & 10.03 & 7.6 & 17.63 & 0.1763 & 0.0535 & 0.056330251 \\
\hline 89.8 & 78.77 & 11.03 & 7.6 & 18.63 & 0.1863 & 0.0600 & 0.066912841 \\
\hline 99.96 & 95.29 & 4.67 & 7.6 & 12.27 & 0.1227 & 0.0184 & 0.014484957 \\
\hline 86.25 & 82.72 & 3.53 & 7.6 & 11.13 & 0.1113 & 0.0060 & 0.008818897 \\
\hline 72.03 & 66.65 & 5.38 & 7.6 & 12.98 & 0.1298 & 0.0148 & 0.018587056 \\
\hline 70.89 & 66.94 & 3.95 & 7.6 & 11.55 & 0.1155 & 0.0134 & 0.010774419 \\
\hline 101.02 & 91.14 & 9.88 & 7.6 & 17.48 & 0.1748 & 0.0519 & 0.054818146 \\
\hline 99.57 & 91.26 & 8.31 & 7.6 & 15.91 & 0.1591 & 0.0474 & 0.040169945 \\
\hline 77.99 & 74.13 & 3.86 & 7.6 & 11.46 & 0.1146 & 0.0100 & 0.010342417 \\
\hline 85.39 & 82.36 & 3.03 & 7.6 & 10.63 & 0.1063 & 0.0120 & 0.006691647 \\
\hline 90.01 & 75.25 & 14.76 & 7.6 & 22.36 & 0.2236 & 0.1170 & 0.114085613 \\
\hline 1006.12 & 990.18 & 16 & 7.6 & 23.6 & 0.236 & 0.1441 & 0.132457283 \\
\hline 1018.7 & 1003.36 & 15.3 & 7.6 & 22.9 & 0.229 & 0.1264 & 0.121921212 \\
\hline 1013.1 & 1002.25 & 10.9 & 7.6 & 18.5 & 0.185 & 0.0559 & 0.065487745 \\
\hline 1000.70 & 992.57 & 8.13 & 7.6 & 15.73 & 0.1573 & 0.0486 & 0.038628006 \\
\hline 1000.50 & 992.38 & 8.12 & 7.6 & 15.72 & 0.1572 & 0.0345 & 0.038543172 \\
\hline 1000.40 & 992.55 & 7.85 & 7.6 & 15.45 & 0.1545 & 0.0449 & 0.036285645 \\
\hline
\end{tabular}


Table A7-2. Modeled streamflow at Site 7, West Run Watershed, Morgantown, WV, U.S.A.

\begin{tabular}{|c|c|c|c|c|c|c|c|c|c|c|c|c|c|}
\hline $\begin{array}{l}\text { Cross- } \\
\text { Section } \\
\text { Area } \\
\left(\mathrm{m}^{2}\right)\end{array}$ & $\begin{array}{c}\text { A (Cross } \\
\text { Section } \\
\text { area of } \\
\text { flow) }\end{array}$ & $\begin{array}{c}\text { P } \\
\text { (Wetted } \\
\text { Perimete } \\
\text { r) }\end{array}$ & $\begin{array}{c}\mathrm{RH}=\mathrm{A} / \mathrm{P} \\
\text { Hydraulic } \\
\text { Radius } \\
\text { (m) }\end{array}$ & $\begin{array}{l}\text { Observed } \\
\text { Slope }(\mathrm{m})\end{array}$ & $\begin{array}{l}\text { Calculated } \\
\text { Slope using } \\
\text { ArcGIS (m) }\end{array}$ & $\begin{array}{c}\text { Roughness } \\
\text { Coefficient } \\
\text { (n) }\end{array}$ & $\begin{array}{c}\text { Manning } \\
\text { Discharge } \\
\left(\mathrm{m}^{3} / \mathrm{s}\right) \text { (Obs } \\
\text { Slope) }\end{array}$ & $\begin{array}{c}\text { Manning } \\
\text { Discharge } \\
\left(\mathrm{m}^{3} / \mathrm{s}\right)(\mathrm{Calc} \\
\text { Slope) }\end{array}$ & $\begin{array}{c}\text { Chezy } \\
\text { Coefficient } \\
\text { (C) }\end{array}$ & $\begin{array}{c}\text { Chezy } \\
\text { Discharge } \\
\left(\mathrm{m}^{3} / \mathrm{s}\right) \text { (Obs } \\
\text { Slope) }\end{array}$ & $\begin{array}{c}\text { Chezy } \\
\text { Discharge } \\
\left(\mathrm{m}^{3} / \mathrm{s}\right)(\text { Calc } \\
\text { Slope) }\end{array}$ & $\begin{array}{c}\text { Dingman \& } \\
\text { Sharma } \\
\text { Discharge } \\
\left(\mathrm{m}^{3} / \mathrm{s}\right) \text { (Obs. } \\
\text { Slope) }\end{array}$ & $\begin{array}{c}\text { Dingman \& } \\
\text { Sharma } \\
\text { Discharge } \\
\left(\mathrm{m}^{3} / \mathrm{s}\right) \text { (Calc } \\
\text { Slope) }\end{array}$ \\
\hline 4.53 & 0.252 & 1.7394 & 0.144878 & 0.02 & 0.044 & 0.105 & 0.093625386 & 0.13886889 & 6.90204119 & 0.093625386 & 0.13886889 & 0.099940867 & 0.113908474 \\
\hline 4.53 & 0.05 & 0.893 & 0.055991 & 0.02 & 0.044 & 0.105 & 0.009856167 & 0.014619059 & 5.890657765 & 0.009856167 & 0.014619059 & 0.010247999 & 0.011680246 \\
\hline 4.53 & 0.051 & 0.9 & 0.056667 & 0.02 & 0.044 & 0.105 & 0.010134002 & 0.015031154 & 5.902445405 & 0.010134002 & 0.015031154 & 0.010539275 & 0.01201223 \\
\hline 4.53 & 0.063 & 0.9266 & 0.067991 & 0.02 & 0.044 & 0.105 & 0.014135085 & 0.020965719 & 6.084413807 & 0.014135085 & 0.020965719 & 0.014524648 & 0.016554594 \\
\hline 4.53 & 0.062 & 0.9265 & 0.066919 & 0.02 & 0.044 & 0.105 & 0.013764113 & 0.020415479 & 6.068319128 & 0.013764113 & 0.020415479 & 0.014164257 & 0.016143836 \\
\hline 4.53 & 0.348 & 2.01 & 0.173134 & 0.02 & 0.044 & 0.105 & 0.145599673 & 0.215959215 & 7.110081278 & 0.145599673 & 0.215959215 & 0.156720416 & 0.178623459 \\
\hline 4.53 & 0.153 & 1.5308 & 0.099948 & 0.02 & 0.044 & 0.105 & 0.044381208 & 0.065827969 & 6.487930622 & 0.044381208 & 0.065827969 & 0.047979099 & 0.054684596 \\
\hline 4.53 & 0.165 & 1.612 & 0.102357 & 0.02 & 0.044 & 0.105 & 0.048628281 & 0.072127396 & 6.513741489 & 0.048628281 & 0.072127396 & 0.052924416 & 0.060321065 \\
\hline 4.53 & 0.075 & 1.2812 & 0.058539 & 0.02 & 0.044 & 0.105 & 0.015229414 & 0.022588871 & 5.934508504 & 0.015229414 & 0.022588871 & 0.01678512 & 0.019130986 \\
\hline 4.53 & 0.07 & 1.265 & 0.055336 & 0.02 & 0.044 & 0.105 & 0.013690798 & 0.020306734 & 5.879114972 & 0.013690798 & 0.020306734 & 0.015135712 & 0.01725106 \\
\hline 4.53 & 0.132 & 1.4984 & 0.088094 & 0.02 & 0.044 & 0.105 & 0.035199007 & 0.052208564 & 6.352846991 & 0.035199007 & 0.052208564 & 0.038362909 & 0.04372446 \\
\hline 4.53 & 0.128 & 1.49 & 0.085906 & 0.02 & 0.044 & 0.105 & 0.033564857 & 0.049784728 & 6.326273804 & 0.033564857 & 0.049784728 & 0.036632506 & 0.041752217 \\
\hline 4.53 & 0.158 & 1.6662 & 0.094827 & 0.02 & 0.044 & 0.105 & 0.044252325 & 0.065636805 & 6.431303829 & 0.044252325 & 0.065636805 & 0.048786155 & 0.055604445 \\
\hline 4.53 & 0.14 & 1.5498 & 0.090334 & 0.02 & 0.044 & 0.105 & 0.037962545 & 0.056307554 & 6.379492004 & 0.037962545 & 0.056307554 & 0.041519201 & 0.047321871 \\
\hline 4.53 & 0.092 & 1.437 & 0.064022 & 0.02 & 0.044 & 0.105 & 0.019830526 & 0.029413423 & 6.023735272 & 0.019830526 & 0.029413423 & 0.022108302 & 0.02519813 \\
\hline 4.53 & 0.1 & 1.3838 & 0.072265 & 0.02 & 0.044 & 0.105 & 0.023367387 & 0.034659436 & 6.146555582 & 0.023367387 & 0.034659436 & 0.025590014 & 0.029166441 \\
\hline 4.53 & 0.203 & 1.5524 & 0.130765 & 0.02 & 0.044 & 0.105 & 0.070439566 & 0.104478761 & 6.785149716 & 0.070439566 & 0.104478761 & 0.074437137 & 0.084840375 \\
\hline 4.53 & 0.273 & 1.941 & 0.140649 & 0.02 & 0.044 & 0.105 & 0.099444268 & 0.147499685 & 6.868051655 & 0.099444268 & 0.147499685 & 0.108485946 & 0.123647801 \\
\hline 4.53 & 0.16723 & 1.381 & 0.121093 & 0.02 & 0.044 & 0.105 & 0.055129861 & 0.081770798 & 6.698806804 & 0.055129861 & 0.081770798 & 0.057503675 & 0.065540314 \\
\hline 4.53 & 0.1141 & 1.136 & 0.10044 & 0.02 & 0.044 & 0.105 & 0.033205974 & 0.049252418 & 6.493246944 & 0.033205974 & 0.049252418 & 0.034076802 & 0.038839332 \\
\hline 4.53 & 0.08129 & 0.976 & 0.083289 & 0.02 & 0.044 & 0.105 & 0.020881147 & 0.030971747 & 6.293736919 & 0.020881147 & 0.030971747 & 0.021242632 & 0.024211474 \\
\hline 4.53 & 0.07926 & 0.998 & 0.079419 & 0.02 & 0.044 & 0.105 & 0.019724021 & 0.029255451 & 6.244024839 & 0.019724021 & 0.029255451 & 0.020232972 & 0.023060706 \\
\hline 4.53 & 0.07606 & 0.99 & 0.076828 & 0.02 & 0.044 & 0.105 & 0.018513823 & 0.027460437 & 6.20960853 & 0.018513823 & 0.027460437 & 0.019024124 & 0.021682911 \\
\hline
\end{tabular}




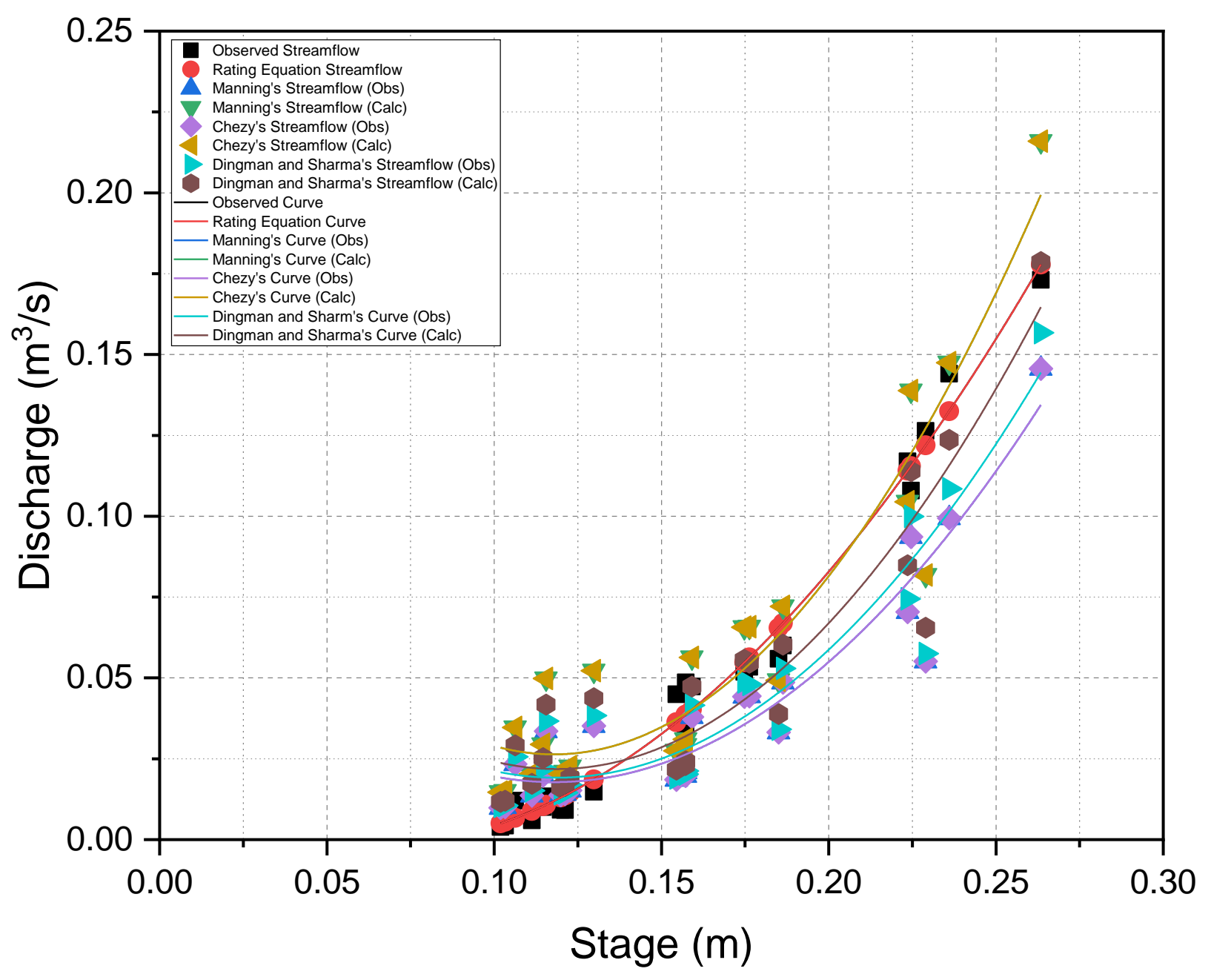

Figure A7-1. Observed and modeled rating curves and streamflow from Site 7, West Run Watershed, Morgantown, West Virginia, U.S.A 
Table A7-3. Polynomial rating equations and $\mathrm{R}^{2}$ values for observed and modeled rating curves at Site 7, West Run Watershed, Morgantown, WV, U.S.A.

\begin{tabular}{ccc}
\hline & $\begin{array}{c}\mathbf{R}^{\mathbf{2}} \\
\text { Value }\end{array}$ & Polynomial Equation \\
\hline Observed Curve & 0.99 & $\mathrm{y}=4.3642 \mathrm{x}^{2}-0.5242 \mathrm{x}+0.0131$ \\
Manning's Curve (Obs Slope) & 0.90 & $\mathrm{y}=5.5033 \mathrm{x}^{2}-1.2968 \mathrm{x}+0.0942$ \\
Manning's Curve (Calc Slope) & 0.90 & $\mathrm{y}=8.1627 \mathrm{x}^{2}-1.9235 \mathrm{x}+0.1397$ \\
$\begin{array}{c}\text { Chezy's Curve (Obs Slope) } \\
\text { Chezy's Curve (Calc Slope) }\end{array}$ & 0.90 & $\mathrm{y}=5.5033 \mathrm{x}^{2}-1.2968 \mathrm{x}+0.0942$ \\
$\begin{array}{c}\text { Dingman and Sharma's Curve } \\
\text { (Obs Slope) }\end{array}$ & 0.89 & $\mathrm{y}=8.1627 \mathrm{x}^{2}-1.9235 \mathrm{x}+0.1397$ \\
$\begin{array}{c}\text { Dingman and Sharma's Curve } \\
\text { (Calc Slope) }\end{array}$ & 0.89 & $\mathrm{y}=5.9797 \mathrm{x}^{2}-1.419 \mathrm{x}+0.1033$ \\
\hline
\end{tabular}

Table A7-4. Descriptive statistics for observed and modeled streamflow used to generate the rating curves for Site 7, West Run Watershed, Morgantown, WV, U.S.A.

\begin{tabular}{|c|c|c|c|c|}
\hline & Sample Size & Mean $\left(\mathrm{m}^{3} / \mathbf{s}\right)$ & St. Dev. & SE of Mean \\
\hline Observed & 23 & 0.051 & 0.05 & 0.01 \\
\hline Manning's & 23 & 0.04 & 0.034 & 0.01 \\
\hline $\begin{array}{l}\text { Curve (Obs } \\
\text { Slope) }\end{array}$ & & & & \\
\hline $\begin{array}{l}\text { Manning's } \\
\text { Curve (Calc } \\
\text { Slope) }\end{array}$ & 23 & 0.059 & 0.05 & 0.01 \\
\hline $\begin{array}{l}\text { Chezy's Curve } \\
\text { (Obs Slope) }\end{array}$ & 23 & 0.04 & 0.034 & 0.01 \\
\hline $\begin{array}{l}\text { Chezy's Curve } \\
\text { (Calc Slope) }\end{array}$ & 23 & 0.059 & 0.05 & 0.01 \\
\hline $\begin{array}{l}\text { Dingman and } \\
\text { Sharma's } \\
\text { Curve (Obs } \\
\text { Slope) }\end{array}$ & 23 & 0.043 & 0.037 & 0.01 \\
\hline $\begin{array}{l}\text { Dingman and } \\
\text { Sharma's } \\
\text { Curve (Calc } \\
\text { Slope) }\end{array}$ & 23 & 0.049 & 0.042 & 0.01 \\
\hline
\end{tabular}


Table A7-5. P-values of the statistical analyses (post-hoc ANOVA) for observed and modeled rating curves at Site 7, West Run Watershed, Morgantown, WV, U.S.A.

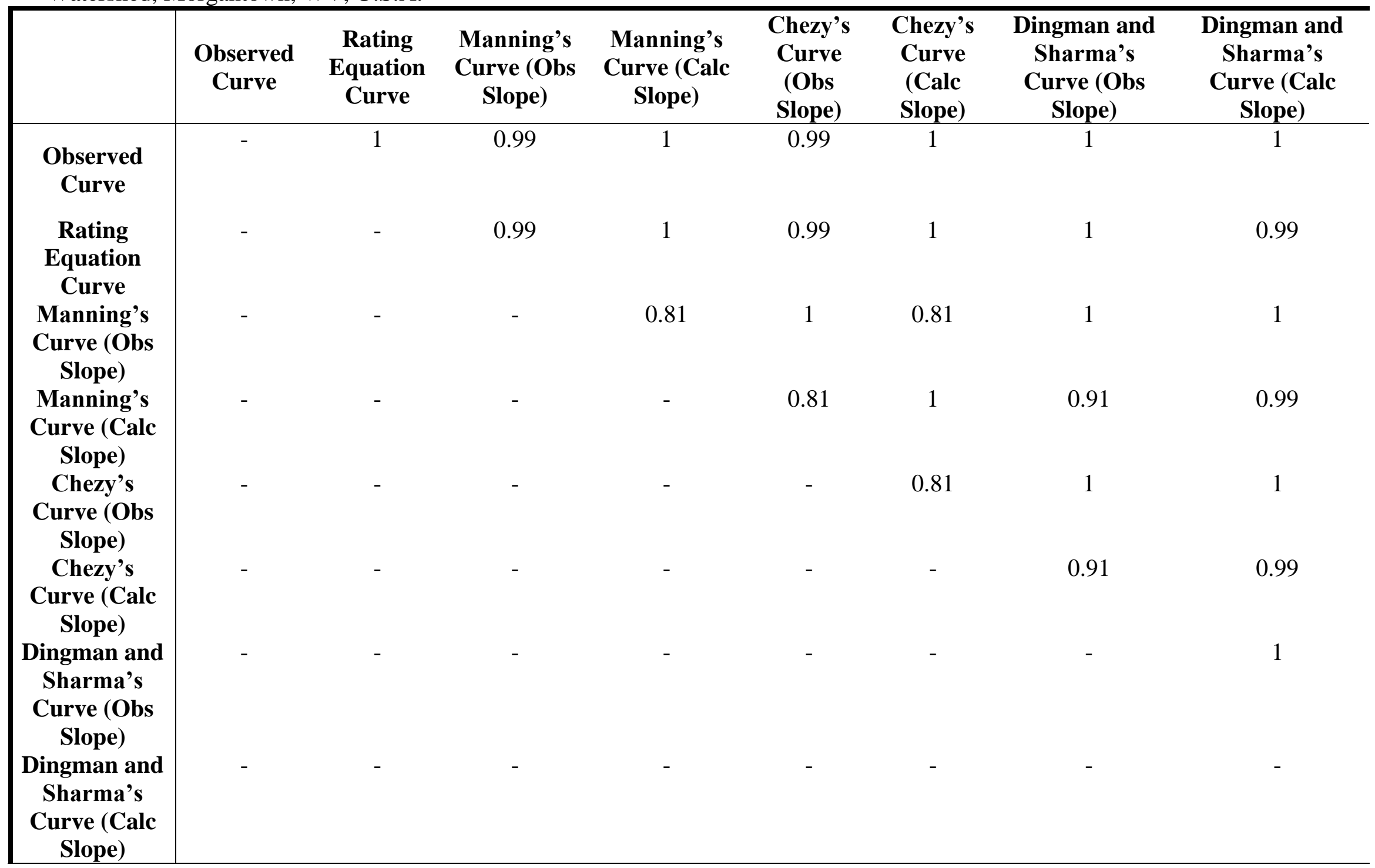




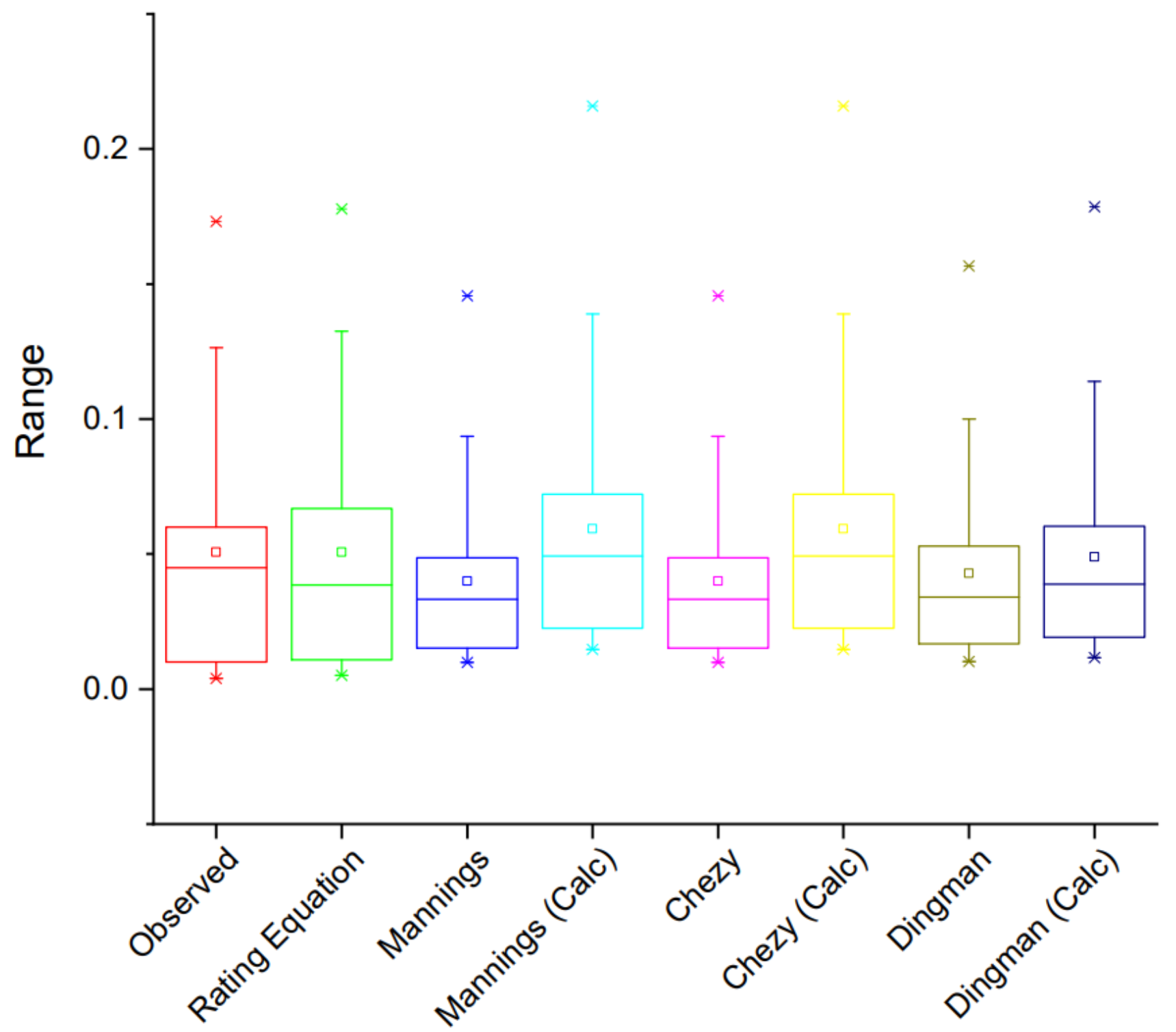

Figure A7-2. Box and whisker plots for the results of the statistical analyses (post-hoc ANOVA) of observed and modeled rating curves at Site 7, West Run Watershed, Morgantown, WV, U.S.A. 


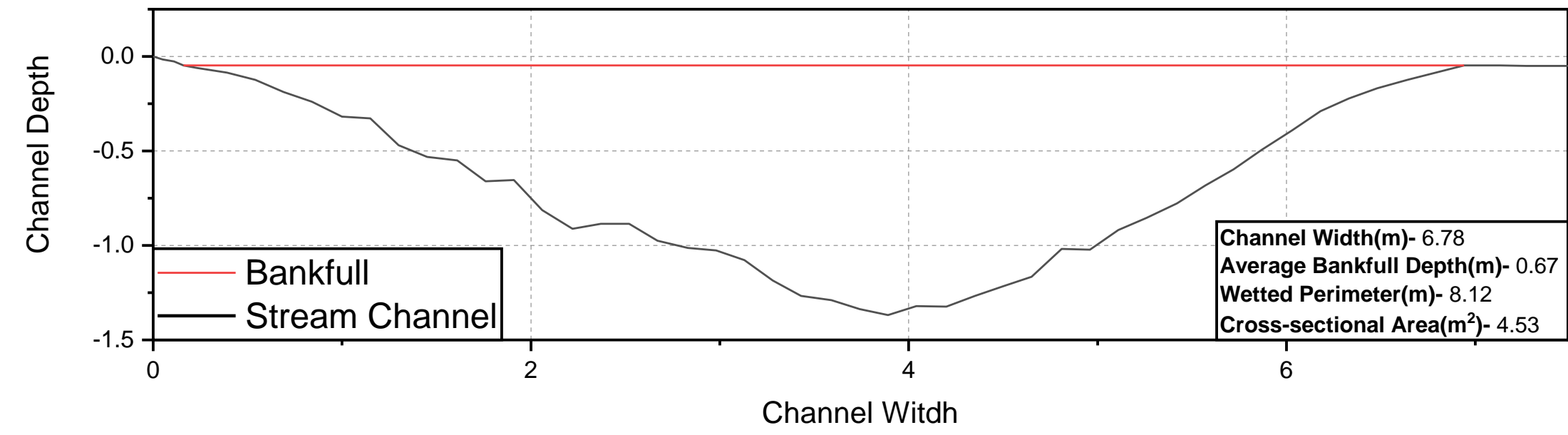

Figure A7-3. Cross-sectional profile of WRW Site 7, West Run Watershed, Morgantown, WV, USA (Figure 2). Channel Width of zero (0) represents the left bank facing downstream. 

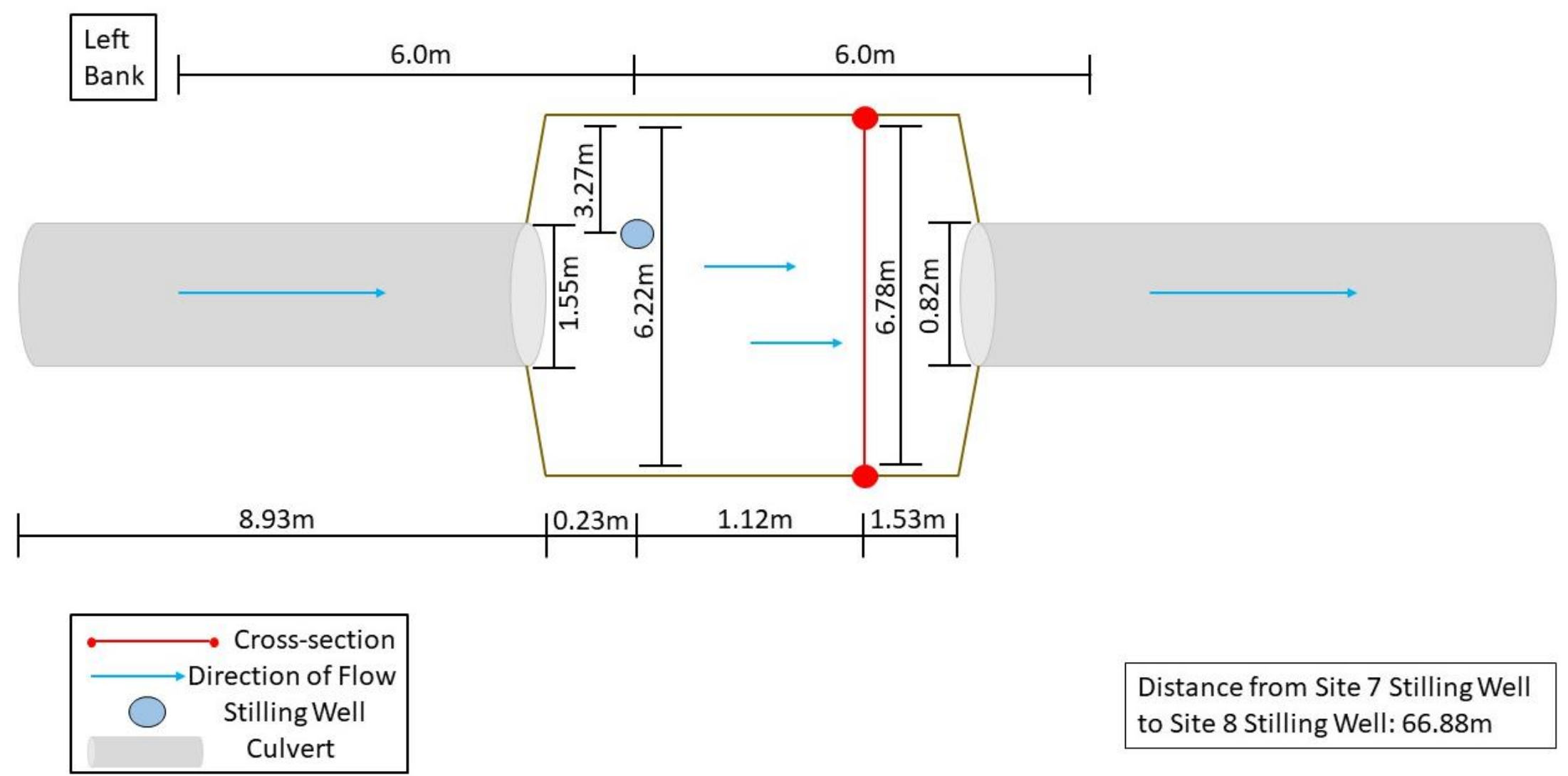

Distance from Site 7 Stilling Well

to Site 8 Stilling Well: $66.88 \mathrm{~m}$

Figure A7-4. Plan view profile of WRW Site 7, West Run Watershed, Morgantown, WV, U.S.A. (Figure 2). Showing the positioning of stilling well in relation to where the streamflow was measured. Along with the channel width at the stilling well, point where crosssections were performed, and $6.0 \mathrm{~m}$ upstream and downstream from the stilling well. 


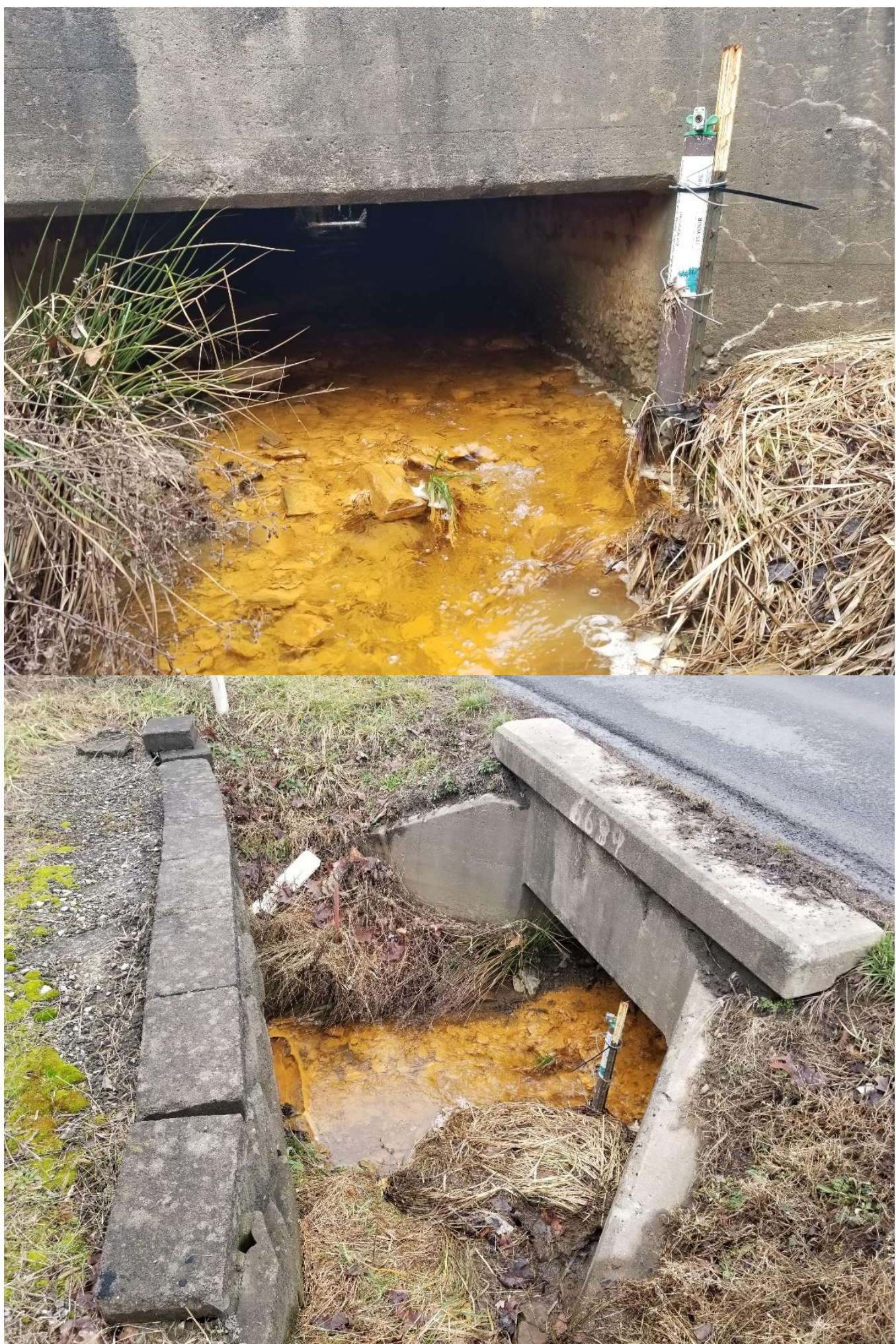

Figure A7-5. Photographs showing channel characteristics at Site \#7, West Run Watershed, Morgantown, WV, U.S.A. Photo 1 was taken looking upstream in the channel. Photo 2 was taken from the left bank looking downstream. 


\section{APPENDIX 8: Site 8}

Table A8-1. Streamflow measurements and stage collected at Site 8, West Run Watershed, Morgantown, WV, U.S.A. (Figure 2).

\begin{tabular}{|c|c|c|c|c|c|c|c|c|c|}
\hline Date & $\begin{array}{l}\text { Mean Depth of } \\
\text { Cross-Section } \\
\text { (m) }\end{array}$ & Stage (PT in cm) & $\begin{array}{c}\text { Barometric } \\
\text { Pressure (in } \mathrm{cm} \text { ) }\end{array}$ & $\begin{array}{c}\text { Pressure } \\
\text { Corrected Stage } \\
\text { (cm) }\end{array}$ & $\begin{array}{l}\text { Stilling Well } \\
\text { Offset (cm) }\end{array}$ & $\begin{array}{l}\text { P-Corrected } \\
\text { Stage + Offset } \\
\text { (cm) }\end{array}$ & $\begin{array}{c}\text { P-Corrected } \\
\text { Stage + Offset } \\
\text { (m) }\end{array}$ & $\begin{array}{c}\text { SonTec } \\
\text { Discharge }(\mathrm{m} 3 / \mathrm{s})\end{array}$ & $\begin{array}{l}\text { Rating Equation } \\
\text { Discharge }(\mathrm{m} 3 / \mathrm{s})\end{array}$ \\
\hline $1 / 2 / 2018$ & 0.0457 & 109.18 & 93.67 & 15.51 & 7 & 22.51 & 0.2251 & 0.0084 & 0.028489316 \\
\hline $1 / 12 / 2018$ & 0.0654 & 87.06 & 70.48 & 16.58 & 7 & 23.58 & 0.2358 & 0.0608 & 0.040200248 \\
\hline $3 / 14 / 2018$ & 0.0693 & 92.54 & 79 & 13.54 & 7 & 20.54 & 0.2054 & 0.0212 & 0.010085902 \\
\hline $3 / 29 / 2018$ & 0.0612 & 94.82 & 78.75 & 16.07 & 7 & 23.07 & 0.2307 & 0.0505 & 0.034467808 \\
\hline 9/9/2018 & 0.1130 & 112.12 & 86.75 & 25.37 & 7 & 32.37 & 0.3237 & 0.2031 & 0.182104913 \\
\hline $10 / 18 / 2018$ & 0.0637 & 115.59 & 99.66 & 15.93 & 7 & 22.93 & 0.2293 & 0.0172 & 0.03294218 \\
\hline $10 / 18 / 2018$ & 0.0652 & 114.28 & 99.69 & 14.59 & 7 & 21.59 & 0.2159 & 0.0177 & 0.019385466 \\
\hline $10 / 18 / 2018$ & 0.0613 & 114.14 & 99.54 & 14.6 & 7 & 21.6 & 0.2160 & 0.0166 & 0.019479622 \\
\hline $10 / 30 / 2018$ & 0.0698 & 104.47 & 89.49 & 14.98 & 7 & 21.98 & 0.2198 & 0.0218 & 0.023135716 \\
\hline $12 / 17 / 2018$ & 0.0872 & 97.46 & 82.02 & 15.44 & 6.4 & 21.84 & 0.2184 & 0.0198 & 0.021771017 \\
\hline $12 / 17 / 2018$ & 0.0899 & 98.44 & 81.9 & 16.54 & 6.4 & 22.94 & 0.2294 & 0.0202 & 0.033050468 \\
\hline $1 / 24 / 2019$ & 0.1710 & 103.7 & 70.37 & 33.33 & 6.4 & 39.73 & 0.3973 & 0.3401 & 0.363599635 \\
\hline $2 / 6 / 2019$ & 0.1561 & 108.16 & 78.7 & 29.46 & 6.4 & 35.86 & 0.3586 & 0.2546 & 0.261045212 \\
\hline $2 / 26 / 2019$ & 0.1039 & 112.29 & 95.31 & 16.98 & 6.4 & 23.38 & 0.2338 & 0.0558 & 0.03791954 \\
\hline $4 / 25 / 2019$ & 0.0936 & 94.06 & 79.24 & 14.82 & 6.4 & 21.22 & 0.2122 & 0.0165 & 0.01597581 \\
\hline $4 / 25 / 2019$ & 0.0875 & 93.43 & 79.32 & 14.11 & 6.4 & 20.51 & 0.2051 & 0.0180 & 0.009837284 \\
\hline $4 / 26 / 2019$ & 0.1235 & 85.02 & 67.4 & 17.62 & 6.4 & 24.02 & 0.2402 & 0.0362 & 0.045366289 \\
\hline 4/26/2019 & 0.1210 & 85.79 & 67.5 & 18.29 & 6.4 & 24.69 & 0.2469 & 0.0374 & 0.053624908 \\
\hline 4/29/2019 & 0.1015 & 103.61 & 89.83 & 13.78 & 6.4 & 20.18 & 0.2018 & 0.0151 & 0.007165132 \\
\hline 4/30/2019 & 0.1225 & 108.86 & 91.38 & 17.48 & 6.4 & 23.88 & 0.2388 & 0.0498 & 0.043700403 \\
\hline $5 / 13 / 2019$ & 0.1106 & 92.19 & 74.05 & 18.14 & 6.4 & 24.54 & 0.2454 & 0.0328 & 0.051734835 \\
\hline $5 / 14 / 2019$ & 0.1030 & 99.04 & 82.35 & 16.69 & 6.4 & 23.09 & 0.2309 & 0.03449 & 0.034687442 \\
\hline $12 / 17 / 2019$ & 0.1490 & 104.61 & 75.15 & 29.46 & 6.4 & 35.86 & 0.3586 & 0.2862 & 0.261045212 \\
\hline $8 / 16 / 2021$ & 0.1330 & 1034.5 & 1004.67 & 29.8 & 6.4 & 36.2 & 0.3620 & 0.2739 & 0.269422308 \\
\hline $8 / 16 / 2021$ & 0.1350 & 1034.4 & 1004.72 & 29.7 & 6.4 & 36.1 & 0.3610 & 0.2882 & 0.266945801 \\
\hline $8 / 16 / 2021$ & 0.1400 & 1035.5 & 1004.72 & 30.8 & 6.4 & 37.2 & 0.3720 & 0.3273 & 0.294767394 \\
\hline $8 / 16 / 2021$ & 0.1400 & 1036.6 & 1004.65 & 31.9 & 6.4 & 38.3 & 0.3830 & 0.3122 & 0.323865028 \\
\hline $8 / 16 / 2021$ & 0.1390 & 1035.9 & 1004.68 & 31.2 & 6.4 & 37.6 & 0.3760 & 0.3097 & 0.30520071 \\
\hline $8 / 16 / 2021$ & 0.1210 & 1033.6 & 1004.66 & 28.9 & 6.4 & 35.3 & 0.3530 & 0.2239 & 0.247513396 \\
\hline $8 / 16 / 2021$ & 0.1140 & 1032.8 & 1004.58 & 28.2 & 6.4 & 34.6 & 0.3460 & 0.2011 & 0.231063696 \\
\hline
\end{tabular}


Table A8-2. Modeled streamflow at Site 8, West Run Watershed, Morgantown, WV, U.S.A.

\begin{tabular}{|c|c|c|c|c|c|c|c|c|c|c|c|c|c|}
\hline $\begin{array}{l}\text { Cross- } \\
\text { Section } \\
\text { Area } \\
\left(\mathrm{m}^{2}\right)\end{array}$ & $\begin{array}{c}\text { A (Cross } \\
\text { Section } \\
\text { area of } \\
\text { flow) }\end{array}$ & $\begin{array}{c}\text { P } \\
\text { (Wetted } \\
\text { Perimete } \\
\text { r) }\end{array}$ & $\begin{array}{c}\mathrm{RH}=\mathrm{A} / \mathrm{P} \\
\text { Hydraulic } \\
\text { Radius } \\
\text { (m) }\end{array}$ & $\begin{array}{l}\text { Observed } \\
\text { Slope }(m)\end{array}$ & $\begin{array}{l}\text { Calculated } \\
\text { Slope using } \\
\text { ArcGIS (m) }\end{array}$ & $\begin{array}{c}\text { Roughness } \\
\text { Coefficient } \\
\text { (n) }\end{array}$ & $\begin{array}{c}\text { Manning } \\
\text { Discharge } \\
\left(\mathrm{m}^{3} / \mathrm{s}\right) \text { (Obs } \\
\text { Slope) }\end{array}$ & $\begin{array}{c}\text { Manning } \\
\text { Discharge } \\
\left(\mathrm{m}^{3} / \mathrm{s}\right) \text { (Calc } \\
\text { Slope) }\end{array}$ & $\begin{array}{c}\text { Chezy } \\
\text { Coefficient } \\
\text { (C) }\end{array}$ & $\begin{array}{c}\text { Chezy } \\
\text { Discharge } \\
\left(\mathrm{m}^{3} / \mathrm{s}\right)(\text { Obs } \\
\text { Slope) }\end{array}$ & $\begin{array}{c}\text { Chezy } \\
\text { Discharge } \\
\left(\mathrm{m}^{3} / \mathrm{s}\right)(\text { Calc } \\
\text { Slope) }\end{array}$ & $\begin{array}{l}\text { Dingman \& } \\
\text { Sharma } \\
\text { Discharge } \\
\text { (m³/s) (Obs. } \\
\text { Slope) }\end{array}$ & $\begin{array}{l}\text { Dingman \& } \\
\text { Sharma } \\
\text { Discharge } \\
\left(\mathrm{m}^{3} / \mathrm{s}\right) \text { (Calc } \\
\text { Slope) }\end{array}$ \\
\hline 1.62 & 0.237 & 1.9645 & 0.120497 & 0.01 & 0.03 & 0.14 & 0.041249092 & 0.071445524 & 5.019972293 & 0.041249092 & 0.071445524 & 0.075057335 & 0.092611041 \\
\hline 1.62 & 0.254 & 1.9995 & 0.126927 & 0.01 & 0.03 & 0.14 & 0.045784229 & 0.079300611 & 5.063659301 & 0.045784229 & 0.079300611 & 0.083158501 & 0.102606833 \\
\hline 1.62 & 0.205 & 1.8975 & 0.108185 & 0.01 & 0.03 & 0.14 & 0.033290802 & 0.05766136 & 4.930600256 & 0.033290802 & 0.05766136 & 0.060824633 & 0.075049729 \\
\hline 1.62 & 0.246 & 1.9829 & 0.123883 & 0.01 & 0.03 & 0.14 & 0.04360455 & 0.075525295 & 5.043212452 & 0.04360455 & 0.075525295 & 0.079265688 & 0.097803605 \\
\hline 1.62 & 0.302 & 2.8934 & 0.104375 & 0.01 & 0.03 & 0.14 & 0.047820181 & 0.082826984 & 4.901229535 & 0.047820181 & 0.082826984 & 0.094302733 & 0.116357373 \\
\hline 1.62 & 0.078 & 1.3464 & 0.057932 & 0.01 & 0.03 & 0.14 & 0.008341553 & 0.014447993 & 4.443160972 & 0.008341553 & 0.014447993 & 0.015227616 & 0.018788908 \\
\hline 1.62 & 0.077 & 1.346 & 0.057207 & 0.01 & 0.03 & 0.14 & 0.008165695 & 0.014143398 & 4.433835489 & 0.008165695 & 0.014143398 & 0.014923429 & 0.018413581 \\
\hline 1.62 & 0.077 & 1.346 & 0.057207 & 0.01 & 0.03 & 0.14 & 0.008165695 & 0.014143398 & 4.433835489 & 0.008165695 & 0.014143398 & 0.014923429 & 0.018413581 \\
\hline 1.62 & 0.091 & 1.4348 & 0.063423 & 0.01 & 0.03 & 0.14 & 0.010337449 & 0.017904987 & 4.510731414 & 0.010337449 & 0.017904987 & 0.018918744 & 0.023343283 \\
\hline 1.62 & 0.13 & 3.244 & 0.040074 & 0.01 & 0.03 & 0.14 & 0.010874025 & 0.018834364 & 4.178454866 & 0.010874025 & 0.018834364 & 0.023924193 & 0.02951936 \\
\hline 1.62 & 0.134 & 3.25 & 0.041231 & 0.01 & 0.03 & 0.14 & 0.011423286 & 0.019785712 & 4.198319994 & 0.011423286 & 0.019785712 & 0.025073748 & 0.030937761 \\
\hline 1.62 & 0.408 & 2.998 & 0.136091 & 0.01 & 0.03 & 0.14 & 0.077105345 & 0.133550375 & 5.122831289 & 0.077105345 & 0.133550375 & 0.149235634 & 0.184137467 \\
\hline 1.62 & 0.371 & 2.8327 & 0.13097 & 0.01 & 0.03 & 0.14 & 0.068343113 & 0.118373745 & 5.090192251 & 0.068343113 & 0.118373745 & 0.131456382 & 0.16220017 \\
\hline 1.62 & 0.15 & 1.6558 & 0.090591 & 0.01 & 0.03 & 0.14 & 0.021611528 & 0.037432265 & 4.78687986 & 0.021611528 & 0.037432265 & 0.039212556 & 0.048383221 \\
\hline 1.62 & 0.135 & 1.635 & 0.082569 & 0.01 & 0.03 & 0.14 & 0.018284499 & 0.031669682 & 4.713475994 & 0.018284499 & 0.031669682 & 0.033392172 & 0.04120162 \\
\hline 1.62 & 0.136 & 1.625 & 0.083692 & 0.01 & 0.03 & 0.14 & 0.0185866655 & 0.032193031 & 4.724105141 & 0.018586655 & 0.032193031 & 0.03386508 & 0.041785128 \\
\hline 1.62 & 0.178 & 1.695 & 0.105015 & 0.01 & 0.03 & 0.14 & 0.028300373 & 0.049017685 & 4.906219952 & 0.028300373 & 0.049017685 & 0.050848662 & 0.062740671 \\
\hline 1.62 & 0.175 & 1.6902 & 0.103538 & 0.01 & 0.03 & 0.14 & 0.027561953 & 0.047738702 & 4.894653538 & 0.027561953 & 0.047738702 & 0.049563317 & 0.061154721 \\
\hline 1.62 & 0.139 & 1.5748 & 0.088265 & 0.01 & 0.03 & 0.14 & 0.019682474 & 0.034091046 & 4.76617733 & 0.019682474 & 0.034091046 & 0.035490234 & 0.043790358 \\
\hline 1.62 & 0.196 & 1.8452 & 0.106222 & 0.01 & 0.03 & 0.14 & 0.031400492 & 0.054387247 & 4.915572077 & 0.031400492 & 0.054387247 & 0.05719238 & 0.070567999 \\
\hline 1.62 & 0.177 & 1.821 & 0.097199 & 0.01 & 0.03 & 0.14 & 0.02672724 & 0.046292937 & 4.843387141 & 0.02672724 & 0.046292937 & 0.048975031 & 0.060428853 \\
\hline 1.62 & 0.165 & 1.8062 & 0.091352 & 0.01 & 0.03 & 0.14 & 0.023905692 & 0.041405872 & 4.79356163 & 0.023905692 & 0.041405872 & 0.043997972 & 0.054287806 \\
\hline 1.62 & 0.386 & 2.889 & 0.13361 & 0.01 & 0.03 & 0.14 & 0.072058593 & 0.124809144 & 5.10714974 & 0.072058593 & 0.124809144 & 0.138816012 & 0.171281001 \\
\hline 1.62 & 0.396 & 3.238 & 0.122298 & 0.01 & 0.03 & 0.14 & 0.06969143 & 0.120709098 & 5.032398465 & 0.06969143 & 0.120709098 & 0.138070386 & 0.170360995 \\
\hline 1.62 & 0.40064 & 3.242 & 0.123578 & 0.01 & 0.03 & 0.14 & 0.070999257 & 0.12297432 & 5.041141027 & 0.070999257 & 0.12297432 & 0.140554278 & 0.173425797 \\
\hline 1.62 & 0.4169 & 3.252 & 0.128198 & 0.01 & 0.03 & 0.14 & 0.075710846 & 0.131135032 & 5.072073333 & 0.075710846 & 0.131135032 & 0.149446829 & 0.184398055 \\
\hline 1.62 & 0.40645 & 3.176 & 0.127975 & 0.01 & 0.03 & 0.14 & 0.073727614 & 0.127699974 & 5.07060449 & 0.073727614 & 0.127699974 & 0.14496153 & 0.178863775 \\
\hline 1.62 & 0.39658 & 3.136 & 0.12646 & 0.01 & 0.03 & 0.14 & 0.071368397 & 0.12361369 & 5.060550426 & 0.071368397 & 0.12361369 & 0.140171812 & 0.172953884 \\
\hline 1.62 & 0.34693 & 3.1 & 0.111913 & 0.01 & 0.03 & 0.14 & 0.057548489 & 0.099676908 & 4.95851911 & 0.057548489 & 0.099676908 & 0.114101804 & 0.140786866 \\
\hline 1.62 & 0.32052 & 3.047 & 0.105192 & 0.01 & 0.03 & 0.14 & 0.051017075 & 0.088364165 & 4.907599094 & 0.051017075 & 0.088364165 & 0.10143735 & 0.125160567 \\
\hline
\end{tabular}




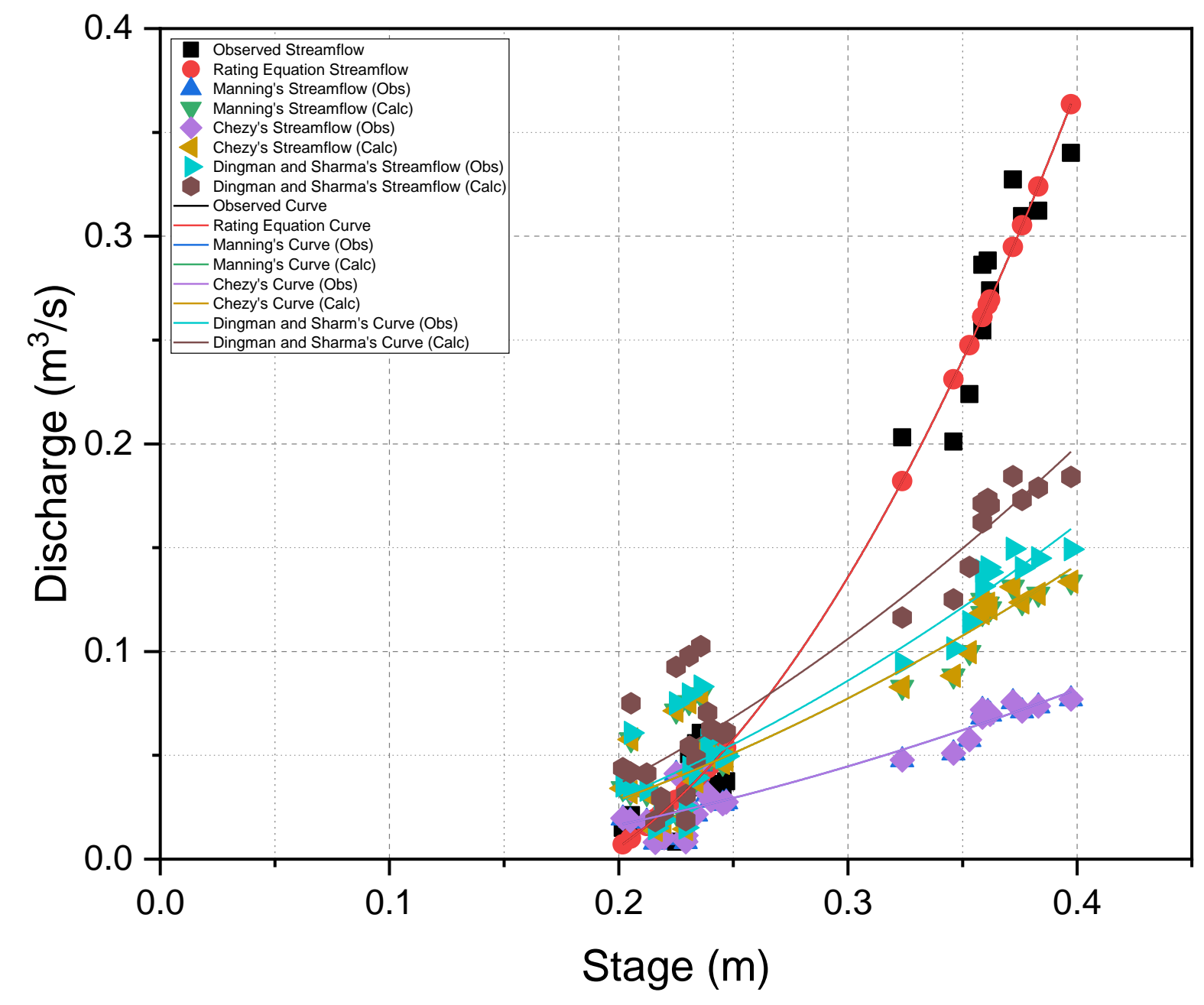

Figure A8-1. Observed and modeled rating curves and streamflow from Site 8, West Run Watershed, Morgantown, West Virginia, U.S.A 
Table A8-3. Polynomial rating equations and $\mathrm{R}^{2}$ values for observed and modeled rating curves at Site 8, West Run Watershed, Morgantown, WV, U.S.A.

\begin{tabular}{ccc}
\hline & $\begin{array}{c}\mathbf{R}^{\mathbf{2}} \\
\text { Value }\end{array}$ & Polynomial Equation \\
\hline $\begin{array}{c}\text { Observed Curve } \\
\text { Manning's Curve (Obs Slope) }\end{array}$ & 0.98 & $\mathrm{y}=5.2729 \mathrm{x}^{2}-1.3358 \mathrm{x}+0.062$ \\
Manning's Curve (Calc Slope) & 0.85 & $\mathrm{y}=0.445 \mathrm{x}^{2}+0.0598 \mathrm{x}-0.0133$ \\
Chezy's Curve (Obs Slope) & 0.85 & $\mathrm{y}=0.7708 \mathrm{x}^{2}+0.1036 \mathrm{x}-0.023$ \\
$\begin{array}{c}\text { Chezy's Curve (Calc Slope) } \\
\text { Dingman and Sharma's Curve }\end{array}$ & 0.85 & $\mathrm{y}=0.445 \mathrm{x}^{2}+0.0598 \mathrm{x}-0.0133$ \\
$\quad 0.88$ & $\mathrm{y}=0.7708 \mathrm{x}^{2}+0.1036 \mathrm{x}-0.023$ \\
$\begin{array}{c}\text { (Obs Slope) } \\
\text { Dingman and Sharma's Curve } \\
\text { (Calc Slope) }\end{array}$ & 0.88 & $\mathrm{y}=0.9378 \mathrm{x}^{2}+0.0967 \mathrm{x}-0.0274$ \\
\hline
\end{tabular}

Table A8-4. Descriptive statistics for observed and modeled streamflow used to generate the rating curves for Site 8, West Run Watershed, Morgantown, WV, U.S.A.

\begin{tabular}{|c|c|c|c|c|}
\hline & Sample Size & Mean $\left(\mathrm{m}^{3} / \mathrm{s}\right)$ & St. Dev. & SE of Mean \\
\hline Observed & 30 & 0.119 & 0.124 & 0.023 \\
\hline Manning's & 30 & 0.039 & 0.024 & 0.004 \\
\hline \multicolumn{5}{|l|}{$\begin{array}{l}\text { Curve (Obs } \\
\text { Slope) }\end{array}$} \\
\hline Manning's & 30 & 0.068 & 0.0240 .042 & 0.008 \\
\hline \multicolumn{5}{|l|}{$\begin{array}{l}\text { Curve (Calc } \\
\text { Slope) }\end{array}$} \\
\hline $\begin{array}{c}\text { Chezy's Curve } \\
\text { (Obs Slope) }\end{array}$ & 30 & 0.039 & 0.024 & 0.004 \\
\hline $\begin{array}{c}\text { Chezy's Curve } \\
\text { (Calc Slope) }\end{array}$ & 30 & 0.068 & 0.042 & 0.008 \\
\hline $\begin{array}{l}\text { Dingman and } \\
\text { Sharma's } \\
\text { Curve (Obs } \\
\text { Slope) }\end{array}$ & 30 & 0.075 & 0.048 & 0.009 \\
\hline $\begin{array}{l}\text { Dingman and } \\
\text { Sharma's } \\
\text { Curve (Calc } \\
\text { Slope) }\end{array}$ & 30 & 0.092 & 0.059 & 0.011 \\
\hline
\end{tabular}


Table A8-5. P-values of the statistical analyses (post-hoc ANOVA) for observed and modeled rating curves at Site 8, West Run Watershed, Morgantown, WV, U.S.A.

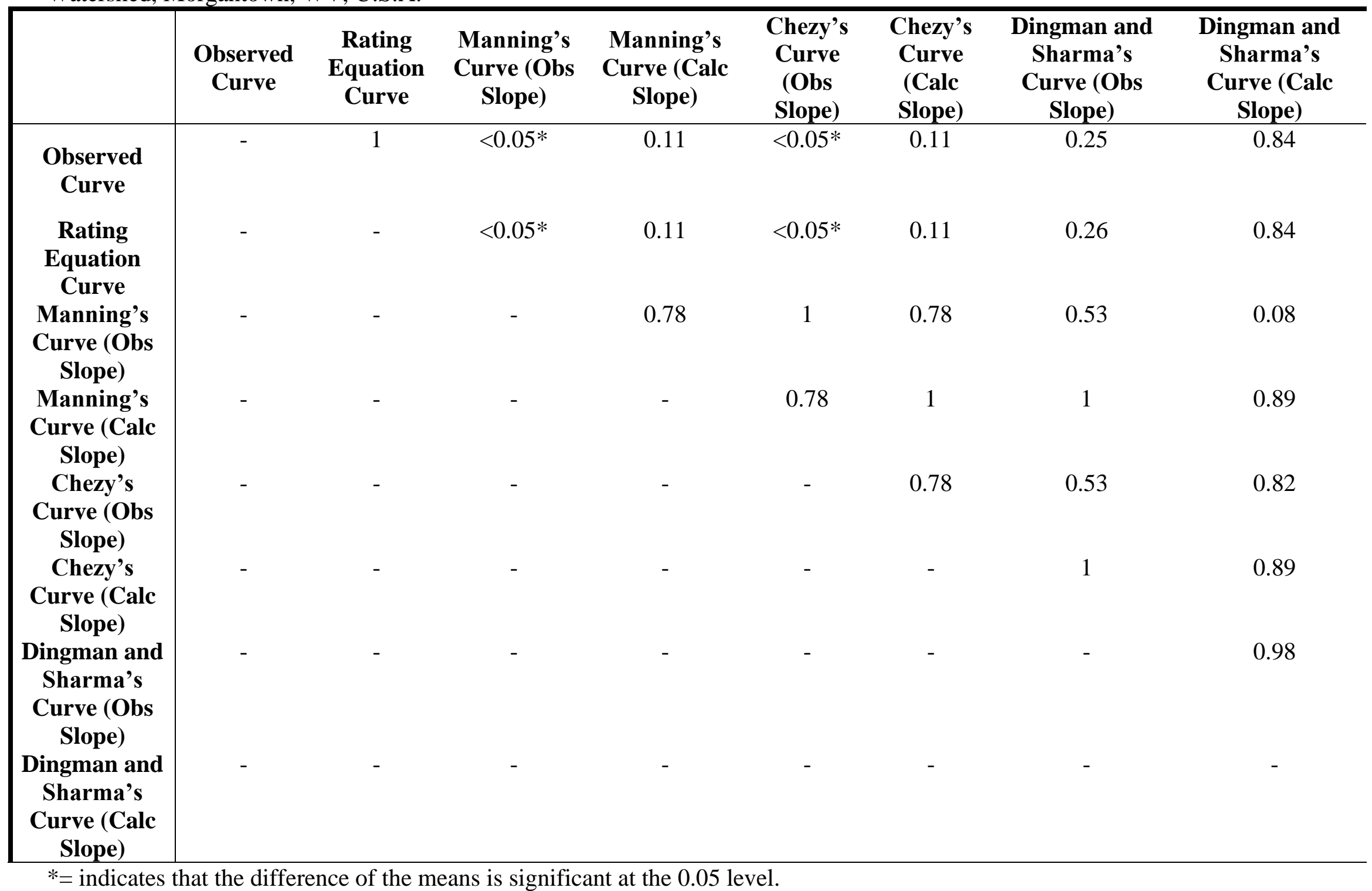




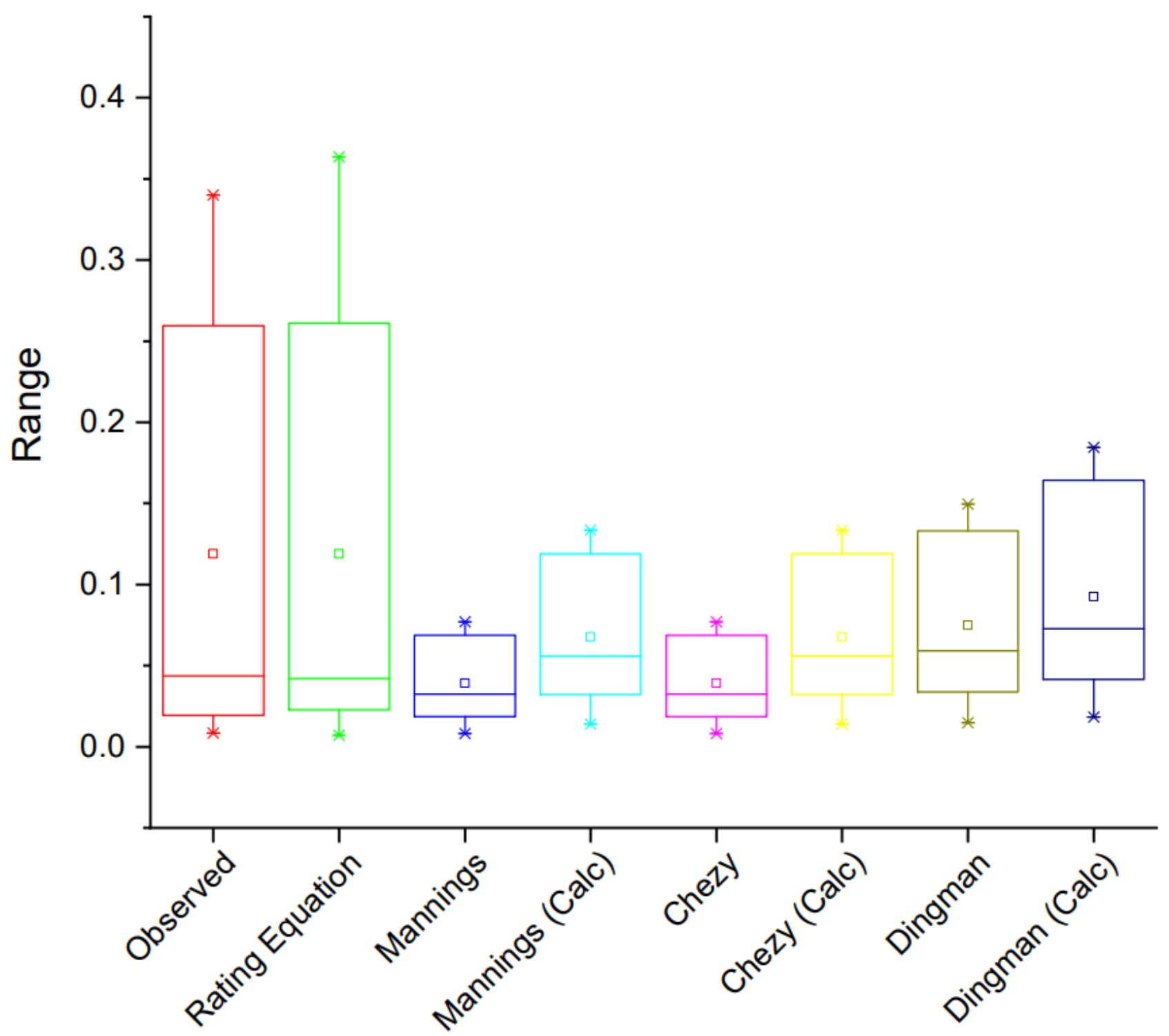

Figure A8-2. Box and whisker plots for the results of the statistical analyses (post-hoc ANOVA) of observed and modeled rating curves at Site 8, West Run Watershed, Morgantown, WV, U.S.A. 


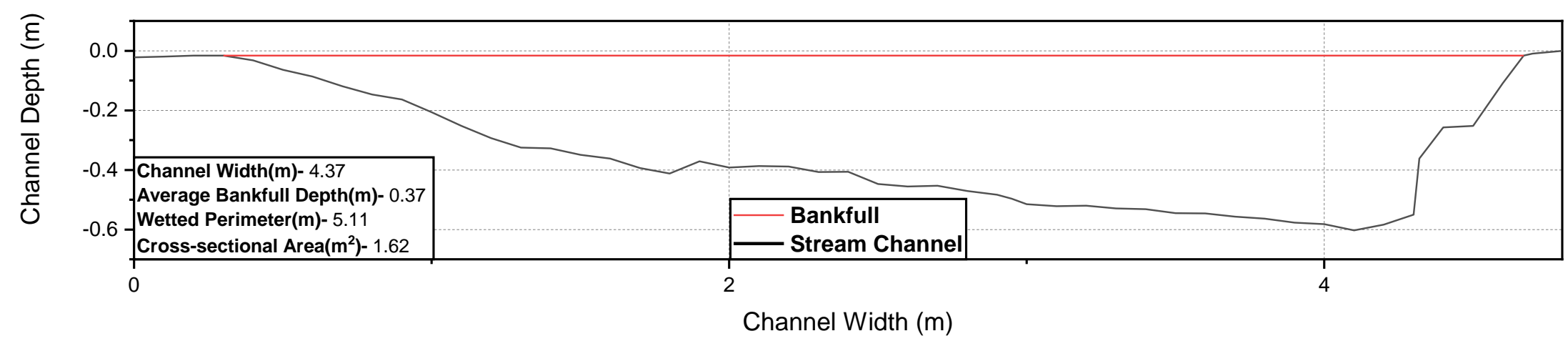

Figure A8-3. Cross-sectional profile of WRW Site 8, West Run Watershed, Morgantown, WV, USA (Figure 2). Channel Width of zero (0) represents the left bank facing downstream. 

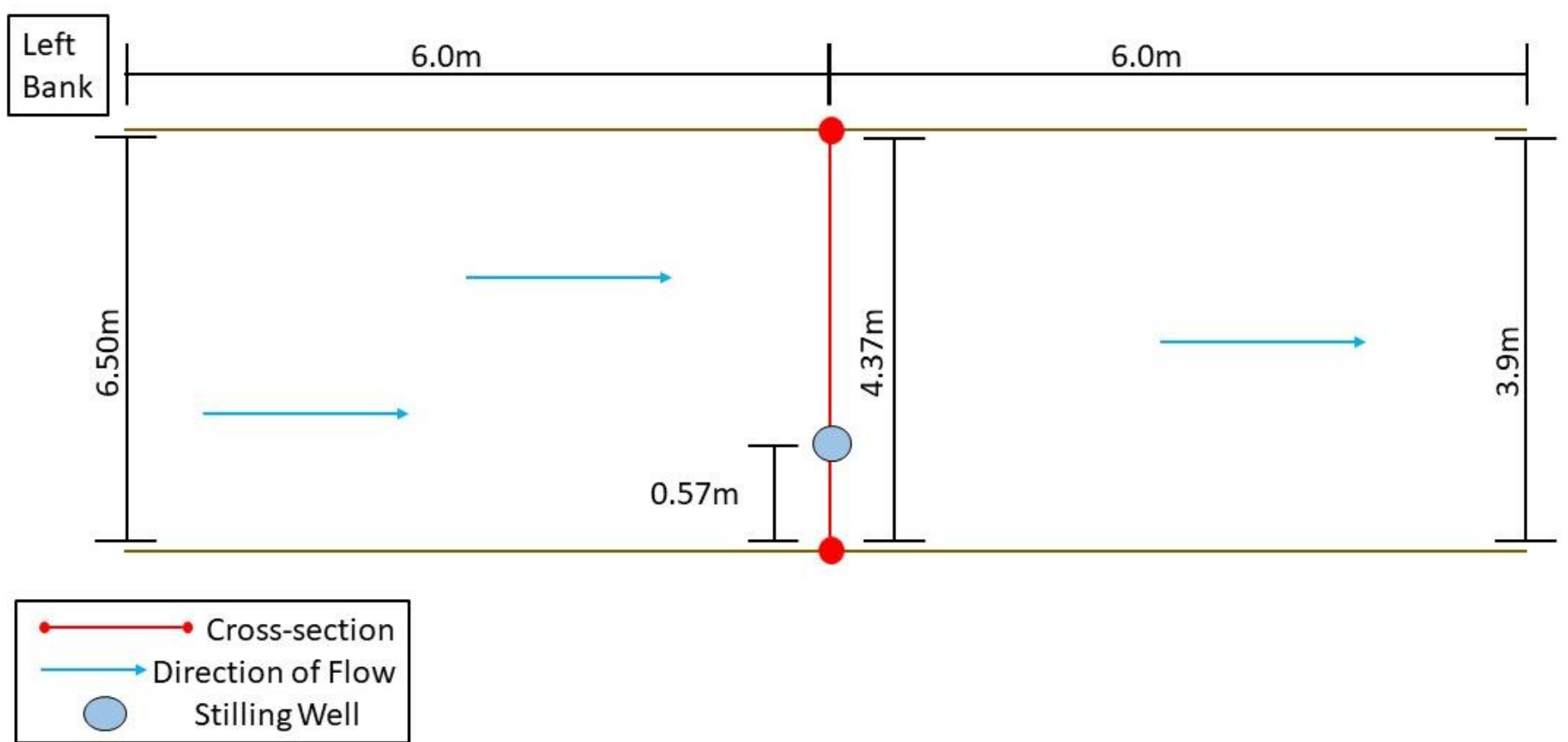

Figure A8-4. Plan view profile of WRW Site 8, West Run Watershed, Morgantown, WV, U.S.A. (Figure 2). Showing the positioning of stilling well in relation to where the streamflow was measured. Along with the channel width at the stilling well, point where crosssections were performed, and $6.0 \mathrm{~m}$ upstream and downstream from the stilling well. 


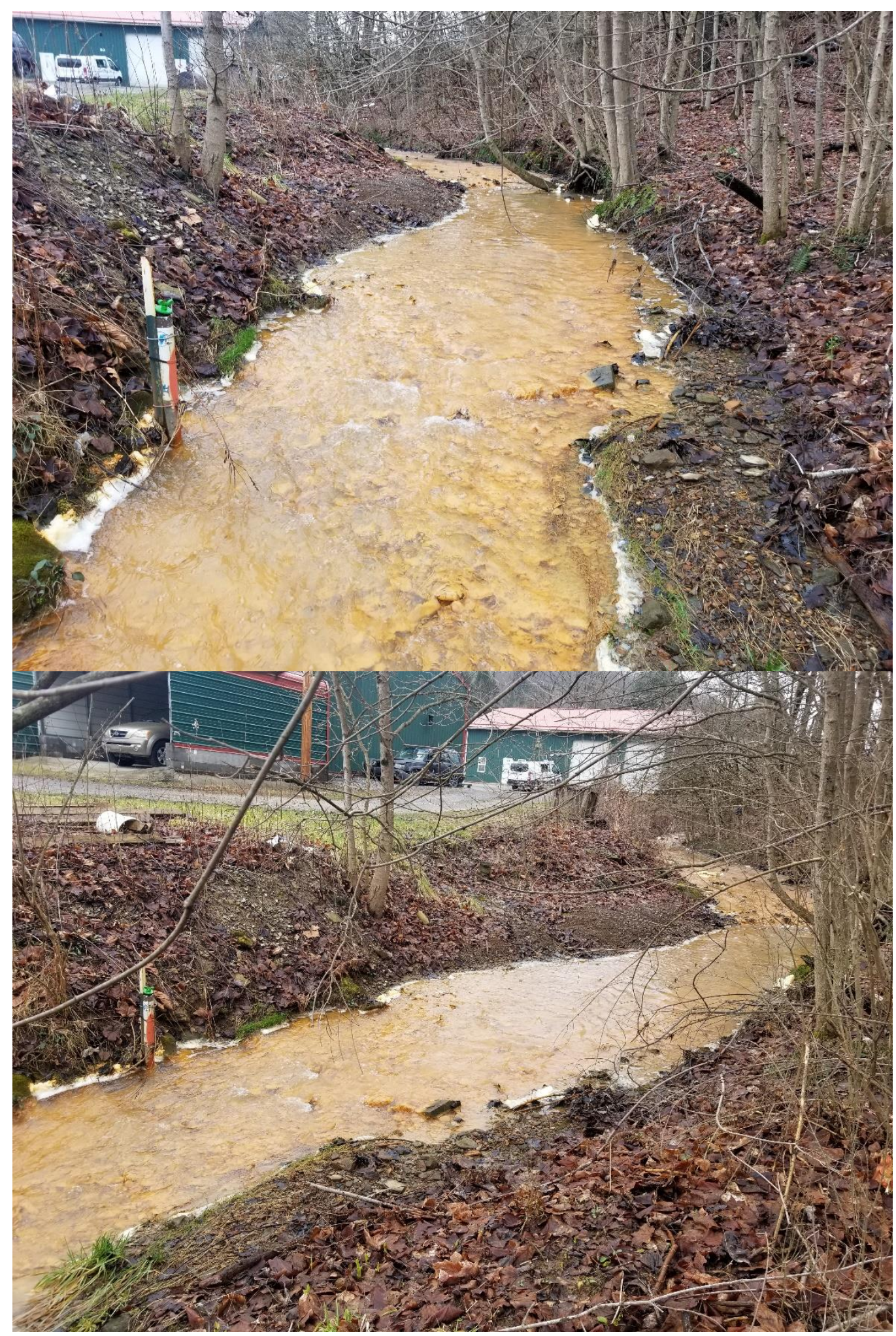

Figure A8-5. Photographs showing channel characteristics at Site \#8, West Run Watershed, Morgantown, WV, U.S.A. Photo 1 was taken looking upstream in the channel. Photo 2 was taken from the right bank looking downstream. 


\section{APPENDIX 9: Site 9}

Table A9-1. Streamflow measurements and stage collected at Site 9, West Run Watershed, Morgantown, WV, U.S.A. (Figure 2).

\begin{tabular}{|c|c|c|c|c|c|c|c|c|c|}
\hline Date & $\begin{array}{l}\text { Mean Depth of } \\
\text { Cross-Section } \\
\text { (m) }\end{array}$ & Stage(PT in $\mathrm{cm}$ ) & $\begin{array}{c}\text { Barometric } \\
\text { Pressure (in } \mathrm{cm} \text { ) }\end{array}$ & $\begin{array}{c}\text { Pressure } \\
\text { Corrected Stage } \\
\text { (cm) }\end{array}$ & $\begin{array}{l}\text { Stilling Well } \\
\text { Offset (cm) }\end{array}$ & $\begin{array}{c}\text { P-Corrected } \\
\text { Stage + Offset } \\
\text { (cm) }\end{array}$ & $\begin{array}{l}\text { P-Corrected } \\
\text { Stage + Offset } \\
\text { (m) }\end{array}$ & $\begin{array}{c}\text { SonTec } \\
\text { Discharge }(\mathrm{m} 3 / \mathrm{s})\end{array}$ & $\begin{array}{l}\text { Rating Equation } \\
\text { Dishcarge }(\mathrm{m} 3 / \mathrm{s})\end{array}$ \\
\hline $12 / 5 / 2017$ & 0.0975 & 91.92 & 79.79 & 12.13 & 4.8 & 16.93 & 0.1693 & 0.0297 & 0.014697514 \\
\hline $1 / 12 / 2018$ & 0.1113 & 86.27 & 69.75 & 16.52 & 4.8 & 21.32 & 0.2132 & 0.0772 & 0.074540896 \\
\hline $2 / 9 / 2018$ & 0.0955 & 105.36 & 92.59 & 12.77 & 4.8 & 17.57 & 0.1757 & 0.0524 & 0.022185834 \\
\hline $3 / 14 / 2018$ & 0.0797 & 92.04 & 79.45 & 12.59 & 4.8 & 17.39 & 0.1739 & 0.0293 & 0.020037102 \\
\hline $3 / 29 / 2018$ & 0.1348 & 96.41 & 80.19 & 16.22 & 4.8 & 21.02 & 0.2102 & 0.0691 & 0.069819466 \\
\hline $4 / 4 / 2018$ & 0.1577 & 98.84 & 79.05 & 19.79 & 4.8 & 24.59 & 0.2459 & 0.1516 & 0.132016542 \\
\hline 4/20/2018 & 0.1019 & 112.38 & 96.4 & 15.98 & 4.8 & 20.78 & 0.2078 & 0.0824 & 0.066109066 \\
\hline $7 / 23 / 2018$ & 0.1030 & 93.23 & 81.17 & 12.06 & 4.8 & 16.86 & 0.1686 & 0.0123 & 0.013904074 \\
\hline $7 / 26 / 2018$ & 0.1189 & 97.87 & 83.88 & 13.99 & 4.8 & 18.79 & 0.1879 & 0.0166 & 0.037629082 \\
\hline $9 / 11 / 2018$ & 0.1680 & 107.97 & 89.59 & 18.38 & 4.8 & 23.18 & 0.2318 & 0.0594 & 0.105882826 \\
\hline $10 / 18 / 2018$ & 0.1548 & 115.07 & 99.8 & 15.27 & 4.8 & 20.07 & 0.2007 & 0.0179 & 0.055479833 \\
\hline $10 / 30 / 2018$ & 0.1536 & 106.34 & 89.76 & 16.58 & 4.8 & 21.38 & 0.2138 & 0.0404 & 0.075496306 \\
\hline $1 / 24 / 2019$ & 0.3362 & 106.38 & 69.36 & 37.02 & 4.8 & 41.82 & 0.4182 & 0.6264 & 0.616767946 \\
\hline $1 / 24 / 2019$ & 0.3332 & 107.28 & 69.5 & 37.78 & 4.8 & 42.58 & 0.4258 & 0.6227 & 0.645191186 \\
\hline $2 / 26 / 2019$ & 0.1637 & 110.89 & 94.85 & 16.04 & 4.8 & 20.84 & 0.2084 & 0.0566 & 0.067031104 \\
\hline $2 / 26 / 2019$ & 0.1606 & 110.58 & 95.1 & 15.48 & 4.8 & 20.28 & 0.2028 & 0.0612 & 0.058569616 \\
\hline $3 / 28 / 2019$ & 0.1329 & 103.66 & 90.39 & 13.27 & 4.8 & 18.07 & 0.1807 & 0.0159 & 0.028329634 \\
\hline $3 / 28 / 2019$ & 0.1323 & 103.53 & 90.05 & 13.48 & 4.8 & 18.28 & 0.1828 & 0.0164 & 0.030986816 \\
\hline $4 / 23 / 2019$ & 0.1515 & 94.34 & 83.11 & 11.23 & 4.8 & 16.03 & 0.1603 & 0.0259 & 0.004880854 \\
\hline $4 / 25 / 2019$ & 0.1338 & 92.3 & 79.28 & 13.02 & 4.8 & 17.82 & 0.1782 & 0.0255 & 0.025225546 \\
\hline $4 / 26 / 2019$ & 0.1990 & 84.14 & 65.45 & 18.69 & 4.8 & 23.49 & 0.2349 & 0.0855 & 0.111452922 \\
\hline 4/29/2019 & 0.1402 & 102.91 & 90.52 & 12.39 & 4.8 & 17.19 & 0.1719 & 0.0306 & 0.017688762 \\
\hline 4/30/2019 & 0.1786 & 106.17 & 90.85 & 15.32 & 4.8 & 20.12 & 0.2012 & 0.0804 & 0.056211376 \\
\hline $5 / 5 / 2021$ & 0.3840 & 1025 & 994.20 & 30.8 & 4.8 & 35.60 & 0.3560 & 0.3830 & 0.4065052 \\
\hline $5 / 5 / 2021$ & 0.3590 & 1023 & 994.45 & 28.6 & 4.8 & 33.40 & 0.3340 & 0.3492 & 0.3416756 \\
\hline $5 / 5 / 2021$ & 0.3460 & 1022.3 & 994.57 & 27.7 & 4.8 & 32.50 & 0.3250 & 0.3587 & 0.31659125 \\
\hline $5 / 5 / 2021$ & 0.3290 & 1021.3 & 994.90 & 26.4 & 4.8 & 31.20 & 0.3120 & 0.2794 & 0.2818312 \\
\hline $5 / 5 / 2021$ & 0.3150 & 1021.2 & 995.17 & 26 & 4.8 & 30.80 & 0.3080 & 0.3120 & 0.271486 \\
\hline
\end{tabular}


Table A9-2. Modeled streamflow at Site 9, West Run Watershed, Morgantown, WV, U.S.A.

\begin{tabular}{|c|c|c|c|c|c|c|c|c|c|c|c|c|c|}
\hline $\begin{array}{l}\text { Cross- } \\
\text { Section } \\
\text { Area } \\
\left(\mathrm{m}^{2}\right)\end{array}$ & $\begin{array}{c}\text { A (Cross } \\
\text { Section } \\
\text { area of } \\
\text { flow) }\end{array}$ & $\begin{array}{c}\text { P } \\
\text { (Wetted } \\
\text { Perimete } \\
\text { r) }\end{array}$ & $\begin{array}{c}\mathrm{RH}=\mathrm{A} / \mathrm{P} \\
\text { Hydraulic } \\
\text { Radius } \\
\text { (m) }\end{array}$ & $\begin{array}{l}\text { Observed } \\
\text { Slope }(\mathrm{m})\end{array}$ & $\begin{array}{l}\text { Calculated } \\
\text { Slope using } \\
\text { ArcGIS (m) }\end{array}$ & $\begin{array}{c}\text { Roughness } \\
\text { Coefficient } \\
\text { (n) }\end{array}$ & $\begin{array}{c}\text { Manning } \\
\text { Discharge } \\
\left(\mathrm{m}^{3} / \mathrm{s}\right) \text { (Obs } \\
\text { Slope) }\end{array}$ & $\begin{array}{c}\text { Manning } \\
\text { Discharge } \\
\left(\mathrm{m}^{3} / \mathrm{s}\right) \text { (Calc } \\
\text { Slope) }\end{array}$ & $\begin{array}{l}\text { Chezy } \\
\text { Coefficient } \\
\text { (C) }\end{array}$ & $\begin{array}{c}\text { Chezy } \\
\text { Discharge } \\
\left(\mathrm{m}^{3} / \mathrm{s}\right) \text { (Obs } \\
\text { Slope) }\end{array}$ & $\begin{array}{c}\text { Chezy } \\
\text { Discharge } \\
\left(\mathrm{m}^{3} / \mathrm{s}\right)(\text { Calc } \\
\text { Slope) }\end{array}$ & $\begin{array}{c}\text { Dingman \& } \\
\text { Sharma } \\
\text { Discharge } \\
\left(\mathrm{m}^{3} / \mathrm{s}\right) \text { (Obs. } \\
\text { Slope) }\end{array}$ & $\begin{array}{c}\text { Dingman \& } \\
\text { Sharma } \\
\text { Discharge } \\
\text { ( } \mathrm{m}^{3} / \mathrm{s} \text { ) (Calc } \\
\text { Slope) }\end{array}$ \\
\hline 5.60 & 0.148 & 1.7660 & 0.083618 & 0.05 & 0.032 & 0.170 & 0.037141508 & 0.029713207 & 3.889866114 & 0.037141508 & 0.029713207 & 0.049753202 & 0.046493903 \\
\hline 5.60 & 0.218 & 1.9244 & 0.113139 & 0.05 & 0.032 & 0.170 & 0.066991248 & 0.053592999 & 4.090908075 & 0.066991248 & 0.053592999 & 0.088538961 & 0.082738832 \\
\hline 5.60 & 0.158 & 1.7901 & 0.088197 & 0.05 & 0.032 & 0.170 & 0.041146872 & 0.032917498 & 3.924578935 & 0.041146872 & 0.032917498 & 0.054972996 & 0.051371751 \\
\hline 5.60 & 0.155 & 1.7834 & 0.08692 & 0.05 & 0.032 & 0.170 & 0.040007407 & 0.032005926 & 3.91505166 & 0.040007407 & 0.032005926 & 0.053488741 & 0.049984729 \\
\hline 5.60 & 0.213 & 1.9141 & 0.111246 & 0.05 & 0.032 & 0.170 & 0.064785567 & 0.051828453 & 4.079423184 & 0.064785567 & 0.051828453 & 0.085679647 & 0.08006683 \\
\hline 5.60 & 0.270 & 2.0316 & 0.132853 & 0.05 & 0.032 & 0.170 & 0.09243392 & 0.073947136 & 4.201905448 & 0.09243392 & 0.073947136 & 0.121475126 & 0.113517371 \\
\hline 5.60 & 0.264 & 2.7948 & 0.094461 & 0.05 & 0.032 & 0.170 & 0.072023707 & 0.057618965 & 3.969720628 & 0.072023707 & 0.057618965 & 0.103268284 & 0.096503246 \\
\hline 5.60 & 0.196 & 2.111 & 0.092847 & 0.05 & 0.032 & 0.170 & 0.052861244 & 0.042288995 & 3.958333528 & 0.052861244 & 0.042288995 & 0.072318229 & 0.06758071 \\
\hline 5.60 & 0.217 & 2.0668 & 0.104993 & 0.05 & 0.032 & 0.170 & 0.063523829 & 0.050819063 & 4.040278404 & 0.063523829 & 0.050819063 & 0.08559651 & 0.079989139 \\
\hline 5.60 & 0.307 & 2.165 & 0.141801 & 0.05 & 0.032 & 0.170 & 0.109806514 & 0.087845212 & 4.247804211 & 0.109806514 & 0.087845212 & 0.145013949 & 0.135514181 \\
\hline 5.60 & 0.271 & 2.059 & 0.131617 & 0.05 & 0.032 & 0.170 & 0.092231796 & 0.073785437 & 4.195366467 & 0.092231796 & 0.073785437 & 0.12159688 & 0.113631148 \\
\hline 5.60 & 0.281 & 1364 & 0.13153 & 0.05 & 0.032 & 0.170 & 0.095592738 & 0.07647419 & 4.194900882 & 0.095592738 & 0.07647419 & 0.126842937 & 0.11853354 \\
\hline 5.60 & 1.021 & 2.8822 & 0.354243 & 0.05 & 0.032 & 0.170 & 0.672351289 & 0.537881031 & 4.948056879 & 0.672351289 & 0.537881031 & 0.856312183 & 0.800215735 \\
\hline 5.60 & 1.010 & 2.89 & 0.349481 & 0.05 & 0.032 & 0.170 & 0.659133131 & 0.527306505 & 4.936907617 & 0.659133131 & 0.527306505 & 0.840935449 & 0.78584632 \\
\hline 5.60 & 0.324 & 2.308 & 0.140381 & 0.05 & 0.032 & 0.170 & 0.11511199 & 0.092089592 & 4.240684338 & 0.11511199 & 0.092089592 & 0.153856998 & 0.143777928 \\
\hline 5.60 & 0.318 & 2.3022 & 0.138129 & 0.05 & 0.032 & 0.170 & 0.111768455 & 0.089414764 & 4.22926687 & 0.111768455 & 0.089414764 & 0.149549483 & 0.139752595 \\
\hline 5.60 & 0.243 & 2.095 & 0.11599 & 0.05 & 0.032 & 0.170 & 0.076019297 & 0.060815438 & 4.107915041 & 0.076019297 & 0.060815438 & 0.101720699 & 0.095057042 \\
\hline 5.60 & 0.242 & 2.0934 & 0.115601 & 0.05 & 0.032 & 0.170 & 0.075537083 & 0.060429667 & 4.105615456 & 0.075537083 & 0.060429667 & 0.101093902 & 0.094471307 \\
\hline 5.60 & 0.265 & 2.0558 & 0.128904 & 0.05 & 0.032 & 0.170 & 0.088945769 & 0.071156616 & 4.180824275 & 0.088945769 & 0.071156616 & 0.117462081 & 0.109767217 \\
\hline 5.60 & 0.255 & 2.1724 & 0.117382 & 0.05 & 0.032 & 0.170 & 0.080409961 & 0.064327969 & 4.116086343 & 0.080409961 & 0.064327969 & 0.108152375 & 0.101067384 \\
\hline 5.60 & 0.364 & 2.2272 & 0.163434 & 0.05 & 0.032 & 0.170 & 0.143119532 & 0.114495626 & 4.349521076 & 0.143119532 & 0.114495626 & 0.187427394 & 0.175149148 \\
\hline 5.60 & 0.267 & 2.1854 & 0.122174 & 0.05 & 0.032 & 0.170 & 0.086470418 & 0.069176334 & 4.143631562 & 0.086470418 & 0.069176334 & 0.115988282 & 0.108389966 \\
\hline 5.60 & 0.354 & 2.338 & 0.151411 & 0.05 & 0.032 & 0.170 & 0.132275226 & 0.105820181 & 4.294482834 & 0.132275226 & 0.105820181 & 0.175941627 & 0.164415807 \\
\hline 5.60 & 0.965 & 3.2826 & 0.293974 & 0.05 & 0.032 & 0.170 & 0.561181001 & 0.448944801 & 4.796627246 & 0.561181001 & 0.448944801 & 0.743872586 & 0.695141982 \\
\hline 5.60 & 0.875 & 3.1558 & 0.277267 & 0.05 & 0.032 & 0.170 & 0.489376587 & 0.39150127 & 4.750079105 & 0.489376587 & 0.39150127 & 0.647827165 & 0.605388433 \\
\hline 5.60 & 0.845 & 3.131 & 0.269882 & 0.05 & 0.032 & 0.170 & 0.464168022 & 0.371334418 & 4.728753606 & 0.464168022 & 0.371334418 & 0.615172131 & 0.574872609 \\
\hline 5.60 & 0.802 & 3.0958 & 0.259061 & 0.05 & 0.032 & 0.170 & 0.428691393 & 0.342953114 & 4.696611718 & 0.428691393 & 0.342953114 & 0.569221636 & 0.531932301 \\
\hline 5.60 & 0.767 & 3.0672 & 0.250065 & 0.05 & 0.032 & 0.170 & 0.400436469 & 0.320349176 & 4.669029559 & 0.400436469 & 0.320349176 & 0.532611508 & 0.497720478 \\
\hline
\end{tabular}




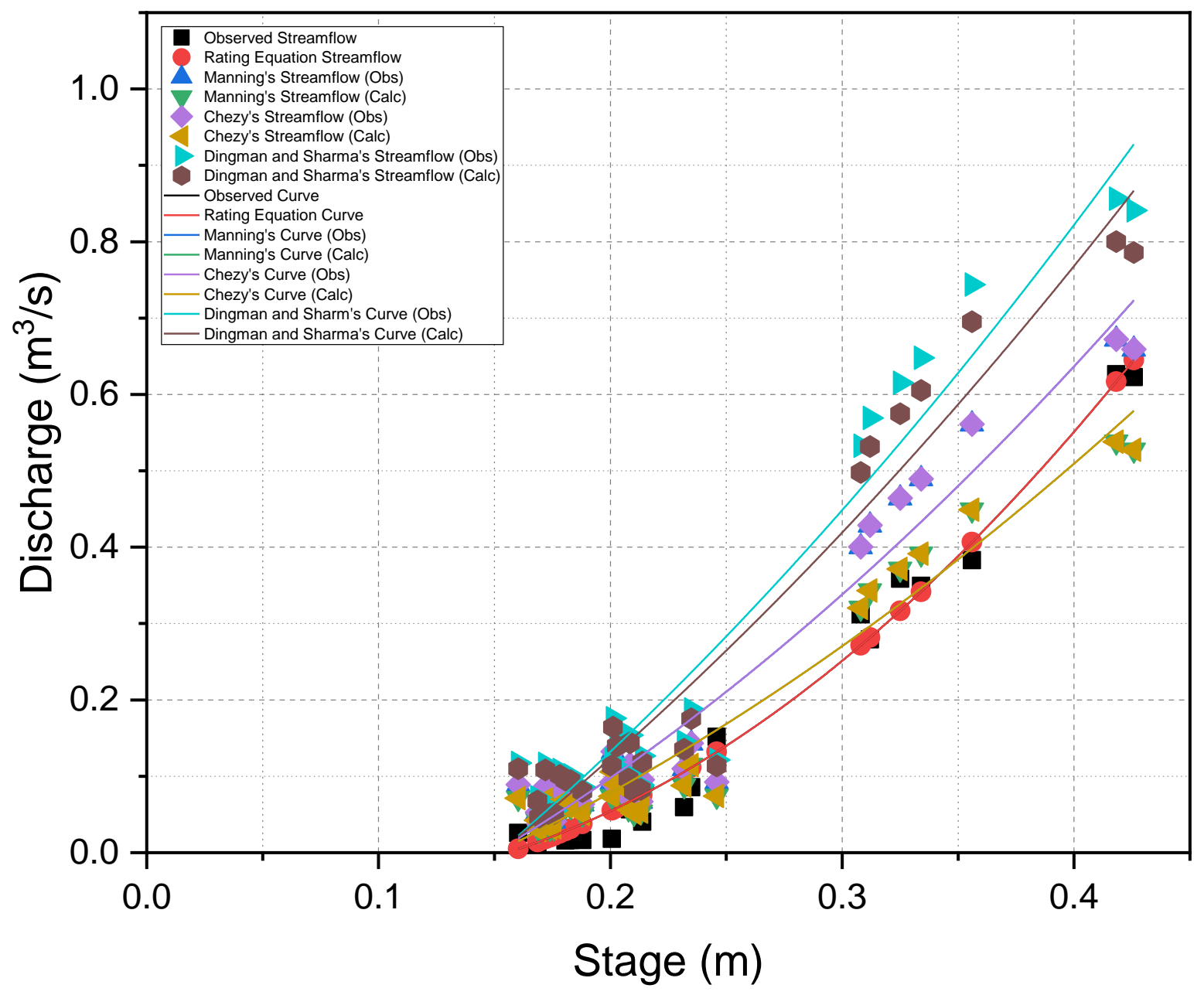

Figure A9-1. Observed and modeled rating curves and streamflow from Site 9, West Run Watershed, Morgantown, West Virginia, U.S.A 
Table A9-3. Polynomial rating equations and $\mathrm{R}^{2}$ values for observed and modeled rating curves at Site 9, West Run Watershed, Morgantown, WV, U.S.A.

\begin{tabular}{ccc}
\hline & $\begin{array}{c}\mathbf{R}^{\mathbf{2}} \\
\text { Value }\end{array}$ & Polynomial Equation \\
\hline Observed Curve & 0.98 & $\mathrm{y}=5.15 \mathrm{x}^{2}-0.6067 \mathrm{x}-0.0302$ \\
Manning's Curve (Obs Slope) & 0.95 & $\mathrm{y}=2.926 \mathrm{x}^{2}+0.9381 \mathrm{x}-0.2067$ \\
Manning's Curve (Calc Slope) & 0.95 & $\mathrm{y}=2.3408 \mathrm{x}^{2}+0.7505 \mathrm{x}-0.1653$ \\
Chezy's Curve (Obs Slope) & 0.95 & $\mathrm{y}=2.926 \mathrm{x}^{2}+0.9381 \mathrm{x}-0.2067$ \\
Chezy's Curve (Calc Slope) & 0.95 & $\mathrm{y}=2.3408 \mathrm{x}^{2}+0.7505 \mathrm{x}-0.1653$ \\
$\begin{array}{c}\text { Dingman and Sharma's Curve } \\
\text { (Obs Slope) }\end{array}$ & 0.94 & $\mathrm{y}=2.8521 \mathrm{x}^{2}+1.738 \mathrm{x}-0.3295$ \\
$\begin{array}{c}\text { Dingman and Sharma's Curve } \\
\text { (Calc Slope) }\end{array}$ & 0.94 & $\mathrm{y}=2.6652 \mathrm{x}^{2}+1.6242 \mathrm{x}-0.3079$ \\
\hline
\end{tabular}

Table A9-4. Descriptive statistics for observed and modeled streamflow used to generate the rating curves for Site 9, West Run Watershed, Morgantown, WV, U.S.A.

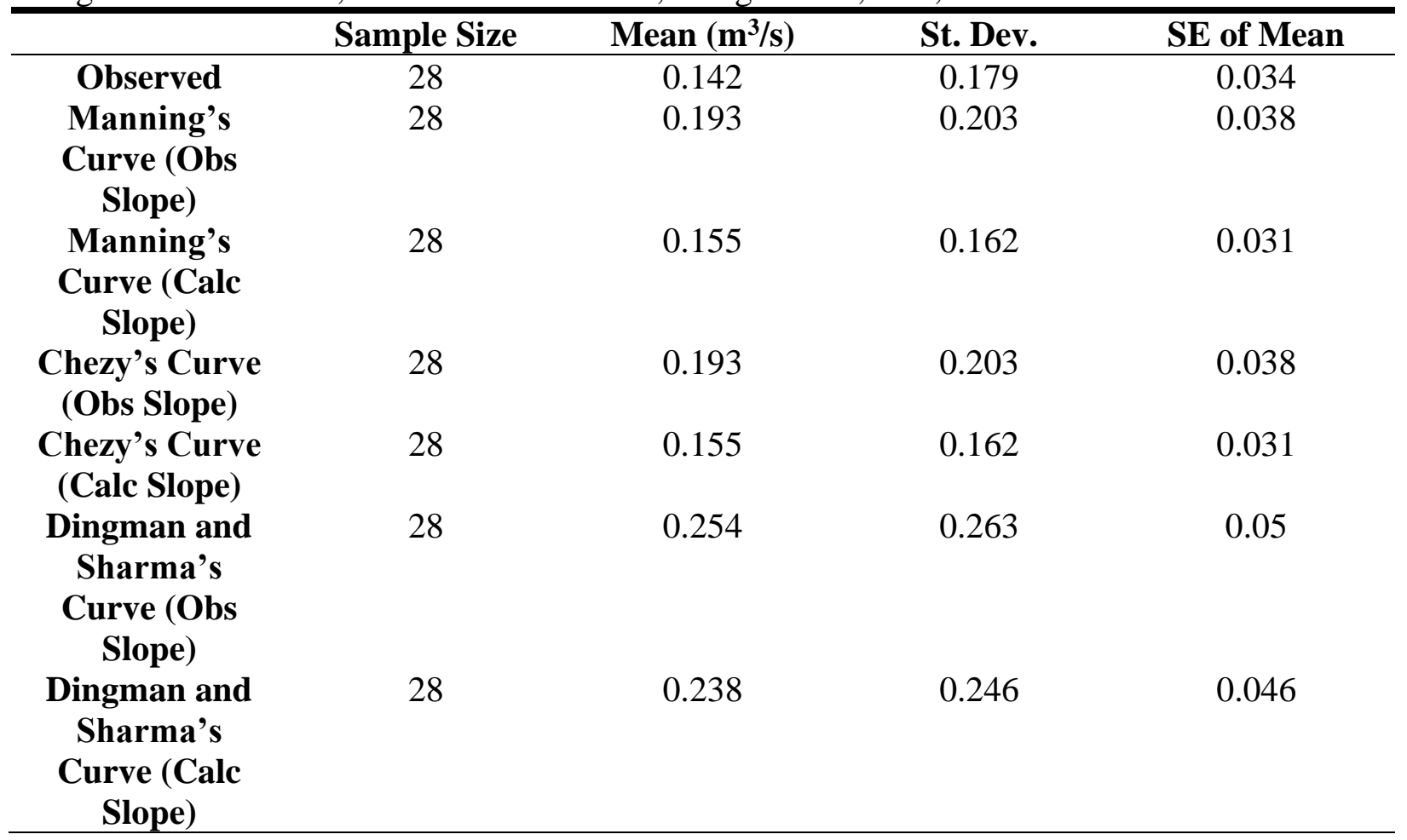


Table A9-5. P-values of the statistical analyses (post-hoc ANOVA) for observed and modeled rating curves at Site 9, West Run Watershed, Morgantown, WV, U.S.A.

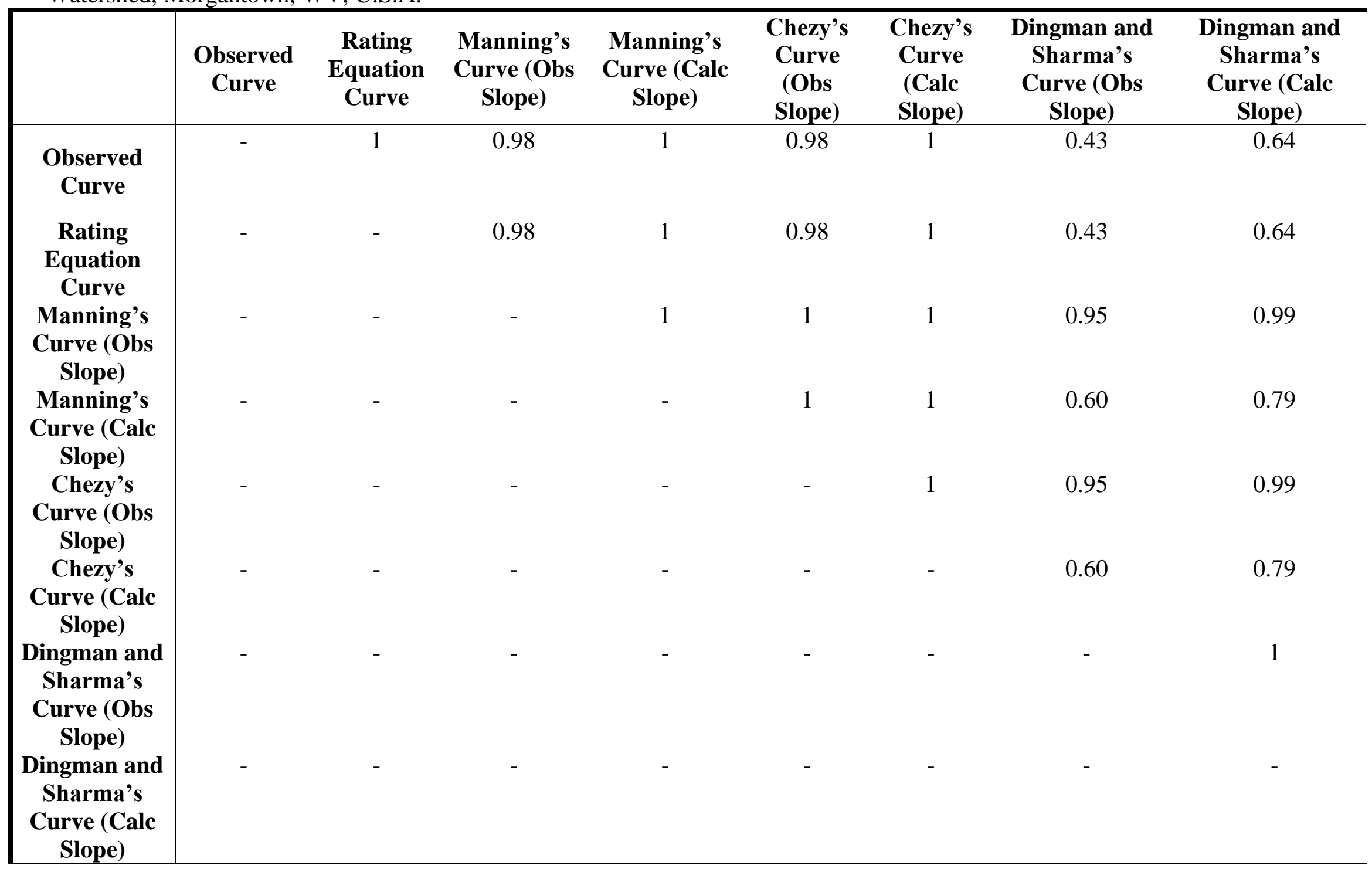




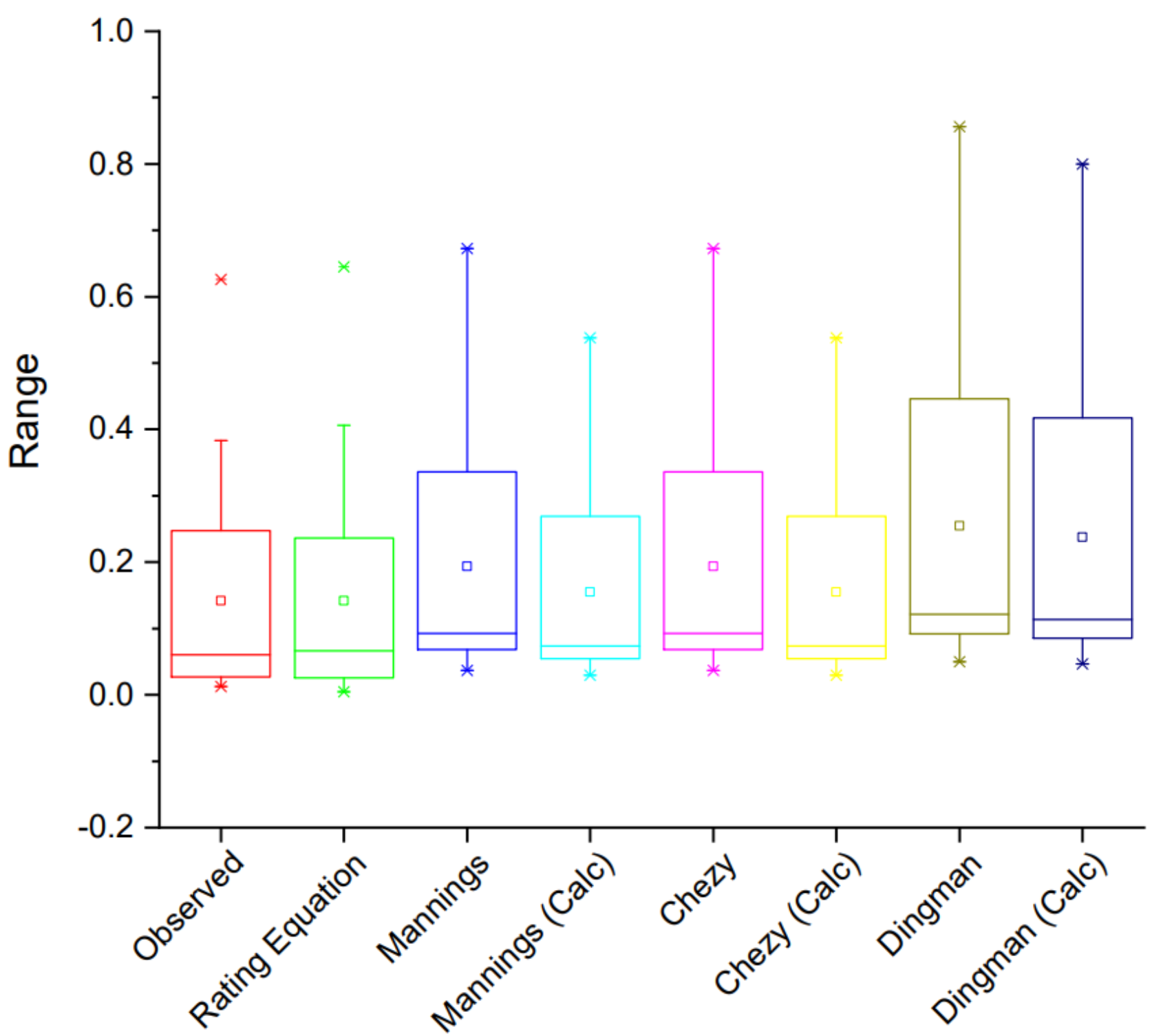

Figure A9-2. Box and whisker plots for the results of the statistical analyses (post-hoc ANOVA) of observed and modeled rating curves at Site 9, West Run Watershed, Morgantown, WV, U.S.A. 


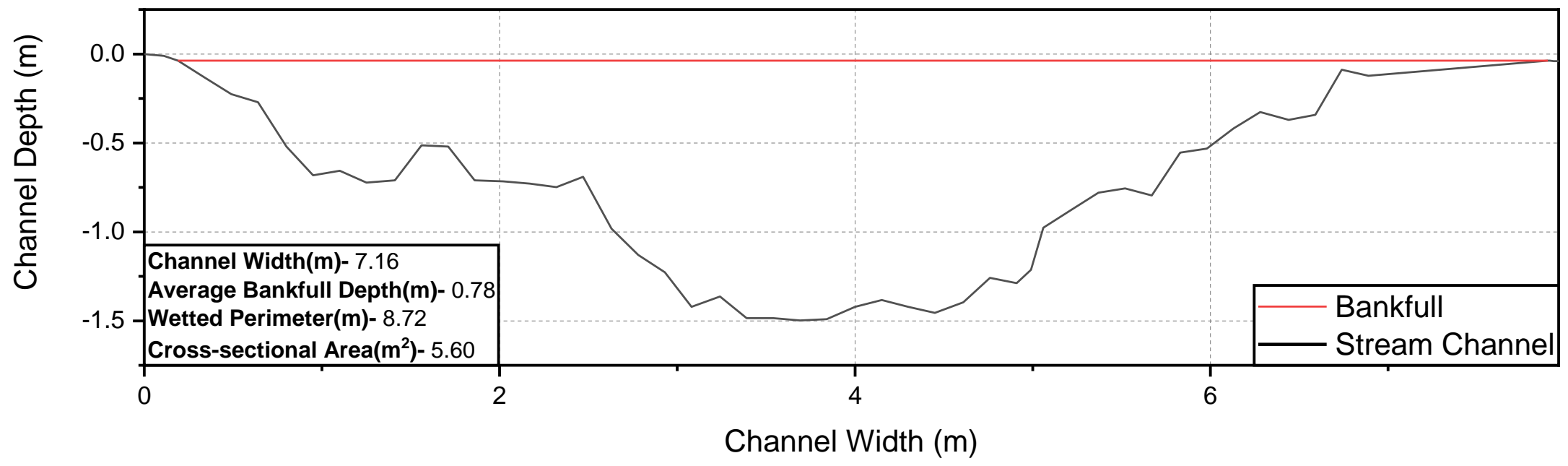

Figure A9-3. Cross-sectional profile of WRW Site 9, West Run Watershed, Morgantown, WV, USA (Figure 2). Channel Width of zero (0) represents the left bank facing downstream. 

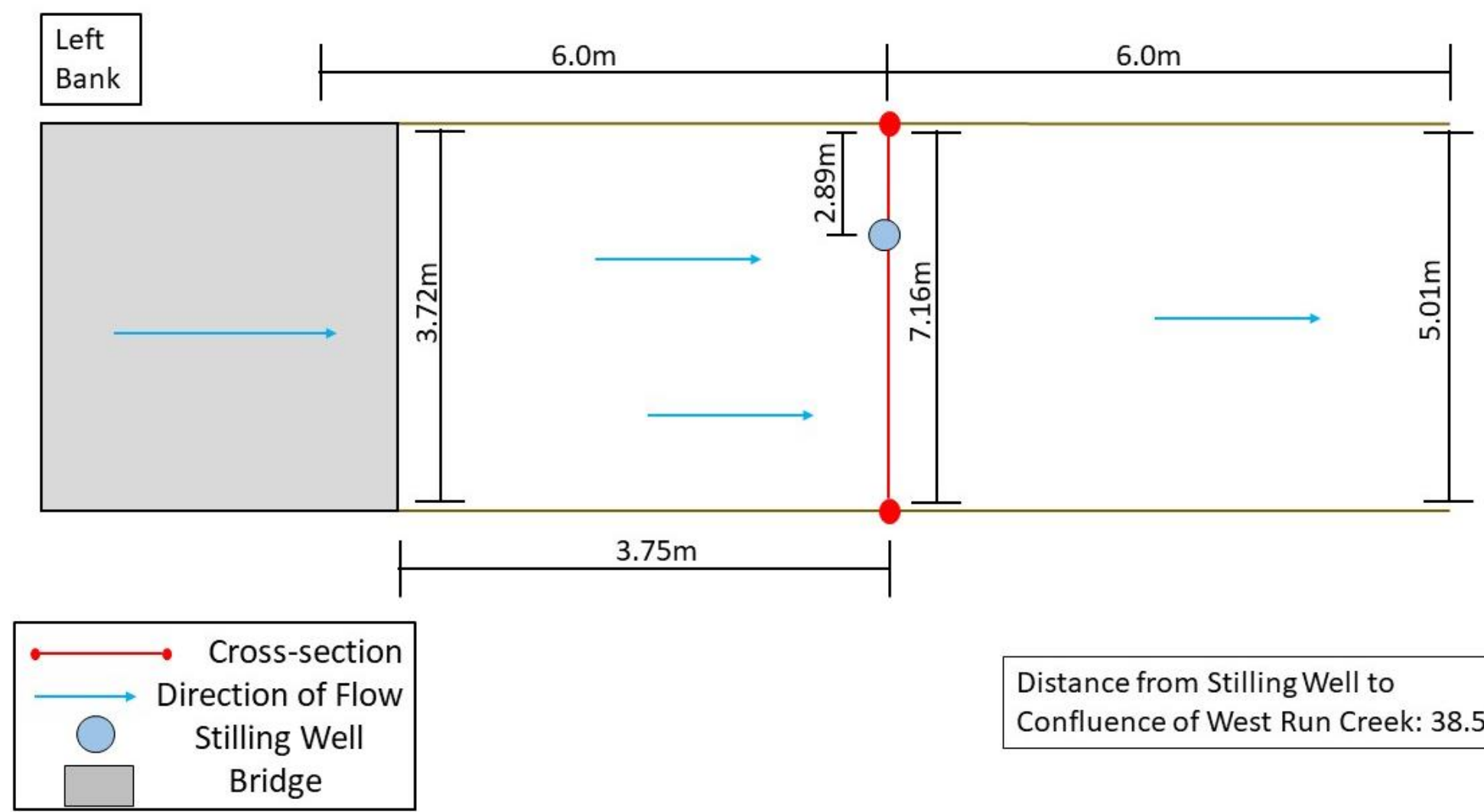

Distance from Stilling Well to

Confluence of West Run Creek: $38.51 \mathrm{~m}$

Figure A9-4. Plan view profile of WRW Site 9, West Run Watershed, Morgantown, WV, U.S.A. (Figure 2). Showing the positioning of stilling well in relation to where the streamflow was measured. Along with the channel width at the stilling well, point where crosssections were performed, and $6.0 \mathrm{~m}$ upstream and downstream from the stilling well. 


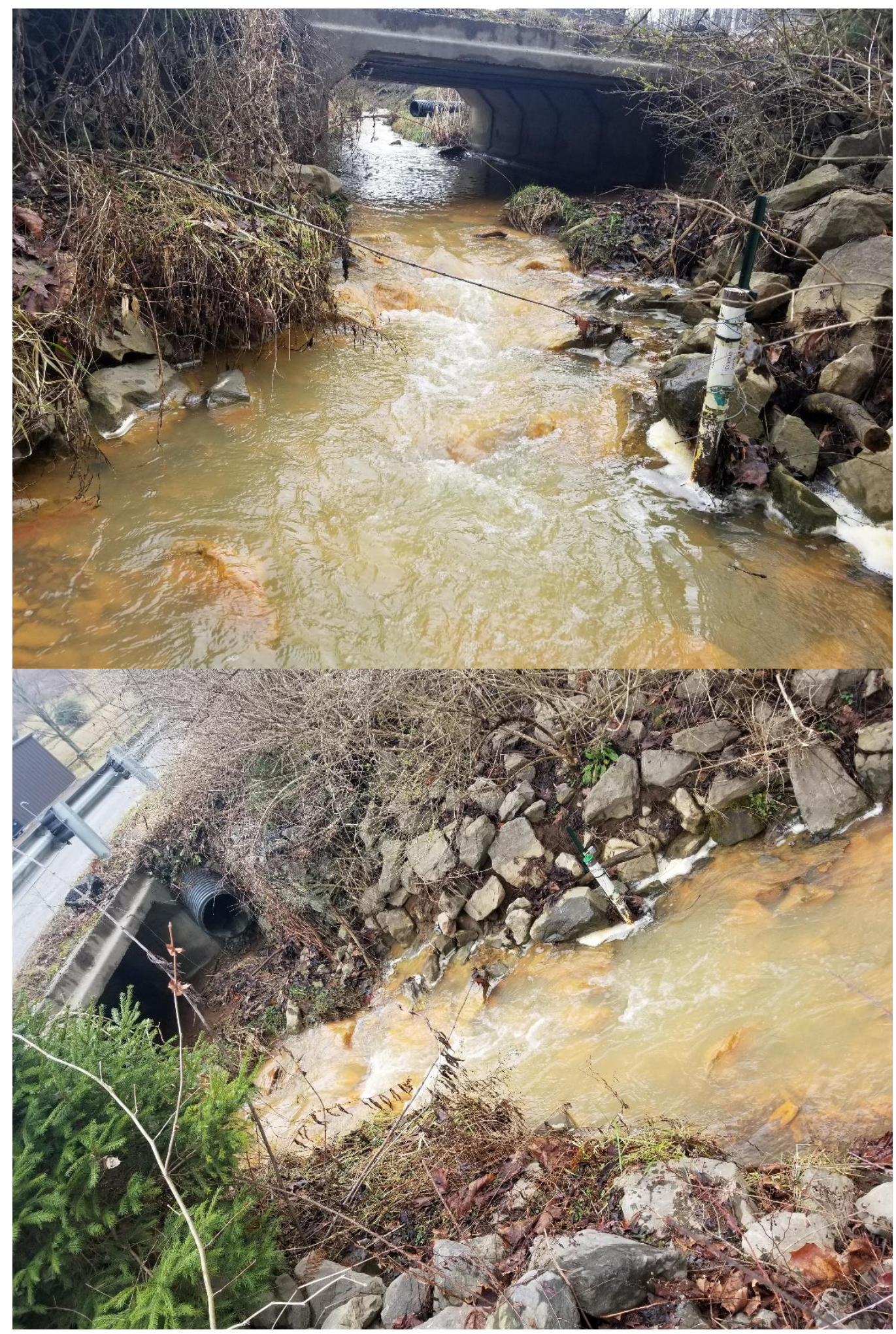

Figure A9-5. Photographs showing channel characteristics at Site \#9, West Run Watershed, Morgantown, WV, U.S.A. Photo 1 was taken looking upstream in the channel. Photo 2 was taken from the right bank looking upstream. 


\section{APPENDIX 10: Site 10}

Table A10-1. Streamflow measurements and stage collected at Site 10, West Run Watershed, Morgantown, WV, U.S.A. (Figure 2).

\begin{tabular}{|c|c|c|c|c|c|c|c|c|c|}
\hline Date & $\begin{array}{l}\text { Mean Depth of } \\
\text { Cross-Section } \\
\text { (m) }\end{array}$ & Stage(PT in cm) & $\begin{array}{c}\text { Barometric } \\
\text { Pressure (in } \mathrm{cm} \text { ) }\end{array}$ & $\begin{array}{c}\text { Pressure } \\
\text { Corrected Stage } \\
\text { (cm) }\end{array}$ & $\begin{array}{l}\text { Stilling Well } \\
\text { Offset }(\mathrm{cm})\end{array}$ & $\begin{array}{l}\text { P-Corrected } \\
\text { Stage + Offset } \\
\text { (cm) }\end{array}$ & $\begin{array}{l}\text { P-Corrected } \\
\text { Stage + Offset } \\
\text { (m) }\end{array}$ & $\begin{array}{c}\text { SonTec } \\
\text { Discharge }(\mathrm{m} 3 / \mathrm{s})\end{array}$ & $\begin{array}{l}\text { Rating Equation } \\
\text { Discharge }(\mathrm{m} 3 / \mathrm{s})\end{array}$ \\
\hline $1 / 23 / 2018$ & 0.1136 & 98.4 & 74.36 & 24.04 & 5.7 & 29.755 & 0.29755 & 0.2171 & 0.152898656 \\
\hline 2/9/2018 & 0.0999 & 115.95 & 93.35 & 22.6 & 5.7 & 28.315 & 0.28315 & 0.1710 & 0.121922274 \\
\hline $3 / 10 / 2018$ & 0.0752 & 103.31 & 83.49 & 19.82 & 5.7 & 25.535 & 0.25535 & 0.1061 & 0.071414889 \\
\hline $3 / 14 / 2018$ & 0.0716 & 99.28 & 79.8 & 19.48 & 5.7 & 25.195 & 0.25195 & 0.0716 & 0.066078135 \\
\hline $3 / 29 / 2018$ & 0.1216 & 105.83 & 79.66 & 26.17 & 5.7 & 31.885 & 0.31885 & 0.2645 & 0.204742161 \\
\hline $4 / 20 / 2018$ & 0.1102 & 121.27 & 96.3 & 24.97 & 5.7 & 30.685 & 0.30685 & 0.2189 & 0.174650413 \\
\hline $7 / 23 / 2018$ & 0.0814 & 97.38 & 81.11 & 16.27 & 5.7 & 21.985 & 0.21985 & 0.0203 & 0.02472087 \\
\hline $7 / 26 / 2018$ & 0.0948 & 101.58 & 83.81 & 17.77 & 5.7 & 23.485 & 0.23485 & 0.0390 & 0.042014599 \\
\hline $9 / 11 / 2018$ & 0.1378 & 112.36 & 89.12 & 23.24 & 5.7 & 28.955 & 0.28955 & 0.1558 & 0.135283928 \\
\hline $10 / 4 / 2018$ & 0.1091 & 104.94 & 84.75 & 20.19 & 5.7 & 25.905 & 0.25905 & 0.0627 & 0.077430654 \\
\hline $10 / 30 / 2018$ & 0.1222 & 111.36 & 89.78 & 21.58 & 5.7 & 27.295 & 0.27295 & 0.0981 & 0.101968558 \\
\hline $12 / 4 / 2018$ & 0.1186 & 106.34 & 84.03 & 22.31 & 5.7 & 28.025 & 0.28025 & 0.0845 & 0.116081441 \\
\hline $12 / 17 / 2018$ & 0.1606 & 108.37 & 82.39 & 25.98 & 5.7 & 31.695 & 0.31695 & 0.1961 & 0.199825603 \\
\hline $1 / 24 / 2019$ & 0.4566 & 130.8 & 69.56 & 61.24 & 5.7 & 66.955 & 0.66955 & 2.0578 & 2.091893987 \\
\hline $1 / 24 / 2019$ & 0.5026 & 130.15 & 69.71 & 60.44 & 5.7 & 66.155 & 0.66155 & 1.9741 & 2.027125134 \\
\hline $2 / 26 / 2019$ & 0.1518 & 121.42 & 95.18 & 26.24 & 5.7 & 31.955 & 0.31955 & 0.1631 & 0.206567943 \\
\hline $2 / 26 / 2019$ & 0.1451 & 121.61 & 95.32 & 26.29 & 5.7 & 32.005 & 0.32005 & 0.1604 & 0.207876827 \\
\hline $3 / 28 / 2019$ & 0.1091 & 111.1 & 90.73 & 20.37 & 5.7 & 26.085 & 0.26085 & 0.0516 & 0.080435675 \\
\hline $4 / 15 / 2019$ & 0.2036 & 104.89 & 72.84 & 32.05 & 5.7 & 37.765 & 0.37765 & 0.3807 & 0.385172995 \\
\hline $4 / 15 / 2019$ & 0.1978 & 105.33 & 73.3 & 32.03 & 5.7 & 37.745 & 0.37745 & 0.3645 & 0.384466434 \\
\hline $4 / 23 / 2019$ & 0.1061 & 102.03 & 82.98 & 19.05 & 5.7 & 24.765 & 0.24765 & 0.0629 & 0.059591021 \\
\hline $4 / 23 / 2019$ & 0.1155 & 101.68 & 82.53 & 19.15 & 5.7 & 24.865 & 0.24865 & 0.0600 & 0.061073509 \\
\hline $4 / 25 / 2019$ & 0.1061 & 99.94 & 79.32 & 20.62 & 5.7 & 26.335 & 0.26335 & 0.0618 & 0.08469448 \\
\hline $4 / 25 / 2019$ & 0.1079 & 100.04 & 79.37 & 20.67 & 5.7 & 26.385 & 0.26385 & 0.0560 & 0.085558125 \\
\hline $4 / 26 / 2019$ & 0.1926 & 94.96 & 65.97 & 28.99 & 5.7 & 34.705 & 0.34705 & 0.2972 & 0.284438919 \\
\hline $4 / 26 / 2019$ & 0.1835 & 94.48 & 66.34 & 28.14 & 5.7 & 33.855 & 0.33855 & 0.2708 & 0.25909024 \\
\hline $4 / 29 / 2019$ & 0.1158 & 110.28 & 90.49 & 19.79 & 5.7 & 25.505 & 0.25505 & 0.0729 & 0.070936631 \\
\hline $4 / 29 / 2019$ & 0.1140 & 110.36 & 90.55 & 19.81 & 5.7 & 25.525 & 0.25525 & 0.0679 & 0.071255311 \\
\hline $4 / 30 / 2019$ & 0.1277 & 112.91 & 90.89 & 22.02 & 5.7 & 27.735 & 0.27735 & 0.1162 & 0.110373863 \\
\hline $4 / 30 / 2020$ & 0.2374 & 1026.7 & 987.41 & 44.958 & 0.0 & 44.958 & 0.44958 & 0.6060 & 0.680391478 \\
\hline $2 / 28 / 2021$ & 0.1590 & 1033.8 & 1001.10 & 32.7 & 5.7 & 38.415 & 0.38415 & 0.3937 & 0.408481243 \\
\hline $2 / 28 / 2021$ & 0.1540 & 1033.1 & 1001.06 & 32 & 5.7 & 37.715 & 0.37715 & 0.4038 & 0.383407781 \\
\hline $2 / 28 / 2021$ & 0.1530 & 1032.6 & 1001.13 & 31.5 & 5.7 & 37.215 & 0.37215 & 0.3855 & 0.36597351 \\
\hline $6 / 13 / 2021$ & 0.2243 & 1036.6 & 995.36 & 41.2 & 5.7 & 46.915 & 0.46915 & 0.6942 & 0.774897876 \\
\hline $6 / 13 / 2021$ & 0.2137 & 1033 & 995.08 & 37.9 & 5.7 & 43.615 & 0.43615 & 0.5788 & 0.619047169 \\
\hline $6 / 13 / 2021$ & 0.1954 & 1032.3 & 995.26 & 37 & 5.7 & 42.715 & 0.42715 & 0.5327 & 0.579537097 \\
\hline $6 / 13 / 2021$ & 0.1942 & 1028.8 & 995.47 & 33.3 & 5.7 & 39.015 & 0.39015 & 0.4312 & 0.430590729 \\
\hline $10 / 16 / 2021$ & 0.3240 & 1044.49 & 991.39 & 53.1 & 5.7 & 58.815 & 0.58815 & 1.4710 & 1.480205345 \\
\hline $10 / 16 / 2021$ & 0.3260 & 1043.43 & 991.43 & 52 & 5.7 & 57.715 & 0.57715 & 1.5325 & 1.405597045 \\
\hline $10 / 16 / 2021$ & 0.3120 & 1041.52 & 991.22 & 50.3 & 5.7 & 56.015 & 0.56015 & 1.3379 & 1.294064371 \\
\hline $10 / 16 / 2021$ & 0.2870 & 1039.55 & 991.45 & 48.1 & 5.7 & 53.815 & 0.53815 & 1.2483 & 1.156525389 \\
\hline
\end{tabular}


Table A10-2. Modeled streamflow at Site 10, West Run Watershed, Morgantown, WV, U.S.A.

\begin{tabular}{|c|c|c|c|c|c|c|c|c|c|c|c|c|c|}
\hline $\begin{array}{c}\text { Cross- } \\
\text { Section } \\
\text { Area } \\
\left(\mathrm{m}^{2}\right)\end{array}$ & $\begin{array}{c}\text { A (Cross } \\
\text { Section } \\
\text { area of } \\
\text { flow) }\end{array}$ & $\begin{array}{c}\text { P } \\
\text { (Wetted } \\
\text { Perimete } \\
\text { r) }\end{array}$ & $\begin{array}{c}\text { RH=A/P } \\
\text { Hydraulic } \\
\text { Radius } \\
\text { (m) }\end{array}$ & $\begin{array}{l}\text { Observed } \\
\text { Slope (m) }\end{array}$ & $\begin{array}{l}\text { Calculated } \\
\text { Slope using } \\
\text { ArcGIS (m) }\end{array}$ & $\begin{array}{c}\text { Roughness } \\
\text { Coefficient } \\
\text { (n) }\end{array}$ & $\begin{array}{c}\text { Manning } \\
\text { Discharge } \\
\left(\mathrm{m}^{3} / \mathrm{s}\right)(\text { Obs } \\
\text { Slope) }\end{array}$ & $\begin{array}{c}\text { Manning } \\
\text { Discharge } \\
\left(\mathrm{m}^{3} / \mathrm{s}\right) \text { (Calc } \\
\text { Slope) }\end{array}$ & $\begin{array}{c}\text { Chezy } \\
\text { Coefficient } \\
\text { (C) }\end{array}$ & $\begin{array}{c}\text { Chezy } \\
\text { Discharge } \\
\left(\mathrm{m}^{3} / \mathrm{s}\right)(\text { Obs } \\
\text { Slope) }\end{array}$ & $\begin{array}{c}\text { Chezy } \\
\text { Discharge } \\
\left(\mathrm{m}^{3} / \mathrm{s}\right) \text { (Calc } \\
\text { Slope) }\end{array}$ & $\begin{array}{c}\text { Dingman \& } \\
\text { Sharma } \\
\text { Discharge } \\
\left(\mathrm{m}^{3} / \mathrm{s}\right) \text { (Obs. } \\
\text { Slope) }\end{array}$ & $\begin{array}{c}\text { Dingman \& } \\
\text { Sharma } \\
\text { Discharge } \\
\left(\mathrm{m}^{3} / \mathrm{s}\right) \text { (Calc } \\
\text { Slope) }\end{array}$ \\
\hline 6.96 & 0.352 & 2.1822 & 0.161453 & 0.01 & 0.005 & 0.085 & 0.122902963 & 0.086905519 & 8.681382645 & 0.122902963 & 0.086905519 & 0.134532699 & 0.114425686 \\
\hline 6.96 & 0.329 & 2.1426 & 0.153719 & 0.01 & 0.005 & 0.085 & 0.111187818 & 0.07862166 & 8.61064008 & 0.111187818 & 0.07862166 & 0.121882359 & 0.103666043 \\
\hline 6.96 & 0.285 & 2.0609 & 0.138283 & 0.01 & 0.005 & 0.085 & 0.089657506 & 0.06339743 & 8.460109899 & 0.089657506 & 0.06339743 & 0.098595096 & 0.083859252 \\
\hline 6.96 & 0.280 & 2.0505 & 0.136341 & 0.01 & 0.005 & 0.085 & 0.087125287 & 0.061606881 & 8.440193429 & 0.087125287 & 0.061606881 & 0.095853161 & 0.081527122 \\
\hline 6.96 & 0.386 & 2.2377 & 0.172644 & 0.01 & 0.005 & 0.085 & 0.140917077 & 0.099643421 & 8.778891489 & 0.140917077 & 0.099643421 & 0.153952787 & 0.130943283 \\
\hline 6.96 & 0.638 & 6.0114 & 0.106132 & 0.01 & 0.005 & 0.085 & 0.168253893 & 0.118973468 & 8.095094375 & 0.168253893 & 0.118973468 & 0.228259796 & 0.194144502 \\
\hline 6.96 & 0.279 & 3.5916 & 0.077681 & 0.01 & 0.005 & 0.085 & 0.059758007 & 0.042255292 & 7.684821441 & 0.059758007 & 0.042255292 & 0.076358427 & 0.064946035 \\
\hline 6.96 & 0.383 & 4.2284 & 0.090578 & 0.01 & 0.005 & 0.085 & 0.090878606 & 0.064260878 & 7.88408914 & 0.090878606 & 0.064260878 & 0.117743786 & 0.100146013 \\
\hline 6.96 & 0.683 & 5.2288 & 0.130623 & 0.01 & 0.005 & 0.085 & 0.206862083 & 0.146273582 & 8.380131878 & 0.206862083 & 0.146273582 & 0.268670327 & 0.228515348 \\
\hline 6.96 & 0.516 & 4.9422 & 0.104407 & 0.01 & 0.005 & 0.085 & 0.134601645 & 0.095177736 & 8.073018948 & 0.134601645 & 0.095177736 & 0.176793626 & 0.150370372 \\
\hline 6.96 & 0.596 & 5.1214 & 0.116374 & 0.01 & 0.005 & 0.085 & 0.167134347 & 0.11818183 & 8.220356796 & 0.167134347 & 0.11818183 & 0.218647057 & 0.185968465 \\
\hline 6.96 & 0.578 & 5.1142 & 0.113019 & 0.01 & 0.005 & 0.085 & 0.158955539 & 0.11239854 & 8.180366522 & 0.158955539 & 0.11239854 & 0.208467403 & 0.177310243 \\
\hline 6.96 & 0.808 & 5.3504 & 0.151017 & 0.01 & 0.005 & 0.085 & 0.269572658 & 0.190616655 & 8.585229829 & 0.269572658 & 0.190616655 & 0.346769042 & 0.294941571 \\
\hline 6.96 & 2.47 & 6.3232 & 0.390625 & 0.01 & 0.005 & 0.085 & 1.55280904 & 1.098001802 & 10.05868204 & 1.55280904 & 1.098001802 & 1.88093717 & 1.599815716 \\
\hline 6.96 & 2.479 & 6.323 & 0.392061 & 0.01 & 0.005 & 0.085 & 1.562283446 & 1.104701219 & 10.06483436 & 1.562283446 & 1.104701219 & 1.891753093 & 1.609015111 \\
\hline 6.96 & 0.74 & 5.1806 & 0.142841 & 0.01 & 0.005 & 0.085 & 0.237892399 & 0.168215329 & 8.505953758 & 0.237892399 & 0.168215329 & 0.305904749 & 0.260184781 \\
\hline 6.96 & 0.742 & 5.1877 & 0.143031 & 0.01 & 0.005 & 0.085 & 0.238746867 & 0.168819529 & 8.507838741 & 0.2387468667 & 0.168819529 & 0.307038016 & 0.261148671 \\
\hline 6.96 & 0.516 & 4.9426 & 0.104398 & 0.01 & 0.005 & 0.085 & 0.134594382 & 0.0951726 & 8.072910054 & 0.134594382 & 0.0951726 & 0.176787903 & 0.150365504 \\
\hline 6.96 & 1.023 & 5.436 & 0.18819 & 0.01 & 0.005 & 0.085 & 0.395233879 & 0.279472556 & 8.905953814 & 0.395233879 & 0.279472556 & 0.499412423 & 0.424771149 \\
\hline 6.96 & 1.022 & 5.43 & 0.188214 & 0.01 & 0.005 & 0.085 & 0.394880797 & 0.279222889 & 8.906141386 & 0.394880797 & 0.279222889 & 0.498865047 & 0.424305583 \\
\hline 6.96 & 0.517 & 5.0892 & 0.101588 & 0.01 & 0.005 & 0.085 & 0.132423674 & 0.093637678 & 8.036271088 & 0.132423674 & 0.093637678 & 0.175265956 & 0.149071024 \\
\hline 6.96 & 0.517 & 5.0892 & 0.101588 & 0.01 & 0.005 & 0.085 & 0.132423674 & 0.093637678 & 8.036271088 & 0.132423674 & 0.093637678 & 0.175265956 & 0.149071024 \\
\hline 6.96 & 0.518 & 5.0894 & 0.10178 & 0.01 & 0.005 & 0.085 & 0.132847367 & 0.093937274 & 8.038807024 & 0.132847367 & 0.093937274 & 0.175796744 & 0.149522482 \\
\hline 6.96 & 0.526 & 5.0928 & 0.103283 & 0.01 & 0.005 & 0.085 & 0.136223772 & 0.096324753 & 8.058470024 & 0.136223772 & 0.096324753 & 0.180038206 & 0.153130022 \\
\hline 6.96 & 0.954 & 5.3384 & 0.178705 & 0.01 & 0.005 & 0.085 & 0.356085501 & 0.251790473 & 8.829523866 & 0.356085501 & 0.251790473 & 0.450714881 & 0.383351854 \\
\hline 6.96 & 0.923 & 5.396 & 0.171053 & 0.01 & 0.005 & 0.085 & 0.334607714 & 0.236603383 & 8.765352129 & 0.334607714 & 0.236603383 & 0.426059495 & 0.362381416 \\
\hline 6.96 & 0.565 & 5.1086 & 0.110598 & 0.01 & 0.005 & 0.085 & 0.153153604 & 0.108295952 & 8.150898763 & 0.153153604 & 0.108295952 & 0.201227901 & 0.171152744 \\
\hline 6.96 & 0.555 & 5.1048 & 0.108721 & 0.01 & 0.005 & 0.085 & 0.148736272 & 0.105172426 & 8.12768349 & 0.148736272 & 0.105172426 & 0.195712299 & 0.166461494 \\
\hline 6.96 & 0.633 & 5.2086 & 0.12153 & 0.01 & 0.005 & 0.085 & 0.182714601 & 0.129198733 & 8.2799591 & 0.182714601 & 0.129198733 & 0.238757148 & 0.203072938 \\
\hline 6.96 & 0.595 & 2.4924 & 0.238704 & 0.01 & 0.005 & 0.085 & 0.269335315 & 0.190448827 & 9.265969828 & 0.269335315 & 0.190448827 & 0.290828599 & 0.247361885 \\
\hline 6.96 & 0.94442 & 6.262 & 0.150818 & 0.01 & 0.005 & 0.085 & 0.314809376 & 0.222603844 & 8.583342181 & 0.314809376 & 0.222603844 & 0.416184924 & 0.353982681 \\
\hline 6.96 & 0.91509 & 6.252 & 0.146368 & 0.01 & 0.005 & 0.085 & 0.299002471 & 0.211426675 & 8.540603255 & 0.299002471 & 0.211426675 & 0.396288741 & 0.337060145 \\
\hline 6.96 & 0.89855 & 6.173 & 0.145561 & 0.01 & 0.005 & 0.085 & 0.292518926 & 0.206842116 & 8.532744395 & 0.292518926 & 0.206842116 & 0.387043871 & 0.329196997 \\
\hline 6.96 & 1.47019 & 7.001 & 0.209997 & 0.01 & 0.005 & 0.085 & 0.611078208 & 0.432097545 & 9.070195307 & 0.611078208 & 0.432097545 & 0.798456346 & 0.679120511 \\
\hline 6.96 & 1.38774 & 6.92 & 0.20054 & 0.01 & 0.005 & 0.085 & 0.5593588861 & 0.395526444 & 9.000806175 & 0.5593588861 & 0.395526444 & 0.732562971 & 0.62307544 \\
\hline 6.96 & 1.25071 & 6.791 & 0.184172 & 0.01 & 0.005 & 0.085 & 0.476306262 & 0.336799388 & 8.87397545 & 0.476306262 & 0.336799388 & 0.626744633 & 0.533072518 \\
\hline 6.96 & 1.21238 & 6.636 & 0.182697 & 0.01 & 0.005 & 0.085 & 0.459241819 & 0.324733004 & 8.862096442 & 0.459241819 & 0.324733004 & 0.602334824 & 0.512310955 \\
\hline 6.96 & 1.94864 & 6.668 & 0.292238 & 0.01 & 0.005 & 0.085 & 1.009570617 & 0.713874229 & 9.583785345 & 1.009570617 & 0.713874229 & 1.268195885 & 1.078653631 \\
\hline 6.96 & 1.9858 & 6.748 & 0.29428 & 0.01 & 0.005 & 0.085 & 1.033610396 & 0.73087292 & 9.594915323 & 1.033610396 & 0.73087292 & 1.300227271 & 1.105897664 \\
\hline 6.96 & 1.87548 & 6.644 & 0.282282 & 0.01 & 0.005 & 0.085 & 0.949471764 & 0.671377923 & 9.528580555 & 0.949471764 & 0.671377923 & 1.195833631 & 1.017106508 \\
\hline 6.96 & 1.70709 & 6.518 & 0.261904 & 0.01 & 0.005 & 0.085 & 0.822114297 & 0.581322594 & 9.410327787 & 0.822114297 & 0.581322594 & 1.039274693 & 0.883946585 \\
\hline
\end{tabular}




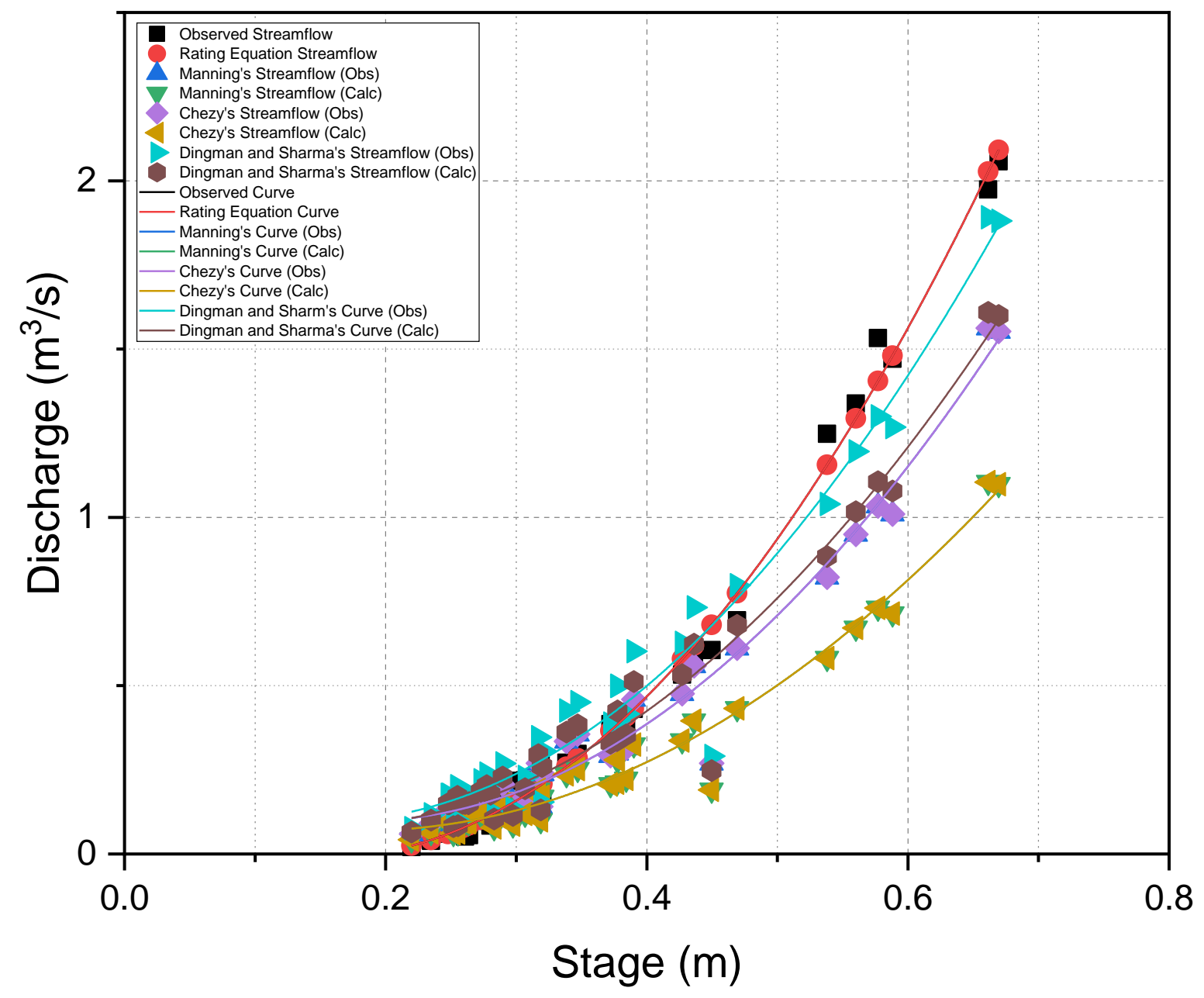

Figure A10-1. Observed and modeled rating curves and streamflow from Site 10, West Run Watershed, Morgantown, West Virginia, USA. 
Table A10-3. Polynomial rating equations and $\mathrm{R}^{2}$ values for observed and modeled rating curves at Site 10, West Run Watershed, Morgantown, WV, U.S.A.

\begin{tabular}{ccc}
\hline & $\begin{array}{c}\mathbf{R}^{\mathbf{2}} \\
\text { Value }\end{array}$ & Polynomial Equation \\
\hline Observed Curve & 0.99 & $\mathrm{y}=7.9224 \mathrm{x}^{2}-2.4494 \mathrm{x}+0.1803$ \\
Manning's Curve (Obs Slope) & 0.97 & $\mathrm{y}=5.985 \mathrm{x}^{2}-2.1592 \mathrm{x}+0.2923$ \\
Manning's Curve (Calc Slope) & 0.97 & $\mathrm{y}=4.2321 \mathrm{x}^{2}-1.5268 \mathrm{x}+0.2067$ \\
Chezy's Curve (Obs Slope) & 0.97 & $\mathrm{y}=5.985 \mathrm{x}^{2}-2.1592 \mathrm{x}+0.2923$ \\
Chezy's Curve (Calc Slope) & 0.97 & $\mathrm{y}=4.2321 \mathrm{x}^{2}-1.5268 \mathrm{x}+0.2067$ \\
$\begin{array}{c}\text { Dingman and Sharma's Curve } \\
\text { (Obs Slope) }\end{array}$ & 0.97 & $\mathrm{y}=6.6746 \mathrm{x}^{2}-2.0624 \mathrm{x}+0.2565$ \\
$\begin{array}{c}\text { Dingman and Sharma's Curve } \\
\text { (Calc Slope) }\end{array}$ & 0.97 & $\mathrm{y}=5.677 \mathrm{x}^{2}-1.7542 \mathrm{x}+0.2181$ \\
\hline
\end{tabular}

Table A10-4. Descriptive statistics for observed and modeled streamflow used to generate the rating curves for Site 10, West Run Watershed, Morgantown, WV, U.S.A.

\begin{tabular}{|c|c|c|c|c|}
\hline & Sample Size & Mean $\left(\mathrm{m}^{3} / \mathrm{s}\right)$ & St. Dev. & SE of Mean \\
\hline Observed & 41 & 0.428 & 0.535 & 0.084 \\
\hline Manning's & 41 & 0.369 & 0.372 & 0.058 \\
\hline $\begin{array}{l}\text { Curve (Obs } \\
\text { Slope) }\end{array}$ & & & & \\
\hline $\begin{array}{l}\text { Manning's } \\
\text { Curve (Calc } \\
\text { Slope) }\end{array}$ & 41 & 0.261 & 0.263 & 0.041 \\
\hline $\begin{array}{c}\text { Chezy's Curve } \\
\text { (Obs Slope) }\end{array}$ & 41 & 0.369 & 0.372 & 0.058 \\
\hline $\begin{array}{c}\text { Chezy's Curve } \\
\text { (Calc Slope) }\end{array}$ & 41 & 0.261 & 0.263 & 0.041 \\
\hline $\begin{array}{l}\text { Dingman and } \\
\text { Sharma's } \\
\text { Curve (Obs } \\
\text { Slope) }\end{array}$ & 41 & 0.465 & 0.457 & 0.071 \\
\hline $\begin{array}{l}\text { Dingman and } \\
\text { Sharma's } \\
\text { Curve (Calc } \\
\text { Slope) }\end{array}$ & 41 & 0.396 & 0.389 & 0.061 \\
\hline
\end{tabular}


Table A10-5. P-values of the statistical analyses (post-hoc ANOVA) for observed and modeled rating curves at Site 10, West Run Watershed, Morgantown, WV, U.S.A.

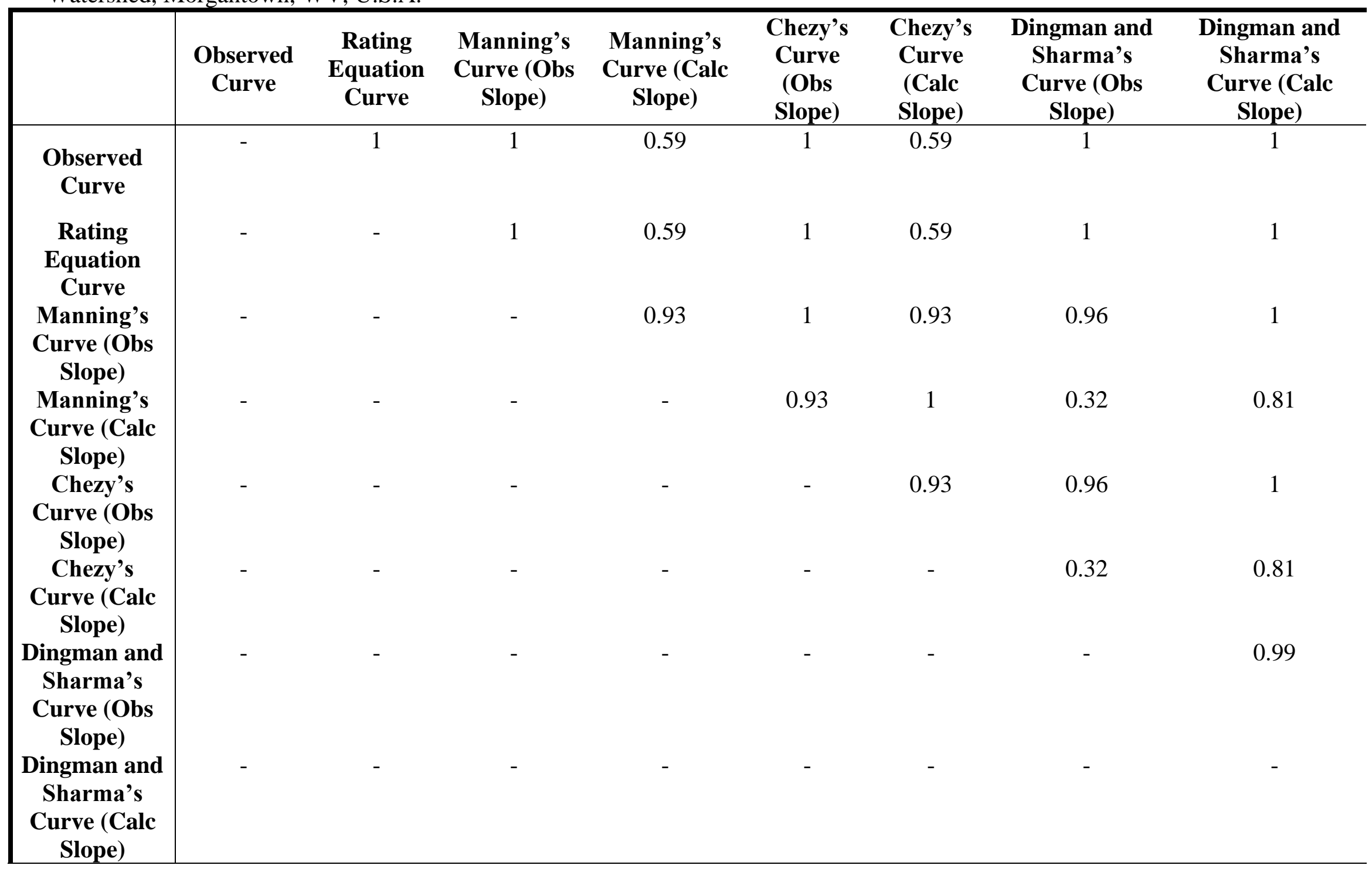




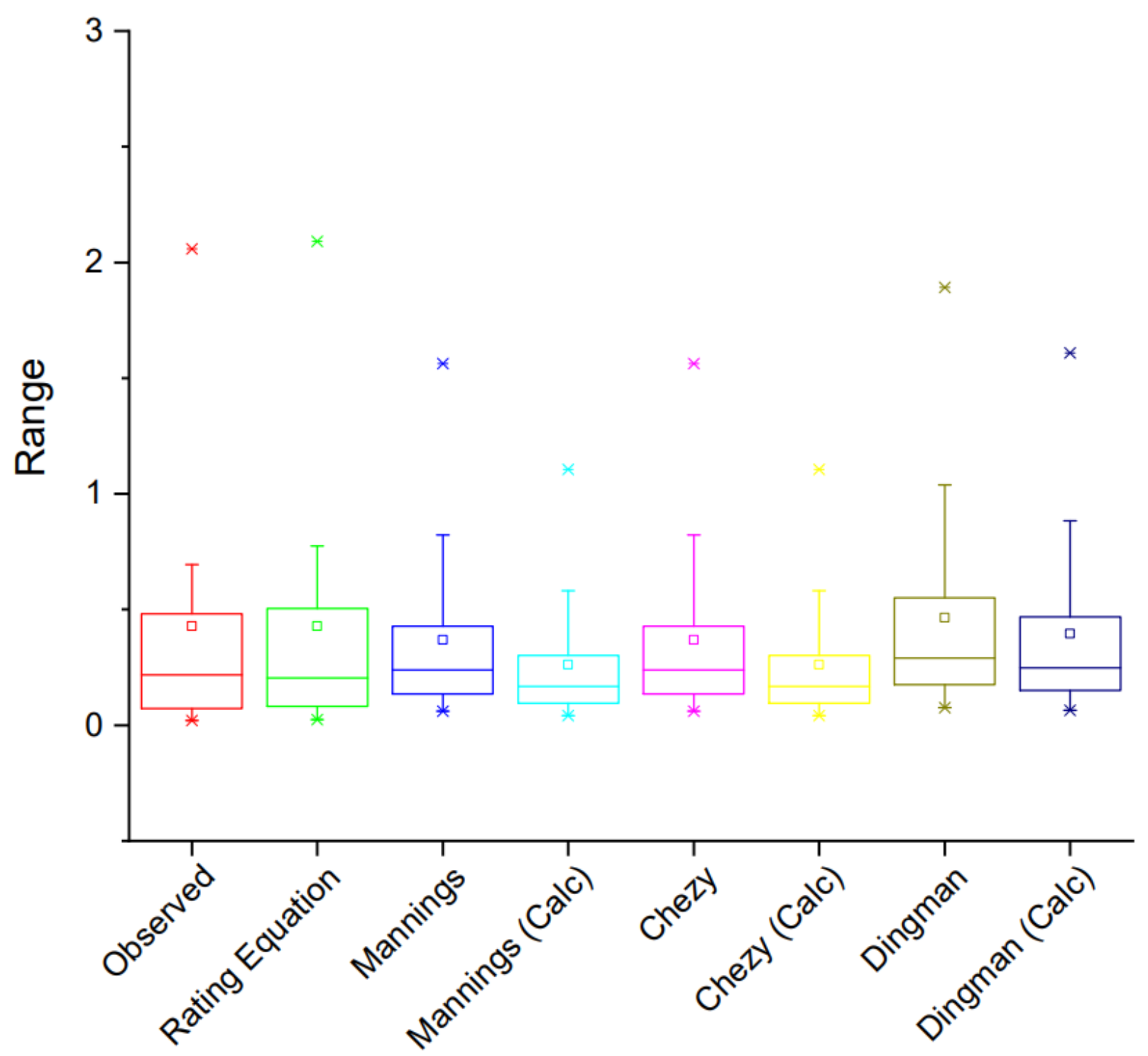

Figure A10-2. Box and whisker plots for the results of the statistical analyses (post-hoc ANOVA) of observed and modeled rating curves at Site 10, West Run Watershed, Morgantown, WV, U.S.A. 


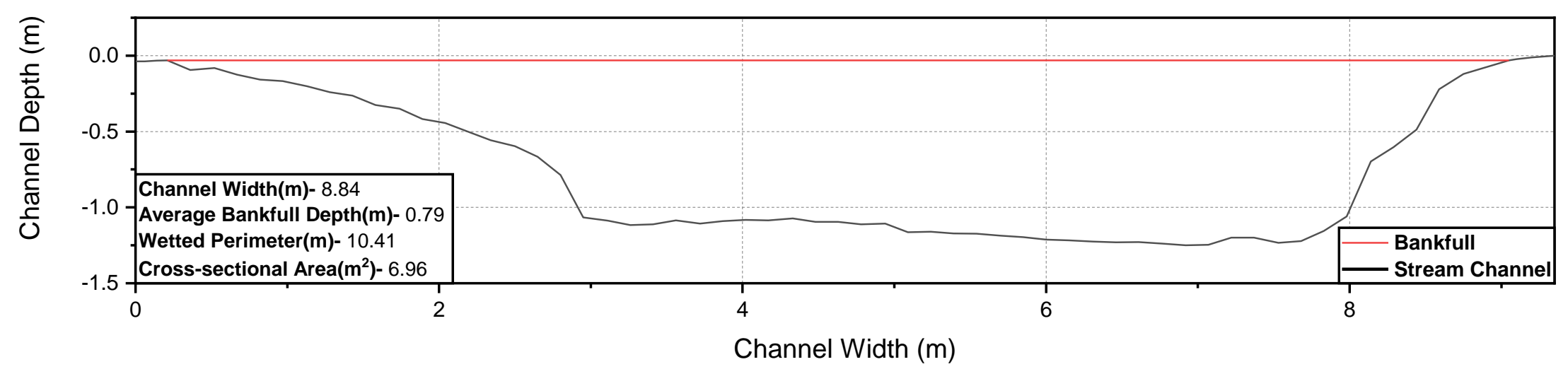

Figure A10-3. Cross-sectional profile of WRW Site 10, West Run Watershed, Morgantown, WV, USA (Figure 2). Channel Width of zero (0) represents the left bank facing downstream. 

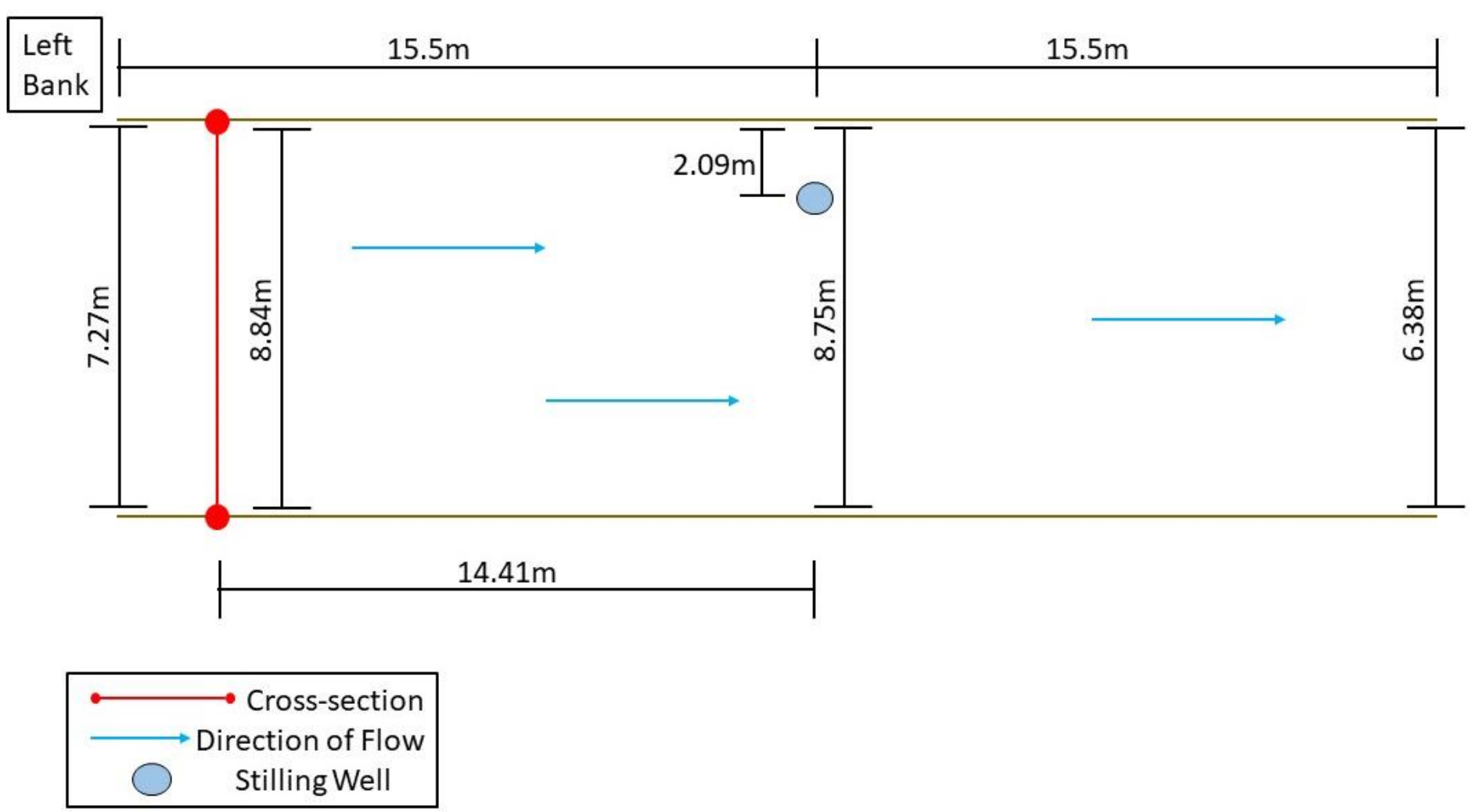

Figure A10-4. Plan view profile of WRW Site 10, West Run Watershed, Morgantown, WV, U.S.A. (Figure 2). Showing the positioning of stilling well in relation to where the streamflow was measured. Along with the channel width at the stilling well, point where cross-sections were performed, and $15.5 \mathrm{~m}$ upstream and downstream from the stilling well. 


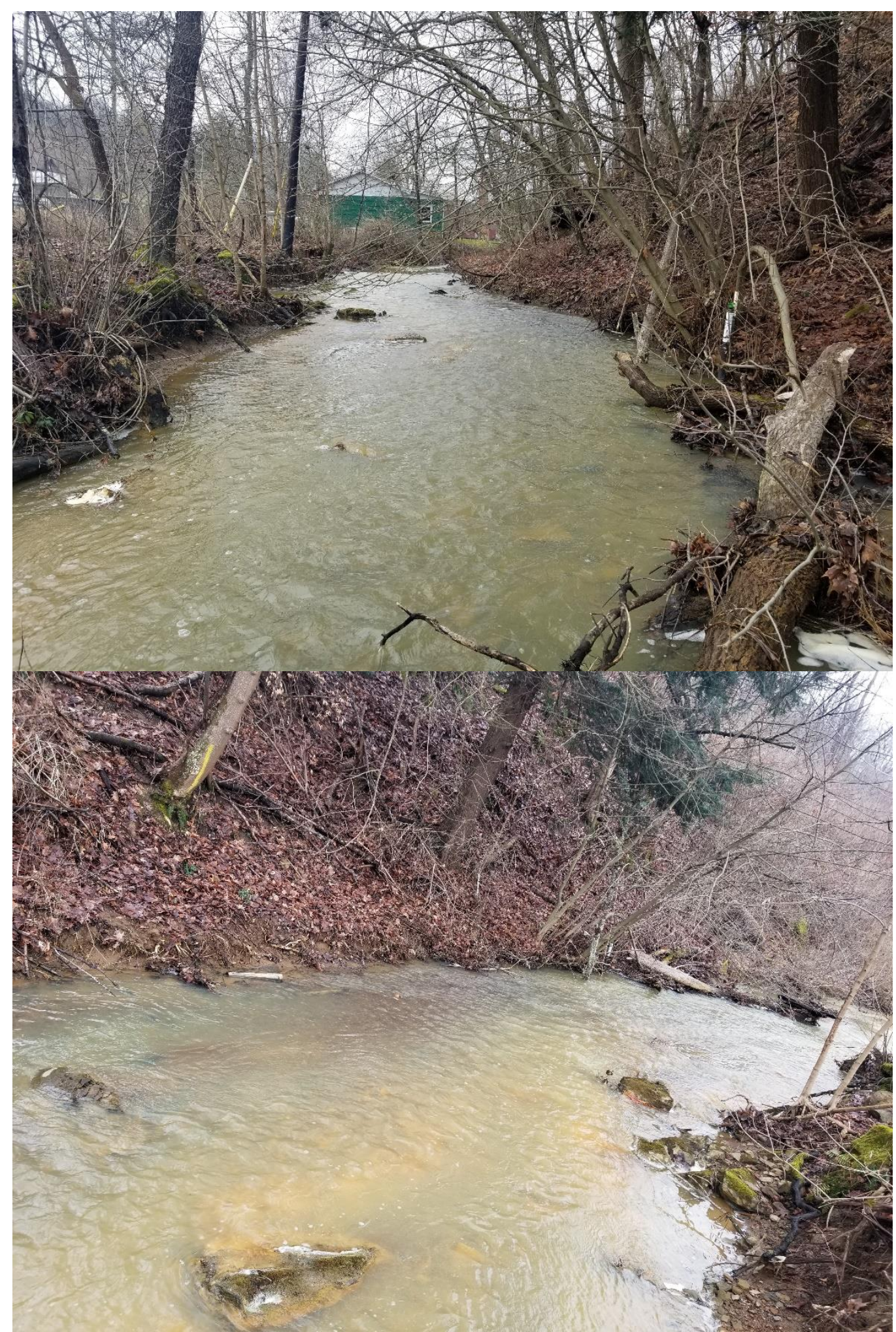

Figure A10-5. Photographs showing channel characteristics at Site \#10, West Run Watershed, Morgantown, WV, U.S.A. Photo 1 was taken looking upstream in the channel. Photo 2 was taken from the right bank looking downstream. 


\section{APPENDIX 11: Site 11}

Table A11-1. Streamflow measurements and stage collected at Site 11, West Run Watershed, Morgantown, WV, U.S.A. (Figure 2).

\begin{tabular}{|c|c|c|c|c|c|c|c|c|c|}
\hline Date & $\begin{array}{l}\text { Mean Depth of } \\
\text { Cross-Section } \\
\text { (m) }\end{array}$ & Stage (PT in cm) & $\begin{array}{c}\text { Barometric } \\
\text { Pressure (in cm) }\end{array}$ & $\begin{array}{c}\text { Pressure } \\
\text { Corrected Stage } \\
\text { (cm) }\end{array}$ & $\begin{array}{l}\text { Stilling Well } \\
\text { Offset (cm) }\end{array}$ & $\begin{array}{l}\text { P-Corrected } \\
\text { Stage + Offset } \\
\text { (cm) }\end{array}$ & $\begin{array}{l}\text { P-Corrected } \\
\text { Stage + Offset } \\
\text { (m) }\end{array}$ & $\begin{array}{c}\text { SonTec } \\
\text { Discharge }(\mathrm{m} 3 / \mathrm{s})\end{array}$ & $\begin{array}{l}\text { Rating Equation } \\
\text { Discharge }(\mathrm{m} 3 / \mathrm{s})\end{array}$ \\
\hline $12 / 5 / 2017$ & 0.3200 & 105.95 & 79.77 & 26.18 & 8.4 & 34.58 & 0.3458 & 0.0202 & 0.01191721 \\
\hline $2 / 9 / 2018$ & 0.3187 & 118.19 & 93.6 & 24.59 & 8.4 & 32.99 & 0.3299 & 0.0158 & 0.009809573 \\
\hline $4 / 4 / 2018$ & 0.3200 & 115.2 & 80.05 & 35.15 & 8.4 & 43.55 & 0.4355 & 0.0699 & 0.060252212 \\
\hline $2 / 6 / 2019$ & 0.3447 & 128.13 & 78.76 & 49.37 & 8.4 & 57.77 & 0.5777 & 0.2867 & 0.263752783 \\
\hline $2 / 6 / 2019$ & 0.3659 & 128.53 & 78.45 & 50.08 & 8.4 & 58.48 & 0.5848 & 0.2958 & 0.277991966 \\
\hline $3 / 19 / 2019$ & 0.2317 & 127.46 & 97.04 & 30.42 & 8.4 & 38.82 & 0.3882 & 0.0144 & 0.027048286 \\
\hline $3 / 19 / 2019$ & 0.2371 & 127.39 & 96.84 & 30.55 & 8.4 & 38.95 & 0.3895 & 0.0177 & 0.027730787 \\
\hline $4 / 23 / 2019$ & 0.1795 & 107.75 & 81.2 & 26.55 & 8.4 & 34.95 & 0.3495 & 0.0154 & 0.012686687 \\
\hline $4 / 23 / 2019$ & 0.1868 & 107.42 & 80.76 & 26.66 & 8.4 & 35.06 & 0.3506 & 0.0159 & 0.012935765 \\
\hline $4 / 26 / 2019$ & 0.2304 & 100.99 & 67.72 & 33.27 & 8.4 & 41.67 & 0.4167 & 0.0344 & 0.044993389 \\
\hline $4 / 26 / 2019$ & 0.2286 & 101.07 & 67.94 & 33.13 & 8.4 & 41.53 & 0.4153 & 0.0309 & 0.043965901 \\
\hline $5 / 13 / 2019$ & 0.2134 & 108.13 & 74.5 & 33.63 & 8.4 & 42.03 & 0.4203 & 0.0357 & 0.047704756 \\
\hline $5 / 13 / 2019$ & 0.2216 & 108.22 & 74.65 & 33.57 & 8.4 & 41.97 & 0.4197 & 0.0387 & 0.047245936 \\
\hline $5 / 14 / 2019$ & 0.2176 & 113.47 & 82.24 & 31.23 & 8.4 & 39.63 & 0.3963 & 0.0295 & 0.031512712 \\
\hline $5 / 14 / 2019$ & 0.2204 & 113.32 & 82.13 & 31.19 & 8.4 & 39.59 & 0.3959 & 0.0305 & 0.031280396 \\
\hline $5 / 15 / 2019$ & 0.1914 & 112.11 & 84.17 & 27.94 & 8.4 & 36.34 & 0.3634 & 0.0248 & 0.016518677 \\
\hline $8 / 16 / 2021$ & 0.2720 & 1042.8 & 1004.34 & 38.5 & 8.4 & 46.9 & 0.4690 & 0.1244 & 0.094183147 \\
\hline $8 / 16 / 2021$ & 0.2480 & 1049.3 & 1004.53 & 44.8 & 8.4 & 53.2 & 0.5320 & 0.1731 & 0.18138444 \\
\hline $8 / 16 / 2021$ & 0.1940 & 1050 & 1004.61 & 45.4 & 8.4 & 53.8 & 0.5380 & 0.2008 & 0.19128219 \\
\hline $8 / 16 / 2021$ & 0.2490 & 1056 & 1004.68 & 51.3 & 8.4 & 59.7 & 0.5970 & 0.2887 & 0.303365228 \\
\hline $8 / 16 / 2021$ & 0.2350 & 1056.1 & 1004.67 & 51.4 & 8.4 & 59.8 & 0.5980 & 0.2794 & 0.30549579 \\
\hline
\end{tabular}


Table A11-2. Modeled streamflow at Site 11, West Run Watershed, Morgantown, WV, U.S.A.

\begin{tabular}{|c|c|c|c|c|c|c|c|c|c|c|c|c|c|}
\hline $\begin{array}{c}\text { Cross- } \\
\text { Section } \\
\text { Area } \\
\left(\mathrm{m}^{2}\right)\end{array}$ & $\begin{array}{c}\text { A (Cross } \\
\text { Section } \\
\text { area of } \\
\text { flow) }\end{array}$ & $\begin{array}{c}\text { P } \\
\text { (Wetted } \\
\text { Perimete } \\
\text { r) }\end{array}$ & $\begin{array}{c}\text { RH=A/P } \\
\text { Hydraulic } \\
\text { Radius } \\
(\mathrm{m})\end{array}$ & $\begin{array}{l}\text { Observed } \\
\text { Slope }(m)\end{array}$ & $\begin{array}{l}\text { Calculated } \\
\text { Slope using } \\
\text { ArcGIS (m) }\end{array}$ & $\begin{array}{c}\text { Roughness } \\
\text { Coefficient } \\
\text { (n) }\end{array}$ & $\begin{array}{c}\text { Manning } \\
\text { Discharge } \\
\left(\mathrm{m}^{3} / \mathrm{s}\right)(\mathrm{Obs} \\
\text { Slope) }\end{array}$ & $\begin{array}{c}\text { Manning } \\
\text { Discharge } \\
\left(\mathrm{m}^{3} / \mathrm{s}\right) \text { (Calc } \\
\text { Slope) }\end{array}$ & $\begin{array}{c}\text { Chezy } \\
\text { Coefficient } \\
\text { (C) }\end{array}$ & $\begin{array}{c}\text { Chezy } \\
\text { Discharge } \\
\left(\mathrm{m}^{3} / \mathrm{s}\right)(\text { Obs } \\
\text { Slope) }\end{array}$ & $\begin{array}{c}\text { Chezy } \\
\text { Discharge } \\
\left(\mathrm{m}^{3} / \mathrm{s}\right) \text { (Calc } \\
\text { Slope) }\end{array}$ & $\begin{array}{c}\text { Dingman \& } \\
\text { Sharma } \\
\text { Discharge } \\
\text { (m²/s) (Obs. } \\
\text { Slope) }\end{array}$ & $\begin{array}{l}\text { Dingman \& } \\
\text { Sharma } \\
\text { Discharge } \\
\text { (m } \mathrm{m}^{3} / \mathrm{s} \text { ) (Calc } \\
\text { Slope) }\end{array}$ \\
\hline 1.03 & 0.429 & 2.3022 & 0.186485 & 0.035 & 0.04 & 0.185 & 0.141714264 & 0.15149892 & 4.085722602 & 0.141714264 & 0.15149892 & 0.227328432 & 0.232081484 \\
\hline 1.03 & 0.404 & 2.2649 & 0.178355 & 0.035 & 0.04 & 0.185 & 0.129434916 & 0.138371746 & 4.055481913 & 0.129434916 & 0.138371746 & 0.207910738 & 0.212257799 \\
\hline 1.03 & 0.572 & 4720 & 0.231581 & 0.035 & 0.04 & 0.185 & 0.218315351 & 0.233388928 & 4.235897213 & 0.218315351 & 0.233388928 & 0.34742485 & 0.354688915 \\
\hline 1.03 & 0.771 & 3.6616 & 0.210564 & 0.035 & 0.04 & 0.185 & 0.27595546 & 0.295008796 & 4.169258774 & 0.27595546 & 0.295008796 & 0.474245436 & 0.484161104 \\
\hline 1.03 & 0.784 & 3.662 & 0.214091 & 0.035 & 0.04 & 0.185 & 0.28373321 & 0.30332356 & 4.180817646 & 0.28373321 & 0.30332356 & 0.486863048 & 0.497042529 \\
\hline 1.03 & 0.512 & 2.6736 & 0.191502 & 0.035 & 0.04 & 0.185 & 0.172020923 & 0.183898102 & 4.103841003 & 0.172020923 & 0.183898102 & 0.282473726 & 0.288379773 \\
\hline 1.03 & 0.524 & 2.6846 & 0.195187 & 0.035 & 0.04 & 0.185 & 0.178304121 & 0.190615124 & 4.116899087 & 0.178304121 & 0.190615124 & 0.292476693 & 0.298591884 \\
\hline 1.03 & 0.383 & 2.493 & 0.15363 & 0.035 & 0.04 & 0.185 & 0.11109949 & 0.118770351 & 3.95586098 & 0.11109949 & 0.118770351 & 0.183999966 & 0.187847093 \\
\hline 1.03 & 0.395 & 2.5 & 0.158 & 0.035 & 0.04 & 0.185 & 0.116742982 & 0.124803497 & 3.974395839 & 0.116742982 & 0.124803497 & 0.192932864 & 0.196966763 \\
\hline 1.03 & 0.527 & 2.7468 & 0.19186 & 0.035 & 0.04 & 0.185 & 0.177280905 & 0.189521259 & 4.105116952 & 0.177280905 & 0.189521259 & 0.292423496 & 0.298537576 \\
\hline 1.03 & 0.523 & 2.7432 & 0.190653 & 0.035 & 0.04 & 0.185 & 0.175197052 & 0.187293527 & 4.100803641 & 0.175197052 & 0.187293527 & 0.289091386 & 0.295135796 \\
\hline 1.03 & 0.487 & 2.7124 & 0.179546 & 0.035 & 0.04 & 0.185 & 0.156738158 & 0.167560139 & 4.059982321 & 0.156738158 & 0.167560139 & 0.259583178 & 0.265010622 \\
\hline 1.03 & 0.507 & 2.7292 & 0.185769 & 0.035 & 0.04 & 0.185 & 0.166923949 & 0.178449208 & 4.083103334 & 0.166923949 & 0.178449208 & 0.275866114 & 0.281634007 \\
\hline 1.03 & 0.465 & 2.5694 & 0.180976 & 0.035 & 0.04 & 0.185 & 0.150451343 & 0.160839251 & 4.065355014 & 0.150451343 & 0.160839251 & 0.246664011 & 0.251821338 \\
\hline 1.03 & 0.47 & 2.5748 & 0.182538 & 0.035 & 0.04 & 0.185 & 0.152943042 & 0.163502989 & 4.071183376 & 0.152943042 & 0.163502989 & 0.250638344 & 0.255878767 \\
\hline 1.03 & 0.423 & 2.5932 & 0.163119 & 0.035 & 0.04 & 0.185 & 0.127704313 & 0.136521653 & 3.995572334 & 0.127704313 & 0.136521653 & 0.211755147 & 0.216182588 \\
\hline 1.03 & 0.51735 & 2.449 & 0.211249 & 0.035 & 0.04 & 0.185 & 0.185571179 & 0.198383935 & 4.171518907 & 0.185571179 & 0.198383935 & 0.297387297 & 0.303605161 \\
\hline 1.03 & 0.56671 & 2.782 & 0.203706 & 0.035 & 0.04 & 0.185 & 0.19840792 & 0.212106988 & 4.1463144 & 0.19840792 & 0.212106988 & 0.326158567 & 0.33297799 \\
\hline 1.03 & 0.68051 & 3.893 & 0.174803 & 0.035 & 0.04 & 0.185 & 0.215144481 & 0.2299999125 & 4.04190985 & 0.215144481 & 0.2299999125 & 0.3802506 & 0.388200995 \\
\hline 1.03 & 0.72116 & 3.394 & 0.212481 & 0.035 & 0.04 & 0.185 & 0.259681166 & 0.277610843 & 4.175561683 & 0.259681166 & 0.277610843 & 0.440082401 & 0.449283778 \\
\hline 1.03 & 0.7171 & 3.518 & 0.203837 & 0.035 & 0.04 & 0.185 & 0.251168174 & 0.268510072 & 4.14676018 & 0.251168174 & 0.268510072 & 0.429975344 & 0.438965399 \\
\hline
\end{tabular}




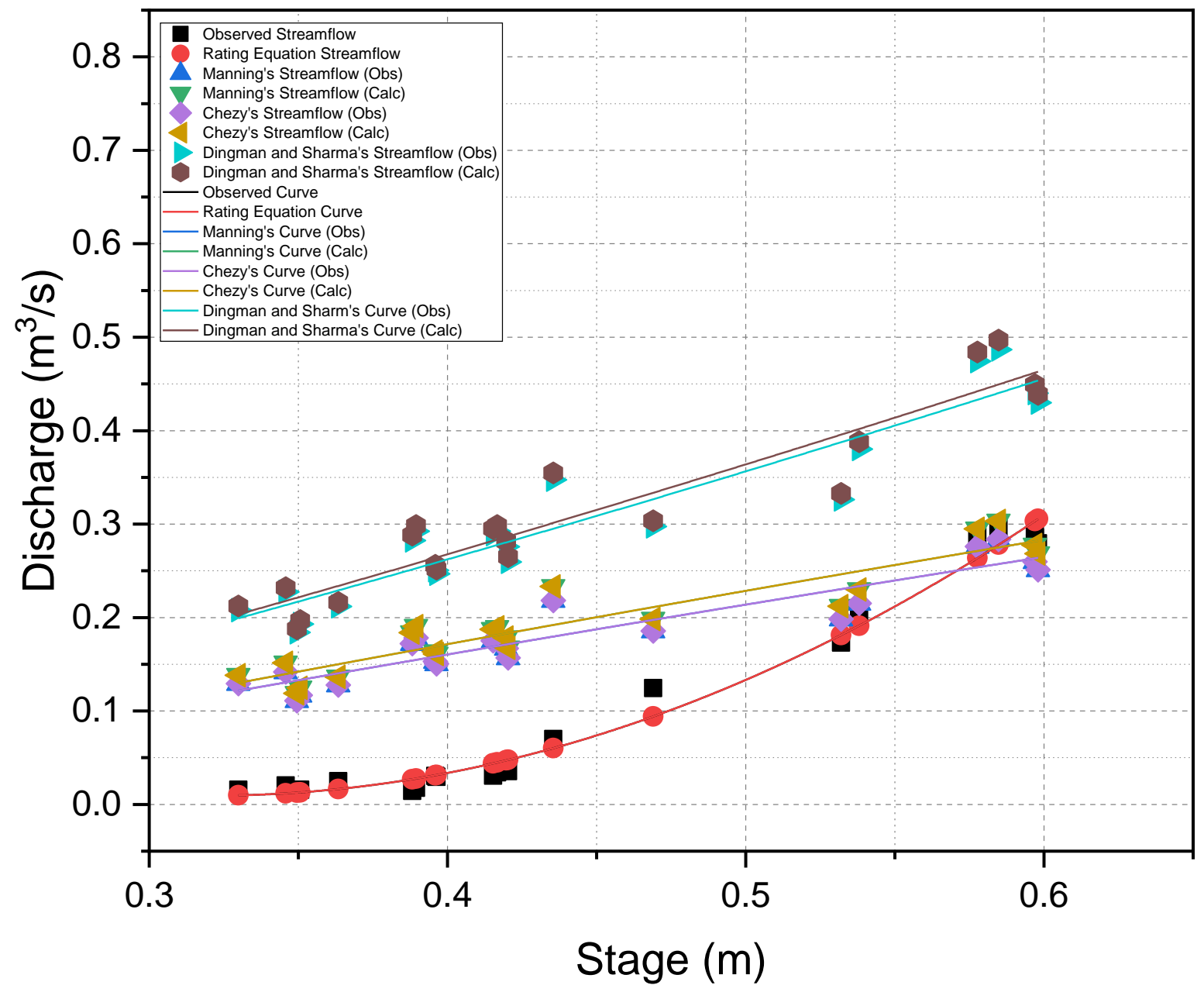

Figure A11-1. Observed and modeled rating curves and streamflow from Site 11, West Run Watershed, Morgantown, West Virginia, U.S.A. 
Table A11-3. Polynomial rating equations and $\mathrm{R}^{2}$ values for observed and modeled rating curves at Site 11, West Run Watershed, Morgantown, WV, U.S.A.

\begin{tabular}{ccc}
\hline & $\begin{array}{c}\mathbf{R}^{\mathbf{2}} \\
\text { Value }\end{array}$ & Polynomial Equation \\
\hline Observed Curve & 0.98 & $\mathrm{y}=3.8475 \mathrm{x}^{2}-2.4672 \mathrm{x}+0.405$ \\
Manning's Curve (Obs Slope) & 0.87 & $\mathrm{y}=-0.1135 \mathrm{x}^{2}+0.6359 \mathrm{x}-0.0757$ \\
Manning's Curve (Calc Slope) & 0.87 & $\mathrm{y}=-0.1213 \mathrm{x}^{2}+0.6798 \mathrm{x}-0.081$ \\
Chezy's Curve (Obs Slope) & 0.87 & $\mathrm{y}=-0.1135 \mathrm{x}^{2}+0.6359 \mathrm{x}-0.0757$ \\
Chezy's Curve (Calc Slope) & 0.87 & $\mathrm{y}=-0.1213 \mathrm{x}^{2}+0.6798 \mathrm{x}-0.081$ \\
$\begin{array}{c}\text { Dingman and Sharma's Curve } \\
\text { (Obs Slope) }\end{array}$ & 0.89 & $\mathrm{y}=0.253 \mathrm{x}^{2}+0.714 \mathrm{x}-0.0638$ \\
$\begin{array}{c}\text { Dingman and Sharma's Curve } \\
\text { (Calc Slope) }\end{array}$ & 0.89 & $\mathrm{y}=0.2583 \mathrm{x}^{2}+0.7289 \mathrm{x}-0.0651$ \\
\hline
\end{tabular}

Table A11-4. Descriptive statistics for observed and modeled streamflow used to generate the rating curves for Site 11, West Run Watershed, Morgantown, WV, U.S.A.

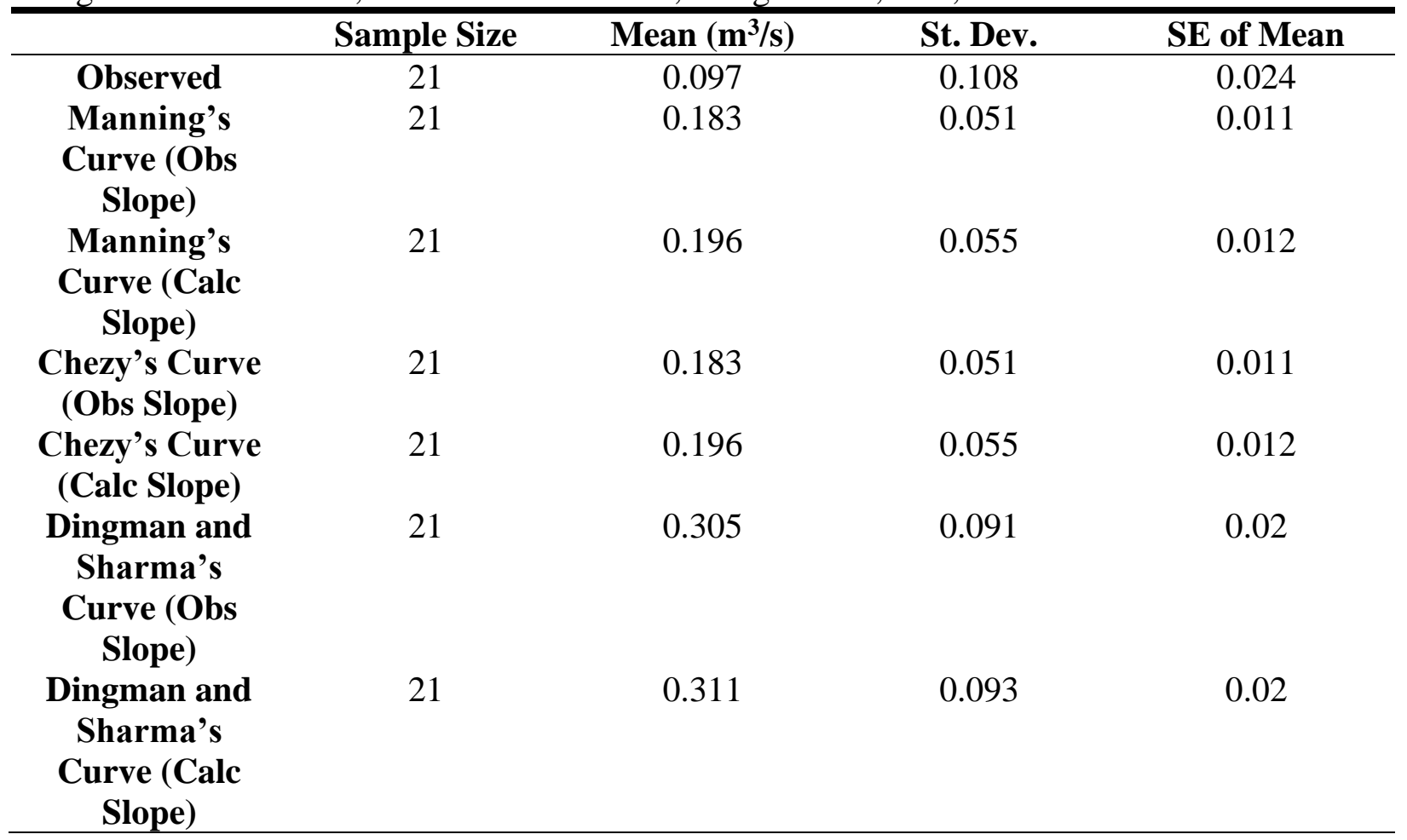


Table A11-5. P-values of the statistical analyses (post-hoc ANOVA) for observed and modeled rating curves at Site 11, West Run Watershed, Morgantown, WV, U.S.A.

\begin{tabular}{|c|c|c|c|c|c|c|c|c|}
\hline & $\begin{array}{l}\text { Observed } \\
\text { Curve }\end{array}$ & $\begin{array}{c}\text { Rating } \\
\text { Equation } \\
\text { Curve }\end{array}$ & $\begin{array}{c}\text { Manning's } \\
\text { Curve (Obs } \\
\text { Slope) }\end{array}$ & $\begin{array}{c}\text { Manning's } \\
\text { Curve (Calc } \\
\text { Slope) }\end{array}$ & $\begin{array}{c}\text { Chezy's } \\
\text { Curve } \\
\text { (Obs } \\
\text { Slope) } \\
\end{array}$ & $\begin{array}{c}\text { Chezy's } \\
\text { Curve } \\
\text { (Calc } \\
\text { Slope) } \\
\end{array}$ & $\begin{array}{c}\text { Dingman and } \\
\text { Sharma's } \\
\text { Curve (Obs } \\
\text { Slope) } \\
\end{array}$ & $\begin{array}{c}\text { Dingman and } \\
\text { Sharma's } \\
\text { Curve (Calc } \\
\text { Slope) } \\
\end{array}$ \\
\hline $\begin{array}{l}\text { Rating } \\
\text { Equation } \\
\text { Curve }\end{array}$ & - & - & $<0.05^{*}$ & $<0.05^{*}$ & $<0.05^{*}$ & $<0.05^{*}$ & $<0.05^{*}$ & $<0.05^{*}$ \\
\hline $\begin{array}{c}\text { Manning's } \\
\text { Curve (Obs } \\
\text { Slope) }\end{array}$ & - & - & - & 1 & 1 & 1 & $<0.05^{*}$ & $<0.05^{*}$ \\
\hline $\begin{array}{c}\text { Manning's } \\
\text { Curve (Calc } \\
\text { Slope) }\end{array}$ & - & - & - & - & 1 & 1 & $<0.05^{*}$ & $<0.05^{*}$ \\
\hline $\begin{array}{c}\text { Chezy's } \\
\text { Curve (Calc } \\
\text { Slope) }\end{array}$ & - & - & - & - & - & - & $<0.05^{*}$ & $<0.05^{*}$ \\
\hline $\begin{array}{l}\text { Dingman and } \\
\text { Sharma's } \\
\text { Curve (Obs } \\
\text { Slope) }\end{array}$ & - & - & - & - & - & - & - & 1 \\
\hline $\begin{array}{l}\text { Dingman and } \\
\text { Sharma's } \\
\text { Curve (Calc } \\
\text { Slope) } \\
\end{array}$ & - & - & - & - & - & - & - & - \\
\hline
\end{tabular}




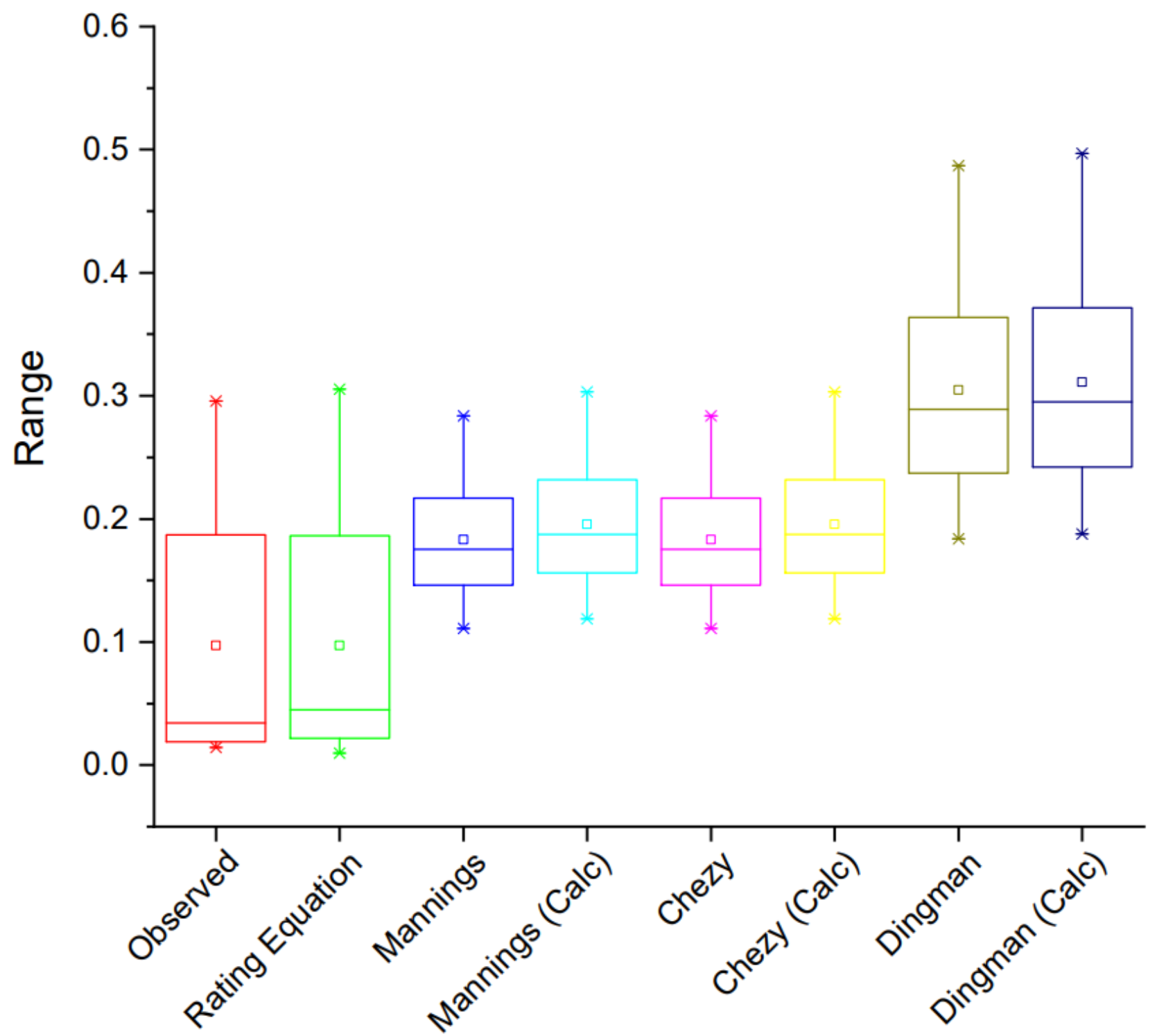

Figure A11-2. Box and whisker plots for the results of the statistical analyses (post-hoc ANOVA) of observed and modeled rating curves at Site 11, West Run Watershed, Morgantown, WV, U.S.A. 


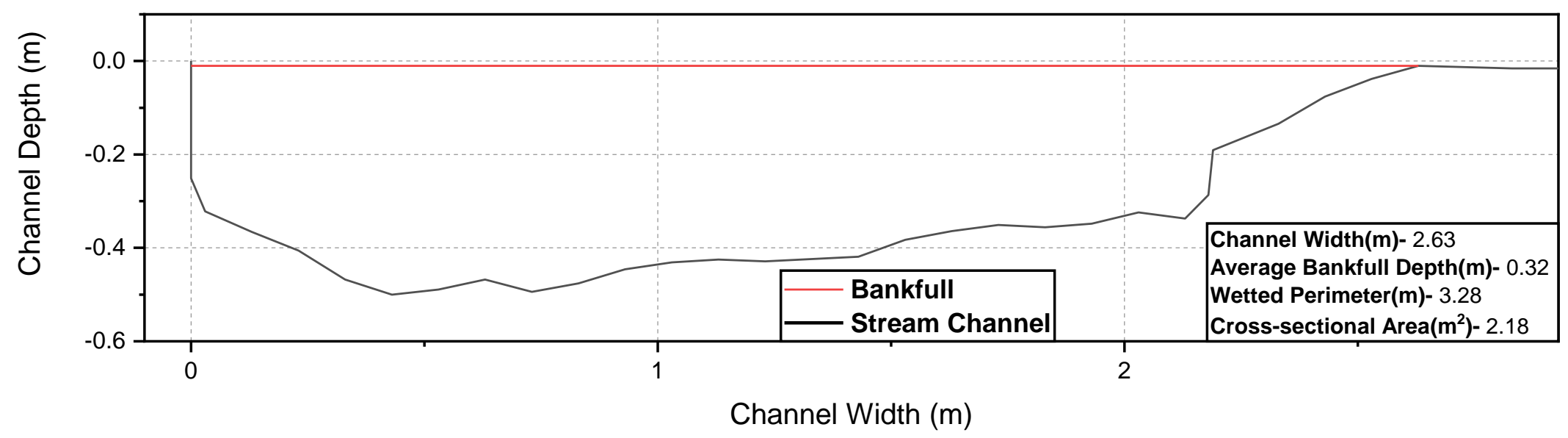

Figure A11-3. Cross-sectional profile of WRW Site 11, West Run Watershed, Morgantown, WV, USA (Figure 2). Channel Width of zero (0) represents the left bank facing downstream. 


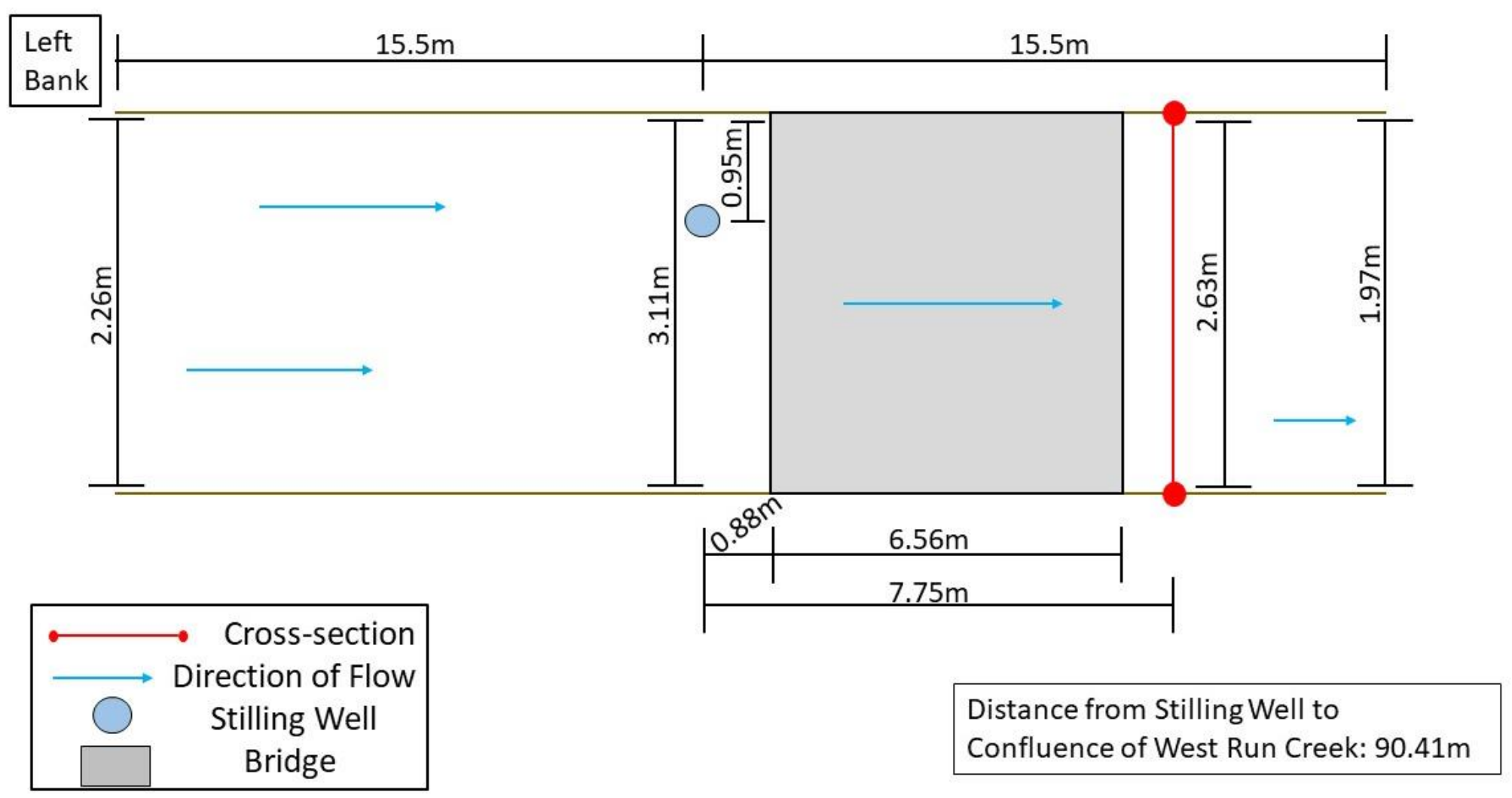

Figure A11-4. Plan view profile of WRW Site 11, West Run Watershed, Morgantown, WV, U.S.A. (Figure 2). Showing the positioning of stilling well in relation to where the streamflow was measured. Along with the channel width at the stilling well, point where cross-sections were performed, and $15.5 \mathrm{~m}$ upstream and downstream from the stilling well. 


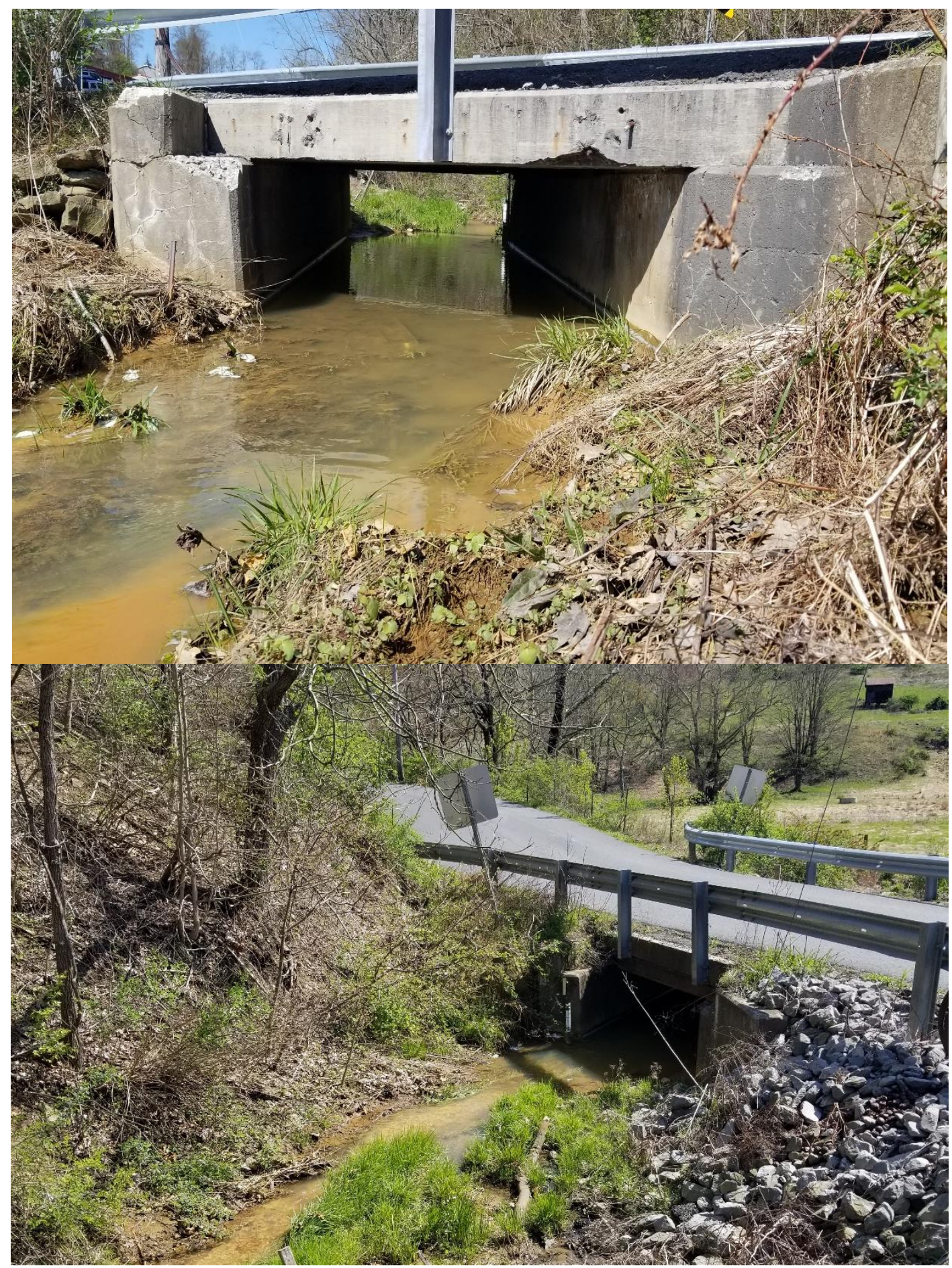

Figure A11-5. Photographs showing channel characteristics at Site \#11, West Run Watershed, Morgantown, WV, U.S.A. Photo 1 was taken looking upstream in the channel. Photo 2 was taken from the right bank looking downstream. 


\section{APPENDIX 12: Site 12}

Table A12-1. Streamflow measurements and stage collected at Site 12, West Run Watershed, Morgantown, WV, U.S.A. (Figure 2).

\begin{tabular}{|c|c|c|c|c|c|c|c|c|c|}
\hline Date & $\begin{array}{l}\text { Mean Depth of } \\
\text { Cross-Section } \\
\text { (m) }\end{array}$ & Stage(PT in cm) & $\begin{array}{c}\text { Barometric } \\
\text { Pressure (in } \mathrm{cm} \text { ) }\end{array}$ & $\begin{array}{c}\text { Pressure } \\
\text { Corrected Stage } \\
\text { (cm) }\end{array}$ & $\begin{array}{l}\text { Stilling Well } \\
\text { Offset }(\mathrm{cm})\end{array}$ & $\begin{array}{l}\text { P-Corrected } \\
\text { Stage + Offset } \\
\text { (cm) }\end{array}$ & $\begin{array}{l}\text { P-Corrected } \\
\text { Stage + Offset } \\
\text { (m) }\end{array}$ & $\begin{array}{c}\text { SonTec } \\
\text { Discharge }(\mathrm{m} 3 / \mathrm{s})\end{array}$ & $\begin{array}{l}\text { Rating Equation } \\
\text { Discharge }(\mathrm{m} 3 / \mathrm{s})\end{array}$ \\
\hline $1 / 21 / 2018$ & 0.0909 & 106.88 & 88.89 & 17.99 & 3.6 & 21.59 & 0.2159 & 0.0248 & 0.066268358 \\
\hline $3 / 23 / 2018$ & 0.0898 & 103.47 & 88.89 & 14.58 & 3.6 & 18.18 & 0.1818 & 0.0191 & 0.030487213 \\
\hline $3 / 29 / 2018$ & 0.1137 & 97.89 & 78.35 & 19.54 & 3.6 & 23.14 & 0.2314 & 0.0684 & 0.083160779 \\
\hline $3 / 30 / 2018$ & 0.1639 & 106.76 & 83.83 & 22.93 & 3.6 & 26.53 & 0.2653 & 0.1240 & 0.121474668 \\
\hline $4 / 5 / 2018$ & 0.1350 & 107.42 & 88.03 & 19.39 & 3.6 & 22.99 & 0.2299 & 0.0506 & 0.081508867 \\
\hline $6 / 14 / 2018$ & 0.1299 & 101.46 & 85.74 & 15.72 & 3.6 & 19.32 & 0.1932 & 0.0195 & 0.042237763 \\
\hline $6 / 14 / 2018$ & 0.1283 & 101.27 & 85.4 & 15.87 & 3.6 & 19.47 & 0.1947 & 0.0197 & 0.043799701 \\
\hline $6 / 14 / 2018$ & 0.1329 & 101.24 & 85.56 & 15.68 & 3.6 & 19.28 & 0.1928 & 0.0167 & 0.041821868 \\
\hline $7 / 23 / 2018$ & 0.0789 & 94.34 & 80.77 & 13.57 & 3.6 & 17.17 & 0.1717 & 0.0057 & 0.020254093 \\
\hline $7 / 23 / 2018$ & 0.0759 & 94.36 & 80.72 & 13.64 & 3.6 & 17.24 & 0.1724 & 0.0050 & 0.020957942 \\
\hline $7 / 26 / 2018$ & 0.0930 & 98.64 & 84.29 & 14.35 & 3.6 & 17.95 & 0.1795 & 0.0077 & 0.028142238 \\
\hline $9 / 11 / 2018$ & 0.2219 & 106.33 & 89.03 & 17.3 & 3.6 & 20.9 & 0.2090 & 0.0456 & 0.058874813 \\
\hline $9 / 20 / 2018$ & 0.1603 & 102.61 & 89.04 & 13.57 & 3.6 & 17.17 & 0.1717 & 0.0144 & 0.020254093 \\
\hline $9 / 20 / 2018$ & 0.1658 & 102.79 & 89.08 & 13.71 & 3.6 & 17.31 & 0.1731 & 0.0169 & 0.021662592 \\
\hline $10 / 2 / 2018$ & 0.1756 & 99.69 & 87.17 & 12.52 & 3.6 & 16.12 & 0.1612 & 0.0171 & 0.009792462 \\
\hline $10 / 2 / 2018$ & 0.1689 & 99.55 & 87.03 & 12.52 & 3.6 & 16.12 & 0.1612 & 0.0124 & 0.009792462 \\
\hline $10 / 16 / 2018$ & 0.1934 & 104.13 & 91.41 & 12.72 & 3.6 & 16.32 & 0.1632 & 0.0137 & 0.011771261 \\
\hline $10 / 16 / 2018$ & 0.1942 & 104.28 & 91.52 & 12.76 & 3.6 & 16.36 & 0.1636 & 0.0150 & 0.012167805 \\
\hline $10 / 18 / 2018$ & 0.1689 & 110.41 & 99.38 & 11.03 & 3.6 & 14.63 & 0.1463 & 0.0089 & 0.004743815 \\
\hline $10 / 18 / 2018$ & 0.1692 & 110.48 & 99.4 & 11.08 & 3.6 & 14.68 & 0.1468 & 0.0088 & 0.004261904 \\
\hline $10 / 25 / 2018$ & 0.1585 & 101.01 & 90.44 & 10.57 & 3.6 & 14.17 & 0.1417 & 0.0084 & 0.009158221 \\
\hline $10 / 25 / 2018$ & 0.1555 & 100.74 & 90.16 & 10.58 & 3.6 & 14.18 & 0.1418 & 0.0088 & 0.009062623 \\
\hline $10 / 30 / 2018$ & 0.2201 & 103.7 & 88.73 & 14.97 & 3.6 & 18.57 & 0.1857 & 0.0159 & 0.034483235 \\
\hline $11 / 1 / 2018$ & 0.2048 & 87.68 & 76.07 & 11.61 & 3.6 & 15.21 & 0.1521 & 0.0113 & 0.00087147 \\
\hline $11 / 13 / 2018$ & 0.2155 & 103.18 & 86.85 & 16.33 & 3.6 & 19.93 & 0.1993 & 0.0200 & 0.048612574 \\
\hline $2 / 26 / 2019$ & 0.24902 & 111.74 & 94.35 & 17.39 & 3.6 & 20.99 & 0.2099 & 0.0246 & 0.059834776 \\
\hline $10 / 31 / 2019$ & 0.1319 & 92.38 & 69.57 & 22.81 & 3.6 & 26.41 & 0.2641 & 0.0577 & 0.120086358 \\
\hline $10 / 31 / 2019$ & 0.1757 & 92.82 & 69.6 & 23.22 & 3.6 & 26.82 & 0.2682 & 0.0956 & 0.124839469 \\
\hline $8 / 28 / 2020$ & 0.127 & 1006.9 & 995.97 & 10.9 & 3.6 & 14.5 & 0.1450 & 0.0433 & 0.00599487 \\
\hline $8 / 28 / 2020$ & 0.13 & 1006.8 & 996.15 & 10.6 & 3.6 & 14.2 & 0.1420 & 0.0385 & 0.008871379 \\
\hline $2 / 24 / 2021$ & 0.168 & 1010.4 & 992.85 & 17.5 & 3.6 & 21.1 & 0.2110 & 0.0970 & 0.061009861 \\
\hline $2 / 24 / 2021$ & 0.164 & 1010.1 & 992.78 & 17.3 & 3.6 & 20.9 & 0.2090 & 0.0929 & 0.058874813 \\
\hline $2 / 24 / 2021$ & 0.17 & 1010.4 & 992.73 & 17.7 & 3.6 & 21.3 & 0.2130 & 0.0980 & 0.063151447 \\
\hline $2 / 24 / 2021$ & 0.178 & 1010.2 & 992.74 & 17.5 & 3.6 & 21.1 & 0.2110 & 0.0864 & 0.061009861 \\
\hline $6 / 14 / 2021$ & 0.237 & 1032 & 993.34 & 38.7 & 3.6 & 42.3 & 0.4230 & 0.3430 & 0.324399679 \\
\hline $6 / 14 / 2021$ & 0.218 & 1025.9 & 993.33 & 32.6 & 3.6 & 36.2 & 0.3620 & 0.2796 & 0.241085757 \\
\hline $6 / 14 / 2021$ & 0.382 & 1066.8 & 993.57 & 73.2 & 3.6 & 76.8 & 0.7680 & 0.9038 & 0.910066573 \\
\hline $6 / 14 / 2021$ & 0.37 & 1058.5 & 993.39 & 65.1 & 3.6 & 68.7 & 0.6870 & 0.7266 & 0.755087167 \\
\hline $6 / 14 / 2021$ & 0.369 & 1050.8 & 993.24 & 57.6 & 3.6 & 61.2 & 0.6120 & 0.5599 & 0.621148957 \\
\hline $6 / 14 / 2021$ & 0.356 & 1040.7 & 992.96 & 47.7 & 3.6 & 51.3 & 0.5130 & 0.5237 & 0.458427607 \\
\hline $6 / 14 / 2021$ & 0.309 & 1038.7 & 993.07 & 45.6 & 3.6 & 49.2 & 0.4920 & 0.4462 & 0.425970301 \\
\hline $6 / 14 / 2021$ & 0.321 & 1035.8 & 993.34 & 42.5 & 3.6 & 46.1 & 0.4610 & 0.4271 & 0.379374461 \\
\hline $9 / 1 / 2021$ & 0.524 & 1047.3 & 988.12 & 59.2 & 3.6 & 62.8 & 0.6280 & 0.6081 & 0.648951005 \\
\hline $9 / 1 / 2021$ & 0.546 & 1047.9 & 988.04 & 59.9 & 3.6 & 63.5 & 0.6350 & 0.6405 & 0.66124597 \\
\hline $9 / 1 / 2021$ & 0.547 & 1053.3 & 987.99 & 65.3 & 3.6 & 68.9 & 0.6890 & 0.7391 & 0.758784701 \\
\hline $9 / 1 / 2021$ & 0.554 & 1054.2 & 987.97 & 66.2 & 3.6 & 69.8 & 0.6980 & 0.8633 & 0.775504509 \\
\hline
\end{tabular}


Table A12-2. Modeled streamflow at Site 12, West Run Watershed, Morgantown, WV, U.S.A.

\begin{tabular}{|c|c|c|c|c|c|c|c|c|c|c|c|c|c|}
\hline $\begin{array}{l}\text { Cross- } \\
\text { Section } \\
\text { Area } \\
\left(\mathrm{m}^{2}\right)\end{array}$ & $\begin{array}{c}\text { A (Cross } \\
\text { Section } \\
\text { area of } \\
\text { flow) }\end{array}$ & $\begin{array}{c}\text { P } \\
\text { (Wetted } \\
\text { Perimete } \\
\text { r) }\end{array}$ & $\begin{array}{c}\mathrm{RH}=\mathrm{A} / \mathrm{P} \\
\text { Hydraulic } \\
\text { Radius } \\
\text { (m) }\end{array}$ & $\begin{array}{l}\text { Observed } \\
\text { Slope }(\mathrm{m})\end{array}$ & $\begin{array}{l}\text { Calculated } \\
\text { Slope using } \\
\text { ArcGIS (m) }\end{array}$ & $\begin{array}{l}\text { Roughness } \\
\text { Coefficient } \\
\text { (n) }\end{array}$ & $\begin{array}{c}\text { Manning } \\
\text { Discharge } \\
\left(\mathrm{m}^{3} / \mathrm{s}\right) \text { (Obs } \\
\text { Slope) }\end{array}$ & $\begin{array}{c}\text { Manning } \\
\text { Discharge } \\
\left(\mathrm{m}^{3} / \mathrm{s}\right)(\text { Calc } \\
\text { Slope) }\end{array}$ & $\begin{array}{c}\text { Chezy } \\
\text { Coefficient } \\
\text { (C) }\end{array}$ & $\begin{array}{c}\text { Chezy } \\
\text { Discharge } \\
\left(\mathrm{m}^{3} / \mathrm{s}\right)(\mathrm{Obs} \\
\text { Slope) }\end{array}$ & $\begin{array}{c}\text { Chezy } \\
\text { Discharge } \\
\left(\mathrm{m}^{3} / \mathrm{s}\right)(\text { Calc } \\
\text { Slope) }\end{array}$ & $\begin{array}{c}\text { Dingman \& } \\
\text { Sharma } \\
\text { Discharge } \\
\text { (m³ } / \mathrm{s} \text { ) (Obs. } \\
\text { Slope) }\end{array}$ & $\begin{array}{l}\text { Dingman \& } \\
\text { Sharma } \\
\text { Discharge } \\
\left(\mathrm{m}^{3} / \mathrm{s}\right) \text { (Calc } \\
\text { Slope) }\end{array}$ \\
\hline 0.88 & 0.222 & 1.9336 & 0.114829 & 0.02 & 0.059 & 0.095 & 0.078086597 & 0.134118134 & 7.338683886 & 0.078086597 & 0.134118134 & 0.078499773 & 0.093232773 \\
\hline 0.88 & 0.168 & 1.8128 & 0.092464 & 0.02 & 0.059 & 0.095 & 0.051021742 & 0.087632719 & 7.078450729 & 0.051021742 & 0.087632719 & 0.051762066 & 0.061476877 \\
\hline 0.88 & 0.247 & 1.9852 & 0.124303 & 0.02 & 0.059 & 0.095 & 0.091495898 & 0.157149365 & 7.436296353 & 0.091495898 & 0.157149365 & 0.09171653 & 0.108930078 \\
\hline 0.88 & 0.301 & 2.0909 & 0.143894 & 0.02 & 0.059 & 0.095 & 0.12298686 & 0.211236869 & 7.619913493 & 0.12298686 & 0.211236869 & 0.12270092 & 0.145729683 \\
\hline 0.88 & 0.244 & 1.9803 & 0.123402 & 0.02 & 0.059 & 0.095 & 0.090170037 & 0.154872125 & 7.427286437 & 0.090170037 & 0.154872125 & 0.090410382 & 0.10737879 \\
\hline 0.88 & 0.186 & 1.8543 & 0.100205 & 0.02 & 0.059 & 0.095 & 0.059673694 & 0.102492935 & 7.17394178 & 0.059673694 & 0.102492935 & 0.060321124 & 0.071642317 \\
\hline 0.88 & 0.188 & 1.8597 & 0.101202 & 0.02 & 0.059 & 0.095 & 0.06084286 & 0.104501044 & 7.185793683 & 0.06084286 & 0.104501044 & 0.061476738 & 0.07301482 \\
\hline 0.88 & 0.185 & 1.8528 & 0.099938 & 0.02 & 0.059 & 0.095 & 0.059363099 & 0.10195947 & 7.17075509 & 0.059363099 & 0.10195947 & 0.060014092 & 0.071277662 \\
\hline 0.88 & 0.096 & 1.3772 & 0.069707 & 0.02 & 0.059 & 0.095 & 0.024205391 & 0.041574125 & 6.752875837 & 0.024205391 & 0.041574125 & 0.024044386 & 0.028557086 \\
\hline 0.88 & 0.087 & 1.2948 & 0.067192 & 0.02 & 0.059 & 0.095 & 0.021405318 & 0.036764841 & 6.711647748 & 0.021405318 & 0.036764841 & 0.021109724 & 0.025071641 \\
\hline 0.88 & 0.113 & 1.4048 & 0.080438 & 0.02 & 0.059 & 0.095 & 0.031345784 & 0.053838152 & 6.915979844 & 0.031345784 & 0.053838152 & 0.030828077 & 0.036613955 \\
\hline 0.88 & 0.254 & 1.587 & 0.16005 & 0.02 & 0.059 & 0.095 & 0.11146272 & 0.191443508 & 7.756262993 & 0.11146272 & 0.191443508 & 0.104971769 & 0.124673088 \\
\hline 0.88 & 0.183 & 1.4636 & 0.125034 & 0.02 & 0.059 & 0.095 & 0.068117956 & 0.116996432 & 7.443568275 & 0.068117956 & 0.116996432 & 0.064739069 & 0.076889432 \\
\hline 0.88 & 0.19 & 1.4748 & 0.128831 & 0.02 & 0.059 & 0.095 & 0.072148168 & 0.123918548 & 7.480772946 & 0.072148168 & 0.123918548 & 0.068467743 & 0.081317911 \\
\hline 0.88 & 0.187 & 1.418 & 0.131876 & 0.02 & 0.059 & 0.095 & 0.072123465 & 0.123876119 & 7.509954238 & 0.072123465 & 0.123876119 & 0.067832247 & 0.080563144 \\
\hline 0.88 & 0.193 & 1.4804 & 0.13037 & 0.02 & 0.059 & 0.095 & 0.073869902 & 0.126875723 & 7.495594781 & 0.073869902 & 0.126875723 & 0.070069637 & 0.083220451 \\
\hline 0.88 & 0.206 & 1.454 & 0.141678 & 0.02 & 0.059 & 0.095 & 0.083341342 & 0.143143455 & 7.600232248 & 0.083341342 & 0.143143455 & 0.078196484 & 0.092872562 \\
\hline 0.88 & 0.207 & 1.455 & 0.142268 & 0.02 & 0.059 & 0.095 & 0.083978215 & 0.144237321 & 7.605497363 & 0.083978215 & 0.144237321 & 0.07877275 & 0.093556982 \\
\hline 0.88 & 0.18 & 1.405 & 0.128114 & 0.02 & 0.059 & 0.095 & 0.068097006 & 0.116960449 & 7.4738164 & 0.068097006 & 0.116960449 & 0.064116967 & 0.076150572 \\
\hline 0.88 & 0.193 & 1.4814 & 0.130282 & 0.02 & 0.059 & 0.095 & 0.073836655 & 0.12681862 & 7.494751243 & 0.073836655 & 0.12681862 & 0.070050713 & 0.083197976 \\
\hline 0.88 & 0.181 & 1.46 & 0.123973 & 0.02 & 0.059 & 0.095 & 0.066991615 & 0.115061877 & 7.432997976 & 0.066991615 & 0.115061877 & 0.063692325 & 0.075646233 \\
\hline 0.88 & 0.178 & 1.4538 & 0.122438 & 0.02 & 0.059 & 0.095 & 0.065336363 & 0.112218888 & 7.417580775 & 0.065336363 & 0.112218888 & 0.062145351 & 0.073808919 \\
\hline 0.88 & 0.251 & 1.583 & 0.15856 & 0.02 & 0.059 & 0.095 & 0.109461229 & 0.188005834 & 7.744175666 & 0.109461229 & 0.188005834 & 0.103132192 & 0.122488255 \\
\hline 0.88 & 0.219 & 1.4768 & 0.148294 & 0.02 & 0.059 & 0.095 & 0.091337782 & 0.156877792 & 7.658260468 & 0.091337782 & 0.156877792 & 0.085563742 & 0.101622522 \\
\hline 0.88 & 0.23 & 1.498 & 0.153538 & 0.02 & 0.059 & 0.095 & 0.098174021 & 0.168619418 & 7.702748744 & 0.098174021 & 0.168619418 & 0.091895239 & 0.109142327 \\
\hline 0.88 & 0.304 & 1.7172 & 0.177032 & 0.02 & 0.059 & 0.095 & 0.142681208 & 0.245063023 & 7.887726535 & 0.142681208 & 0.245063023 & 0.134937184 & 0.160262475 \\
\hline 0.88 & 0.161 & 1.4828 & 0.108578 & 0.02 & 0.059 & 0.095 & 0.05454808 & 0.093689404 & 7.270544627 & 0.05454808 & 0.093689404 & 0.052650672 & 0.062532259 \\
\hline 0.88 & 0.214 & 1.5704 & 0.136271 & 0.02 & 0.059 & 0.095 & 0.084360826 & 0.144894477 & 7.551101521 & 0.084360826 & 0.144894477 & 0.080507548 & 0.095617371 \\
\hline 0.88 & 0.135 & 0.13198 & 1.022882 & 0.02 & 0.059 & 0.095 & 0.204021338 & 0.350418155 & 10.56608262 & 0.204021338 & 0.350418155 & 0.105029577 & 0.124741746 \\
\hline 0.88 & 0.138 & 1.3264 & 0.104041 & 0.02 & 0.059 & 0.095 & 0.045443684 & 0.07805209 & 7.219001913 & 0.045443684 & 0.07805209 & 0.043197623 & 0.051305042 \\
\hline 0.88 & 0.179 & 1.4022 & 0.127657 & 0.02 & 0.059 & 0.095 & 0.067557432 & 0.116033701 & 7.469363116 & 0.067557432 & 0.116033701 & 0.063608284 & 0.075546419 \\
\hline 0.88 & 0.175 & 1.3946 & 0.125484 & 0.02 & 0.059 & 0.095 & 0.065296269 & 0.112150025 & 7.448025005 & 0.065296269 & 0.112150025 & 0.061520355 & 0.073066623 \\
\hline 0.88 & 0.181 & 1.4066 & 0.128679 & 0.02 & 0.059 & 0.095 & 0.068676572 & 0.117955886 & 7.479301749 & 0.068676572 & 0.117955886 & 0.064648731 & 0.076782138 \\
\hline 0.88 & 0.19 & 1.423 & 0.133521 & 0.02 & 0.059 & 0.095 & 0.073888604 & 0.126907845 & 7.525485296 & 0.073888604 & 0.126907845 & 0.069454006 & 0.082489278 \\
\hline 0.88 & 0.41458 & 2.227 & 0.186161 & 0.02 & 0.059 & 0.095 & 0.201214138 & 0.345596632 & 7.954100666 & 0.201214138 & 0.345596632 & 0.198111503 & 0.23529348 \\
\hline 0.88 & 0.36464 & 2.112 & 0.172652 & 0.02 & 0.059 & 0.095 & 0.168307175 & 0.289077066 & 7.854854179 & 0.168307175 & 0.289077066 & 0.165361666 & 0.196397086 \\
\hline 0.88 & 0.87329 & 3.05 & 0.286325 & 0.02 & 0.059 & 0.095 & 0.564749227 & 0.969988651 & 8.545802191 & 0.564749227 & 0.969988651 & 0.563926123 & 0.669764946 \\
\hline 0.88 & 0.81755 & 2.95 & 0.277136 & 0.02 & 0.059 & 0.095 & 0.517329511 & 0.888542614 & 8.499468706 & 0.517329511 & 0.888542614 & 0.515176533 & 0.611865932 \\
\hline 0.88 & 0.73045 & 2.719 & 0.268647 & 0.02 & 0.059 & 0.095 & 0.452726667 & 0.777583586 & 8.455512625 & 0.4527266667 & 0.777583586 & 0.445824583 & 0.529497864 \\
\hline 0.88 & 0.62361 & 2.465 & 0.252986 & 0.02 & 0.059 & 0.095 & 0.371337288 & 0.637792737 & 8.371290619 & 0.371337288 & 0.637792737 & 0.361552476 & 0.429409393 \\
\hline 0.88 & 0.63581 & 2.675 & 237686 & 0.02 & 0.059 & 0.095 & 0.363179332 & 0.623780987 & 8.284703867 & 0.363179332 & 0.623780987 & 0.360748275 & 0.428454258 \\
\hline 0.88 & 0.65961 & 2.699 & 244391 & 0.02 & 0.059 & 0.095 & 0.383826411 & 0.65924351 & 8.323202337 & 0.383826411 & 0.65924351 & 0.380853113 & 0.452332414 \\
\hline 0.88 & 1.67806 & 4.248 & 395024 & 0.02 & 0.059 & 0.095 & 1.344871724 & 2.309893041 & 9.016684858 & 1.344871724 & 2.309893041 & 1.379901923 & 1.638884774 \\
\hline 0.88 & 1.7489 & 4.292 & 407479 & 0.02 & 0.059 & 0.095 & 1.430956878 & 2.45774915 & 9.063458255 & 1.430956878 & 2.45774915 & 1.466578364 & 1.741828828 \\
\hline 0.88 & 1.95909 & 4.675 & 0.419057 & 0.02 & 0.059 & 0.095 & 1.633155842 & 2.805037275 & 9.105878618 & 1.633155842 & 2.805037275 & 1.69429393 & 2.012282523 \\
\hline 0.88 & 2.06942 & 4.842 & 0.42739 & 0.02 & 0.059 & 0.095 & 1.747924243 & 3.002158477 & 9.135809552 & 1.747924243 & 3.002158477 & 1.821041524 & 2.162818368 \\
\hline
\end{tabular}




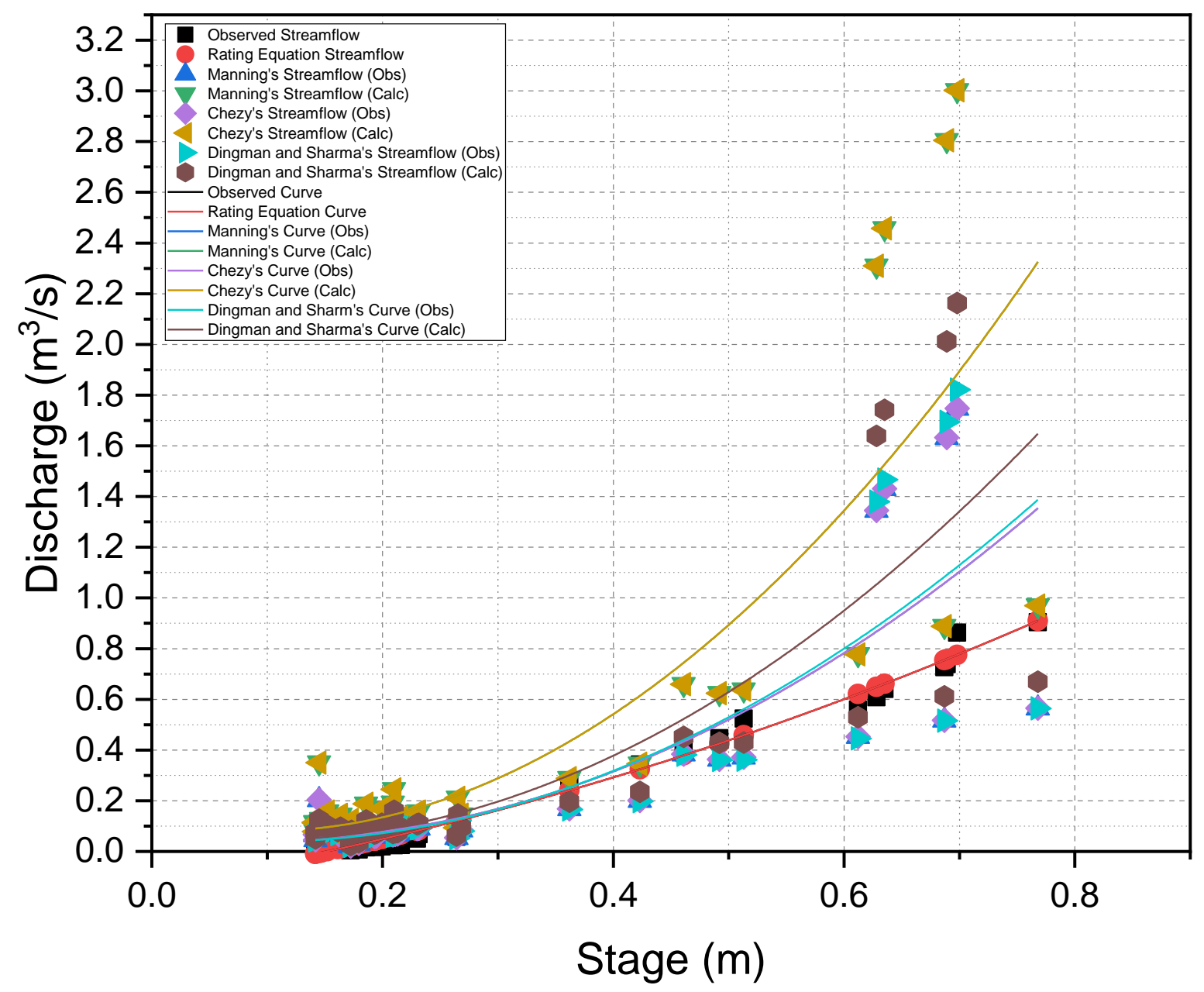

Figure A12-1. Observed and modeled rating curves and streamflow from Site 12, West Run Watershed, Morgantown, West Virginia, U.S.A. 
Table A12-3. Polynomial rating equations and $\mathrm{R}^{2}$ values for observed and modeled rating curves at Site 12, West Run Watershed, Morgantown, WV, U.S.A.

\begin{tabular}{ccc}
\hline & $\mathbf{R}^{\mathbf{2}}$ & Polynomial Equation \\
Value & \\
\hline $\begin{array}{c}\text { Observed Curve } \\
\text { Manning's Curve (Obs Slope) }\end{array}$ & 0.99 & $\mathrm{y}=0.8172 \mathrm{x}^{2}+0.7243 \mathrm{x}-0.1282$ \\
Manning's Curve (Calc Slope) & 0.70 & $\mathrm{y}=2.8829 \mathrm{x}^{2}-0.5451 \mathrm{x}+0.0722$ \\
$\begin{array}{c}\text { Chezy's Curve (Obs Slope) } \\
\text { Chezy's Curve (Calc Slope) }\end{array}$ & 0.70 & $\mathrm{y}=4.9515 \mathrm{x}^{2}-0.9362 \mathrm{x}+0.1239$ \\
$\begin{array}{c}\text { Dingman and Sharma's Curve } \\
\text { (Obs Slope) }\end{array}$ & 0.69 & $\mathrm{y}=2.8829 \mathrm{x}^{2}-0.5451 \mathrm{x}+0.0722$ \\
$\begin{array}{c}\text { Dingman and Sharma's Curve } \\
\text { (Calc Slope) }\end{array}$ & 0.69 & $\mathrm{y}=2.9515 \mathrm{x}^{2}-0.9362 \mathrm{x}+0.1239$ \\
& & $\mathrm{y}=3.5044 \mathrm{x}^{2}-0.6425 \mathrm{x}+0.0742$ \\
\hline
\end{tabular}

Table A12-4. Descriptive statistics for observed and modeled streamflow used to generate the rating curves for Site 12, West Run Watershed, Morgantown, WV, U.S.A.

\begin{tabular}{|c|c|c|c|c|}
\hline & Sample Size & Mean $\left(m^{3} / \mathbf{s}\right)$ & St. Dev. & SE of Mean \\
\hline Observed & 46 & 0.18 & 0.266 & 0.039 \\
\hline Manning's & 46 & 0.257 & 0.423 & 0.062 \\
\hline \multicolumn{5}{|l|}{$\begin{array}{l}\text { Curve (Obs } \\
\text { Slope) }\end{array}$} \\
\hline Manning's & 46 & 0.441 & 0.727 & 0.107 \\
\hline \multicolumn{5}{|l|}{$\begin{array}{l}\text { Curve (Calc } \\
\text { Slope) }\end{array}$} \\
\hline $\begin{array}{c}\text { Chezy's Curve } \\
\text { (Obs Slope) }\end{array}$ & 46 & 0.257 & 0.423 & 0.062 \\
\hline $\begin{array}{l}\text { Chezy's Curve } \\
\text { (Calc Slope) }\end{array}$ & 46 & 0.441 & 0.727 & 0.107 \\
\hline $\begin{array}{l}\text { Dingman and } \\
\text { Sharma's }\end{array}$ & 46 & 0.256 & 0.439 & 0.065 \\
\hline $\begin{array}{l}\text { Curve (Obs } \\
\text { Slope) }\end{array}$ & & & & \\
\hline $\begin{array}{l}\text { Dingman and } \\
\text { Sharma's }\end{array}$ & 46 & 0.305 & 0.521 & 0.077 \\
\hline $\begin{array}{l}\text { Curve (Calc } \\
\text { Slope) }\end{array}$ & & & & \\
\hline
\end{tabular}


Table A12-5. P-values of the statistical analyses (post-hoc ANOVA) for observed and modeled rating curves at Site 12, West Run Watershed, Morgantown, WV, U.S.A.

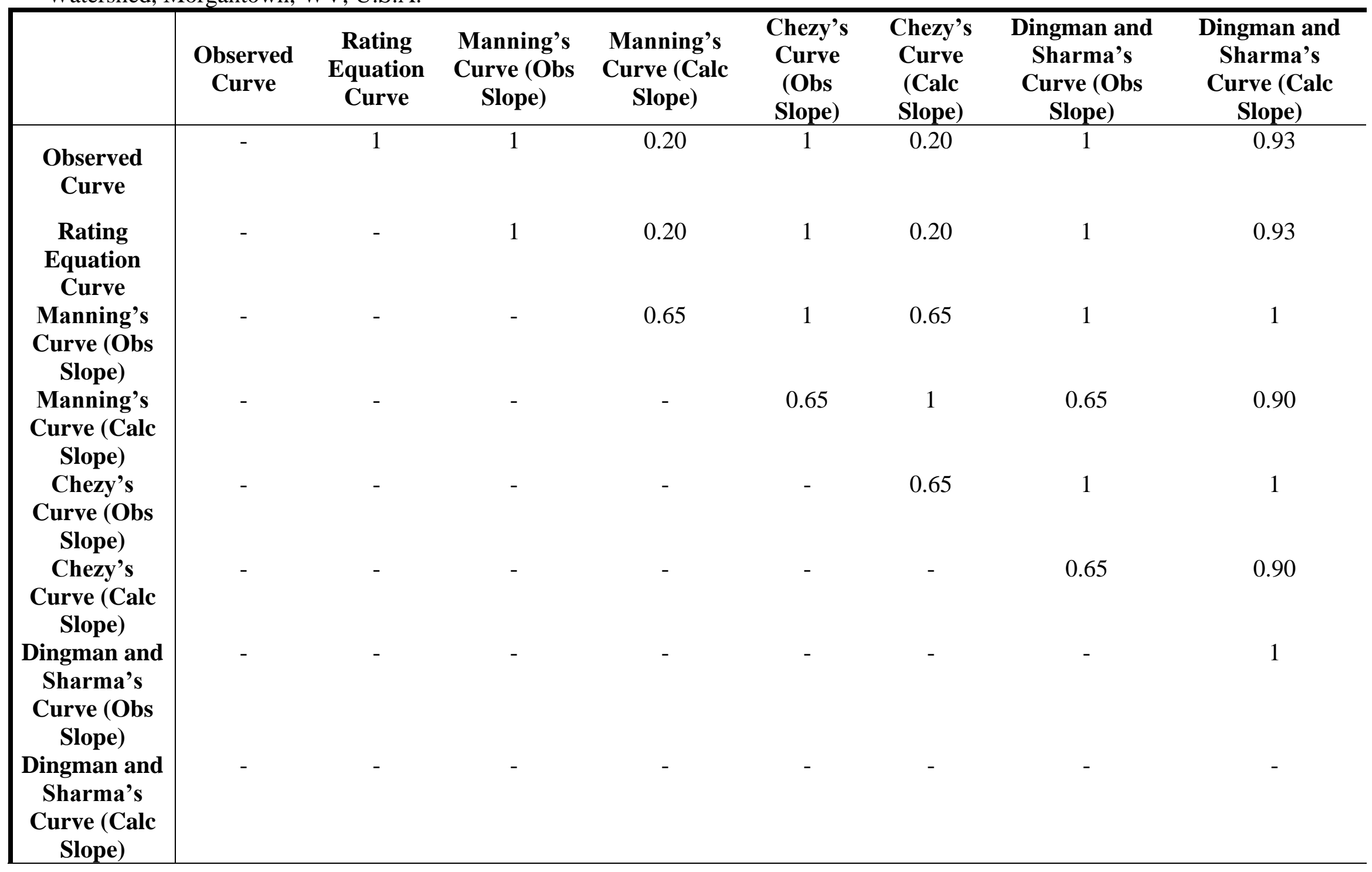




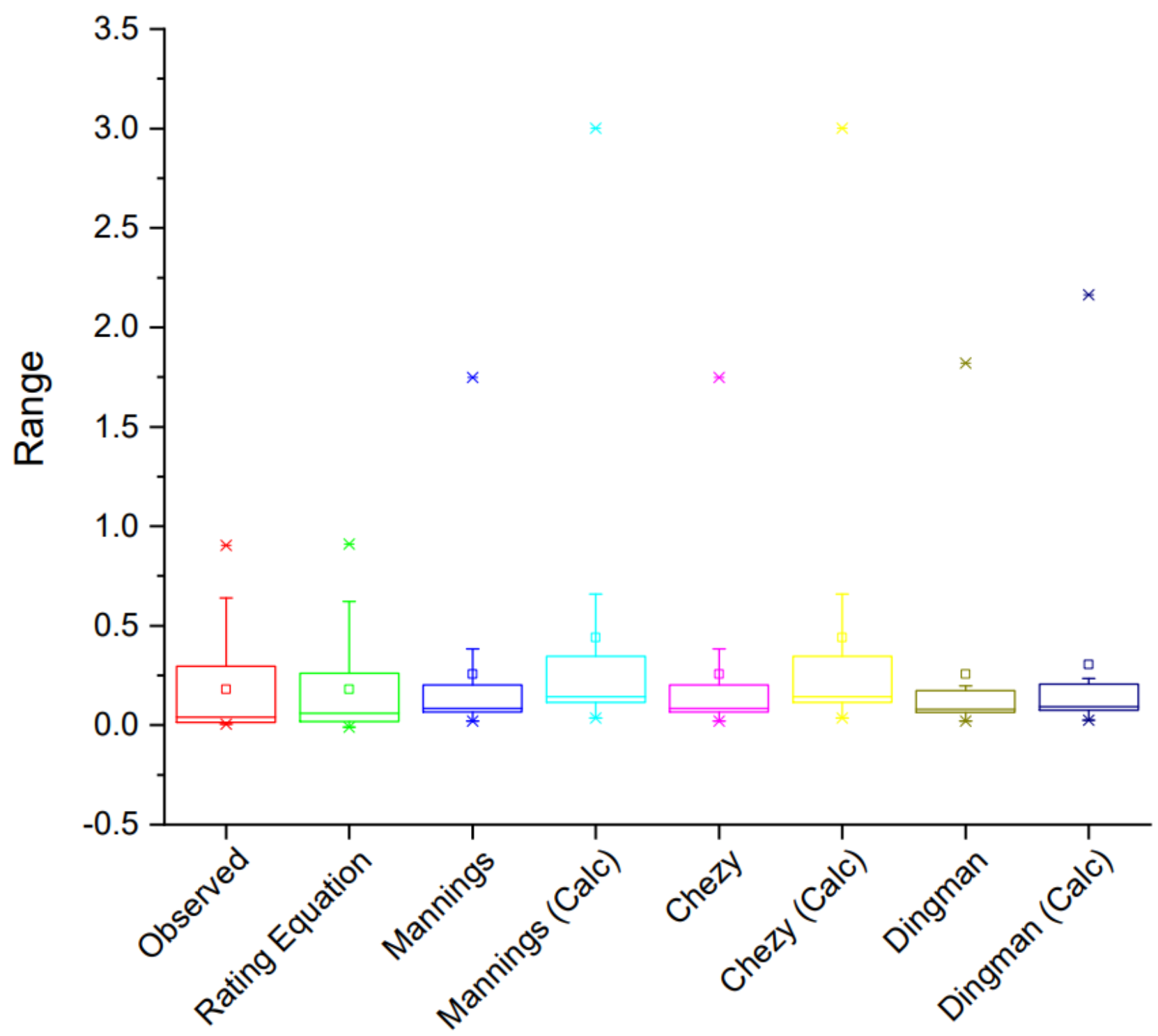

Figure A12-2. Box and whisker plots for the results of the statistical analyses (post-hoc ANOVA) of observed and modeled rating curves at Site 12, West Run Watershed, Morgantown, WV, U.S.A. 


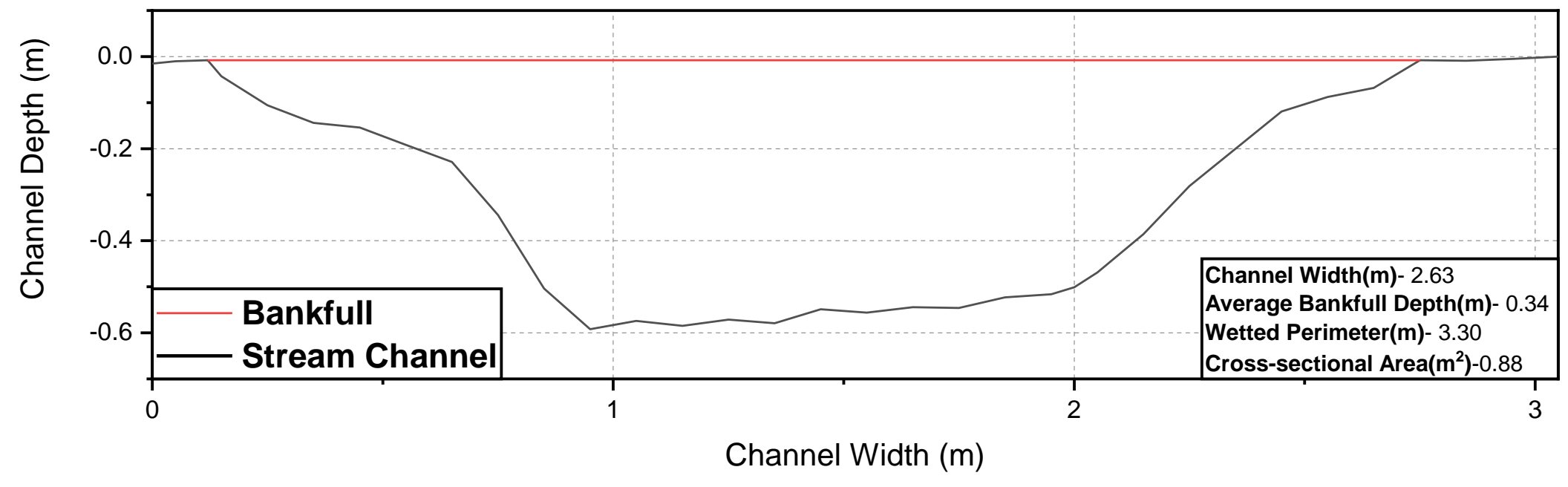

Figure A12-3. Cross-sectional profile of WRW Site 12, West Run Watershed, Morgantown, WV, USA (Figure 2). Channel Width of zero (0) represents the left bank facing downstream. 


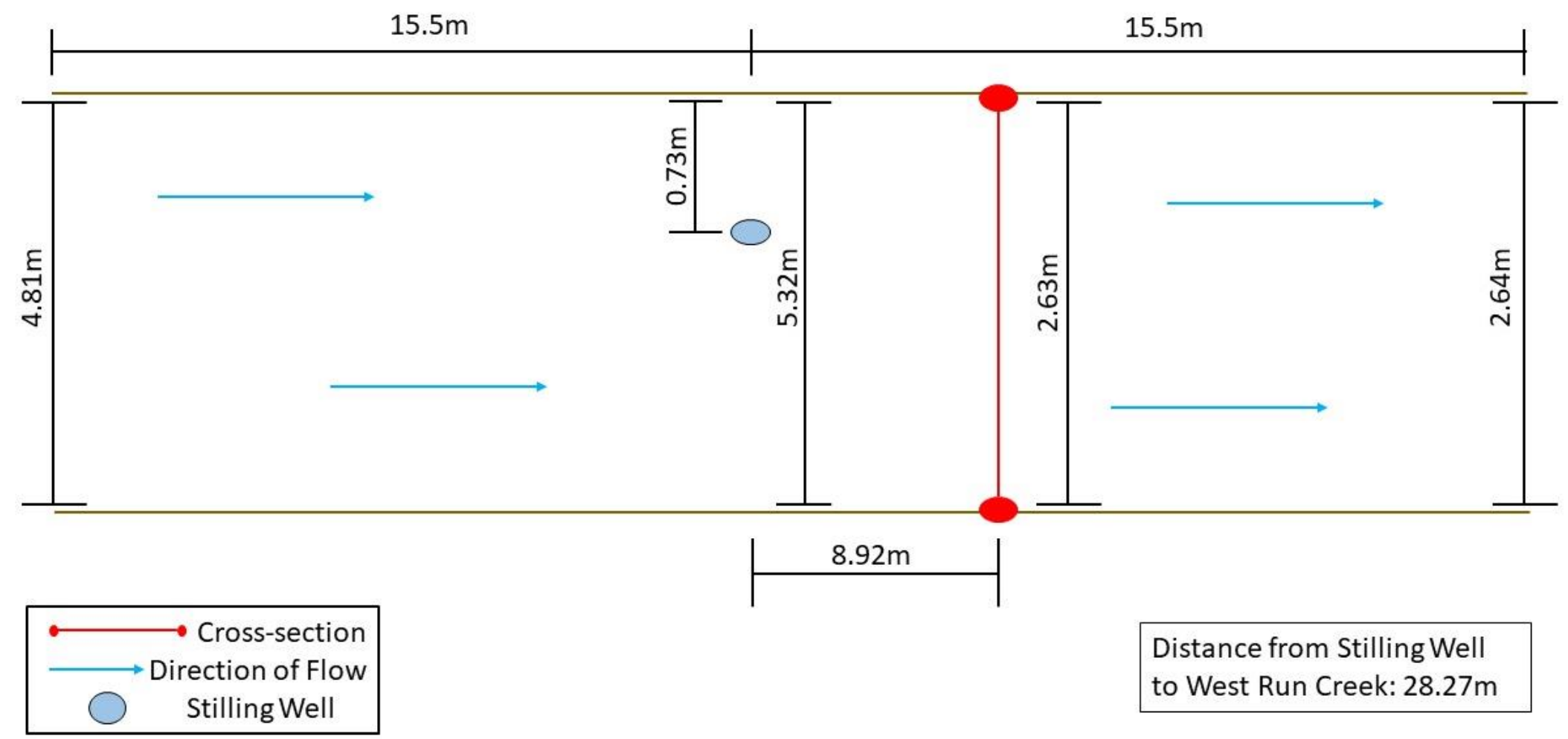

Figure A12-4. Plan view profile of WRW Site 12, West Run Watershed, Morgantown, WV, U.S.A. (Figure 2). Showing the positioning of stilling well in relation to where the streamflow was measured. Along with the channel width at the stilling well, point where cross-sections were performed, and $15.5 \mathrm{~m}$ upstream and downstream from the stilling well. 


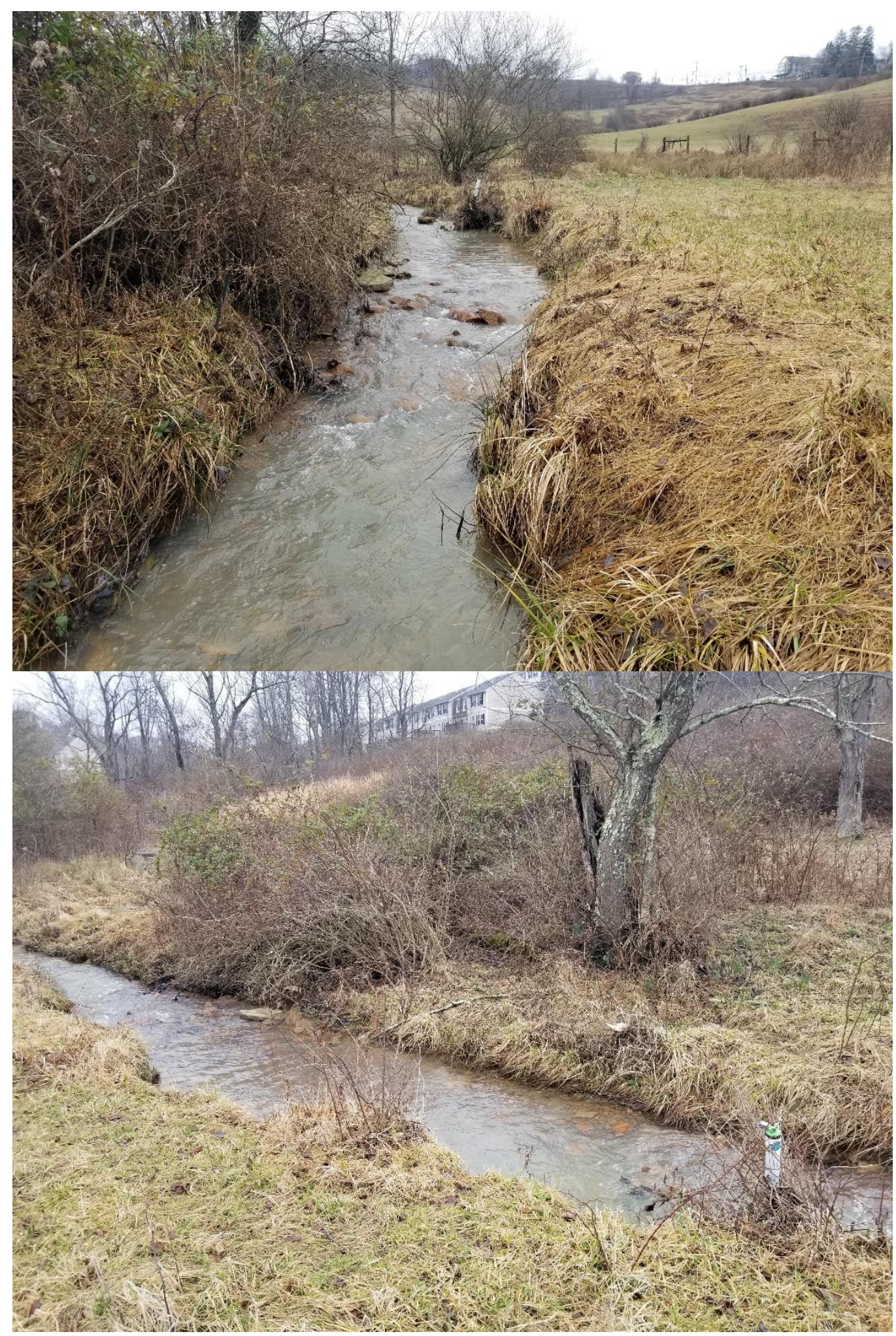

Figure A12-5. Photographs showing channel characteristics at Site \#12, West Run Watershed, Morgantown, WV, U.S.A. Photo 1 was taken looking upstream in the channel. Photo 2 was taken from the left bank looking downstream. 


\section{APPENDIX 13: Site 13}

Table A13-1. Streamflow measurements and stage collected at Site 13, West Run Watershed, Morgantown, WV, U.S.A. (Figure 2).

\begin{tabular}{|c|c|c|c|c|c|c|c|c|c|}
\hline Date & $\begin{array}{l}\text { Mean Depth of } \\
\text { Cross-Section }(\mathrm{m})\end{array}$ & Stage(PT in cm) & $\begin{array}{c}\text { Barometric } \\
\text { Pressure (in } \mathrm{cm} \text { ) }\end{array}$ & $\begin{array}{c}\text { Pressure } \\
\text { Corrected Stage } \\
\text { (cm) }\end{array}$ & $\begin{array}{l}\text { Stilling Well } \\
\text { Offset }(\mathrm{cm})\end{array}$ & $\begin{array}{l}\text { P-Corrected } \\
\text { Stage + Offset } \\
\text { (cm) }\end{array}$ & $\begin{array}{c}\text { P-Corrected } \\
\text { Stage + Offset } \\
\text { (m) }\end{array}$ & $\begin{array}{c}\text { SonTec } \\
\text { Discharge } \\
\text { (m3/s) }\end{array}$ & $\begin{array}{l}\text { Rating Equation } \\
\text { Discharge }(\mathrm{m} 3 / \mathrm{s})\end{array}$ \\
\hline $9 / 21 / 2017$ & 0.1826 & 103.67 & 88.10 & 15.57 & 7 & 22.57 & 0.2257 & 0.0331 & 0.0273 \\
\hline 9/28/2017 & 0.1612 & 102.26 & 85.56 & 16.70 & 7 & 23.7 & 0.237 & 0.0250 & 0.0369 \\
\hline 10/5/2017 & 0.1403 & 108.20 & 92.08 & 16.12 & 7 & 23.12 & 0.2312 & 0.0207 & 0.0318 \\
\hline 10/5/2017 & 0.1605 & 108.30 & 92.22 & 16.08 & 7 & 23.08 & 0.2308 & 0.0208 & 0.0315 \\
\hline $10 / 8 / 2017$ & 0.1940 & 103.19 & 82.86 & 20.33 & 7 & 27.33 & 0.2733 & 0.0461 & 0.0756 \\
\hline 10/9/2017 & 0.2345 & 104.54 & 78.43 & 26.11 & 7 & 33.11 & 0.3311 & 0.1227 & 0.1615 \\
\hline $10 / 9 / 2017$ & 0.2232 & 103.55 & 80.12 & 23.43 & 7 & 30.43 & 0.3043 & 0.0887 & 0.1180 \\
\hline 10/9/2017 & 0.2010 & 103.38 & 81.00 & 22.38 & 7 & 29.38 & 0.2938 & 0.0748 & 0.1027 \\
\hline $10 / 10 / 2017$ & 0.1918 & 106.66 & 88.87 & 17.79 & 7 & 24.79 & 0.2479 & 0.0379 & 0.0473 \\
\hline $10 / 11 / 2017$ & 0.1824 & 102.56 & 83.11 & 19.45 & 7 & 26.45 & 0.2645 & 0.0526 & 0.0651 \\
\hline $10 / 23 / 2017$ & 0.1540 & 97.92 & 82.79 & 15.13 & 7 & 22.13 & 0.2213 & 0.0247 & 0.0238 \\
\hline $10 / 23 / 2017$ & 0.1845 & 94.47 & 76.28 & 18.19 & 7 & 25.19 & 0.2519 & 0.0458 & 0.0514 \\
\hline $10 / 24 / 2017$ & 0.2276 & 101.74 & 75.83 & 25.91 & 7 & 32.91 & 0.3291 & 0.1761 & 0.1581 \\
\hline $10 / 24 / 2017$ & 0.2108 & 99.82 & 75.94 & 23.88 & 7 & 30.88 & 0.3088 & 0.1475 & 0.1248 \\
\hline $10 / 29 / 2017$ & 0.3348 & 111.70 & 72.76 & 38.94 & 7 & 45.94 & 0.4594 & 0.3930 & 0.4591 \\
\hline $10 / 29 / 2017$ & 0.2995 & 111.19 & 72.47 & 38.72 & 7 & 45.72 & 0.4572 & 0.4266 & 0.4528 \\
\hline $10 / 30 / 2017$ & 0.2423 & 109.11 & 76.49 & 32.62 & 7 & 39.62 & 0.3962 & 0.2470 & 0.2941 \\
\hline $11 / 3 / 2017$ & 0.1484 & 105.96 & 88.07 & 17.89 & 7 & 24.89 & 0.2489 & 0.0670 & 0.0483 \\
\hline $11 / 6 / 2017$ & 0.3548 & 137.46 & 85.87 & 51.59 & 7 & 58.59 & 0.5859 & 0.8132 & 0.8967 \\
\hline $11 / 7 / 2017$ & 0.3278 & 120.14 & 87.83 & 32.31 & 7 & 39.31 & 0.3931 & 0.2888 & 0.2870 \\
\hline $1 / 21 / 2018$ & 0.1836 & 111.94 & 88.54 & 23.40 & 7.9 & 31.3375 & 0.313375 & 0.1671 & 0.1320 \\
\hline $3 / 16 / 2018$ & 0.1567 & 105.31 & 86.48 & 18.83 & 7.9 & 26.7675 & 0.267675 & 0.1000 & 0.0688 \\
\hline $3 / 23 / 2018$ & 0.1648 & 110.56 & 88.98 & 21.58 & 7.9 & 29.5175 & 0.295175 & 0.1442 & 0.1046 \\
\hline $3 / 30 / 2018$ & 0.4115 & 135.92 & 83.96 & 51.96 & 7.9 & 59.8975 & 0.598975 & 0.8180 & 0.9501 \\
\hline $4 / 5 / 2018$ & 0.2848 & 125.91 & 87.48 & 38.43 & 7.9 & 46.3675 & 0.463675 & 0.4426 & 0.4716 \\
\hline $7 / 6 / 2018$ & 0.2600 & 116.84 & 91.22 & 25.62 & 7.9 & 33.5575 & 0.335575 & 0.1452 & 0.1694 \\
\hline $7 / 18 / 2018$ & 0.1448 & 98.76 & 86.61 & 12.15 & 7.9 & 20.0875 & 0.200875 & 0.0212 & 0.0101 \\
\hline $7 / 23 / 2018$ & 0.1911 & 94.15 & 80.74 & 13.41 & 7.9 & 21.3475 & 0.213475 & 0.0480 & 0.0181 \\
\hline $7 / 26 / 2018$ & 0.2271 & 102.13 & 84.16 & 17.97 & 7.9 & 25.9075 & 0.259075 & 0.0621 & 0.0590 \\
\hline $9 / 18 / 2018$ & 0.3389 & 122.10 & 81.06 & 41.04 & 7.9 & 48.9775 & 0.489775 & 0.5045 & 0.5511 \\
\hline 9/20/2018 & 0.2719 & 112.99 & 89.17 & 23.82 & 7.9 & 31.7575 & 0.317575 & 0.1599 & 0.1387 \\
\hline $10 / 2 / 2018$ & 0.3130 & 110.65 & 87.69 & 22.96 & 7.9 & 30.8975 & 0.308975 & 0.1346 & 0.1251 \\
\hline $10 / 2 / 2018$ & 0.3048 & 110.53 & 87.55 & 22.98 & 7.9 & 30.9175 & 0.309175 & 0.1252 & 0.1254 \\
\hline $11 / 1 / 2018$ & 0.2829 & 95.70 & 75.67 & 20.03 & 7.9 & 27.9675 & 0.279675 & 0.1005 & 0.0836 \\
\hline $1 / 15 / 2019$ & 0.2533 & 110.32 & 87.74 & 22.58 & 7.9 & 30.5175 & 0.305175 & 0.1089 & 0.1193 \\
\hline $1 / 15 / 2019$ & 0.2698 & 110.43 & 87.64 & 22.79 & 7.9 & 30.7275 & 0.307275 & 0.1005 & 0.1225 \\
\hline $2 / 26 / 2019$ & 0.3261 & 126.28 & 94.10 & 32.18 & 7.9 & 40.1175 & 0.401175 & 0.2875 & 0.3058 \\
\hline $10 / 31 / 2019$ & 0.3436 & 107.31 & 68.48 & 38.83 & 7.9 & 46.73 & 0.4673 & 0.4770 & 0.4823 \\
\hline $1 / 4 / 2020$ & 0.3753 & 120.86 & 73.76 & 47.10 & 7.9 & 55 & 0.55 & 0.7432 & 0.7580 \\
\hline $1 / 4 / 2020$ & 0.3676 & 120.37 & 73.47 & 46.90 & 7.9 & 54.8 & 0.548 & 0.6746 & 0.7506 \\
\hline $1 / 4 / 2020$ & 0.4338 & 116.98 & 71.88 & 45.10 & 7.9 & 53 & 0.53 & 0.7071 & 0.6857 \\
\hline $4 / 9 / 2020$ & 0.4170 & 1032.70 & 980.95 & 51.80 & 7.9 & 59.7 & 0.597 & 0.8740 & 0.9420 \\
\hline $4 / 9 / 2020$ & 0.4140 & 1032.30 & 980.70 & 51.60 & 7.9 & 59.5 & 0.595 & 0.9384 & 0.9337 \\
\hline $4 / 9 / 2020$ & 0.4180 & 1031.70 & 980.76 & 50.90 & 7.9 & 58.8 & 0.588 & 0.9231 & 0.9052 \\
\hline $4 / 9 / 2020$ & 0.4100 & 1030.90 & 980.95 & 49.90 & 7.9 & 57.8 & 0.578 & 0.9098 & 0.8652 \\
\hline $4 / 9 / 2020$ & 0.4040 & 1029.90 & 980.85 & 49.00 & 7.9 & 56.9 & 0.569 & 0.8939 & 0.8300 \\
\hline $4 / 9 / 2020$ & 0.3850 & 1029.50 & 980.83 & 48.70 & 7.9 & 56.6 & 0.566 & 0.8515 & 0.8184 \\
\hline $4 / 9 / 2020$ & 0.3950 & 1029.70 & 981.55 & 48.10 & 7.9 & 56 & 0.56 & 0.7990 & 0.7955 \\
\hline $4 / 9 / 2020$ & 0.3820 & 1029.20 & 981.87 & 47.30 & 7.9 & 55.2 & 0.552 & 0.8007 & 0.7654 \\
\hline $4 / 9 / 2020$ & 0.3920 & 1029.40 & 983.23 & 46.20 & 7.9 & 54.1 & 0.541 & 0.8113 & 0.7250 \\
\hline $4 / 9 / 2020$ & 0.3920 & 1028.10 & 983.18 & 44.90 & 7.9 & 52.8 & 0.528 & 0.7707 & 0.6787 \\
\hline 4/9/2020 & 0.3770 & 1028.40 & 983.52 & 44.90 & 7.9 & 52.8 & 0.528 & 0.7634 & 0.6787 \\
\hline $4 / 9 / 2020$ & 0.4020 & 1029.10 & 984.10 & 45.00 & 7.9 & 52.9 & 0.529 & 0.7868 & 0.6822 \\
\hline
\end{tabular}


Table A13-2. Modeled streamflow at Site 13, West Run Watershed, Morgantown, WV, U.S.A.

\begin{tabular}{|c|c|c|c|c|c|c|c|c|c|c|c|c|c|}
\hline $\begin{array}{c}\text { Cross- } \\
\text { Section } \\
\text { Area }\left(\mathrm{m}^{2}\right)\end{array}$ & $\begin{array}{c}\text { A (Cross } \\
\text { Section } \\
\text { area of } \\
\text { flow) }\end{array}$ & $\begin{array}{c}\text { P } \\
\text { (Wetted } \\
\text { Perimete } \\
\text { r) }\end{array}$ & $\begin{array}{c}\text { RH=A/P } \\
\text { Hydraulic } \\
\text { Radius } \\
\text { (m) }\end{array}$ & $\begin{array}{l}\text { Observed } \\
\text { Slope (m) }\end{array}$ & $\begin{array}{l}\text { Calculated } \\
\text { Slope using } \\
\text { ArcGIS (m) }\end{array}$ & $\begin{array}{l}\text { Roughness } \\
\text { Coefficient } \\
\text { (n) }\end{array}$ & $\begin{array}{c}\text { Manning } \\
\text { Discharge } \\
\left(\mathrm{m}^{3} / \mathrm{s}\right)(\mathrm{Obs} \\
\text { Slope) }\end{array}$ & $\begin{array}{c}\text { Manning } \\
\text { Discharge } \\
\left(\mathrm{m}^{3} / \mathrm{s}\right) \text { (Calc } \\
\text { Slope) }\end{array}$ & $\begin{array}{c}\text { Chezy } \\
\text { Coefficient } \\
\text { (C) }\end{array}$ & $\begin{array}{c}\text { Chezy } \\
\text { Discharge } \\
\left(\mathrm{m}^{3} / \mathrm{s}\right)(\text { Obs } \\
\text { Slope) }\end{array}$ & $\begin{array}{c}\text { Chezy } \\
\text { Discharge } \\
\left(\mathrm{m}^{3} / \mathrm{s}\right) \text { (Calc } \\
\text { Slope) }\end{array}$ & $\begin{array}{c}\text { Dingman \& } \\
\text { Sharma } \\
\text { Discharge } \\
\left(\mathrm{m}^{3} / \mathrm{s}\right)(\text { Obs. } \\
\text { Slope) }\end{array}$ & $\begin{array}{c}\text { Dingman \& } \\
\text { Sharma } \\
\text { Discharge } \\
\left(\mathrm{m}^{3} / \mathrm{s}\right)(\text { Calc } \\
\text { Slope) }\end{array}$ \\
\hline 2.72 & 0.238 & 1.9665 & 0.120862 & 0.0075 & 0.008 & 0.064 & 0.078618 & 0.081196321 & 10.98672684 & 0.078618 & 0.081196321 & 0.070793065 & 0.071848251 \\
\hline 2.72 & 0.256 & 2.0034 & 0.127638 & 0.0075 & 0.008 & 0.064 & 0.087715572 & 0.090592253 & 11.08707286 & 0.087715572 & 0.090592253 & 0.078835578 & 0.08001064 \\
\hline 2.72 & 0.246 & 1.9846 & 0.124183 & 0.0075 & 0.008 & 0.064 & 0.083007883 & 0.085730173 & 11.03647664 & 0.083007883 & 0.085730173 & 0.074674654 & 0.075787696 \\
\hline 2.72 & 0.246 & 1.9833 & 0.123943 & 0.0075 & 0.008 & 0.064 & 0.082686162 & 0.085397901 & 11.03291826 & 0.082686162 & 0.085397901 & 0.074390237 & 0.07549904 \\
\hline 2.72 & 0.306 & 1.967 & 0.155567 & 0.0075 & 0.008 & 0.064 & 0.119770573 & 0.123698516 & 11.45881049 & 0.119770573 & 0.123698516 & 0.105334469 & 0.106904501 \\
\hline 2.72 & 0.406 & 2.2678 & 0.178972 & 0.0075 & 0.008 & 0.064 & 0.174418876 & 0.180139041 & 11.72962589 & 0.174418876 & 0.180139041 & 0.155168474 & 0.157481293 \\
\hline 2.72 & 0.363 & 2.2002 & 0.165029 & 0.0075 & 0.008 & 0.064 & 0.147826663 & 0.152674721 & 11.5721329 & 0.147826663 & 0.152674721 & 0.131822666 & 0.133787511 \\
\hline 2.72 & 0.346 & 2.1721 & 0.159454 & 0.0075 & 0.008 & 0.064 & 0.13781099 & 0.142330578 & 11.50603705 & 0.13781099 & 0.142330578 & 0.123013203 & 0.124846741 \\
\hline 2.72 & 0.273 & 2.0379 & 0.134011 & 0.0075 & 0.008 & 0.064 & 0.096775215 & 0.099949013 & 11.17746818 & 0.096775215 & 0.099949013 & 0.086838398 & 0.088132743 \\
\hline 2.72 & 0.300 & 2.0885 & 0.143446 & 0.0075 & 0.008 & 0.064 & 0.111088687 & 0.114731903 & 11.30494147 & 0.111088687 & 0.114731903 & 0.099470284 & 0.10095291 \\
\hline 2.72 & 0.231 & 1.9518 & 0.118172 & 0.0075 & 0.008 & 0.064 & 0.075159159 & 0.077624046 & 10.94559112 & 0.075159159 & 0.077624046 & 0.067733593 & 0.068743177 \\
\hline 2.72 & 0.279 & 2.0503 & 0.136313 & 0.0075 & 0.008 & 0.064 & 0.100167994 & 0.10345306 & 11.20923922 & 0.100167994 & 0.10345306 & 0.089833891 & 0.091172884 \\
\hline 2.72 & 0.403 & 2.2630 & 0.177943 & 0.0075 & 0.008 & 0.064 & 0.172383679 & 0.178037098 & 11.71836392 & 0.172383679 & 0.178037098 & 0.15338415 & 0.155670373 \\
\hline 2.72 & 0.370 & 2.2120 & 0.167397 & 0.0075 & 0.008 & 0.064 & 0.152188882 & 0.157180002 & 11.5996434 & 0.152188882 & 0.157180002 & 0.135656838 & 0.137678832 \\
\hline 2.72 & 0.611 & 2.5056 & 0.243701 & 0.0075 & 0.008 & 0.064 & 0.322368698 & 0.332940959 & 12.34893507 & 0.322368698 & 0.332940959 & 0.283463214 & 0.287688294 \\
\hline 2.72 & 0.607 & 2.5027 & 0.242579 & 0.0075 & 0.008 & 0.064 & 0.319530726 & 0.330009915 & 12.33944149 & 0.319530726 & 0.330009915 & 0.281033211 & 0.285222071 \\
\hline 2.72 & 0.510 & 2.4061 & 0.211856 & 0.0075 & 0.008 & 0.064 & 0.245136207 & 0.253175586 & 12.06406446 & 0.245136207 & 0.253175586 & 0.216872825 & 0.220105361 \\
\hline 2.72 & 0.275 & 2.0410 & 0.134588 & 0.0075 & 0.008 & 0.064 & 0.097620018 & 0.100821521 & 11.1854779 & 0.097620018 & 0.100821521 & 0.087584352 & 0.088889816 \\
\hline 2.72 & 0.812 & 2.6014 & 0.312327 & 0.0075 & 0.008 & 0.064 & 0.506099027 & 0.522696828 & 12.87028523 & 0.506099027 & 0.522696828 & 0.437628687 & 0.444151636 \\
\hline 2.72 & 0.729 & 2.8806 & 0.253072 & 0.0075 & 0.008 & 0.064 & 0.394676469 & 0.407620104 & 12.42684233 & 0.394676469 & 0.407620104 & 0.354266159 & 0.359546572 \\
\hline 2.72 & 0.378 & 2.2238 & 0.169792 & 0.0075 & 0.008 & 0.064 & 0.15666651 & 0.161804476 & 11.6271442 & 0.15666651 & 0.161804476 & 0.13959068 & 0.141671309 \\
\hline 2.72 & 0.305 & 2.0979 & 0.145218 & 0.0075 & 0.008 & 0.064 & 0.113895579 & 0.117630848 & 11.32809097 & 0.113895579 & 0.117630848 & 0.101945711 & 0.103465234 \\
\hline 2.72 & 0.349 & 2.1758 & 0.160188 & 0.0075 & 0.008 & 0.064 & 0.13910954 & 0.143671715 & 11.51485176 & 0.13910954 & 0.143671715 & 0.124155839 & 0.126006408 \\
\hline 2.72 & 0.833 & 2.6034 & 0.320095 & 0.0075 & 0.008 & 0.064 & 0.527668192 & 0.544973366 & 12.92309309 & 0.527668192 & 0.544973366 & 0.455293056 & 0.462079296 \\
\hline 2.72 & 0.121 & 891 & 0.063987 & 0.0075 & 0.008 & 0.064 & 0.026193805 & 0.027052845 & 9.881791044 & 0.026193805 & 0.027052845 & 024865502 & 0.025236127 \\
\hline 2.72 & 0.575 & 2.7302 & 0.210607 & 0.0075 & 0.008 & 0.064 & 0.275423351 & 0.284456013 & 12.05217946 & 0.275423351 & 0.284456013 & 0.249190903 & 0.252905147 \\
\hline 2.72 & 0.165 & 1.4326 & 0.115175 & 0.0075 & 0.008 & 0.064 & 0.052853522 & 0.054586883 & 10.89882951 & 0.052853522 & 0.054586883 & 0.045258975 & 0.04593357 \\
\hline 2.72 & 0.248 & 1.6774 & 0.147848 & 0.0075 & 0.008 & 0.064 & 0.093830861 & 0.096908096 & 11.36202829 & 0.093830861 & 0.096908096 & 0.080662242 & 0.08186453 \\
\hline 2.72 & 0.26 & 1.5972 & 0.162785 & 0.0075 & 0.008 & 0.064 & 0.104889827 & 0.108329748 & 11.54575578 & 0.104889827 & 0.108329748 & 0.088605729 & 0.089926417 \\
\hline 2.72 & 0.878 & 3.2688 & 0.2686 & 0.0075 & 0.008 & 0.064 & 0.494594502 & 0.510815006 & 12.55078973 & 0.494594502 & 0.510815006 & 0.451246642 & 0.45797257 \\
\hline 2.72 & 0.497 & 2.3726 & 0.209475 & 0.0075 & 0.008 & 0.064 & 0.23720743 & 0.24498678 & 12.04135434 & 0.23720743 & 0.24498678 & 0.209571025 & 0.212694726 \\
\hline 2.72 & 0.453 & 2.074 & 0.218419 & 0.0075 & 0.008 & 0.064 & 0.222318273 & 0.229609325 & 12.12555431 & 0.222318273 & 0.229609325 & 0.191148731 & 0.193997844 \\
\hline 2.72 & 0.418 & 1.9816 & 0.210941 & 0.0075 & 0.008 & 0.064 & 0.200432033 & 0.207005314 & 12.05535695 & 0.200432033 & 0.207005314 & 0.17153642 & 0.174093207 \\
\hline 2.72 & 0.345 & 1.7848 & 0.193299 & 0.0075 & 0.008 & 0.064 & 0.156071203 & 0.161189645 & 11.88114462 & 0.156071203 & 0.161189645 & 0.132253162 & 0.134224423 \\
\hline 2.72 & 0.483 & 2.4116 & 0.200282 & 0.0075 & 0.008 & 0.064 & 0.223730757 & 0.231068132 & 11.95162621 & 0.223730757 & 0.231068132 & 0.199057789 & 0.202024788 \\
\hline 2.72 & 0.514 & 2.4444 & 0.210277 & 0.0075 & 0.008 & 0.064 & 0.245946704 & 0.254012663 & 12.049023 & 0.245946704 & 0.254012663 & 0.218337597 & 0.221591965 \\
\hline 2.72 & 0.746 & 2.9382 & 0.253897 & 0.0075 & 0.008 & 0.064 & 0.404757092 & 0.418031327 & 12.43358225 & 0.404757092 & 0.418031327 & 0.364450108 & 0.369882315 \\
\hline 2.72 & 0.759 & 8972 & 261977 & 0.0075 & 0.008 & 0.064 & 0.420501904 & 0.434292499 & 12.4986731 & 0.420501904 & 0.434292499 & 0.376600916 & 0.382214233 \\
\hline 2.72 & 1.001 & 3.4176 & 0.292896 & 0.0075 & 0.008 & 0.064 & 0.597392775 & 0.616984605 & 12.73323733 & 0.597392775 & 0.616984605 & 0.54481212 & 0.552932661 \\
\hline 2.72 & 0.952 & 3.3262 & 0.286212 & 0.0075 & 0.008 & 0.064 & 0.559474116 & 0.577822383 & 12.68434729 & 0.559474116 & 0.577822383 & 0.508942859 & 0.516528761 \\
\hline 2.72 & 0.959 & 3.0776 & .311606 & 0.0075 & 0.008 & 0.064 & 596449329 & 0.616010218 & 12.86533497 & .596449329 & 0.616010218 & 531090153 & 0.539006165 \\
\hline 2.72 & 1.3316 & 4.034 & 30094 & 0.0075 & 0.008 & 0.064 & 0.860629786 & 0.888854621 & 12.98951716 & 0.860629786 & 0.888854621 & 0.798726434 & 0.810631622 \\
\hline 2.72 & 1.29309 & 3.952 & 0.327199 & 0.0075 & 0.008 & 0.064 & 0.83084617 & 0.858094235 & 12.97045851 & 0.83084617 & 0.858094235 & 0.768984708 & 0.780446589 \\
\hline 2.72 & 1.30587 & 3.96 & 0.329765 & 0.0075 & 0.008 & 0.064 & 0.843439188 & 0.871100247 & 12.98735821 & 0.843439188 & 0.871100247 & 0.78034201 & 0.791973175 \\
\hline 2.72 & 1.26406 & 3.906 & 0.32362 & 0.0075 & 0.008 & 0.064 & 806260369 & 0.832702128 & 12.94670545 & 806260369 & 0.832702128 & 0.745487092 & 0.756598736 \\
\hline 2.72 & 1.23155 & 3.856 & 0.319385 & 0.0075 & 0.008 & 0.064 & 0.778656754 & 0.804193238 & .91831479 & .778656754 & 0.804193238 & 0.71924808 & 0.729968627 \\
\hline 2.72 & 1.15838 & 3.78 & 0.30645 & 0.0075 & 0.008 & 0.064 & 0.712483059 & 0.735849339 & 12.82960349 & 0.712483059 & 0.735849339 & 0.658405472 & 0.668219147 \\
\hline 2.72 & 1.17406 & 3.762 & 0.312084 & 0.0075 & 0.008 & 0.064 & 0.730951593 & 0.754923559 & 12.868619 & 0.730951593 & 0.754923559 & 673763937 & 0.683806533 \\
\hline 2.72 & 2006 & & & & 008 & & 583557206 & 705974847 & 12.80459233 & 683557206 & .705974847 & 0.629973429 & 0.639363318 \\
\hline 2.72 & 1.11135 & 3.619 & 0.307088 & 0.0075 & 0.008 & 0.064 & 0.684504581 & 0.706953291 & 12.83405032 & 0.684504581 & 0.706953291 & 0.627683061 & 0.637038812 \\
\hline 2.72 & 1.07535 & 3.527 & 0.304891 & 0.0075 & 0.008 & 0.064 & 0.659168963 & 0.680786778 & 12.81870312 & 0.659168963 & 0.680786778 & 0.602168679 & 0.611144132 \\
\hline 2.72 & 1.03471 & 3.497 & 0.295885 & 0.0075 & 0.008 & 0.064 & 0.62170541 & 0.642094587 & 12.75480613 & 0.62170541 & 0.642094587 & 0.568700915 & 0.577177524 \\
\hline 2.72 & 1.08769 & 3.509 & 0.309972 & 0.0075 & 0.008 & 0.064 & 0.674119627 & 0.696227757 & 12.85405994 & 0.674119627 & 0.696227757 & 0.614329938 & 0.623486657 \\
\hline
\end{tabular}




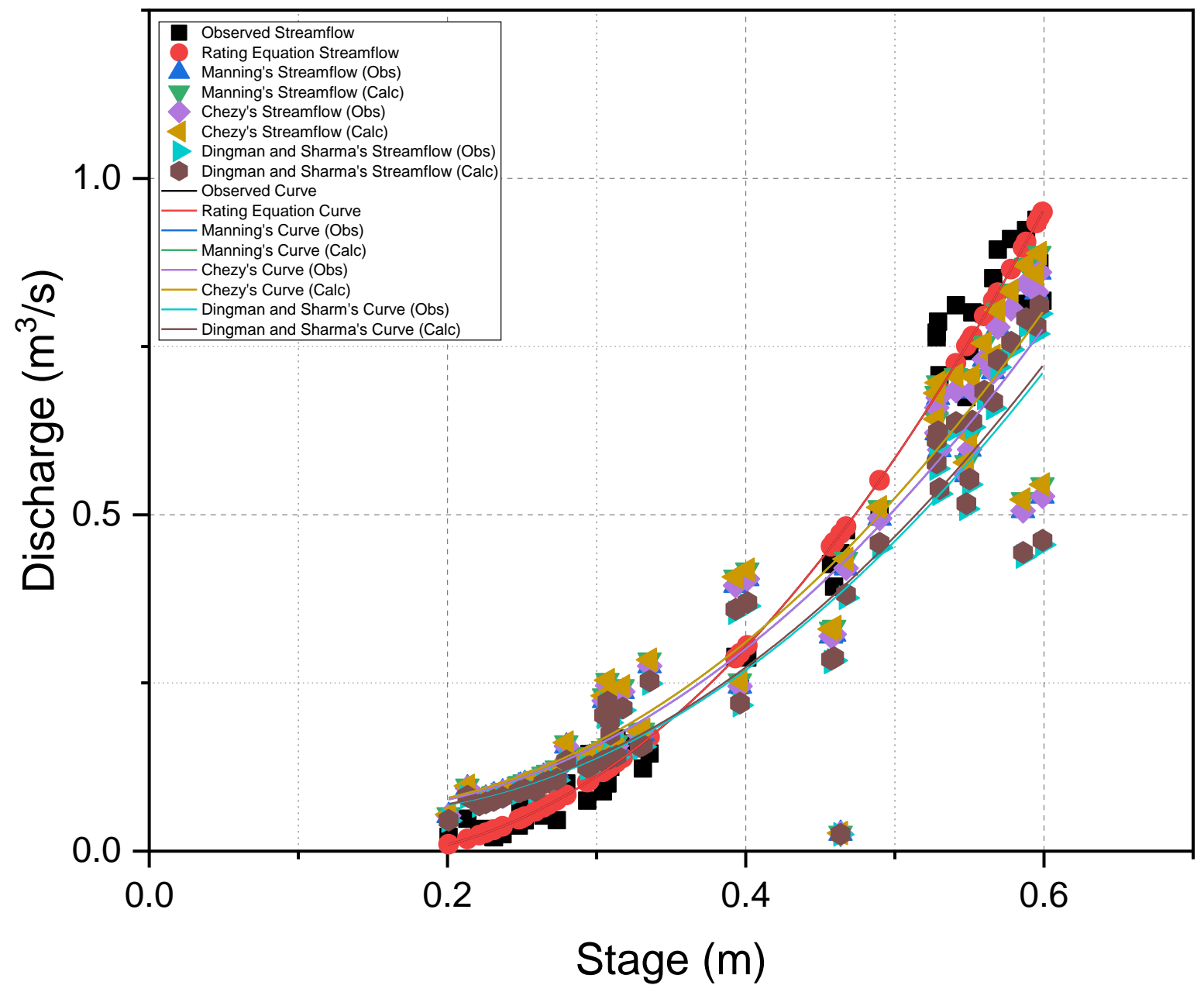

Figure A13-1. Observed and modeled rating curves and streamflow from Site 13, West Run Watershed, Morgantown, West Virginia, U.S.A. 
Table A13-3. Polynomial rating equations and $\mathrm{R}^{2}$ values for observed and modeled rating curves at Site 13, West Run Watershed, Morgantown, WV, U.S.A.

\begin{tabular}{ccc}
\hline & $\begin{array}{c}\mathbf{R}^{\mathbf{2}} \\
\text { Value }\end{array}$ & Polynomial Equation \\
\hline Observed Curve & 0.98 & $\mathrm{y}=4.4741 \mathrm{x}^{2}-1.2173 \mathrm{x}+0.0741$ \\
Manning's Curve (Obs Slope) & 0.88 & $\mathrm{y}=3.1634 \mathrm{x}^{2}-0.7756 \mathrm{x}+0.1051$ \\
Manning's Curve (Calc Slope) & 0.88 & $\mathrm{y}=3.2671 \mathrm{x}^{2}-0.801 \mathrm{x}+0.1086$ \\
Chezy's Curve (Obs Slope) & 0.88 & $\mathrm{y}=3.1634 \mathrm{x}^{2}-0.7756 \mathrm{x}+0.1051$ \\
$\begin{array}{c}\text { Chezy's Curve (Calc Slope) } \\
\text { Dingman and Sharma's Curve } \\
\text { (Obs Slope) }\end{array}$ & 0.88 & $\mathrm{y}=3.2671 \mathrm{x}^{2}-0.801 \mathrm{x}+0.1086$ \\
$\begin{array}{c}\text { Dingman and Sharma's Curve } \\
\text { (Calc Slope) }\end{array}$ & 0.88 & $\mathrm{y}=3.047 \mathrm{x}^{2}-0.8263 \mathrm{x}+0.1122$ \\
\hline
\end{tabular}

Table A13-4. Descriptive statistics for observed and modeled streamflow used to generate the rating curves for Site 13, West Run Watershed, Morgantown, WV, U.S.A.

\begin{tabular}{|c|c|c|c|c|}
\hline & Sample Size & Mean $\left(\mathrm{m}^{3} / \mathrm{s}\right)$ & St. Dev. & SE of Mean \\
\hline Observed & 53 & 0.365 & 0.336 & 0.046 \\
\hline Manning's & 53 & 0.344 & 0.263 & 0.036 \\
\hline \multicolumn{5}{|l|}{$\begin{array}{l}\text { Curve (Obs } \\
\text { Slope) }\end{array}$} \\
\hline & 53 & 0.355 & 0.271 & 0.037 \\
\hline \multicolumn{5}{|l|}{$\begin{array}{c}\text { Curve (Calc } \\
\text { Slope) }\end{array}$} \\
\hline $\begin{array}{c}\text { Chezy's Curve } \\
\text { (Obs Slope) }\end{array}$ & 53 & 0.344 & 0.263 & 0.036 \\
\hline $\begin{array}{l}\text { Chezy's Curve } \\
\text { (Calc Slope) }\end{array}$ & 53 & 0.355 & 0.271 & 0.037 \\
\hline $\begin{array}{c}\text { Dingman and } \\
\text { Sharma's } \\
\text { Curve (Obs } \\
\text { Slope) }\end{array}$ & 53 & 0.311 & 0.243 & 0.033 \\
\hline $\begin{array}{l}\text { Dingman and } \\
\text { Sharma's } \\
\text { Curve (Calc } \\
\text { Slope) }\end{array}$ & 53 & 0.316 & 0.247 & 0.034 \\
\hline
\end{tabular}


Table A13-5. P-values of the statistical analyses (post-hoc ANOVA) for observed and modeled rating curves at Site 13, West Run Watershed, Morgantown, WV, U.S.A.

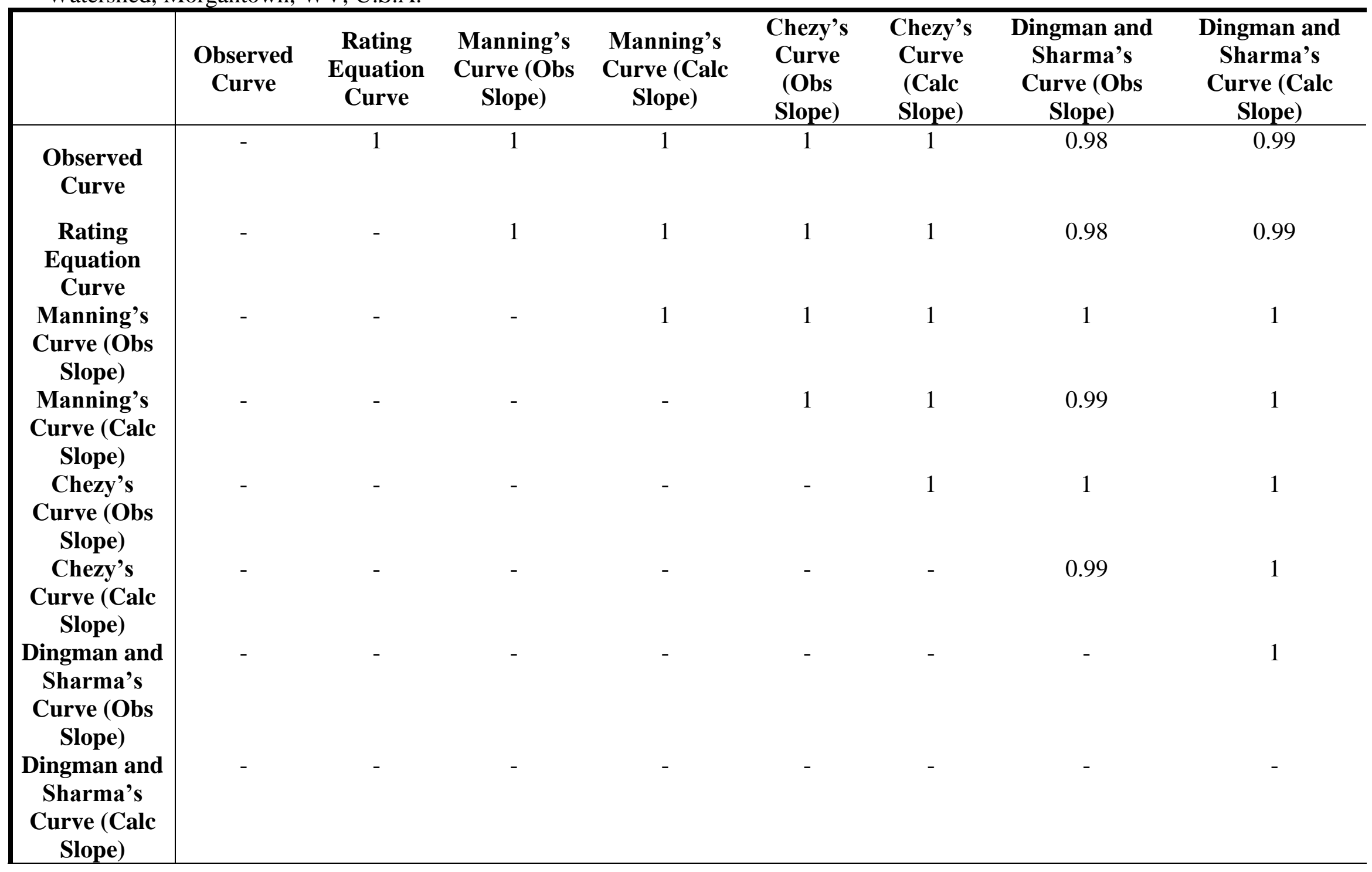




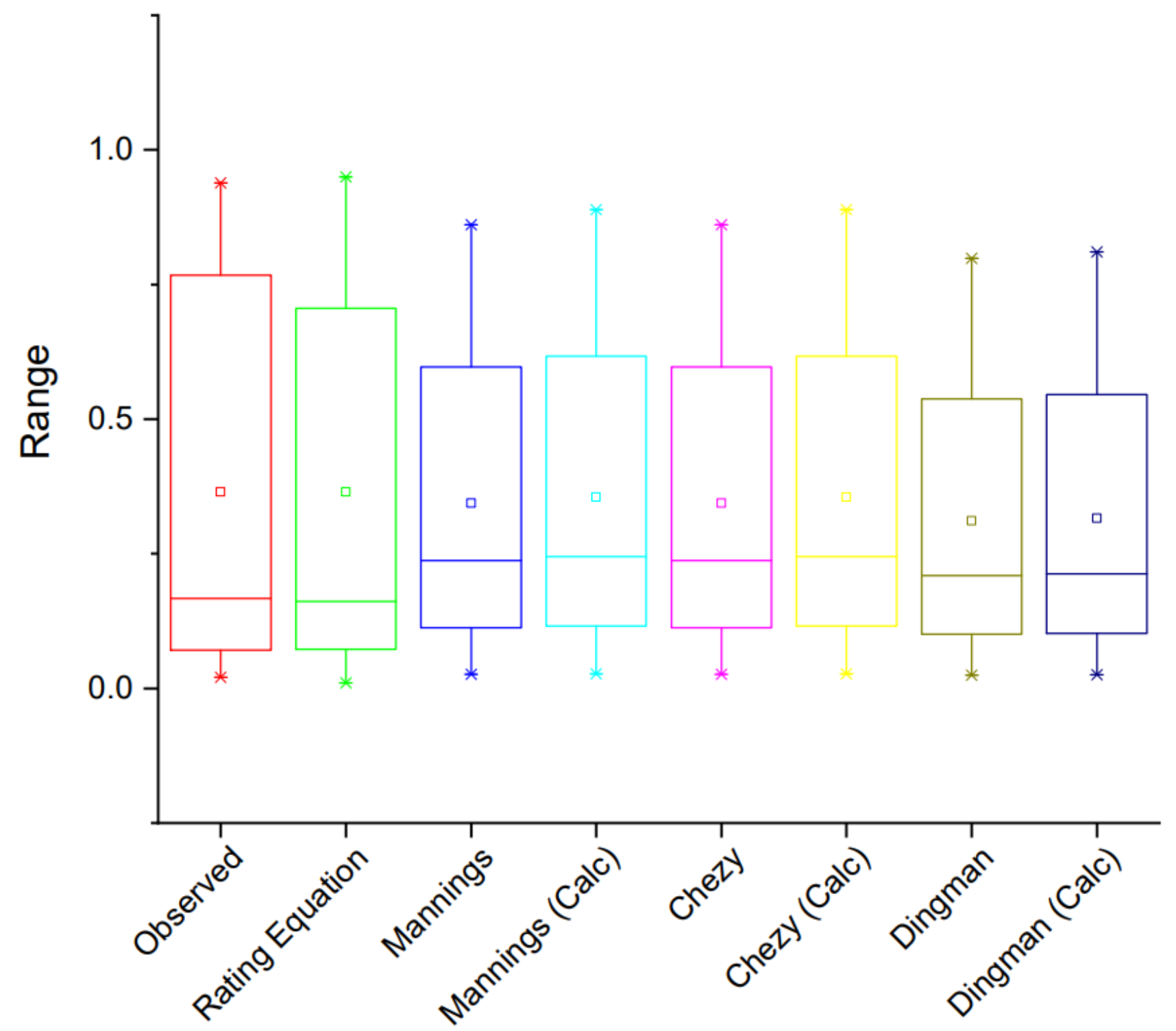

Figure A13-2. Box and whisker plots for the results of the statistical analyses (post-hoc ANOVA) of observed and modeled rating curves at Site 13, West Run Watershed, Morgantown, WV, U.S.A. 


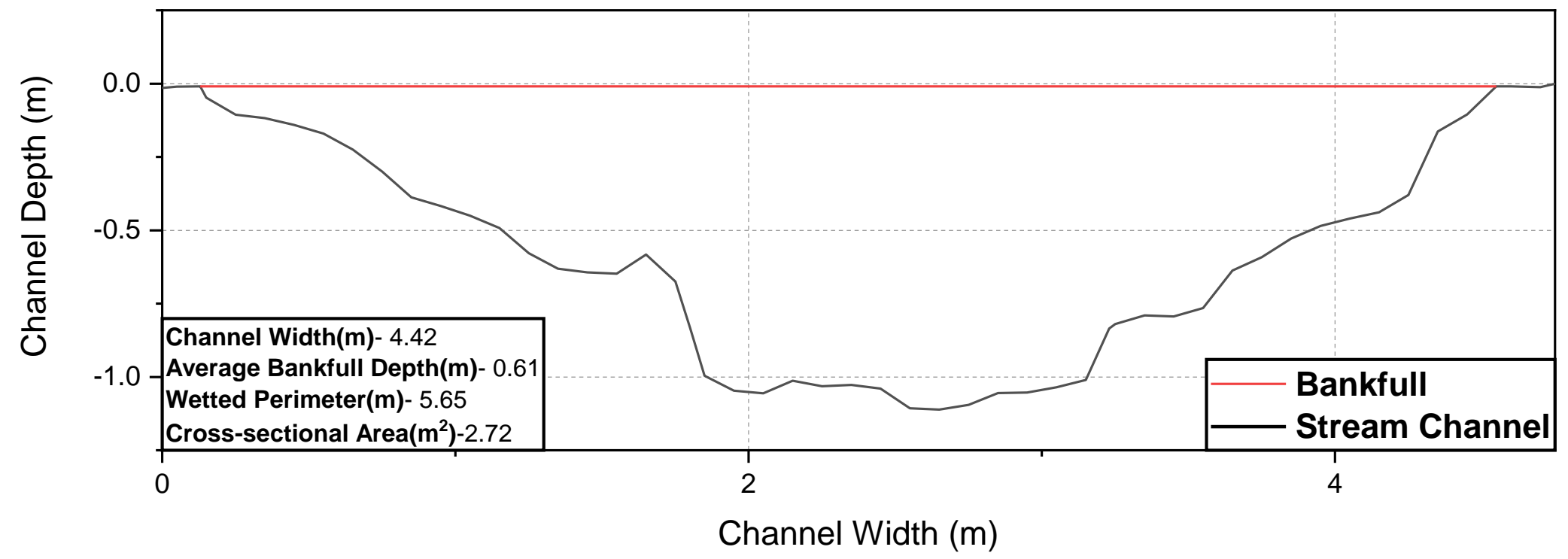

Figure A13-3. Cross-sectional profile of WRW Site 13, West Run Watershed, Morgantown, WV, USA (Figure 2). Channel Width of zero (0) represents the left bank facing downstream. 

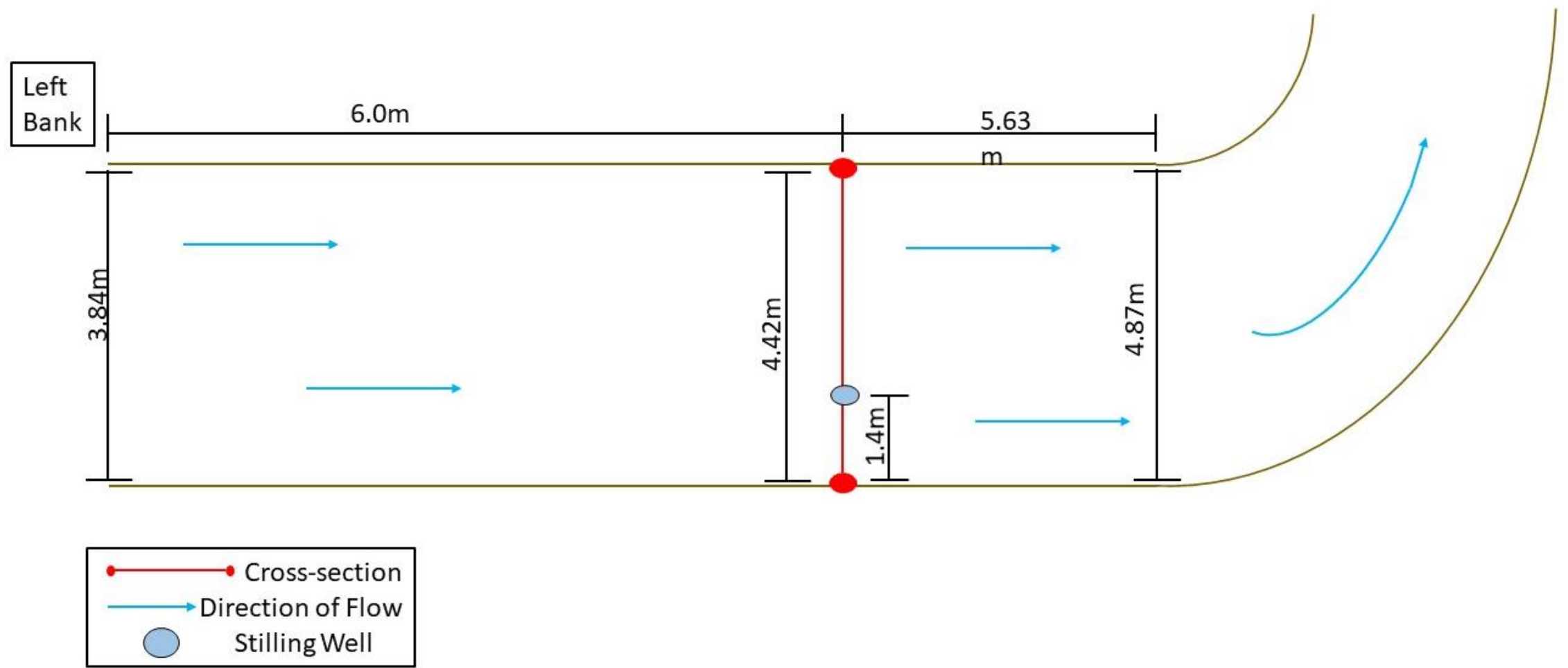

Figure A13-4. Plan view profile of WRW Site 13, West Run Watershed, Morgantown, WV, U.S.A. (Figure 2). Showing the positioning of stilling well in relation to where the streamflow was measured. Along with the channel width at the stilling well, point where cross-sections were performed, and $6.0 \mathrm{~m}$ upstream and downstream from the stilling well. 


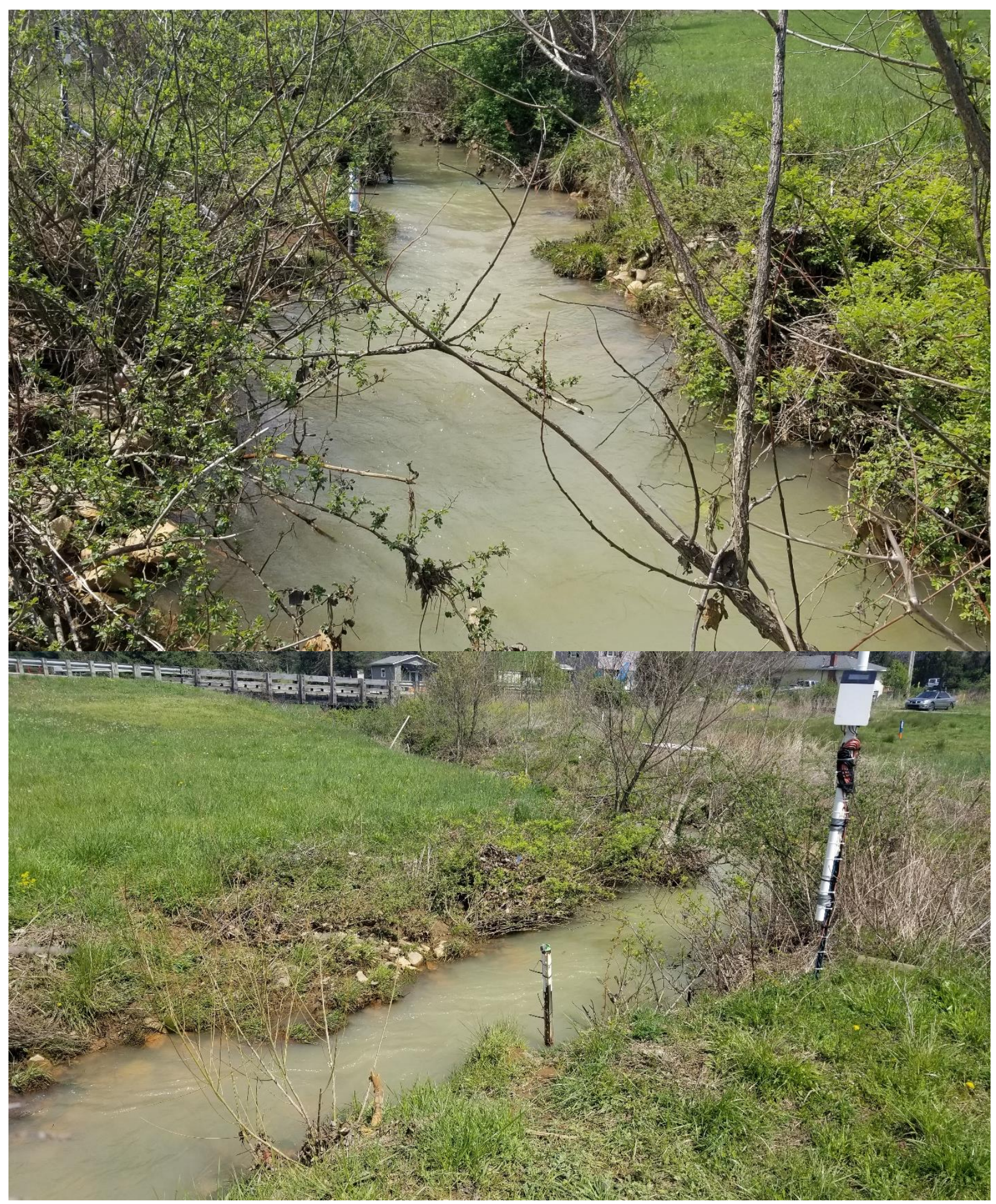

Figure A13-5. Photographs showing channel characteristics at Site \#13, West Run Watershed, Morgantown, WV, U.S.A. Photo 1 was taken looking upstream in the channel. Photo 2 was taken from the right bank looking downstream. 


\section{APPENDIX 14: Site 14}

Table A14-1. Streamflow measurements and stage collected at Site 14, West Run Watershed, Morgantown, WV, U.S.A. (Figure 2).

\begin{tabular}{|c|c|c|c|c|c|c|c|c|c|}
\hline Date & $\begin{array}{l}\text { Mean Depth of } \\
\text { Cross-Section } \\
\text { (m) }\end{array}$ & Stage(PT in cm) & $\begin{array}{c}\text { Barometric } \\
\text { Pressure (in cm) }\end{array}$ & $\begin{array}{c}\text { Pressure } \\
\text { Corrected Stage } \\
\text { (cm) }\end{array}$ & $\begin{array}{c}\text { Stilling Well } \\
\text { Offset (cm) }\end{array}$ & $\begin{array}{l}\text { P-Corrected } \\
\text { Stage + Offset } \\
\text { (cm) }\end{array}$ & $\begin{array}{l}\text { P-Corrected } \\
\text { Stage + Offset } \\
\text { (m) }\end{array}$ & $\begin{array}{c}\text { SonTec } \\
\text { Discharge }(\mathrm{m} 3 / \mathrm{s})\end{array}$ & $\begin{array}{l}\text { Rating Equation } \\
\text { Discharge }(\mathrm{m} 3 / \mathrm{s})\end{array}$ \\
\hline $10 / 9 / 2017$ & 0.0988 & 99.12 & \begin{tabular}{|l|l|}
79.4 \\
\end{tabular} & 19.72 & 4 & 23.72 & 0.2372 & 0.0135 & 0.0253 \\
\hline $10 / 9 / 2017$ & 0.0787 & 99.44 & 80.88 & 18.56 & 4 & 22.56 & 0.2256 & 0.0146 & 0.0209 \\
\hline $10 / 9 / 2017$ & 0.0803 & 98.93 & 80.83 & 18.1 & 4 & 22.1 & 0.221 & 0.0076 & 0.0199 \\
\hline $10 / 24 / 2017$ & 0.1134 & 98.3 & 75.47 & 22.83 & 4 & 26.83 & 0.2683 & 0.0366 & 0.0512 \\
\hline $10 / 24 / 2017$ & 0.1053 & 98.3 & 76.43 & 21.87 & 4 & 25.87 & 0.2587 & 0.0353 & 0.0410 \\
\hline $10 / 29 / 2017$ & 0.1372 & 100.48 & 72.13 & 28.35 & 4 & 32.35 & 0.3235 & 0.0958 & 0.1473 \\
\hline $10 / 30 / 2017$ & 0.1119 & 102.9 & 76.96 & 25.94 & 4 & 29.94 & 0.2994 & 0.0613 & 0.0974 \\
\hline $11 / 3 / 2017$ & 0.0832 & 107 & 88.2 & 18.8 & 4 & 22.8 & 0.228 & 0.0160 & 0.0215 \\
\hline $11 / 7 / 2017$ & 0.1836 & 114.78 & 87.28 & 27.5 & 4 & 31.5 & 0.315 & 0.1158 & 0.1283 \\
\hline $1 / 21 / 2018$ & 0.1254 & 111.87 & 88.21 & 23.66 & 4.1 & 27.76 & 0.2776 & 0.0601 & 0.0629 \\
\hline $3 / 23 / 2018$ & 0.1174 & 106.41 & 88.66 & 17.75 & 4.1 & 21.85 & 0.2185 & 0.0396 & 0.0195 \\
\hline 4/5/2018 & 0.1549 & 117.05 & 87.52 & 29.53 & 4.1 & 33.63 & 0.3363 & 0.1332 & 0.1787 \\
\hline $9 / 20 / 2018$ & 0.1097 & 108.51 & 89.35 & 19.16 & 4.1 & 23.26 & 0.2326 & 0.0386 & 0.0232 \\
\hline $9 / 20 / 2018$ & 0.0963 & 108.54 & 89.33 & 19.21 & 4.1 & 23.31 & 0.2331 & 0.0332 & 0.0234 \\
\hline $10 / 2 / 2018$ & 0.1042 & 104.88 & 88.13 & 16.75 & 4.1 & 20.85 & 0.2085 & 0.0266 & 0.0195 \\
\hline $10 / 2 / 2018$ & 0.1049 & 104.65 & 87.99 & 16.66 & 4.1 & 20.76 & 0.2076 & 0.0258 & 0.0196 \\
\hline $10 / 16 / 2018$ & 0.1116 & 108.76 & 90.62 & 18.14 & 4.1 & 22.24 & 0.2224 & 0.0298 & 0.0201 \\
\hline $10 / 16 / 2018$ & 0.1018 & 108.46 & 90.18 & 18.28 & 4.1 & 22.38 & 0.2238 & 0.0345 & 0.0204 \\
\hline 1/15/2019 & 0.1167 & 107.57 & 87.52 & 20.05 & 4.1 & 24.15 & 0.2415 & 0.0337 & 0.0277 \\
\hline $1 / 15 / 2019$ & 0.1061 & 107.58 & 87.48 & 20.1 & 4.1 & 24.2 & 0.242 & 0.0356 & 0.0280 \\
\hline $2 / 26 / 2019$ & 0.1259 & 117.6 & 94 & 23.6 & 4.1 & 27.7 & 0.277 & 0.0715 & 0.0621 \\
\hline $2 / 26 / 2019$ & 0.1219 & 117.39 & 93.74 & 23.65 & 4.1 & 27.75 & 0.2775 & 0.0794 & 0.0628 \\
\hline $2 / 13 / 2020$ & 0.2531 & 1036.1 & 990.03 & 46.1 & 4.1 & 50.2 & 0.502 & 0.8412 & 0.8967 \\
\hline $2 / 13 / 2020$ & 0.2493 & 1036.4 & 990.11 & 46.3 & 4.1 & 50.4 & 0.504 & 0.9001 & 0.9089 \\
\hline $2 / 13 / 2020$ & 0.2534 & 1037.7 & 990.20 & 47.5 & 4.1 & 51.6 & 0.516 & 0.8418 & 0.9838 \\
\hline $9 / 1 / 2021$ & 0.2880 & 1032.5 & 988.39 & 44.1 & 4.1 & 48.2 & 0.482 & 0.8089 & 0.7794 \\
\hline $9 / 1 / 2021$ & 0.2890 & 1033.2 & 988.44 & 44.8 & 4.1 & 48.9 & 0.489 & 0.8972 & 0.8195 \\
\hline $9 / 1 / 2021$ & 0.3060 & 1032.5 & 988.39 & 44.1 & 4.1 & 48.2 & 0.482 & 0.8232 & 0.7794 \\
\hline $9 / 1 / 2021$ & 0.3060 & 1033.2 & 988.33 & 44.9 & 4.1 & 49 & 0.49 & 0.7790 & 0.8253 \\
\hline $9 / 1 / 2021$ & 0.2880 & 1031.6 & 988.29 & 43.3 & 4.1 & 47.4 & 0.474 & 0.7860 & 0.7348 \\
\hline 9/1/2021 & 0.2860 & 1032 & 988.26 & 43.7 & 4.1 & 47.8 & 0.478 & 0.7664 & 0.7569 \\
\hline $9 / 1 / 2021$ & 0.2850 & 1030.9 & 988.26 & 42.6 & 4.1 & 46.7 & 0.467 & 0.7721 & 0.6969 \\
\hline 9/1/2021 & 0.3020 & 1030.7 & 988.28 & 42.4 & 4.1 & 46.5 & 0.465 & 0.7751 & 0.6863 \\
\hline 9/1/2021 & 0.3010 & 1029.3 & 988.44 & 40.9 & 4.1 & 45 & 0.45 & 0.5700 & 0.6092 \\
\hline
\end{tabular}


Table A14-2. Modeled streamflow at Site 14, West Run Watershed, Morgantown, WV, U.S.A.

\begin{tabular}{|c|c|c|c|c|c|c|c|c|c|c|c|c|c|}
\hline $\begin{array}{l}\text { Cross- } \\
\text { Section } \\
\text { Area } \\
\left(\mathrm{m}^{2}\right)\end{array}$ & $\begin{array}{l}\text { A (Cross } \\
\text { Section } \\
\text { area of } \\
\text { flow) }\end{array}$ & $\begin{array}{c}\text { P } \\
\text { (Wetted } \\
\text { Perimete } \\
\text { r) }\end{array}$ & $\begin{array}{c}\mathrm{RH}=\mathrm{A} / \mathrm{P} \\
\text { Hydraulic } \\
\text { Radius } \\
(\mathrm{m})\end{array}$ & $\begin{array}{l}\text { Observe } \\
\text { d Slope } \\
\text { (m) }\end{array}$ & $\begin{array}{l}\text { Calculated } \\
\text { Slope using } \\
\text { ArcGIS (m) }\end{array}$ & $\begin{array}{c}\text { Roughness } \\
\text { Coefficient } \\
\text { (n) }\end{array}$ & $\begin{array}{c}\text { Manning } \\
\text { Discharge } \\
\left(\mathrm{m}^{3} / \mathrm{s}\right)(\mathrm{Obs} \\
\text { Slope) }\end{array}$ & $\begin{array}{c}\text { Manning } \\
\text { Discharge } \\
\left(\mathrm{m}^{3} / \mathrm{s}\right)(\text { Calc } \\
\text { Slope) }\end{array}$ & $\begin{array}{c}\text { Chezy } \\
\text { Coefficient } \\
\text { (C) }\end{array}$ & $\begin{array}{c}\text { Chezy } \\
\text { Discharge } \\
\left(\mathrm{m}^{3} / \mathrm{s}\right)(\mathrm{Obs} \\
\text { Slope) }\end{array}$ & $\begin{array}{c}\text { Chezy } \\
\text { Discharge } \\
\left(\mathrm{m}^{3} / \mathrm{s}\right)(\text { Calc } \\
\text { Slope) }\end{array}$ & $\begin{array}{c}\text { Dingman \& } \\
\text { Sharma } \\
\text { Discharge } \\
\left.\text { ( } \mathrm{m}^{3} / \mathrm{s}\right) \text { (Obs. } \\
\text { Slope) }\end{array}$ & $\begin{array}{c}\text { Dingman \& } \\
\text { Sharma } \\
\text { Discharge } \\
\text { (m } \mathrm{m}^{3} / \mathrm{s} \text { ) (Calc } \\
\text { Slope) }\end{array}$ \\
\hline 0.83 & 0.256 & 2.0040 & 0.127757 & 0.04 & 0.027 & 0.09 & 0.144319006 & 0.118570162 & 7.885358322 & 0.144319006 & 0.118570162 & 0.10878974 & 0.102115419 \\
\hline 0.83 & 0.238 & 1.9661 & 0.120801 & 0.04 & 0.027 & 0.09 & 0.128979722 & 0.105967655 & 7.812128341 & 0.128979722 & 0.105967655 & 0.097416028 & 0.091439491 \\
\hline 0.83 & 0.230 & 1.9508 & 0.117988 & 0.04 & 0.027 & 0.09 & 0.123045002 & 0.101091785 & 7.781504722 & 0.123045002 & 0.101091785 & 0.093012962 & 0.087306557 \\
\hline 0.83 & 0.306 & 2.0998 & 0.145565 & 0.04 & 0.027 & 0.09 & 0.1879556 & 0.154421283 & 8.058741423 & 0.1879556 & 0.154421283 & 0.141097243 & 0.132440835 \\
\hline 0.83 & 0.290 & 2.0711 & 0.140184 & 0.04 & 0.027 & 0.09 & 0.174107187 & 0.14304365 & 8.008303451 & 0.174107187 & 0.14304365 & 0.130851673 & 0.122823837 \\
\hline 0.83 & 0.394 & 2.2493 & 0.175054 & 0.04 & 0.027 & 0.09 & 0.273808396 & 0.224956553 & 8.310354816 & 0.273808396 & 0.224956553 & 0.204443436 & 0.191900698 \\
\hline 0.83 & 0.355 & 2.1872 & 0.162436 & 0.04 & 0.027 & 0.09 & 0.235044452 & 0.193108722 & 8.207382234 & 0.235044452 & 0.193108722 & 0.175880641 & 0.165090249 \\
\hline 0.83 & 0.241 & 1.9741 & 0.122256 & 0.04 & 0.027 & 0.09 & 0.132109856 & 0.108539323 & 7.827733246 & 0.132109856 & 0.108539323 & 0.099737718 & 0.093618744 \\
\hline 0.83 & 0.154 & 1.2072 & 0.127568 & 0.04 & 0.027 & 0.09 & 086723315 & 0.071250474 & 7.883415306 & 0.086723315 & 0.071250474 & 0.059893559 & 0.05621905 \\
\hline 0.83 & 0.320 & 2.1268 & 0.150694 & 0.04 & 0.027 & 0.09 & 0.201684088 & 0.165700386 & 8.105382694 & 0.201684088 & 0.165700386 & 0.151247107 & 0.141967998 \\
\hline 0.83 & 0.226 & 1.9424 & 0.116445 & 0.04 & 0.027 & 0.09 & 119855718 & 0.09847152 & 7.764449225 & 0.119855718 & 0.09847152 & 0.09064613 & 0.085084931 \\
\hline 0.83 & 0.414 & 2.2802 & 0.181639 & 0.04 & 0.027 & 0.09 & 0.295190399 & 0.24252366 & 8.361653393 & 0.295190399 & 0.24252366 & 0.220167112 & 0.206659716 \\
\hline 0.83 & 0.109 & 1.2102 & 0.090068 & 0.04 & 0.027 & 0.09 & 0.048669873 & 0.039986381 & 7.439076911 & 0.048669873 & 0.039986381 & 0.034741674 & 0.03261025 \\
\hline 0.83 & 0.103 & 1.2558 & 0.082019 & 0.04 & 0.027 & 0.09 & 0.043208502 & 0.035499407 & 7.323920389 & 0.043208502 & 0.035499407 & 0.031314572 & 0.029393403 \\
\hline 0.83 & 0.111 & 1.2754 & 0.087032 & 0.04 & 0.027 & 0.09 & 0.048442682 & 0.039799724 & 7.396681497 & 0.048442682 & 0.039799724 & 0.035007105 & 0.032859396 \\
\hline 0.83 & 0.12 & 1.3528 & 0.088705 & 0.04 & 0.027 & 0.09 & 0.053039632 & 0.043576504 & 7.420196947 & 0.053039632 & 0.043576504 & 0.038652749 & 0.036281377 \\
\hline 0.83 & 0.119 & 1.2902 & 0.092234 & 0.04 & 0.027 & 0.09 & 0.053983503 & 0.044351974 & 7.468599041 & 0.053983503 & 0.044351974 & 0.038877137 & 0.036491999 \\
\hline 0.83 & 0.109 & 1.2708 & 0.085773 & 0.04 & 0.027 & 0.09 & 0.047110044 & 0.038704851 & 7.378742801 & 0.047110044 & 0.038704851 & 0.034069261 & 0.03197909 \\
\hline 0.83 & 0.116 & 1.2242 & 0.094756 & 0.04 & 0.027 & 0.09 & 0.053577513 & 0.044018419 & 7.502253928 & 0.053577513 & 0.044018419 & 0.038139341 & 0.035799468 \\
\hline 0.83 & 0.113 & 1.2792 & 0.088336 & 0.04 & 0.027 & 0.09 & 0.049807253 & 0.040920834 & 7.415051232 & 0.049807253 & 0.040920834 & 0.035961577 & 0.033755311 \\
\hline 0.83 & 0.182 & 1.6998 & 0.107071 & 0.04 & 0.027 & 0.09 & 0.091195747 & 0.074924951 & 7.656608087 & 0.091195747 & 0.074924951 & 0.067928947 & 0.063761462 \\
\hline 0.83 & 0.167 & 1.6158 & 0.103354 & 0.04 & 0.027 & 0.09 & 0.081731575 & 0.067149341 & 7.611652772 & 0.081731575 & 0.067149341 & 0.060547984 & 0.056833326 \\
\hline 0.83 & 0.783 & 2.6402 & 0.296568 & 0.04 & 0.027 & 0.09 & 0.773806794 & 0.635747154 & 9.073572488 & 0.773806794 & 0.635747154 & 0.565397964 & 0.530710431 \\
\hline 0.83 & 0.7714 & 2.6326 & 0.293018 & 0.04 & 0.027 & 0.09 & 0.756246932 & 0.621320256 & 9.055378688 & 0.756246932 & 0.621320256 & 0.552915333 & 0.518993617 \\
\hline 0.83 & 0.76995 & 2.6028 & 0.295816 & 0.04 & 0.027 & 0.09 & 0.759622511 & 0.624093577 & 9.0697318 & 0.759622511 & 0.624093577 & 0.553797447 & 0.519821613 \\
\hline 0.83 & 0.750776 & 2.557 & 0.293616 & 0.04 & 0.027 & 0.09 & 0.737027717 & 0.605530059 & 9.058453331 & 0.737027717 & 0.605530059 & 0.536051854 & 0.503164724 \\
\hline 0.83 & 0.75414 & 2.559 & 0.294701 & 0.04 & 0.027 & 0.09 & 0.742152993 & 0.609740903 & 9.064024227 & 0.742152993 & 0.609740903 & 0.539666067 & 0.506557202 \\
\hline 0.83 & 0.802976 & 2.593 & 0.30967 & 0.04 & 0.027 & 0.09 & 0.81675092 & 0.671029354 & 9.139184682 & 0.81675092 & 0.671029354 & 0.59251237 & 0.55616135 \\
\hline 0.83 & 0.802976 & 2.593 & 0.30967 & 0.04 & 0.027 & 0.09 & 0.81675092 & 0.671029354 & 9.139184682 & 0.81675092 & 0.671029354 & 0.59251237 & 0.55616135 \\
\hline 0.83 & 0.749935 & 2.557 & 0.293287 & 0.04 & 0.027 & 0.09 & 0.735652231 & 0.604399982 & 9.056761366 & 0.735652231 & 0.604399982 & 0.535107615 & 0.502278414 \\
\hline 0.83 & 0.72263 & 2.553 & 0.283051 & 0.04 & 0.027 & 0.09 & 0.692276763 & 0.568763399 & 9.003298224 & 0.692276763 & 0.568763399 & 0.50509814 & 0.474110039 \\
\hline 0.83 & 0.719266 & 2.551 & 0.281954 & 0.04 & 0.027 & 0.09 & 0.687272916 & 0.564652319 & 8.997474388 & 0.687272916 & 0.564652319 & 0.501561617 & 0.470790485 \\
\hline 0.83 & 0.719266 & 2.585 & 0.278246 & 0.04 & 0.027 & 0.09 & 0.68123325 & 0.559690227 & 8.977641748 & 0.68123325 & 0.559690227 & 0.498912355 & 0.468303756 \\
\hline 0.83 & 0.679905 & 2.583 & 0.263223 & 0.04 & 0.027 & 0.09 & 0.62056166 & 0.50984343 & 8.894976302 & 0.62056166 & 0.50984343 & 0.456786258 & 0.428762124 \\
\hline
\end{tabular}




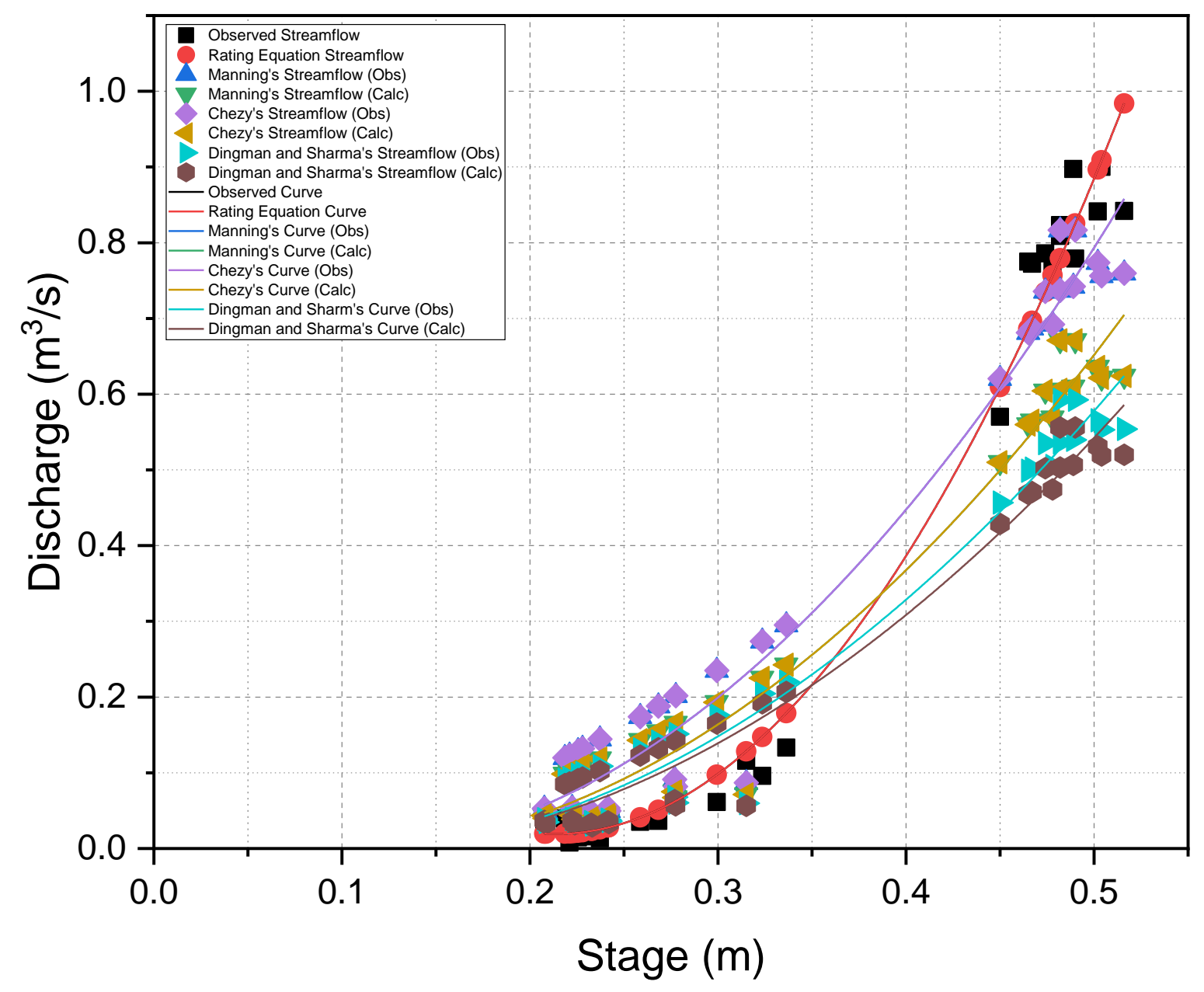

Figure A14-1. Observed and modeled rating curves and streamflow from Site 14, West Run Watershed, Morgantown, West Virginia, U.S.A. 
Table A14-3. Polynomial rating equations and $\mathrm{R}^{2}$ values for observed and modeled rating curves at Site 14, West Run Watershed, Morgantown, WV, U.S.A.

\begin{tabular}{ccc}
\hline & $\begin{array}{c}\mathbf{R}^{\mathbf{2}} \\
\text { Value }\end{array}$ & Polynomial Equation \\
\hline $\begin{array}{c}\text { Observed Curve } \\
\text { Manning's Curve (Obs Slope) }\end{array}$ & 0.99 & $\mathrm{y}=10.518 \mathrm{x}^{2}-4.4843 \mathrm{x}+0.4972$ \\
Manning's Curve (Calc Slope) & 0.91 & $\mathrm{y}=-1.617 \mathrm{x}^{2}+2.6303 \mathrm{x}-0.4351$ \\
Chezy's Curve (Obs Slope) & 0.91 & $\mathrm{y}=-1.3285 \mathrm{x}^{2}+2.161 \mathrm{x}-0.3575$ \\
Chezy's Curve (Calc Slope) & 0.91 & $\mathrm{y}=-1.617 \mathrm{x}^{2}+2.6303 \mathrm{x}-0.4351$ \\
$\begin{array}{c}\text { Dingman and Sharma's Curve } \\
\text { (Obs Slope) }\end{array}$ & 0.91 & $\mathrm{y}=-1.3285 \mathrm{x}^{2}+2.161 \mathrm{x}-0.3575$ \\
$\begin{array}{c}\text { Dingman and Sharma's Curve } \\
\text { (Calc Slope) }\end{array}$ & 0.91 & $\mathrm{y}=-1.1147 \mathrm{x}^{2}+1.9015 \mathrm{x}-0.3156$ \\
\hline
\end{tabular}

Table A14-4. Descriptive statistics for observed and modeled streamflow used to generate the rating curves for Site 14, West Run Watershed, Morgantown, WV, U.S.A.

\begin{tabular}{|c|c|c|c|c|}
\hline & Sample Size & Mean $\left(\mathrm{m}^{3} / \mathrm{s}\right)$ & St. Dev. & SE of Mean \\
\hline Observed & 34 & 0.312 & 0.368 & 0.063 \\
\hline Manning's & 34 & 0.243 & 0.179 & 0.031 \\
\hline \multicolumn{5}{|l|}{$\begin{array}{l}\text { Curve (Obs } \\
\text { Slope) }\end{array}$} \\
\hline & 34 & 0.199 & 0.147 & 0.025 \\
\hline \multicolumn{5}{|l|}{$\begin{array}{c}\text { Curve (Calc } \\
\text { Slope) }\end{array}$} \\
\hline $\begin{array}{c}\text { Chezy's Curve } \\
\text { (Obs Slope) }\end{array}$ & 34 & 0.243 & 0.179 & 0.031 \\
\hline $\begin{array}{l}\text { Chezy's Curve } \\
\text { (Calc Slope) }\end{array}$ & 34 & 0.199 & 0.147 & 0.025 \\
\hline $\begin{array}{c}\text { Dingman and } \\
\text { Sharma's } \\
\text { Curve (Obs } \\
\text { Slope) }\end{array}$ & 34 & 0.181 & 0.134 & 0.023 \\
\hline $\begin{array}{l}\text { Dingman and } \\
\text { Sharma's } \\
\text { Curve (Calc } \\
\text { Slope) }\end{array}$ & 34 & 0.17 & 0.126 & 0.022 \\
\hline
\end{tabular}


Table A14-5. P-values of the statistical analyses (post-hoc ANOVA) for observed and modeled rating curves at Site 14, West Run Watershed, Morgantown, WV, U.S.A.

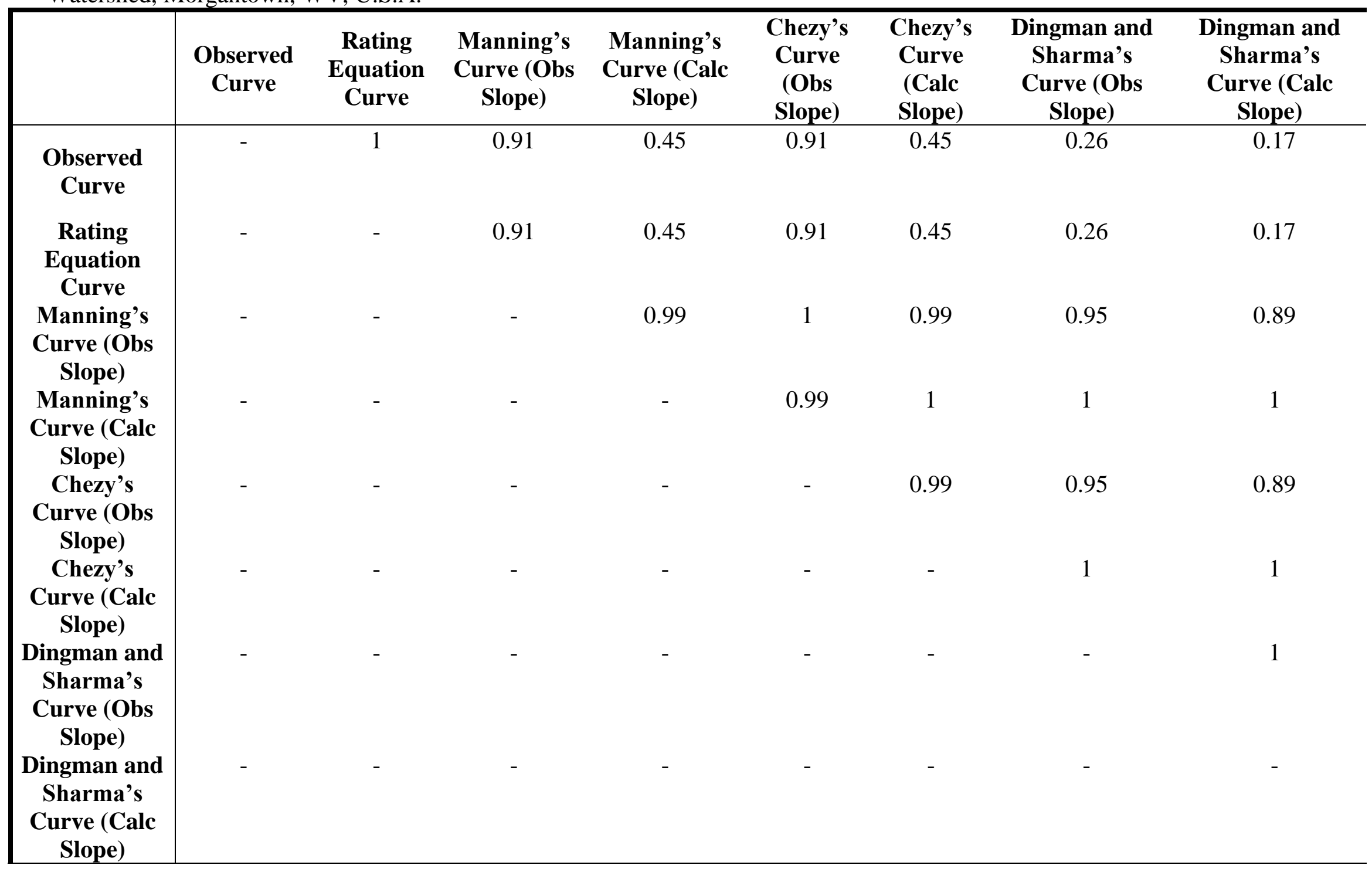




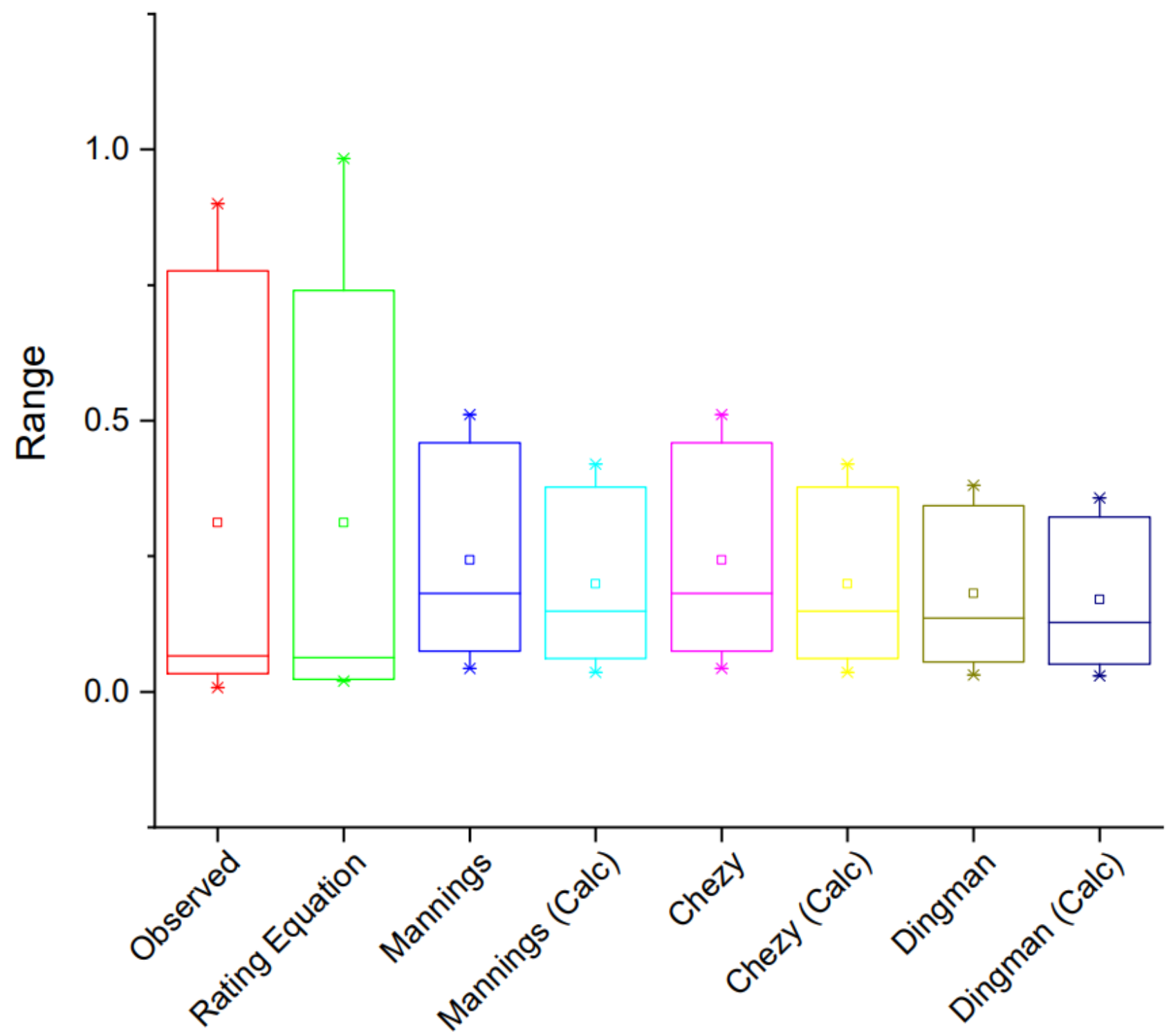

Figure A14-2. Box and whisker plots for the results of the statistical analyses (post-hoc ANOVA) of observed and modeled rating curves at Site 14, West Run Watershed, Morgantown, WV, U.S.A. 


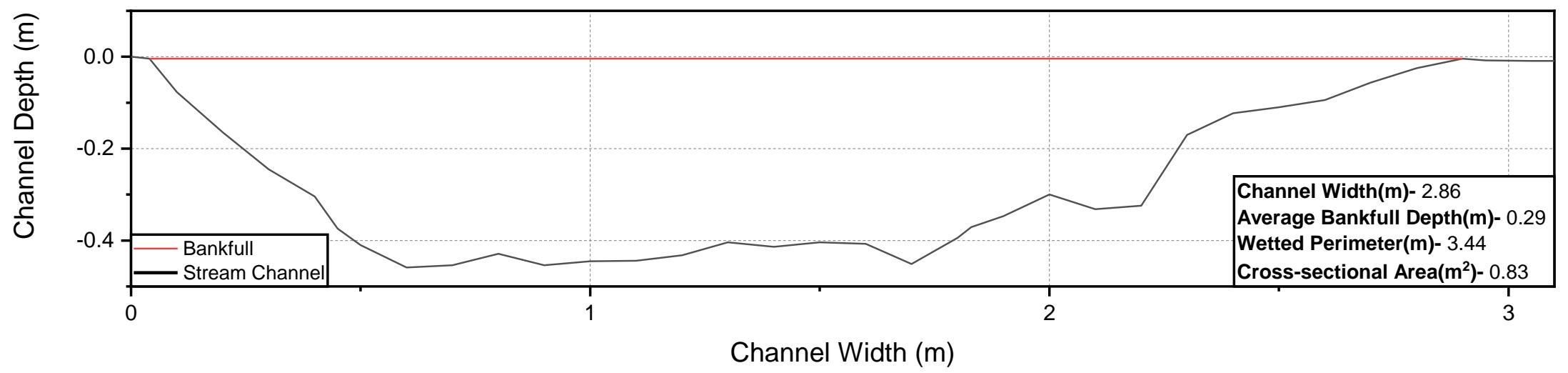

Figure A14-3. Cross-sectional profile of WRW Site 14, plotting the stream channel's shape, water surface, and bankfull. The profile is created with a Channel Width of $0=$ Left Bank facing downstream. 


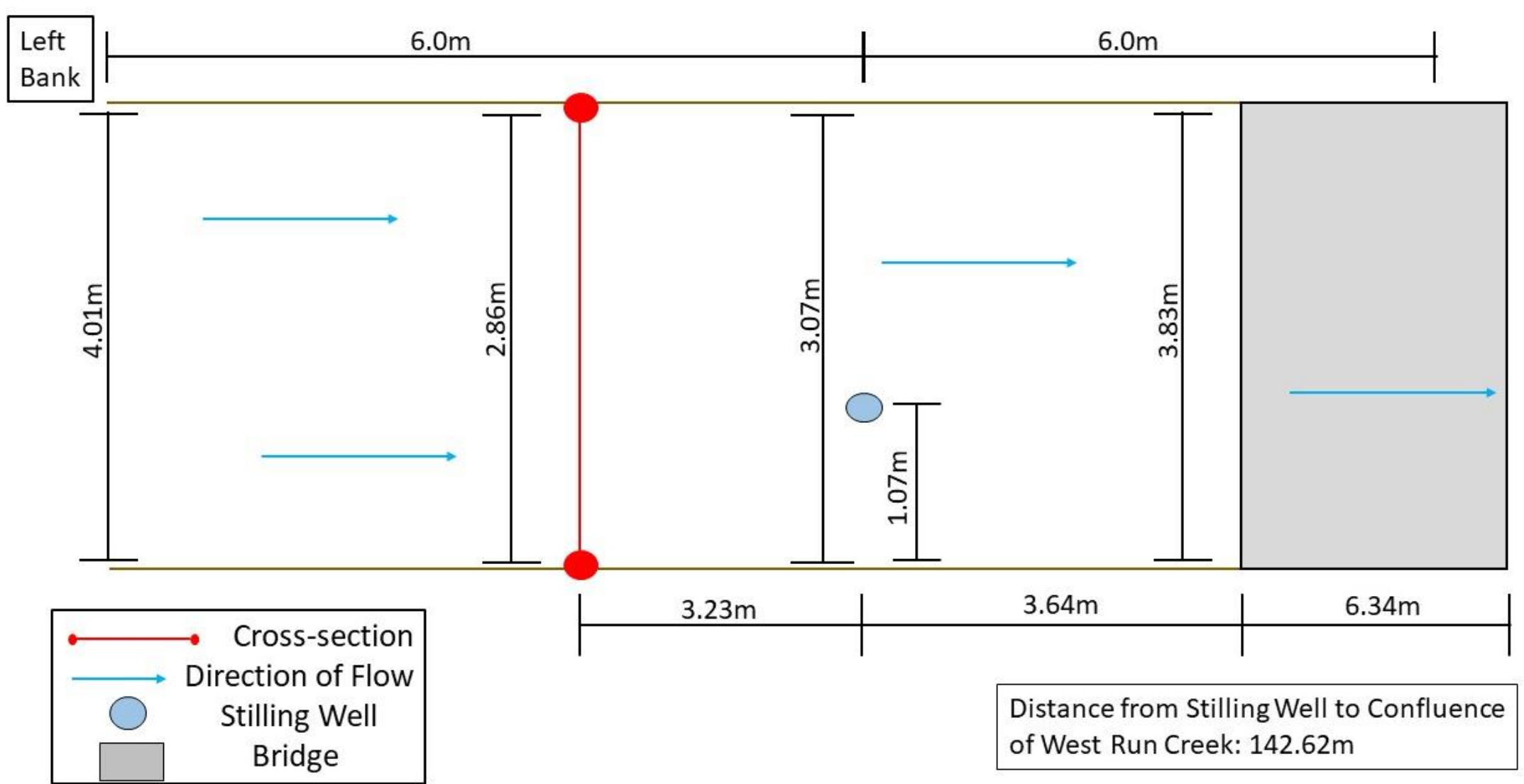

Figure A14-4. Plan view profile of WRW Site 14, West Run Watershed, Morgantown, WV, U.S.A. (Figure 2). Showing the positioning of stilling well in relation to where the streamflow was measured. Along with the channel width at the stilling well, point where cross-sections were performed, and $6.0 \mathrm{~m}$ upstream and downstream from the stilling well. 


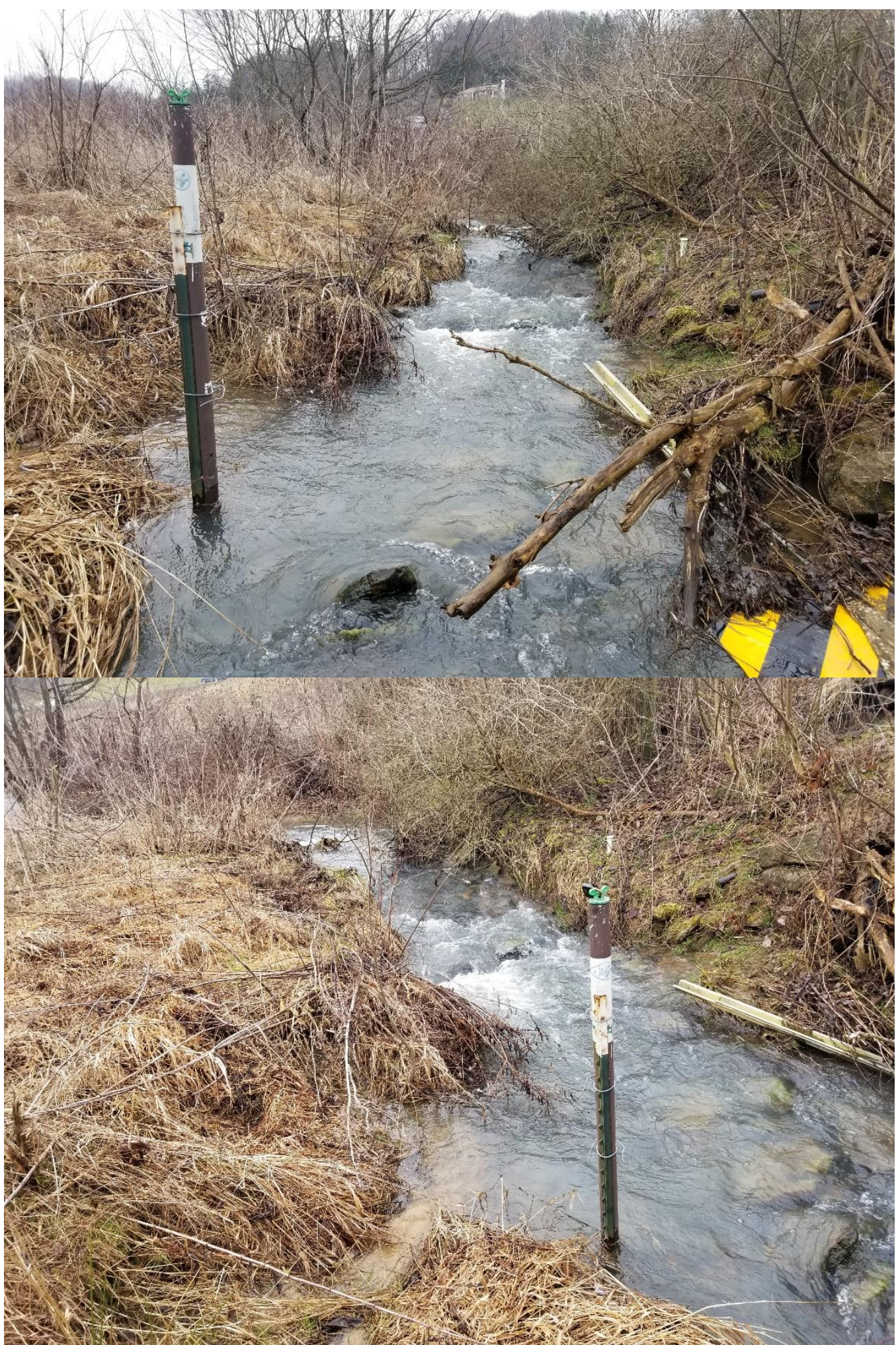

Figure A14-5. Photographs showing channel characteristics at Site \#14, West Run Watershed, Morgantown, WV, U.S.A. Photo 1 was taken looking upstream in the channel. Photo 2 was taken from the right bank looking upstream. 


\section{APPENDIX 15: Site 15}

Table A15-1. Streamflow measurements and stage collected at Site 15, West Run Watershed, Morgantown, WV, U.S.A. (Figure 2).

\begin{tabular}{|c|c|c|c|c|c|c|c|c|c|}
\hline Date & $\begin{array}{l}\text { Mean Depth of } \\
\text { Cross-Section } \\
\text { (m) }\end{array}$ & Stage(PT in cm) & $\begin{array}{c}\text { Barometric } \\
\text { Pressure (in cm) }\end{array}$ & $\begin{array}{c}\text { Pressure } \\
\text { Corrected Stage } \\
\text { (cm) }\end{array}$ & $\begin{array}{l}\text { Stilling Well } \\
\text { Offset }(\mathrm{cm})\end{array}$ & $\begin{array}{l}\text { P-Corrected } \\
\text { Stage + Offset } \\
\text { (cm) }\end{array}$ & $\begin{array}{l}\text { P-Corrected } \\
\text { Stage + Offset } \\
\text { (m) }\end{array}$ & $\begin{array}{c}\text { SonTec } \\
\text { Discharge }(\mathrm{m} 3 / \mathrm{s})\end{array}$ & $\begin{array}{l}\text { Rating Equation } \\
\text { Discharge }(\mathrm{m} 3 / \mathrm{s})\end{array}$ \\
\hline 9/21/2017 & 0.0733 & 132.36 & 87.33 & 45.03 & 10 & 55.03 & 0.5503 & 0.0016 & 0.0200 \\
\hline $9 / 28 / 2017$ & 0.0609 & 129.94 & 85.75 & 44.19 & 10 & 54.19 & 0.5419 & 0.0014 & 0.0154 \\
\hline $10 / 5 / 2017$ & 0.0651 & 135.23 & 91.61 & 43.62 & 10 & 53.62 & 0.5362 & 0.0013 & 0.0125 \\
\hline $10 / 8 / 2017$ & 0.0768 & 125.05 & 81.69 & 43.36 & 10 & 53.36 & 0.5336 & 0.0080 & 0.0113 \\
\hline $10 / 9 / 2017$ & 0.0972 & 125.17 & 80.22 & 44.95 & 10 & 54.95 & 0.5495 & 0.0220 & 0.0196 \\
\hline $10 / 9 / 2017$ & 0.1724 & 125.45 & 80.83 & 44.62 & 10 & 54.62 & 0.5462 & 0.0127 & 0.0177 \\
\hline $10 / 9 / 2017$ & 0.0753 & 125.41 & 81.11 & 44.3 & 10 & 54.3 & 0.543 & 0.0171 & 0.0160 \\
\hline $10 / 10 / 2017$ & 0.0534 & 131.53 & 88.93 & 42.6 & 10 & 52.6 & 0.526 & 0.0052 & 0.0078 \\
\hline 10/11/2017 & 0.0650 & 124.98 & 82.68 & 42.3 & 10 & 52.3 & 0.523 & 0.0062 & 0.0066 \\
\hline 10/23/2017 & 0.0553 & 121.99 & 81.28 & 40.71 & 10 & 50.71 & 0.5071 & 0.0026 & 0.0007 \\
\hline 10/23/2017 & 0.1142 & 122.09 & 75.14 & 46.95 & 10 & 56.95 & 0.5695 & 0.0425 & 0.0320 \\
\hline $10 / 24 / 2017$ & 0.1004 & 120.97 & 75.68 & 45.29 & 10 & 55.29 & 0.5529 & 0.0391 & 0.0215 \\
\hline 10/24/2017 & 0.0991 & 120.23 & 75.39 & 44.84 & 10 & 54.84 & 0.5484 & 0.0323 & 0.0189 \\
\hline $10 / 29 / 2017$ & 0.1067 & 119.27 & 71.96 & 47.31 & 10 & 57.31 & 0.5731 & 0.0641 & 0.0345 \\
\hline $10 / 30 / 2017$ & 0.1050 & 122.52 & 77.45 & 45.07 & 10 & 55.07 & 0.5507 & 0.0390 & 0.0202 \\
\hline $11 / 3 / 2017$ & 0.0781 & 130.27 & 88.09 & 42.18 & 10 & 52.18 & 0.5218 & 0.0096 & 0.0061 \\
\hline $11 / 6 / 2017$ & 0.1360 & 139.53 & 86.95 & 52.58 & 10 & 62.58 & 0.6258 & 0.1250 & 0.0794 \\
\hline $11 / 6 / 2017$ & 0.1275 & 140.18 & 88.13 & 52.05 & 10 & 62.05 & 0.6205 & 0.0835 & 0.0742 \\
\hline 11/7/2017 & 0.1194 & 139.7 & 88.06 & 51.64 & 10 & 61.64 & 0.6164 & 0.0744 & 0.0703 \\
\hline 11/7/2017 & 0.1315 & 140.14 & 87.26 & 52.88 & 10 & 62.88 & 0.6288 & 0.1105 & 0.0825 \\
\hline $1 / 21 / 2018$ & 0.0862 & 133.87 & 87.84 & 46.03 & 10.2 & 56.23 & 0.5623 & 0.0246 & 0.0273 \\
\hline $3 / 16 / 2018$ & 0.0705 & 130.76 & 85.8 & 44.96 & 10.2 & 55.16 & 0.5516 & 0.0038 & 0.0208 \\
\hline $3 / 23 / 2018$ & 0.0791 & 134.69 & 88.54 & 46.15 & 10.2 & 56.35 & 0.5635 & 0.0129 & 0.0280 \\
\hline $3 / 30 / 2018$ & 0.1219 & 136.81 & 84.83 & 51.98 & 10.2 & 62.18 & 0.6218 & 0.0997 & 0.0755 \\
\hline 4/5/2018 & 0.0716 & 135.58 & 87.75 & 47.83 & 10.2 & 58.03 & 0.5803 & 0.0422 & 0.0397 \\
\hline $7 / 6 / 2018$ & 0.0689 & 136.1 & 90.7 & 45.4 & 10.2 & 55.6 & 0.556 & 0.0225 & 0.0234 \\
\hline $7 / 6 / 2018$ & 0.0570 & 136 & 90.75 & 45.25 & 10.2 & 55.45 & 0.5545 & 0.0155 & 0.0225 \\
\hline 9/20/2018 & 0.0777 & 133.33 & 88.83 & 44.5 & 10.2 & 54.7 & 0.547 & 0.0169 & 0.0182 \\
\hline 9/20/2018 & 0.0983 & 132.99 & 88.48 & 44.51 & 10.2 & 54.71 & 0.5471 & 0.0172 & 0.0182 \\
\hline $10 / 2 / 2018$ & 0.0796 & 134.19 & 89.32 & 44.87 & 10.2 & 55.07 & 0.5507 & 0.0128 & 0.0202 \\
\hline $10 / 16 / 2018$ & 0.0924 & 136.49 & 92.06 & 44.43 & 10.2 & 54.63 & 0.5463 & 0.0135 & 0.0178 \\
\hline $10 / 16 / 2018$ & 0.0921 & 136.13 & 91.7 & 44.43 & 10.2 & 54.63 & 0.5463 & 0.0142 & 0.0178 \\
\hline $11 / 1 / 2018$ & 0.0975 & 118.94 & 76.1 & 42.84 & 10.2 & 53.04 & 0.5304 & 0.0091 & 0.0098 \\
\hline $11 / 13 / 2018$ & 0.0985 & 133.67 & 87.02 & 46.65 & 10.2 & 56.85 & 0.5685 & 0.0219 & 0.0314 \\
\hline $1 / 15 / 2019$ & 0.0850 & 134.1 & 88.19 & 45.91 & 10.2 & 56.11 & 0.5611 & 0.0105 & 0.0265 \\
\hline $1 / 15 / 2019$ & 0.0860 & 133.82 & 87.99 & 45.83 & 10.2 & 56.03 & 0.5603 & 0.0092 & 0.0260 \\
\hline $1 / 29 / 2019$ & 0.1009 & 122.53 & 76.57 & 45.96 & 10.2 & 56.16 & 0.5616 & 0.0165 & 0.0268 \\
\hline $7 / 11 / 2019$ & 0.4313 & 193.72 & 80.33 & 113.39 & 10.2 & 123.59 & 1.2359 & 1.7344 & 1.7559 \\
\hline $12 / 10 / 2019$ & 0.1268 & 140.13 & 81.16 & 58.97 & 10.2 & 69.17 & 0.6917 & 0.1249 & 0.1579 \\
\hline $12 / 17 / 2019$ & 0.1386 & 137.68 & 75.86 & 61.82 & 10.2 & 72.02 & 0.7202 & 0.1924 & 0.1996 \\
\hline $2 / 13 / 2020$ & 0.1326 & 1052.3 & 991.29 & 61 & 10.2 & 71.2 & 0.712 & 0.2879 & 0.1871 \\
\hline $2 / 13 / 2020$ & 0.1517 & 1051.4 & 991.72 & 59.7 & 10.2 & 69.9 & 0.699 & 0.2551 & 0.1682 \\
\hline $12 / 31 / 2020$ & 0.1040 & 1067 & 1005.92 & 61.048 & 10.2 & 71.248 & 0.71248 & 0.1360 & 0.1878 \\
\hline $12 / 31 / 2020$ & 0.0970 & 1067.1 & 1006.15 & 60.919 & 10.2 & 71.119 & 0.71119 & 0.1180 & 0.1859 \\
\hline $12 / 31 / 2020$ & 0.1020 & 1067.5 & 1006.54 & 61.023 & 10.2 & 71.223 & 0.71223 & 0.1400 & 0.1875 \\
\hline 2/28/2021 & 0.3810 & 1094.9 & 995.29 & 99.6 & 10.2 & 109.8 & 1.098 & 1.2464 & 1.1907 \\
\hline $2 / 28 / 2021$ & 0.3940 & 1090.8 & 995.20 & 95.6 & 10.2 & 105.8 & 1.058 & 1.1415 & 1.0471 \\
\hline $2 / 28 / 2021$ & 0.3950 & 1087.2 & 995.09 & 92.1 & 10.2 & 102.3 & 1.023 & 0.9689 & 0.9290 \\
\hline $2 / 28 / 2021$ & 0.3760 & 1084 & 994.94 & 89.1 & 10.2 & 99.3 & 0.993 & 0.8691 & 0.8333 \\
\hline $2 / 28 / 2021$ & 0.3810 & 1083.4 & 994.56 & 88.8 & 10.2 & 99 & 0.99 & 0.7542 & 0.8241 \\
\hline 2/28/2021 & 0.4080 & 1084.6 & 993.92 & 90.7 & 10.2 & 100.9 & 1.009 & 0.7256 & 0.8837 \\
\hline
\end{tabular}


Table A15-2. Modeled streamflow at Site 15, West Run Watershed, Morgantown, WV, U.S.A.

\begin{tabular}{|c|c|c|c|c|c|c|c|c|c|c|c|c|c|}
\hline $\begin{array}{c}\text { Cross- } \\
\text { Section } \\
\text { Area } \\
\left(\mathrm{m}^{2}\right)\end{array}$ & $\begin{array}{c}\text { A (Cross } \\
\text { Section } \\
\text { area of } \\
\text { flow) }\end{array}$ & $\begin{array}{c}\text { P } \\
\text { (Wetted } \\
\text { Perimete } \\
\text { r) }\end{array}$ & $\begin{array}{c}\text { RH=A/P } \\
\text { Hydraulic } \\
\text { Radius } \\
\text { (m) }\end{array}$ & $\begin{array}{l}\text { Observed } \\
\text { Slope }(m)\end{array}$ & $\begin{array}{l}\text { Calculated } \\
\text { Slope using } \\
\text { ArcGIS (m) }\end{array}$ & $\begin{array}{l}\text { Roughness } \\
\text { Coefficient } \\
\text { (n) }\end{array}$ & $\begin{array}{c}\text { Manning } \\
\text { Discharge } \\
\left(\mathrm{m}^{3} / \mathrm{s}\right) \text { (Obs } \\
\text { Slope) }\end{array}$ & $\begin{array}{c}\text { Manning } \\
\text { Discharge } \\
\left(\mathrm{m}^{3} / \mathrm{s}\right) \text { (Calc } \\
\text { Slope) }\end{array}$ & $\begin{array}{c}\text { Chezy } \\
\text { Coefficient } \\
\text { (C) }\end{array}$ & $\begin{array}{c}\text { Chezy } \\
\text { Discharge } \\
\left.\text { ( } \mathrm{m}^{3} / \mathrm{s}\right) \text { (Obs } \\
\text { Slope) }\end{array}$ & $\begin{array}{c}\text { Chezy } \\
\text { Discharge } \\
\left(\mathrm{m}^{3} / \mathrm{s}\right) \text { (Calc } \\
\text { Slope) }\end{array}$ & $\begin{array}{c}\text { Dingman \& } \\
\text { Sharma } \\
\text { Discharge } \\
\left(\mathrm{m}^{3} / \mathrm{s}\right) \text { (Obs. } \\
\text { Slope) }\end{array}$ & $\begin{array}{c}\text { Dingman \& } \\
\text { Sharma } \\
\text { Discharge } \\
\text { (m } \mathrm{m}^{3} / \mathrm{s} \text { ) (Calc } \\
\text { Slope) }\end{array}$ \\
\hline 2.6 & 0.756 & 2.5883 & 0.291951 & 0.01 & 0.041 & 0.135 & 0.246341803 & 0.498804134 & 6.033250233 & 0.246341803 & 0.498804134 & 0.417295599 & 0.540941857 \\
\hline 2.6 & 0.742 & 2.5837 & 0.287291 & 0.01 & 0.041 & 0.135 & 0.239389746 & 0.484727291 & 6.017089305 & 0.239389746 & 0.484727291 & 0.406003993 & 0.526304506 \\
\hline 2.6 & 0.733 & 2.5802 & 0.284156 & 0.01 & 0.041 & 0.135 & 0.234733215 & 0.475298535 & 6.006098371 & 0.234733215 & 0.475298535 & 0.398422018 & 0.516475963 \\
\hline 2.6 & 0.064 & 0.9916 & 0.064542 & 0.01 & 0.041 & 0.135 & 0.007627962 & 0.015445445 & 4.691446925 & 0.007627962 & 0.015445445 & 0.012607333 & 0.016342934 \\
\hline 2.6 & 0.754 & 2.5879 & 0.291505 & 0.01 & 0.041 & 0.135 & 0.245675041 & 0.497454043 & 6.031712736 & 0.245675041 & 0.497454043 & 0.4162141 & 0.539539906 \\
\hline 2.6 & 0.749 & 2.5861 & 0.28967 & 0.01 & 0.041 & 0.135 & 0.242935057 & 0.491906 & 6.025367071 & 0.242935057 & 0.491906 & 0.411766539 & 0.533774516 \\
\hline 2.6 & 0.744 & 2.5843 & 0.287898 & 0.01 & 0.041 & 0.135 & 0.240294011 & 0.486558289 & 6.019207923 & 0.240294011 & 0.486558289 & 0.407474616 & 0.52821088 \\
\hline 2.6 & 0.717 & 2.5732 & 0.278602 & 0.01 & 0.041 & 0.135 & 0.226520987 & 0.45867004 & 5.986369688 & 0.226520987 & 0.45867004 & 0.385014114 & 0.499095246 \\
\hline 2.6 & 0.712 & 2.5710 & 0.276981 & 0.01 & 0.041 & 0.135 & 0.224134603 & 0.453837981 & 5.980550147 & 0.224134603 & 0.453837981 & 0.381109284 & 0.494033401 \\
\hline 2.6 & 0.687 & 2.5579 & 0.268477 & 0.01 & 0.041 & 0.135 & 0.211701669 & 0.428663208 & 5.949551258 & 0.211701669 & 0.428663208 & 0.360703232 & 0.467580959 \\
\hline 2.6 & 0.786 & 2.5967 & 0.302808 & 0.01 & 0.041 & 0.135 & 0.262645653 & 0.531816915 & 6.07007477 & 0.262645653 & 0.531816915 & 0.443643156 & 0.575096295 \\
\hline 2.6 & 0.760 & 2.5897 & 0.293405 & 0.01 & 0.041 & 0.135 & 0.248515623 & 0.503205784 & 6.038244979 & 0.248515623 & 0.503205784 & 0.420819404 & 0.545509779 \\
\hline 2.6 & 0.753 & 2.5873 & 0.290893 & 0.01 & 0.041 & 0.135 & 0.244759854 & 0.495600931 & 6.029598151 & 0.244759854 & 0.495600931 & 0.414729145 & 0.537614954 \\
\hline 2.6 & 0.792 & 2.5979 & 0.304877 & 0.01 & 0.041 & 0.135 & 0.265768438 & 0.538140073 & 6.076968242 & 0.265768438 & 0.538140073 & 0.448668136 & 0.581610196 \\
\hline 2.6 & 0.756 & 2.5885 & 0.292175 & 0.01 & 0.041 & 0.135 & 0.246675555 & 0.49947993 & 6.034018864 & 0.2466755555 & 0.49947993 & 0.417836833 & 0.541643461 \\
\hline 2.6 & 0.710 & 2.5700 & 0.276334 & 0.01 & 0.041 & 0.135 & 0.223183695 & 0.451912539 & 5.978219953 & 0.223183695 & 0.451912539 & 0.379552241 & 0.492015 \\
\hline 2.6 & 0.251 & 2.1038 & 0.119308 & 0.01 & 0.041 & 0.135 & 0.045059476 & 0.091238484 & 5.197299888 & 0.045059476 & 0.091238484 & 0.08007957 & 0.103807448 \\
\hline 2.6 & 0.868 & 2.6036 & 0.333267 & 0.01 & 0.041 & 0.135 & 0.308954073 & 0.625584318 & 6.167817557 & 0.308954073 & 0.625584318 & 0.517436898 & 0.670755401 \\
\hline 2.6 & 0.861 & 2.6039 & 0.330719 & 0.01 & 0.041 & 0.135 & 0.305059683 & 0.617698779 & 6.159933655 & 0.305059683 & 0.617698779 & 0.511291271 & 0.662788801 \\
\hline 2.6 & 0.881 & 2.6026 & 0.338483 & 0.01 & 0.041 & 0.135 & 0.316935161 & 0.64174479 & 6.183805415 & 0.316935161 & 0.64174479 & 0.529996791 & 0.687036837 \\
\hline 2.6 & 0.775 & 2.5940 & 0.298702 & 0.01 & 0.041 & 0.135 & 0.256463097 & 0.519298192 & 6.056279659 & 0.256463097 & 0.519298192 & 0.433674091 & 0.562173359 \\
\hline 2.6 & 0.758 & 2.5890 & 0.292677 & 0.01 & 0.041 & 0.135 & 0.247427403 & 0.501002306 & 6.035748002 & 0.247427403 & 0.501002306 & 0.419055792 & 0.543223602 \\
\hline 2.6 & 0.777 & 2.5944 & 0.299383 & 0.01 & 0.041 & 0.135 & 0.257487738 & 0.521372933 & 6.058579774 & 0.257487738 & 0.521372933 & 0.435328153 & 0.564317525 \\
\hline 2.6 & 0.870 & 2.6035 & 0.334078 & 0.01 & 0.041 & 0.135 & 0.310195471 & 0.628097957 & 6.170319116 & 0.310195471 & 0.628097957 & 0.519393571 & 0.673291843 \\
\hline 2.6 & 0.804 & 2.6000 & 0.309049 & 0.01 & 0.041 & 0.135 & 0.27207806 & 0.550916083 & 6.09075049 & 0.27207806 & 0.550916083 & 0.458799853 & 0.594743978 \\
\hline 2.6 & 0.121 & 1.891 & 0.063987 & 0.01 & 0.041 & 0.135 & 0.014338845 & 0.029033948 & 4.684700939 & 0.014338845 & 0.029033948 & 0.026520489 & 0.03437861 \\
\hline 2.6 & 0.119 & 1.8666 & 0.063752 & 0.01 & 0.041 & 0.135 & 0.014067286 & 0.028484084 & 4.681828649 & 0.014067286 & 0.028484084 & 0.025968784 & 0.033663433 \\
\hline 2.6 & 0.101 & 1.4506 & 0.069626 & 0.01 & 0.041 & 0.135 & 0.012662032 & 0.0256386661 & 4.751111051 & 0.012662032 & 0.025638661 & 0.022192958 & 0.028768816 \\
\hline 2.6 & 0.125 & 1.5536 & 0.080458 & 0.01 & 0.041 & 0.135 & 0.017256661 & 0.034942076 & 4.867000209 & 0.017256661 & 0.034942076 & 0.030195381 & 0.039142386 \\
\hline 2.6 & 0.097 & 1.378 & 0.070392 & 0.01 & 0.041 & 0.135 & 0.012249536 & 0.02480342 & 4.7597774992 & 0.012249536 & 0.02480342 & 0.021258323 & 0.027557244 \\
\hline 2.6 & 0.12 & 1.4796 & 0.081103 & 0.01 & 0.041 & 0.135 & 0.016654775 & 0.033723348 & 4.873478473 & 0.016654775 & 0.033723348 & 0.028875607 & 0.037431558 \\
\hline 2.6 & 0.119 & 1.4792 & 0.080449 & 0.01 & 0.041 & 0.135 & 0.016427062 & 0.033262266 & 4.866905444 & 0.016427062 & 0.033262266 & 0.028501083 & 0.036946061 \\
\hline 2.6 & 0.119 & 1.4138 & 0.08417 & 0.01 & 0.041 & 0.135 & 0.016929827 & 0.034280287 & 4.903724494 & 0.016929827 & 0.034280287 & 0.029021304 & 0.037620426 \\
\hline 2.6 & 0.143 & 1.645 & 0.08693 & 0.01 & 0.041 & 0.135 & 0.020786547 & 0.04208955 & 4.930162727 & 0.020786547 & 0.04208955 & 0.03646817 & 0.047273827 \\
\hline 2.6 & 0.11 & 1.4654 & 0.075065 & 0.01 & 0.041 & 0.135 & 0.014499396 & 0.02935904 & 4.811040149 & 0.014499396 & 0.02935904 & 0.025279296 & 0.032769646 \\
\hline 2.6 & 0.111 & 1.4672 & 0.075654 & 0.01 & 0.041 & 0.135 & 0.014707707 & 0.029780838 & 4.817316437 & 0.014707707 & 0.029780838 & 0.025629142 & 0.033223153 \\
\hline 2.6 & 0.131 & 1.4968 & 0.08752 & 0.01 & 0.041 & 0.135 & 0.019128278 & 0.038731811 & 4.935723453 & 0.019128278 & 0.038731811 & 0.032994305 & 0.042770642 \\
\hline 2.6 & 2.169 & 5.8916 & 0.368151 & 0.01 & 0.041 & 0.135 & 0.825296461 & 1.671097967 & 6.271006938 & 0.825296461 & 1.671097967 & 1.577174413 & 2.044497134 \\
\hline 2.6 & 0.242 & 2.1586 & 0.11211 & 0.01 & 0.041 & 0.135 & 0.041678338 & 0.084392202 & 5.143673937 & 0.041678338 & 0.084392202 & 0.074835808 & 0.09700994 \\
\hline 2.6 & 0.338 & 2.7152 & 0.124484 & 0.01 & 0.041 & 0.135 & 0.062420347 & 0.126391571 & 5.234220862 & 0.062420347 & 0.126391571 & 0.115478727 & 0.149695509 \\
\hline 2.6 & 0.521 & 4.1892 & 0.124367 & 0.01 & 0.041 & 0.135 & 0.096155701 & 0.194700456 & 5.233400878 & 0.096155701 & 0.194700456 & 0.191765311 & 0.248586096 \\
\hline 2.6 & 0.433 & 3.1614 & 0.136965 & 0.01 & 0.041 & 0.135 & 0.085223577 & 0.172564592 & 5.318236415 & 0.085223577 & 0.172564592 & 0.160428096 & 0.207963546 \\
\hline 2.6 & 0.183 & 1.9618 & 0.093282 & 0.01 & 0.041 & 0.135 & 0.02788142 & 0.056455573 & 4.988450014 & 0.02788142 & 0.056455573 & 0.05009685 & 0.064940736 \\
\hline 2.6 & 0.167 & 1.9094 & 0.087462 & 0.01 & 0.041 & 0.135 & 0.024374127 & 0.049353846 & 4.935178027 & 0.024374127 & 0.049353846 & 0.04385418 & 0.056848338 \\
\hline 2.6 & 0.174 & 1.9182 & 0.09071 & 0.01 & 0.041 & 0.135 & 0.026020705 & 0.052687911 & 4.96526149 & 0.026020705 & 0.052687911 & 0.046694224 & 0.060529898 \\
\hline 2.6 & 1.943 & 5.866 & 0.331231 & 0.01 & 0.041 & 0.135 & 0.68901106 & 1.395141064 & 6.16152226 & 0.68901106 & 1.395141064 & 1.328824542 & 1.722560262 \\
\hline 2.6 & 2.043 & 5.9704 & 0.342188 & 0.01 & 0.041 & 0.135 & 0.740362745 & 1.4991203 & 6.195034384 & 0.740362745 & 1.4991203 & 1.427866216 & 1.850948356 \\
\hline 2.6 & 1.984 & 5.818 & 0.341011 & 0.01 & 0.041 & 0.135 & 0.717331441 & 1.452485464 & 6.191476421 & 0.717331441 & 1.452485464 & 1.377717914 & 1.785940924 \\
\hline 2.6 & 1.863 & 5.7054 & 0.326533 & 0.01 & 0.041 & 0.135 & 0.654380362 & 1.325019245 & 6.1468699944 & 0.654380362 & 1.325019245 & 1.257671242 & 1.63032397 \\
\hline 2.6 & 1.887 & 5.715 & 0.330184 & 0.01 & 0.041 & 0.135 & 0.667741818 & 1.352074131 & 6.158271651 & 0.667741818 & 1.352074131 & 1.282388025 & 1.662364429 \\
\hline 2.6 & 2.053 & 5.8452 & 0.351228 & 0.01 & 0.041 & 0.135 & 0.757033149 & 1.532875296 & 6.222016529 & 0.757033149 & 1.532875296 & 1.451124972 & 1.881098769 \\
\hline
\end{tabular}




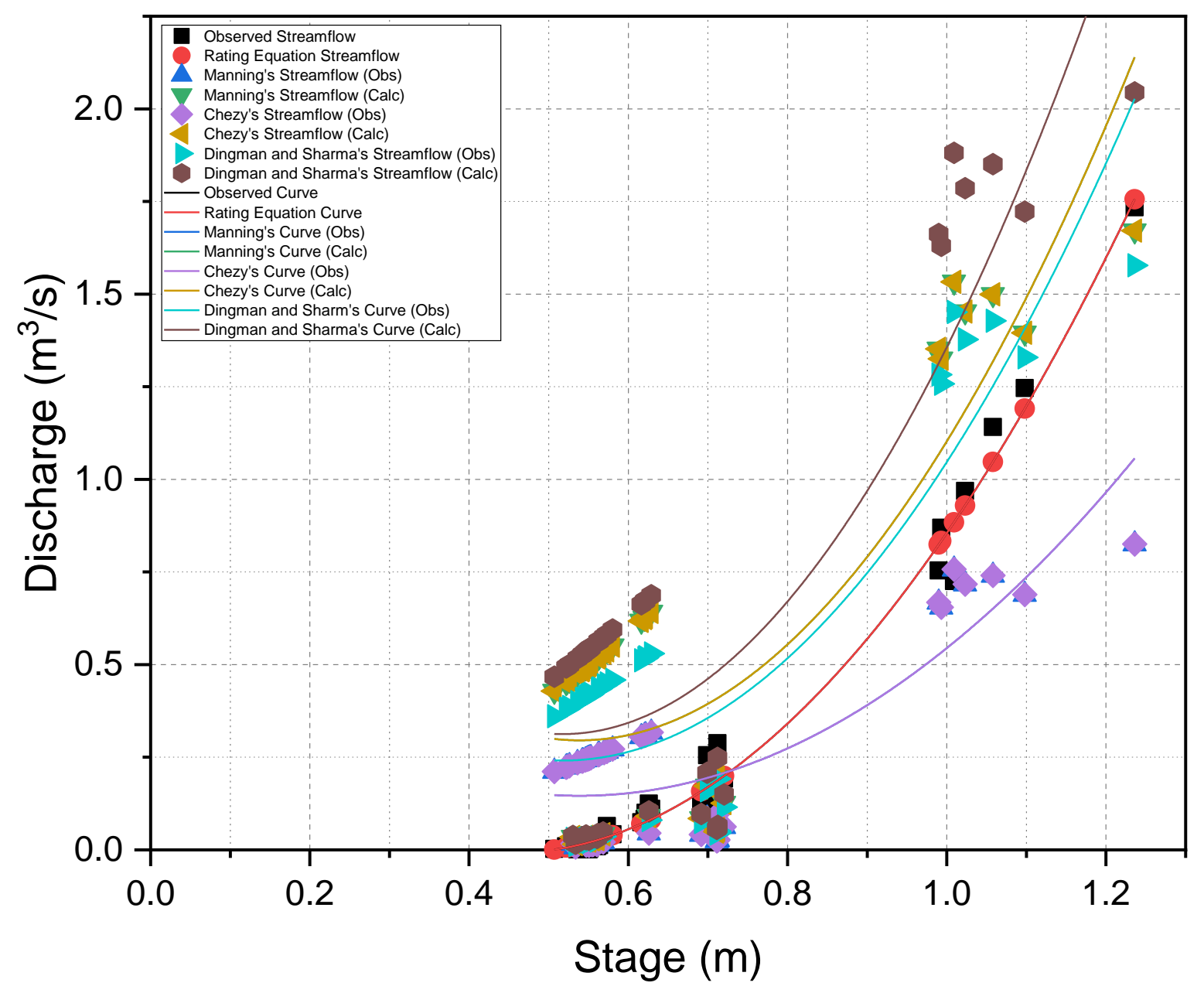

Figure A15-1. Observed and modeled rating curves and streamflow from Site 15, West Run Watershed, Morgantown, West Virginia, U.S.A. 
Table A15-3. Polynomial rating equations and $\mathrm{R}^{2}$ values for observed and modeled rating curves at Site 15, West Run Watershed, Morgantown, WV, U.S.A.

\begin{tabular}{ccc}
\hline & $\begin{array}{c}\mathbf{R}^{\mathbf{2}} \\
\text { Value }\end{array}$ & Polynomial Equation \\
\hline $\begin{array}{c}\text { Observed Curve } \\
\text { Manning's Curve (Obs Slope) }\end{array}$ & 0.99 & $\mathrm{y}=2.8601 \mathrm{x}^{2}-2.5768 \mathrm{x}+0.5719$ \\
Manning's Curve (Calc Slope) & 0.68 & $\mathrm{y}=1.8729 \mathrm{x}^{2}-2.0178 \mathrm{x}+0.6895$ \\
Chezy's Curve (Obs Slope) & 0.68 & $\mathrm{y}=3.7924 \mathrm{x}^{2}-4.0858 \mathrm{x}+1.3961$ \\
$\begin{array}{c}\text { Chezy's Curve (Calc Slope) } \\
\text { Dingman and Sharma's Curve } \\
\text { (Obs Slope) }\end{array}$ & 0.68 & $\mathrm{y}=1.8729 \mathrm{x}^{2}-2.0178 \mathrm{x}+0.6895$ \\
$\begin{array}{c}\text { Dingman and Sharma's Curve } \\
\text { (Calc Slope) }\end{array}$ & 0.73 & $\mathrm{y}=3.7924 \mathrm{x}^{2}-4.0858 \mathrm{x}+1.3961$ \\
& & $\mathrm{y}=3.461 \mathrm{x}^{2}-3.5824 \mathrm{x}+1.1681$ \\
\end{tabular}

Table A15-4. Descriptive statistics for observed and modeled streamflow used to generate the rating curves for Site 15, West Run Watershed, Morgantown, WV, U.S.A.

\begin{tabular}{|c|c|c|c|c|}
\hline & Sample Size & Mean $\left(\mathrm{m}^{3} / \mathrm{s}\right)$ & St. Dev. & SE of Mean \\
\hline Observed & 51 & 0.191 & 0.377 & 0.053 \\
\hline Manning's & 51 & 0.226 & 0.228 & 0.032 \\
\hline \multicolumn{5}{|l|}{$\begin{array}{l}\text { Curve (Obs } \\
\text { Slope) }\end{array}$} \\
\hline & 51 & 0.458 & 0.462 & 0.065 \\
\hline \multicolumn{5}{|l|}{$\begin{array}{c}\text { Curve (Calc } \\
\text { Slope) }\end{array}$} \\
\hline $\begin{array}{c}\text { Chezy's Curve } \\
\text { (Obs Slope) }\end{array}$ & 51 & 0.226 & 0.228 & 0.032 \\
\hline $\begin{array}{l}\text { Chezy's Curve } \\
\text { (Calc Slope) }\end{array}$ & 51 & 0.458 & 0.462 & 0.065 \\
\hline $\begin{array}{c}\text { Dingman and } \\
\text { Sharma's }\end{array}$ & 51 & 0.407 & 0.437 & 0.061 \\
\hline $\begin{array}{l}\text { Curve (Obs } \\
\text { Slope) }\end{array}$ & & & & \\
\hline $\begin{array}{l}\text { Dingman and } \\
\text { Sharma's }\end{array}$ & 51 & 0.527 & 0.566 & 0.079 \\
\hline $\begin{array}{l}\text { Curve (Calc } \\
\text { Slope) }\end{array}$ & & & & \\
\hline
\end{tabular}


Table A15-5. P-values of the statistical analyses (post-hoc ANOVA) for observed and modeled rating curves at Site 15, West Run Watershed, Morgantown, WV, U.S.A.

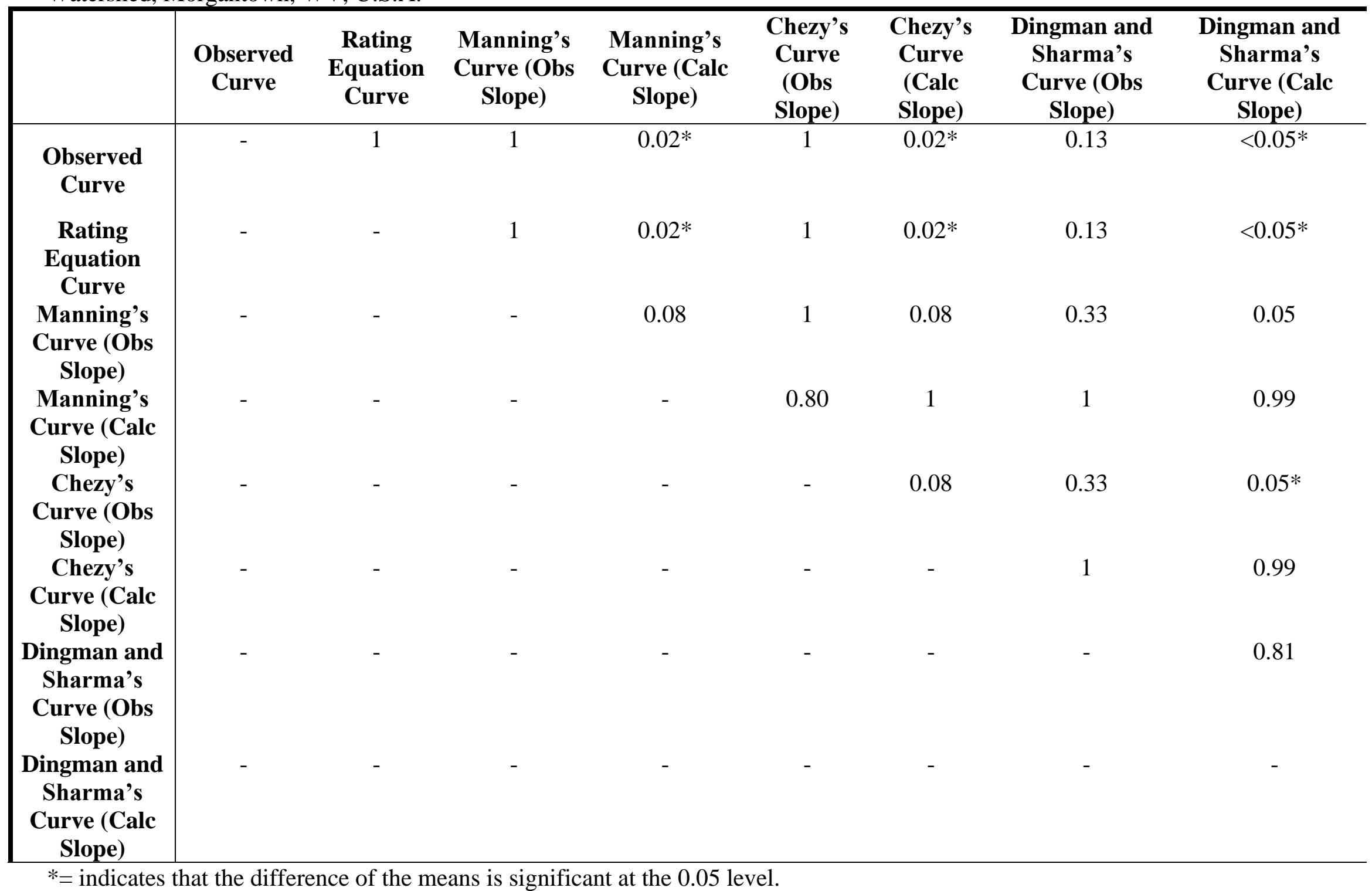




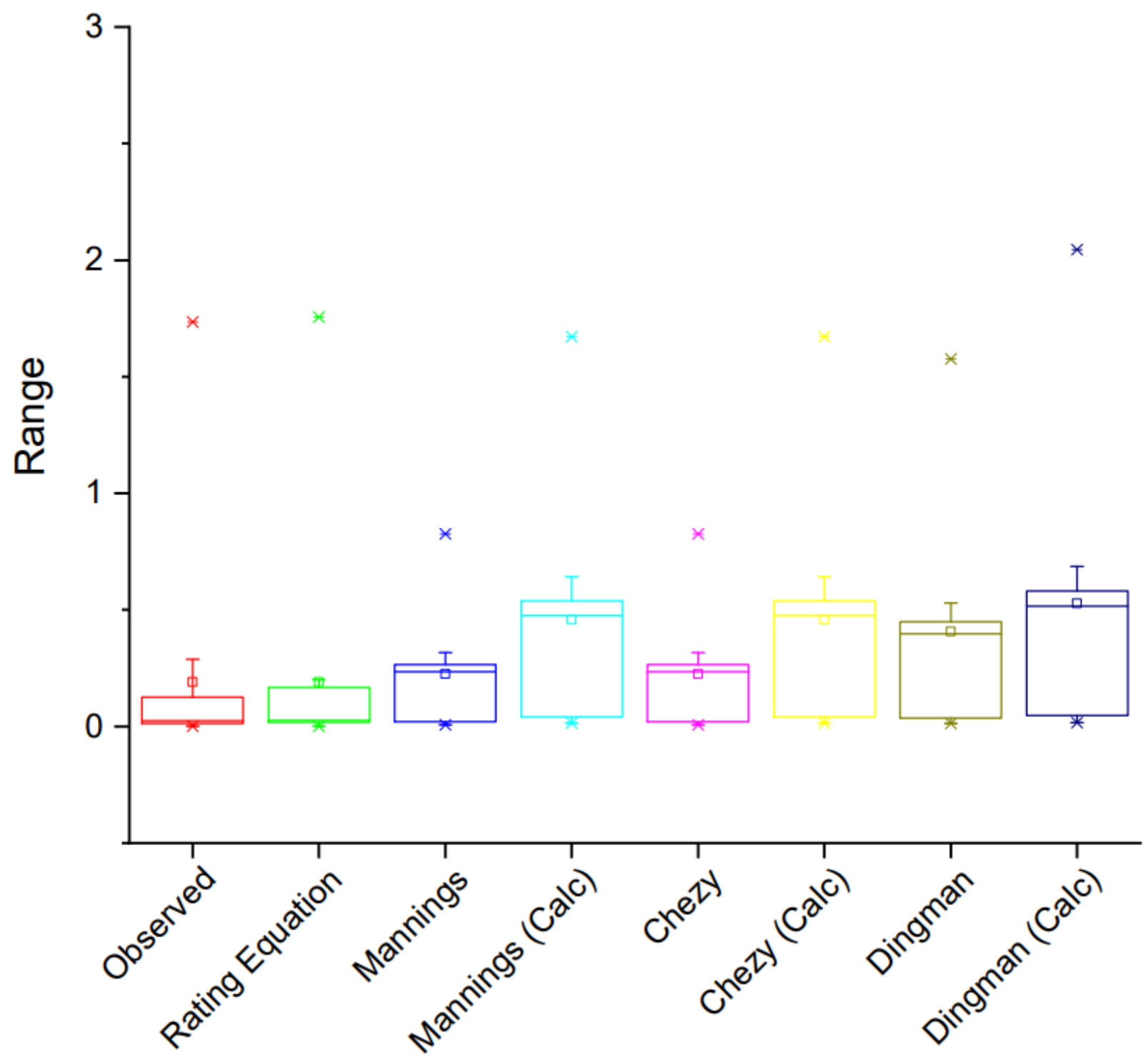

Figure A15-2. Box and whisker plots for the results of the statistical analyses (post-hoc ANOVA) of observed and modeled rating curves at Site 15, West Run Watershed, Morgantown, WV, U.S.A. 


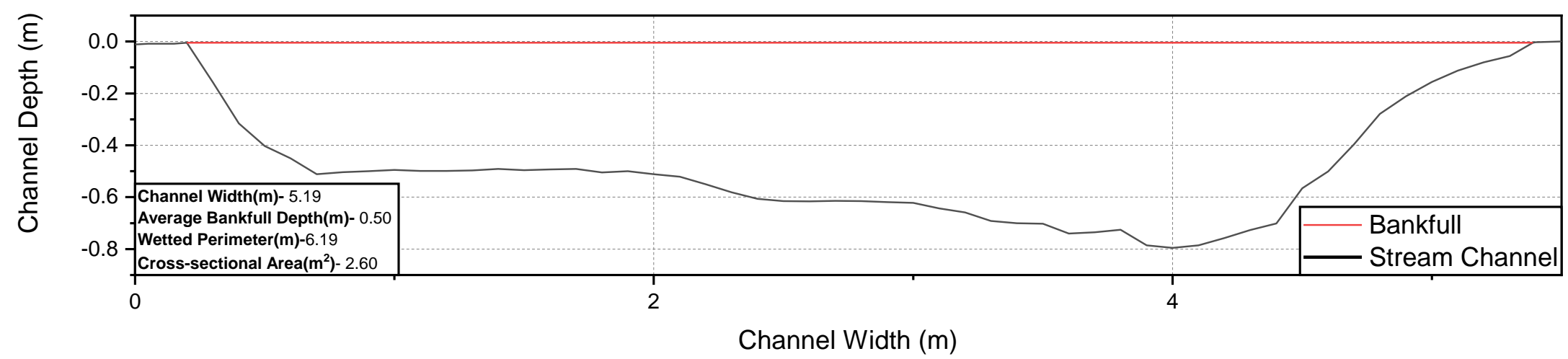

Figure A15-3. Cross-sectional profile of WRW Site 15, plotting the stream channel's shape, water surface, and bankfull. The profile is created with a Channel Width of $0=$ Left Bank facing downstream. 


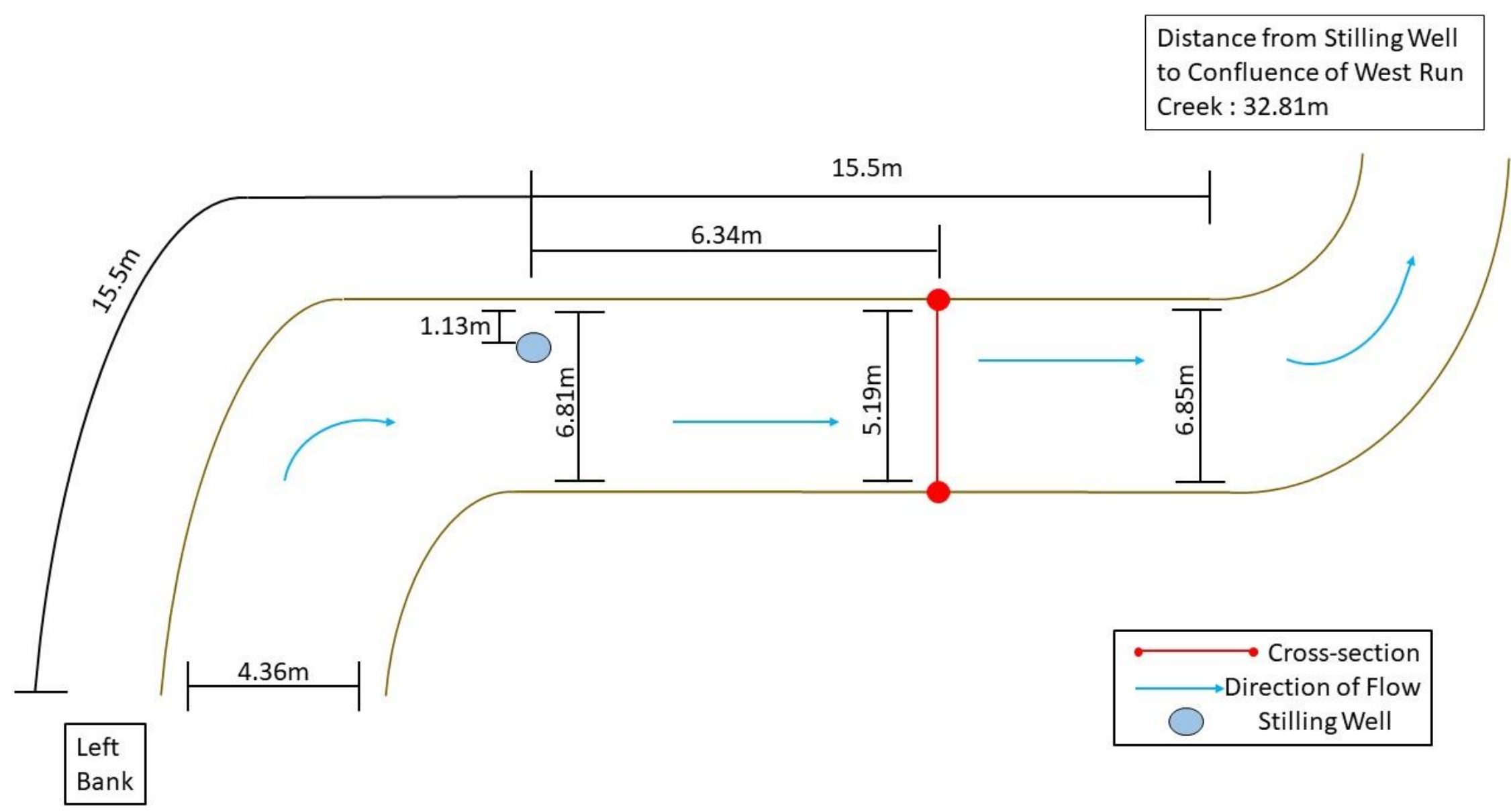

Figure A15-4. Plan view profile of WRW Site 15, West Run Watershed, Morgantown, WV, U.S.A. (Figure 2). Showing the positioning of stilling well in relation to where the streamflow was measured. Along with the channel width at the stilling well, point where cross-sections were performed, and $15.5 \mathrm{~m}$ upstream and downstream from the stilling well. 


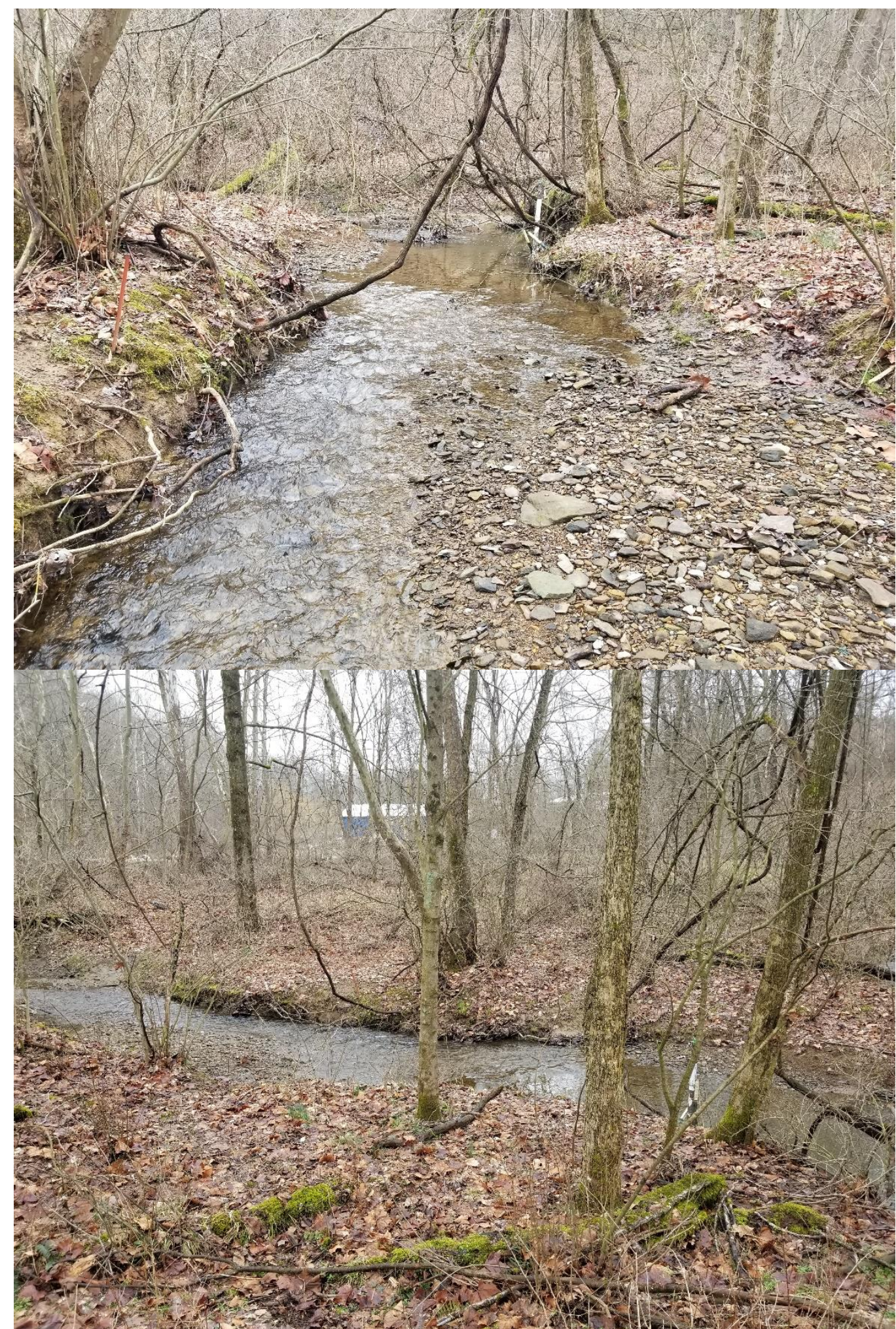

Figure A15-5. Photographs showing channel characteristics at Site \#15, West Run Watershed, Morgantown, WV, U.S.A. Photo 1 was taken looking upstream in the channel. Photo 2 was taken from the left bank looking downstream. 


\section{APPENDIX 16: Site 16}

Table A16-1. Streamflow measurements and stage collected at Site 16, West Run Watershed, Morgantown, WV, U.S.A. (Figure 2).

\begin{tabular}{|c|c|c|c|c|c|c|c|c|c|}
\hline Date & $\begin{array}{l}\text { Mean Depth of } \\
\text { Cross-Section } \\
\text { (m) }\end{array}$ & Stage(PT in cm) & $\begin{array}{c}\text { Barometric } \\
\text { Pressure (in cm) }\end{array}$ & $\begin{array}{c}\text { Pressure } \\
\text { Corrected Stage } \\
\text { (cm) }\end{array}$ & $\begin{array}{l}\text { Stilling Well } \\
\text { Offset (cm) }\end{array}$ & $\begin{array}{l}\text { P-Corrected } \\
\text { Stage + Offset } \\
\text { (cm) }\end{array}$ & $\begin{array}{l}\text { P-Corrected } \\
\text { Stage + Offset } \\
\text { (m) }\end{array}$ & $\begin{array}{c}\text { SonTec } \\
\text { Discharge }(\mathrm{m} 3 / \mathrm{s})\end{array}$ & $\begin{array}{l}\text { Rating Equation } \\
\text { Discharge }(\mathrm{m} 3 / \mathrm{s})\end{array}$ \\
\hline $3 / 16 / 2018$ & 0.0305 & 94.54 & 86.4 & 8.14 & 4.1 & 12.2675 & 0.122675 & 0.0026 & 0.0010 \\
\hline $3 / 23 / 2018$ & 0.0457 & 97.78 & 88.65 & 9.13 & 4.1 & 13.2575 & 0.132575 & 0.0050 & 0.0013 \\
\hline $4 / 5 / 2018$ & 0.0445 & 102.36 & 88.31 & 14.05 & 4.1 & 18.1775 & 0.181775 & 0.0129 & 0.0071 \\
\hline $10 / 2 / 2018$ & 0.0744 & 100.99 & 89.07 & 11.92 & 4.1 & 16.0475 & 0.160475 & 0.0017 & 0.0037 \\
\hline $10 / 2 / 2018$ & 0.0738 & 100.76 & 88.81 & 11.95 & 4.1 & 16.0775 & 0.160775 & 0.0015 & 0.0037 \\
\hline $10 / 2 / 2018$ & 0.0725 & 100.61 & 88.8 & 11.81 & 4.1 & 15.9375 & 0.159375 & 0.0023 & 0.0035 \\
\hline $10 / 16 / 2018$ & 0.0958 & 105.06 & 92.28 & 12.78 & 4.1 & 16.9075 & 0.169075 & 0.0040 & 0.0049 \\
\hline $10 / 16 / 2018$ & 0.0942 & 105.03 & 92.33 & 12.7 & 4.1 & 16.8275 & 0.168275 & 0.0029 & 0.0047 \\
\hline $10 / 25 / 2018$ & 0.0710 & 102.63 & 90.72 & 11.91 & 4.1 & 16.0375 & 0.160375 & 0.0006 & 0.0036 \\
\hline $11 / 1 / 2018$ & 0.0985 & 87.83 & 76.15 & 11.68 & 4.1 & 15.8075 & 0.158075 & 0.0033 & 0.0034 \\
\hline $11 / 13 / 2018$ & 0.0954 & 100.76 & 86.96 & 13.8 & 4.1 & 17.9275 & 0.179275 & 0.0036 & 0.0066 \\
\hline $1 / 29 / 2019$ & 0.0722 & 90.56 & 76.77 & 13.79 & 4.1 & 17.9175 & 0.179175 & 0.0045 & 0.0066 \\
\hline $12 / 10 / 2019$ & 0.1361 & 98.71 & 80.83 & 17.88 & 4.1 & 22.0075 & 0.220075 & 0.0214 & 0.0167 \\
\hline $2 / 13 / 2020$ & 0.0983 & 1021.4 & 990.81 & 30.6 & 4.1 & 34.7 & 0.347 & 0.0769 & 0.0804 \\
\hline $6 / 13 / 2021$ & 0.1088 & 1023.9 & 996.62 & 27.3 & 4.1 & 31.4 & 0.314 & 0.0680 & 0.0592 \\
\hline $6 / 13 / 2021$ & 0.1207 & 1027.5 & 998.26 & 29.2 & 4.1 & 33.3 & 0.333 & 0.0719 & 0.0710 \\
\hline $6 / 13 / 2021$ & 0.1140 & 1031.6 & 996.84 & 34.8 & 4.1 & 38.9 & 0.389 & 0.1110 & 0.1123 \\
\hline $6 / 13 / 2021$ & 0.1289 & 1036 & 996.67 & 39.3 & 4.1 & 43.4 & 0.434 & 0.1548 & 0.1524 \\
\hline $6 / 13 / 2021$ & 0.1155 & 1034 & 996.21 & 37.8 & 4.1 & 41.9 & 0.419 & 0.1399 & 0.1384 \\
\hline $6 / 13 / 2021$ & 0.0927 & 1029.3 & 995.58 & 33.7 & 4.1 & 37.8 & 0.378 & 0.0931 & 0.1035 \\
\hline $8 / 10 / 2021$ & 0.1120 & 1043.6 & 1005.44 & 38.2 & 4.1 & 42.3 & 0.423 & 0.1445 & 0.1421 \\
\hline $8 / 10 / 2021$ & 0.1020 & 1039.6 & 1005.00 & 34.6 & 4.1 & 38.7 & 0.387 & 0.1103 & 0.1107 \\
\hline
\end{tabular}


Table A16-2. Modeled streamflow at Site 16, West Run Watershed, Morgantown, WV, U.S.A.

\begin{tabular}{|c|c|c|c|c|c|c|c|c|c|c|c|c|c|}
\hline $\begin{array}{l}\text { Cross- } \\
\text { Section } \\
\text { Area } \\
\left(\mathrm{m}^{2}\right)\end{array}$ & $\begin{array}{c}\text { A (Cross } \\
\text { Section } \\
\text { area of } \\
\text { flow) }\end{array}$ & $\begin{array}{c}\text { P } \\
\text { (Wetted } \\
\text { Perimete } \\
\text { r) }\end{array}$ & $\begin{array}{l}\text { RH=A/P } \\
\text { Hydraulic } \\
\text { Radius } \\
\text { (m) }\end{array}$ & $\begin{array}{l}\text { Observed } \\
\text { Slope }(m)\end{array}$ & $\begin{array}{l}\text { Calculated } \\
\text { Slope using } \\
\text { ArcGIS (m) }\end{array}$ & $\begin{array}{c}\text { Roughness } \\
\text { Coefficient } \\
\text { (n) }\end{array}$ & $\begin{array}{c}\text { Manning } \\
\text { Discharge } \\
\left(\mathrm{m}^{3} / \mathrm{s}\right) \text { (Obs } \\
\text { Slope) }\end{array}$ & $\begin{array}{c}\text { Manning } \\
\text { Discharge } \\
\left(\mathrm{m}^{3} / \mathrm{s}\right) \text { (Calc } \\
\text { Slope) }\end{array}$ & $\begin{array}{c}\text { Chezy } \\
\text { Coefficient } \\
\text { (C) }\end{array}$ & $\begin{array}{c}\text { Chezy } \\
\text { Discharge } \\
\left(\mathrm{m}^{3} / \mathrm{s}\right)(\text { Obs } \\
\text { Slope) }\end{array}$ & $\begin{array}{c}\text { Chezy } \\
\text { Discharge } \\
\left(\mathrm{m}^{3} / \mathrm{s}\right) \text { (Calc } \\
\text { Slope) }\end{array}$ & $\begin{array}{l}\text { Dingman \& } \\
\text { Sharma } \\
\text { Discharge } \\
\left(\mathrm{m}^{3} / \mathrm{s}\right) \text { (Obs. } \\
\text { Slope) }\end{array}$ & $\begin{array}{l}\text { Dingman \& } \\
\text { Sharma } \\
\text { Discharge } \\
\text { ( } \mathrm{m}^{3} / \mathrm{s} \text { ) (Calc } \\
\text { Slope) }\end{array}$ \\
\hline 1.57 & 0.073 & 1.5796 & 0.046382 & 0.04 & 0.084 & 0.135 & 0.014011763 & 0.020304974 & 4.440088034 & 0.014011763 & 0.020304974 & 0.01671801 & 0.01846992 \\
\hline 1.57 & 0.089 & 1.6207 & 0.054953 & 0.04 & 0.084 & 0.135 & 0.019071568 & 0.027637328 & 4.567349244 & 0.019071568 & 0.027637328 & 0.022496394 & 0.024853831 \\
\hline 1.57 & 0.168 & 1.8127 & 0.092446 & 0.04 & 0.084 & 0.135 & 0.050757772 & 0.073554999 & 4.980976624 & 0.050757772 & 0.073554999 & 0.058140625 & 0.064233283 \\
\hline 1.57 & 0.072 & 1.137 & 0.063325 & 0.04 & 0.084 & 0.135 & 0.016946372 & 0.024557627 & 4.676578587 & 0.016946372 & 0.024557627 & 0.018552462 & 0.020496607 \\
\hline 1.57 & 0.073 & 1.1382 & 0.064136 & 0.04 & 0.084 & 0.135 & 0.017328273 & 0.025111053 & 4.686517877 & 0.017328273 & 0.025111053 & 0.018951393 & 0.020937343 \\
\hline 1.57 & 0.072 & 1.1364 & 0.063358 & 0.04 & 0.084 & 0.135 & 0.016952337 & 0.02456627 & 4.676990022 & 0.016952337 & 0.02456627 & 0.01855638 & 0.020500935 \\
\hline 1.57 & 0.098 & 1.1886 & 0.08245 & 0.04 & 0.084 & 0.135 & 0.027503156 & 0.03985586 & 4.886875668 & 0.027503156 & 0.03985586 & 0.029600977 & 0.032702915 \\
\hline 1.57 & 0.093 & 1.1792 & 0.078867 & 0.04 & 0.084 & 0.135 & 0.025338223 & 0.036718574 & 4.850823556 & 0.025338223 & 0.036718574 & 0.027347045 & 0.03021279 \\
\hline 1.57 & 0.07 & 1.1328 & 0.061794 & 0.04 & 0.084 & 0.135 & 0.016209046 & 0.02348914 & 4.657544698 & 0.016209046 & 0.02348914 & 0.017774592 & 0.019637223 \\
\hline 1.57 & 0.113 & 3.115 & 0.036276 & 0.04 & 0.084 & 0.135 & 0.018345164 & 0.026584668 & 4.261897137 & 0.018345164 & 0.026584668 & 0.025190158 & 0.027829879 \\
\hline 1.57 & 0.109 & 3.049 & 0.035749 & 0.04 & 0.084 & 0.135 & 0.017524089 & 0.025394817 & 4.251521801 & 0.017524089 & 0.025394817 & 0.024006599 & 0.026522292 \\
\hline 1.57 & 0.082 & 1.2872 & 0.063704 & 0.04 & 0.084 & 0.135 & 0.019377093 & 0.028080076 & 4.68123958 & 0.019377093 & 0.028080076 & 0.021661698 & 0.023931665 \\
\hline 1.57 & 0.121 & 1.3392 & 0.090352 & 0.04 & 0.084 & 0.135 & 0.036094543 & 0.052305962 & 4.961993829 & 0.036094543 & 0.052305962 & 0.039319223 & 0.043439554 \\
\hline 1.57 & 0.157 & 1.7966 & 0.087387 & 0.04 & 0.084 & 0.135 & 0.045803084 & 0.066374974 & 4.934474864 & 0.045803084 & 0.066374974 & 0.052661268 & 0.058179735 \\
\hline 1.57 & 0.148 & 2.275 & 0.065055 & 0.04 & 0.084 & 0.135 & 0.035465941 & 0.051395031 & 4.69763876 & 0.035465941 & 0.051395031 & 0.043666747 & 0.048242662 \\
\hline 1.57 & 0.151 & 2.376 & 0.063552 & 0.04 & 0.084 & 0.135 & 0.035625435 & 0.051626161 & 4.679376432 & 0.035625435 & 0.051626161 & 0.044290837 & 0.048932151 \\
\hline 1.57 & 0.243 & 2.362 & 0.102879 & 0.04 & 0.084 & 0.135 & 0.079041181 & 0.114541553 & 5.070537063 & 0.079041181 & 0.114541553 & 0.093835772 & 0.103668987 \\
\hline 1.57 & 0.27493 & 2.392 & 0.114937 & 0.04 & 0.084 & 0.135 & 0.09628508 & 0.139530337 & 5.165072132 & 0.09628508 & 0.139530337 & 0.113374051 & 0.125254716 \\
\hline 1.57 & 0.23795 & 2.289 & 0.103954 & 0.04 & 0.084 & 0.135 & 0.077936676 & 0.112940974 & 5.079327521 & 0.077936676 & 0.112940974 & 0.091933845 & 0.101567753 \\
\hline 1.57 & 0.18348 & 2.167 & 0.08467 & 0.04 & 0.084 & 0.135 & 0.052412898 & 0.075953505 & 4.90856487 & 0.052412898 & 0.075953505 & 0.062431422 & 0.068973721 \\
\hline 1.57 & 0.18 & 1.824 & 0.098684 & 0.04 & 0.084 & 0.135 & 0.056946519 & 0.082523346 & 5.035479629 & 0.056946519 & 0.082523346 & 0.064901605 & 0.071702758 \\
\hline 1.57 & 0.16287 & 1.804 & 0.090283 & 0.04 & 0.084 & 0.135 & 0.048559443 & 0.070369319 & 4.961355253 & 0.048559443 & 0.070369319 & 0.055699738 & 0.061536611 \\
\hline
\end{tabular}




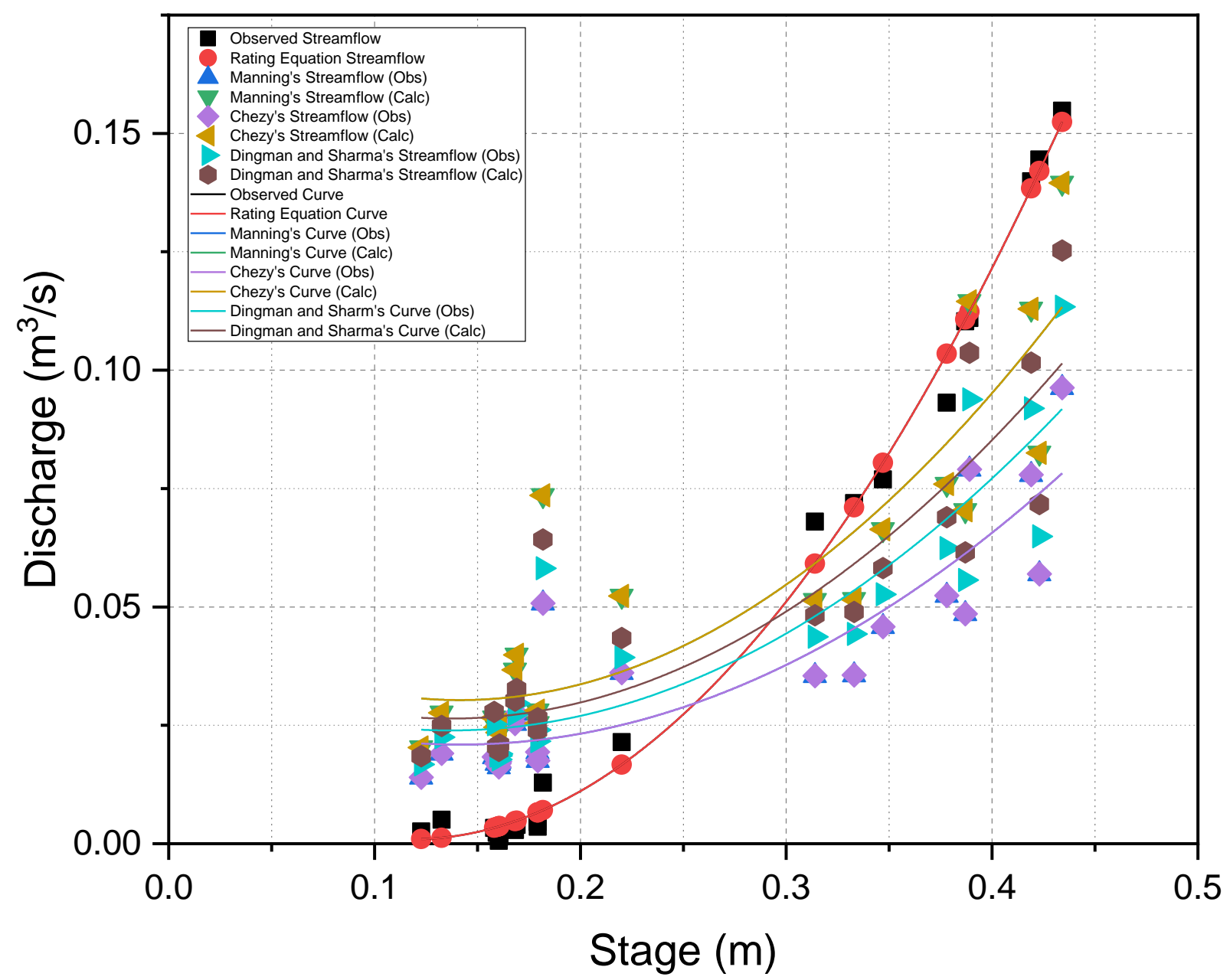

Figure A16-1. Observed and modeled rating curves and streamflow from Site 16, West Run Watershed, Morgantown, West Virginia, U.S.A. 
Table A16-3. Polynomial rating equations and $\mathrm{R}^{2}$ values for observed and modeled rating curves at Site 16, West Run Watershed, Morgantown, WV, U.S.A.

\begin{tabular}{ccc}
\hline & $\mathbf{R}^{\mathbf{2}}$ & Polynomial Equation \\
Value & \\
\hline $\begin{array}{c}\text { Observed Curve } \\
\text { Manning's Curve (Obs Slope) }\end{array}$ & 0.79 & $\mathrm{y}=1.5195 \mathrm{x}^{2}-0.3594 \mathrm{x}+0.0222$ \\
Manning's Curve (Calc Slope) & 0.79 & $\mathrm{y}=0.6688 \mathrm{x}^{2}-0.1891 \mathrm{x}+0.0343$ \\
$\begin{array}{c}\text { Chezy's Curve (Obs Slope) } \\
\text { Chezy's Curve (Calc Slope) }\end{array}$ & 0.79 & $\mathrm{y}=0.9692 \mathrm{x}^{2}-0.274 \mathrm{x}+0.0497$ \\
Dingman and Sharma's Curve & 0.79 & $\mathrm{y}=0.6688 \mathrm{x}^{2}-0.1891 \mathrm{x}+0.0343$ \\
$\begin{array}{c}\text { (Obs Slope) } \\
\text { Dingman and Sharma's Curve } \\
\text { (Calc Slope) }\end{array}$ & 0.80 & $\mathrm{y}=0.9692 \mathrm{x}^{2}-0.274 \mathrm{x}+0.0497$ \\
& & $\mathrm{y}=0.7683 \mathrm{x}^{2}-0.2102 \mathrm{x}+0.0383$ \\
\hline
\end{tabular}

Table A16-4. Descriptive statistics for observed and modeled streamflow used to generate the rating curves for Site 16, West Run Watershed, Morgantown, WV, U.S.A.

\begin{tabular}{|c|c|c|c|c|}
\hline & Sample Size & Mean $\left(\mathrm{m}^{3} / \mathrm{s}\right)$ & St. Dev. & SE of Mean \\
\hline Observed & 22 & 0.047 & 0.056 & 0.012 \\
\hline Manning's & 22 & 0.037 & 0.024 & 0.005 \\
\hline \multicolumn{5}{|l|}{$\begin{array}{l}\text { Curve (Obs } \\
\text { Slope) }\end{array}$} \\
\hline & 22 & 0.054 & 0.034 & 0.007 \\
\hline \multicolumn{5}{|l|}{$\begin{array}{c}\text { Curve (Calc } \\
\text { Slope) }\end{array}$} \\
\hline $\begin{array}{c}\text { Chezy's Curve } \\
\text { (Obs Slope) }\end{array}$ & 22 & 0.037 & 0.024 & 0.005 \\
\hline $\begin{array}{l}\text { Chezy's Curve } \\
\text { (Calc Slope) }\end{array}$ & 22 & 0.054 & 0.034 & 0.007 \\
\hline $\begin{array}{l}\text { Dingman and } \\
\text { Sharma's } \\
\text { Curve (Obs } \\
\text { Slope) }\end{array}$ & 22 & 0.044 & 0.028 & 0.006 \\
\hline $\begin{array}{l}\text { Dingman and } \\
\text { Sharma's } \\
\text { Curve (Calc } \\
\text { Slope) }\end{array}$ & 22 & 0.048 & 0.031 & 0.007 \\
\hline
\end{tabular}


Table A16-5. P-values of the statistical analyses (post-hoc ANOVA) for observed and modeled rating curves at Site 16, West Run Watershed, Morgantown, WV, U.S.A.

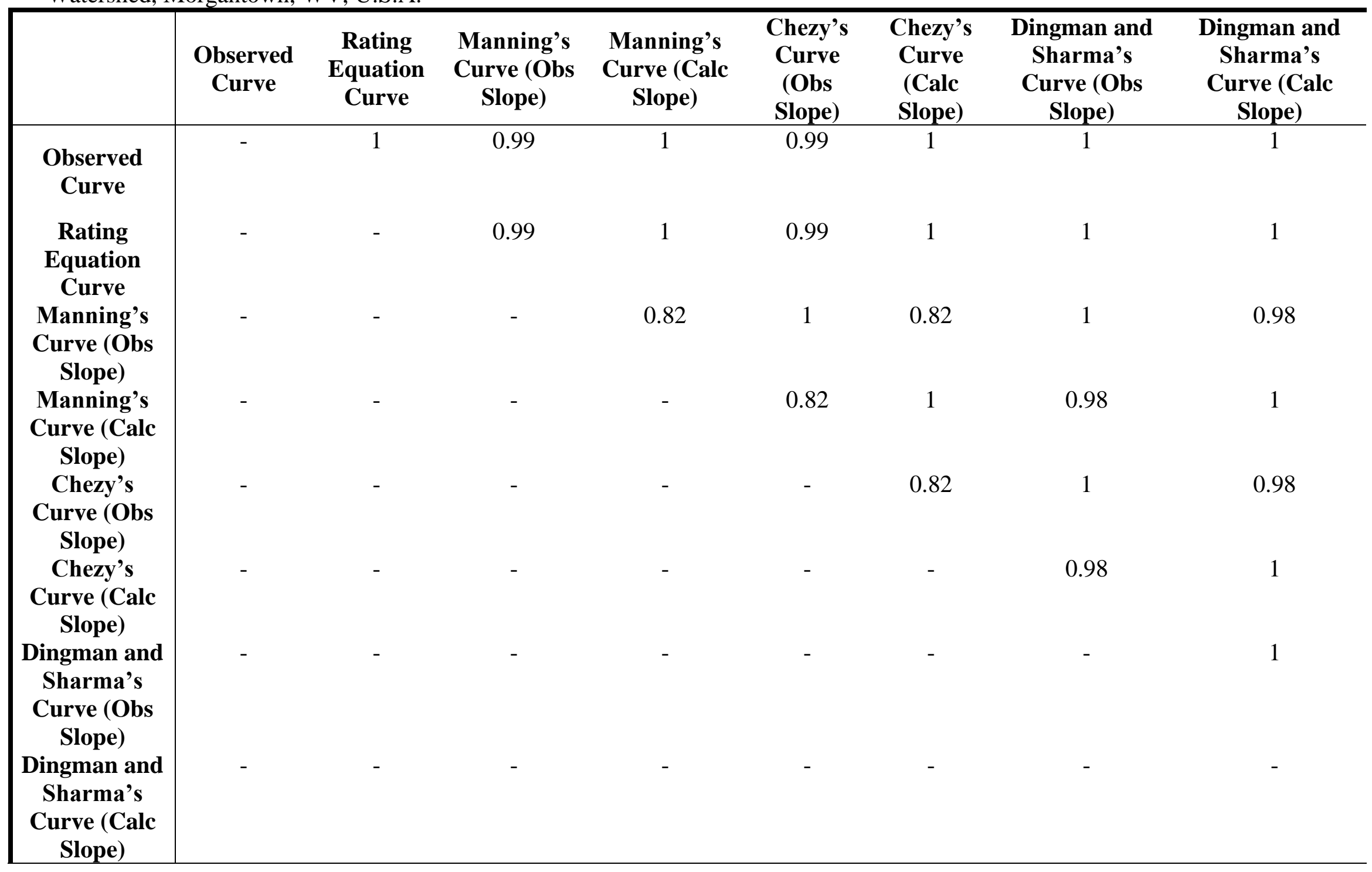




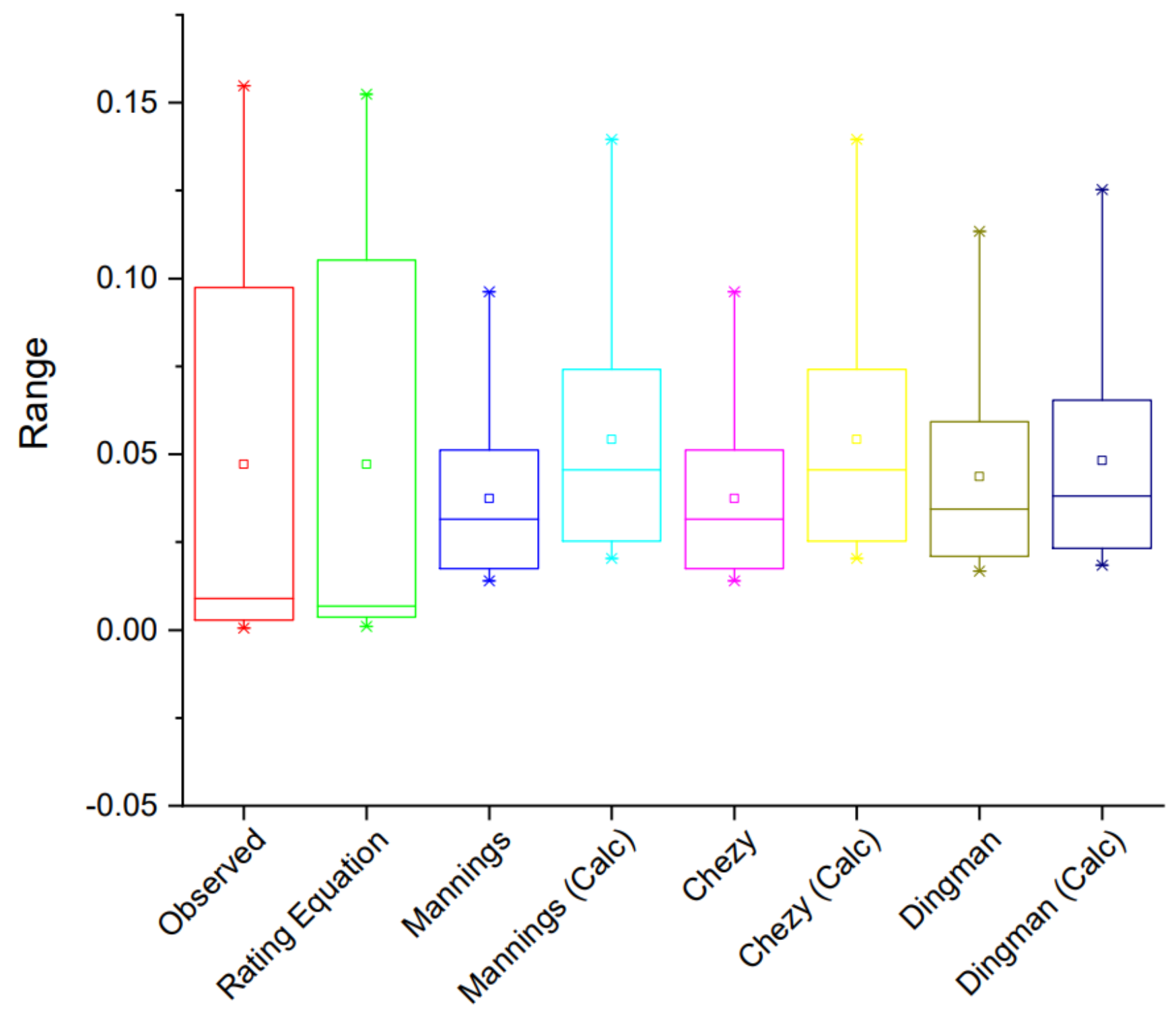

Figure A16-2. Box and whisker plots for the results of the statistical analyses (post-hoc ANOVA) of observed and modeled rating curves at Site 16, West Run Watershed, Morgantown, WV, U.S.A. 


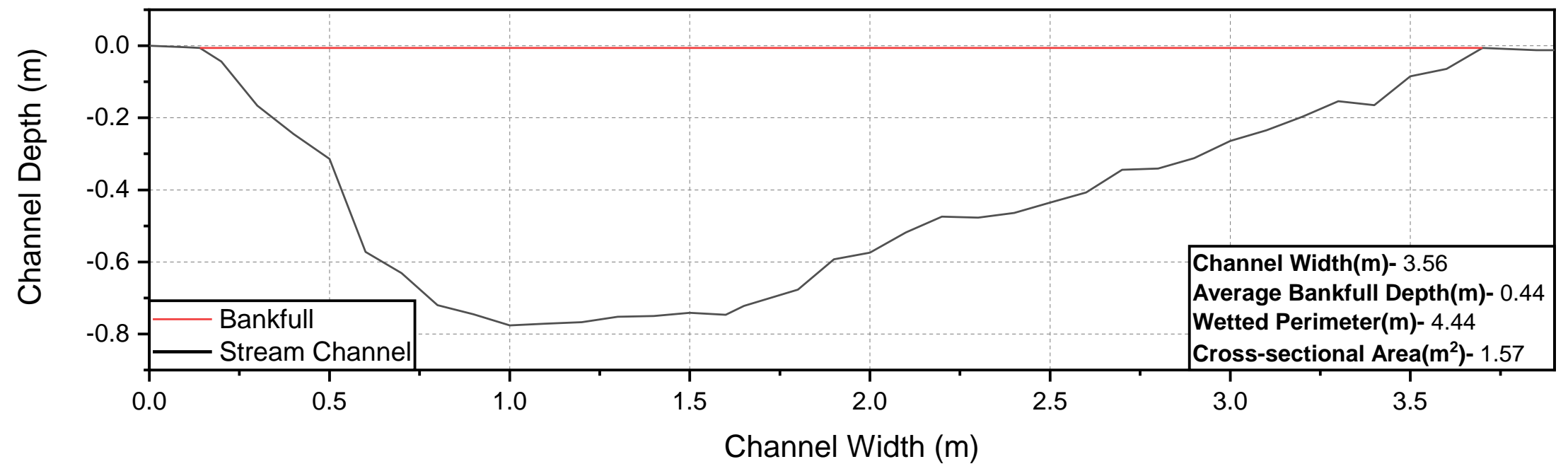

Figure A16-3. Cross-sectional profile of WRW Site 16, plotting the stream channel's shape, water surface, and bankfull. The profile is created with a Channel Width of $0=$ Left Bank facing downstream. 


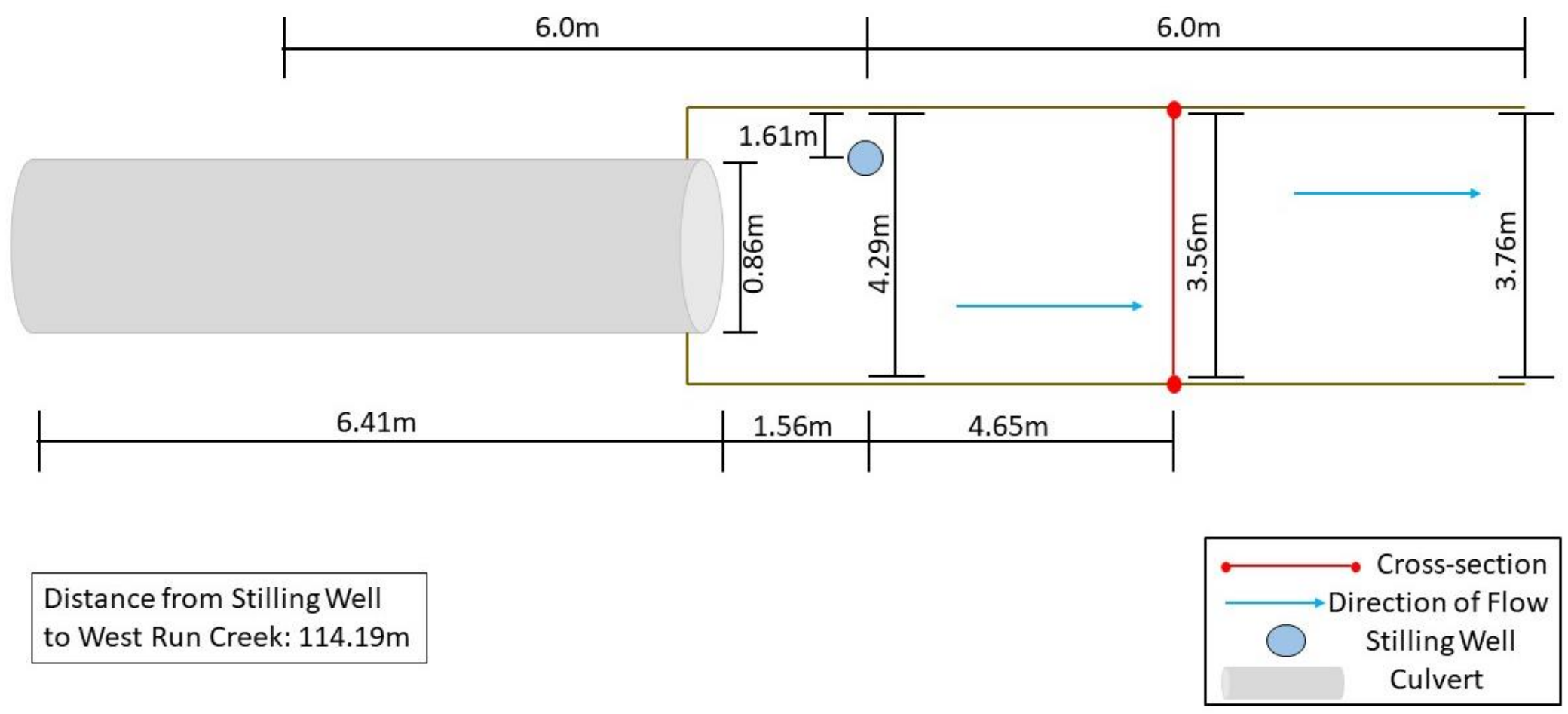

Figure A16-4. Plan view profile of WRW Site 16, West Run Watershed, Morgantown, WV, U.S.A. (Figure 2). Showing the positioning of stilling well in relation to where the streamflow was measured. Along with the channel width at the stilling well, point where cross-sections were performed, and $6.0 \mathrm{~m}$ upstream and downstream from the stilling well. 

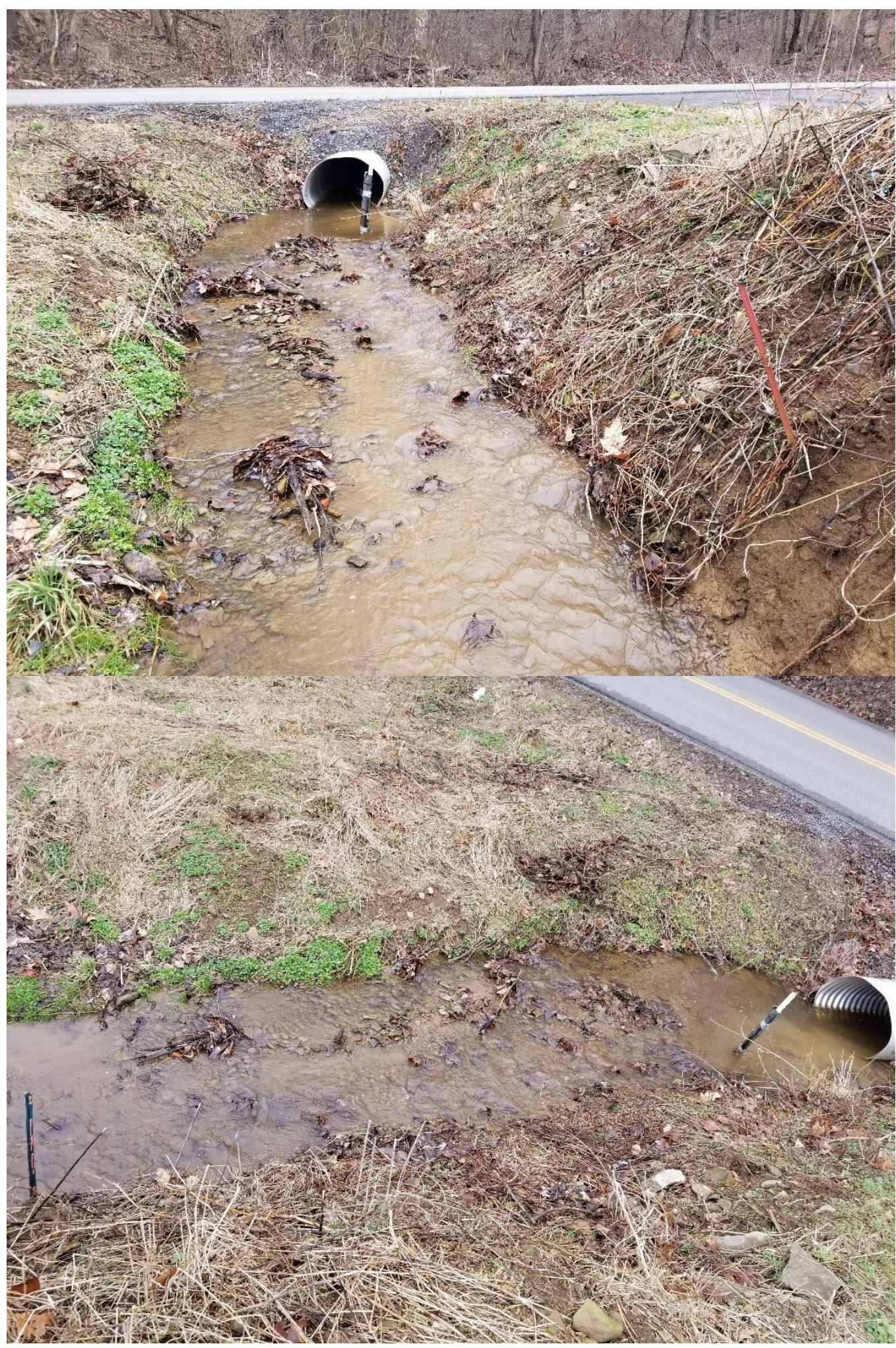

Figure A16-5. Photographs showing channel characteristics at Site \#16, West Run Watershed, Morgantown, WV, U.S.A. Photo 1 was taken looking upstream in the channel. Photo 2 was taken from the left bank looking upstream. 


\section{APPENDIX 17: Site 17}

Table A17-1. Streamflow measurements and stage collected at Site 17, West Run Watershed, Morgantown, WV, U.S.A. (Figure 2).

\begin{tabular}{|c|c|c|c|c|c|c|c|c|c|}
\hline Date & $\begin{array}{l}\text { Mean Depth of } \\
\text { Cross-Section } \\
\text { (m) }\end{array}$ & Stage(PT in cm) & $\begin{array}{c}\text { Barometric } \\
\text { Pressure (in } \mathrm{cm} \text { ) }\end{array}$ & $\begin{array}{c}\text { Pressure } \\
\text { Corrected Stage } \\
\text { (cm) }\end{array}$ & $\begin{array}{l}\text { Stilling Well } \\
\text { Offset (cm) }\end{array}$ & $\begin{array}{l}\text { P-Corrected } \\
\text { Stage + Offset } \\
\text { (cm) }\end{array}$ & $\begin{array}{l}\text { P-Corrected } \\
\text { Stage + Offset } \\
\text { (m) }\end{array}$ & $\begin{array}{c}\text { SonTec } \\
\text { Discharge }(\mathrm{m} 3 / \mathrm{s})\end{array}$ & $\begin{array}{l}\text { Rating Equation } \\
\text { Discharge }(\mathrm{m} 3 / \mathrm{s})\end{array}$ \\
\hline $10 / 24 / 2017$ & 0.0831 & 136.09 & 75.55 & 60.54 & 0 & 60.54 & 0.6054 & 0.0016 & 0.0067 \\
\hline $10 / 24 / 2017$ & 0.0550 & 135.64 & 75.57 & 60.07 & 0 & 60.07 & 0.6007 & 0.0011 & 0.0055 \\
\hline $11 / 6 / 2017$ & 0.2248 & 154.15 & 88.06 & 66.09 & 0 & 66.09 & 0.6609 & 0.0134 & 0.0324 \\
\hline $11 / 7 / 2017$ & 0.2202 & 150.13 & 87.11 & 63.02 & 0 & 63.02 & 0.6302 & 0.0142 & 0.0157 \\
\hline $1 / 15 / 2019$ & 0.0884 & 141.36 & 88.56 & 52.8 & 2 & 54.8 & 0.548 & 0.0041 & 0.0015 \\
\hline $1 / 29 / 2019$ & 0.0686 & 134.53 & 76.6 & 57.93 & 2 & 59.93 & 0.5993 & 0.0118 & 0.0051 \\
\hline $6 / 18 / 2019$ & 0.0741 & 141.53 & 82.79 & 58.74 & 2 & 60.74 & 0.6074 & 0.0133 & 0.0073 \\
\hline $6 / 18 / 2019$ & 0.0744 & 141.33 & 82.67 & 58.66 & 2 & 60.66 & 0.6066 & 0.0152 & 0.0070 \\
\hline $12 / 10 / 2019$ & 0.1131 & 148.35 & 81.2 & 67.15 & 2 & 69.15 & 0.6915 & 0.0334 & 0.0554 \\
\hline $1 / 4 / 2020$ & 0.1257 & 141.17 & 73.63 & 67.54 & 2 & 69.54 & 0.6954 & 0.0517 & 0.0587 \\
\hline $1 / 4 / 2020$ & 0.1372 & 140.78 & 74.01 & 66.77 & 2 & 68.77 & 0.6877 & 0.0565 & 0.0522 \\
\hline $2 / 24 / 2021$ & 0.1580 & 1058.9 & 996.73 & 62.2 & 2 & 64.2 & 0.642 & 0.0313 & 0.0214 \\
\hline $2 / 24 / 2021$ & 0.1540 & 1058.6 & 996.16 & 62.4 & 2 & 64.4 & 0.644 & 0.0299 & 0.0224 \\
\hline $2 / 24 / 2021$ & 0.1660 & 1058.8 & 995.83 & 63 & 2 & 65 & 0.65 & 0.0319 & 0.0258 \\
\hline $2 / 24 / 2021$ & 0.1620 & 1058.5 & 995.78 & 62.7 & 2 & 64.7 & 0.647 & 0.0323 & 0.0241 \\
\hline $2 / 24 / 2021$ & 0.1650 & 1058.1 & 995.44 & 62.7 & 2 & 64.7 & 0.647 & 0.0331 & 0.0241 \\
\hline $2 / 24 / 2021$ & 0.1550 & 1058 & 995.24 & 62.8 & 2 & 64.8 & 0.648 & 0.0334 & 0.0246 \\
\hline $2 / 24 / 2021$ & 0.1690 & 1057.5 & 995.04 & 62.5 & 2 & 64.5 & 0.645 & 0.0323 & 0.0230 \\
\hline $2 / 24 / 2021$ & 0.1660 & 1057.1 & 994.69 & 62.4 & 2 & 64.4 & 0.644 & 0.0364 & 0.0224 \\
\hline $2 / 28 / 2021$ & 0.2410 & 1076.1 & 993.76 & 82.3 & 2 & 84.3 & 0.843 & 0.3023 & 0.2603 \\
\hline $2 / 28 / 2021$ & 0.2210 & 1076.4 & 993.75 & 82.6 & 2 & 84.6 & 0.846 & 0.3112 & 0.2659 \\
\hline $2 / 28 / 2021$ & 0.2080 & 1078.1 & 993.67 & 84.4 & 2 & 86.4 & 0.864 & 0.3193 & 0.3007 \\
\hline $2 / 28 / 2021$ & 0.2130 & 1079.7 & 993.49 & 86.2 & 2 & 88.2 & 0.882 & 0.304 & 0.3376 \\
\hline $2 / 28 / 2021$ & 0.2060 & 1078 & 992.84 & 85.2 & 2 & 87.2 & 0.872 & 0.2837 & 0.3168 \\
\hline $2 / 28 / 2021$ & 0.2190 & 1075.3 & 992.90 & 82.4 & 2 & 84.4 & 0.844 & 0.3039 & 0.2621 \\
\hline $2 / 28 / 2021$ & 0.2250 & 1077.5 & 992.63 & 84.9 & 2 & 86.9 & 0.869 & 0.3108 & 0.3107 \\
\hline $2 / 28 / 2021$ & 0.2110 & 1077.9 & 992.26 & 85.6 & 2 & 87.6 & 0.876 & 0.2792 & 0.3251 \\
\hline $9 / 1 / 2021$ & 0.3130 & 1077.9 & 989.21 & 88.7 & 2 & 90.7 & 0.907 & 0.3541 & 0.3925 \\
\hline $9 / 1 / 2021$ & 0.3140 & 1078.1 & 989.46 & 88.6 & 2 & 90.6 & 0.906 & 0.4142 & 0.3903 \\
\hline $9 / 1 / 2021$ & 0.3130 & 1077 & 989.57 & 87.4 & 2 & 89.4 & 0.894 & 0.4145 & 0.3635 \\
\hline $9 / 1 / 2021$ & 0.3060 & 1076.4 & 989.69 & 86.7 & 2 & 88.7 & 0.887 & 0.3567 & 0.3483 \\
\hline $9 / 1 / 2021$ & 0.2980 & 1077.5 & 989.83 & 87.7 & 2 & 89.7 & 0.897 & 0.3735 & 0.3701 \\
\hline $9 / 1 / 2021$ & 0.2980 & 1077.2 & 989.97 & 87.2 & 2 & 89.2 & 0.892 & 0.3872 & 0.3591 \\
\hline $9 / 1 / 2021$ & 0.2920 & 1076.6 & 989.94 & 86.7 & 2 & 88.7 & 0.887 & 0.3578 & 0.3483 \\
\hline $9 / 1 / 2021$ & 0.2860 & 1076.5 & 990.04 & 86.5 & 2 & 88.5 & 0.885 & 0.3719 & 0.3440 \\
\hline $9 / 1 / 2021$ & 0.2880 & 1075.9 & 990.03 & 85.9 & 2 & 87.9 & 0.879 & 0.3177 & 0.3313 \\
\hline $9 / 1 / 2021$ & 0.2850 & 1075.7 & 990.09 & 85.6 & 2 & 87.6 & 0.876 & 0.3119 & 0.3251 \\
\hline $9 / 1 / 2021$ & 0.2740 & 1074.5 & 990.28 & 84.2 & 2 & 86.2 & 0.862 & 0.3013 & 0.2967 \\
\hline $9 / 1 / 2021$ & 0.2530 & 1073.9 & 990.22 & 83.7 & 2 & 85.7 & 0.857 & 0.2713 & 0.2869 \\
\hline $9 / 1 / 2021$ & 0.2520 & 1074.8 & 990.24 & 84.6 & 2 & 86.6 & 0.866 & 0.2695 & 0.3047 \\
\hline $9 / 1 / 2021$ & 0.2730 & 1074.3 & 990.27 & 84 & 2 & 86 & 0.86 & 0.268 & 0.2928 \\
\hline $9 / 1 / 2021$ & 0.2640 & 1074.2 & 990.37 & 83.8 & 2 & 85.8 & 0.858 & 0.2477 & 0.2888 \\
\hline
\end{tabular}


Table A17-2. Modeled streamflow at Site 17, West Run Watershed, Morgantown, WV, U.S.A.

\begin{tabular}{|c|c|c|c|c|c|c|c|c|c|c|c|c|c|}
\hline $\begin{array}{l}\text { Cross- } \\
\text { Section } \\
\text { Area } \\
\left(\mathrm{m}^{2}\right)\end{array}$ & $\begin{array}{c}\text { A (Cross } \\
\text { Section } \\
\text { area of } \\
\text { flow) }\end{array}$ & $\begin{array}{c}\text { P } \\
\text { (Wetted } \\
\text { Perimete } \\
\text { r) }\end{array}$ & $\begin{array}{c}\text { RH=A/P } \\
\text { Hydraulic } \\
\text { Radius } \\
\text { (m) }\end{array}$ & $\begin{array}{l}\text { Observed } \\
\text { Slope }(m)\end{array}$ & $\begin{array}{l}\text { Calculated } \\
\text { Slope using } \\
\text { ArcGIS (m) }\end{array}$ & $\begin{array}{c}\text { Roughness } \\
\text { Coefficient } \\
\text { (n) }\end{array}$ & $\begin{array}{c}\text { Manning } \\
\text { Discharge } \\
\left(\mathrm{m}^{3} / \mathrm{s}\right) \text { (Obs } \\
\text { Slope) }\end{array}$ & $\begin{array}{c}\text { Manning } \\
\text { Discharge } \\
\left(\mathrm{m}^{3} / \mathrm{s}\right)(\text { Calc } \\
\text { Slope) }\end{array}$ & $\begin{array}{c}\text { Chezy } \\
\text { Coefficient } \\
\text { (C) }\end{array}$ & $\begin{array}{c}\text { Chezy } \\
\text { Discharge } \\
\left(\mathrm{m}^{3} / \mathrm{s}\right) \text { (Obs } \\
\text { Slope) }\end{array}$ & $\begin{array}{c}\text { Chezy } \\
\text { Discharge } \\
\left(\mathrm{m}^{3} / \mathrm{s}\right) \text { (Calc } \\
\text { Slope) }\end{array}$ & $\begin{array}{c}\text { Dingman \& } \\
\text { Sharma } \\
\text { Discharge } \\
\left(\mathrm{m}^{3} / \mathrm{s}\right) \text { (Obs. } \\
\text { Slope) }\end{array}$ & $\begin{array}{c}\text { Dingman \& } \\
\text { Sharma } \\
\text { Discharge } \\
\left(\mathrm{m}^{3} / \mathrm{s}\right) \text { (Calc } \\
\text { Slope) }\end{array}$ \\
\hline 0.85 & 0.051 & 0.7762 & 0.065705 & 0.02 & 0.06 & 0.16 & 0.007340003 & 0.012713258 & 3.970203552 & 0.007340003 & 0.012713258 & 0.011181969 & 0.013310364 \\
\hline 0.85 & 0.045 & 0.7578 & 0.059382 & 0.02 & 0.06 & 0.16 & 0.006054052 & 0.010485925 & 3.903818964 & 0.006054052 & 0.010485925 & 0.009272168 & 0.011037048 \\
\hline 0.85 & 0.214 & 1.3814 & 0.154915 & 0.02 & 0.06 & 0.16 & 0.054559662 & 0.094500106 & 4.580319124 & 0.054559662 & 0.094500106 & 0.084744776 & 0.100875241 \\
\hline 0.85 & 0.207 & 1.3518 & 0.153129 & 0.02 & 0.06 & 0.16 & 0.05236856 & 0.090705006 & 4.571474847 & 0.05236856 & 0.090705006 & 0.081125283 & 0.096566808 \\
\hline 0.85 & 0.067 & 0.9388 & 0.071368 & 0.02 & 0.06 & 0.16 & 0.010189142 & 0.017648112 & 4.025288115 & 0.010189142 & 0.017648112 & 0.015917919 & 0.018947762 \\
\hline 0.85 & 0.047 & 0.8232 & 0.057094 & 0.02 & 0.06 & 0.16 & 0.006159629 & 0.01066879 & 3.878336017 & 0.006159629 & 0.01066879 & 0.009605227 & 0.011433502 \\
\hline 0.85 & 0.056 & 0.9098 & 0.061552 & 0.02 & 0.06 & 0.16 & 0.007716336 & 0.013365085 & 3.927236298 & 0.007716336 & 0.013365085 & 0.012156855 & 0.014470812 \\
\hline 0.85 & 0.057 & 0.9106 & 0.062596 & 0.02 & 0.06 & 0.16 & 0.007942697 & 0.013757155 & 3.938261522 & 0.007942697 & 0.013757155 & 0.012495681 & 0.014874131 \\
\hline 0.85 & 0.112 & 1.2172 & 0.092014 & 0.02 & 0.06 & 0.16 & 0.020176713 & 0.034947093 & 4.199420499 & 0.020176713 & 0.034947093 & 0.032194006 & 0.038321868 \\
\hline 0.85 & 0.125 & 1.2424 & 0.100612 & 0.02 & 0.06 & 0.16 & 0.02390034 & 0.041396603 & 4.262405652 & 0.02390034 & 0.041396603 & 0.037952005 & 0.045175854 \\
\hline 0.85 & 0.136 & 1.2654 & 0.107476 & 0.02 & 0.06 & 0.16 & 0.027173233 & 0.04706542 & 4.309549404 & 0.027173233 & 0.04706542 & 0.043019506 & 0.051207912 \\
\hline 0.85 & 0.192 & 1.5342 & 0.125147 & 0.02 & 0.06 & 0.16 & 0.042459585 & 0.073542158 & 4.42028114 & 0.042459585 & 0.073542158 & 0.068514089 & 0.081555178 \\
\hline 0.85 & 0.188 & 1.5266 & 0.123149 & 0.02 & 0.06 & 0.16 & 0.041131504 & 0.071241855 & 4.408445227 & 0.041131504 & 0.071241855 & 0.066414062 & 0.079055428 \\
\hline 0.85 & 0.203 & 1.5516 & 0.130833 & 0.02 & 0.06 & 0.16 & 0.046241853 & 0.080093239 & 4.453137056 & 0.046241853 & 0.080093239 & 0.074452487 & 0.0886239 \\
\hline 0.85 & 0.197 & 1.5428 & 0.12769 & 0.02 & 0.06 & 0.16 & 0.044153551 & 0.076476194 & 4.435127575 & 0.044153551 & 0.076476194 & 0.071182194 & 0.084731134 \\
\hline 0.85 & 0.201 & 1.5496 & 0.129711 & 0.02 & 0.06 & 0.16 & 0.04552417 & 0.078850176 & 4.446750463 & 0.04552417 & 0.078850176 & 0.073339746 & 0.087299359 \\
\hline 0.85 & 0.188 & 1.528 & 0.123037 & 0.02 & 0.06 & 0.16 & 0.041106376 & 0.071198332 & 4.407771778 & 0.041106376 & 0.071198332 & 0.066389715 & 0.079026446 \\
\hline 0.85 & 0.219 & 1.6326 & 0.134142 & 0.02 & 0.06 & 0.16 & 0.050724216 & 0.08785692 & 4.471714533 & 0.050724216 & 0.08785692 & 0.082198998 & 0.097844896 \\
\hline 0.85 & 0.215 & 1.6266 & 0.132178 & 0.02 & 0.06 & 0.16 & 0.049310409 & 0.085408133 & 4.460733722 & 0.049310409 & 0.085408133 & 0.079967448 & 0.095188589 \\
\hline 0.85 & 0.404 & 2.098 & 0.192564 & 0.02 & 0.06 & 0.16 & 0.119076749 & 0.206246979 & 4.749442829 & 0.119076749 & 0.206246979 & 0.194811927 & 0.231892761 \\
\hline 0.85 & 0.388 & 2.1956 & 0.176717 & 0.02 & 0.06 & 0.16 & 0.107997179 & 0.1870566 & 4.681946369 & 0.107997179 & 0.1870566 & 0.179519184 & 0.213689171 \\
\hline 0.85 & 0.381 & 2.2456 & 0.169665 & 0.02 & 0.06 & 0.16 & 0.103208399 & 0.178762191 & 4.65027654 & 0.103208399 & 0.178762191 & 0.172886816 & 0.205794387 \\
\hline 0.85 & 0.39 & 2.2558 & 0.172888 & 0.02 & 0.06 & 0.16 & 0.106979927 & 0.18529467 & 4.664882257 & 0.106979927 & 0.18529467 & 0.179029352 & 0.213106104 \\
\hline 0.85 & 0.376 & 2.2404 & 0.167827 & 0.02 & 0.06 & 0.16 & 0.101117048 & 0.175139864 & 4.641842467 & 0.101117048 & 0.175139864 & 0.169488448 & 0.201749168 \\
\hline 0.85 & 0.384 & 2.1916 & 0.175214 & 0.02 & 0.06 & 0.16 & 0.106277059 & 0.184077266 & 4.675287684 & 0.106277059 & 0.184077266 & 0.176745493 & 0.210387531 \\
\hline 0.85 & 0.378 & 2.127 & 0.177715 & 0.02 & 0.06 & 0.16 & 0.105609509 & 0.182921035 & 4.686342967 & 0.105609509 & 0.182921035 & 0.174496795 & 0.207710812 \\
\hline 0.85 & 0.354 & 2.0986 & 0.168684 & 0.02 & 0.06 & 0.16 & 0.095524331 & 0.165452995 & 4.645783312 & 0.095524331 & 0.165452995 & 0.158237755 & 0.188356999 \\
\hline 0.85 & 0.54929 & 2.379 & 0.230891 & 0.02 & 0.06 & 0.16 & 0.182726502 & 0.316491586 & 4.895321572 & 0.182726502 & 0.316491586 & 0.30036556 & 0.357537652 \\
\hline 0.85 & 0.55103 & 2.381 & 0.231428 & 0.02 & 0.06 & 0.16 & 0.183589353 & 0.317986087 & 4.897216741 & 0.183589353 & 0.317986087 & 0.301762139 & 0.359200059 \\
\hline 0.85 & 0.54813 & 2.379 & 0.230404 & 0.02 & 0.06 & 0.16 & 0.182083814 & 0.315378417 & 4.89359705 & 0.182083814 & 0.315378417 & 0.299368383 & 0.356350671 \\
\hline 0.85 & 0.53593 & 2.365 & 0.226609 & 0.02 & 0.06 & 0.16 & 0.176070947 & 0.304963825 & 4.880071344 & 0.176070947 & 0.304963825 & 0.289637228 & 0.344767272 \\
\hline 0.85 & 0.522 & 2.349 & 0.222222 & 0.02 & 0.06 & 0.16 & 0.169274098 & 0.293191339 & 4.864198226 & 0.169274098 & 0.293191339 & 0.278639283 & 0.331675959 \\
\hline 0.85 & 0.52229 & 2.349 & 0.222346 & 0.02 & 0.06 & 0.16 & 0.169430863 & 0.293462862 & 4.864648511 & 0.169430863 & 0.293462862 & 0.278882821 & 0.331965853 \\
\hline 0.85 & 0.50022 & 2.299 & 0.217582 & 0.02 & 0.06 & 0.16 & 0.159945044 & 0.277032942 & 4.847119172 & 0.159945044 & 0.277032942 & 0.262823742 & 0.312850062 \\
\hline 0.85 & 0.49035 & 2.287 & 0.214408 & 0.02 & 0.06 & 0.16 & 0.15526058 & 0.268919213 & 4.835262094 & 0.15526058 & 0.268919213 & 0.255246387 & 0.30383042 \\
\hline 0.85 & 0.48339 & 2.252 & 0.214649 & 0.02 & 0.06 & 0.16 & 0.153171816 & 0.265301367 & 4.836170051 & 0.153171816 & 0.265301367 & 0.251115035 & 0.298912699 \\
\hline 0.85 & 0.47729 & 2.246 & 0.212507 & 0.02 & 0.06 & 0.16 & 0.150230832 & 0.260207434 & 4.828091009 & 0.150230832 & 0.260207434 & 0.246411267 & 0.293313607 \\
\hline 0.85 & 0.45987 & 2.224 & 0.206776 & 0.02 & 0.06 & 0.16 & 0.142133666 & 0.246182731 & 4.806143497 & 0.142133666 & 0.246182731 & 0.233330179 & 0.277742643 \\
\hline 0.85 & 0.40413 & 2.106 & 0.191895 & 0.02 & 0.06 & 0.16 & 0.118838708 & 0.20583468 & 4.746685649 & 0.118838708 & 0.20583468 & 0.194614044 & 0.231657213 \\
\hline 0.85 & 0.39368 & 2.066 & 0.190552 & 0.02 & 0.06 & 0.16 & 0.11522509 & 0.199575711 & 4.74113356 & 0.11522509 & 0.199575711 & 0.188195058 & 0.224016426 \\
\hline 0.85 & 0.42677 & 2.108 & 0.202453 & 0.02 & 0.06 & 0.16 & 0.130058203 & 0.225267415 & 4.789246936 & 0.130058203 & 0.225267415 & 0.211956424 & 0.252300571 \\
\hline 0.85 & 0.41284 & 2.092 & 0.197342 & 0.02 & 0.06 & 0.16 & 0.123686845 & 0.214231899 & 4.768883344 & 0.123686845 & 0.214231899 & 0.201790121 & 0.240199196 \\
\hline
\end{tabular}




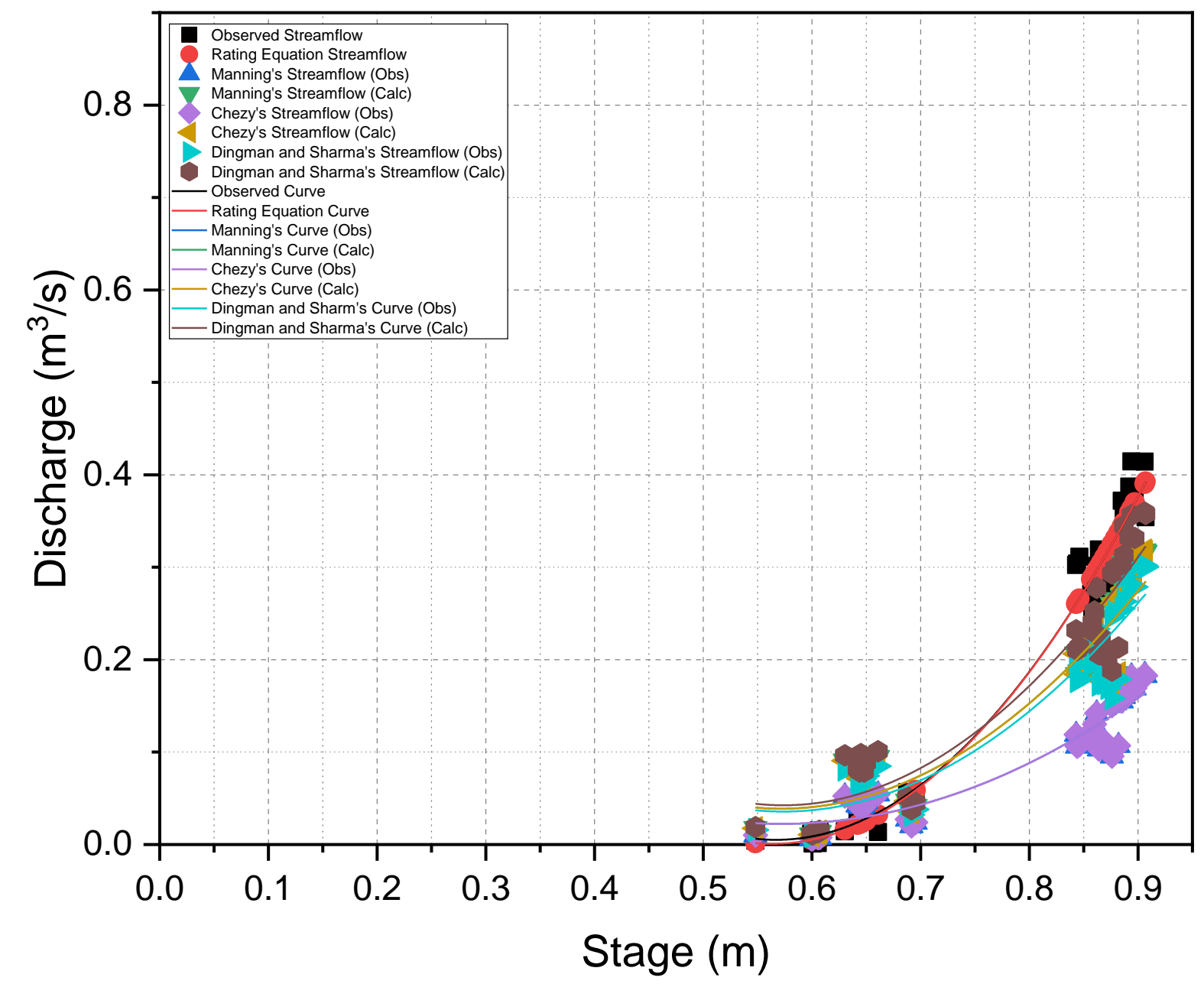

Figure A17-1. Observed and modeled rating curves and streamflow from Site 17, West Run Watershed, Morgantown, West Virginia, U.S.A. 
Table A17-3. Polynomial rating equations and $\mathrm{R}^{2}$ values for observed and modeled rating curves at Site 17, West Run Watershed, Morgantown, WV, U.S.A.

\begin{tabular}{ccc}
\hline & $\begin{array}{c}\mathbf{R}^{\mathbf{2}} \\
\text { Value }\end{array}$ & Polynomial Equation \\
\hline Observed Curve & 0.98 & $\mathrm{y}=3.3489 \mathrm{x}^{2}-3.7972 \mathrm{x}+1.0815$ \\
Manning's Curve (Obs Slope) & 0.89 & $\mathrm{y}=1.2628 \mathrm{x}^{2}-1.4439 \mathrm{x}+0.4352$ \\
Manning's Curve (Calc Slope) & 0.89 & $\mathrm{y}=2.1873 \mathrm{x}^{2}-2.501 \mathrm{x}+0.7537$ \\
Chezy's Curve (Obs Slope) & 0.89 & $\mathrm{y}=1.2628 \mathrm{x}^{2}-1.4439 \mathrm{x}+0.4352$ \\
Chezy's Curve (Calc Slope) & 0.89 & $\mathrm{y}=2.1873 \mathrm{x}^{2}-2.501 \mathrm{x}+0.7537$ \\
$\begin{array}{c}\text { Dingman and Sharma's Curve } \\
\text { (Obs Slope) }\end{array}$ & 0.90 & $\mathrm{y}=2.1191 \mathrm{x}^{2}-2.4314 \mathrm{x}+0.7331$ \\
$\begin{array}{c}\text { Dingman and Sharma's Curve } \\
\text { (Calc Slope) }\end{array}$ & 0.90 & $\mathrm{y}=2.5225 \mathrm{x}^{2}-2.8942 \mathrm{x}+0.8726$ \\
\hline
\end{tabular}

Table A17-4. Descriptive statistics for observed and modeled streamflow used to generate the rating curves for Site 17, West Run Watershed, Morgantown, WV, U.S.A.

\begin{tabular}{|c|c|c|c|c|}
\hline & Sample Size & Mean $\left(\mathrm{m}^{3} / \mathrm{s}\right)$ & St. Dev. & SE of Mean \\
\hline Observed & 42 & 0.188 & 0.154 & 0.024 \\
\hline Manning's & 42 & 0.089 & 0.059 & 0.009 \\
\hline \multicolumn{5}{|l|}{$\begin{array}{l}\text { Curve (Obs } \\
\text { Slope) }\end{array}$} \\
\hline & 42 & 0.154 & 0.103 & 0.016 \\
\hline \multicolumn{5}{|l|}{$\begin{array}{c}\text { Curve (Calc } \\
\text { Slope) }\end{array}$} \\
\hline $\begin{array}{c}\text { Chezy's Curve } \\
\text { (Obs Slope) }\end{array}$ & 42 & 0.089 & 0.059 & 0.009 \\
\hline $\begin{array}{l}\text { Chezy's Curve } \\
\text { (Calc Slope) }\end{array}$ & 42 & 0.154 & 0.103 & 0.016 \\
\hline $\begin{array}{c}\text { Dingman and } \\
\text { Sharma's }\end{array}$ & 42 & 0.146 & 0.098 & 0.015 \\
\hline $\begin{array}{l}\text { Curve (Obs } \\
\text { Slope) }\end{array}$ & & & & \\
\hline $\begin{array}{l}\text { Dingman and } \\
\text { Sharma's }\end{array}$ & 42 & 0.174 & 0.117 & 0.018 \\
\hline $\begin{array}{l}\text { Curve (Calc } \\
\text { Slope) }\end{array}$ & & & & \\
\hline
\end{tabular}


Table A17-5. P-values of the statistical analyses (post-hoc ANOVA) for observed and modeled rating curves at Site 17, West Run Watershed, Morgantown, WV, U.S.A.

\begin{tabular}{|c|c|c|c|c|c|c|c|c|}
\hline & $\begin{array}{l}\text { Observed } \\
\text { Curve }\end{array}$ & $\begin{array}{c}\text { Rating } \\
\text { Equation } \\
\text { Curve }\end{array}$ & $\begin{array}{c}\text { Manning's } \\
\text { Curve (Obs } \\
\text { Slope) }\end{array}$ & $\begin{array}{l}\text { Manning's } \\
\text { Curve (Calc } \\
\text { Slope) }\end{array}$ & $\begin{array}{c}\text { Chezy's } \\
\text { Curve } \\
\text { (Obs } \\
\text { Slope) } \\
\end{array}$ & $\begin{array}{c}\text { Chezy's } \\
\text { Curve } \\
\text { (Calc } \\
\text { Slope) } \\
\end{array}$ & $\begin{array}{c}\text { Dingman and } \\
\text { Sharma's } \\
\text { Curve (Obs } \\
\text { Slope) } \\
\end{array}$ & $\begin{array}{l}\text { Dingman and } \\
\text { Sharma's } \\
\text { Curve (Calc } \\
\text { Slope) }\end{array}$ \\
\hline $\begin{array}{c}\text { Rating } \\
\text { Equation } \\
\text { Curve }\end{array}$ & - & - & $<0.05^{*}$ & 0.86 & $<0.05^{*}$ & 0.86 & 0.69 & 1 \\
\hline $\begin{array}{c}\text { Manning's } \\
\text { Curve (Obs } \\
\text { Slope) }\end{array}$ & - & - & - & 0.13 & 1 & 0.13 & 0.27 & $<0.05^{*}$ \\
\hline $\begin{array}{l}\text { Manning's } \\
\text { Curve (Calc } \\
\text { Slope) }\end{array}$ & - & - & - & - & 0.13 & 1 & 1 & 0.99 \\
\hline $\begin{array}{c}\text { Chezy's } \\
\text { Curve (Calc } \\
\text { Slope) }\end{array}$ & - & - & - & - & - & - & 1 & 0.99 \\
\hline $\begin{array}{l}\text { Dingman and } \\
\text { Sharma's } \\
\text { Curve (Obs } \\
\text { Slope) }\end{array}$ & - & - & - & - & - & - & - & 0.95 \\
\hline $\begin{array}{l}\text { Dingman and } \\
\text { Sharma's } \\
\text { Curve (Calc } \\
\text { Slope) }\end{array}$ & - & - & - & - & - & - & - & - \\
\hline
\end{tabular}




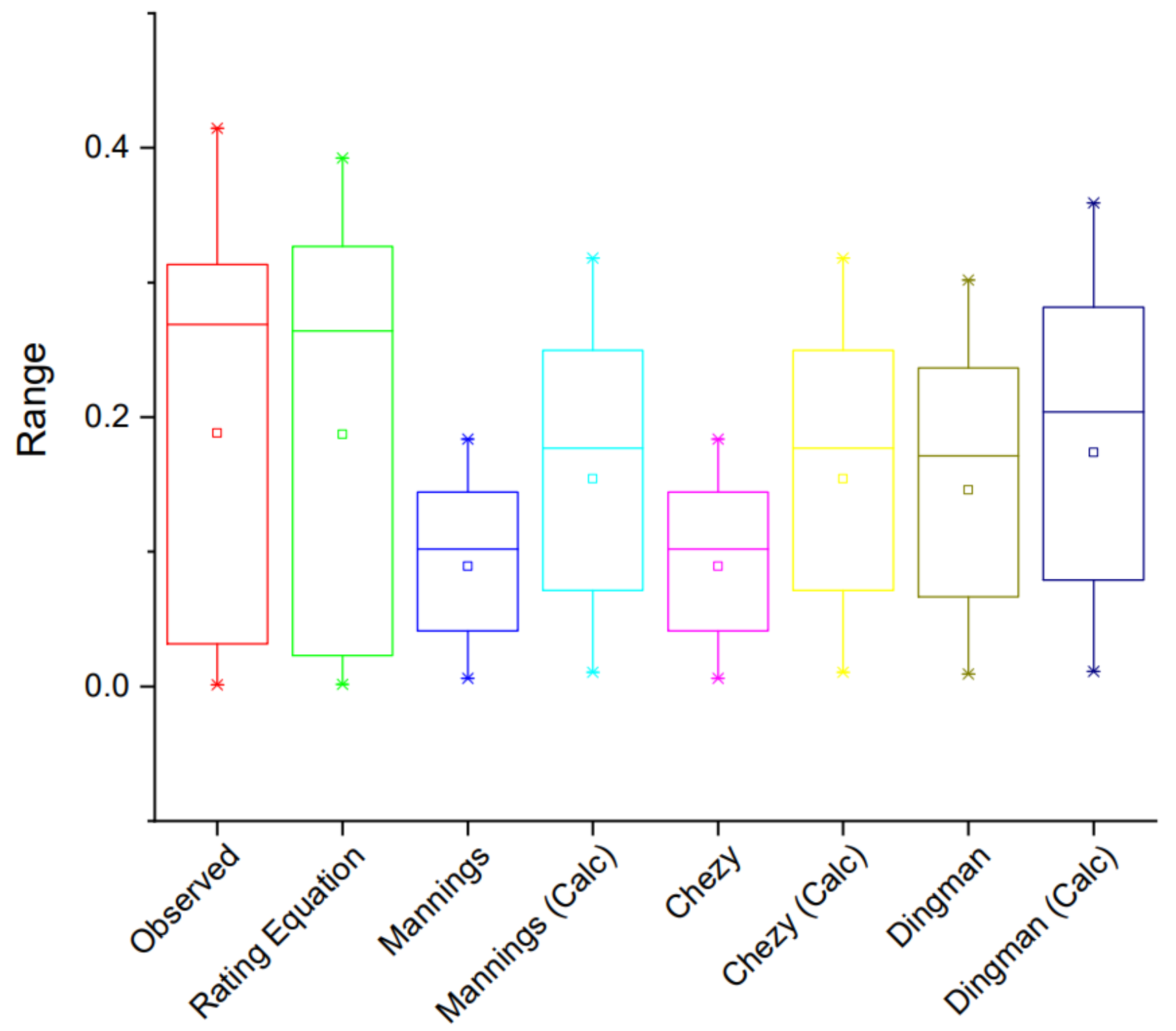

Figure A17-2. Box and whisker plots for the results of the statistical analyses (post-hoc ANOVA) of observed and modeled rating curves at Site 17, West Run Watershed, Morgantown, WV, U.S.A. 


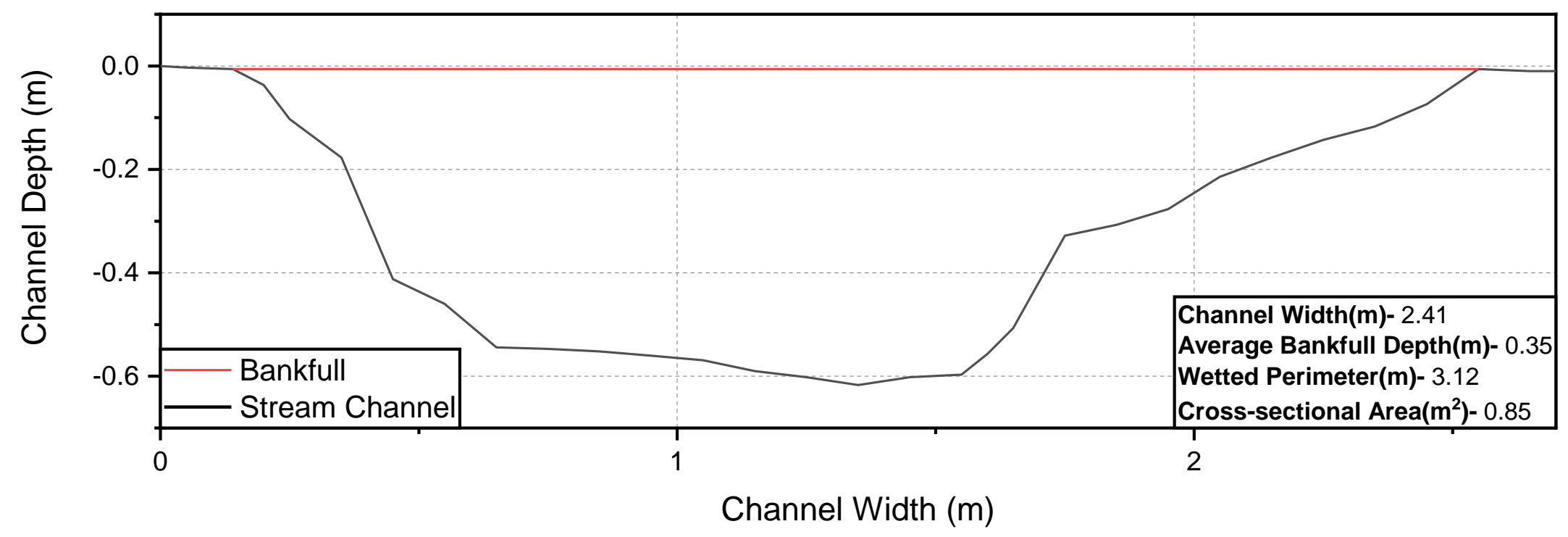

Figure A17-3. Cross-sectional profile of WRW Site 17, plotting the stream channel's shape, water surface, and bankfull. The profile is created with a Channel Width of $0=$ Left Bank facing downstream. 


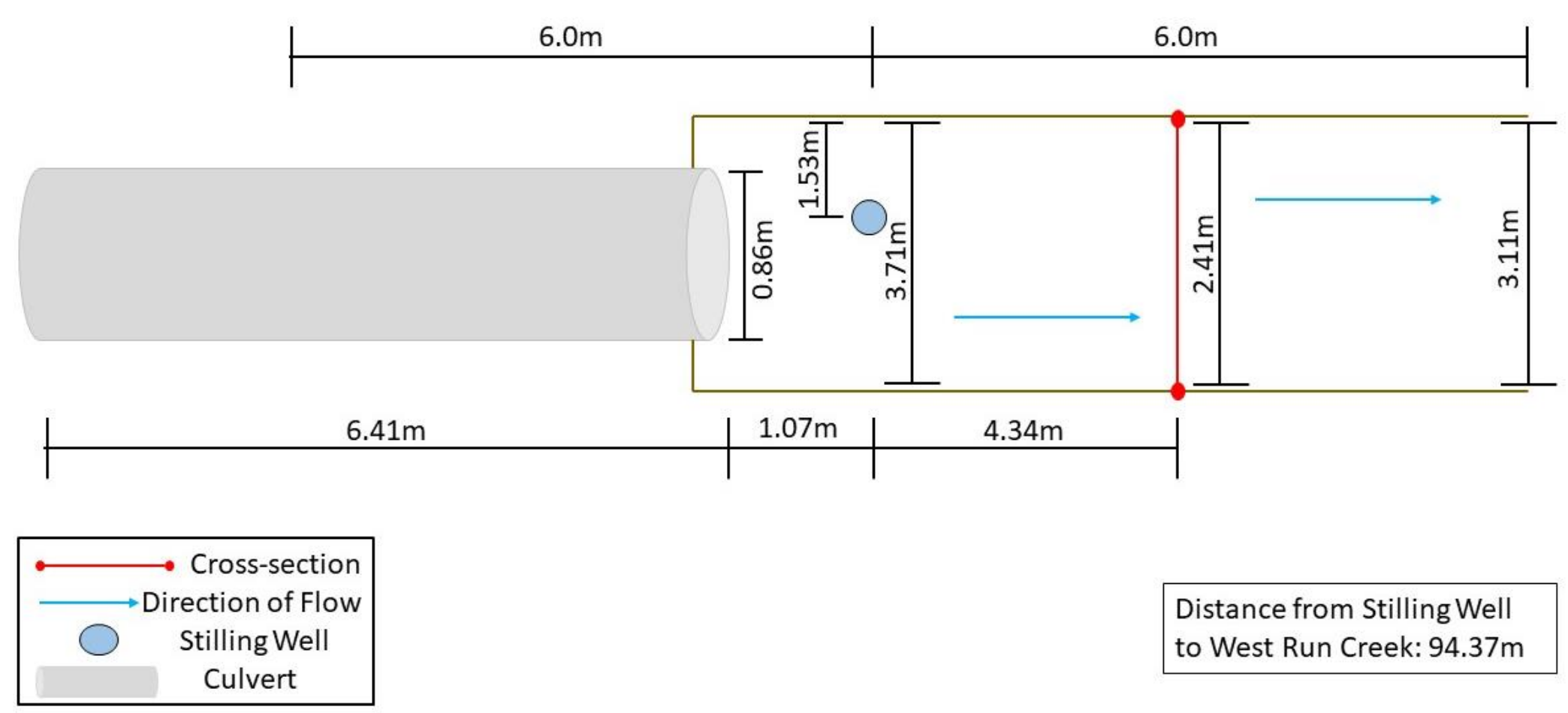

Figure A17-4. Plan view profile of WRW Site 17, West Run Watershed, Morgantown, WV, U.S.A. (Figure 2). Showing the positioning of stilling well in relation to where the streamflow was measured. Along with the channel width at the stilling well, point where cross-sections were performed, and $6.0 \mathrm{~m}$ upstream and downstream from the stilling well. 


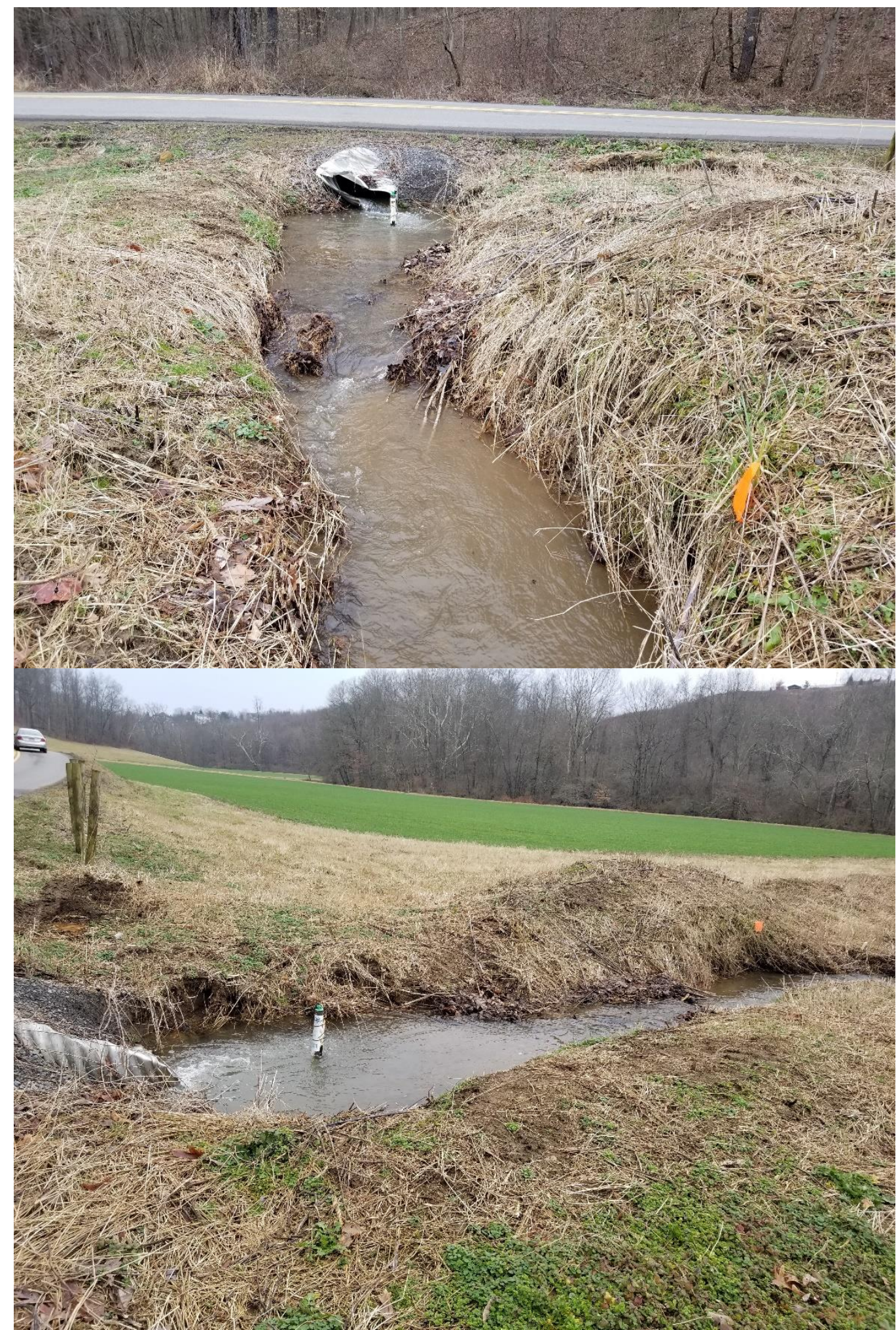

Figure A17-5. Photographs showing channel characteristics at Site \#17, West Run Watershed, Morgantown, WV, U.S.A. Photo 1 was taken looking upstream in the channel. Photo 2 was taken from the right bank looking downstream. 


\section{APPENDIX 18: Site 18}

Table A18-1. Streamflow measurements and stage collected at Site 18, West Run Watershed, Morgantown, WV, U.S.A. (Figure 2).

\begin{tabular}{|c|c|c|c|c|c|c|c|c|c|}
\hline Date & $\begin{array}{l}\text { Mean Depth of } \\
\text { Cross-Section } \\
\text { (m) }\end{array}$ & Stage (PT in cm) & $\begin{array}{c}\text { Barometric } \\
\text { Pressure (in cm) }\end{array}$ & $\begin{array}{c}\text { Pressure } \\
\text { Corrected Stage } \\
\text { (cm) }\end{array}$ & $\begin{array}{l}\text { Stilling Well } \\
\text { Offset (cm) }\end{array}$ & $\begin{array}{c}\text { P-Corrected } \\
\text { Stage + Offset } \\
\text { (cm) }\end{array}$ & $\begin{array}{c}\text { P-Corrected } \\
\text { Stage + Offset } \\
\text { (m) }\end{array}$ & $\begin{array}{c}\text { SonTec } \\
\text { Discharge }(\mathrm{m} 3 / \mathrm{s})\end{array}$ & $\begin{array}{c}\text { Estimated } \\
\text { Discharge }(\mathrm{m} 3 / \mathrm{s})\end{array}$ \\
\hline $9 / 21 / 2017$ & 0.2637 & 114.29 & 87.84 & 26.45 & 6 & 32.45 & 0.3245 & 0.0418 & 0.0007 \\
\hline $9 / 28 / 2017$ & 0.1158 & 111.9 & 85.49 & 26.41 & 6 & 32.41 & 0.3241 & 0.0233 & 0.0021 \\
\hline $10 / 5 / 2017$ & 0.1090 & 116.99 & 91.34 & 25.65 & 6 & 31.65 & 0.3165 & 0.0223 & 0.0294 \\
\hline $10 / 8 / 2017$ & 0.1435 & 109.84 & 81.69 & 28.15 & 6 & 34.15 & 0.3415 & 0.0521 & 0.0609 \\
\hline $10 / 9 / 2017$ & 0.1952 & 110.82 & 78.84 & 31.98 & 6 & 37.98 & 0.3798 & 0.1786 & 0.2020 \\
\hline $10 / 9 / 2017$ & 0.1724 & 110.87 & 80.9 & 29.97 & 6 & 35.97 & 0.3597 & 0.1151 & 0.1276 \\
\hline $10 / 9 / 2017$ & 0.1536 & 110.07 & 81.11 & 28.96 & 6 & 34.96 & 0.3496 & 0.0946 & 0.0905 \\
\hline 10/10/2017 & 0.1098 & 115.27 & 88.5 & 26.77 & 6 & 32.77 & 0.3277 & 0.0466 & 0.0109 \\
\hline $10 / 11 / 2017$ & 0.1309 & 112.1 & 82.56 & 29.54 & 6 & 35.54 & 0.3554 & 0.0655 & 0.1117 \\
\hline $10 / 23 / 2017$ & 0.1117 & 106 & 80.29 & 25.71 & 6 & 31.71 & 0.3171 & 0.0283 & 0.0273 \\
\hline $10 / 23 / 2017$ & 0.1622 & 103.76 & 74.71 & 29.05 & 6 & 35.05 & 0.3505 & 0.0986 & 0.0938 \\
\hline $10 / 24 / 2017$ & 0.2372 & 109.22 & 75.74 & 33.48 & 6 & 39.48 & 0.3948 & 0.2460 & 0.2580 \\
\hline $10 / 24 / 2017$ & 0.2227 & 108.21 & 76.09 & 32.12 & 6 & 38.12 & 0.3812 & 0.2235 & 0.2072 \\
\hline $10 / 29 / 2017$ & 0.3028 & 113.19 & 71.65 & 41.54 & 6 & 47.54 & 0.4754 & 0.5503 & 0.5677 \\
\hline $10 / 30 / 2017$ & 0.2489 & 113.76 & 77.47 & 36.29 & 6 & 42.29 & 0.4229 & 0.3584 & 0.3644 \\
\hline $11 / 3 / 2017$ & 0.1732 & 117.29 & 88.52 & 28.77 & 6 & 34.77 & 0.3477 & 0.0887 & 0.0835 \\
\hline $11 / 6 / 2017$ & 0.3737 & 136.88 & 88.27 & 48.61 & 6 & 54.61 & 0.5461 & 0.8692 & 0.8508 \\
\hline $11 / 7 / 2017$ & 0.3496 & 134.8 & 86.54 & 48.26 & 6 & 54.26 & 0.5426 & 0.9298 & 0.8365 \\
\hline $3 / 8 / 2018$ & 0.2179 & 107.06 & 76.76 & 30.3 & 6.4 & 36.7 & 0.367 & 0.2563 & 0.1545 \\
\hline $3 / 16 / 2018$ & 0.1770 & 114.48 & 86.64 & 27.84 & 6.4 & 34.24 & 0.3424 & 0.1370 & 0.0642 \\
\hline $3 / 23 / 2018$ & 0.1947 & 117.93 & 88.41 & 29.52 & 6.4 & 35.92 & 0.3592 & 0.1998 & 0.1257 \\
\hline $3 / 30 / 2018$ & 0.3923 & 138.1 & 85.78 & 52.32 & 6.4 & 58.72 & 0.5872 & 1.2084 & 1.0203 \\
\hline $4 / 5 / 2018$ & 0.2957 & 130.64 & 88.78 & 41.86 & 6.4 & 48.26 & 0.4826 & 0.6417 & 0.5960 \\
\hline $6 / 18 / 2018$ & 0.2762 & 119.37 & 86.92 & 32.45 & 6.4 & 38.85 & 0.3885 & 0.1835 & 0.2344 \\
\hline $6 / 21 / 2018$ & 0.2670 & 110.57 & 78.91 & 31.66 & 6.4 & 38.06 & 0.3806 & 0.1581 & 0.2049 \\
\hline $6 / 21 / 2018$ & 0.2670 & 110.57 & 79.01 & 31.56 & 6.4 & 37.96 & 0.3796 & 0.1536 & 0.2012 \\
\hline $6 / 21 / 2018$ & 0.2612 & 110.53 & 78.96 & 31.57 & 6.4 & 37.97 & 0.3797 & 0.1607 & 0.2016 \\
\hline $6 / 21 / 2018$ & 0.2600 & 110.49 & 79.02 & 31.47 & 6.4 & 37.87 & 0.3787 & 0.1580 & 0.1979 \\
\hline $6 / 22 / 2018$ & 0.1204 & 115.04 & 78.17 & 36.87 & 6.4 & 43.27 & 0.4327 & 0.3875 & 0.4019 \\
\hline $6 / 22 / 2018$ & 0.1149 & 114.24 & 78.31 & 35.93 & 6.4 & 42.33 & 0.4233 & 0.3586 & 0.3659 \\
\hline $6 / 22 / 2018$ & 0.1119 & 113.58 & 78.16 & 35.42 & 6.4 & 41.82 & 0.4182 & 0.3505 & 0.3465 \\
\hline $6 / 22 / 2018$ & 0.1106 & 113.58 & 78.16 & 35.42 & 6.4 & 41.82 & 0.4182 & 0.3370 & 0.3465 \\
\hline $6 / 27 / 2018$ & 0.1079 & 118.05 & 81.22 & 36.83 & 6.4 & 43.23 & 0.4323 & 0.2937 & 0.4004 \\
\hline $6 / 27 / 2018$ & 0.1094 & 115.84 & 80.88 & 34.96 & 6.4 & 41.36 & 0.4136 & 0.3020 & 0.3290 \\
\hline $6 / 27 / 2018$ & 0.1100 & 114.42 & 80.59 & 33.83 & 6.4 & 40.23 & 0.4023 & 0.3240 & 0.2863 \\
\hline $7 / 6 / 2018$ & 0.1350 & 128.83 & 91.04 & 37.79 & 6.4 & 44.19 & 0.4419 & 0.4384 & 0.4373 \\
\hline $7 / 6 / 2018$ & 0.1177 & 127.17 & 91 & 36.17 & 6.4 & 42.57 & 0.4257 & 0.3728 & 0.3751 \\
\hline $7 / 26 / 2018$ & 0.1155 & 114.08 & 83.54 & 30.54 & 6.4 & 36.94 & 0.3694 & 0.1055 & 0.1633 \\
\hline $9 / 20 / 2018$ & 0.1649 & 121.06 & 88.35 & 32.71 & 6.4 & 39.11 & 0.3911 & 0.2043 & 0.2442 \\
\hline $10 / 25 / 2018$ & 0.1192 & 120.32 & 90.79 & 29.53 & 6.4 & 35.93 & 0.3593 & 0.0694 & 0.1261 \\
\hline 11/1/2018 & 0.1893 & 108.99 & 77.32 & 31.67 & 6.4 & 38.07 & 0.3807 & 0.1721 & 0.2053 \\
\hline 11/1/2018 & 0.1917 & 108.41 & 76.99 & 31.42 & 6.4 & 37.82 & 0.3782 & 0.1729 & 0.1960 \\
\hline $11 / 13 / 2018$ & 0.2429 & 123.54 & 86.42 & 37.12 & 6.4 & 43.52 & 0.4352 & 0.3341 & 0.4115 \\
\hline $10 / 31 / 2019$ & 0.3993 & 122.4 & 68.25 & 54.15 & 6.4 & 60.55 & 0.6055 & 1.2005 & 1.0969 \\
\hline $12 / 10 / 2019$ & 0.4880 & 153.85 & 80.9 & 72.95 & 6.4 & 79.35 & 0.7935 & 1.7393 & 1.9258 \\
\hline $12 / 17 / 2019$ & 0.6046 & 161.36 & 76.38 & 84.98 & 6.4 & 91.38 & 0.9138 & 2.5587 & 2.4960 \\
\hline $1 / 4 / 2020$ & 0.4296 & 135.09 & 73.82 & 61.27 & 6.4 & 67.67 & 0.6767 & 1.3566 & 1.4019 \\
\hline $4 / 8 / 2020$ & 0.4810 & 1051.6 & 988.36 & 63.2 & 6.4 & 69.6 & 0.696 & 1.4515 & 1.4865 \\
\hline $4 / 30 / 2020$ & 0.5810 & 1066.4 & 988.61 & 77.8 & 6.4 & 84.2 & 0.842 & 2.1604 & 2.1519 \\
\hline $4 / 30 / 2020$ & 0.5430 & 1060.8 & 987.36 & 73.4 & 6.4 & 79.8 & 0.798 & 1.9381 & 1.9466 \\
\hline $4 / 30 / 2020$ & 0.5270 & 1059 & 988.51 & 70.5 & 6.4 & 76.9 & 0.769 & 1.8271 & 1.8135 \\
\hline $4 / 30 / 2020$ & 0.5080 & 1056.6 & 988.64 & 68 & 6.4 & 74.4 & 0.744 & 1.7150 & 1.7002 \\
\hline $4 / 30 / 2020$ & 0.4930 & 1053.9 & 987.84 & 66.1 & 6.4 & 72.5 & 0.725 & 1.6176 & 1.6150 \\
\hline
\end{tabular}


Table A18-2. Modeled streamflow at Site 18, West Run Watershed, Morgantown, WV, U.S.A.

\begin{tabular}{|c|c|c|c|c|c|c|c|c|c|c|c|c|c|}
\hline $\begin{array}{l}\text { Cross- } \\
\text { Section } \\
\text { Area } \\
\left(\mathrm{m}^{2}\right)\end{array}$ & $\begin{array}{c}\text { A (Cross } \\
\text { Section } \\
\text { area of } \\
\text { flow) }\end{array}$ & $\begin{array}{c}\text { P } \\
\text { (Wetted } \\
\text { Perimete } \\
\text { r) }\end{array}$ & $\begin{array}{c}\text { RH=A/P } \\
\text { Hydraulic } \\
\text { Radius } \\
\text { (m) }\end{array}$ & $\begin{array}{l}\text { Observed } \\
\text { Slope }(m)\end{array}$ & $\begin{array}{l}\text { Calculated } \\
\text { Slope using } \\
\text { ArcGIS (m) }\end{array}$ & $\begin{array}{l}\text { Roughness } \\
\text { Coefficient } \\
\text { (n) }\end{array}$ & $\begin{array}{c}\text { Manning } \\
\text { Discharge } \\
\left(\mathrm{m}^{3} / \mathrm{s}\right)(\mathrm{Obs} \\
\text { Slope) }\end{array}$ & $\begin{array}{c}\text { Manning } \\
\text { Discharge } \\
\left(\mathrm{m}^{3} / \mathrm{s}\right) \text { (Calc } \\
\text { Slope) }\end{array}$ & $\begin{array}{c}\text { Chezy } \\
\text { Coefficient } \\
\text { (C) }\end{array}$ & $\begin{array}{c}\text { Chezy } \\
\text { Discharge } \\
\left(\mathrm{m}^{3} / \mathrm{s}\right) \text { (Obs } \\
\text { Slope) }\end{array}$ & $\begin{array}{c}\text { Chezy } \\
\text { Discharge } \\
\left(\mathrm{m}^{3} / \mathrm{s}\right) \text { (Calc } \\
\text { Slope) }\end{array}$ & $\begin{array}{c}\text { Dingman \& } \\
\text { Sharma } \\
\text { Discharge } \\
\left(\mathrm{m}^{3} / \mathrm{s}\right) \text { (Obs. } \\
\text { Slope) }\end{array}$ & $\begin{array}{c}\text { Dingman \& } \\
\text { Sharma } \\
\text { Discharge } \\
\text { (m } \mathrm{m}^{3} / \mathrm{s} \text { ) (Calc } \\
\text { Slope) }\end{array}$ \\
\hline 9.35 & 0.395 & 2.2517 & 0.175571 & 0.01 & 0.017 & 0.088 & 0.140859767 & 0.183658666 & 8.503404607 & 0.140859767 & 0.183658666 & 0.15924322 & 0.177513244 \\
\hline 9.35 & 0.395 & 2.2507 & 0.175364 & 0.01 & 0.017 & 0.088 & 0.140521917 & 0.183218164 & 8.501735051 & 0.140521917 & 0.183218164 & 0.158866777 & 0.177093613 \\
\hline 9.35 & 0.383 & 2.2317 & 0.171422 & 0.01 & 0.017 & 0.088 & 0.134154945 & 0.174916648 & 8.46957739 & 0.134154945 & 0.174916648 & 0.151769384 & 0.169181933 \\
\hline 9.35 & 0.459 & 3.487 & 0.131632 & 0.01 & 0.017 & 0.088 & 0.134969976 & 0.175979319 & 8.104833875 & 0.134969976 & 0.175979319 & 0.169078086 & 0.188476468 \\
\hline 9.35 & 0.803 & 4.5054 & 0.178231 & 0.01 & 0.017 & 0.088 & 0.288993229 & 0.37680107 & 8.524737726 & 0.288993229 & 0.37680107 & 0.367841699 & 0.410044292 \\
\hline 9.35 & 0.657 & 4.1548 & 0.15813 & 0.01 & 0.017 & 0.088 & 0.218319668 & 0.284654021 & 8.356412479 & 0.218319668 & 0.284654021 & 0.2771067 & 0.308899238 \\
\hline 9.35 & 0.585 & 4.1172 & 0.142087 & 0.01 & 0.017 & 0.088 & 0.181012734 & 0.236011731 & 8.208736433 & 0.181012734 & 0.236011731 & 0.231703258 & 0.258286646 \\
\hline 9.35 & 0.400 & 2.2596 & 0.177222 & 0.01 & 0.017 & 0.088 & 0.143572437 & 0.187195555 & 8.516681537 & 0.143572437 & 0.187195555 & 0.16226514 & 0.180881871 \\
\hline 9.35 & 0.445 & 2.3237 & 0.191354 & 0.01 & 0.017 & 0.088 & 0.167786787 & 0.218767205 & 8.6262793 & 0.167786787 & 0.218767205 & 0.189188176 & 0.210893795 \\
\hline 9.35 & 0.384 & 2.2333 & 0.171734 & 0.01 & 0.017 & 0.088 & 0.134653993 & 0.175567327 & 8.472147052 & 0.134653993 & 0.175567327 & 0.152325894 & 0.169802292 \\
\hline 9.35 & 0.437 & 2.3128 & 0.188872 & 0.01 & 0.017 & 0.088 & 0.163407696 & 0.213057569 & 8.607529708 & 0.163407696 & 0.213057569 & 0.184326466 & 0.2054743 \\
\hline 9.35 & 0.977 & 4.5362 & 0.215379 & 0.01 & 0.017 & 0.088 & 0.39891479 & 0.520121251 & 8.798008747 & 0.39891479 & 0.520121251 & 0.499417803 & 0.556716164 \\
\hline 9.35 & 0.921 & 4.4952 & 0.204885 & 0.01 & 0.017 & 0.088 & 0.363734112 & 0.474251259 & 8.725073545 & 0.363734112 & 0.474251259 & 0.456791001 & 0.509198776 \\
\hline 9.35 & 0.636 & 2.5253 & 0.251908 & 0.01 & 0.017 & 0.088 & 0.288337124 & 0.375945614 & 9.030761931 & 0.288337124 & 0.375945614 & 0.321442789 & 0.358322021 \\
\hline 9.35 & 0.552 & 2.4523 & 0.22524 & 0.01 & 0.017 & 0.088 & 0.232365864 & 0.30296802 & 8.863898451 & 0.232365864 & 0.30296802 & 0.260450264 & 0.290331805 \\
\hline 9.35 & 0.432 & 2.3065 & 0.187451 & 0.01 & 0.017 & 0.088 & 0.160923844 & 0.209819023 & 8.596700647 & 0.160923844 & 0.209819023 & 0.181567399 & 0.202398684 \\
\hline 9.35 & 1.686 & 5.2584 & 0.32063 & 0.01 & 0.017 & 0.088 & 0.897520132 & 1.17022308 & 9.401229464 & 0.897520132 & 1.17022308 & 1.110560593 & 1.237975559 \\
\hline 9.35 & 0.743 & 2.5841 & 0.287677 & 0.01 & 0.017 & 0.088 & 0.368128087 & 0.479980303 & 9.232830414 & 0.368128087 & 0.479980303 & 0.406939565 & 0.453627869 \\
\hline 9.35 & 0.463 & 2.3486 & 0.197207 & 0.01 & 0.017 & 0.088 & 0.178318112 & 0.232498372 & 8.669707128 & 0.178318112 & 0.232498372 & 0.200866153 & 0.22391159 \\
\hline 9.35 & 0.424 & 2.2944 & 0.184754 & 0.01 & 0.017 & 0.088 & 0.15625904 & 0.203736861 & 8.57596377 & 0.15625904 & 0.203736861 & 0.176382912 & 0.196619378 \\
\hline 9.35 & 0.451 & 2.3320 & 0.193274 & 0.01 & 0.017 & 0.088 & 0.171211199 & 0.223232092 & 8.640649963 & 0.171211199 & 0.223232092 & 0.192987641 & 0.215129173 \\
\hline 9.35 & 0.815 & 2.6016 & 0.313092 & 0.01 & 0.017 & 0.088 & 0.426793659 & 0.556470849 & 9.364024627 & 0.426793659 & 0.556470849 & 0.468612798 & 0.522376891 \\
\hline 9.35 & 0.648 & 2.5335 & 0.255632 & 0.01 & 0.017 & 0.088 & 0.296431019 & 0.386498762 & 9.052877665 & 0.296431019 & 0.386498762 & 0.3301962 & 0.368079713 \\
\hline 9.35 & 1.599 & 6.3432 & 0.252081 & 0.01 & 0.017 & 0.088 & 0.725090972 & 0.945402961 & 9.031793601 & 0.725090972 & 0.945402961 & 0.947909815 & 1.056663806 \\
\hline 9.35 & 1.505 & 6.1728 & 0.243812 & 0.01 & 0.017 & 0.088 & 0.6674571 & 0.870257586 & 8.981724097 & 0.6674571 & 0.870257586 & 0.871181774 & 0.971132732 \\
\hline 9.35 & 1.505 & 6.1728 & 0.243812 & 0.01 & 0.017 & 0.088 & 0.6674571 & 0.870257586 & 8.981724097 & 0.6674571 & 0.870257586 & 0.871181774 & 0.971132732 \\
\hline 9.35 & 1.474 & 6.1616 & 0.239224 & 0.01 & 0.017 & 0.088 & 0.645481995 & 0.841605555 & 8.953331367 & 0.645481995 & 0.841605555 & 0.84373466 & 0.940536602 \\
\hline 9.35 & 1.466 & 6.1588 & 0.238033 & 0.01 & 0.017 & 0.088 & 0.639847599 & 0.834259201 & 8.945891765 & 0.639847599 & 0.834259201 & 0.836694749 & 0.932689001 \\
\hline 9.35 & 0.826 & 7.0988 & 0.116358 & 0.01 & 0.017 & 0.088 & 0.223714489 & 0.291688007 & 7.939927051 & 0.223714489 & 0.291688007 & 0.320606547 & 0.357389837 \\
\hline 9.35 & 0.787 & 7.0876 & 0.111039 & 0.01 & 0.017 & 0.088 & 0.206605755 & 0.269380948 & 7.878252876 & 0.206605755 & 0.269380948 & 0.297307129 & 0.331417269 \\
\hline 9.35 & 0.75 & 6.9298 & 0.108228 & 0.01 & 0.017 & 0.088 & 0.193555552 & 0.252365564 & 7.844659331 & 0.193555552 & 0.252365564 & 0.278112069 & 0.310019954 \\
\hline 9.35 & 0.741 & 6.927 & 0.106973 & 0.01 & 0.017 & 0.088 & 0.189751062 & 0.247405116 & 7.829418323 & 0.189751062 & 0.247405116 & 0.27292462 & 0.304237348 \\
\hline 9.35 & 1.219 & 5.663 & 0.215257 & 0.01 & 0.017 & 0.088 & 0.497537473 & 0.648709498 & 8.797180817 & 0.497537473 & 0.648709498 & 0.647294554 & 0.721558861 \\
\hline 9.35 & 1.178 & 5.34 & 0.220599 & 0.01 & 0.017 & 0.088 & 0.488725846 & 0.637220542 & 8.833198705 & 0.488725846 & 0.637220542 & 0.627959721 & 0.700005737 \\
\hline 9.35 & 1.19 & 5.691 & 0.209102 & 0.01 & 0.017 & 0.088 & 0.476397938 & 0.621146917 & 8.754749494 & 0.476397938 & 0.621146917 & 0.622009023 & 0.693372314 \\
\hline 9.35 & 0.947 & 7.2802 & 0.130079 & 0.01 & 0.017 & 0.088 & 0.276272985 & 0.360215901 & 8.088818785 & 0.276272985 & 0.360215901 & 0.393530087 & 0.438679918 \\
\hline 9.35 & 0.815 & 7.1692 & 0.113681 & 0.01 & 0.017 & 0.088 & 0.217336605 & 0.283372263 & 7.909186443 & 0.217336605 & 0.283372263 & 0.312679486 & 0.348553301 \\
\hline 9.35 & 0.519 & 4.727 & 0.109795 & 0.01 & 0.017 & 0.088 & 0.135229836 & 0.176318135 & 7.863470957 & 0.135229836 & 0.176318135 & 0.181618783 & 0.202455963 \\
\hline 9.35 & 0.804 & 5.2066 & 0.154419 & 0.01 & 0.017 & 0.088 & 0.262971046 & 0.342872295 & 8.323403849 & 0.262971046 & 0.342872295 & 0.347842647 & 0.387750744 \\
\hline 9.35 & 0.535 & 4.7292 & 0.113127 & 0.01 & 0.017 & 0.088 & 0.142205102 & 0.185412768 & 7.902751843 & 0.142205102 & 0.185412768 & 0.190468068 & 0.212320529 \\
\hline 9.35 & 0.909 & 5.1798 & 0.175489 & 0.01 & 0.017 & 0.088 & 0.323778847 & 0.422155968 & 8.502744775 & 0.323778847 & 0.422155968 & 0.422797626 & 0.471305331 \\
\hline 9.35 & 0.92 & 5.1842 & 0.177462 & 0.01 & 0.017 & 0.088 & 0.330148409 & 0.43046086 & 8.518602259 & 0.330148409 & 0.43046086 & 0.430727204 & 0.480144672 \\
\hline 9.35 & 1.185 & 5.363 & 0.220958 & 0.01 & 0.017 & 0.088 & 0.492163475 & 0.641702662 & 8.835594037 & 0.492163475 & 0.641702662 & 0.632750643 & 0.705346323 \\
\hline 9.35 & 2.404 & 6.8186 & 0.352565 & 0.01 & 0.017 & 0.088 & 1.363362331 & 1.777606998 & 9.551183803 & 1.363362331 & 1.777606998 & 1.748914482 & 1.94956799 \\
\hline 9.35 & 3.533 & 8.215 & 0.430067 & 0.01 & 0.017 & 0.088 & 2.287450361 & 2.982470379 & 9.872792426 & 2.287450361 & 2.982470379 & 2.974566368 & 3.315839303 \\
\hline 9.35 & 4.515 & 8.6772 & 0.520329 & 0.01 & 0.017 & 0.088 & 3.3191523 & 4.327645131 & 10.19131798 & 3.3191523 & 4.327645131 & 4.280175273 & 4.771241128 \\
\hline 9.35 & 2.816 & 7.4122 & 0.379914 & 0.01 & 0.017 & 0.088 & 1.678573358 & 2.188591895 & 9.670855957 & 1.678573358 & 2.188591895 & 2.169352148 & 2.418242602 \\
\hline 9.35 & 3.26206 & 7.744 & 0.421237 & 0.01 & 0.017 & 0.088 & 2.083021119 & 2.715927258 & 9.838716076 & 2.083021119 & 2.715927258 & 2.686417082 & 2.994630558 \\
\hline 9.35 & 4.29328 & 8.553 & 0.501962 & 0.01 & 0.017 & 0.088 & 3.081439902 & 4.017706084 & 10.13045888 & 3.081439902 & 4.017706084 & 3.977102577 & 4.4333396806 \\
\hline 9.35 & 3.97393 & 8.401 & 0.473031 & 0.01 & 0.017 & 0.088 & 2.741555399 & 3.57455091 & 10.03072212 & 2.741555399 & 3.57455091 & 3.547135262 & 3.954099205 \\
\hline 9.35 & 3.77186 & 8.217 & 0.459031 & 0.01 & 0.017 & 0.088 & 2.550553343 & 3.325514698 & 9.980624293 & 2.550553343 & 3.325514698 & 3.296653764 & 3.674879887 \\
\hline 9.35 & 3.63715 & 8.179 & 0.444694 & 0.01 & 0.017 & 0.088 & 2.407978155 & 3.139619396 & 9.927978512 & 2.407978155 & 3.139619396 & 3.11913414 & 3.47699338 \\
\hline 9.35 & 3.49548 & 8.073 & 0.432984 & 0.01 & 0.017 & 0.088 & 2.273380142 & 2.964125058 & 9.883921922 & 2.273380142 & 2.964125058 & 2.945499803 & 3.283437922 \\
\hline
\end{tabular}




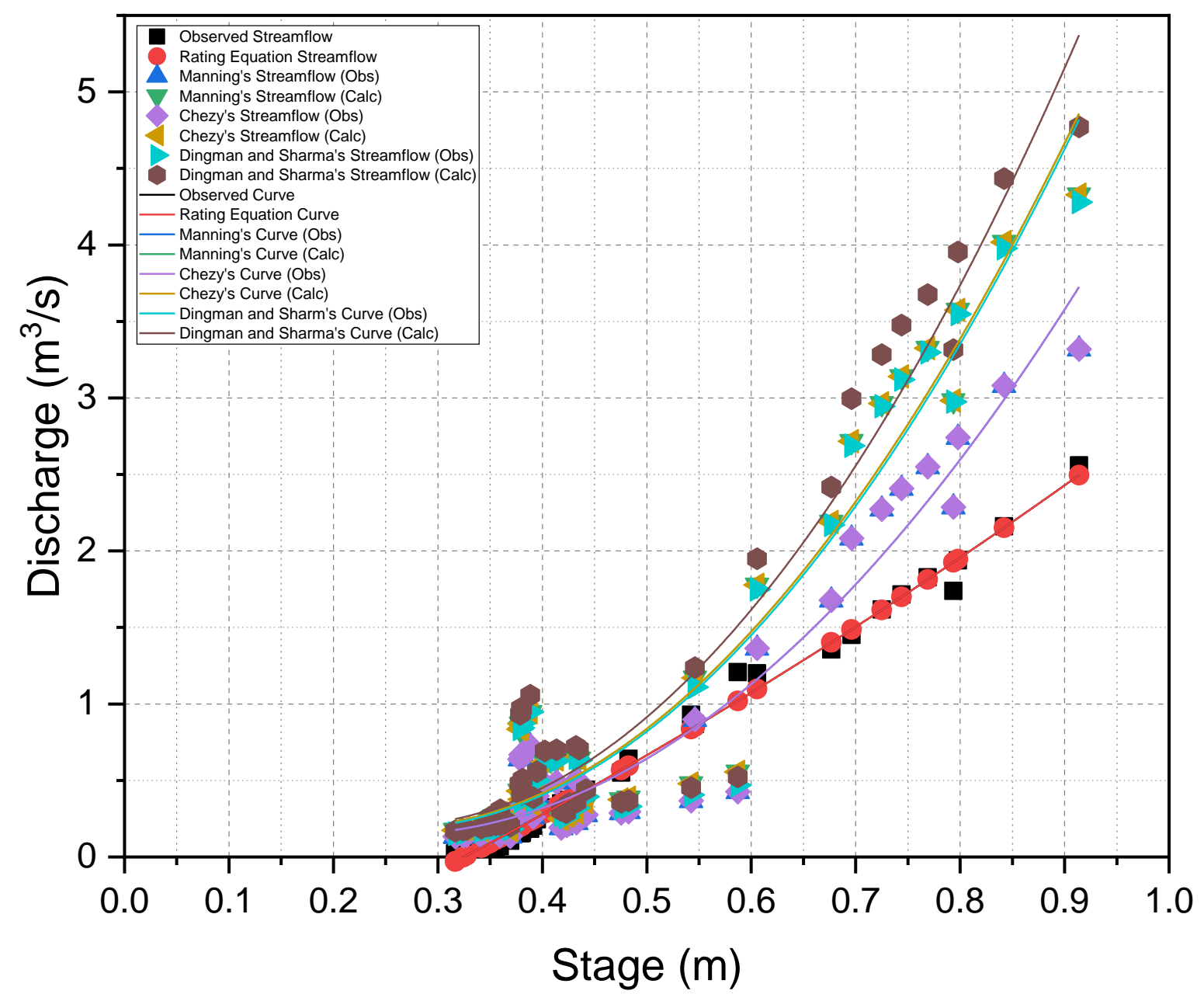

Figure A18-1. Observed and modeled rating curves and streamflow from Site 18, West Run Watershed, Morgantown, West Virginia, U.S.A. 
Table A18-3. Polynomial rating equations and $\mathrm{R}^{2}$ values for observed and modeled rating curves at Site 18, West Run Watershed, Morgantown, WV, U.S.A.

\begin{tabular}{ccc}
\hline & $\mathbf{R}^{\mathbf{2}}$ & Polynomial Equation \\
Value & \\
\hline $\begin{array}{c}\text { Observed Curve } \\
\text { Manning's Curve (Obs Slope) }\end{array}$ & 0.99 & $\mathrm{y}=1.0725 \mathrm{x}^{2}+2.9085 \mathrm{x}-1.0574$ \\
Manning's Curve (Calc Slope) & 0.94 & $\mathrm{y}=8.2173 \mathrm{x}^{2}-4.167 \mathrm{x}+0.6718$ \\
$\begin{array}{c}\text { Chezy's Curve (Obs Slope) } \\
\text { Chezy's Curve (Calc Slope) }\end{array}$ & 0.94 & $\mathrm{y}=10.714 \mathrm{x}^{2}-5.4331 \mathrm{x}+0.8759$ \\
Dingman and Sharma's Curve & 0.93 & $\mathrm{y}=8.2173 \mathrm{x}^{2}-4.167 \mathrm{x}+0.6718$ \\
$\begin{array}{c}\text { (Obs Slope) } \\
\text { Dingman and Sharma's Curve } \\
\text { (Calc Slope) }\end{array}$ & 0.93 & $\mathrm{y}=10.714 \mathrm{x}^{2}-5.4331 \mathrm{x}+0.8759$ \\
& & $\mathrm{y}=11.957 \mathrm{x}^{2}-6.1338 \mathrm{x}+0.9915$ \\
\hline
\end{tabular}

Table A18-4. Descriptive statistics for observed and modeled streamflow used to generate the rating curves for Site 18, West Run Watershed, Morgantown, WV, U.S.A.

\begin{tabular}{|c|c|c|c|c|}
\hline & Sample Size & Mean $\left(\mathbf{m}^{3} / \mathbf{s}\right)$ & St. Dev. & SE of Mean \\
\hline Observed & 53 & 0.549 & 0.651 & 0.089 \\
\hline Manning's & 53 & 0.705 & 0.869 & 0.119 \\
\hline $\begin{array}{l}\text { Curve (Obs } \\
\text { Slope) }\end{array}$ & & & & \\
\hline $\begin{array}{c}\text { Manning's } \\
\text { Curve (Calc }\end{array}$ & 53 & 0.919 & 1.133 & 0.156 \\
\hline Slope) & & & & \\
\hline $\begin{array}{c}\text { Chezy's Curve } \\
\text { (Obs Slope) }\end{array}$ & 53 & 0.705 & 0.869 & 0.119 \\
\hline $\begin{array}{l}\text { Chezy's Curve } \\
\text { (Calc Slope) }\end{array}$ & 53 & 0.919 & 1.133 & 0.156 \\
\hline $\begin{array}{c}\text { Dingman and } \\
\text { Sharma's } \\
\text { Curve (Obs } \\
\text { Slope) }\end{array}$ & 53 & 0.904 & 1.127 & 0.155 \\
\hline $\begin{array}{l}\text { Dingman and } \\
\text { Sharma's } \\
\text { Curve (Calc } \\
\text { Slope) }\end{array}$ & 53 & 1.008 & 1.257 & 0.173 \\
\hline
\end{tabular}


Table A18-5. P-values of the statistical analyses (post-hoc ANOVA) for observed and modeled rating curves at Site 18, West Run Watershed, Morgantown, WV, U.S.A.

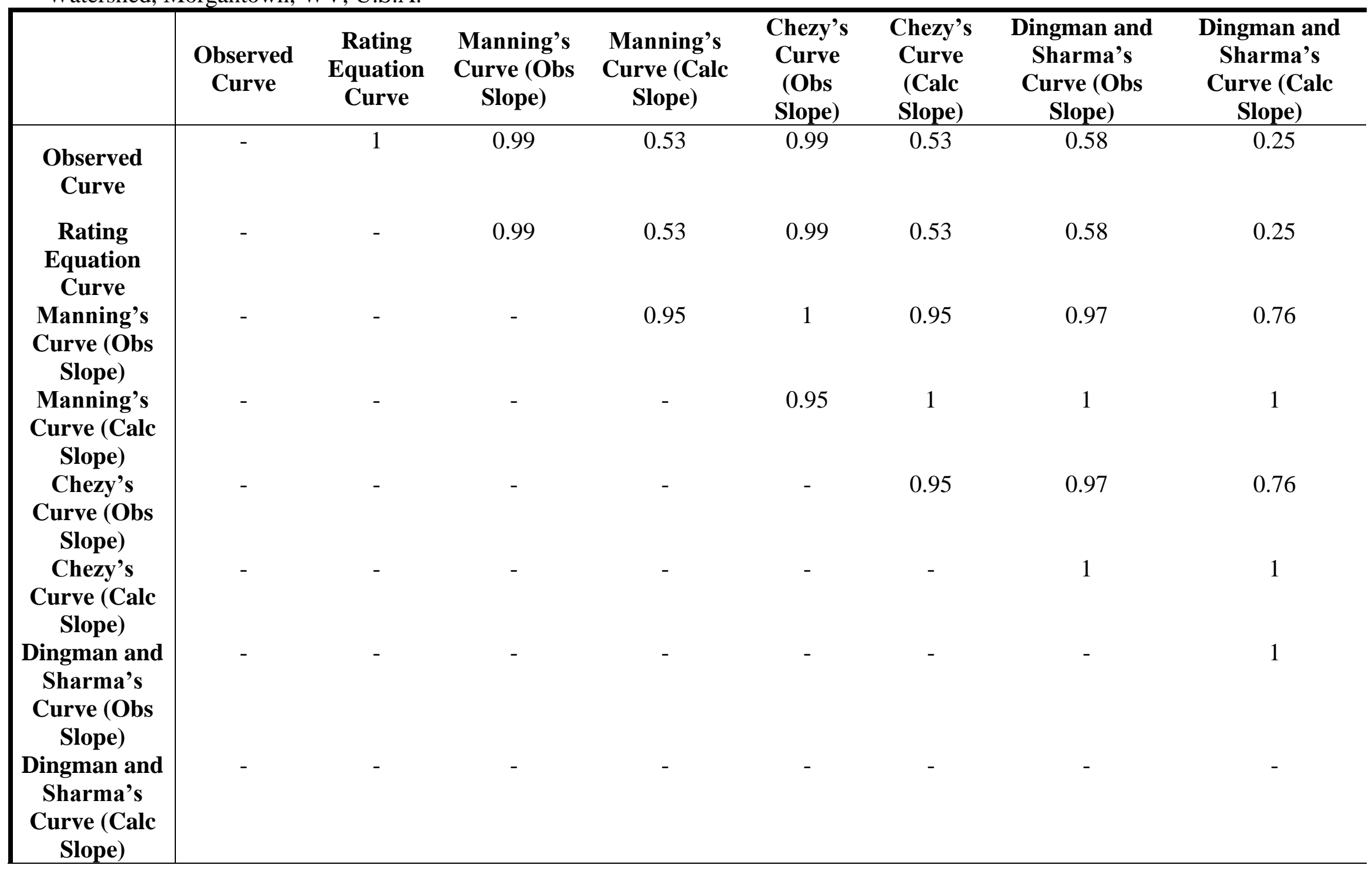




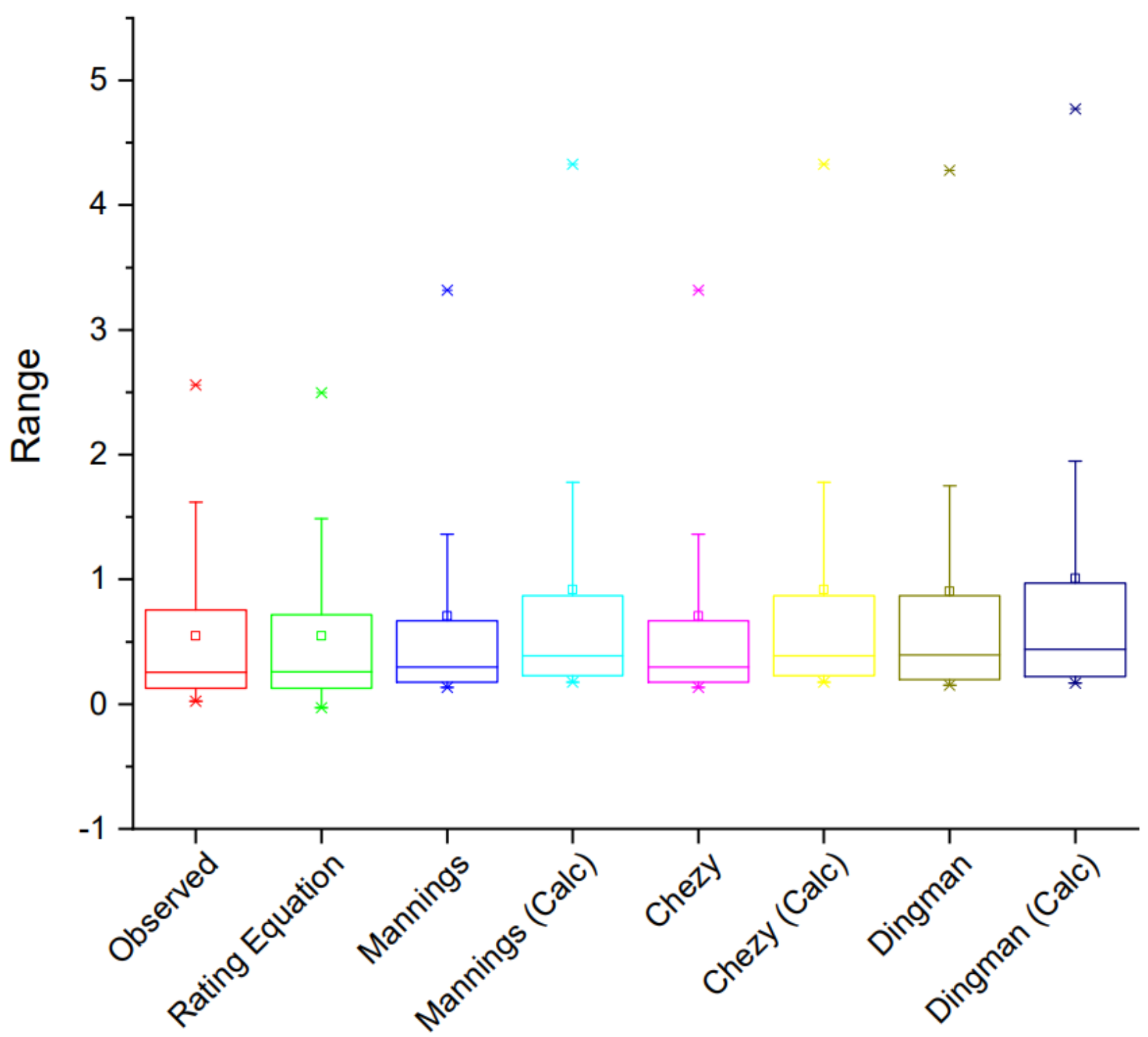

Figure A18-2. Box and whisker plots for the results of the statistical analyses (post-hoc ANOVA) of observed and modeled rating curves at Site 18, West Run Watershed, Morgantown, WV, U.S.A. 


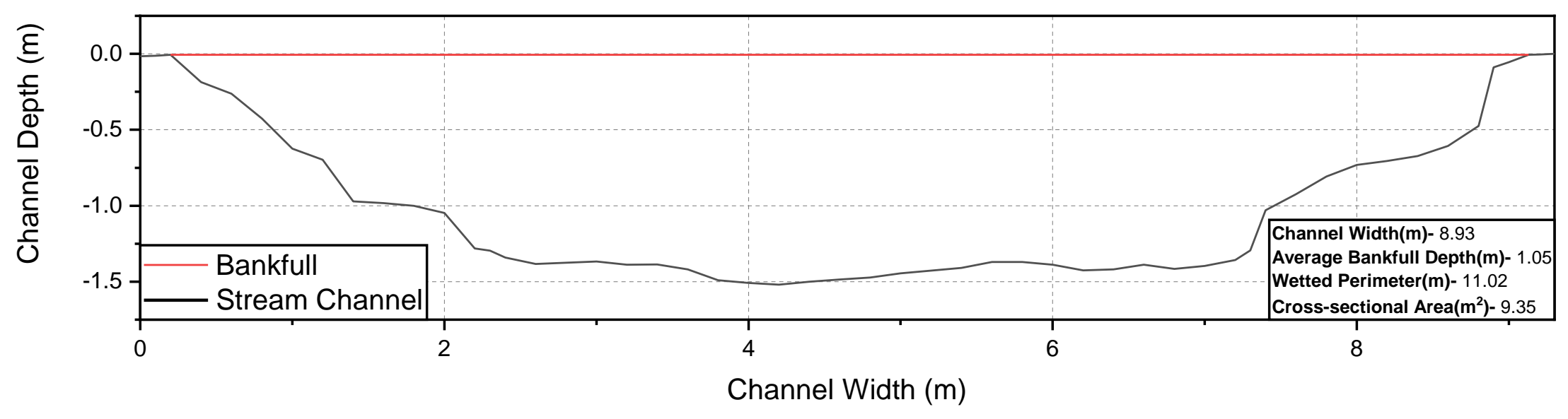

Figure A18-3. Cross-sectional profile of WRW Site 18, plotting the stream channel's shape, water surface, and bankfull. The profile is created with a Channel Width of $0=$ Left Bank facing downstream. 


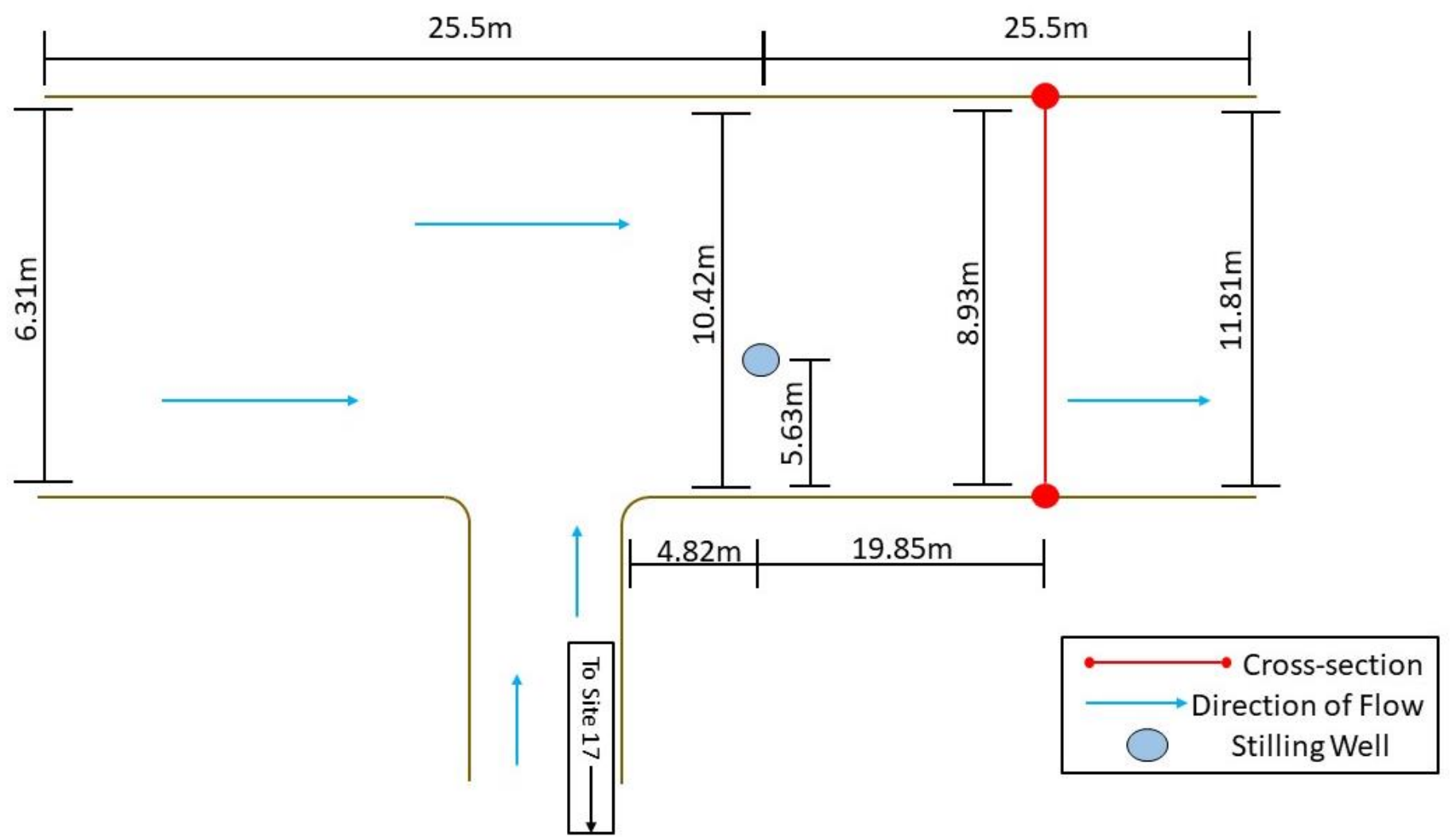

Figure A18-4. Plan view profile of WRW Site 18, West Run Watershed, Morgantown, WV, U.S.A. (Figure 2). Showing the positioning of stilling well in relation to where the streamflow was measured. Along with the channel width at the stilling well, point where cross-sections were performed, and $25.5 \mathrm{~m}$ upstream and downstream from the stilling well. 


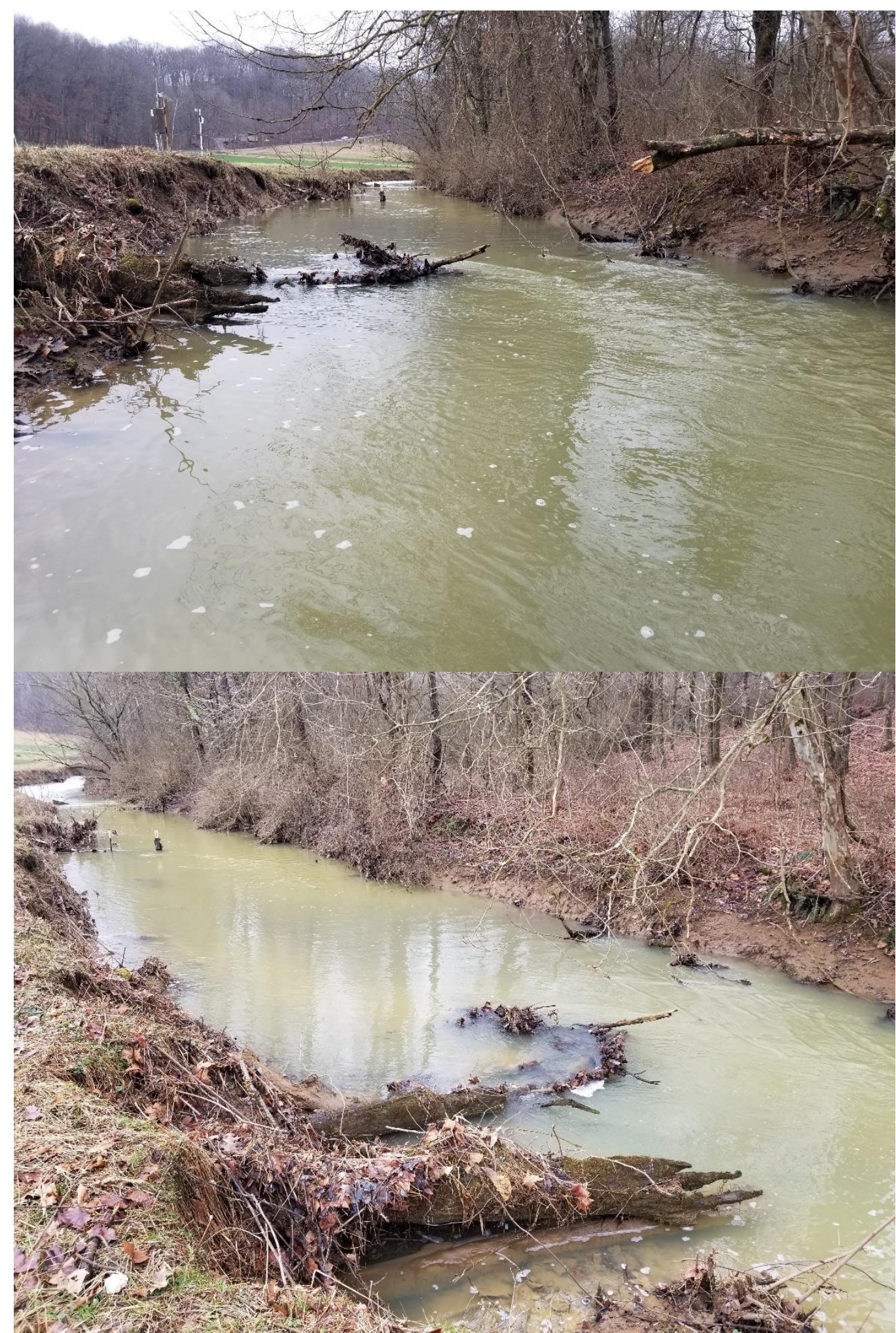

Figure A18-5. Photographs showing channel characteristics at Site \#18, West Run Watershed, Morgantown, WV, U.S.A. Photo 1 was taken looking upstream in the channel. Photo 2 was taken from the right bank looking upstream. 


\section{APPENDIX 19: Site 19}

Table A19-1. Streamflow measurements and stage collected at Site 19, West Run Watershed, Morgantown, WV, U.S.A. (Figure 2).

\begin{tabular}{|c|c|c|c|c|c|c|c|c|c|}
\hline Date & $\begin{array}{l}\text { Mean Depth of } \\
\text { Cross-Section } \\
\text { (m) }\end{array}$ & Stage(PT in cm) & $\begin{array}{c}\text { Barometric } \\
\text { Pressure (in cm) }\end{array}$ & $\begin{array}{c}\text { Pressure } \\
\text { Corrected Stage } \\
\text { (cm) }\end{array}$ & $\begin{array}{l}\text { Stilling Well } \\
\text { Offset }(\mathrm{cm})\end{array}$ & $\begin{array}{l}\text { P-Corrected } \\
\text { Stage + Offset } \\
\text { (cm) }\end{array}$ & $\begin{array}{l}\text { P-Corrected } \\
\text { Stage + Offset } \\
\text { (m) }\end{array}$ & $\begin{array}{c}\text { SonTec } \\
\text { Discharge }(\mathrm{m} 3 / \mathrm{s})\end{array}$ & $\begin{array}{l}\text { Rating Equation } \\
\text { Discharge }(\mathrm{m} 3 / \mathrm{s})\end{array}$ \\
\hline $10 / 25 / 2018$ & 0.1445 & 110.38 & 89.9 & 20.48 & 5.4 & 25.88 & 0.2588 & 0.0761 & 0.186297134 \\
\hline $10 / 25 / 2018$ & 0.1417 & 110.43 & 90.38 & 20.05 & 5.4 & 25.45 & 0.2545 & 0.0735 & 0.174754214 \\
\hline $10 / 30 / 2018$ & 0.1798 & 115.93 & 88.99 & 26.94 & 5.4 & 32.34 & 0.3234 & 0.3506 & 0.397006917 \\
\hline $10 / 30 / 2018$ & 0.1777 & 115 & 89.27 & 25.73 & 5.4 & 31.13 & 0.3113 & 0.3240 & 0.3522164 \\
\hline $11 / 1 / 2018$ & 0.1649 & 99.77 & 76.96 & 22.81 & 5.4 & 28.21 & 0.2821 & 0.1878 & 0.254232472 \\
\hline $11 / 13 / 2018$ & 0.1841 & 112.61 & 86.07 & 26.54 & 5.4 & 31.94 & 0.3194 & 0.3572 & 0.381928632 \\
\hline $11 / 29 / 2018$ & 0.1646 & 109.53 & 86.11 & 23.42 & 5.4 & 28.82 & 0.2882 & 0.2130 & 0.273520933 \\
\hline $1 / 15 / 2019$ & 0.1658 & 112.74 & 89.6 & 23.14 & 5.4 & 28.54 & 0.2854 & 0.1757 & 0.264589785 \\
\hline $1 / 15 / 2019$ & 0.1762 & 112.54 & 89.33 & 23.21 & 5.4 & 28.61 & 0.2861 & 0.1825 & 0.266810254 \\
\hline $1 / 29 / 2019$ & 0.1768 & 102.37 & 75.46 & 26.91 & 5.4 & 32.31 & 0.3231 & 0.3986 & 0.395866744 \\
\hline $3 / 19 / 2019$ & 0.1597 & 115.41 & 96.42 & 18.99 & 5.4 & 24.39 & 0.2439 & 0.1853 & 0.147623064 \\
\hline $3 / 20 / 2019$ & 0.1506 & 104.49 & 87.26 & 17.23 & 5.4 & 22.63 & 0.2263 & 0.1390 & 0.106734129 \\
\hline $4 / 2 / 2019$ & 0.1655 & 104.08 & 87.19 & 16.89 & 5.4 & 22.29 & 0.2229 & 0.1001 & 0.09943344 \\
\hline $4 / 23 / 2019$ & 0.1643 & 103.11 & 83.79 & 19.32 & 5.4 & 24.72 & 0.2472 & 0.2409 & 0.155867687 \\
\hline 4/23/2019 & 0.1664 & 102.89 & 83.93 & 18.96 & 5.4 & 24.36 & 0.2436 & 0.2262 & 0.146882603 \\
\hline $4 / 25 / 2019$ & 0.1369 & 99.59 & 78.24 & 21.35 & 5.4 & 26.75 & 0.2675 & 0.2572 & 0.210599158 \\
\hline $4 / 25 / 2019$ & 0.1305 & 99.29 & 77.75 & 21.54 & 5.4 & 26.94 & 0.2694 & 0.2455 & 0.216075264 \\
\hline $4 / 30 / 2019$ & 0.1475 & 109.99 & 91.08 & 18.91 & 5.4 & 24.31 & 0.2431 & 0.1999 & 0.145651853 \\
\hline $4 / 30 / 2019$ & 0.1478 & 110.09 & 91.04 & 19.05 & 5.4 & 24.45 & 0.2445 & 0.1982 & 0.149108511 \\
\hline $5 / 15 / 2019$ & 0.1320 & 106.03 & 84.32 & 21.71 & 5.4 & 27.11 & 0.2711 & 0.2865 & 0.221026221 \\
\hline $4 / 8 / 2020$ & 0.2500 & 1033.8 & 989.01 & 44.8 & 5.4 & 50.20 & 0.502 & 1.4547 & 1.343534119 \\
\hline $4 / 8 / 2020$ & 0.2410 & 1032.9 & 989.07 & 43.8 & 5.4 & 49.20 & 0.492 & 1.3286 & 1.276408901 \\
\hline $4 / 8 / 2020$ & 0.2320 & 1031.9 & 989.31 & 42.6 & 5.4 & 48.00 & 0.48 & 1.2676 & 1.19807088 \\
\hline $4 / 8 / 2020$ & 0.2270 & 1031.6 & 989.23 & 42.4 & 5.4 & 47.80 & 0.478 & 1.2070 & 1.185249175 \\
\hline $4 / 8 / 2020$ & 0.2150 & 1031.5 & 989.57 & 41.9 & 5.4 & 47.30 & 0.473 & 1.0553 & 1.153488201 \\
\hline $8 / 10 / 2021$ & 0.3180 & 1945.3 & 1001.96 & 43.3 & 5.4 & 48.70 & 0.487 & 1.4569 & 1.243474769 \\
\hline $8 / 10 / 2021$ & 0.3520 & 1054.9 & 1001.64 & 53.3 & 5.4 & 58.70 & 0.587 & 2.0810 & 1.981764549 \\
\hline $8 / 10 / 2021$ & 0.3380 & 1054.5 & 1002.25 & 52.2 & 5.4 & 57.60 & 0.576 & 1.8514 & 1.892348947 \\
\hline $8 / 10 / 2021$ & 0.3270 & 1054.4 & 1002.11 & 52.3 & 5.4 & 57.70 & 0.577 & 1.9042 & 1.900393841 \\
\hline $8 / 10 / 2021$ & 0.3160 & 1052.2 & 1001.78 & 50.4 & 5.4 & 55.80 & 0.558 & 1.5265 & 1.750406711 \\
\hline $8 / 10 / 2021$ & 0.3050 & 1051.5 & 1001.69 & 49.8 & 5.4 & 55.20 & 0.552 & 1.6234 & 1.704299309 \\
\hline
\end{tabular}


Table A19-2. Modeled streamflow at Site 19, West Run Watershed, Morgantown, WV, U.S.A.

\begin{tabular}{|c|c|c|c|c|c|c|c|c|c|c|c|c|c|}
\hline $\begin{array}{l}\text { Cross- } \\
\text { Section } \\
\text { Area } \\
\left(\mathrm{m}^{2}\right)\end{array}$ & $\begin{array}{l}\text { A (Cross } \\
\text { Section } \\
\text { area of } \\
\text { flow) }\end{array}$ & $\begin{array}{c}\text { P } \\
\text { (Wetted } \\
\text { Perimete } \\
\text { r) }\end{array}$ & $\begin{array}{c}\mathrm{RH}=\mathrm{A} / \mathrm{P} \\
\text { Hydraulic } \\
\text { Radius } \\
(\mathrm{m})\end{array}$ & $\begin{array}{l}\text { Observed } \\
\text { Slope (m) }\end{array}$ & $\begin{array}{l}\text { Calculated } \\
\text { Slope using } \\
\text { ArcGIS (m) }\end{array}$ & $\begin{array}{c}\text { Roughness } \\
\text { Coefficient } \\
\text { (n) }\end{array}$ & $\begin{array}{c}\text { Manning } \\
\text { Discharge } \\
\left(\mathrm{m}^{3} / \mathrm{s}\right) \text { (Obs } \\
\text { Slope) }\end{array}$ & $\begin{array}{c}\text { Manning } \\
\text { Discharge } \\
\left(\mathrm{m}^{3} / \mathrm{s}\right) \text { (Calc } \\
\text { Slope) }\end{array}$ & $\begin{array}{c}\text { Chezy } \\
\text { Coefficient } \\
\text { (C) }\end{array}$ & $\begin{array}{c}\text { Chezy } \\
\text { Discharge } \\
\text { (m³/s) (Obs } \\
\text { Slope) }\end{array}$ & $\begin{array}{c}\text { Chezy } \\
\text { Discharge } \\
\left(\mathrm{m}^{3} / \mathrm{s}\right) \text { (Calc } \\
\text { Slope) }\end{array}$ & $\begin{array}{l}\text { Dingman \& } \\
\text { Sharma } \\
\text { Discharge } \\
\left(\mathrm{m}^{3} / \mathrm{s}\right) \text { (Obs. } \\
\text { Slope) }\end{array}$ & $\begin{array}{l}\text { Dingman \& } \\
\text { Sharma } \\
\text { Discharge } \\
\left(\mathrm{m}^{3} / \mathrm{s}\right) \text { (Calc } \\
\text { Slope) }\end{array}$ \\
\hline 15.51 & 0.826 & 6.0042 & 0.13757 & 0.015 & 0.011 & 0.135 & 0.19969867 & 0.171011724 & 5.322149229 & 0.19969867 & 0.171011724 & 0.372930225 & 0.349914355 \\
\hline 15.51 & 0.824 & 5.9997 & 0.13734 & 0.015 & 0.011 & 0.135 & 0.198992874 & 0.170407316 & 5.320664125 & 0.198992874 & 0.170407316 & 0.371622259 & 0.348687111 \\
\hline 15.51 & 1.26 & 7.3694 & 0.170977 & 0.015 & 0.011 & 0.135 & 0.352134046 & 0.301549581 & 5.518520167 & 0.352134046 & 0.301549581 & 0.66759034 & 0.626389141 \\
\hline 15.51 & 1.2 & 7.3687 & 0.162851 & 0.015 & 0.011 & 0.135 & 0.324653449 & 0.278016604 & 5.473913873 & 0.324653449 & 0.278016604 & 0.618295063 & 0.580136185 \\
\hline 15.51 & 1.081 & 6.883 & 0.157054 & 0.015 & 0.011 & 0.135 & 0.285475935 & 0.244466986 & 5.440943535 & 0.285475935 & 0.244466986 & 0.53913402 & 0.505860668 \\
\hline 15.51 & 1.319 & 7.5314 & 0.175133 & 0.015 & 0.011 & 0.135 & 0.374572633 & 0.32076484 & 5.540654613 & 0.374572633 & 0.32076484 & 0.711205009 & 0.667312074 \\
\hline 15.51 & 1.142 & 7.2632 & 0.157231 & 0.015 & 0.011 & 0.135 & 0.301812136 & 0.258456472 & 5.441967139 & 0.301812136 & 0.258456472 & 0.5752513 & 0.539748924 \\
\hline 15.51 & 0.973 & 6.1986 & 0.156971 & 0.015 & 0.011 & 0.135 & 0.256864559 & 0.219965667 & 5.44046603 & 0.256864559 & 0.219965667 & 0.476413524 & 0.447011049 \\
\hline 15.51 & 0.974 & 6.1988 & 0.157127 & 0.015 & 0.011 & 0.135 & 0.257299163 & 0.220337839 & 5.441368276 & 0.257299163 & 0.220337839 & 0.477177786 & 0.447728143 \\
\hline 15.51 & 1.308 & 7.7448 & 0.168888 & 0.015 & 0.011 & 0.135 & 0.362563958 & 0.310481225 & 5.507220784 & 0.362563958 & 0.310481225 & 0.694096616 & 0.651259548 \\
\hline 15.51 & 0.924 & 6.1102 & 0.151223 & 0.015 & 0.011 & 0.135 & 0.237936752 & 0.203756861 & 5.406742117 & 0.237936752 & 0.203756861 & 0.441753368 & 0.414489989 \\
\hline 15.51 & 0.872 & 6.092 & 0.143139 & 0.015 & 0.011 & 0.135 & 0.216470842 & 0.185374554 & 5.357460732 & 0.216470842 & 0.185374554 & 0.403764844 & 0.378845975 \\
\hline 15.51 & 0.782 & 5.0552 & 0.154692 & 0.015 & 0.011 & 0.135 & 0.204439223 & 0.175071291 & 5.427222582 & 0.204439223 & 0.175071291 & 0.366537923 & 0.343916562 \\
\hline 15.51 & 0.926 & 5.9674 & 0.155176 & 0.015 & 0.011 & 0.135 & 0.242590285 & 0.207741909 & 5.43005053 & 0.242590285 & 0.207741909 & 0.447471161 & 0.419854901 \\
\hline 15.51 & 0.926 & 5.9674 & 0.155176 & 0.015 & 0.011 & 0.135 & 0.242590285 & 0.207741909 & 5.43005053 & 0.242590285 & 0.207741909 & 0.447471161 & 0.419854901 \\
\hline 15.51 & 1.012 & 7.6648 & 0.132032 & 0.015 & 0.011 & 0.135 & 0.238055835 & 0.203858838 & 5.285825792 & 0.238055835 & 0.203858838 & 0.46553104 & 0.436800192 \\
\hline 15.51 & 0.974 & 7.7288 & 0.126022 & 0.015 & 0.011 & 0.135 & 0.222110323 & 0.190203917 & 5.244942275 & 0.222110323 & 0.190203917 & 0.436876255 & 0.409913873 \\
\hline 15.51 & 0.854 & 6.086 & 0.140322 & 0.015 & 0.011 & 0.135 & 0.209212203 & 0.179158627 & 5.33974542 & 0.209212203 & 0.179158627 & 0.390886328 & 0.366762273 \\
\hline 15.51 & 0.845 & 6.0106 & 0.140585 & 0.015 & 0.011 & 0.135 & 0.207265885 & 0.1774919 & 5.341411599 & 0.207265885 & 0.1774919 & 0.386347851 & 0.362503895 \\
\hline 15.51 & 0.985 & 7.7318 & 0.127396 & 0.015 & 0.011 & 0.135 & 0.22624822 & 0.1937474 & 5.254428677 & 0.22624822 & 0.1937474 & 0.444593362 & 0.417154709 \\
\hline 15.51 & 2.05896 & 8.73 & 0.235849 & 0.015 & 0.011 & 0.135 & 0.713042716 & 0.610613302 & 5.822442064 & 0.713042716 & 0.610613302 & 1.350711175 & 1.267350291 \\
\hline 15.51 & 1.96664 & 8.635 & 0.227752 & 0.015 & 0.011 & 0.135 & 0.665393284 & 0.569808766 & 5.788641483 & 0.665393284 & 0.569808766 & 1.262188763 & 1.184291155 \\
\hline 15.51 & 1.88117 & 8.564 & 0.21966 & 0.015 & 0.011 & 0.135 & 0.621308787 & 0.532057058 & 5.753844611 & 0.621308787 & 0.532057058 & 1.18087704 & 1.10799769 \\
\hline 15.51 & 1.81846 & 8.478 & 0.214492 & 0.015 & 0.011 & 0.135 & 0.591138403 & 0.506220684 & 5.731055597 & 0.591138403 & 0.506220684 & 1.124078565 & 1.054704606 \\
\hline 15.51 & 1.72219 & 8.431 & 0.204269 & 0.015 & 0.011 & 0.135 & 0.541910509 & 0.464064435 & 5.684599779 & 0.541910509 & 0.464064435 & 1.034198504 & 0.970371609 \\
\hline 15.51 & 2.56529 & 8.7713 & 0.292464 & 0.015 & 0.011 & 0.135 & 1.025407913 & 0.878106875 & 6.035014465 & 1.025407913 & 0.878106875 & 1.905224278 & 1.787640903 \\
\hline 15.51 & 2.8138 & 8.705 & 0.32324 & 0.015 & 0.011 & 0.135 & 1.20232364 & 1.029608453 & 6.136493895 & 1.20232364 & 1.029608453 & 2.210195864 & 2.073790774 \\
\hline 15.51 & 2.73019 & 8.753 & 0.311915 & 0.015 & 0.011 & 0.135 & 1.139187895 & 0.975542231 & 6.100127167 & 1.139187895 & 0.975542231 & 2.103142232 & 1.973344095 \\
\hline 15.51 & 2.62538 & 8.693 & 0.302011 & 0.015 & 0.011 & 0.135 & 1.07214213 & 0.918127668 & 6.06740959 & 1.07214213 & 0.918127668 & 1.982994201 & 1.860611155 \\
\hline 15.51 & 2.51941 & 8.595 & 0.293125 & 0.015 & 0.011 & 0.135 & 1.008585426 & 0.863700958 & 6.03728567 & 1.008585426 & 0.863700958 & 1.867001924 & 1.751777491 \\
\hline 15.51 & 2.41316 & 8.535 & 0.282737 & 0.015 & 0.011 & 0.135 & 0.943089785 & 0.807613842 & 6.001088022 & 0.943089785 & 0.807613842 & 1.7495509 & 1.641575108 \\
\hline
\end{tabular}




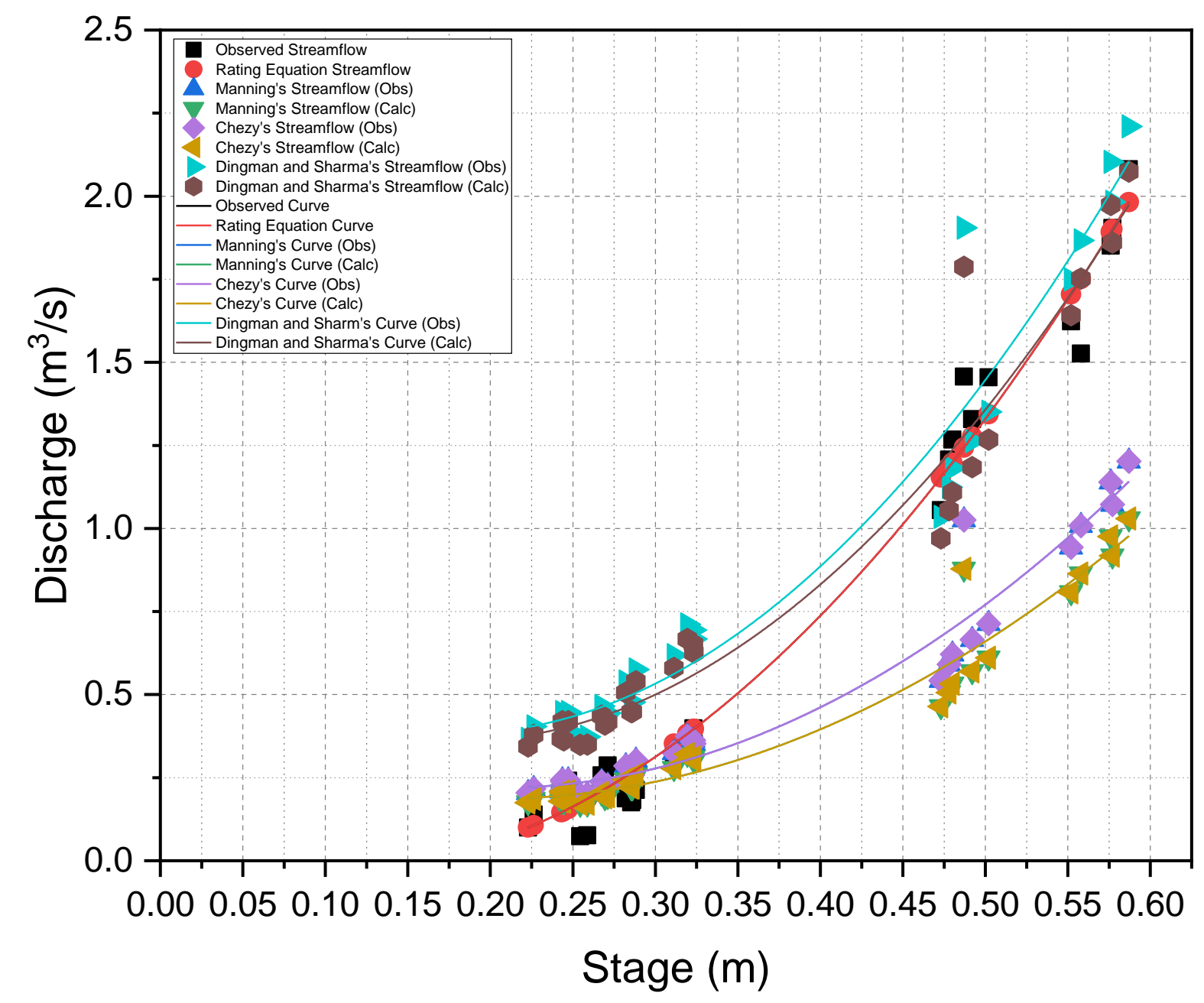

Figure A19-1. Observed and modeled rating curves and streamflow from Site 19, West Run Watershed, Morgantown, West Virginia, U.S.A. 
Table A19-3. Polynomial rating equations and $\mathrm{R}^{2}$ values for observed and modeled rating curves at Site 19, West Run Watershed, Morgantown, WV, U.S.A.

\begin{tabular}{ccc}
\hline & $\begin{array}{c}\mathbf{R}^{\mathbf{2}} \\
\text { Value }\end{array}$ & Polynomial Equation \\
\hline $\begin{array}{c}\text { Observed Curve } \\
\text { Manning's Curve (Obs Slope) }\end{array}$ & 0.98 & $\mathrm{y}=8.3797 \mathrm{x}^{2}-1.6169 \mathrm{x}+0.0435$ \\
Manning's Curve (Calc Slope) & 0.95 & $\mathrm{y}=6.2508 \mathrm{x}^{2}-2.5353 \mathrm{x}+0.4757$ \\
$\begin{array}{c}\text { Chezy's Curve (Obs Slope) } \\
\text { Chezy's Curve (Calc Slope) }\end{array}$ & 0.95 & $\mathrm{y}=5.3528 \mathrm{x}^{2}-2.1711 \mathrm{x}+0.4074$ \\
$\begin{array}{c}\text { Dingman and Sharma's Curve } \\
\text { (Obs Slope) }\end{array}$ & 0.95 & $\mathrm{y}=6.2508 \mathrm{x}^{2}-2.5353 \mathrm{x}+0.4757$ \\
$\begin{array}{c}\text { Dingman and Sharma's Curve } \\
\text { (Calc Slope) }\end{array}$ & 0.95 & $\mathrm{y}=5.3528 \mathrm{x}^{2}-2.1711 \mathrm{x}+0.4074$ \\
& & $\mathrm{y}=10.387 \mathrm{x}^{2}-3.7392 \mathrm{x}+0.7198$ \\
\end{tabular}

Table A19-4. Descriptive statistics for observed and modeled streamflow used to generate the rating curves for Site 19, West Run Watershed, Morgantown, WV, U.S.A.

\begin{tabular}{|c|c|c|c|c|}
\hline & Sample Size & Mean $\left(\mathrm{m}^{3} / \mathrm{s}\right)$ & St. Dev. & SE of Mean \\
\hline Observed & 31 & 0.683 & 0.663 & 0.119 \\
\hline Manning's & 31 & 0.474 & 0.33 & 0.059 \\
\hline \multicolumn{5}{|l|}{$\begin{array}{l}\text { Curve (Obs } \\
\text { Slope) }\end{array}$} \\
\hline & 31 & 0.406 & 0.283 & 0.051 \\
\hline \multicolumn{5}{|l|}{$\begin{array}{c}\text { Curve (Calc } \\
\text { Slope) }\end{array}$} \\
\hline $\begin{array}{c}\text { Chezy's Curve } \\
\text { (Obs Slope) }\end{array}$ & 31 & 0.474 & 0.33 & 0.059 \\
\hline $\begin{array}{l}\text { Chezy's Curve } \\
\text { (Calc Slope) }\end{array}$ & 31 & 0.406 & 0.283 & 0.051 \\
\hline $\begin{array}{c}\text { Dingman and } \\
\text { Sharma's }\end{array}$ & 31 & 0.887 & 0.609 & 0.109 \\
\hline $\begin{array}{l}\text { Curve (Obs } \\
\text { Slope) }\end{array}$ & & & & \\
\hline $\begin{array}{l}\text { Dingman and } \\
\text { Sharma's }\end{array}$ & 31 & 0.833 & 0.571 & 0.103 \\
\hline $\begin{array}{l}\text { Curve (Calc } \\
\text { Slope) }\end{array}$ & & & & \\
\hline
\end{tabular}


Table A19-5. P-values of the statistical analyses (post-hoc ANOVA) for observed and modeled rating curves at Site 19, West Run Watershed, Morgantown, WV, U.S.A.

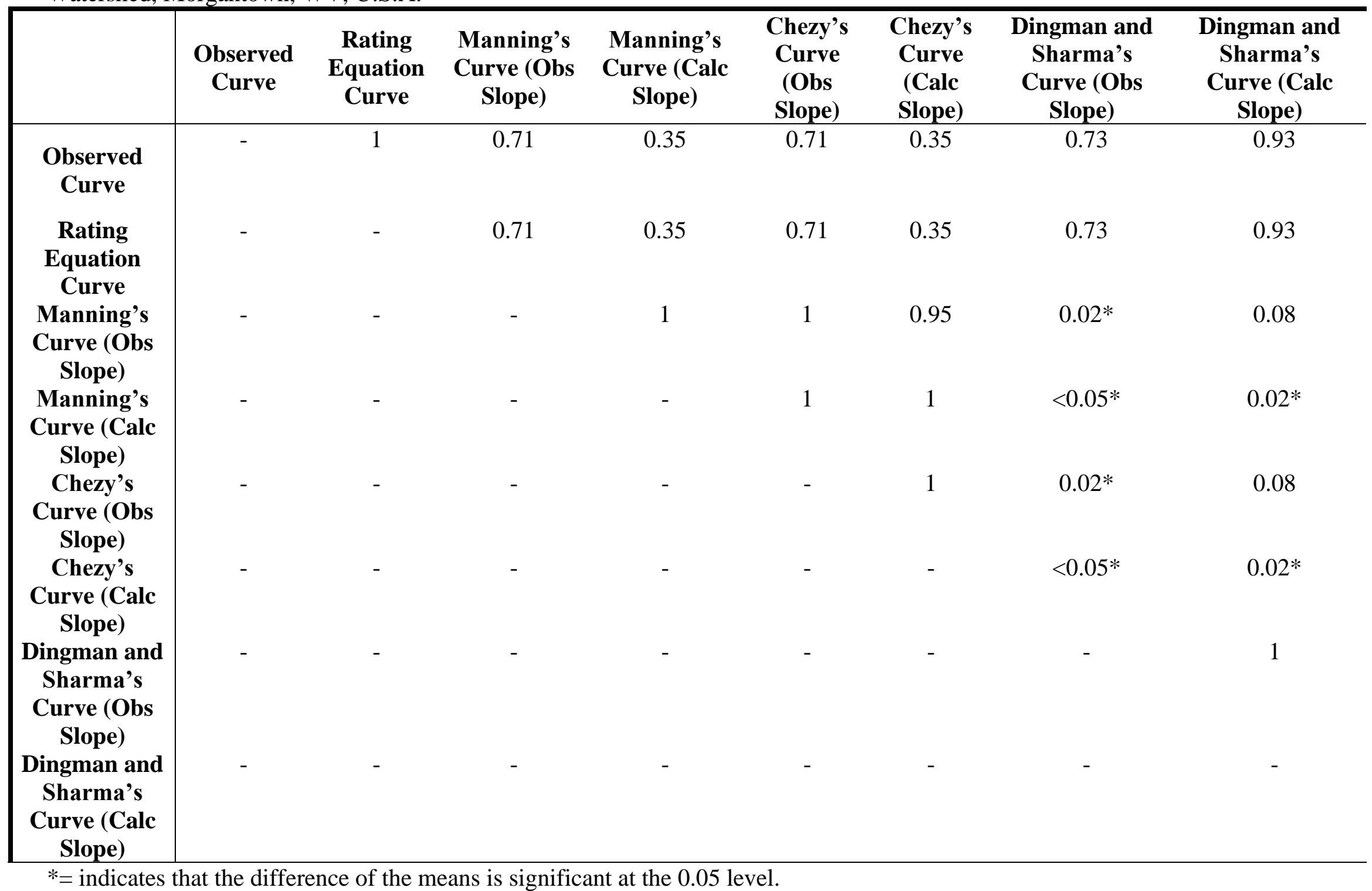




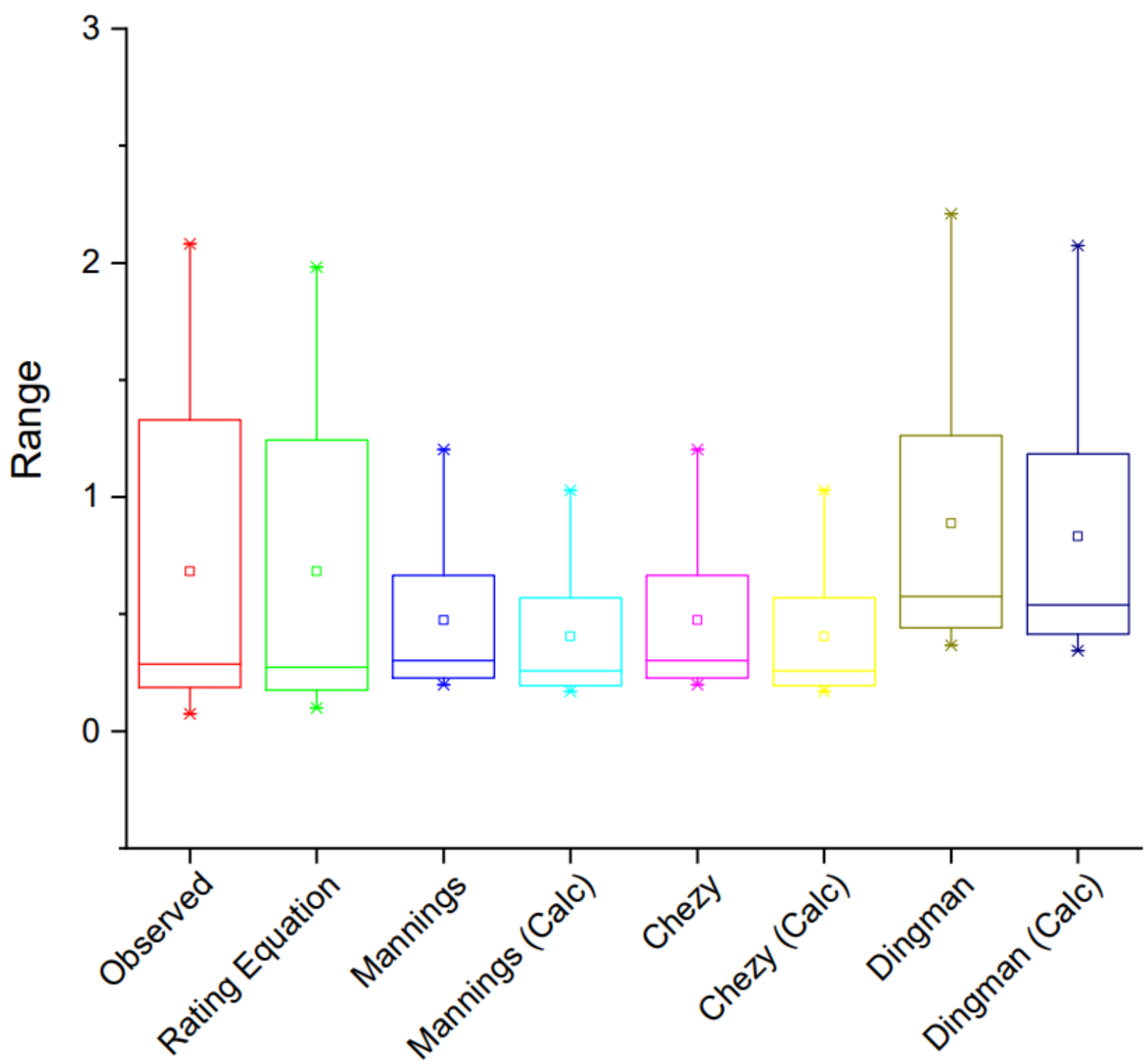

Figure A19-2. Box and whisker plots for the results of the statistical analyses (post-hoc ANOVA) of observed and modeled rating curves at Site 19, West Run Watershed, Morgantown, WV, U.S.A 


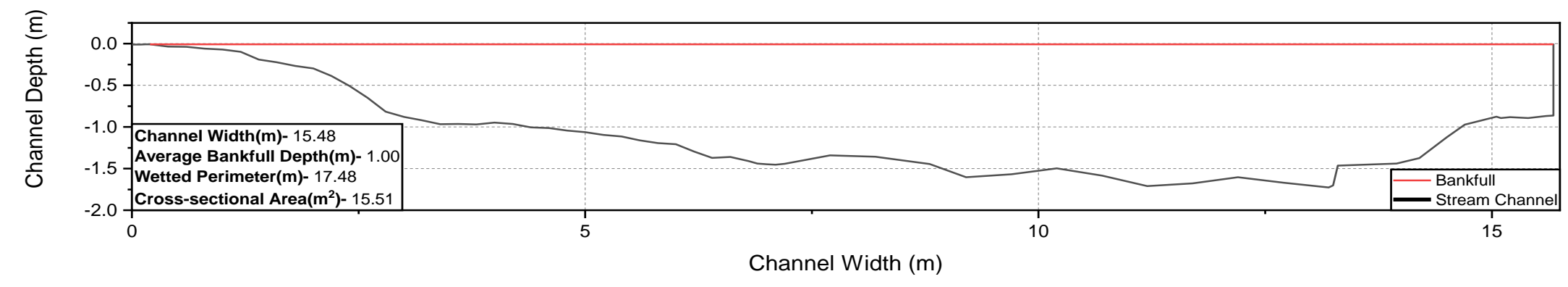

Figure A19-3. Cross-sectional profile of WRW Site 19, plotting the stream channel's shape, water surface, and bankfull. The profile is created with a Channel Width of $0=$ Left Bank facing downstream. 


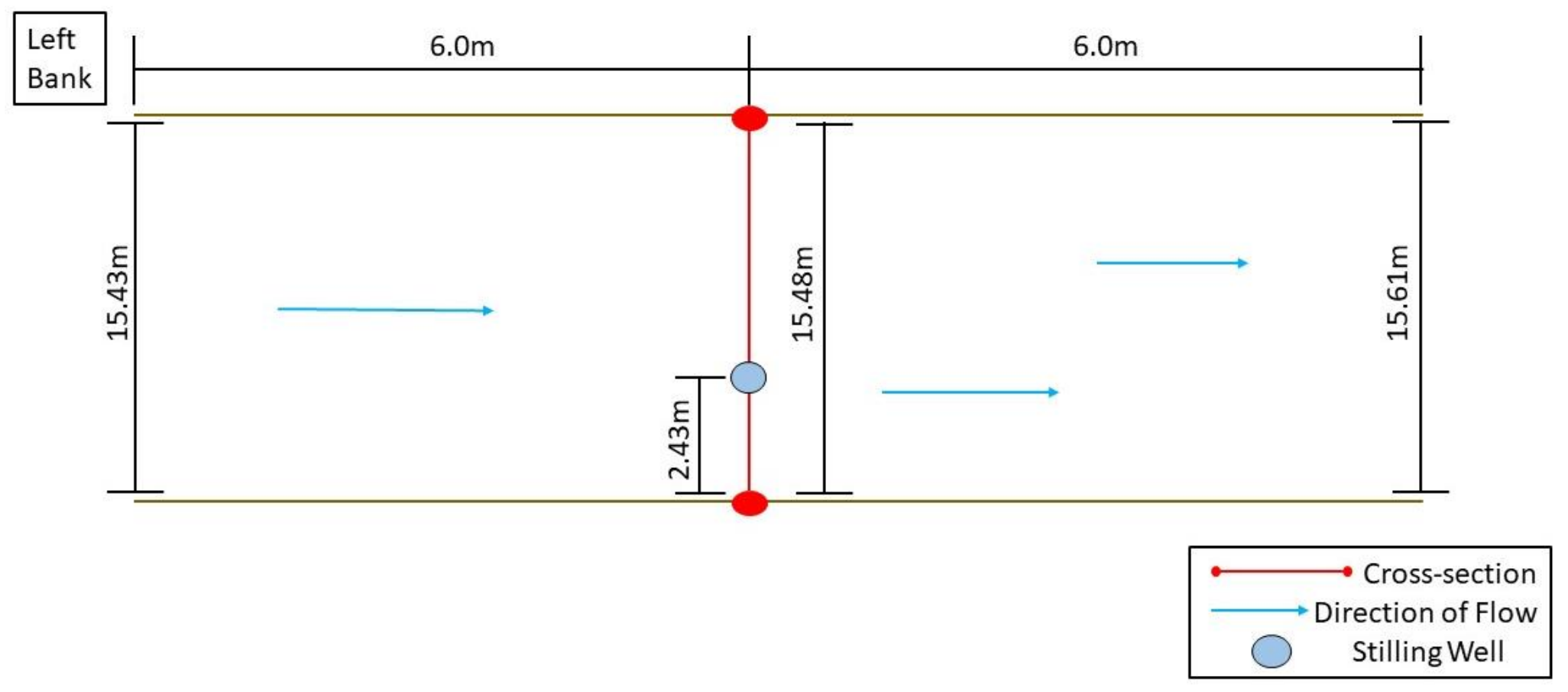

Figure A19-4. Plan view profile of WRW Site 19, West Run Watershed, Morgantown, WV, U.S.A. (Figure 2). Showing the positioning of stilling well in relation to where the streamflow was measured. Along with the channel width at the stilling well, point where cross-sections were performed, and $6.0 \mathrm{~m}$ upstream and downstream from the stilling well. 


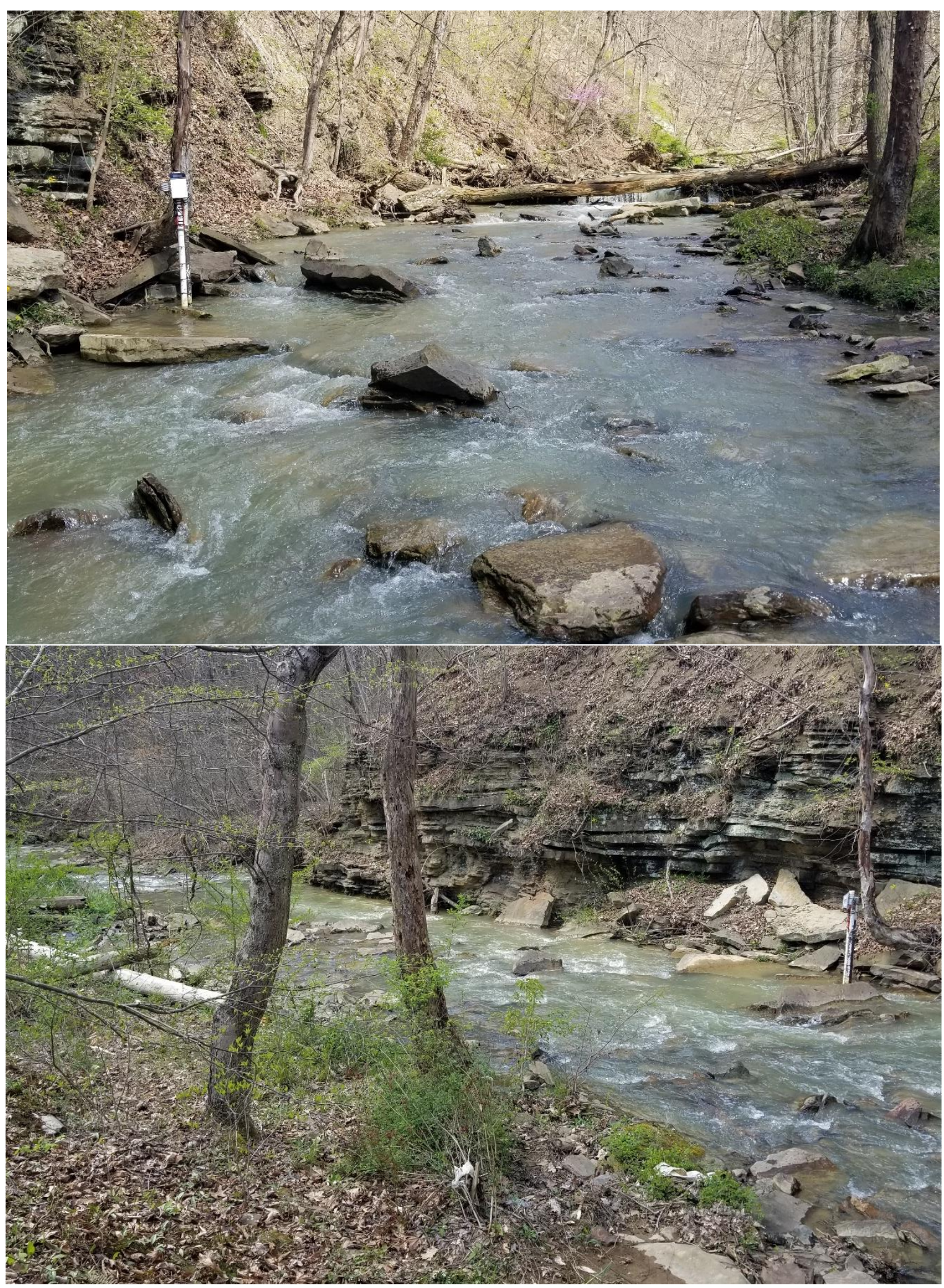

Figure A19-5. Photographs showing channel characteristics at Site \#19, West Run Watershed, Morgantown, WV, U.S.A. Photo 1 was taken looking upstream in the channel. Photo 2 was taken from the left bank looking downstream. 


\section{APPENDIX 20: Site 20}

Table A20-1. Streamflow measurements and stage collected at Site 20, West Run Watershed, Morgantown, WV, U.S.A. (Figure 2).

\begin{tabular}{|c|c|c|c|c|c|c|c|c|c|}
\hline Date & $\begin{array}{l}\text { Mean Depth of } \\
\text { Cross-Section } \\
\text { (m) }\end{array}$ & Stage(PT in cm) & $\begin{array}{c}\text { Barometric } \\
\text { Pressure (in cm) }\end{array}$ & $\begin{array}{c}\text { Pressure } \\
\text { Corrected Stage } \\
\text { (cm) }\end{array}$ & $\begin{array}{c}\text { Stilling Well } \\
\text { Offset (cm) }\end{array}$ & $\begin{array}{l}\text { P-Corrected } \\
\text { Stage + Offset } \\
\text { (cm) }\end{array}$ & $\begin{array}{l}\text { P-Corrected } \\
\text { Stage + Offset } \\
\text { (m) }\end{array}$ & $\begin{array}{c}\text { SonTec } \\
\text { Discharge }(\mathrm{m} 3 / \mathrm{s})\end{array}$ & $\begin{array}{l}\text { Rating Equation } \\
\text { Discharge }(\mathrm{m} 3 / \mathrm{s})\end{array}$ \\
\hline $12 / 8 / 2017$ & 0.0953 & 118.01 & 87.7 & 30.31 & 3.4 & 33.71 & 0.3371 & 0.0115 & 0.02585634 \\
\hline $1 / 12 / 2018$ & 0.2022 & 122.41 & 73.53 & 48.88 & 3.4 & 52.28 & 0.5228 & 0.4135 & 0.344404025 \\
\hline $2 / 1 / 2018$ & 0.1082 & 111.67 & 80.55 & 31.12 & 3.4 & 34.52 & 0.3452 & 0.0231 & 0.026526594 \\
\hline $3 / 23 / 2018$ & 0.1101 & 119.13 & 88.07 & 31.06 & 3.4 & 34.46 & 0.3446 & 0.0239 & 0.026435578 \\
\hline $3 / 28 / 2018$ & 0.1556 & 124.93 & 82.54 & 42.39 & 3.4 & 45.79 & 0.4579 & 0.2313 & 0.161004481 \\
\hline $4 / 2 / 2018$ & 0.1480 & 128.67 & 85.85 & 42.82 & 3.4 & 46.22 & 0.4622 & 0.2076 & 0.1707603 \\
\hline $4 / 5 / 2018$ & 0.1368 & 125.44 & 89.91 & 35.53 & 3.4 & 38.93 & 0.3893 & 0.0841 & 0.051337766 \\
\hline $10 / 25 / 2018$ & 0.0710 & 119.23 & 89.99 & 29.24 & 3.4 & 32.64 & 0.3264 & 0.0091 & 0.026820166 \\
\hline $10 / 30 / 2018$ & 0.1186 & 122.25 & 88.27 & 33.98 & 3.4 & 37.38 & 0.3738 & 0.0321 & 0.038542118 \\
\hline $10 / 30 / 2018$ & 0.1207 & 122.14 & 88.55 & 33.59 & 3.4 & 36.99 & 0.3699 & 0.0306 & 0.036018095 \\
\hline $11 / 1 / 2018$ & 0.0927 & 107.37 & 76.93 & 30.44 & 3.4 & 33.84 & 0.3384 & 0.0114 & 0.025882647 \\
\hline $11 / 13 / 2018$ & 0.1616 & 122.49 & 86.2 & 36.29 & 3.4 & 39.69 & 0.3969 & 0.0653 & 0.059225649 \\
\hline $11 / 29 / 2018$ & 0.1058 & 117.71 & 85.97 & 31.74 & 3.4 & 35.14 & 0.3514 & 0.0143 & 0.027854662 \\
\hline $1 / 15 / 2019$ & 0.1125 & 122.14 & 89.69 & 32.45 & 3.4 & 35.85 & 0.3585 & 0.0176 & 0.03024359 \\
\hline $1 / 15 / 2019$ & 0.1085 & 122.41 & 89.96 & 32.45 & 3.4 & 35.85 & 0.3585 & 0.0183 & 0.03024359 \\
\hline $1 / 29 / 2019$ & 0.1868 & 113.39 & 75.48 & 37.91 & 3.4 & 41.31 & 0.4131 & 0.0797 & 0.07958367 \\
\hline $3 / 19 / 2019$ & 0.0866 & 127.26 & 95.69 & 31.57 & 3.4 & 34.97 & 0.3497 & 0.0160 & 0.027420189 \\
\hline $3 / 20 / 2019$ & 0.0780 & 117.38 & 87.68 & 29.7 & 3.4 & 33.1 & 0.331 & 0.0070 & 0.026147861 \\
\hline $4 / 2 / 2019$ & 0.0847 & 117.22 & 86.96 & 30.26 & 3.4 & 33.66 & 0.3366 & 0.0076 & 0.025854495 \\
\hline $4 / 23 / 2019$ & 0.0908 & 111.37 & 83.52 & 27.85 & 3.4 & 31.25 & 0.3125 & 0.0138 & 0.031215625 \\
\hline $4 / 23 / 2019$ & 0.0921 & 111.19 & 83.49 & 27.7 & 3.4 & 31.1 & 0.311 & 0.0139 & 0.031902309 \\
\hline $4 / 25 / 2019$ & 0.1728 & 114.14 & 78.77 & 35.37 & 3.4 & 38.77 & 0.3877 & 0.0871 & 0.049812477 \\
\hline $4 / 25 / 2019$ & 0.1811 & 116.62 & 78.66 & 37.96 & 3.4 & 41.36 & 0.4136 & 0.0990 & 0.080288764 \\
\hline $4 / 26 / 2019$ & 0.1716 & 106.71 & 69.53 & 37.18 & 3.4 & 40.58 & 0.4058 & 0.0882 & 0.069812738 \\
\hline $4 / 30 / 2019$ & 0.0893 & 117.71 & 90.46 & 27.25 & 3.4 & 30.65 & 0.3065 & 0.0128 & 0.034210566 \\
\hline $4 / 30 / 2019$ & 0.0872 & 117.93 & 90.71 & 27.22 & 3.4 & 30.62 & 0.3062 & 0.0135 & 0.034377687 \\
\hline $5 / 13 / 2019$ & 0.1500 & 109.72 & 75.03 & 34.69 & 3.4 & 38.09 & 0.3809 & 0.0636 & 0.043855091 \\
\hline $5 / 14 / 2019$ & 0.2298 & 125.67 & 81.13 & 44.54 & 3.4 & 47.94 & 0.4794 & 0.2524 & 0.213183077 \\
\hline $5 / 14 / 2019$ & 0.2121 & 123.89 & 81.21 & 42.68 & 3.4 & 46.08 & 0.4608 & 0.2103 & 0.167546664 \\
\hline $5 / 15 / 2019$ & 0.1219 & 114.85 & 84.27 & 30.58 & 3.4 & 33.98 & 0.3398 & 0.0268 & 0.025945727 \\
\hline $7 / 21 / 2020$ & 0.2750 & 1074.7 & 1001.39 & 73.3 & 3.4 & 76.7 & 0.767 & 2.0314 & 1.728376619 \\
\hline $7 / 21 / 2020$ & 0.2860 & 1067.6 & 1001.06 & 66.5 & 3.4 & 69.9 & 0.699 & 1.3820 & 1.232850773 \\
\hline $7 / 21 / 2020$ & 0.2670 & 1065.6 & 1001.23 & 64.4 & 3.4 & 67.8 & 0.678 & 1.0757 & 1.097002075 \\
\hline $7 / 21 / 2020$ & 0.2560 & 1062.6 & 1001.40 & 61.2 & 3.4 & 64.6 & 0.646 & 0.8295 & 0.905585525 \\
\hline $7 / 26 / 2021$ & 0.3110 & 1078.9 & 999.98 & 78.9 & 3.4 & 82.3 & 0.823 & 2.2885 & 2.200291531 \\
\hline $7 / 26 / 2021$ & 0.2540 & 1067.6 & 999.75 & 67.9 & 3.4 & 71.3 & 0.713 & 1.3516 & 1.327921043 \\
\hline $7 / 26 / 2021$ & 0.2330 & 1062.3 & 999.69 & 62.6 & 3.4 & 66 & 0.66 & 1.0829 & 0.98701368 \\
\hline $7 / 26 / 2021$ & 0.1980 & 1057.9 & 999.38 & 58.5 & 3.4 & 61.9 & 0.619 & 0.9513 & 0.758721941 \\
\hline 9/9/2021 & 0.1770 & 1054.4 & 996.19 & 58.2 & 3.4 & 61.6 & 0.616 & 0.6279 & 0.743231117 \\
\hline $9 / 9 / 2021$ & 0.2540 & 1063.1 & 995.93 & 67.2 & 3.4 & 70.6 & 0.706 & 1.2630 & 1.279935461 \\
\hline $9 / 9 / 2021$ & 0.2740 & 1068.7 & 995.51 & 73.2 & 3.4 & 76.6 & 0.766 & 1.3765 & 1.720473557 \\
\hline 9/9/2021 & 0.2430 & 1064.8 & 995.74 & 69.1 & 3.4 & 72.5 & 0.725 & 1.1076 & 1.412278 \\
\hline $9 / 22 / 2021$ & 0.3850 & 1076.4 & 991.19 & 85.2 & 3.4 & 88.6 & 0.886 & 3.0483 & 2.800114229 \\
\hline $9 / 22 / 2021$ & 0.3670 & 1074 & 991.81 & 82.2 & 3.4 & 85.6 & 0.856 & 2.5765 & 2.505383501 \\
\hline $9 / 22 / 2021$ & 0.3340 & 1072.2 & 991.92 & 80.3 & 3.4 & 83.7 & 0.837 & 2.1401 & 2.327279203 \\
\hline $9 / 22 / 2021$ & 0.3140 & 1068.5 & 992.07 & 76.4 & 3.4 & 79.8 & 0.798 & 1.7689 & 1.982490811 \\
\hline
\end{tabular}


Table A20-2. Modeled streamflow at Site 20, West Run Watershed, Morgantown, WV, U.S.A.

\begin{tabular}{|c|c|c|c|c|c|c|c|c|c|c|c|c|c|}
\hline $\begin{array}{l}\text { Cross- } \\
\text { Section } \\
\text { Area } \\
\left(\mathrm{m}^{2}\right)\end{array}$ & $\begin{array}{c}\text { A (Cross } \\
\text { Section } \\
\text { area of } \\
\text { flow) }\end{array}$ & $\begin{array}{c}\text { P } \\
\text { (Wetted } \\
\text { Perimete } \\
\text { r) }\end{array}$ & $\begin{array}{c}\mathrm{RH}=\mathrm{A} / \mathrm{P} \\
\text { Hydraulic } \\
\text { Radius } \\
\text { (m) }\end{array}$ & $\begin{array}{l}\text { Observed } \\
\text { Slope (m) }\end{array}$ & $\begin{array}{l}\text { Calculated } \\
\text { Slope using } \\
\text { ArcGIS (m) }\end{array}$ & $\begin{array}{c}\text { Roughness } \\
\text { Coefficient } \\
\text { (n) }\end{array}$ & $\begin{array}{c}\text { Manning } \\
\text { Discharge } \\
\left(\mathrm{m}^{3} / \mathrm{s}\right) \text { (Obs } \\
\text { Slope) }\end{array}$ & $\begin{array}{c}\text { Manning } \\
\text { Discharge } \\
\left(\mathrm{m}^{3} / \mathrm{s}\right) \text { (Calc } \\
\text { Slope) }\end{array}$ & $\begin{array}{l}\text { Chezy } \\
\text { Coefficient } \\
\text { (C) }\end{array}$ & $\begin{array}{c}\text { Chezy } \\
\text { Discharge } \\
\left(\mathrm{m}^{3} / \mathrm{s}\right)(\mathrm{Obs} \\
\text { Slope) }\end{array}$ & $\begin{array}{c}\text { Chezy } \\
\text { Discharge } \\
\left(\mathrm{m}^{3} / \mathrm{s}\right)(\text { Calc } \\
\text { Slope) }\end{array}$ & $\begin{array}{c}\text { Dingman \& } \\
\text { Sharma } \\
\text { Discharge } \\
\left(\mathrm{m}^{3} / \mathrm{s}\right) \text { (Obs. } \\
\text { Slope) }\end{array}$ & $\begin{array}{c}\text { Dingman \& } \\
\text { Sharma } \\
\text { Discharge } \\
\text { ( } \mathrm{m}^{3} / \mathrm{s} \text { ) (Calc } \\
\text { Slope) }\end{array}$ \\
\hline 5.63 & 0.415 & 2.2821 & 0.182048 & 0.03 & 0.011 & 0.11 & 0.210121766 & 0.127235048 & 6.843919932 & 0.210121766 & 0.127235048 & 0.2112983 & 0.174792917 \\
\hline 5.63 & 0.712 & 2.5708 & 0.276873 & 0.03 & 0.011 & 0.11 & 0.476105441 & 0.288296161 & 7.339289577 & 0.476105441 & 0.288296161 & 0.469919119 & 0.38873258 \\
\hline 5.63 & 0.428 & 2.3008 & 0.18618 & 0.03 & 0.011 & 0.11 & 0.219925379 & 0.13317143 & 6.869567006 & 0.219925379 & 0.13317143 & 0.221005576 & 0.182823095 \\
\hline 5.63 & 0.427 & 2.2995 & 0.185874 & 0.03 & 0.011 & 0.11 & 0.219193848 & 0.132728467 & 6.867688195 & 0.219193848 & 0.132728467 & 0.220281584 & 0.182224186 \\
\hline 5.63 & 0.608 & 2.5036 & 0.242936 & 0.03 & 0.011 & 0.11 & 0.372866918 & 0.225782132 & 7.181070429 & 0.372866918 & 0.225782132 & 0.370854372 & 0.306782957 \\
\hline 5.63 & 0.615 & 2.5092 & 0.245131 & 0.03 & 0.011 & 0.11 & 0.379341763 & 0.229702844 & 7.191844875 & 0.379341763 & 0.229702844 & 0.377121521 & 0.311967349 \\
\hline 5.63 & 0.499 & 2.3932 & 0.208401 & 0.03 & 0.011 & 0.11 & 0.276044622 & 0.16715332 & 6.999878894 & 0.276044622 & 0.16715332 & 0.276361518 & 0.228615355 \\
\hline 5.63 & 0.314 & 4.5618 & 0.068832 & 0.03 & 0.011 & 0.11 & 0.083041119 & 0.050283895 & 5.819775287 & 0.083041119 & 0.050283895 & 0.103115088 & 0.085300199 \\
\hline 5.63 & 0.525 & 4.5848 & 0.114509 & 0.03 & 0.011 & 0.11 & 0.194933517 & 0.118038106 & 6.335007492 & 0.194933517 & 0.118038106 & 0.230987673 & 0.191080615 \\
\hline 5.63 & 0.518 & 4.5824 & 0.113041 & 0.03 & 0.011 & 0.11 & 0.190687494 & 0.115467012 & 6.321402474 & 0.190687494 & 0.115467012 & 0.226209006 & 0.187127544 \\
\hline 5.63 & 0.402 & 4.5282 & 0.088777 & 0.03 & 0.011 & 0.11 & 0.125968212 & 0.07627754 & 6.071892262 & 0.125968212 & 0.07627754 & 0.152539992 & 0.126186108 \\
\hline 5.63 & 0.764 & 5.0472 & 0.151371 & 0.03 & 0.011 & 0.11 & 0.341682863 & 0.206899248 & 6.636632796 & 0.341682863 & 0.206899248 & 0.401044002 & 0.331756814 \\
\hline 5.63 & 0.46 & 4.5546 & 0.100997 & 0.03 & 0.011 & 0.11 & 0.157083596 & 0.095118841 & 6.203811305 & 0.157083596 & 0.095118841 & 0.188124064 & 0.155622425 \\
\hline 5.63 & 0.489 & 4.5682 & 0.107044 & 0.03 & 0.011 & 0.11 & 0.173587841 & 0.105112658 & 6.26423353 & 0.173587841 & 0.105112658 & 0.206866978 & 0.171127181 \\
\hline 5.63 & 0.48 & 4.6374 & 0.103506 & 0.03 & 0.011 & 0.11 & 0.166617379 & 0.100891834 & 6.229240446 & 0.166617379 & 0.100891834 & 0.199705038 & 0.165202589 \\
\hline 5.63 & 0.868 & 5.0216 & 0.172853 & 0.03 & 0.011 & 0.11 & 0.424104363 & 0.256807945 & 6.785058291 & 0.424104363 & 0.256807945 & 0.491203056 & 0.406339354 \\
\hline 5.63 & 0.382 & 4.5928 & 0.083174 & 0.03 & 0.011 & 0.11 & 0.114609827 & 0.069399697 & 6.006271409 & 0.114609827 & 0.069399697 & 0.139978403 & 0.115794748 \\
\hline 5.63 & 0.363 & 4.8042 & 0.075559 & 0.03 & 0.011 & 0.11 & 0.102156247 & 0.06185868 & 5.910917609 & 0.102156247 & 0.06185868 & 0.126879386 & 0.104958809 \\
\hline 5.63 & 0.375 & 4.5898 & 0.081703 & 0.03 & 0.011 & 0.11 & 0.111179371 & 0.067322453 & 5.988438115 & 0.111179371 & 0.067322453 & 0.13600036 & 0.112503979 \\
\hline 5.63 & 0.407 & 4.6042 & 0.088398 & 0.03 & 0.011 & 0.11 & 0.127171317 & 0.077006057 & 6.067559162 & 0.127171317 & 0.077006057 & 0.154502927 & 0.127809913 \\
\hline 5.63 & 0.407 & 4.6042 & 0.088398 & 0.03 & 0.011 & 0.11 & 0.127171317 & 0.077006057 & 6.067559162 & 0.127171317 & 0.077006057 & 0.154502927 & 0.127809913 \\
\hline 5.63 & 0.816 & 5.0694 & 0.160966 & 0.03 & 0.011 & 0.11 & 0.380201506 & 0.230223445 & 6.704960873 & 0.380201506 & 0.230223445 & 0.444030062 & 0.367316299 \\
\hline 5.63 & 0.856 & 5.0864 & 0.168292 & 0.03 & 0.011 & 0.11 & 0.410850553 & 0.248782365 & 6.754883406 & 0.410850553 & 0.248782365 & 0.478105133 & 0.395504321 \\
\hline 5.63 & 0.81 & 5.067 & 0.159858 & 0.03 & 0.011 & 0.11 & 0.375672182 & 0.227480803 & 6.697247271 & 0.375672182 & 0.227480803 & 0.438988306 & 0.363145593 \\
\hline 5.63 & 0.402 & 4.6748 & 0.085993 & 0.03 & 0.011 & 0.11 & 0.123320707 & 0.074674397 & 6.039734081 & 0.123320707 & 0.074674397 & 0.150608244 & 0.124588103 \\
\hline 5.63 & 0.391 & 4.6704 & 0.083719 & 0.03 & 0.011 & 0.11 & 0.117822026 & 0.07134478 & 6.012813887 & 0.117822026 & 0.07134478 & 0.144231057 & 0.119312683 \\
\hline 5.63 & 0.709 & 5.0242 & 0.141117 & 0.03 & 0.011 & 0.11 & 0.302598698 & 0.183232611 & 6.559496946 & 0.302598698 & 0.183232611 & 0.357228532 & 0.295511213 \\
\hline 5.63 & 1.157 & 5.4888 & 0.210793 & 0.03 & 0.011 & 0.11 & 0.645265734 & 0.390727805 & 7.01320672 & 0.645265734 & 0.390727805 & 0.74497001 & 0.616263741 \\
\hline 5.63 & 1.067 & 5.4534 & 0.195658 & 0.03 & 0.011 & 0.11 & 0.566235472 & 0.342872605 & 6.92665397 & 0.566235472 & 0.342872605 & 0.657570117 & 0.54396367 \\
\hline 5.63 & 0.557 & 4.8158 & 0.115661 & 0.03 & 0.011 & 0.11 & 0.208200119 & 0.126071433 & 6.345586574 & 0.208200119 & 0.126071433 & 0.24858174 & 0.205635007 \\
\hline 5.63 & 1.952 & 7.638 & 0.255564 & 0.03 & 0.011 & 0.11 & 1.237792542 & 0.749520606 & 7.241980338 & 1.237792542 & 0.749520606 & 1.486069987 & 1.229326064 \\
\hline 5.63 & 1.593 & 6.1358 & 0.259624 & 0.03 & 0.011 & 0.11 & 1.020814363 & 0.618133793 & 7.261027445 & 1.020814363 & 0.618133793 & 1.178265918 & 0.974700395 \\
\hline 5.63 & 1.446 & 5.9446 & 0.243246 & 0.03 & 0.011 & 0.11 & 0.887224118 & 0.537240883 & 7.182598505 & 0.887224118 & 0.537240883 & 1.024712534 & 0.847675976 \\
\hline 5.63 & 1.364 & 5.8454 & 0.233346 & 0.03 & 0.011 & 0.11 & 0.81404623 & 0.492929471 & 7.133029235 & 0.81404623 & 0.492929471 & 0.941117153 & 0.778523121 \\
\hline 5.63 & 2.27496 & 7.937 & 0.286627 & 0.03 & 0.011 & 0.11 & 1.557231919 & 0.942950754 & 7.38176495 & 1.557231919 & 0.942950754 & 1.861930897 & 1.540250594 \\
\hline 5.63 & 1.81625 & 7.671 & 0.236768 & 0.03 & 0.011 & 0.11 & 1.09452579 & 0.662768279 & 7.150360238 & 1.09452579 & 0.662768279 & 1.324490498 & 1.095662186 \\
\hline 5.63 & 1.63045 & 7.476 & 0.218091 & 0.03 & 0.011 & 0.11 & 0.930181195 & 0.563252685 & 7.053104962 & 0.930181195 & 0.563252685 & 1.129271416 & 0.934170528 \\
\hline 5.63 & 1.37438 & 7.33 & 0.187501 & 0.03 & 0.011 & 0.11 & 0.708940853 & 0.429285005 & 6.877666668 & 0.708940853 & 0.429285005 & 0.869975109 & 0.719672078 \\
\hline 5.63 & 1.3378 & 7.942 & 0.168446 & 0.03 & 0.011 & 0.11 & 0.642490445 & 0.389047284 & 6.755915355 & 0.642490445 & 0.389047284 & 0.807509741 & 0.667998667 \\
\hline 5.63 & 1.93413 & 8.128 & 0.237959 & 0.03 & 0.011 & 0.11 & 1.169467744 & 0.708147886 & 7.156340165 & 1.169467744 & 0.708147886 & 1.428745402 & 1.181905278 \\
\hline 5.63 & 2.09772 & 8.206 & 0.255632 & 0.03 & 0.011 & 0.11 & 1.330432357 & 0.805616799 & 7.242302309 & 1.330432357 & 0.805616799 & 1.617195859 & 1.337797706 \\
\hline 5.63 & 1.84471 & 8.068 & 0.228645 & 0.03 & 0.011 & 0.11 & 1.086102598 & 0.657667783 & 7.108877277 & 1.086102598 & 0.657667783 & 1.330163196 & 1.100354828 \\
\hline 5.63 & 3.04722 & 8.695 & 0.350457 & 0.03 & 0.011 & 0.11 & 2.385033965 & 1.444209786 & 7.633312087 & 2.385033965 & 1.444209786 & 2.843015564 & 2.35183616 \\
\hline 5.63 & 2.89683 & 8.621 & 0.33602 & 0.03 & 0.011 & 0.11 & 2.204623985 & 1.334966118 & 7.579982603 & 2.204623985 & 1.334966118 & 2.634439408 & 2.179295091 \\
\hline 5.63 & 2.58329 & 8.402 & 0.307461 & 0.03 & 0.011 & 0.11 & 1.852968751 & 1.122028299 & 7.468597629 & 1.852968751 & 1.122028299 & 2.222806677 & 1.838778931 \\
\hline 5.63 & 2.41664 & 8.324 & 0.290322 & 0.03 & 0.011 & 0.11 & 1.66839864 & 1.010265547 & 7.397539558 & 1.66839864 & 1.010265547 & 2.008935357 & 1.661857528 \\
\hline
\end{tabular}




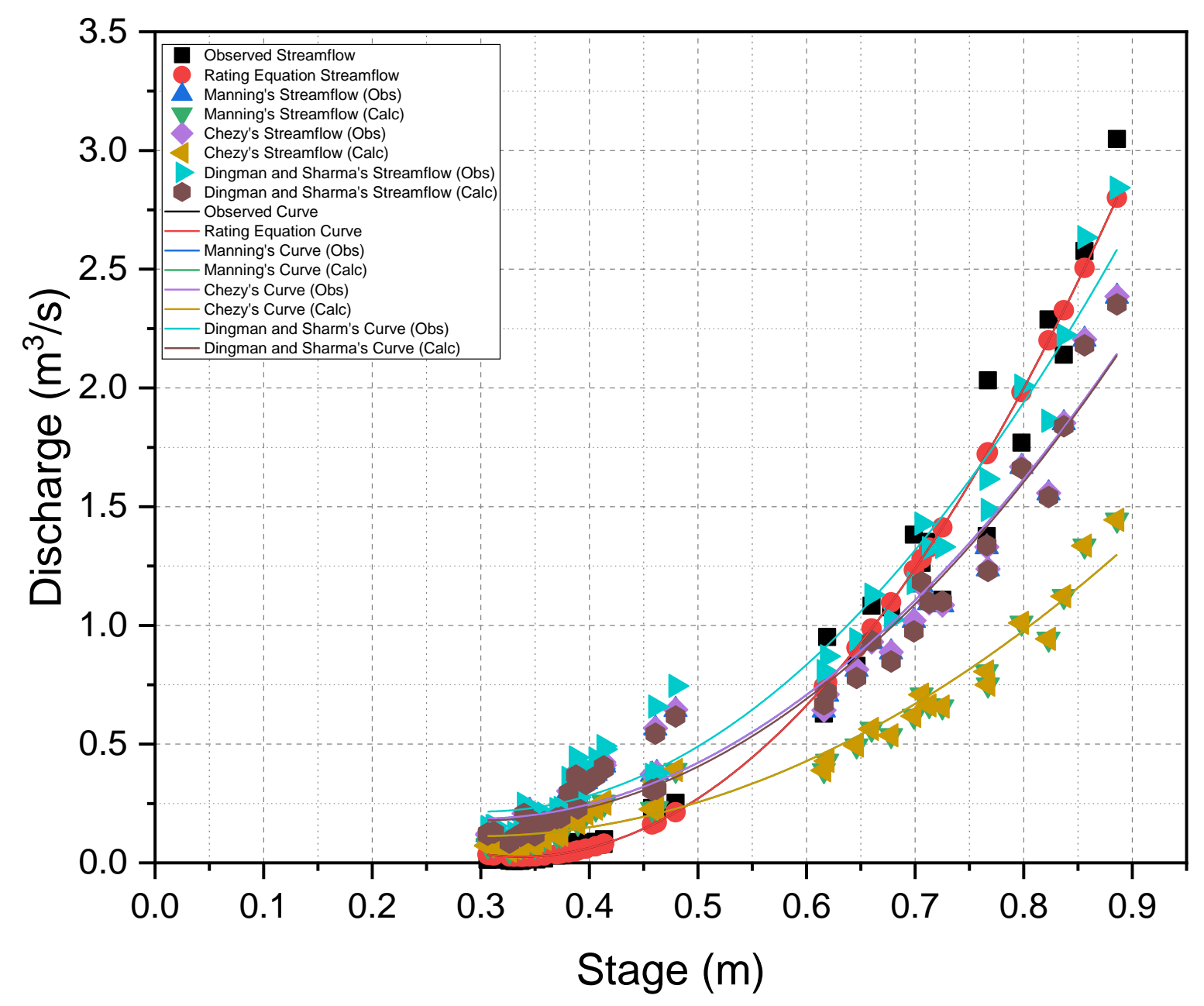

Figure A20-1. Observed and modeled rating curves and streamflow from Site 20, West Run Watershed, Morgantown, West Virginia, U.S.A. 
Table A20-3. Polynomial rating equations and $\mathrm{R}^{2}$ values for observed and modeled rating curves at Site 20, West Run Watershed, Morgantown, WV, U.S.A.

\begin{tabular}{ccc}
\hline & $\begin{array}{c}\mathbf{R}^{\mathbf{2}} \\
\text { Value }\end{array}$ & Polynomial Equation \\
\hline Observed Curve & 0.98 & $\mathrm{y}=9.1928 \mathrm{x}^{2}-6.1895 \mathrm{x}+1.0677$ \\
Manning's Curve (Obs Slope) & 0.96 & $\mathrm{y}=5.6124 \mathrm{x}^{2}-3.3138 \mathrm{x}+0.6755$ \\
Manning's Curve (Calc Slope) & 0.96 & $\mathrm{y}=3.3985 \mathrm{x}^{2}-2.0066 \mathrm{x}+0.409$ \\
Chezy's Curve (Obs Slope) & 0.96 & $\mathrm{y}=5.6124 \mathrm{x}^{2}-3.3138 \mathrm{x}+0.6755$ \\
Chezy's Curve (Calc Slope) & 0.96 & $\mathrm{y}=3.3985 \mathrm{x}^{2}-2.0066 \mathrm{x}+0.409$ \\
$\begin{array}{c}\text { Dingman and Sharma's Curve } \\
\text { (Obs Slope) }\end{array}$ & 0.97 & $\mathrm{y}=7.0352 \mathrm{x}^{2}-4.2963 \mathrm{x}+0.8733$ \\
$\begin{array}{c}\text { Dingman and Sharma's Curve } \\
\text { (Calc Slope) }\end{array}$ & 0.97 & $\mathrm{y}=5.8198 \mathrm{x}^{2}-3.5541 \mathrm{x}+0.7224$ \\
\hline
\end{tabular}

Table A20-4. Descriptive statistics for observed and modeled streamflow used to generate the rating curves for Site 20, West Run Watershed, Morgantown, WV, U.S.A.

\begin{tabular}{|c|c|c|c|c|}
\hline & Sample Size & Mean $\left(\mathrm{m}^{3} / \mathrm{s}\right)$ & St. Dev. & SE of Mean \\
\hline Observed & 44 & 0.606 & 0.834 & 0.126 \\
\hline Manning's & 44 & 0.628 & 0.601 & 0.091 \\
\hline $\begin{array}{l}\text { Curve (Obs } \\
\text { Slope) }\end{array}$ & & & & \\
\hline $\begin{array}{l}\text { Manning's } \\
\text { Curve (Calc } \\
\text { Slope) }\end{array}$ & 44 & 0.38 & 0.364 & 0.055 \\
\hline $\begin{array}{c}\text { Chezy's Curve } \\
\text { (Obs Slope) }\end{array}$ & 44 & 0.628 & 0.601 & 0.091 \\
\hline $\begin{array}{c}\text { Chezy's Curve } \\
\text { (Calc Slope) }\end{array}$ & 44 & 0.38 & 0.364 & 0.055 \\
\hline $\begin{array}{l}\text { Dingman and } \\
\text { Sharma's } \\
\text { Curve (Obs } \\
\text { Slope) }\end{array}$ & 44 & 0.744 & 0.724 & 0.109 \\
\hline $\begin{array}{l}\text { Dingman and } \\
\text { Sharma's } \\
\text { Curve (Calc } \\
\text { Slope) }\end{array}$ & 44 & 0.616 & 0.599 & 0.09 \\
\hline
\end{tabular}


Table A20-5. P-values of the statistical analyses (post-hoc ANOVA) for observed and modeled rating curves at Site 20, West Run Watershed, Morgantown, WV, U.S.A.

\begin{tabular}{|c|c|c|c|c|c|c|c|c|}
\hline & $\begin{array}{c}\text { Observed } \\
\text { Curve }\end{array}$ & $\begin{array}{l}\text { Rating } \\
\text { Equation } \\
\text { Curve }\end{array}$ & $\begin{array}{c}\text { Manning's } \\
\text { Curve (Obs } \\
\text { Slope) }\end{array}$ & $\begin{array}{c}\text { Manning's } \\
\text { Curve (Calc } \\
\text { Slope) }\end{array}$ & $\begin{array}{c}\text { Chezy's } \\
\text { Curve } \\
\text { (Obs } \\
\text { Slope) } \\
\end{array}$ & $\begin{array}{c}\text { Chezy's } \\
\text { Curve } \\
\text { (Calc } \\
\text { Slope) } \\
\end{array}$ & $\begin{array}{c}\text { Dingman and } \\
\text { Sharma's } \\
\text { Curve (Obs } \\
\text { Slope) } \\
\end{array}$ & $\begin{array}{c}\text { Dingman and } \\
\text { Sharma's } \\
\text { Curve (Calc } \\
\text { Slope) } \\
\end{array}$ \\
\hline $\begin{array}{l}\text { Rating } \\
\text { Equation } \\
\text { Curve }\end{array}$ & - & - & 1 & 0.71 & 1 & 0.71 & 0.97 & 1 \\
\hline $\begin{array}{c}\text { Manning's } \\
\text { Curve (Obs } \\
\text { Slope) }\end{array}$ & - & - & - & 0.60 & 1 & 0.60 & 0.99 & 1 \\
\hline $\begin{array}{l}\text { Manning's } \\
\text { Curve (Calc } \\
\text { Slope) }\end{array}$ & - & - & - & - & 0.60 & 1 & 0.13 & 0.66 \\
\hline $\begin{array}{c}\text { Chezy's } \\
\text { Curve (Calc } \\
\text { Slope) }\end{array}$ & - & - & - & - & - & - & 0.13 & 0.66 \\
\hline $\begin{array}{l}\text { Dingman and } \\
\text { Sharma's } \\
\text { Curve (Obs } \\
\text { Slope) }\end{array}$ & - & - & - & - & - & - & - & 0.98 \\
\hline $\begin{array}{l}\text { Dingman and } \\
\text { Sharma's } \\
\text { Curve (Calc } \\
\text { Slope) }\end{array}$ & - & - & - & - & - & - & - & - \\
\hline
\end{tabular}




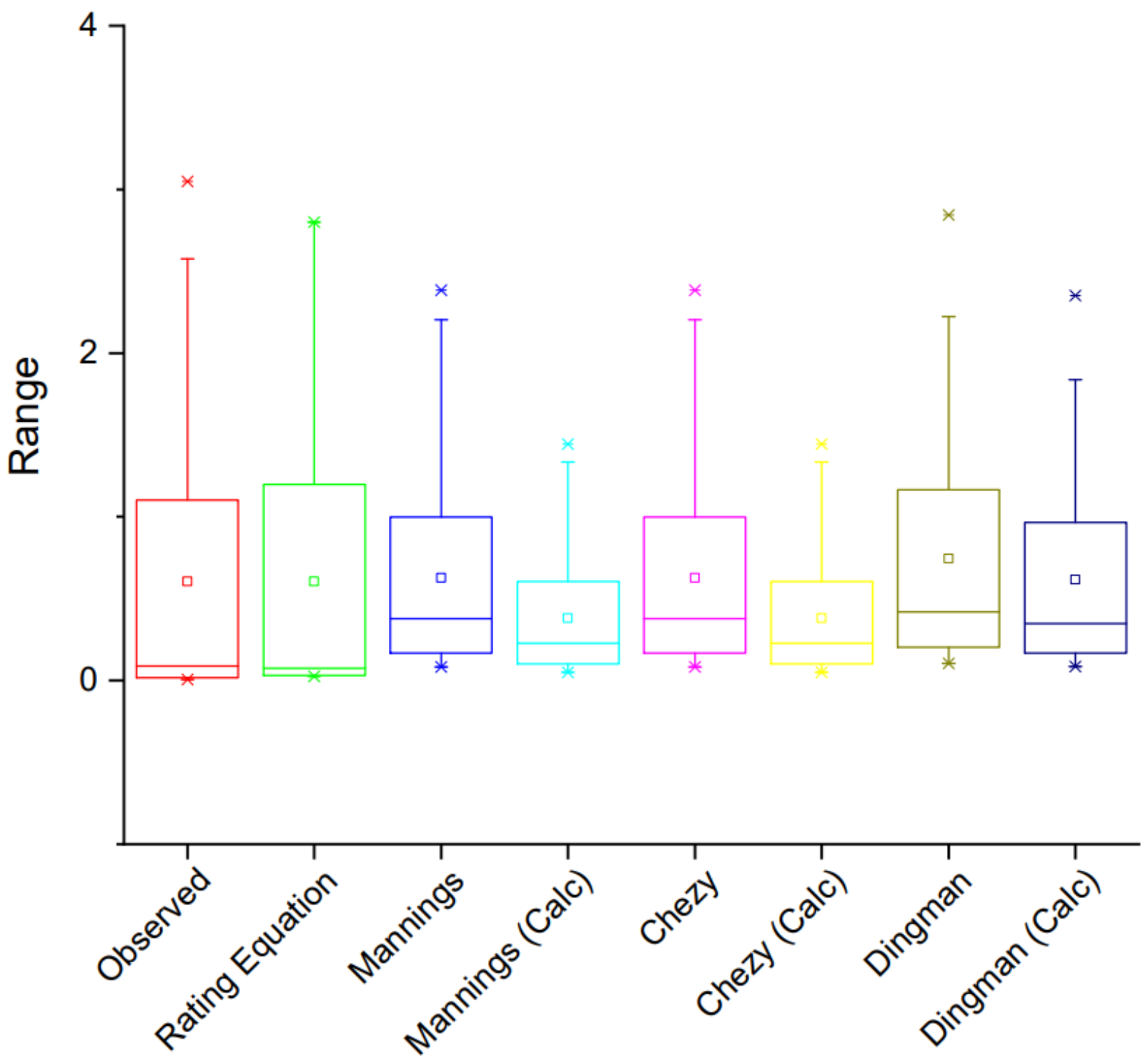

Figure A20-2. Box and whisker plots for the results of the statistical analyses (post-hoc ANOVA) of observed and modeled rating curves at Site 20, West Run Watershed, Morgantown, WV, U.S.A. 


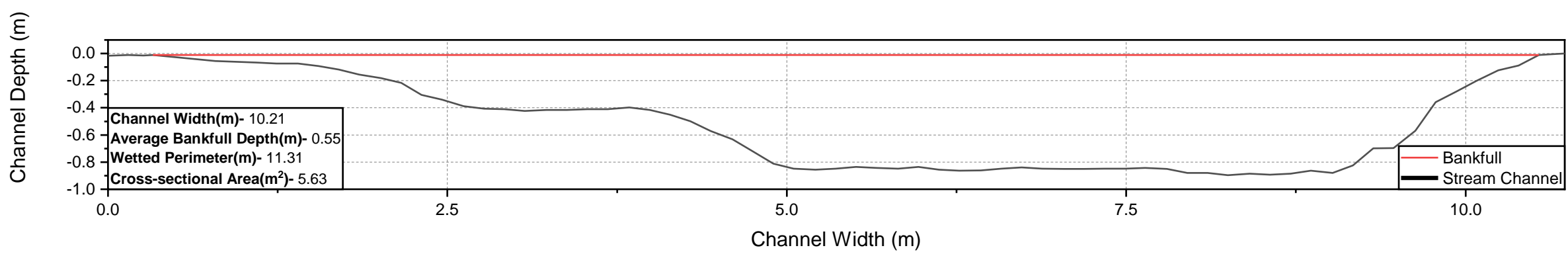

Figure A20-3. Cross-sectional profile of WRW Site 20, plotting the stream channel's shape, water surface, and bankfull. The profile is created with a Channel Width of $0=$ Left Bank facing downstream. 

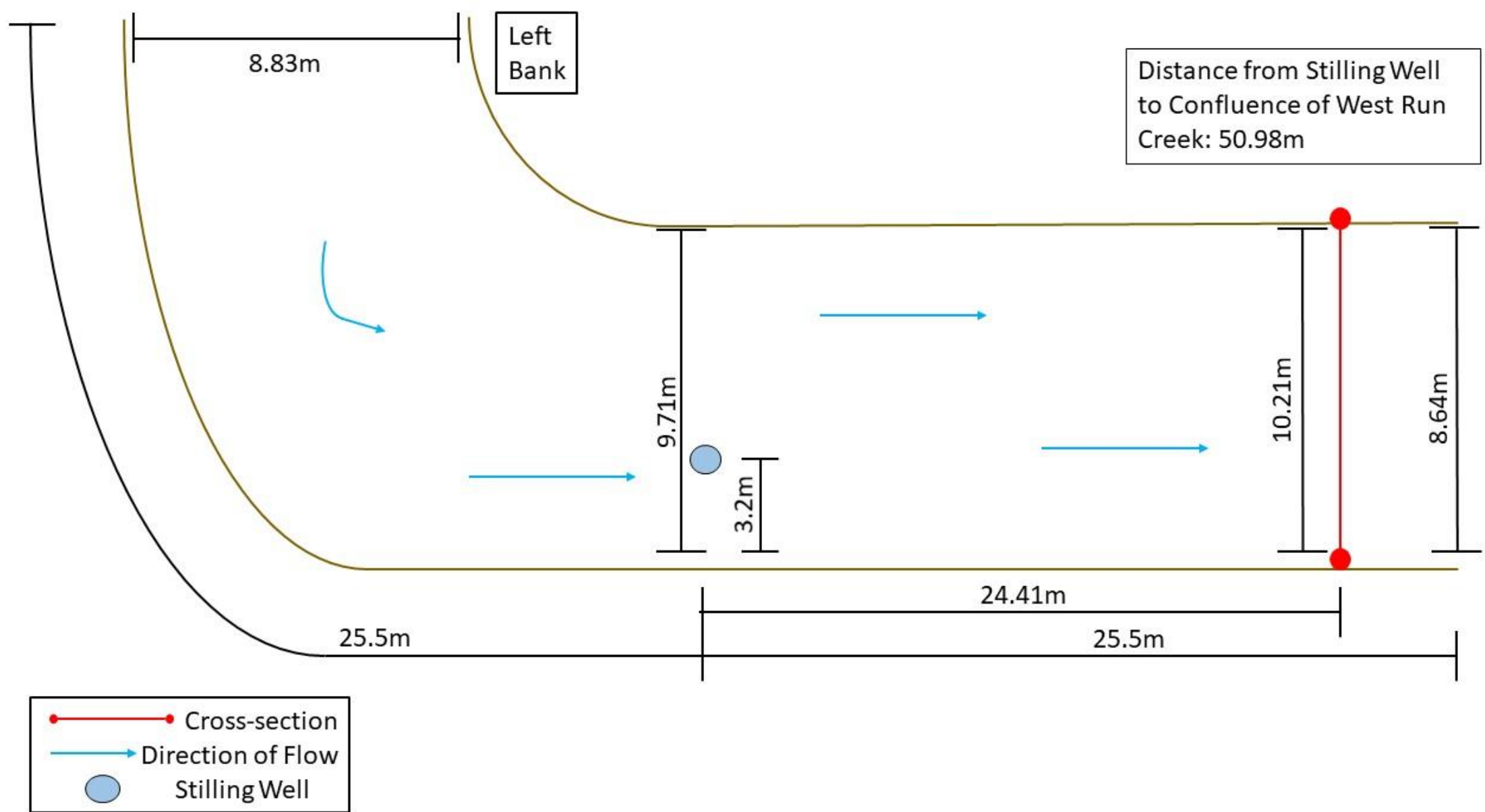

Figure A20-4. Plan view profile of WRW Site 20, West Run Watershed, Morgantown, WV, U.S.A. (Figure 2). Showing the positioning of stilling well in relation to where the streamflow was measured. Along with the channel width at the stilling well, point where cross-sections were performed, and $25.5 \mathrm{~m}$ upstream and downstream from the stilling well. 


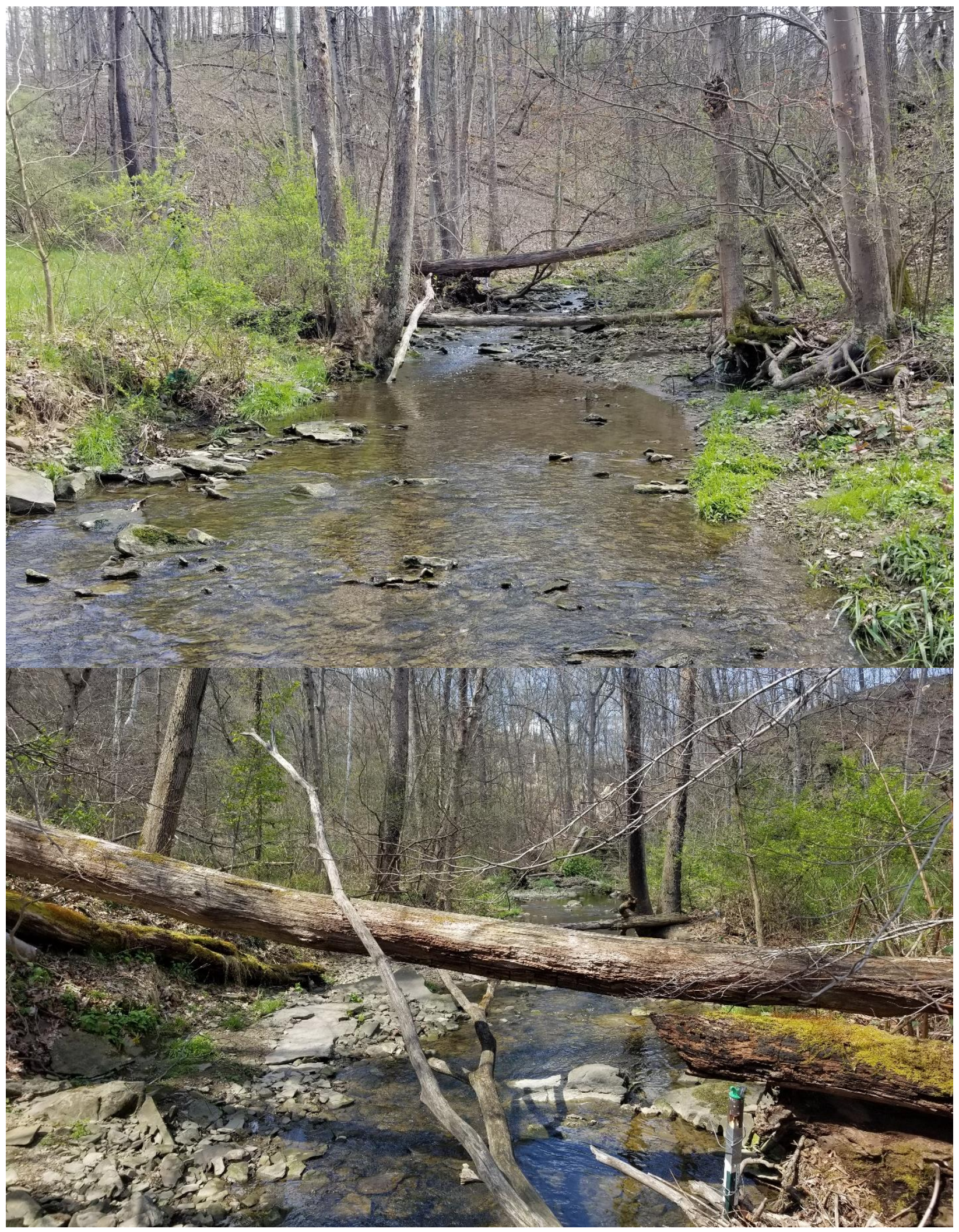

Figure A20-5. Photographs showing channel characteristics at Site \#20, West Run Watershed, Morgantown, WV, U.S.A. Photo 1 was taken looking upstream in the channel. Photo 2 was taken from the right bank looking downstream. 


\section{APPENDIX 21: Site 21}

Table A21-1. Streamflow measurements and stage collected at Site 21, West Run Watershed, Morgantown, WV, U.S.A. (Figure 2).

\begin{tabular}{|c|c|c|c|c|c|c|c|c|c|}
\hline Date & $\begin{array}{l}\text { Mean Depth of } \\
\text { Cross-Section } \\
\text { (m) }\end{array}$ & Stage(PT in cm) & $\begin{array}{c}\text { Barometric } \\
\text { Pressure (in cm) }\end{array}$ & $\begin{array}{c}\text { Pressure } \\
\text { Corrected Stage } \\
\text { (cm) }\end{array}$ & $\begin{array}{l}\text { Stilling Well } \\
\text { Offset }(\mathrm{cm})\end{array}$ & $\begin{array}{l}\text { P-Corrected } \\
\text { Stage + Offset } \\
\text { (cm) }\end{array}$ & $\begin{array}{l}\text { P-Corrected } \\
\text { Stage + Offset } \\
\text { (m) }\end{array}$ & $\begin{array}{c}\text { SonTec } \\
\text { Discharge }(\mathrm{m} 3 / \mathrm{s})\end{array}$ & $\begin{array}{l}\text { Rating Equation } \\
\text { Discharge }(\mathrm{m} 3 / \mathrm{s})\end{array}$ \\
\hline $10 / 23 / 2018$ & 0.2374 & 104.91 & 86.3 & 18.61 & 17.8 & 36.4 & 0.3641 & 0.0911 & 0.10643814 \\
\hline $10 / 23 / 2018$ & 0.2402 & 104.76 & 86.05 & 18.71 & 17.8 & 36.5 & 0.3651 & 0.1104 & 0.11093318 \\
\hline $1 / 16 / 2019$ & 0.2003 & 109.09 & 87.33 & 21.76 & 17.8 & 39.6 & 0.3956 & 0.1909 & 0.25337654 \\
\hline $1 / 16 / 2019$ & 0.2070 & 109.57 & 87.76 & 21.81 & 17.8 & 39.6 & 0.3961 & 0.1790 & 0.255797903 \\
\hline $1 / 29 / 2019$ & 0.2198 & 103.79 & 76.21 & 27.58 & 17.8 & 45.4 & 0.4538 & 0.4779 & 0.55390459 \\
\hline 2/19/2019 & 0.2015 & 124.36 & 100.46 & 23.9 & 17.8 & 41.7 & 0.417 & 0.2867 & 0.359499007 \\
\hline 2/19/2019 & 0.2042 & 124.45 & 100.08 & 24.37 & 17.8 & 42.2 & 0.4217 & 0.3067 & 0.383488691 \\
\hline 3/19/2019 & 0.1820 & 117.39 & 97.02 & 20.37 & 17.8 & 38.2 & 0.3817 & 0.1614 & 0.187176123 \\
\hline 3/19/2019 & 0.1762 & 117.33 & 97.18 & 20.15 & 17.8 & 38.0 & 0.3795 & 0.1672 & 0.176895401 \\
\hline $3 / 20 / 2019$ & 0.1850 & 107.92 & 88.65 & 19.27 & 17.8 & 37.1 & 0.3707 & 0.1564 & 0.13631101 \\
\hline $4 / 2 / 2019$ & 0.1801 & 106.1 & 87.34 & 18.76 & 17.8 & 36.6 & 0.3656 & 0.0969 & 0.113184872 \\
\hline 4/3/2019 & 0.1785 & 109.63 & 90.72 & 18.91 & 17.8 & 36.7 & 0.3671 & 0.1230 & 0.119956637 \\
\hline 4/15/2019 & 0.2405 & 112.32 & 79.91 & 32.41 & 17.8 & 50.2 & 0.5021 & 0.9193 & 0.831927683 \\
\hline 4/15/2019 & 0.2356 & 112.21 & 80.37 & 31.84 & 17.8 & 49.6 & 0.4964 & 0.8528 & 0.797766696 \\
\hline 4/23/2019 & 0.1926 & 103.81 & 83.77 & 20.04 & 17.8 & 37.8 & 0.3784 & 0.2202 & 0.171775233 \\
\hline $4 / 25 / 2019$ & 0.1942 & 101.71 & 77.88 & 23.83 & 17.8 & 41.6 & 0.4163 & 0.3588 & 0.355947103 \\
\hline 4/26/2019 & 0.2402 & 99.75 & 68.68 & 31.07 & 17.8 & 48.9 & 0.4887 & 0.8477 & 0.752193389 \\
\hline $4 / 30 / 2019$ & 0.1658 & 111.53 & 91.31 & 20.22 & 17.8 & 38.0 & 0.3802 & 0.2121 & 0.180160699 \\
\hline 4/30/2019 & 0.1670 & 111.38 & 91.17 & 20.21 & 17.8 & 38.0 & 0.3801 & 0.2187 & 0.179693894 \\
\hline 5/14/2019 & 0.2286 & 111.64 & 81.98 & 29.66 & 17.8 & 47.5 & 0.4746 & 0.7683 & 0.670450925 \\
\hline 5/15/2019 & 0.1972 & 106.65 & 84.42 & 22.23 & 17.8 & 40.0 & 0.4003 & 0.3711 & 0.276247171 \\
\hline $5 / 22 / 2020$ & 0.2402 & 1043.4 & 1001.45 & 42 & 17.8 & 59.8 & 0.598 & 1.2582 & 1.460874052 \\
\hline $10 / 29 / 2020$ & 0.3510 & 1038.6 & 985.64 & 53 & 17.8 & 70.8 & 0.708 & 2.3660 & 2.308289632 \\
\hline
\end{tabular}


Table A21-2. Modeled streamflow at Site 21, West Run Watershed, Morgantown, WV, U.S.A.

\begin{tabular}{|c|c|c|c|c|c|c|c|c|c|c|c|c|c|}
\hline $\begin{array}{l}\text { Cross- } \\
\text { Section } \\
\text { Area } \\
\left(\mathrm{m}^{2}\right)\end{array}$ & $\begin{array}{c}\text { A (Cross } \\
\text { Section } \\
\text { area of } \\
\text { flow) }\end{array}$ & $\begin{array}{c}\text { P } \\
\text { (Wetted } \\
\text { Perimete } \\
\text { r) }\end{array}$ & $\begin{array}{c}\text { RH=A/P } \\
\text { Hydraulic } \\
\text { Radius } \\
\text { (m) }\end{array}$ & $\begin{array}{l}\text { Observed } \\
\text { Slope }(m)\end{array}$ & $\begin{array}{l}\text { Calculated } \\
\text { Slope using } \\
\text { ArcGIS (m) }\end{array}$ & $\begin{array}{l}\text { Roughness } \\
\text { Coefficient } \\
\text { (n) }\end{array}$ & $\begin{array}{c}\text { Manning } \\
\text { Discharge } \\
\left(\mathrm{m}^{3} / \mathrm{s}\right) \text { (Obs } \\
\text { Slope) }\end{array}$ & $\begin{array}{c}\text { Manning } \\
\text { Discharge } \\
\left.\text { (m } \mathrm{m}^{3} / \mathrm{s}\right) \text { (Calc } \\
\text { Slope) }\end{array}$ & $\begin{array}{c}\text { Chezy } \\
\text { Coefficient } \\
\text { (C) }\end{array}$ & $\begin{array}{c}\text { Chezy } \\
\text { Discharge } \\
\left(\mathrm{m}^{3} / \mathrm{s}\right)(\text { Obs } \\
\text { Slope) }\end{array}$ & $\begin{array}{c}\text { Chezy } \\
\text { Discharge } \\
\left(\mathrm{m}^{3} / \mathrm{s}\right) \text { (Calc } \\
\text { Slope) }\end{array}$ & $\begin{array}{l}\text { Dingman \& } \\
\text { Sharma } \\
\text { Discharge } \\
\left(\mathrm{m}^{3} / \mathrm{s}\right) \text { (Obs. } \\
\text { Slope) }\end{array}$ & $\begin{array}{l}\text { Dingman \& } \\
\text { Sharma } \\
\text { Discharge } \\
\left(\mathrm{m}^{3} / \mathrm{s}\right) \text { (Calc } \\
\text { Slope) }\end{array}$ \\
\hline 11.03 & 1.317 & 5.9662 & 0.220744 & 0.01 & 0.029 & 0.115 & 0.418292341 & 0.712326189 & 6.760053829 & 0.418292341 & 0.712326189 & 0.715922563 & 0.878393085 \\
\hline 11.03 & 1.318 & 5.967 & 0.220882 & 0.01 & 0.029 & 0.115 & 0.41878439 & 0.713164118 & 6.760757963 & 0.41878439 & 0.713164118 & 0.716739392 & 0.879395284 \\
\hline 11.03 & 1.435 & 7.5638 & 0.189719 & 0.01 & 0.029 & 0.115 & 0.411998186 & 0.701607629 & 6.59154878 & 0.411998186 & 0.701607629 & 0.745193013 & 0.914306133 \\
\hline 11.03 & 1.483 & 7.5772 & 0.195719 & 0.01 & 0.029 & 0.115 & 0.434708612 & 0.740282091 & 6.625839217 & 0.434708612 & 0.740282091 & 0.784220659 & 0.962190662 \\
\hline 11.03 & 1.623 & 7.8302 & 0.207274 & 0.01 & 0.029 & 0.115 & 0.494292995 & 0.841750639 & 6.689491462 & 0.494292995 & 0.841750639 & 0.891987233 & 1.094413639 \\
\hline 11.03 & 1.565 & 8.1748 & 0.191442 & 0.01 & 0.029 & 0.115 & 0.452037681 & 0.769792433 & 6.601485807 & 0.452037681 & 0.769792433 & 0.827974486 & 1.015873923 \\
\hline 11.03 & 1.587 & 8.1804 & 0.194 & 0.01 & 0.029 & 0.115 & 0.462466924 & 0.787552794 & 6.616107566 & 0.462466924 & 0.787552794 & 0.846124827 & 1.03814328 \\
\hline 11.03 & 1.345 & 7.755 & 0.173436 & 0.01 & 0.029 & 0.115 & 0.363734726 & 0.619417918 & 6.493700285 & 0.363734726 & 0.619417918 & 0.666322044 & 0.81753629 \\
\hline 11.03 & 1.301 & 7.743 & 0.168023 & 0.01 & 0.029 & 0.115 & 0.344475348 & 0.58662038 & 6.459469211 & 0.344475348 & 0.58662038 & 0.632748658 & 0.776343804 \\
\hline 11.03 & 1.297 & 7.38 & 0.175745 & 0.01 & 0.029 & 0.115 & 0.353859787 & 0.602601503 & 6.508028239 & 0.353859787 & 0.602601503 & 0.641902085 & 0.787574498 \\
\hline 11.03 & 1.318 & 7.6754 & 0.171717 & 0.01 & 0.029 & 0.115 & 0.354073832 & 0.602966009 & 6.482928399 & 0.354073832 & 0.602966009 & 0.648072036 & 0.795144649 \\
\hline 11.03 & 1.251 & 7.367 & 0.169811 & 0.01 & 0.029 & 0.115 & 0.333582989 & 0.568071361 & 6.470878811 & 0.333582989 & 0.568071361 & 0.606884756 & 0.744610382 \\
\hline 11.03 & 2.162 & 9.4728 & 0.228232 & 0.01 & 0.029 & 0.115 & 0.702116852 & 1.195661915 & 6.797747778 & 0.702116852 & 1.195661915 & 1.297697301 & 1.592195015 \\
\hline 11.03 & 2.155 & 9.472 & 0.227513 & 0.01 & 0.029 & 0.115 & 0.698371473 & 1.189283764 & 6.794170227 & 0.698371473 & 1.189283764 & 1.291137918 & 1.584147055 \\
\hline 11.03 & 1.379 & 7.548 & 0.182697 & 0.01 & 0.029 & 0.115 & 0.386089516 & 0.657486754 & 6.550245168 & 0.386089516 & 0.657486754 & 0.700549105 & 0.859530796 \\
\hline 11.03 & 1.671 & 8.9992 & 0.185683 & 0.01 & 0.029 & 0.115 & 0.472926489 & 0.805364791 & 6.567966324 & 0.472926489 & 0.805364791 & 0.88327745 & 1.083727269 \\
\hline 11.03 & 2.178 & 9.5484 & 0.228101 & 0.01 & 0.029 & 0.115 & 0.707041463 & 1.204048224 & 6.797095495 & 0.707041463 & 1.204048224 & 1.308668187 & 1.60565562 \\
\hline 11.03 & 1.416 & 8.8638 & 0.159751 & 0.01 & 0.029 & 0.115 & 0.362516365 & 0.617343124 & 6.405347716 & 0.362516365 & 0.617343124 & 0.684874927 & 0.840299539 \\
\hline 11.03 & 1.412 & 8.792 & 0.160601 & 0.01 & 0.029 & 0.115 & 0.362772926 & 0.617780032 & 6.411013074 & 0.362772926 & 0.617780032 & 0.684055997 & 0.839294763 \\
\hline 11.03 & 2.072 & 9.525 & 0.217533 & 0.01 & 0.029 & 0.115 & 0.651691048 & 1.109789864 & 6.743566131 & 0.651691048 & 1.109789864 & 1.211077215 & 1.485917481 \\
\hline 11.03 & 1.668 & 8.8524 & 0.188423 & 0.01 & 0.029 & 0.115 & 0.476710682 & 0.811809039 & 6.584022845 & 0.476710682 & 0.811809039 & 0.88659794 & 1.087801307 \\
\hline 11.03 & 2.306 & 10.0814 & 0.228738 & 0.01 & 0.029 & 0.115 & 0.749987054 & 1.277181931 & 6.8002555583 & 0.749987054 & 1.277181931 & 1.40089664 & 1.718814276 \\
\hline 11.03 & 3.423 & 10.456 & 0.327372 & 0.01 & 0.029 & 0.115 & 1.413849801 & 2.407699453 & 7.218977924 & 1.413849801 & 2.407699453 & 2.569878383 & 3.153083194 \\
\hline
\end{tabular}




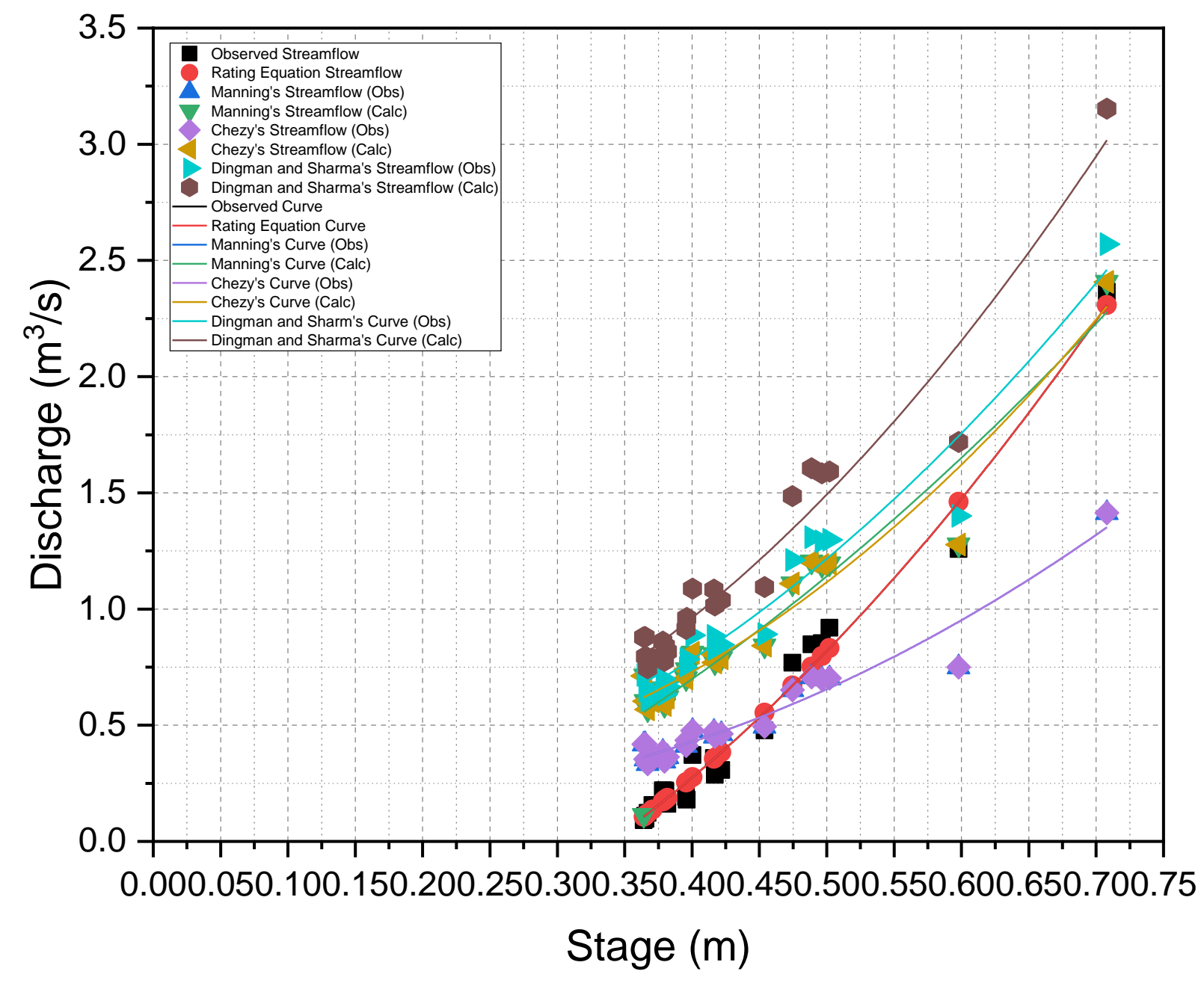

Figure A21-1. Observed and modeled rating curves and streamflow from Site 21, West Run Watershed, Morgantown, West Virginia, U.S.A. 
Table A21-3. Polynomial rating equations and $\mathrm{R}^{2}$ values for observed and modeled rating curves at Site 21, West Run Watershed, Morgantown, WV, U.S.A.

\begin{tabular}{ccc}
\hline & $\begin{array}{c}\mathbf{R}^{\mathbf{2}} \\
\text { Value }\end{array}$ & Polynomial Equation \\
\hline $\begin{array}{c}\text { Observed Curve } \\
\text { Manning's Curve (Obs Slope) }\end{array}$ & 0.98 & $\mathrm{y}=5.563 \mathrm{x}^{2}+0.4385 \mathrm{x}-0.7907$ \\
Manning's Curve (Calc Slope) & 0.90 & $\mathrm{y}=3.5201 \mathrm{x}^{2}-0.9027 \mathrm{x}+0.2264$ \\
Chezy's Curve (Obs Slope) & 0.94 & $\mathrm{y}=3.4025 \mathrm{x}^{2}+1.3579 \mathrm{x}-0.3888$ \\
$\begin{array}{c}\text { Chezy's Curve (Calc Slope) } \\
\text { Dingman and Sharma's Curve } \\
\text { (Obs Slope) }\end{array}$ & 0.94 & $\mathrm{y}=3.5201 \mathrm{x}^{2}-0.9027 \mathrm{x}+0.2264$ \\
$\begin{array}{c}\text { Dingman and Sharma's Curve } \\
\text { (Calc Slope) }\end{array}$ & 0.95 & $\mathrm{y}=5.9945 \mathrm{x}^{2}-1.5373 \mathrm{x}+0.3855$ \\
& & $\mathrm{y}=5.3559 \mathrm{x}^{2}-0.4927 \mathrm{x}+0.1239$ \\
\end{tabular}

Table A21-4. Descriptive statistics for observed and modeled streamflow used to generate the rating curves for Site 21, West Run Watershed, Morgantown, WV, U.S.A.

\begin{tabular}{|c|c|c|c|c|}
\hline & Sample Size & Mean $\left(\mathrm{m}^{3} / \mathrm{s}\right)$ & St. Dev. & SE of Mean \\
\hline Observed & 23 & 0.467 & 0.524 & 0.109 \\
\hline Manning's & 23 & 0.514 & 0.237 & 0.049 \\
\hline \multicolumn{5}{|l|}{$\begin{array}{l}\text { Curve (Obs } \\
\text { Slope) }\end{array}$} \\
\hline & 23 & 0.85 & 0.433 & 0.09 \\
\hline \multicolumn{5}{|l|}{$\begin{array}{c}\text { Curve (Calc } \\
\text { Slope) }\end{array}$} \\
\hline $\begin{array}{c}\text { Chezy's Curve } \\
\text { (Obs Slope) }\end{array}$ & 23 & 0.514 & 0.237 & 0.049 \\
\hline $\begin{array}{l}\text { Chezy's Curve } \\
\text { (Calc Slope) }\end{array}$ & 23 & 0.85 & 0.433 & 0.09 \\
\hline $\begin{array}{l}\text { Dingman and } \\
\text { Sharma's } \\
\text { Curve (Obs } \\
\text { Slope) }\end{array}$ & 23 & 0.941 & 0.435 & 0.091 \\
\hline $\begin{array}{l}\text { Dingman and } \\
\text { Sharma's } \\
\text { Curve (Calc } \\
\text { Slope) }\end{array}$ & 23 & 1.155 & 0.534 & 0.111 \\
\hline
\end{tabular}


Table A21-5. P-values of the statistical analyses (post-hoc ANOVA) for observed and modeled rating curves at Site 21, West Run Watershed, Morgantown, WV, U.S.A.

\begin{tabular}{|c|c|c|c|c|c|c|c|c|}
\hline & $\begin{array}{l}\text { Observed } \\
\text { Curve }\end{array}$ & $\begin{array}{l}\text { Rating } \\
\text { Equation } \\
\text { Curve }\end{array}$ & $\begin{array}{c}\text { Manning's } \\
\text { Curve (Obs } \\
\text { Slope) }\end{array}$ & $\begin{array}{c}\text { Manning's } \\
\text { Curve (Calc } \\
\text { Slope) }\end{array}$ & $\begin{array}{c}\text { Chezy's } \\
\text { Curve } \\
\text { (Obs } \\
\text { Slope) } \\
\end{array}$ & $\begin{array}{c}\text { Chezy's } \\
\text { Curve } \\
\text { (Calc } \\
\text { Slope) } \\
\end{array}$ & $\begin{array}{c}\text { Dingman and } \\
\text { Sharma's } \\
\text { Curve (Obs } \\
\text { Slope) } \\
\end{array}$ & $\begin{array}{c}\text { Dingman and } \\
\text { Sharma's } \\
\text { Curve (Calc } \\
\text { Slope) } \\
\end{array}$ \\
\hline $\begin{array}{l}\text { Rating } \\
\text { Equation } \\
\text { Curve }\end{array}$ & - & - & 1 & $0.03 *$ & 1 & $0.03 *$ & $<0.05^{*}$ & $<0.05^{*}$ \\
\hline $\begin{array}{c}\text { Manning's } \\
\text { Curve (Obs } \\
\text { Slope) }\end{array}$ & - & - & - & 0.08 & 1 & 0.08 & $0.02 *$ & $<0.05^{*}$ \\
\hline $\begin{array}{c}\text { Manning's } \\
\text { Curve (Calc } \\
\text { Slope) }\end{array}$ & - & - & - & - & 0.08 & 1 & 1 & 0.34 \\
\hline $\begin{array}{c}\text { Chezy's } \\
\text { Curve (Calc } \\
\text { Slope) }\end{array}$ & - & - & - & - & - & - & 1 & 0.35 \\
\hline $\begin{array}{l}\text { Dingman and } \\
\text { Sharma's } \\
\text { Curve (Obs } \\
\text { Slope) }\end{array}$ & - & - & - & - & - & - & - & 0.69 \\
\hline $\begin{array}{l}\text { Dingman and } \\
\text { Sharma's } \\
\text { Curve (Calc } \\
\text { Slope) } \\
\end{array}$ & - & - & - & - & - & - & - & - \\
\hline
\end{tabular}




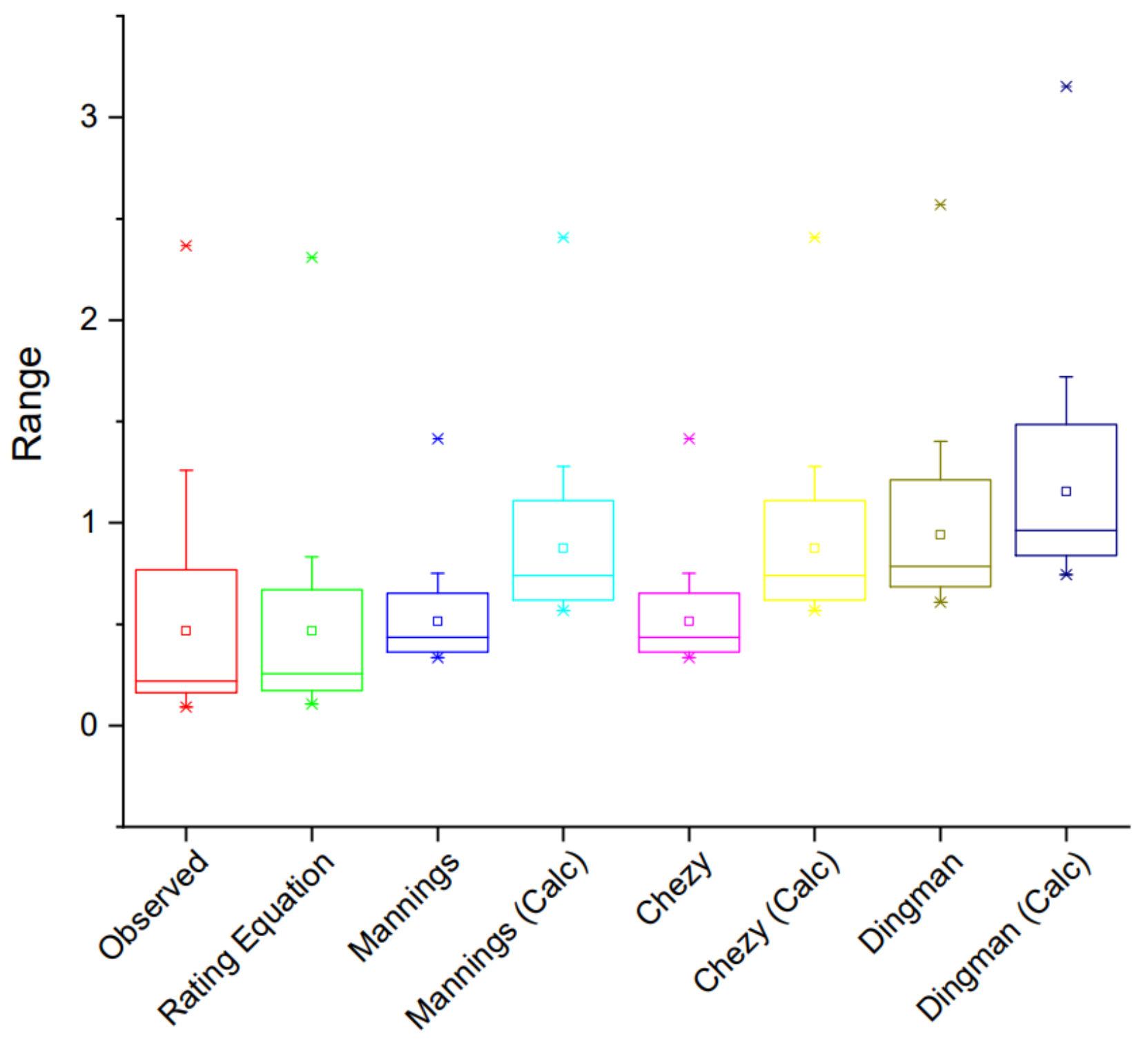

Figure A21-2. Box and whisker plots for the results of the statistical analyses (post-hoc ANOVA) of observed and modeled rating curves at Site 21, West Run Watershed, Morgantown, WV, U.S.A. 


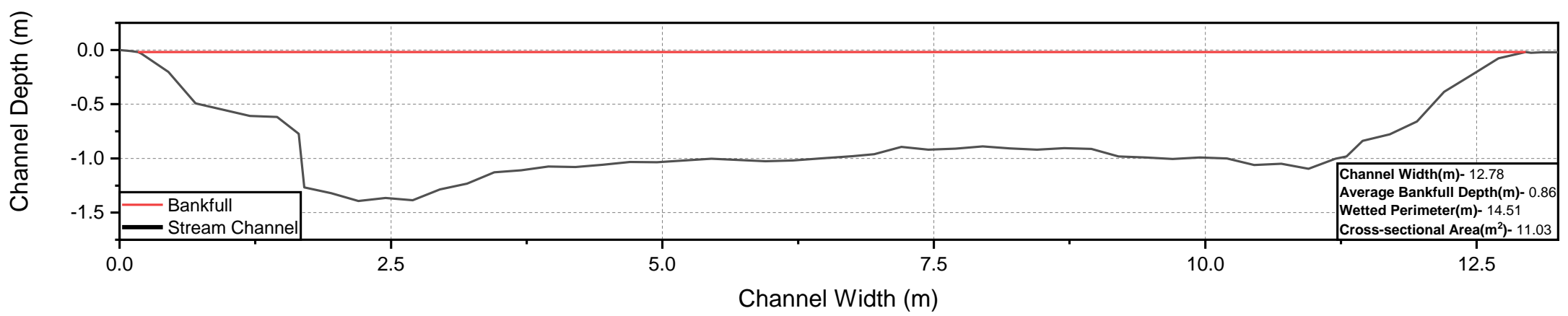

Figure A21-3. Cross-sectional profile of WRW Site 21, plotting the stream channel's shape, water surface, and bankfull. The profile is created with a Channel Width of $0=$ Left Bank facing downstream. 


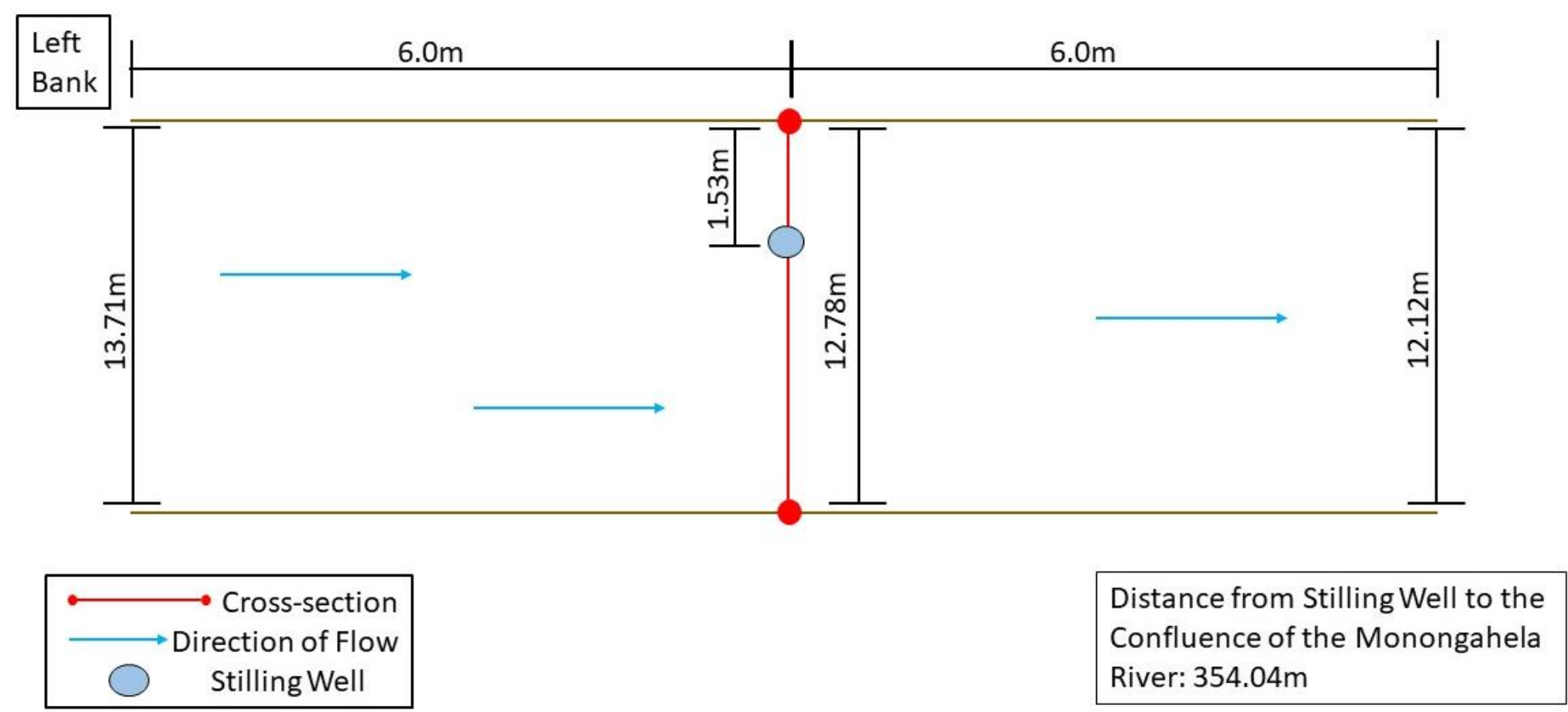

Figure A21-4. Plan view profile of WRW Site 21, West Run Watershed, Morgantown, WV, U.S.A. (Figure 2). Showing the positioning of stilling well in relation to where the streamflow was measured. Along with the channel width at the stilling well, point where cross-sections were performed, and $6.0 \mathrm{~m}$ upstream and downstream from the stilling well. 


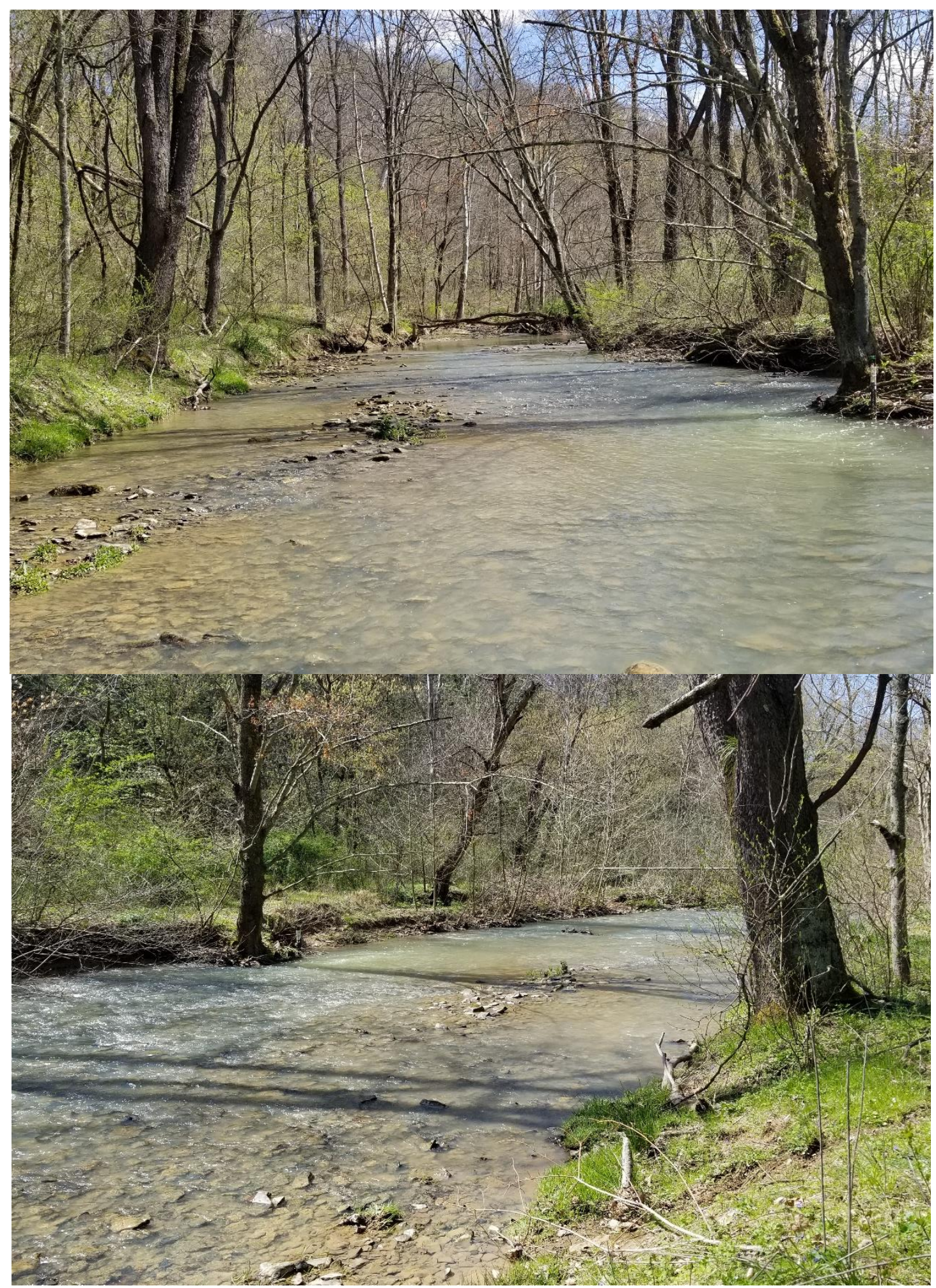

Figure A21-5. Photographs showing channel characteristics at Site \#21, West Run Watershed, Morgantown, WV, U.S.A. Photo 1 was taken looking upstream in the channel. Photo 2 was taken from the right bank looking downstream. 